\title{
Geen kwestie van leeftijd : verzorgingsstaat, wetenschap en discussies rond ouderen in Nederland, 1945-1982
}

Citation for published version (APA):

Bijsterveld, K. T. (1995). Geen kwestie van leeftijd : verzorgingsstaat, wetenschap en discussies rond ouderen in Nederland, 1945-1982. [Doctoral Thesis, Maastricht University]. Van Gennep. https://doi.org/10.26481/dis.19950101kb

Document status and date:

Published: 01/01/1995

DOI:

10.26481/dis.19950101kb

Document Version:

Publisher's PDF, also known as Version of record

Please check the document version of this publication:

- A submitted manuscript is the version of the article upon submission and before peer-review. There can be important differences between the submitted version and the official published version of record.

People interested in the research are advised to contact the author for the final version of the publication, or visit the DOI to the publisher's website.

- The final author version and the galley proof are versions of the publication after peer review.

- The final published version features the final layout of the paper including the volume, issue and page numbers.

Link to publication

\footnotetext{
General rights rights.

- You may freely distribute the URL identifying the publication in the public portal. please follow below link for the End User Agreement:

www.umlib.nl/taverne-license

Take down policy

If you believe that this document breaches copyright please contact us at:

repository@maastrichtuniversity.nl

providing details and we will investigate your claim.
}

Copyright and moral rights for the publications made accessible in the public portal are retained by the authors and/or other copyright owners and it is a condition of accessing publications that users recognise and abide by the legal requirements associated with these

- Users may download and print one copy of any publication from the public portal for the purpose of private study or research.

- You may not further distribute the material or use it for any profit-making activity or commercial gain

If the publication is distributed under the terms of Article $25 \mathrm{fa}$ of the Dutch Copyright Act, indicated by the "Taverne" license above, 
Karin Bijsterveld

Geen kwestie van leeftijd 
Kennis

Openbare mening

Politiek

een serie onder redactie van

René Boomkens, Elsbeth Etty, Lolle Nauta, Dick Pels, Gerard de Vries 


\section{Karin Bijsterveld}

\section{Geen kwestie van leeftijd}

Verzorgingsstaat, wetenschap

en discussies rond ouderen in Nederland, 1945-1982 
O 1995 Karin Bijsterveld / Uitgeverij en boekhandel Van Gennep bv, Spuistraat 283, 1012 VR Amsterdam

Boekverzorging: Hannie Pijnappels, Amsterdam

Zetwerk: Ad Rem Tekst, Amsterdam

Druk- en bindwerk: Koninklijke Wöhrmann bv, Zutphen

ISBN 90-5515-090-8 / NUGI 65I / CIP 


\section{Inhoud}

Voorwoord

I Het verleden van de ouderdom

I Inleiding

2 Historisch onderzoek naar de maatschappelijke definitie van de ouderdom

- Produkt, proces, posities

- De politieke economie van het ouder worden

- De standaardisering van de levensloop

- De ontdekking van de ouderdom

- Overeenkomsten en verschillen

3 Kanttekeningen

4 Grenzen: ontstaan, soorten, betekenis en dynamiek

5 Een kwestie van leeftijd?

2 Bevolkingsveroudering: het profiel van een publiek probleem

I Inleiding

2 De eeuw der ouderdom

- Het karakter van een oud volk

- De som der delen

- De voortgang der structuurwijzigingen

- Maakbaarheid en marge

- Het dilemma van de verdubbeling

3 Het ontstaan van instanties

4 Een ongrijpbare groep

5 Een uitgemaakte zaak?

6 Slot

3 Vrouw, ongehuwd en oud: de verzorgingsstaat en het onderscheid naar sociale categorie

I Inleiding

2 Een moderne tragedie 
3 Deelbelang en belangengroep

- Een spel van vergelijkingen $\quad 94$

- Weduwen van koek 99

4 Advocaat van de staat $\quad$ IO2

-Onvoldoende relevant $\quad 103$

- Geen rechtsgrond $\quad 104$

5 De versplintering van een categorie $\quad$ I09

6 Slot

4 Natuurlijk verouderen: de geriatrie en het karakter van een levensfase

I Inleiding

2 Een typische ouderdomskwaal

- In 's mensen erfelijke natuur besloten

- Gevaren van bedrust

3 De perken te buiten: de geriatrie en de geriatrische afdeling van het ziekenhuis

- Meester op vele wapens

- Van alles wat, van alles te weinig

- Voor Koningin en vaderland

4 Naar Brits model

- Een groot verschil

- In vergelijking met andere landen

- Overheid en particulier initiatief

- Een onzichtbaar 'netwerk'

5 Slot

5 Ommuurde ouderdom: de ruimtelijke orde van verzorgingshuizen

1 Inleiding

2 'Classificeering' en het ontstaan van het pensiontehuis

3 Het verlangen naar individualiteit: de 'massa der bejaarden' en burgerlijk wonen

- Twee tegengestelde elementen $\quad 166$

- Niet stand, maar toestand 
4 Publieke en private ruimten: het tehuis als gezin, hotel, dorp en voorstad

- Gezin en hotel

- Dorp en voorstad

-Veel voorzieningen, hoge gebouwen $\quad$ 18I

-Een beschutte verbinding met buiten $\quad$ I 84

5 Een nieuwe horizon: tehuizen ter discussie $\quad$ I88

$\begin{array}{ll}- \text { Een zelfstandige woning } & \text { I89 }\end{array}$

- Het ware verzorgingstehuis $\quad 192$

-De blik gewend 196

- Afremmen, de wijk nemen en groepsverzorging $\quad 199$

6 Slot 204

\section{De dynamiek van grenzen}

I Inleiding

2 Een grens gepasseerd: voorbereiding op de pensionering

- Een slagboom in het bestaan

-Een overschat probleem?

- Nieuwe grenzen - een oude voorziening 230

3 De oogst van het onderzoek naar grenzen 239

4 Slot: geen kwestie van leeftijd 253

Noten $\quad 254$

Lijst van afkortingen $\quad 344$

Verantwoording van geraadpleegde bronnen en geïnterviewde personen

Literatuur $\quad 354$

Personenregister 



\section{Voorwoord}

Het afronden van dit boek was geen kwestie van leeftijd, maar een kwestie van tijd. Niet eerder werd ik me zo bewust van het verstrijken van tijd als in de jaren dat ik aan deze studie werkte. Loeide de sirene op de eerste van de maand, dan rekende ik uit hoeveel weken ik nog had voordat het boek - in de vorm van een proefschrift - af moest zijn. Vierde ik mijn verjaardag, dan deed het er weinig toe of ik dertig of éénendertig was geworden; wél dat de 'deadline' voor de promotie dichterbij kwam.

De gesprekken met promotor Gerard de Vries waren rustpunten. Ook wanneer ik mijn stukken weer eens op het allerlaatste moment had ingeleverd, wist hij orde op zaken te stellen en de grote lijnen aan te geven. Bovendien heeft hij het intrigerende vermogen zo over verbeteringen te praten, dat je al bij het verlaten van zijn kamer meent ze zelf bedacht te hebben. Zowel Gerards begeleiding als zijn bijdragen aan de vaak spannende bijeenkomsten in het kader van de 'Netherlands Graduate School Science and Technology Studies' heb ik bijzonder gewaardeerd. Dat geldt ook voor het contact met mijn hardwerkende, enthousiaste en zelden saaie collega's binnen de Faculteiten der Cultuurwetenschappen en Gezondheidswetenschappen van de Rijksuniversiteit Limburg. Ik heb genoten van de discussies tijdens colloquia en rond de koffietafel en heb geleerd van de vele publikaties die ik in mijn postvakje vond. Ik verheug me op de samenwerking die nog komen gaat.

Een deel van mijn collega's, binnen en buiten de genoemde instituten, wil ik in het bijzonder bedanken. Dat zijn in de eerste plaats Klasien Horstman en Jessica Mesman, met wie ik een artikel schreef dat de basis vormde voor hoofdstuk drie. Wiebe Bijker en Ger Wackers namen taken van mij over zodat ik mij 
aan het schrijven kon zetten. Rob Houtepen, Eddy Houwaart, Annemieke Klijn, Sjaak Koenis, Annemarie Mol, Monique Stavenuiter, Paul Thung, Jo Wachelder en Jeroen Winkels voorzagen het proefschrift als geheel, of vroege delen daaruit, van commentaar. Sabine Kuipers, Maaike Luxembourg, Anja Servais en Marleen Vara zorgden in een eerder of later stadium voor noten, literatuur, opmaak en tabellen. Deze en vele andere collega's hebben bovendien de tijd genomen naar mijn verhalen te luisteren toen in het afgelopen jaar ongewenste en gewenste revoluties mijn persoonlijk leven in hoog tempo veranderden.

Ook buiten de kring van collega's ben ik veel mensen dank verschuldigd. Daartoe behoren de geïnterviewden: G.P.A. Braam, C.P.M. Knipscheer, J.M.A. Munnichs, M. van Saane en R.J. van Zonneveld. De laatste drie leenden tevens archiefstukken en publikaties aan mij uit. J.M.A. Munnichs en R.J. van Zonneveld gaven bovendien commentaar op eerder gepubliceerde artikelen. Ook Helma Erkelens, J. Everts en F.H.J. Nierstrasz stuurden mij bronnenmateriaal. Daarnaast zorgden mijn ouders, zussen, 'zwagers' en Ellen Lisa van Woerden voor logies en gezelligheid tijdens archiefonderzoek en hielp Dorien van Rheenen bij het opsporen van ontbrekende jaargangen van tijdschriften.

Rein de Wilde ten slotte, was co-promotor, maar ruilde deze rol vlak voor de afronding van dit boek in voor die van vriend. Voor mij had hij niets beters kunnen doen.

Maastricht, oktober 1995 


\section{Het verleden van de ouderdom}

\section{Inleiding}

In 1982 beschreef H.J.A. Hofland een denkbeeldig bericht op de voorpagina van een ochtendblad van 3 januari 2000 . Een dag daarvoor hadden zich tienduizend bejaarden - mensen in de leeftijd van so tot 85 jaar - op de Dam verzameld. Met spandoeken en spreekkoren demonstreerden zij tegen de Gerontopol, het systeem van voorzieningen en maatregelen voor oudere leeftijdsgroepen. 'Toen de kop van de stoet bij de Stopera was gekomen, probeerden raddraaiers de vreedzame betoging een andere wending te geven. De straat werd opengebroken, er werden stenen gegooid en men trachtte de bureaus van de gerontologische dienst te bezetten, waarbij vele bejaarden een ongekende brutaliteit aan de dag legden. Voor de autoriteiten kwam dit onbeheerste gedrag als een volslagen verrassing. Nadat snel versterkingen waren aangevoerd, had de politie weinig moeite met het herstel van de orde. De menigte vluchtte naar alle kanten uiteen. Enkele prothesen bleven op het slagveld achter; de eigenaars of eigenaressen daarvan hebben zich nog niet gemeld."

In de analyse die Hofland van zijn zelfverzonnen bericht gaf, beschreef hij hoe in de loop van de jaren tachtig en negentig de pensioenplichtige leeftijd steeds verder was verlaagd en hoe uiteindelijk iedereen boven de vijftig 'arbeidsvrij' was geworden. Op illegaal werk werd scherp gecontroleerd, het verlies aan salaris werd opgevangen via een uitkering en de overheid zorgde voor eenvoudige en betaalbare, maar niet erg populaire huisvesting. Een onvoorzien gevolg van dit alles was dat de vijf miljoen arbeidsvrijen steeds negatiever door de rest van de samenleving werden bejegend. In reactie op deze situatie hadden de arbeids- 
vrijen inmiddels een nieuwe partij opgericht ter verdediging van hun belangen: Werkers 2000. Tot macht had dat echter niet geleid, eerder tot 'institutionalisering van het bedelaarsdom'. 'Wie jonger is dan 50', schreef Hofland over het jaar 2000, 'woont nog in een democratie; wie Abraham gezien heeft, komt terecht in een politiestaat."

In het toekomstvisioen van Hofland begon het bejaarde bestaan op de leeftijd van vijftig jaar. Wie een blik op Abraham geworpen had, behoorde tot de sociale categorie der bejaarden. Het meest essentiële van de komende ouderenproblematiek lag voor Hofland, afgaande op zijn analyse, in de onmacht van de verplicht arbeidsvrijen en hun geronto-politieke afzondering via uitkeringen en bijzondere huisvesting. En typerend voor het uiterlijk en het gedrag van de ouderen van het jaar 2000 waren niet alleen prothesen en een gebrek aan verzetskracht, maar ook brutaliteit en onbeheerst gedrag.

De boodschap van Hoflands dystopische schets lag voor een belangrijk deel in de grenzen die hij trok om de ouderdom en de ouderdomsproblematiek te karakteriseren. Al op de eerste pagina van zijn betoog bakende Hofland de groep bejaarden af: het ging om de 'arbeidsvrijen', een 'vrijheid' die verkregen werd op de leeftijd van vijftig jaar. Die grens gaf tevens het cruciale verschil aan tussen bejaarden en de anderen en raakte daarmee de kern van de problematiek die Hofland aan de kaak stelde: bejaarden werden onderworpen aan de Gerontopol - jongeren niet. Bejaarden leefden binnen een politiestaat, anderen binnen een democratie. Ook liet Hofland onuitgesproken verwachtingen over de normale manier van doen van bejaarden contrasteren met het toekomstig gedrag van ouderen - door te spreken over de 'volslagen verrassing' van het 'onbeheerste gedrag'. Daarmee sprak hij niet alleen over het naderende millennium, maar gaf hij tussen de regels door ook commentaar op - en liet zich inspireren door - zijn eigen tijd. Voor Hoflands begrenzing van de categorie 'bejaarden' stond een geëxtrapoleerde versie van de vervroegde uittreding van de jaren zeventig model. Zijn omschrijving van de ouderenproblematiek toonde grote verwantschap met de maatschappijkritische geluiden van diezelfde jaren zeven- 
tig en zijn typering van het doen en laten van de futuristische oudere leek ten dele geënt op de krakersrellen van het begin van de jaren tachtig.

Het kan verkeren. Inmiddels weten we dat de vervroegde uittreding onder verwijzing naar de hoge kosten ervan geleidelijk werd teruggedraaid en dat deskundigen plannen opperen om de Algemene Ouderdomswet (AOW) pas bij zeventig jaar te laten ingaan. Juist in de jaren tachtig werd de 'zorgzame samenleving' als alternatief voor een omvangrijk zorgsysteem gepresenteerd en werden institutionele voorzieningen voor ouderen ten gunste van 'zorg-op-maat' in de eigen omgeving ingedamd. Ouderenpartijen zijn inmiddels op het parlementaire toneel verschenen, maar in het grijze deel der natie valt vijf jaar voor het magische jaar 2000 met de beste wil van de wereld geen militante massa te zien. Binnen de ruime categorie 'ouderen' zijn de verschillen groot. Tot de vele ouderen van vandaag behoren immers zowel degenen met alleen AOw en zij die in bejaardenwoningen en verzorgingshuizen zijn gehuisvest, als de bewoners van een appartement-met-videobewaking in één van de chique 'residences'.

Hoflands gedachtenexperiment van 1982 en de confrontatie daarvan met dat wat ons nu bekend is, geeft aan hoe weinig vanzelfsprekend de grenzen zijn waarmee hij de ouderdom omlijnde. Wat de overgang naar de ouderdom markeert, wat binnen en buiten de perken van normaal ouderdomsgedrag valt, wat wel en niet tot de essentie van de ouderdomsproblematiek gerekend wordt en waar de onderkomens van ouderen op de plattegronden van stad en ommeland zijn gesitueerd, ligt niet voor eens en altijd vast. Dat dergelijke grenzen tijds- en cultuurafhankelijk zijn, wordt in geval van een toekomst die inmiddels verleden tijd is, gemakkelijk zichtbaar. Dat ook in de huidige discussies rond ouderen voortdurend grenzen worden getrokken, valt echter niet steeds onmiddellijk op.

Met de regelmaat van de klok verschijnen kranteartikelen over de gevolgen van de vergrijzing voor de omvang van de gezondheidszorg en de betaalbaarheid van pensioenvoorzieningen. Politieke redacties doen voorspellingen over de levensduur en het parlementaire gedrag van ouderenpartijen. Opiniepagina's 
worden gevuld met debatten over de mogelijkheid van een zelfgekozen dood voor ouderen of de voors en tegens van moederschap op latere leeftijd. In persberichten wordt aangekondigd dat bejaardenoorden hun langste tijd hebben gehad. In veel van dergelijke analyses, berichten en ingezonden brieven staan, net als in Hoflands betoog, grenzen op het spel.

Sommige van die grenzen worden expliciet naar voren geschoven: moet voor medisch ingrijpen een maximale leeftijdsgrens worden vastgesteld om de kosten van de gezondheidszorg in een verouderende samenleving te kunnen beheersen? Wat gebeurt er met het politieke bedrijf wanneer traditionele ideologische scheidslijnen tussen partijen worden vervangen en doorkruist door grenzen tussen - voor specifieke sociale categorieën sprekende - belangengroepen? Overschrijdt een vrouw die na haar vijftigste het leven aan een baby schenkt niet de grenzen van het 'natuurlijke'? Bestaat er nog een werkelijk onderscheid tussen het verzorgingshuis en het verpleeghuis? Andere grenzen blijven meer impliciet of zijn inmiddels zo vanzelfsprekend dat ze amper meer worden opgemerkt. Zo wordt geruisloos vastgelegd wie wel en wie niet tot de ouderen behoren of wat wel en wat niet tot het probleem van de vergrijzing gerekend mag worden.

Dergelijke grenzen maken verschil. Waar grenzen openlijk onderwerp van discussie zijn, is dat het meest duidelijk. Een maximale leeftijdsgrens voor de toelating tot bepaalde medische interventies kan iemand letterlijk maken of breken. Een politiek bedrijf dat stoelt op schermutselingen tussen belangengroepen kent andere spelregels en leidt vermoedelijk tot een ander beleid dan een politieke context waarin partijen op ideologische gronden van elkaar verschillen. Wie meent dat het baren van kinderen na de menopauze de grenzen van het natuurlijke overschrijdt, laat impliciet weten een dergelijke kunstgreep niet aanvaardbaar te vinden. En een ambtenaar die schrijft dat verzorgings- en verpleeghuizen nauwelijks nog van elkaar verschillen, stelt een instelling waarbinnen ouderen ruimtelijk bijeen worden gebracht gelijk aan een niet-categorale voorziening. Een samensmelting zou de geografische plaats van ouderen diffuser maken. 
Maar ook grenzen die in stilte naar voren worden geschoven hebben betekenis. Wie de vergrijzing voorstelt als een zaak die de nationale schatkist geld gaat kosten, laat - bedoeld of onbedoeld - kwesties die niet in financiële kaders te vangen zijn, buiten beeld. Wie consequent de term 'ouderen' gebruikt, heeft een andere bevolkingsgroep voor ogen, richt zich op een ander publiek en ziet mogelijk andere kansen en problemen, dan wie over 'bejaarden' spreekt. De grenzen van het vergrijzingsprobleem, de grenzen van de groep ouderen, de grenzen van wat voor ouderen 'natuurlijk' is en de geografische grenzen van voorzieningen: ze doen ertoe.

Over de geschiedenis van dergelijke grenzen gat dit boek. De ouderdom kreeg in het verleden - en krijgt nog steeds - via verschillende grenzen een gezicht. Met die 'grenzen' wordt gedoeld op datgene aan de hand waarvan de ouderdom wordt afgebakend, omlijnd, gekarakteriseerd of getypeerd. Hoe ontstonden die grenzen en wat hebben ze te betekenen gehad? Hoflands fantasie over een met ouderen bevolkte toekomst bracht niet alleen die toekomst, maar ook zijn eigen tijd voor het voetlicht. Omgekeerd zegt een geschiedenis van de ouderdom niet alleen iets over het verleden, maar kan zo'n geschiedenis ook huidige verwikkelingen rond ouderen van hun vanzelfsprekendheid ontdoen.

De geschiedenis van de manier waarop de ouderdom van andere levensfasen werd onderscheiden, is binnen de historiografie van de ouderdom geen nieuw thema. Over die geschiedenis is de laatste tien tot vijftien jaar veel gepubliceerd. Aan het eind van de jaren zeventig ontstond binnen de toen nog prille geschiedschrijving van ouderen en ouderdom bijzondere belangstelling voor de sociale definitie, constitutie of constructie van de ouderdom. De discussie over het verleden van de ouderdom draaide tot dan toe ondermeer om de vraag of er ooit een gouden eeuw voor ouderen was geweest: een periode waarin ouderen een goede positie en een behoorlijk aanzien hadden gehad. Daarnaast ontstond aandacht voor de vraag hoe de ouderdom zich in de loop der tijd als afzonderlijke levensfase had uitgekristalliseerd. Het betrof een 
benadering die veranderingen rond de ouderdom met sociale structuren in verband wilde brengen. Daarbij concentreerden de betrokken onderzoekers - sociologen met historische interesse en historici met sociologische belangstelling - zich vooral op de geschiedenis van na $1850 .{ }^{3}$

Deze onderzoekers hadden met elkaar gemeen dat zij de maatschappelijke 'vormgeving' van de ouderdom onderstreepten. Een jaartje ouder worden was naar hun mening een individueel gegeven. De ouderdom en 'het bejaard-zijn' karakteriseerden zij daarentegen als cultureel variabele en maatschappelijk geconstrueerde fenomenen. Die gedachte leverde historici en sociologen nieuwe vragen over het verleden op en deed hen met een andere bril naar gangbare stellingen kijken. Dat leidde tot een specifieke benadering van de geschiedenis van de ouderdom en biedt redenen om deze manier van kijken hierna, ondanks onderlinge verschillen in theorie en terminologie, onder de gemeenschappelijke noemer van de 'definitie-benadering' te brengen. Maar wat hield hun bewering dat de ouderdom een sociale definitie, constructie of constitutie was nu eigenlijk in? Wat werd door hen gedefinieerd, geconstrueerd of geconstitueerd geacht? En hoe stelden zij zich het verloop van definitie, constructie of constitutie voor?

Over die vragen gaat dit hoofdstuk. Door na te gaan op welke manieren over de maatschappelijke definitie van de ouderdom is geschreven (paragraaf 2) en welke kanttekeningen daarbij te plaatsen zijn (paragraaf 3 ), kan duidelijk worden wat de definitiebenadering wel en niet te bieden heeft. Met dat als decor zal (in paragraaf 4) nogmaals, maar nu uitvoeriger aan de orde komen om welke vragen en begrippen deze studie draait en tot welke opzet (paragraaf 5) dat hier heeft geleid. De opmerkingen over de definitie-van-de-ouderdom-historiografie zijn op een enkele uitzondering na gebaseerd op publikaties van de laatste tien tot vijftien jaar over de geschiedenis van het ouder worden in de Verenigde Staten, Groot-Brittannië, Frankrijk, Duitsland en Nederland. In die landen kreeg de ouderdom, aldus deze publikaties, in de tweede helft van de negentiende en vooral de twintigste eeuw een wezenlijk nieuw gezicht. 
2 Historisch onderzoek naar de maatschappelijke definitie van de ouderdom

\section{Produkt, proces, posities}

Wie de geschiedschrijving van ouderen en ouderdom op een rij zet, zal het definitie-denken het vaakst aantreffen in studies die zich concentreren op het verleden van pensioenvoorzieningen, medisch-wetenschappelijk werk en institutionele zorg. ${ }^{4} \mathrm{De}$ grootste gemene deler van dergelijke publikaties is de bewering dat in de loop van de negentiende en twintigste eeuw de ouderdom van een weinig uitgekristalliseerd verschijnsel veranderde tot een aanwijsbaar sociaal probleem, een afzonderlijk object van zorg, een strikt afgebakende sociale categorie of een duidelijk omlijnde levensfase. Juist pensioenregelingen, zorgvoorzieningen en medisch-wetenschappelijke denkbeelden speelden, zo luidt doorgaans de redenering, in deze veranderingen een gewichtige rol.

Veel van de betrokken auteurs, van wie de namen nog volgen, plaatsen deze ontwikkelingen onder de noemers 'sociale constitutie', 'constructie' of 'definitie' van de ouderdom. Maar ook andere termen worden gebruikt. Zo spreken enkelen van 'Prägung', 'Profilierung' of 'creation' van de ouderdom. Dergelijke verschillen in woordkeus zijn echter niet van wezenlijk belang. De genoemde termen vervullen in het bedoelde type betoog steeds dezelfde functie: ze geven uitdrukking aan de maatschappelijke bepaaldheid van de ouderdom.

Opvallend is dat nagenoeg alle auteurs de termen 'definitie', 'constitutie' en 'constructie' zowel voor het proces van definitie als voor het produkt ervan gebruiken. Op het niveau van de gehanteerde begrippen wordt dus geen onderscheid gemaakt tussen het resultaat - de gedefinieerde levensfase, de afgebakende categorie, het benoemde probleem, het zichtbaar geworden object van zorg - en de ontwikkeling die daaraan voorafgaat. Dat dit verschil tussen produkt en proces in de definitie-benadering doorgaans buiten beschouwing wordt gelaten, hangt - zo zal nog duidelijk worden - nauw samen met de theoretische posities die in deze literatuur worden ingenomen. Die theoretische posi- 
ties hebben vooral betrekking op de structurele achtergronden van de veranderingen rond de ouderdom. Want hoewel de bedoelde beschouwingen in hun gerichtheid op de thema's pensionering, wetenschap en institutionele zorg op elkaar lijken, lopen de gehanteerde verklaringsschema's zeer uiteen. Drie benaderingen zijn daarbinnen te onderscheiden: een politiek-economische, een levensloop-sociologische en een historische.

\section{De politieke economie van het ouder worden}

Tot de eersten die over een 'sociale constructie van de ouderdom' spraken, behoorde een groep overwegend marxistisch en neo-marxistisch geïnspireerde sociologen. Deze onderzoekers, onder wie Caroll Estes, Anne-Marie Guillemard, Robin Means, John Myles, Chris Phillipson, Peter Townsend en Alan Walker, hadden en hebben grote bezwaren tegen de gedachte dat de problemen van ouderen hoofdzakelijk van biologische, psychologische en daarmee van individuele aard zouden zijn. De ware wortels van de geringe status en zwakke inkomenspositie van ouderen in de democratische staten van het Westen liggen volgens hen op het maatschappelijk vlak. Daarbij wijten zij de structurele afhankelijkheid van ouderen in de eerste plaats aan de economische verhoudingen binnen het industrieel kapitalisme. Die economische verhoudingen, alsook het overheidsbeleid in het verlengde daarvan, bepalen zowel de manier waarop de samenleving over het proces van oud worden denkt als de daadwerkelijke sociale positie en ervaringen van ouderen. Dergelijke verbanden willen de sociologen in kwestie via een 'politieke economie van het ouder worden' en historisch onderzoek blootleggen.

Zo keert een deel van deze onderzoekers zich tegen de bewering dat de oorsprong van het moderne pensioneringsbeleid van overheid en ondernemingen zou liggen in een combinatie van vergrijzing en economische groei. Een beschrijving waarin de pensionering functioneert als een via de welvaart mogelijk gemaakte 'oplossing' voor de individuele 'noden' van een toenemend aantal ouderen, overtuigt hen niet. Ook neo-klassieke micro-economische verklaringen waarin pensionering als het be- 
lang van alle betrokkenen figureert, worden door hen verworpen. In plaats daarvan zoeken zij de achtergronden van de negentiende- en twintigste-eeuwse pensioenregelingen vooral in de behoefte aan rationalisering - met name tijdbesparing - in een op loonarbeid gebaseerde industrie, in het streven naar efficiency binnen de organisatie van overheid en bedrijfsleven, in het afdwingen van loyaliteit van werknemers aan ondernemingen en in de bestrijding van nationale werkloosheid. Of werknemers daarbij zelf veel in de melk te brokkelen hebben gehad en hun pensionering steeds verwelkomden, betwijfelen zij. Het bestaan van de sociale categorie 'ouderen' moet volgens hen dan ook niet als de oorzaak, maar als het gevolg van pensioenregelingen worden gezien. De leeftijdsgrenzen en inkomensmaatregelen binnen die regelingen gaven de verschijningsvorm van de ouderdom immers eenheid en regelmaat.

Een soortgelijke omkering ondernemen verschillende aanhangers van de politiek-economische benadering ten aanzien van de activiteiten van de mensen in het ouderenwerk, gerontologen en geriaters: ook in deze kringen zou zijn meegewerkt aan het ontstaan van de afhankelijkheid, passiviteit en segregatie van ouderen. Zoals de bedoelde auteurs de pensionering weigeren te zien als logisch antwoord op de nood van ouderen, zo weigeren zij het werk van ouderdomsdeskundigen te beschouwen als belangeloze reactie op de ontdekking van de ouderenproblematiek. Tegenover de veronderstelling dat gerontologen, geriaters en functionarissen in de zorgsector bestaande problemen ontdekten en daarvoor oplossingen zochten, plaatsen zij de bewering dat ouderdomsdeskundigen met hun werk het 'bestaan' van problemen en zorgpraktijken rond ouderen construeerden dan wel legitimeerden. Een visie die in een gematigde versie overigens ook door enkele auteurs buiten de political economy-kring wordt verkondigd. Zo zou, aldus Thomas Cole, de invloedrijke moderniseringsthese van de socio-gerontoloog Emest Burgess - via een preoccupatie met het isolement van en het gebrek aan rollen voor ouderen - de groei van een professionele 'aging industry' hebben gestimuleerd. Naar Cole's mening hebben de gerontologie en de geriatrie er helaas toe bijgedragen dat de ouder- 
dom tot een 'probleem' is gereduceerd. ${ }^{6}$ Ook gerontologen zélf beweren dat de gerontologie de ouderdom definieert, al lijken zij geneigd dat verschijnsel eerder op een onvolkomen geacht verleden van de gerontologie te projecteren, dan op de huidige situatie.

De sociologen van politiek-economische huize zijn daarentegen ook wat het laatste betreft zeker van hun zaak. Naar hun mening hebben de gerontologie, de geriatrie en het ouderenwerk tot op de dag van vandaag als verlengstukken van staat en economie gefunctioneerd en zo de bestaande sociale arrangementen rond de ouderdom bekrachtigd. Phillipson verdedigt bij voorbeeld de stelling dat gerontologische opvattingen over de goede en kwade kanten van de pensionering eenzelfde golfbeweging hebben vertoond als de vraag naar oudere arbeidskrachten. Op een soortgelijke manier verklaart Robin Means de hardnekkige preoccupatie van naoorlogse Britse politici, ambtenaren, onderzoekers en zorgdeskundigen met bejaardentehuizen voor een belangrijk deel uit de afwezigheid van de economische noodzaak om minder kostbare voorzieningen te treffen. ${ }^{\text {* Ande- }}$ ren identificeren het werk van gerontologen en geriaters met een vergaande medicalisering van de ouderdom. ${ }^{9}$

Hoewel de genoemde onderzoekers ten aanzien van pensioenregelingen, ouderenwerk, geneeskunde en wetenschap steeds dezelfde redeneertrant volgen, heeft hun positie op de laatstgenoemde twee gebieden een radicalere status dan op de eerstgenoemde twee. Dat heeft zowel te maken met de fase waarin de geschiedschrijving van gerontologie en geriatrie zich bevindt, als met een kennistheoretische consequentie van de politiek-economischebenadering.

Een groot deel van de geschiedschrijving van gerontologie en geriatrie beperkt zich vooralsnog tot overzichten van de in de loop der tijd verschenen ouderdomsliteratuur en de institutionele ontwikkelingen binnen beide vakgebieden. In dit type disciplinegeschiedenis wordt het ontstaan en de betekenis van de termen 'gerontologie' en 'geriatrie' besproken, de inhoud van de vakgebieden afgebakend en de instelling van verenigingen, leerstoelen en studierichtingen op een rijtje gezet. ${ }^{10}$ Voor zover der- 
gelijke studies ingaan op de achtergronden van het ontstaan van de gerontologie en geriatrie wordt vaak verwezen naar ontwikkelingen in de 'moederdisciplines' als de biologie, de geneeskunde, de sociologie en de psychologie." Daarnaast wordt de opkomst van het gerontologisch onderzoek dikwijls in verband gebracht met de vergrijzing van de bevolking en de daarmee samenhangende problemen. Die problemen zouden een elite van artsen, onderzoekers, politici en mensen uit de wereld van het maatschappelijk werk ertoe gebracht hebben de wetenschappelijke bestudering van verouderingsvraagstukken op de agenda te plaatsen. In een dergelijk betoog krijgt de gerontologie dus de door de politiek-economisch sociologen vermaledijde plaats van het antwoord op reële, dringende problemen. ${ }^{2}$

Tegenover dit 'realistische' beeld van wetenschap, waarin wetenschappelijke kennis wordt voorgesteld als een afspiegeling van een buiten die wetenschap liggende werkelijkheid, plaatsen de verdedigers van de politieke economie van het ouder worden een 'relativistisch' beeld. Met de ontwikkeling van kennis, aldus dat relativisme, verandert ook het object van die kennis: wereld en werkelijkheid zijn mede het produkt van de activiteiten van onderzoekers. De inzichten van de politiek-economisch sociologen zijn daarmee niet alleen in politieke zin radicaal maar ook in kennistheoretische zin, al wordt de laatste kwestie zelden met zoveel woorden aan de orde gesteld.

De sociale constructie van de ouderdom staat in de publikaties van de radicale sociologen - kortom - voor één maatschappelijke constellatie die ouderen in een positie van afhankelijkheid manoeuvreert. Staat en industrie, wetten en regelingen, wetenschappelijke ouderdomstheorieën en praktische zorginitiatieven hebben naar hun mening zowel het denken over de ouderdom als het leven van ouderen - over de hoofden van de betrokkenen heen - op een beklemmende manier verankerd. Het maatschappelijk establishment, zo luidt dan ook hun stellige overtuiging, heeft het bestaan van ouderen en ouderenproblemen niet zozeer 'onderkend', als wel zelf in het leven geroepen. 


\section{De standaardisering van de levensloop}

In de jaren waarin de politiek economen een eigen school ontwikkelden, werd binnen de historiografie van ouderen en ouderdom ook een andere invalshoek belangrijk: die van de socioloog Martin Kohli. Zijn werk wordt veel geciteerd. Het onderzoek waarin de sporen van zijn stellingen zichtbaar zijn, is inhoudelijk echter minder homogeen dan dat van de politiek economen. Naar Kohli's mening is het ontstaan van de ouderdom als duidelijk omlijnde levensfase - de 'constitutie' van de ouderdom - onderdeel van een geleidelijke 'standaardisering', 'chronologisering' en 'institutionalisering' van de gehele levensloop. In de afgelopen eeuwen, aldus Kohli, is het doorsnee westers mensenleven in steeds strikter afgebakende en 'genormeerde' levensfasen opgedeeld. Die opdeling had en heeft zowel consequenties voor de posities die mensen innemen als voor hun biografische perspectieven en persoonlijke activiteiten.

De standaardisering van de levensloop wordt door Kohli met verschillende verschuivingen in verband gebracht. Ieders leven werd, zo is zijn redenering, in de loop van de negentiende en twintigste eeuw door verlenging van de gemiddelde levensduur voorspelbaarder. Daarnaast zorgde het Westers arbeidsstelsel voor een driedeling van de levensloop in een periode van voorbereiding op de arbeidsmarkt, deelname aan arbeid en afscheid van de arbeidsmarkt. Die driedeling werd vervolgens via wettelijk geregelde rechten en plichten als schoolgaan en pensionering steeds strikter georganiseerd. Dat wettelijk kader ontstond ondermeer uit de behoefte aan rationalisering - het voorspelbaar en berekenbaar maken - van de industriële samenleving. Ook zou de noodzaak tot sociale controle en 'toelatingsregels' in een wereld waarin mensen onafhankelijker geworden zijn van familie, geografie en stand een rol hebben gespeeld. Bovendien zou leeftijd hebben gefunctioneerd als een manier om de vele rollen en verantwoordelijkheden van individuen in de moderne samenleving met elkaar te integreren en te synchroniseren. ${ }^{13}$

Dat laatste betekent overigens niet dat Kohli de persoonlijke handelingen en perspectieven van mensen automatisch in het verlengde van de institutionele veranderingen legt. Hoewel 
Kohli ervan uitgaat dat de standaardisering van de levensloop zowel gevolgen heeft gehad voor de posities van mensen als voor hun doen en denken, wil hij uitdrukkelijk aandacht voor de spanning tussen de levensloop als sociaal geordende realititeit en de biografie in termen van individuele perspectieven en handelingen. ${ }^{14}$

In ieder geval heeft de levensloop-sociologie van Kohli een sterk functionalistische inslag. Dit functionalisme is echter van een ander type dan dat van de onderzoekers uit de politiek-economische hoek. Terwijl de eersten de Westerse omgang met ouderen en de ouderdom als functioneel voor het kapitalisme zien, acht Kohli de standaardisering van de levensloop en de ouderdom steeds functioneel voor de modernisering van de samenleving. Wat in dat proces van modernisering het meest belangrijk is geweest, veranderingen op het niveau van produktie en arbeid of op het niveau van de overheid, is onder levensloop-sociologen een punt van discussie. Dat standaardisering functioneel is voor een moderne samenleving, staat echter voor Kohli en anderen vast. In deze manier van denken is hij ondermeer door de Amerikaan Chudacoff gevolgd. Zo ziet de laatste geen reden om leeftijdsbepalingen rond leerplicht en pensionering af te schaffen, ook al is ageism het gevolg. Een moderne, complexe maatschappij zou het zonder dergelijke organisatorische ingrepen, zo meent Chudacoff, eenvoudig niet redden. ${ }^{3}$

\section{De ontdekking van de ouderdom}

Zowel de radicale sociologen als Kohli en degenen die hem volgen hebben geprobeerd de sociale 'constructie' of 'constitutie' van de ouderdom in een functioneel kader te plaatsen. De meeste historici hebben zich, voor zover zij zich met soortgelijke kwesties bezighielden, veel eclectischer getoond. Vaak maken zij gebruik van een combinatie van verschillende theorieën en verklaringstypen. In hun publikaties, ten dele geïnspireerd door de vele studies naar de ontdekking van het kind, is de 'profilering' van de ouderdom als levensfase, als sociale categorie, als sociaal probleem of als object van zorg doorgaans het gevolg van één of enkele relatief onafhankelijke ontwikkelingen. Daarbij kan het zo- 
wel gaan om demografische ontwikkelingen als om veranderingen in de inrichting van de samenleving. ${ }^{16}$ Wat betreft het laatste heeft de 'institutionalisering van de pensionering' verreweg de meeste onderzoeksaandacht gekregen. De overgang van een niet strikt aan leeftijd gebonden en slechts voor enkelen gewaarborgd afscheid van het beroepsleven naar collectieve pensioenregelingen is inmiddels voor een groot aantal landen zorgvuldig gedocumenteerd. ${ }^{17}$

De bedoelde historici hebben de invoering van pensioenfondsen en pensioenwetgeving tegen een waslijst van achtergronden geplaatst. Daarvan vertoont een deel verwantschap met de redeneringen van de 'political economy'-groep. Zo acht Carole Haber de pensionering zowel economisch-demografisch gedetermineerd als cultureel gelegitimeerd. Het ontstaan van de negentiende-eeuwse pensioenregelingen in de Verenigde Staten liep volgens haar parallel aan de groeiende nadruk van artsen en onderzoekers op de afname van fysieke en mentale capaciteiten tijdens de ouderdom. Bovendien werd het problematische van de ouderdom onderstreept door het toenemend aantal activiteiten ten behoeve van ouderen in de sfeer van het maatschappelijk werk en de institutionele zorg. Die toevallige onderlinge consistentie van pensioenregelingen en door deskundigen gedragen ouderdomsconcepten zou verklaren waarom publiek verzet tegen de uitstoot van oudere werknemers vrijwel uitbleef. ${ }^{18}$ Andere historici hebben geschreven over de begrenzing en 'consolidatie' van de ouderdom als levensfase via politieke debatten over pensioneringsleeftijden. Uit hun studies valt af te leiden dat zowel de omstandigheden op de arbeidsmarkt, de conditie van de schatkist, stereotypen van ouderen als acties van verschillende belangengroepen een rol hebben gespeeld in de keuze voor bepaalde leeftijdsgrenzen binnen de pensioenwetgeving. ${ }^{19}$

Christoph Conrad heeft echter - vergelijkbaar met de opmerkingen van Kohli - benadrukt dat deze institutionalisering van de pensionering slechts iets laat zien van de formele, wettelijke definitie van de ouderdom. Daarmee is nog niets gezegd over de werking van die pensionering in de praktijk. Volgens hem is het juist interessant om na te gaan hoe de dagelijkse omgang met 
dergelijke regels is verlopen en wat de graad van overeenstemming is geweest tussen wettelijke normen en de praktijk van alledag. Wat bij de radicale sociologen dus min of meer een gegeven is - de gedachten over en de positie van ouderen 'volgen' uit kapitalistische verhoudingen en de daarmee verbonden overheidsmaatregelen - is bij Conrad een vraag. ${ }^{20}$

Evenmin is voor iedereen vanzelfsprekend dat het ontstaan van pensioenvoorzieningen en de ontwikkeling van medischwetenschappelijke kennis over de ouderdom, als in de uitkomst van Carole Habers onderzoek, 'toevallig' parallel liepen. Zo vermoedt Kirk dat wetgevers in Westeuropese landen zich lieten beïnvloeden door medische opvattingen. De leeftijdsgrenzen die zij voor hun pensioenregelingen kozen, vloeiden niet logisch voort uit sociaal-economische kwesties en waren in overeenstemming met algemeen toegankelijke, medische literatuur over het begin van de ouderdom. "Verschillende historici behandelen de inbreng van medisch-wetenschappelijk werk in publieke opvattingen en praktijken rond de ouderdom overigens veel voorzichtiger dan de aanhangers van de politieke economie van het ouder worden. Zij laten bij voorbeeld in het midden of het bejaardenvraagstuk zoals dat door ouderdomsdeskundigen werd omschreven daadwerkelijk bestaan heeft of niet. Dat gebeurt door verwijzingen naar problemen en feiten rond de ouderdom uitsluitend voor rekening van de historische actoren te laten komen. Zo schrijft W. Andrew Achenbaum dat de 'karakterisering' van de ouderdom als probleem bij artsen, opvoeders en ambtenaren in de Verenigde Staten zo'n gevoelige snaar raakte, dat de oprichting van de Gerontological Society of America er het gevolg van was. En Richard Calhoun beschrijft dat naoorlogse Amerikaanse onderzoekers het aantal ouderen, hun economische last en de niet te keren realiteit van de moderne industriële samenleving zo 'gegeven' achtten, dat zij er niet meer omheen konden en deze onfortuinlijke situatie wilden corrigeren. ${ }^{23}$

Een ander type visie op wat zich via de wetenschap voltrokken heeft, is verdedigd door de medisch-historicus David Armstrong. Geïnspireerd door het werk van Foucault en diens normaliseringstheorie behandelt Armstrong de naoorlogse opkomst 
van de geriatrie in Groot-Brittannië. Die opkomst verbindt hij aan het gebruik van surveys: enquêtes naar de levensomstandigheden en lichamelijke toestand van grote groepen, via steekproeven geselecteerde, ouderen. Zo laat hij zien dat medici via deze 'surveys' nieuwe criteria voor ziekte en gezondheid ontwikkelden. Wat 'ziek' of 'gezond' was kon niet meer bepaald worden aan de hand van een voor iedereen geldende norm, maar alleen nog aan de hand van wat normaal was voor een bepaalde leeftijd. Chronische ziekte werd daarmee van een statische entiteit tot een dynamisch proces, en toezicht over een langere periode werd belangrijker dan de momentane diagnose. Ook bleken vele bejaarden ziek te zijn zonder dat zij dit wisten; degenen die ziekten rapporteerden, vormden dus slechts het topje van de 'klinische ijsberg'. Bovendien werd duidelijk dat het mede van de omgeving afhing of een zieke bejaarde al dan niet gewoon kon blijven functioneren. Deze elementen - de variabele criteria, de klinische ijsberg en de context-gebonden aard van geriatrische ziekten - resulteerden in de constatering dat Groot-Britannië een veelomvattende organisatie van geriatrische diensten nodig had. Daarin zouden preventief toezicht en de integratie van ziekenhuizen en extramurale dienstverlening voorop moeten staan. In het verlengde van die uitgangspunten werd het daghospitaal uitgevonden en werd het huisbezoek door geriatrische teams aangeprezen. Zo leidden de 'surveys', aldus Armstrong, ondermeer via een typering van de spreiding en sociale context van ziekten, tot de ontwikkeling van bepaalde voorzieningen. ${ }^{23}$

De meeste historici brengen de opkomst van dergelijke voorzieningen - en daarmee de definitie van de ouderdom als object van zorg-overigens in verband met meer dan alleen de activiteiten van artsen en onderzoekers. Zo is over de zorg voor ouderen binnen de muren van instellingen en de achtergronden daarvan bijzonder veel geschreven. ${ }^{4}$ Dusdanig veel zelfs dat sommige historici meenden te moeten benadrukken dat intramurale huisvesting slechts het lot van een klein deel der ouderen is geweest en het leven van ouderen minder sterk heeft bepaald dan veel studies zouden suggereren. ${ }^{25}$ Hans-Joachim von Kondratowitz heeft daar tegenin gebracht dat een dergelijke vi- 
sie de alledaagse 'Definitionsmacht des Heims' zou onderschatten. Hoe het tehuis ook werd gezien, als bedreiging van een zelfstandig bestaan of als verdiende kroon op de levensloop, het was hoe dan ook een realiteit wartoe iedere oudere zich in deze eeuw moest verhouden. Hijzelf interpreteert de opkomst van het Duitse 'Altersheim' in de negentiende eeuw in de eerste plaats als consequentie van demografische veranderingen - een toenemend aantal ouderen en alleenstaande vrouwen - en interventies op het niveau van overheid en particulier initiatief. Naar zijn inzicht is het tehuis, vooral in deze eeuw, in 'gefamiliseerde' vorm gepropageerd als een manier om schaarse woningen voor grote gezinnen vrij te maken. In het verlengde van zijn opmerking over 'Definitionsmacht' wil Von Kondratowitz de opkomst ervan echter ook zien als een transformatie van een tamelijk ongereguleerde levensvorm tot een ruimtelijk gedefinieerde en sociaal gestandaardiseerde ouderdom - overigens zonder daarmee te willen suggereren dat aan alle vrijheid van ouderen een einde kwam. $^{36}$

Niet alleen de afbakening van de ouderdom als een naar leeftijd en ruimte gedefinieerd object van zorg is door historici onder de loep genomen, hetzelfde geldt voor de definitie van de ouderdom als sociaal probleem. Zo is ondermeer gewezen op het ontstaan van vanzelfsprekende koppelingen tussen ouderdom en armoede, ouderdom en ziekte en ouderdom en improduktiviteit. Ook de bezorgdheid over de 'vergrijzing' - de veroudering van de bevolking - is door verschillende onderzoekers gehistoriseerd, al schrijft het gros van de historici aan deze bezorgdheid een onontkoombare status toe. ${ }^{17}$ Toch zijn de problemen die met vergrijzing in verband zijn gebracht wel degelijk historisch variabel gebleken. Sommige onderzoekers hebben laten zien dat het probleem van de economische last van bevolkingsveroudering niet overal en altijd even zwaar is aangezet. Er zijn tijden en landen geweest waarin overheidsvertegenwoordigers en deskundigen zich meer zorgen maakten over de dalende vruchtbaarheid dan over het stijgend aantal ouderen. Degenen die het laatste wel bedreigend vonden, zochten de problemen soms eerder in een verval van de natie dan in een lege schatkist. 
Hier en daar werd zelfs geprobeerd de vermeende demografische rampspoed te nuanceren. ${ }^{2 x}$ Bovendien wordt de neiging het vergrijzingsvraagstuk als een financieel probleem te definiëren tegenwoordig ter discussie gesteld. ${ }^{20}$

Historici die de profilering van de ouderdom als levensfase, als sociaal probleem, als object van zorg of als sociale categorie tot onderwerp van studie maakten, hebben de herkomst van deze profilering dus op uiteenlopende terreinen gezocht. De institutionalisering van de pensionering heeft daarbij de meeste aandacht gekregen, maar ook ontwikkelingen binnen de wetenschap en zorgsectoren zijn - al dan niet in combinatie met pensioenregelingen - als bronnen van die profilering beschreven .

\section{Overeenkomsten en verschillen}

De genoemde historici hebben met de politiek economen en de levensloop-sociologen gemeen dat zij de maatschappelijke maakbaarheid van de ouderdom voor het voetlicht wilden en willen brengen. Ook thematisch toont het werk van de drie genoemde 'groepen' grote overeenkomsten. Zo ziet vrijwel iedereen de verbreiding van het instituut pensionering in de negentiende en twintigste eeuw als een belangrijke spil in het zich uitkristalliseren van de ouderdom. Naarmate pensionering gebruikelijker werd, zo luidt de gedachtengang, nam de geregelde en 'gesloten' kant van de ouderdom ten koste van de 'open' en ongeregelde kant toe.

De theoretische kaders waarin dit alles wordt geplaatst verschillen niettemin aanmerkelijk van elkaar. Zo loopt de veronderstelde inhoud en werking van de sociale constructies per traditie sterk uiteen. Terwijl maatschappijkritische sociologen de structureel afhankelijke en 'gesegregeerde' positie van ouderen als sociale categorie benadrukken, gat het Kohli en verschillende van de genoemde historici meer om het ontstaan van de ouderdom als duidelijk omlijnde en op een bepaalde manier ingevulde levensfase. Waar de eersten uitgaan van een allesbepalende invloed van economische verhoudingen, beleid en kennis op de handelingsruimte van ouderen, hebben de levensloop-sociologen en enkele van de historici nog veel vragen over de verhou- 
ding tussen institutionele regels en individueel gedrag. En terwijl de aanhangers van de politieke economie en de beoefenaren van de levensloop-sociologie de ontwikkelingen in beleid, wetenschap, geneeskunde en de zorgsector in één en hetzelfde functionele kader onderbrengen, laten historici deze ontwikkelingen ofwel parallel lopen ofwel in een historisch contingente relatie tot elkaar staan.

Gezien deze posities is het niet verwonderlijk dat vrijwel geen van de betrokkenen een onderscheid maakt tussen het proces en het produkt van definitie. Dat onderscheid heeft pas zin wanneer datgene wat en door wie er geconstrueerd wordt, iets uitmaakt voor de manier waarop dat construct tot stand komt en verankerd raakt. Maar die veronderstelling wordt noch door de politiek economen, noch door de levensloop-sociologen gedeeld. In de redeneertrant van de eersten bestaat er geen wezenlijk verschil tussen de manier waarop wetenschap de ouderdom 'produceert' en de manier waarop de staat dat doet. De bron en wijze van produktie zijn niet relevant, omdat de uiteindelijke oorzaak van de 'status aparte' van ouderen ligt bij de structuur van de economie. $\mathrm{Al}$ het andere ligt automatisch in het verlengde daarvan. Ook voor Kohli liggen de produkten van constructie - de gestandaardiseerde levensfasen - in een vaste, functionele relatie tot één grondoorzaak: modernisering en rationalisering van de samenleving. Slechts de genoemde historici zouden gezien hun aandacht voor gescheiden ontwikkelingen oog kunnen hebben voor de verschillende wijzen waarop de ouderdom wordt gedefinieerd. Velen van hen zijn helaas onvoldoende duidelijk over wat zich tussen de bron van definitie en het uiteindelijke produkt van definitie afspeelt.

\section{Kanttekeningen}

Voor een deel van het onderzoek naar de maatschappelijke definitie van de ouderdom geldt een tekort aan specificiteit. Vaak is niet geheel duidelijk waar de termen 'constructie', 'constitutie' en 'definitie' van de ouderdom precies voor staan. Bovendien la- 
ten verschillende verklaringsschema's weinig ruimte voor een gedetailleerde analyse van wat er aan het uiteindelijke produkt de gestandaardiseerde levensfase, de afgebakende sociale categorie, de afhankelijke positie van ouderen - voorafgaat en in welke verhouding dat staat tot de bron van de definitie. Zo kan een kader als dat van Kohli, waarin de rationalisering van de moderne samenleving centraal staat, wel verhelderen waarom er méér regels en daarmee scherper afgebakende levensfasen zijn ontstaan, maar niet waarom bepaalde grenzen zijn vastgelegd en andere niet, of waarom sommige grenzen zijn verschoven of verdwenen. Dat dit laatste wel degelijk van belang is, kan aan de hand van de volgende kanttekeningen duidelijk worden.

Veel van de betogen over de definitie van de ouderdom kenmerken zich door een grote mate van lineariteit: vanaf het midden van de negentiende eeuw 'duwen' ontwikkelingen in de sfeer van de industrialisatie, verwetenschappelijking en professionalisering de ouderdom eenduidig in de richting van een toenemende verafhankelijking, standaardisering of medicalisering. Voor omgekeerde bewegingen is niet of nauwelijks aandacht. Dit geldt het sterkst voor de historische verhandelingen in de politiek-economische traditie. Maar ook de genoemde levensloop-sociologen zijn op dit punt aangevallen.

Terwijl Kohli nieuwe ontwikkelingen als de vrijwillige uittreding, vervroegde pensionering, toenemende werkloosheid en arbeidsongeschiktheid niet zonder meer als een ondermijning van de standaardisering van de levensloop wil zien, doen anderen dat wel. ${ }^{30}$ Anne-Marie Guillemard beschouwt de recente veranderingen zelfs als tekenen van een 'de-institutionalisering' van de levensloop. Aangezien ouderen de arbeidsmarkt steeds vaker via arbeidsongeschiktheid en werkloosheid verlaten en beide verschijnselen meer met het onvermogen tot werken en de arbeidsmarkt te maken hebben dan met leeftijd, is er volgens Guillemard sprake van een wezenlijk nieuwe situatie. Dat de vervroegde vrijwillige uittreding wel degelijk op leeftijd gebaseerd is, ziet Guillemard niet als een weerlegging van haar stelling. Want juist die vervroegde vrijwillige uittreding, zo onderstreept ze, staat in- 
middels in veel landen onder druk. "Weer anderen zien in de recente ontwikkelingen zowel een 'ontchronologisering' - het ontstaan van een grotere variatie in uittredingsleeftijden - als een toenemende institutionalisering van de levensloop: het universeler worden van een levensfase waarin niet gewerkt wordt. ${ }^{32} \mathrm{Hoe}$ het ook zij: aan de gedachte dat de ouderdom in de loop van de vorige én deze eeuw steeds gestandaardiseerder is geworden, valt dus wel het een en ander af te dingen. Bovendien is door verschillende auteurs opgemerkt, dat wie zich concentreert op een analyse van veranderingen rond betaalde arbeid, vooral de levensloop van mannen onderzoekt.." Want hoewel levensloopsociologen én politiek economen zich realiseren dat de ouderdom van mannen en vrouwen niet hetzelfde gezicht hoeft te hebben, heeft dat vooralsnog slechts enkele auteurs ertoe bewogen systematisch op zoek te gaan naar sekse-afhankelijke verschillen in de geschiedenis van de ouderdom. ${ }^{34}$

Ook de bijdragen van wetenschap en geneeskunde aan het 'gezicht' van de ouderdom zouden wel eens minder rechtlijnig kunnen zijn dan door veel van de eerder genoemde onderzoekers is gesuggereerd. Pat Thane en Von Kondratowitz hebben laten zien dat zich op medisch-wetenschappelijk terrein zowel constanten als opmerkelijke veranderingen hebben voorgedaan. Thane toont aan dat de vraag welke verouderingsverschijnselen als natuurlijk dan wel onnatuurlijk moesten worden beschouwd voortdurend, maar met wisselende uitkomsten, op de agenda van onderzoekers heeft gestaan. En aan de hand van Duitse encyclopedieën betoogt Von Kondratowitz dat de wetenschappelijke thematisering van de ouderdom voor 1800 het karakter had van een strikte classificatie op basis van 'natuurlijke historie' en juridische noties. Tussen 1800 en 1840 vertoonde die thematisering echter een optimistisch ontwikkelingsperspectief, terwijl deze vanaf het midden van de negentiende eeuw weer veranderde in een negatieve classificatie op grond van biologische en medische concepten: een medicalisering van de ouderdom. Daarmee maakt Von Kondratowitz rechtlijnige ontwikkelingen binnen de ouderdomswetenschappen minder aannemelijk. Hij geeft immers an dat op dit terrein zowel een verschuiving van statische naar 
dynamische ouderdomsconcepten te traceren valt als een verschuiving in omgekeerde richting. ${ }^{35}$

Von Kondratowitz laat daarbij helaas in het midden wat dit alles maatschappelijk precies betekende. Blijkbaar acht hij de behandeling van veranderingen op het niveau van een bepaalde bron genoeg om daarmee in brede zin van medicalisering te kunnen spreken. Bij veel van het onderzoek naar de definitie en constructie van de ouderdom is dit verbonden met een veronderstelde almacht van de bestudeerde instituties. Die macht wordt dan zo alomtegenwoordig geacht dat de maatschappelijke inbedding van de 'definities' en 'constructies' afkomstig van die instituties geen nadere verklaring behoeft. Dat laatste geldt trouwens niet voor alle benaderingen in dezelfde mate. Zo leggen vooral de verdedigers van de politiek-economische benadering een grote macht bij economie, staat en wetenschap. Juist op dat punt hebben zij veel kritiek moeten incasseren.

Richard Smith heeft bij voorbeeld beweerd dat voor het ontstaan van de structurele afhankelijkheid van ouderen familieverhoudingen en demografische veranderingen minstens zo belangrijk waren als het industrieel kapitalisme. De omstandigheid dat ouderen, althans in Engeland, al sinds de middeleeuwen veelal een zelfstandige huishouding voerden, werkte het ontstaan van collectieve zorgarrangementen sterk in de hand. ${ }^{36}$ Van recente datum is de - overigens omstreden - kritiek dat de welvaartsinspanningen voor ouderen in deze eeuw niet zo uniek zijn als veelal wordt beweerd. Die 'uniciteit' zou slechts een gevolg zijn van een hardnekkige whiggish history, waarbinnen zeventiendeen achttiende-eeuwse regelingen ten behoeve van ouderen zijn genegeerd dan wel ondergewaardeerd ${ }^{37}$ Daar komt bij dat verschillende onderzoekers erop wijzen dat ouderen en hun belangenorganisaties wel degelijk brood in de pensionering zagen en zich daar ook actief voor hebben ingezet. Zij achten het dan ook niet juist om ouderen slechts een marginale rol in het ontstaan van hun positie toe te kennen of pensionering louter als een periode van afhankelijkheid voor te stellen. ${ }^{3 *}$

Die vermeend marginale rol van ouderen is inderdaad een 
zwak punt in de redeneringen van de 'radicalen'. Zij lijken ervan overtuigd dat ouderen zelf in de sociale constructie van de ouderdom geen deel gehad kunnen hebben, al was het alleen maar omdat binnen een 'political economy of ageing' structurele argumenten worden geprefereerd boven intentionele. Conform die houding weet Alan Walker, één van de genoemde radicale sociologen, zich dan ook geen raad met de toegenomen acceptatie van pensionering. Werknemers zouden naar zijn mening louter 'verleid' zijn tot deelname aan pensioenregelingen en op die manier in de val van een laag inkomen zijn gelopen. Voor constructies van de ouderdom met een andere uitkomst dan die van een gedwongen structurele afhankelijkheid is in een dergelijk betoog doorgaans geen plaats. ${ }^{19}$ Iets soortgelijks geldt voor de mate waarin de sociale constructie van de ouderdom als 'verankerd' wordt beschouwd. Veel van de politiek-economisch sociologen achten veranderingen slechts mogelijk wanneer de produktie- en arbeidsverhoudingen zich drastisch zouden wijzigen. De marges voor verandering zijn binnen deze benadering per definitie klein. Bovendien verschijnt de twintigste eeuw in dit type redeneringen vaak als een 'geïntensiveerde' versie van de negentiende eeuw. Aan het eigene van de contemporaine verzorgingsstaat wordt verhoudingsgewijs weinig aandacht besteed.

De veronderstelde 'almacht van de instituties' speelt overigens evenzeer ten aanzien van wetenschap en geneeskunde. Ook rond deze domeinen creëren de aanhangers van de politiek-economische benadering een wat complot-achtige sfeer. Gerontologen en geriaters worden zonder meer als de 'ontwerpers' van de ouderdom voorgesteld. Van grenzen die de samenleving, de praktijk of het beleid de wetenschap stelt wordt niet gerept en van een eigengereide receptie van gerontologische ideeën door beleidsmakers en anderen is geen sprake. Impliciet wordt aangenomen dat gerontologische probleemdefinities en oplossingen zich geruisloos over de samenleving verspreiden. Een geruisloosheid die in de optiek van de radicale sociologen een vanzelfsprekend element is in het innige verbond tussen wetenschap en maatschappelijk establishment. En dat terwijl door gerontologen en anderen vaak is gewezen op communicatieproblemen tussen 
praktijkmensen en wetenschappers, ${ }^{4^{\circ}}$ alsook op het instrumenteel, conceptueel en legitimerend gebruik van onderzoeksresultaten door beleidsmakers. ${ }^{4}$

Recent hebben verschillende aanhangers van de politiekeconomische benadering hun denkbeelden zodanig herzien, dat in hun betogen voortaan enige ruimte is voor intentionele naast structurele factoren. Door in hun analyses het begrip moral econo$m y$ op te voeren, hebben zij het bestaan van humanitaire motieven voor het ontstaan van ouderdomsvoorzieningen als de pensionering kunnen erkennen en van een verklarend kader voorzien. Want 'moral economy' verwijst ondermeer naar de binnen de economie gedeelde waarden die de basis vormen voor het verschijnsel van reciprociteit tussen verschillende groepen. Dergelijke waarden reflecteren zowel de wensen van ondergeschikte klassen als de belangen van dominante klassen. Zo kunnen pensioenregelingen zowel een wens van werknemers zijn - waarbij die wens een reflectie is van de waarde dat het 'eerlijk' is om werknemers een waardige oude dag te bezorgen - als een functie hebben voor het kapitalisme in het algemeen en werkgevers in het bijzonder. Want pensioenregelingen stellen werkgevers in staat dure werknemers te lozen, sociale controle over hun personeel uit te oefenen en een gevaarlijke werkloosheid onder jongeren weg te nemen. ${ }^{42}$

Op het eerste gezicht lijkt de introductie van dit begrip zowel de inhoud als het 'landschap' van het onderzoek naar de maatschappelijke definitie van de ouderdom ingrijpend gewijzigd te hebben. Zo valt op dat aan de studie waarin 'moral economy' een hoofdrol speelt, ook Kohli een hoofdstuk heeft geleverd. Toch zijn deze veranderingen minder groot dan een eerste indruk doet denken. Recensent Robert Hudson heeft er terecht op gewezen dat de bijdrage van Kohli uit de toon valt. Weliswaar acht Kohli de pensionering deel van een nieuwe 'morele economie' - die van een samenleving waarin arbeid centraal staat maar dat betekent niet dat zijn visie op de achtergronden van de institutionalisering van de levensloop veranderd is. Die institutionalisering, zo valt uit zijn betoog af te leiden, acht hij zowel functioneel voor de overleving van het kapitalisme - zonder dat 
te betreuren - als voor het bestaan van sociale orde in een moderne samenleving als geheel. ${ }^{4}$ Daarnaast is de positie van de politiek economen in zoverre niet veranderd, dat zij er nog steeds stilzwijgend van uitgaan dat de verspreiding van regels en kennis afkomstig van het bedrijfsleven, de wetenschap of de overheid 'als vanzelf verloopt en zo de ouderdom definieert. Weliswaar wordt het aan de samenleving 'opleggen' van bepaalde constructies genuanceerd door het aanwezig veronderstellen van gedeelde waarden - die verschillende belangen kunnen dienen -, maar dat maakt de verspreiding van die constructies niet minder geruisloos. Integendeel: juist die gedeelde waarden zorgen voor een onproblematisch transport.

Ook bij genuanceerde politiek economen blijft de 'verwerking' van wetenschappelijke kennis en overheidsregels buiten de domeinen van wetenschap en staat een proces dat 'als vanzelf plaatsvindt. Die verwerking wordt als een onproblematische verspreiding of diffusie van constructies voorgesteld. Maar zo eenvoudig ligt het niet. Een enkel voorbeeld.

$\mathrm{De}$ in de vorige paragraaf genoemde medisch-historicus Armstrong schrijft in zijn analyse, net als de radicale sociologen, een groot ordenend vermogen toe aan wetenschap en geneeskunde. De geriatrische 'survey' leidde immers via een omweg tot een veel omvattend voorzieningensysteem. En ook bij Armstrong is een beschrijving van de opvattingen en werkwijze van artsen blijkbaar genoeg om de diffusie ervan te verklaren. De zwakheid daarvan blijkt vooral wanneer Armstrongs geschiedenis wordt vergeleken met de situatie in Nederland. Ook in Nederland werd in sociaal-geneeskundig onderzoek veelvuldig gebruik gemaakt van 'surveys'. ${ }^{4}$ Nederlandse artsen die belast waren met de zorg voor ouderen lieten zich niet zelden door geriaters in Engeland inspireren. ${ }^{45}$ Hun visie op de juiste zorg voor ouderen verschilde niet wezenlijk van die van de Engelse geriaters. Toch ontstond in Nederland geen vergelijkbaar netwerk van geriatrische teams en daghospitalen. Integendeel: de geriatrie werd pas in 1983 als klinisch specialisme erkend en er werden aanvankelijk verpleeghuizen in plaats van gespecialiseerde 
ziekenhuisafdelingen opgericht. Als mogelijke verklaringen daarvoor, alsook voor soortgelijke ontwikkelingen elders, is gewezen op de naar organen gestructureerde indeling van specialismen, de lage status van de ouderdomsgeneeskunde binnen culturen waarin vitaliteit hoog aangeschreven staat, de ziektegeoriënteerde financiering van medische zorg, de inrichting van ziekenhuizen - gericht op 'acute care' - en de zoektocht naar 'tovermiddelen' voor genezing. ${ }^{46} \mathrm{Het}$ louter aanwezig zijn van bepaalde kennis kan de ontwikkeling van voorzieningen dus niet voldoende verklaren.

De binnen het definitie-onderzoek gangbare veronderstellingen met betrekking tot de lineariteit van ontwikkelingen rond de ouderdom, de almacht van de definiërende instanties en de gemakkelijke diffusie van definities staan allesbehalve los van elkaar. Wie impliciet of expliciet uitgaat van machtige instanties, kijkt minder op van rechtlijnige ontwikkelingen - die vloeien immers voort uit stabiele machtsverhoudingen - en een geruisloze verspreiding van hetgeen deze instanties voorstaan. Dat leidt tot een veronachtzaming van de mate waarin definities afkomstig van bedrijfsleven, staat of wetenschap (zoals opvattingen over het begin of de aard van de ouderdom) stabiel zijn en in de praktijk van de ouderdomszorg zijn ingebed, alsook van de manier waarop die inbedding plaatsvindt. Die veronachtzaming ligt zelfs voor een deel besloten in het gebruik van de term 'definitie'. Daarin wordt, zo kwam immers al eerder aan de orde, geen onderscheid gemaakt tussen produkt en proces. In deze studie zullen dan ook andere termen worden gebruikt en andere vragen worden gesteld.

4 Grenzen: ontstaan, soorten, betekenis en dynamiek

Het meest kenmerkende van de definitie-benadering ligt in de omkering van een aantal vanzelfsprekend lijkende volgorden. Waar in andere betogen - zoals die van gerontologen - de overheid, ondernemingen, wetenschap en geneeskunde ouderdomsvoorzieningen en concepten scheppen als reactie op de noden 
van ouderen, krijgen deze instituties in het onderzoek naar de maatschappelijke definitie van de ouderdom een meer initiërende en ordenende rol toebedeeld. Door de nadruk te leggen op de regulering en standaardisering die van deze instanties uitgaat, wordt het bestaan van 'ouderen' en hun 'problemen' niet meer als uitgangspunt van historische ontwikkelingen genomen, maar als de consequentie daarvan beschouwd.

De historici en sociologen van de definitie-benadering hebben terecht vraagtekens geplaatst bij de gedachte dat staat en wetenschap niet meer gedaan zouden hebben dan 'reageren' op de noden van een verouderende bevolking. Zo is de veel geopperde gedachte dat het ontstaan van de gerontologie te verklaren zou zijn uit het toenemende aantal ouderen beslist minder aannemelijk dan ze lijkt. Wat Nederland aangaat zijn bevolkingsontwikkelingen bij voorbeeld zowel ingezet ter verklaring van de naoorlogse opkomst van gerontologisch onderzoek als voor het lange uitblijven daarvan. In het eerste geval wordt erop gewezen dat het percentage ouderen in de bevolking alsook de problemen van ouderen in het decennium na de oorlog toenamen. ${ }^{47}$ In het tweede geval wordt beweerd dat de late belangstelling voor de sociale gerontologie in Nederland gerelateerd zou zijn aan het relatief lage percentage ouderen in ons land. Hier bleef het geboortenniveau immers tot ver in jaren zestig hoog. ${ }^{47}$ In concrete gevallen is de stelling dat onderzoekers 'slechts' reageerden op de veranderende werkelijkheid van alledag minder gemakkelijk aantoonbaar dan het op het eerste gezicht oogt.

Maar ook de omkering van de definitie-onderzoekers brengt nieuwe vragen en problemen met zich mee, waarop de laatsten voor zover ze de problemen zelf al zagen - lang niet altijd antwoord hebben kunnen geven. Daarvoor zijn de door hen gehanteerde verklaringsschema's, zoals gezegd, doorgaans te weinig specifiek. De verhaallijnen suggereren een te grote mate van eenrichtingsverkeer. Aan staat, economie en wetenschap wordt een te groot ordenend vermogen toegeschreven. Bovendien blijven de verschillende processen van 'overdracht' vaak onduidelijk. 
Deze problemen van lineariteit, almacht en diffusie kunnen wellicht verholpen worden door nóg een omkering uit te voeren. Het definitie-onderzoek heeft weliswaar duidelijk gemaakt dat het bestaan van de sociale categorie ouderen en hun problemen als het eindpunt en niet als het begin van een bepaalde ontwikkeling moet worden gezien, maar de wegen tussen de opstelling van overheidsregels, de produktie van wetenschappelijke kennis of de vorming van voorzieningen en dat eindpunt worden niet overal even helder uitgewerkt. Het zijn dergelijke wegen, en niet de door de definitie-denkers gewraakte volgorde, die in deze studie naar voren zullen worden gehaald.

Dat gebeurt op de volgende manieren. In de eerste plaats zal niet zozeer gesproken worden over de constructie of definitie van de ouderdom, maar zal steeds gevraagd worden naar het ontstaan, verschuiven, verdwijnen en verankeren van grenzen van de ouderdom. Met die grenzen, zo werd aan het begin van dit hoofdstuk al gezegd, wordt gedoeld op datgene aan de hand waarvan de ouderdom wordt afgebakend, omlijnd, gekarakteriseerd en getypeerd. Het spreken in termen van 'grenzen' in plaats van 'definities' heeft als voordeel dat het eerder besproken probleem van de afwezigheid van een analytisch onderscheid tussen het proces en produkt van definitie wordt ondervangen. Met een grens wordt immers naar een produkt verwezen (datgene aan de hand waarvan de ouderdom wordt afgebakend), terwijl het ontstaan, verschuiven, verdwijnen en verankeren naar een proces verwijst. Ook wordt op die manier de richting van veranderingen opengelaten en een a priori lineariteit voorkomen. Bovendien maken de gekozen formuleringen het mogelijk om tussen verschillende typen grenzen te differentiëren.

Zo wordt hier in de tweede plaats een onderscheid gemaakt tussen verschillende soorten grenzen. In het definitie-onderzoek wordt doorgaans gesproken van de definitie van 'de ouderdom'. Dat de onderzoekers daarbij op de ouderdom in verschillende gedaanten doelen - de ouderdom als levensfase, sociale categorie, probleem etcetera - wordt vaak wel uit de context van hun betoog duidelijk, maar aan dergelijke verschillen verbinden zij geen methodologische of theoretische consequenties. Zo wordt 
de definitie van de ouderdom door politiek economen en levensloop-sociologen, ongeacht wat en door wie er gedefinieerd wordt, immers in één functioneel kader geplaatst. In deze studie zal de aanpak echter verschillen al naar gelang de grens die in het geding is. Daarbij gaat het om de grenzen van de ouderdom als publiek probleem, sociale categorie, levensfase en ruimtelijk gesitueerd object van zorg.

Het tweede hoofdstuk gaat over de manieren waarop het probleem van bevolkingsveroudering in Nederland omschreven werd. In dergelijke omschrijvingen werd een 'profiel' geschetst, waarin werd aangegeven wat 'binnen' en 'buiten' het probleem viel. Op die manier werden de grenzen van de kwestie - althans op papier - vastgelegd. Het derde hoofdstuk concentreert zich op iets wat de grens van de ouderdom als sociale categorie markeert: de pensioengerechtigde leeftijd. Oudere ongehuwde vrouwen konden zich niet in deze markering vinden en probeerden aan te tonen dat hun sociale categorie zodanig van andere ouderen verschilde, dat zij voor een andere pensioengerechtigde leeftijd in aanmerking kwamen. Het vierde hoofdstuk heeft het onderscheid tussen natuurlijk en onnatuurlijk verouderen - en tegelijkertijd de grens van de ouderdom als levensfase - tot onderwerp, terwijl het vijfde hoofdstuk het ontstaan van de indeling en ligging van verzorgingshuizen beschrijft. In dat hoofdstuk draait het om de grenzen van de ouderdom als geografisch afgebakend object van zorg.

Voor elk van deze typen grenzen is een afzonderlijke aanpak toegepast. Want afhankelijk van het soort grens dat in het geding is, is een andere context relevant en spelen andere mechanismen en achtergronden in de ontwikkeling van die grens een rol. Daarbij is het van belang onderscheid te maken tussen een soort grens en de markering van die grens. De pensioengerechtigde leeftijd kan - om een voorbeeld te noemen - zowel de grens van de ouderdom als sociale categorie markeren, als de grens van de ouderdom als levensfase. In het eerste geval slaat de pensioengerechtigde leeftijd op een criterium waarmee de sociale categorie wordt afgebakend die recht heeft op een pensioenvoorziening. In het tweede geval slaat de pensioengerechtigde leeftijd op het 
moment waarop individuen van het werkende bestaan in het gepensioneerde bestaan terechtkomen, en zo van de ene naar de andere levensfase overgaan. Om welk soort grens het gaat, hangt af van de inzet van de discussie die bestudeerd wordt.

Gezien de verschillen tussen soorten grenzen, kan de inzet van één theoretisch kader niet volstaan. In deze studie zal een heuristisch gebruik worden gemaakt van theoretische perspectieven uit verschillende disciplinaire tradities, waaronder rechtssociologische, wetenschapssociologische en cultureel-antropologische. Deze perspectieven maken het mogelijk om de mechanismen rond en de achtergronden van het ontstaan, verschuiven, verdwijnen en verankeren van grenzen op verschillende niveaus te onderzoeken. Bovendien staan deze perspectieven het toe om degenen die grenzen probeerden te trekken-overheidsvertegenwoordigers, onderzoekers, artsen, architecten en vele anderen - ten tonele te voeren, zonder a priori aan te nemen dat zij ook de hoofdrolspelers in het vastleggen van grenzen waren.

De volgorde waarin de verschillende soorten grenzen worden besproken is niet willekeurig. Hoewel de hoofdstukken los van elkaar gelezen kunnen worden, is de opbouw zodanig dat niet alleen steeds een andere grens wordt behandeld, maar dat tegelijkertijd in stappen naar een alternatief voor het huidige definitie-onderzoek wordt toegewerkt. Het tweede hoofdstuk, over de grenzen van het probleem van bevolkingsveroudering, is ondermeer bedoeld om het brede veld van degenen die zich over ouderenkwesties uitspraken, te introduceren. Het hoofdstuk heeft echter ook tot doel om de kritiek op de definitie-benadering die in het eerste hoofdstuk op logische gronden en op basis van secundaire literatuur werd geformuleerd, nogmaals met eigen empirisch onderzoek te onderbouwen. Het hoofdstuk eindigt met de constatering dat het niet bij kritiek kan blijven en dat in de volgende hoofdstukken - drie tot en met vijf - alternatieven voor het definitie-onderzoek zullen worden geïntroduceerd. Voor de hoofdstukken drie en vier geldt dat de daarin gebruikte perspectieven wat hun gerichtheid op staat en wetenschap betreft nog dicht bij het definitie-onderzoek staan. Dat geldt echter niet meer voor het antropologische en 'ruimtelijke' 
perspectief van het vijfde hoofdstuk. Daarmee neemt het nieuwe van de benadering die in deze studie centraal staat, in de loop van de hoofdstukken toe. Op die manier kan geleidelijk worden duidelijk gemaakt wat de winst is van een geschiedenis van de ouderdom in termen van 'grenzen'.

Daarnaast zal in alle hoofdstukken worden onderzocht wat de betekenis van de verschillende grenzen is geweest voor de praktijk van de ouderenzorg. Die 'betekenis' wordt op twee manieren uitgewerkt. Op sommige plaatsen wordt besproken wat grenzen voor de praktijk uitmaakten door na te gaan wat met die grenzen verbonden raakte of wat door (verschuivende) grenzen in beweging werd gezet. Op andere plaatsen wordt nagegaan hoe grenzen door historische actoren werden ingezet om een nieuwe praktijk - een voorziening, een regeling, een vak - te bewerkstelligen.

Ten slotte zal, in het zesde en laatste hoofdstuk, op de dynamiek van grenzen worden ingegaan. Juist omdat zaken als de pensioengerechtigde leeftijd zowel een sociale categorie als een levensfase kunnen markeren en juist omdat die grenzen een eigen context hebben, is het mogelijk een dynamiek van grenzen te laten zien. Bovendien wordt in dit laatste hoofdstuk een bepaalde heuristiek gepresenteerd voor het doen van onderzoek naar de geschiedenis van de ouderdom. Die heuristiek biedt een alternatief voor de huidige geschiedschrijving over de definitie van de ouderdom.

5 Een kwestie van leeftijd?

Dat in deze studie de grenzen van de ouderdom als publiek probleem, sociale categorie, levensfase en ruimtelijk gesitueerd object van zorg centraal staan, betekent niet dat de grenzen rond de ouderdom daarmee uitputtend behandeld zijn. Wel biedt de keuze voor deze grenzen de mogelijkheid om uiteenlopende debatten rond ouderen voor het voetlicht te halen. De geschiedenis van de gekozen grenzen zal namelijk gevolgd worden aan de hand van verschillende discussies rond ouderen in Nederland 
tussen 1945 en 1982 . Zo draait het tweede hoofdstuk om debatten over de gevolgen van bevolkingsveroudering, het derde hoofdstuk om de politieke strijd van ongehuwde vrouwen voor een verlaging van hun pensioengerechtigde leeftijd, het vierde hoofdstuk om visies op natuurlijke veroudering en de controversiële erkenning van de klinische geriatrie, en het vijfde hoofdstuk om de veel besproken bouw van verzorgingshuizen. Deze kwesties hielden de gemoederen niet steeds op dezelfde manier bezig. Pas in de jaren zestig en zeventig ontstonden bij voorbeeld werkelijk hevige meningsverschillen over de gevolgen van vergrijzing en de bouw van verzorgingshuizen. Maar 'vraagstukken' waren het zeker. Het zesde en laatste hoofdstuk ten slotte, stelt de dynamiek van grenzen aan de orde aan de hand van een geschiedenis van de 'voorbereiding op de pensionering'.

De genoemde kwesties zullen hoofdzakelijk gevolgd worden over de jaren 1945-1982. Dat de aandacht zich vooral richt op de naoorlogse periode betekent niet dat vóór I945 ouderdomsvraagstukken nog nergens aan de orde waren. Maar het besef van het bestaan van een algemeen 'bejaardenvraagstuk' was typisch iets van na de oorlog, zeker in Nederland. Niettemin neemt zowel het tweede als het vijfde hoofdstuk een 'aanloop' vanaf de jaren twintig - dit om de naoorlogse periode meer reliëf te geven. Het jaar 1982 is om verschillende redenen als sluitstuk van de te onderzoeken periode gekozen, al houdt een dergelijke keuze altijd iets willekeurigs. In dat jaar verscheen een nieuwe regeringsnota over ouderenbeleid, werd een herziene stuurgroep voor de planning van gerontologisch onderzoek ingesteld en organiseerde het particulier initiatief het congres 'Oud in Nederland'. Het waren gebeurtenissen die destijds zowel oude discussies oprakelden als nieuwe debatten op gang brachten. Een deel van de thema's die toen werden geïntroduceerd, later samengevat onder de noemer 'zorgzame samenleving', zou na 1982 de discussies rond ouderen langdurig gaan beheersen. Achteraf bieden de genoemde gebeurtenissen van 1982 dan ook een goede gelegenheid de grenzen van de ouderdom even te 'bevriezen'.

Het in kaart brengen van die grenzen is gebeurd aan de hand van zeer verschillende bronnen: publikaties van gerontologisch 
en geriatrisch deskundigen, verslagen van congressen en fora, beleidsrapporten en handelingen van de Staten-Generaal, rapporten en brochures van organisaties op het gebied van ouderenzorg en ouderenbelangen, artikelen uit tijdschriften op terreinen als de demografie, de sociale geneeskunde, het maatschappelijk werk en de huisvesting, archiefmateriaal van bij ouderenonderzoek en -zorg betrokken instanties en enkele interviews. Een verantwoording van deze bronnen is achterin dit boek te vinden. Ter documentatie van de ouderenzorg in Nederland, waarover nog maar weinig is gepubliceerd, is daarnaast een uitgebreid notenapparaat opgenomen. Over de selectie van het bronnenmateriaal zijn hier nog twee opmerkingen op hun plaats. Wat de publikaties van artsen en onderzoekers betreft is hoofdzakelijk gebruikgemaakt van in Nederland gepubliceerd materiaal: het gaat immers om bijdragen aan discussies die in en over Nederland zijn gevoerd. Bovendien is daarbij geen onderscheid gemaakt tussen onderzoeksverslagen, bijdragen aan praktijk-tijdschriften, lezingen voor een groot publiek en dergelijke. Dat is niet alleen achterwege gelaten omdat het onderscheid tussen datgene wat wel en niet wetenschappelijk werd geacht in de loop van de tijd veranderde en het dus moeilijk is om publikaties met terugwerkende kracht de maat te nemen, maar ook omdat het belangrijk is om het vastleggen van grenzen door gerontologisch en geriatrisch deskundigen over verschillende 'genres' heen te volgen. Het gat in deze studie immers niet alleen om het trekken van grenzen op papier, maar ook om wat die grenzen voor de praktijk betekenden.

Hoe de grenzen van de ouderdom zich ontwikkelden, was allesbehalve een kwestie van leeftijd. Maar in discussies rond ouderen werd uiteraard veelvuldig naar leeftijd verwezen. Er werden regels, wetten, eigenschappen, waarden, ruimten en voorzieningen mee verbonden. Zo was leeftijd de aanleiding tot beschouwingen over het vooruitzicht van een ouder wordende bevolking. Nederland stond aan de vooravond van een demografische aardverschuiving, zo meenden velen na de oorlog: geen grijs verleden, maar een grijze toekomst moest onder ogen worden gezien. 


\section{Bevolkingsveroudering: het profiel van een publiek probleem ${ }^{\mathrm{I}}$}

\section{Inleiding}

Op 27 september 1947 wees De Groene Amsterdammer de inwoners van Nederland op een dramatische wending. "Wij worden ouder: voor het eerst in onze geschiedenis krijgen wij het probleem te verwerken, dat een groot, en steeds groter wordend, deel van onze bevolking uit oude mensen bestaat. Dat tegelijkertijd het gezinsverband, dat hen kan opnemen en verzorgen steeds losser wordt, en dat de huisvrouw naast het huishouden haar eigen betaalde werk moet of wil doen. Dat de huizen kleiner worden, de behuizing krapper, drie generaties in een woning doodgewoon, personeel een luxe. Grootvader en -moeder zitten in de weg, in plaats van hun eigen milieu te kunnen handhaven. Het leven, de voedselvoorziening is gecompliceerder - zij verkommeren. Wij hebben arbeid broodnodig, herscholing zou hen productief houden - zij staren de eindeloze uren uit het raam. ${ }^{\prime 2}$ NEDERLAND WORDT OUDER MAAR WIL HET NIET WETEN, meldde de kop in kapitalen.

Vijfendertig jaar later verkondigde de arts-epidemioloog P. van der Maas tijdens een symposium een andere boodschap. Nederland werd ouder, zo schreef ook hij, maar de natie maakte zich daarover veel te veel zorgen. Ten onrechte werd de vergrijzing beschouwd als een '(...) dreiging van een nauwelijks geringere omvang dan milieurampen, kernoorlog of een totale economische crisis. Heel Nederland één groot verpleegtehuis, met een niet te stillen behoefte aan prothesen, rolstoelen en dieetvoedsel, doch geen jongere meer om dat alles te produceren en uit te delen. ${ }^{3}$ Dat was volgens Van der Maas het beeld dat de Nederlandse pers schetste van de maatschappelijke consequenties 
van ontgroening en vergrijzing. Een beeld dat hijzelf als een eigentijdse mythe typeerde. Naar zijn mening zou de behoefte aan gezondheidszorg weliswaar toenemen, maar was het moeilijk voorspelbaar hoe groot die behoefte precies zou zijn. Dat de improduktiviteit van bejaarden geld kostte, was duidelijk. Maar wie bejaarden 'te duur' vond, kon dat met evenveel recht van andere niet-produktieven zeggen. Van iedere zes Nederlanders die niet aan het arbeidsproces deelnamen, was immers slechts één bejaard. Waar bovendien een groot deel van de jonge generatie in de verzorgende sector wilde werken, maar dikwijls werkloos moest toezien, was niet zozeer de verzorgingsbehoefte van bejaarden als wel maatschappelijke verstarring het probleem. Een eenvoudige oplossing bestond niet. Maar het probleem diende wel in het juiste perspectief geplaatst te worden.

Terwijl De Groene Amsterdammer het publiek wakker wilde schudden, probeerde Van der Maas het demografisch doemdenken-overigens tegen de gangbare mening in - te temperen. Toch was dat niet het enige verschil. Ook het kader waarin beide artikelen de vergrijzing plaatsten was anders. De Groene noemde de veroudering van de bevolking in één adem met de verslapping van familiebanden, het buitenshuis werken van vrouwen, het tekort aan woonruimte, de onbetaalbaarheid van personeel, de complexiteit van het bestaan en de schaarste aan arbeidskrachten. Van der Maas bracht vergrijzing in verband met de zorgbehoefte van bejaarden, de kosten van improduktiviteit en het spook van de werkloosheid. Beide artikelen bespraken ouderen in 'tal en last'. Maar de begrippen die de schakel vormden tussen 'tal' en 'last' waren in 1947 grotendeels andere dan in 1982.

Over dergelijke verschuivingen in het denken over en ordenen van problemen rond ouderen gaat dit hoofdstuk. Waar stond 'het probleem der oudeliedenzorg' voor? Wat werd met 'het bejaardenvraagstuk' bedoeld? Hoe werd 'de vergrijzing' weergegeven en welke kwesties werden eraan gekoppeld? Wie stonden model voor de 'oudelieden', 'ouden van dagen', 'bejaarden', 'ouderen' en 'senioren' waarover werd gesproken? Waar lagen, anders gezegd, in de loop der tijd de grenzen van het probleem 
(paragraaf 2) en de grenzen van de groep (paragraaf 4) waarover werd geschreven, vergaderd en gedebatteerd?

Dit hoofdstuk draait echter niet alleen om het veranderende profiel van het vergrijzingsprobleem. Het heeft ook tot doel om een deel van de instanties die zich met ouderenkwesties bezighielden - instanties die ook in de andere hoofdstukken zullen figureren - aan de lezer voor te stellen. Want door wie en waar werden de grenzen van het probleem aangebracht? Wie bewogen zich in het lezingen- en vergadercircuit rond ouderen? Via welke organisaties en kanalen stonden deze mensen met elkaar in contact? En hoe verhielden die instellingen zich tot elkaar? Bovendien zal - zij het globaal - worden nagegaan wat de grenzen van het probleem uitmaakten voor de praktijk van de ouderenzorg en wat deze grenzen deed verschuiven (paragraaf 5 ). In veel van het definitie-onderzoek wordt, zo bleek in het vorige hoofdstuk, het ontstaan van definities afgeleid uit de functie die zij in een kapitalistische of moderne samenleving vervullen. Daar komt bij dat de kracht van die definities groot wordt geacht: zij leiden immers tot een afhankelijke, geïnstitutionaliseerde of gemedicaliseerde ouderdom. In dit hoofdstuk zullen deze veronderstellingen nogmaals, maar dit keer aan de hand van eigen empirisch onderzoek naar de Nederlandse situatie, worden bekritiseerd. Die kritiek roept vervolgens nieuwe vragen op, die op hun beurt de opmaat zullen vormen tot de hoofdstukken drie tot en met vijf.

Voor de antwoorden op de vragen die in dit hoofdstuk centraal staan, zijn de publikaties van de deelnemers aan de discussies belangrijke bronnen. Daarnaast is gebruik gemaakt van de notulen en vergaderstukken van een deel van de vele commissies, werkgroepen en overlegorganen die rond ouderenvraagstukken geformeerd werden. In de jaren tussen I94S en 1982 kwamen tientallen groepjes mensen bijeen in zaaltjes van restaurants en hotels of vergaderruimten van ziekenhuizen, ministeries en onderzoeksinstituten, om kwesties rond ouderen te bespreken. Daar werden nota's opgesteld, lezingen aangehoord, rapporten geschreven, beleidsstukken bediscussieerd, normen vastgesteld en organisaties vernieuwd. Daar kwamen de behoeften van ou- 
deren, hun maatschappelijke positie en de gevolgen van een vergrijzende bevolking ter tafel. Sommige stellingen werden in bepaalde perioden in vergaderingen en daarbuiten honderden malen verdedigd. Steeds is naar die bronnen verwezen die duidelijk kunnen maken hoe breed een bepaalde gedachte gedragen werd en wie de meest spraakmakende vertegenwoordigers van die gedachte waren.

De manier waarop de problemen rond ouderen werden gepresenteerd, verschilde per periode. Toch betekent dat niet dat de geschiedenis van deze vraagstukken als een reeks eendimensionale probleemdefinities voorgesteld kan worden. Daarvoor hadden de besprekingen en publikaties, waarin dissidente gedachten, klemmende onzekerheden en deelproblemen naar voren werden gebracht, te veel verschillende niveaus. Dat maakt dat de hieronder gebruikte periodisering haar beperkingen heeft. De indeling van de naoorlogse perioden geldt voor de toon en thematiek van de meer algemene verhandelingen: de inleiding van een handboek, het openingswoord voor een congres, de toelichting op een begroting, het voorwoord van een rapport, het redactioneel van een tijdschrift, de opdracht van een commissie.

De caesuren zijn gelegd bij gezichtsbepalende congressen en beleidsnota's. Dat er voor gekozen is aanvankelijk congressen en later beleidsnota's als caesuur te nemen, is niet toevallig en weerspiegelt een klimaatswijziging waarvan de inhoud nog aan de orde zal komen. Maar de beschrijving van het ideeëngoed in de verschillende perioden betekent niet dat voorafgaand aan en volgend op de caesuren dat ideeëngoed nog niet of nooit meer voorkwam. Het laat slechts de hoofdstroom zien van aandachtsverschuivingen in de naoorlogse definities van de problematiek rond ouderen. Evenmin betekent 'naoorlogs' dat nooit eerder iemand zich om ouderen en veroudering had bekommerd. Voor de naoorlogse grenzen van 'het vraagstuk der oudeliedenzorg' werd in het interbellum de basis gelegd. Hoe? 


\section{Het karakter van een oud volk}

Van het demografisch alarm na 1945 was niet zozeer de inhoud nieuw, als wel de toon. Dat de bevolking verouderde, werd ook in het interbellum geconstateerd. Aan de hand van geboortenen sterftecijfers lieten deskundigen in de jaren twintig zien dat in veel Europese landen de gemiddelde levensduur steeg en het geboortencijfer daalde. Daardoor werden de betreffende naties geleidelijk ouder, een verschijnsel waarvoor een decennium later in Nederland de term 'vergrijzing' werd geïntroduceerd. ${ }^{+}$Maar terwijl deze veranderingen na de oorlog veelal als gegeven werden aanvaard, stonden in het interbellum voor- en tegenstanders van geboortendaling in felle debatten tegenover elkaar. En terwijl vergrijzing na de oorlog steeds werd geassocieerd met de vele problemen van het land en zijn bejaarden, zagen vooroorlogse deskundigen in een ouder wordend volk niet louter nadelen.

Anders dan een land als Frankrijk had Nederland in de jaren twintig vooralsnog een hoog geboortencijfer. Volgens het confessionele deel van Nederland moest dit zo blijven. Een omvangrijke bevolking was een zegen voor de staat en een hoog kindertal een gave Gods. Nieuw-malthusianen daarentegen wilden de bevolkingsgroei op economische gronden afremmen: geboortenbeperking was voor hen een middel ter bestrijding van de armoede. H.W. Methorst, directeur van het Centraal Bureau voor de Statistiek, koos geen partij in deze discussie. Naar zijn mening viel er weinig te sturen. leder land zou eenzelfde soort ontwikkeling doormaken. Aanvankelijk daalde het sterftecijfer sneller dan het geboortencijfer. Daardoor steeg het geboortensurplus soms naar angstwekkende hoogte. Maar zodra de moderne begrippen van hygiëne, zorg voor het pasgeboren kind en opvoeding tot de verschillende lagen van de bevolking waren doorgedrongen, begon ook het geboortencijfer gestaag te dalen. Aan deze verschuivingen viel niet te ontkomen, schreef Methorst, al nam de omvang van de Nederlandse bevolking daardoor tijdelijk zeer snel toe. 'Krachten gelegen in de natuur der dingen, facto- 
ren voortvloeiend uit de evolutie, welke de volkeren der aarde op verschillende wijzen en in verschillend tempo doormaken, zijn hier werkzaam. Laten wij intusschen voortgaan met de vervulling van de beschavingstaak (...), strevend naar verhooging van het welvaartspeil der geheele bevolking, vermijdend alles wat de volksziel kan schaden en alles wat een economische ontwikkeling in de weg staat (...), dan zullen wij met vertrouwen de toekomst kunnen tegemoet zien (...) $)^{\text {s }}$

$\mathrm{Al}$ ging de aandacht in Nederland in eerste instantie uit naar de groei van de bevolking, ook de consequenties van vergrijzing werden besproken. Een deel van de kwesties die daarbij werden aangeroerd, verdween nooit meer van de agenda. Zo bekeken economen de voors en tegens van bevolkingsveroudering voor de arbeidsmarkt, de produktie, de consumptie en de 'demografische last': de kosten verbonden aan het levensonderhoud van de niet-produktieve, afhankelijke bevolking. ${ }^{6}$ Het laatste betrof zowel de uitgaven voor 0-1 4 jarigen als die voor mensen van 65 jaar en ouder. In dat verband werd ook over de uitbouw van de oudedagsverzorging gediscussieerd. Via pensioenfondsen voor ambtenaren en de verzekeringswetten van 1913 en 1919 voor werklieden en hen gelijkende groepen bestonden inmiddels bescheiden, door de staat georganiseerde pensioenen. Het debat over de juiste rechtsgrond voor en vormgeving van deze regelingen was echter nog allerminst uitgewoed. ?

In het interbellum werd echter ook een kwestie aan de orde gesteld die na de oorlog vrijwel geheel van het toneel zou verdwijnen: de mentaliteit van een oude bevolking. In een periode waarin zaken als de kracht van een volk en het voortbestaan der natie velen tot nadenken stemden, was ook het karakter van een ouder wordend volk een punt van overweging. De sfeer waarin dat gebeurde was die van gematigd optimisme. Zo zag de arts J.G. Sleeswijk in de jaren twintig verschillende sociale voordelen in een ouder wordende bevolking. Want hoewel hij de middelbare leeftijd het meest produktief achtte, zouden belangrijke geleerden voortaan in leven blijven, zouden mensen minder vaak aan beroertes en kanker overlijden en zou de samenleving van de rust en raad van wijze oude mensen kunnen profiteren. Boven- 
dien zou in een land met verhoudingsgewijs veel oude mensen minder kans bestaan op zware sociale conflicten en politieke onrust." Soortgelijke opvattingen werden in een biologische beschouwing over leven, dood, levensduur en onsterfelijkheid geponeerd. Volgens deze beschouwing zou bij een verschuivende leeftijdsstructuur ook de mentaliteit van de bevolking veranderen. Meer conservatisme en een grotere weerstand tegen vernieuwing waren waarschijnlijk. Daar stond tegenover dat ervaring, zuinigheid en voorzichtigheid in een oude bevolking meer gewicht zouden krijgen dan wanneer krachtige, maar meer onstuimige jongeren de toon aangaven. ${ }^{\circ}$ Ook de econoom C.A. Verrijn Stuart dacht in deze termen. Het samenleven van personen van verschillende generaties achtte hij van groot belang voor een geleidelijke cultuurontwikkeling. 'Het onstuimig idealisme van de jeugd wordt nu geleid door de kalme, in ervaring gerijpte, kritiek der ouderen; en het licht te bedachtzaam conservatisme dezer laatsten door de frisse impulsen der jongeren voor gemakzuchtig indommelen behoed. ${ }^{\text {to }}$

Wellicht ontleenden deze auteurs hun karakteristieken van ouderen - die zij vervolgens op het volk als geheel projecteerden - aan enkele beschouwingen die in het interbellum over de psyche van de oude dag verschenen. De begrippen 'omzichtigheid' en 'rust' waren bij voorbeeld ook in J. van der Speks psychologie van de oude dag aanwezig, al achtte hij 'regressie' en 'algehele vervlakking' dominant." De typering die de psychiater H.C. Rümke van de ouderdom gaf, werd zelfs letterlijk in één van de toekomstprojecties opgenomen. Hij omschreef de senectus van de man, een fase beginnend tussen de 65 en de 70 , als het achterblijven in een badplaats waar het seizoen voorbij was. 'Het is leeg geworden (...) Met de enkele mensen, die er nog zijn, ontstaat een merkwaardig gemeenschapsgevoel. Men is alleen, gelegenheid tot verstrooiing is er niet meer, men kan niet meer in de wereld uitgaan. (...) Hield men tevoren geen rekening (...) met de temperatuur van het water, nu moet men de goede dagen uitzoeken. Deze aanvaarde beperking der mogelijkheden, geeft een ongekend gevoel van vrede, dat men in het volle seizoen niet kende. Er is een diepere rust gekomen, de mens keert zich meer 
en meer naar binnen (...) Niet alleen brengt hij zijn tijd door met terugkijken, er ontstaan plotseling nieuwe belangstellingen. (...) De interessen worden zuiverder en meer algemeen-menselijk. ${ }^{12}$ Dit type veranderingen, zo schreef de directeur-generaal van het Centraal Bureau voor de Statistiek Ph.J. Idenburg in de jaren veertig, zou zich in de geestelijke houding en culturele ontwikkeling - het levensritme - van het ouder wordende Nederland gaan weerspiegelen. ${ }^{13}$

Idenburgs voorspelling, kort na de Tweede Wereldoorlog gedaan, was één van de laatste van dit type. Na 1945 kwam een dergelijke associatie van vergrijzing met de evolutie van een volk nog maar sporadisch voor. De meest gebruikelijke naoorlogse koppeling, die tussen bevolkingsveroudering en de vraag naar voorzieningen, was daarentegen juist in het interbellum zeldzaam. Hoewel 'het vraagstuk der oudeliedenzorg' in die jaren binnen de wereld van de armenzorg bijzonder actueel was, draaide deze kwestie aanvankelijk niet om het toenemend aantal ouderen en hun behoeften, maar om een nieuw type ouderen en hun verzorging.

Aanleiding tot de bezinning op de traditionele oudeliedenzorg was de invoering van de twee al genoemde verzekeringswetten die de lagere inkomensgroepen in staat stelden een bescheiden ouderdomsrente op te bouwen. De verankering van ouderdomsvoorzieningen in armenzorg werd daarmee verbroken en maakte de oudeliedenzorg meer dan voorheen een vraagstuk op zichzelf. Tegelijkertijd werden de armenzorg-instellingen geconfronteerd met een verrassende verschuiving in hun cliẻntenbestand. Die verschuiving bestond uit een afname van het aantal ondersteuning-vragenden 'uit de lagere volksklassen' en een toename van het aantal aanvragen van mensen uit de hogere maatschappelijke lagen. Tot de laatsten behoorden veel 'nieuwe armen': burgers van wie het inkomen in korte tijd, ondermeer door inflatie, sterk was gedaald. ${ }^{14}$ Maar onder de beter gesitueerde aanvragers waren ook mensen die om andere redenen huisvesting en verzorging zochten. Dergelijke ouderen hadden, aldus de tijdgenoten die de veranderingen analyseerden, 
moeite met het vinden van geschikte huishoudelijke hulp, konden niet meer worden opgenomen in de kleiner wordende woningen van hun kinderen of zagen hun oude woningen in de centra van de steden opgeofferd aan city-vorming, verkeersverbredingen en woningverbeteringen. ${ }^{15}$ Dat alles riep de vraag op of de bestaande middelen en methoden van de armenzorg nog wel aan de eisen van de tijd voldeden.

Veel leden van de armenzorg-elite beantwoordden die vraag ontkennend. Voor hen was zonder meer duidelijk dat het oude conglomeraat van armenhuizen, oude mannen- en vrouwengestichten, gast- en proveniershuizen en hofjes niet meer voldeed. Vooral de oudeliedengestichten moesten het ontgelden. De stedelijke huizen met hun desolate, kille zalen en diep gezonken bewoners waren volstrekt ongeschikt voor de aanzwellende stroom respectabele burgers. Voor de laatsten creëerden organisaties als Pro Senectute, Vredeheim en Ons Thuis daarom in de loop van de jaren tien en twintig een nieuw type tehuizen: klein, met aparte kamers en grote aandacht voor de 'ongerepte zelfstandigheid". ${ }^{16}$ Daarnaast werden, veelal door kerken, grotere inrichtingen gebouwd of uitgebreid die tegen verschillende prijzen verschillende niveaus van privacy - klassen - boden en ontstond in de grote steden een ware explosie aan particuliere, commerciële pensions. ${ }^{17}$

Bovendien constateerden armenzorg-deskundigen dat ook de bevolking van de traditionele gestichten veranderde. Het aantal verpleegden liep terug, het fatsoenspeil werd hoger en het percentage invaliden onder de verpleegden nam toe. Deze verslechtering van de gezondheidstoestand onder de bewoners werd eveneens een gevolg van de ouderdomsrente geacht. Doordat mensen zich langer zelf konden redden, steeg de gemiddelde leeftijd en arriveerden in de gestichten steeds meer 'afgeleefde stakkers'. " Dat én de omstandigheid dat de bestaande tehuizen doorgaans alleen gezonde mensen wilden opnemen, deed velen noteren dat er behoefte bestond aan afzonderlijke tehuizen voor invaliden en chronisch zieken.

Op deze manier breidde het vraagstuk van de oudeliedenzorg zich van de lagere naar de betere standen uit en werden 'sociale 
omstandigheden' en 'validiteit' - naast armoede - afzonderlijke grondslagen voor hulp. Dat maakte een grotere groep ouderen onderwerp van publieke aandacht, een omstandigheid waarin bevolkingsveroudering een relevant gegeven werd. De drie rapporten die de stad Amsterdam in 1918, 1924 en 1942 over haar oudeliedenzorg liet verschijnen, illustreren dit. Het eerste rapport sprak over een stijgende vraag naar 'verpleging' - ook onder 'waardige oudelieden' - maar niet van een toename van het totaal aantal oudelieden. Ook het tweede geschrift wees alleen op de toenemende behoefte aan opneming onder 'de betere standen'. Het rapport uit de jaren veertig gaf na de inleiding echter cijfers die zowel een verdubbeling van het absolute aantal bejaarden in Amsterdam en Nederland tussen 1920 en 1940 lieten zien als een relatieve bevolkingsveroudering. ${ }^{19}$ Cijfers, die een deel van de in Amsterdam geconstateerde tekorten aan hulp voor ouderen konden verklaren.

\section{De som der delen}

Wat voor de oorlog een novum was, werd daarna gebruik. Algemene verhandelingen over ouderen kregen een vast ritme doordat opvallend veel overzichtspublikaties openden met de constatering dat de bevolking verouderde. Soms stond deze 'onvermurwbare' statistiek los van de rest van het betoog. Vaker werd expliciet een link gelegd met de moeilijkheden van bejaarden en die van de samenleving.

Opvallend was het acute karakter dat aan de vraagstukken werd toegeschreven. In de context van de naoorlogse ontreddering en tekorten, werden ook de problemen van bejaarden als nijpend en de plichten voor de rest van de bevolking als zeer bezwarend voorgesteld. 'Het wordt voor de werkers tussen de 20 en 60 jaar bij de tegenwoordige sociale omstandigheden een bijna ondragelijke last om alle leeftijdgroepen te onderhouden', schreef iemand in 1948. De aanwezigheid van 'een groot onproductief en ongezond segment van mensenmateriaal' bracht, zo luidde zijn stelling, de nationale economie in gevaar en werkte het communisme onder oude mensen in de hand. ${ }^{20}$ Een ander sloot een greep naar de macht door bejaarden niet uit. Het was 
immers '(...) gevaarlijk om massa's van deze ongelukkigen en ontevredenen te veroordelen tot het onnuttig en parasiterend bestaan (....)'s' Sleeswijk, voor de oorlog nog zo hoopvol gestemd, zag de vergrijzing nu met lede ogen aan. Het vooruitzicht dat een steeds kleiner aantal personen in de produktieve leeftijd het belastinggeld zou moeten opbrengen, terwijl een groeiend aantal ouden van dagen geheel of gedeeltelijk op kosten van de gemeenschap zou moeten leven, was weinig opwekkend. 'Wij staan hier voor een probleem, dat zich in de geschiedenis der mensheid nog nooit heeft voorgedaan en dat in onze ontredderde wereld vooralsnog tot schier onoverkomelijke moeilijkheden aanleiding geeft', zo stelde hij in een door hemzelf geredigeerd handboek over ouderdomsgeneeskunde. ${ }^{12}$

Velen waren ervan overtuigd in een nieuw tijdperk te zijn beland. Tijdens de oorlog noteerde de sociaal-geneeskundige J.H. Tuntler dat na de eeuw van het kind nu de eeuw der ouderdom was aangebroken. Zoals de kindersterfte was gedaald, zou mogelijk het sterven van ouderen uitgesteld kunnen worden. Terwijl kinderziekenhuizen ontvolkt waren geraakt, zou een toenemende behoefte ontstaan aan inrichtingen voor ouden van dagen. Terwijl weeshuizen bijna overbodig waren geworden, zou de bevolking van verpleeghuizen vermeerderen. Zoals vroeger de huizen der 'engeltjesmaaksters' moesten worden bestreden, zou nu de strijd tegen slecht ingerichte en geëxploiteerde tehuizen voor oude mensen moeten worden opgevoerd. Waar huisbezoek bij de kinderbescherming een groot nut had bewezen, zou georganiseerd huisbezoek ook bij de oudeliedenzorg nodig zijn. ${ }^{23} \mathrm{Na}$ de oorlog werd dit type vergelijking zeer geliefd. In het verlengde daarvan werd de zorg voor ouderen regelmatig aan die voor kinderen gespiegeld. Zoleek het verschillende mensen, onder wie de hoogleraar sociale geneeskunde P. Muntendam, zinvol om naast consultatiebureaus voor zuigelingen ook consultatie- of adviesbureaus voor oudelieden op te richten. Anderen vroegen zich af of er naar analogie van de jeugdconcerten ook bejaardenconcerten moesten komen. En artsen meenden dat het de ouderdomsgeneeskunde wel eens net zo zou kunnen vergaan als de kindergeneeskunde, waarvoor inmiddels vier leerstoelen bestonden. ${ }^{4}$ 
Aan de gevolgen van vergrijzing voor de demografische last en daarmee voor het niet-bejaarde deel van de bevolking werd in uiteenlopende kringen gerefereerd. De geciteerde artsen stipten de kwestie aan, economen maakten er een steeds terugkerend agendapunt van, politici en adviseurs namen de zaak mee in hun voorbereidingen van de Algemene Ouderdomswet - een regeling die de Noodwet Ouderdomsvoorziening van 1947 moest vervangen. ${ }^{25}$ Maar minstens zo vaak werd de opmerking dat de bevolking verouderde verbonden met een opsomming van de problemen van bejaarden zelf. Deels liep die koppeling via de gedachte dat meer ouderen - in de toekomst - meer zorg nodig zouden hebben. Een andere, veelal impliciete veronderstelling was dat een hoger aantal ouderen de urgentie van de bestaande moeilijkheden van deze groep verscherpte.

Bij de opsomming van deze moeilijkheden fungeerde het vaderlandse voorzieningenstelsel als checklist. Het 'langslopen' ervan maakte onvervulde behoeften, vergeten groepen en lacunes zichtbaar en gaf orde aan wat in deze jaren 'het vraagstuk der oudeliedenzorg', 'het probleem der bejaardenzorg', 'het ouderdomsvraagstuk', 'het oudelieden-vraagstuk' of 'het bejaardenprobleem' werd genoemd. Want problemen werden veelal ingedeeld naar voorzieningen, terwijl voorzieningen op hun beurt de facetten vormden van het veelzijdige oudeliedenvraagstuk. In 1949 gaf J. Everts, bestuurder op het gebied van het maatschappelijk werk, een typerend overzicht van de 'enorme problemen' van bevolkingsveroudering. Er was een huisvestingsprobleem, zo schreef hij, omdat de oudeliedengestichten de vraag naar opname niet aankonden. De zaak had een economische kant omdat ouden van dagen, via een verzekeringsstelsel, op basis van de bestaande produktie gevoed moesten worden. De kwestie van de invalide en chronisch zieke ouden van dagen drong zich op omdat voor hen in ziekenhuizen geen plaats was. De behoefte van ouden van dagen aan algemene voorlichting, mede op te vangen middels consultatiebureaus, en het 'cultureel aspect' dienden daar nog aan toegevoegd te worden. ${ }^{26}$

Een dergelijk raster lag ook over de vele inleidende besprekingen van 's lands ouderdomszorg en de lokale studies naar de 
levensomstandigheden van bejaarden. De consensus over de aard, niet over de oplossingen, van de deelproblemen was groot. Vragen rond arbeid, welstand, huisvesting, geneeskundige zorg, sociale dienstverlening en tijdsbesteding werden consequent aan de orde gesteld en vormden de bouwstenen van de sociale, medische en economische kanten van het vraagstuk. Slechts het 'psycho-hygiënisch' aspect leek zich aan de koppeling met voorzieningen te onttrekken, al werd dit facet soms met de adviesbureaus verbonden. Was het zinvol om ouderen nog een bijdrage aan de produktie te laten leveren? Boden de pensioenvoorzieningen voldoende zekerheid? Op welke manier moest de huisvesting van bejaarden vormgegeven worden? Wat diende er met de chronisch zieke en invalide ouden van dagen te gebeuren? Aan welke hulp hadden de buiten tehuizen wonende oudelieden de meeste behoefte? En hoe moest de zo noodzakelijke tijdsbesteding van bejaarden georganiseerd worden? ${ }^{27}$

Deze vragen kwamen in de opzet van het eerste naoorlogse, door het particulier initiatief en onderzoekers georganiseerde congres 'De oudeliedenzorg' in 1950 terug. Vier prae-adviezen, over huisvesting, sociologische aspecten, adviesbureaus en tijdsbesteding, behandelden de voornaamste facetten van het vraagstuk der bejaardenzorg en dienden als voorzetten voor een bewogen discussie. De openingslezing gaf goed weer hoe tussen de jaren twintig en de jaren vijftig het perspectief was veranderd. Voor de oorlog, zo vertelde de spreker, was ook al eens een bijeenkomst aan de oudeliedenzorg gewijd. Maar destijds was slechts een onderdeel van het veelomvattende probleem van de bejaardenzorg aan de orde geweest: de verzorging in gestichten. 'Thans' was dat probleem 'in zijn geheel' aan de orde..$^{28}$ Dat de betrokkenen in de jaren twintig ook al meenden de gehele toestand van die zorg in kaart te hebben gebracht, leek de inleider zich niet bewust te zijn. Het geheel van 1920 was in 1950 een deel geworden.

\section{De voortgang der structuurvijzigingen}

Het congres van 1950 dekte een groot deel van wat in de naoorlogse jaren tot het vraagstuk der oudeliedenzorg gerekend 
werd, maar vormde tegelijkertijd de opening tot een periode waarin de betrokken deskundigen probeerden de kern van het bejaardenprobleem vast te stellen. In het gestaag uitdijende scala van 'noden' van bejaarden werd een patroon ontdekt."

Volgens één van de prae-adviseurs van het congres, de psychiater F.M. Havermans, lag die kern in een 'psychisch moment': de vereenzaming van de bejaarden. Die eenzaamheid wortelde zowel in het gevoel overbodig te zijn - op het moment dat het werk hem niet meer lukte of gegund werd - als in het verlies van het gezin. Want de familieband was losser geworden, het contact tussen ouders en kinderen afgenomen, en het aanzien van bejaarden verminderd. Deze familiestructuur viel niet meer terug te draaien: daar lag de oplossing in ieder geval niet. De bejaarde sloot zich bovendien ook zelf van de omgeving af. $\mathrm{Zijn}$ minderwaardigheidsgevoelens over de psychische en lichamelijke achteruitgang leidden via overcompensatie tot ultra-conservatisme en halsstarrigheid. Overbrugging van deze kloof tussen bejaarde en omgeving was niet mogelijk. Een oplossing lag slechts in berusting en in rijping van de gedachte aan het nabije hiernamaals. Gerontologische studies die alleen een medische, een economische en een sociale zijde aan het vraagstuk der bejaarden zagen, waren dan ook onvolledig. Het kernprobleem was een psychologisch probleem en de oplossing ervan was uitsluitend van wereldbeschouwelijke aard. ${ }^{30}$

Havermans betoog stond niet alleen. Al langer werd vereenzaming tot de voornaamste problemen van bejaarden gerekend. Stellingen daarover werden omzoomd door opmerkingen over kleiner wordende gezinnen, krappere woningen, een tekort aan personeel en het ontbreken van zinvolle taken voor bejaarden." Maar in de geschriften en discussies van de eerste helft van de jaren vijftig werden nutteloosheid, overbodigheid, isolement en eenzaamheid steeds vaker tot de centrale problemen van bejaarden gedefinieerd. In bittere termen werd een wereld geschetst waarin voor de bejaarde geen plaats meer was. Een wereld die hem financieel zelfstandiger had gemaakt, maar meer dan ooit aan zijn lot overliet: hem restte slechts de leegte. De voorgestelde oplossingen voor dit lot wisselden, maar aanpassing en opvoe- 
ding van bejaarden zelf - bij voorbeeld tot een zinvolle tijdsbesteding - en een liefdevolle omarming en respectvolle benadering van bejaarden door anderen, waren vaste ingrediënten. Niet zelden werd in overweging gegeven om bejaarden, zowel met het oog op hun levensvreugde als met het oog op de economische last van bevolkingsveroudering, vrijwillig aan het werk te houden. ${ }^{32}$ Maar het doel van het merendeel van de voorgestelde oplossingen was, zo valt uit de destijds gekozen formuleringen af te leiden, niet zozeer een maatschappelijke verandering, als wel een verandering in de manier waarop de bejaarde de samenleving ervoer. Bejaarden dienden bovenal het gevoel te krijgen weer harmonisch deel te zijn van de gemeenschap. Goede bejaardenzorg bood bejaarden geborgenheid, een plaats temidden van de zijnen, en bestreed met alle mogelijke middelen het besef van overbodigheid. ${ }^{33}$

Aanvankelijk stonden deze passages over de leegheid van het bejaarde bestaan op zichzelf. Maar omstreeks 1953 verscheen een aantal publikaties, deels bedoeld voor een lezerskring van vakmensen en deels voor het grote publiek, waarin deze elementen werden opgenomen in een samenhangend historisch-sociologisch betoog. Zo legden auteurs als de historica A. Romein-Verschoor, de socioloog P.J. Bouman en de hoge ambtenaar P.C.J. van Loon ieder op hun eigen manier uit, dat in de overgang van de oude statische agrarische gemeenschap naar de moderne dynamische stedelijk-industriële maatschappij het respect voor de ouderdom verminderd was. De familie van drie generaties had plaatsgemaakt voor het gesloten gezinstype van twee generaties en had het patriarchaal gezag doen afnemen. Het verhoogde tempo binnen het arbeidsproces en het gebureaucratiseerde ontslag op een vaststaande leeftijd hadden ouderen naar de rand van de samenleving geduwd: ervaring en wijsheid hadden geen betekenis meer. Voortaan lag de nadruk op jeugdig elan, activiteit en prestaties. En waar traditionele banden verloren waren gegaan, nam ook het contact tussen ouderen en jongeren af. ${ }^{34}$ Dit proces, zo meenden Bouman en Romein-Verschoor, werd nog eens versterkt door de veroudering van de bevolking, ondermeer 
doordat ouderen hun zeldzaamheidswaarde verloren. In de beschouwingen van anderen figureerden bevolkingsveroudering en modernisering - als kwantitatieve versus kwalitatieve verandering - echter onafhankelijk van elkaar. ${ }^{35}$

Hoewel niet iedereen zich onmiddellijk liet overtuigen, kwam dit type betoog zeer vaak voor. ${ }^{36} \mathrm{Het}$ verklaarde de moeilijkheden van bejaarden en gaf aan dat de oplossing van de problematiek in ieder geval niet gezocht moest worden in het tegenhouden van de modernisering. Hoezeer de veranderde positie van bejaarden ook betreurd werd, de structuurwijzigingen werden niet omkeerbaar geacht. Voor zover er maatschappelijk iets diende te veranderen, betrof dat voornamelijk de opvoeding tot een grotere waardering voor de ouderdom. Dat nam echter niet weg dat de aandacht voor de mentaliteit van niet-bejaarden geringer was dan de aandacht voor de opvang en aanpassing van bejaarden zelf.

'Het voorgaande overziende', schreef A.A. Wirtz in 1956 in een voor die tijd typerend betoog, 'moet worden vastgesteld, dat de vele problemen van (...) de bejaarde mens direct samenhangen met de structuur en het geestelijk klimaat van onze moderne samenleving.' Waar moesten, zo vroeg hij zich vervolgens af, stadsbejaarden worden gehuisvest nu de kleinere behuizingen en de onrustige tijdgeest opneming in het gezin van de kinderen veelal ongewenst en onmogelijk maakte? Door wie en hoe dienden bejaarden verzorgd te worden bij ziekte en ongemak? Hoe zou de levensleegheid van talloze bejaarden op zinvolle, en zo mogelijk nuttige en zelfs produktieve wijze gevuld kunnen worden? Wie zou de bejaarden tegemoet treden en opbeuren in hun eenzaamheid en geestelijke verlatenheid? Hier lagen vele problemen, verzuchtte Wirtz - problemen van medische zorg, huisvesting, zinvolle tijdsbesteding en welstand. Maar één ding stond vast: de gehele bejaardenzorg diende gedragen te worden door een diep respect en eerbied voor de 'zelfstandige persoonlijkheid' van de bejaarde."

Deze zorg om de gevolgen van een nieuwe sociale orde bereikte een hoogtepunt in het midden van de jaren vijftig. Tijdens het 
tweede grote naoorlogse congres, 'Het Bejaardenvraagstuk' in 1956, werd veelvuldig naar die gevolgen verwezen en de structuurveranderingen gingen gelden als de grondoorzaken van de bejaardenproblematiek. Bovendien werd het gebruikelijk om in rapporten over bejaardenkwesties een paragraaf over de plaats van de bejaarden in de samenleving op te nemen en werd de eenzaamheid van bejaarden onderwerp van onderzoek. ${ }^{38}$

Ook het inmiddels opgerichte Ministerie van Maatschappelijk Werk analyseerde het bejaardenvraagstuk in termen van de overgang van een traditionele naar een moderne samenleving. 'De ouderen hebben recht op een plaats in de samenleving, die overeenkomt met hun behoeften', zo stond in de memorie van toelichting op de begroting voor 1957. Maar gezien de toenemende veroudering van de bevolking en de 'voortgang der structuurwijzigingen' - een verschraling van contacten door pensionering en huisvesting buiten het vertrouwde milieu en een veranderende mentaliteit en houding van de jongere generaties - was dit een vraagstuk dat een nationale krachtsinspanning vereiste. ${ }^{39}$ Samen met het adagium dat bejaarden zo lang mogelijk zelfstandig zouden moeten blijven wonen, leidde dat op verschillende niveaus tot de oproep voorzieningen op te zetten die de 'integratie' van bejaarden binnen wijk en familie konden bevorderen. Daarbij werd gedacht aan verschillende vormen van 'open bejaardenwerk', zoals huisbezoek, tafeltje-dek-je, gezinszorg, bejaardensociëteiten en dienstencentra. Dergelijke voorzieningen dienden de zelfstandigheid te bevorderen én het gevaar van een status aparte te weren. Daarnaast bleef het van belang allerlei vormen van hulpbehoevendheid, waarvan de definities steeds verfijnder werden, via verpleging en huisvesting op te vangen. ${ }^{40}$

Tijdens dit 'dichten van de dijk' ontdekten de betrokken deskundigen in de tweede helft van de jaren vijftig en de eerste helft van de jaren zestig voortdurend nieuwe gaten: de zorg voor psychisch gestoorde bejaarden, het tekort aan moderne verpleegtehuizen, de noodzaak van sociaal-culturele activiteiten, het nut van bejaardengymnastiek, de zin van bejaardenwerkplaatsen. ${ }^{4}$ In het verlengde daarvan groeide de ergernis over het fragmentari- 
sche karakter van het voorzieningenstelsel zelf en ontstond de roep om een 'gesloten circuit' van zorg. En niet alleen het tekort aan samenhang in het stelsel van voorzieningen, maar ook een gebrek aan lijn in onderzoek en beleid werd ter discussie gesteld. ${ }^{42}$ Tegelijkertijd groeide echter de twijfel over de effecten van de vele voorzieningen. Bejaarden dienden, aldus de hoofdstelling van het derde grote naoorlogse congres in 1963 , deel te zijn van de samenleving. Maar maakten de voorzieningen zelf, zo vroegen enkele deskundigen zich af, de bejaarden niet te veel een groep 'en marge'?

\section{Maakbaarheid en marge}

Ook na 1963 bleef de analyse van het bejaardenvraagstuk aan de hand van verwijzingen naar structuurveranderingen populair. $\mathrm{Al}$ werd op grond van sociologisch onderzoek inmiddels kritiek geleverd op de pessimistische en romantiserende lading ervan - het bewuste raamwerk bleef in gebruik. ${ }^{44}$ De voorgestelde remedie tegen de structuurwijzigingen veranderde niettemin drastisch. Van aanvaarding van de bestaande orde verschoof het accent in de loop van de jaren zestig naar een aanval op de maatschappij die de bejaarden ten onrechte naar de marge van de samenleving drukte. Niet de houding van de individuele bejaarde, maar de gehele maatschappij was aan revisie toe. Niet alleen de mentaliteit, maar ook de materiële basis moest veranderd worden. Niet het gevoel nog mee te doen, maar de daadwerkelijke deelname van de bejaarde werd het doel.

Werd voorheen vrijwel iedere nieuwe activiteit voor bejaarden enthousiast onthaald, in de eerste helft van de jaren zestig werd de ontvangst aanmerkelijk gereserveerder. Die reserve ging verder dan de al jaren geuite waarschuwing de bejaarden, tot behoud van hun waardigheid, niet te veel te bemoederen en te beschermen. ${ }^{45}$ Op spottende toon vermeldde de redactie van een ouderenblad in 1964 dat de verslagen van traditionele bustochten voor bejaarden 'onverwoestbaar optimistisch' waren. En dat terwijl bejaarden in deze sfeer van genoegzame filantropie, aldus het blad, te veel tot object gereduceerd werden. ${ }^{46}$ Ook keerden deskundigen, bewindslieden en parlementsleden zich steeds vaker 
tegen het opzetten van aparte bejaardenvoorzieningen. Lezen hield de geest actief, maar aparte bejaardenlectuur was niet gewenst. Hulp moest er zijn, maar niet alle bejaarden behoefden zorg en met de oprichting van speciale diensten moest voorzichtig worden omgesprongen: daarmee werden bejaarden immers in een uitzonderingspositie geplaatst. ${ }^{47}$

Deze terughoudendheid ten aanzien van afzonderlijke voorzieningen voor bejaarden kreeg een pendant in de gedachte dat over bejaarden zo gewoon mogelijk moest worden gedaan. De bejaarde diende niet langer gezien te worden als een uitzondering waarvoor op 'het schouwtoneel van het leven' geen plaats meer was, noteerde de Minister van Maatschappelijk Werk in 1962. Een rustig bestaan was verre van noodzakelijk..$^{48}$ Integendeel, meende een staatssecretaris vier jaar later. Gepensioneerden waren normale, volwassen medemensen die het niet verdienden als kinderen uitgerangeerd te worden. ${ }^{49}$ De poging de ouder wordende mens in het maatschappelijk leven te integreren, zo noteerde een koepelorganisatie op het terrein van de ouderenzorg, was misschien wel de kern van het bejaardenprobleem. ${ }^{50}$

Een soortgelijke nadruk op het 'gewone' van de bejaarde was aanwezig bij aanhangers van de zogenaamde activity-theorie. Deze theorie ontstond in de Verenigde Staten als reactie op de in I96I geïntroduceerde disengagement-theorie. De laatstgenoemde theorie veronderstelde dat bejaarden niet louter door de samenleving werden uitgestoten, maar ook zelf onthechting zochten een onthechting die het welzijn van bejaarden ten goede kwam. De 'activity'-theorie bracht daar tegenin dat het de bejaarde beter zou gaan wanneer hij of zij het 'volwassen' activiteitenniveau zoveel mogelijk zou handhaven. Vanaf midden jaren zestig werd in Nederlandse publikaties geregeld naar dit sociaal-psychologische debat verwezen en werd veelal geen van beide standpunten volledig onderschreven. ${ }^{\text {st }}$ In de praktijk kreeg de gedachte van de bejaarde als gewone en actieve burger niettemin de meeste aanhang. Al waarschuwden verschillende mensen tegen het gevaar van een nieuwe 'activerende' betutteling van bejaarden en werd een zeker isolement door sommigen 'natuurlijk' geacht, het recht op het gewone stond in de meeste betogen centraal. ${ }^{52}$ 
Zoals adolescenten tijdens manifestaties hun identiteit vorm gaven, zo moesten ook bejaarden op hun strepen gaan staan, meenden hulpverleners. Volgens J.C.M. Hattinga Verschure brak de tijd van 'dolle opaas en dolle omaas' aan en was het wachten nog slechts op de 'geronto-provo'-beweging. De democratisering en de revolte van de jaren zestig zouden voor de deur van de bejaarden geen halt houden, voorspelden anderen. ${ }^{33}$ De bejaardenbonden, die zich tot dan toe vooral hadden ingezet voor een betere financiële positie, recreatie-mogelijkheden en een goede toegang tot tehuizen en bejaardenwoningen, veranderden hun strategieën inderdaad. Nadrukkelijker wezen zij op het maatschappelijk nut en de verfoeide achterstelling van ouderen..$^{54}$ Maar een geronto-provobeweging bleef uit, hoewel "emancipatie' het nieuwe wachtwoord werd in onderzoek, praktijk en beleid. ${ }^{35}$ Bovendien werd de sfeer in kringen van bejaardenorganisaties langzaam maar zeker cynischer. In de jaren zeventig verscheen een satirische 'praat-platenstrip oudjes kijken' waarin ouderen opzettelijk in clichés - kreukelig, knorrig, seksloos, nutteloos, verborgen onder een glazen stolp - werden verpakt. ${ }^{56}$ In diverse publikaties werden bejaarden verbeeld als mensen die in de 'emancipatie-race' hopeloos achter liepen en als gekooiden die uit hun instituten moesten worden bevrijd. 'Oud is out' en 'oud zit fout' werden gevleugelde woorden. ${ }^{57}$ Dergelijke benaderingen waren zeker niet onomstreden. Maar de berusting en aanvaarding van de jaren vijftig lagen inmiddels wel erg ver weg. ${ }^{5 \pi}$

In 1973 verscheen bij voorbeeld een artikel van de hand van de socioloog H.Ph. Milikowski waarin hij het bejaardenprobleem voorstelde als een klassenprobleem: gegoede ouderen konden kopen wat zij wilden, hielden hun sociale contacten en hadden volop ontplooiingskansen. De ware problemen lagen bij de lagere klassen. ${ }^{39}$ Maar vaker werden bejaardenproblemen met name door sociologen en tot ver in de jaren tachtig - beschreven als een kwestie van discriminatie, marginalisering en stigmatisering. Bejaarden waren, aldus dit standpunt, een minderheid als andere minderheden en het bejaardenvraagstuk onderscheidde zich niet wezenlijk van het rassenvraagstuk. ${ }^{60}$ In het 
beleid van het kabinet-Den Uyl weerklonk die gedachte ondermeer in het begrip 'deprivatie' van bejaarden. ${ }^{61}$

Soms werd de essentie van het bejaardenvraagstuk - de door de maatschappij aan ouderen opgelegde positie van achterstand en isolement - onderstreept door te benadrukken dat het probleem niet in de eerste plaats van demografische aard was. ${ }^{62}$ Ook tijdens het hoogtepunt van het structuur-betoog, in het midden van de jaren vijftig, werd er door een enkeling op gewezen dat bevolkingsveroudering niet automatisch leidde tot verschijnselen die als problematisch werden ervaren. Daarvoor zou meer nodig zijn. ${ }^{63}$ Deze stelling werd in de loop van de jaren zestig en zeventig niet alleen scherper geformuleerd, maar bovendien van 'schuldigen' voorzien. Volgens J.C. van Dam riep de maatschappij met haar inrichting en sociaal-economische opvattingen zelf een bejaardenvraagstuk op. En in het midden van de jaren zeventig ontstond binnen het Gerontologisch Centrum onenigheid over een van de onderzoeksprojecten: het 'verplaatsingsonderzoek'. Volgens een deel van de onderzoekers had het Gerontologisch Centrum met dit onderzoek, waarin werd onderzocht in hoeverre en waardoor de verplaatsing van bejaarden van een woning naar een tehuis problemen veroorzaakte, zelf een vraagstuk geschapen. '[V] oor een slordige I miljoen guldens', luidde de aanklacht, 'worden 550 oudere mensen slachtoffer gemaakt van een krankzinnig uitgebreid vragenpakket, waarmee gerontologen het door henzelf in het leven geroepen demon, dat luistert naar de naam Verplaatsingsproblematiek bij bejaarden, trachten te bezweren. ${ }^{164}$

De meerderheid van de deskundigen van de jaren zeventig zag echter geen verzonnen, maar werkelijke problemen van bejaarden: achterstandsproblemen die zowel via een verbetering van de inkomenspositie en participatiekansen van bejaarden als via een maatschappelijke mentaliteitsverandering weggewerkt moesten worden. Zo zouden volgens velen het eenzijdig produktiviteitsdenken verlaten, de gettovorming gestopt en de negatieve beeldvorming van ouderen doorbroken moeten worden. ${ }^{65}$ Niettemin bleek over de te volgen strategie nog veel discussie mogelijk. Werkten voorzieningen als de Pas 65 en het be- 
staan van afzonderlijke belangenorganisaties voor ouderen het isolement van bejaarden in de hand of juist tegen? Waren bejaardenpartijen of een Raad voor het Bejaardenbeleid zinvol of juist contraproduktief? Dienden bejaardentehuizen gebouwd of juist afgebroken te worden? ${ }^{66}$ Bovendien viel het niet iedereen even gemakkelijk de positieve waarde van bejaarden te definiëren. De discriminatie was in kaart gebracht, de voorziening verdacht en de emancipatie een streven. Bejaarden zouden hun levenservaring dienstbaar kunnen maken aan anderen en vrijwilligerswerk kunnen doen, zo meenden de ouderenbonden. Ook verwijzingen naar de wijsheid en rust van ouderen - die een lange traditie kenden - kwamen geregeld voor. Daarnaast zagen sommigen in de ouderen van de toekomst een politieke machtsfactor van groot belang en een marktsegment van aantrekkelijke omvang. ${ }^{67}$

Anderen vonden echter niet wat zij zochten. Aan het begin van de jaren zeventig ging een kleine groep onderzoekers in werkgroep-verband op zoek naar een nieuwe filosofie van de ouderdom. Die filosofie, zo meenden de werkgroepsleden, moest de 'slogans' van het bejaardenwerk - zelfstandigheid, integratie, de ouderdom komt met gebreken - kunnen relativeren. De concept-nota die het resultaat was van hun beraadslagingen vonden zijzelf echter niet vernieuwend genoeg. Het eindprodukt van de werkgroep was dan ook een lijst met vragen, waarin ondermeer opnieuw naar een filosofie over de betekenis van de ouderdom werd gevraagd. ${ }^{68}$

\section{Het dilemma van de verdubbeling}

In het midden van de jaren zeventig werd het bejaardenprobleem in de eerste plaats als het probleem van een gediscrimineerde minderheid gepresenteerd. Maar tegelijkertijd figureerde deze minderheid als een dreigende meerderheid. Hoewel de demografische discussie in Nederland zich in deze jaren concentreerde op de gevaren van bevolkingsgroei en overbevolking, kreeg de veroudering van de bevolking via een andere ingang hernieuwde aandacht. Dat ging gepaard met een andere benaming. Terwijl tot in de jaren zeventig het begrip "bejaardenvraagstuk' werd gebezigd, werd in de loop van dat decennium en 
het begin van de jaren tachtig steeds vaker van 'vergrijzing', 'vergrijzingsvraagstuk' en 'vergrijzingsproblematiek' gesproken. ${ }^{69}$

De erkenning dat de Nederlandse bevolking verouderde, was na de oorlog zowel een kapstok voor het 'probleem der oudeliedenzorg' als voor 'het bejaardenvraagstuk'. Maar het gegeven werd, zo is aangegeven, niet steeds op dezelfde manier ingezet. Meer ouderen brachten meer 'zorgen voor morgen' met zich mee, was één van de gedachten. Maar bevolkingsveroudering onderstreepte ook de urgentie van de contemporaine noden van bejaarden. In de definitie van 'het bejaardenvraagstuk' zagen sommige auteurs de veroudering van de bevolking zelfs als een van de oorzaken van de veranderingen in de maatschappelijke waardering van oude mensen. Anderen zagen de verschuivende leeftijdsstructuur echter als een kwantitatieve verandering die los stond van de kwalitatieve maatschappelijke modernisering. $\mathrm{Al}-$ leen aan het eind van de jaren zestig en in de eerste helft van de jaren zeventig deden verschillende mensen pogingen om de definitie van het bejaardenprobleem als een demografisch probleem aan de kant te schuiven.

Ook de angst voor de last die het bejaarde, niet-produktieve deel van de bevolking op de werkenden zou leggen, was vrijwel steeds aanwezig. Maar in de loop van de jaren zestig en zeventig won deze angst nog extra aan belang. Vanaf het midden van de jaren zestig wezen vooral overheidsvertegenwoordigers steeds vaker op de hoge kosten van voorzieningen voor bejaarden. ${ }^{70}$ Voor deze kosten had de overheid via subsidieregelingen en wetgeving als de Algemene Bijstandswet een steeds grotere verantwoordelijkheid gekregen. Eind jaren zestig nam de zorg over de stijging van de bijstandsuitkeringen aan bejaarden in tehuizen zo toe, dat besloten werd de groei van intramurale voorzieningen af te remmen en het open bejaardenwerk een grotere stimulans te geven dan voorheen. Dat beleid kreeg een gezicht in de Nota Bejaardenbeleid van 1970 en kreeg een vervolg in de Nota Bejaardenbeleid van 1975 en de nota Bouwstenen voor een ouderenbeleid van 1982 , zij het dat in de tweede helft van de jaren zeventig ook de uitgaven voor de extramurale zorg werden beteugeld. In deze sfeer kregen de kosten van vergrijzing bijzondere aandacht. 
Meer ouderen zouden een groter beroep doen op sociale zekerheids- en gezondheidszorgvoorzieningen en op die manier de schatkist bezwaren. Nog steeds werd vergrijzing gekoppeld aan de urgentie van de bestaande problemen van ouderen. Maar meer en meer werd de ouderen- en vergrijzingsproblematiek een probleem van collectieve lasten. ${ }^{11}$

De wereld van ouderenbonden, ouderenzorg en gerontologie diende de overheid danig van repliek en veroordeelde de nadruk op de last die ouderen voor de schatkist zouden betekenen als eenzijdig en paniekerig. Een dergelijk spookbeeld van de vergrijzing kwam volgens sommigen voort uit vrees voor de ouderdom zelf. ${ }^{2}$ Bovendien werd de overheid soms verweten dat zij nieuwe begrippen als 'zelfzorg' en 'mantelzorg' - door Hattinga Verschure in de eerste helft van de jaren zeventig als reactie op de veronderstelde negatieve effecten van het leven in instellingen geïntroduceerd - misbruikte door bezuinigingen als een stimulering van zelfzorg te presenteren. ${ }^{33}$ Inderdaad noemden overheidsvertegenwoordigers de economische gevolgen van vergrijzing en het belang van zelfzorg in één adem, zij het soms zonder causaal verband..$^{74}$

Toch werden demografische scenario's, vraag en aanbod, betaalbaarheid, 'nieuw realisme' en de 'wankele verzorgingsstaat' steeds vaker een prominent onderdeel van de meer algemene analyses. Eind jaren zeventig, begin jaren tachtig kwam in het gemiddelde vergrijzingsbetoog de berekening van het toekomstige aantal bejaarden, hun beroep op voorzieningen en de daarmee samenhangende kosten centraal te staan. Aan nieuwe thema's - de positie van vrouwen, de vervroegde pensionering, de arbeidsongeschiktheidsverklaring van oudere werknemersontbrak het niet. Het opwerpen van financieel-economische vragen werd echter vanzelfsprekend. Bovendien verschoof de 'orde' van de problemen rond ouderen nog op een andere manier. Naast de zorg om de positie van ouderen in het heden, ging het denken in termen van een toekomst bevolkt met ouderen een steeds grotere rol spelen. ${ }^{75}$

In 1984 liet het Ministerie van Welzijn, Volksgezondheid en Cultuur een voorlichtingsbrochure verschijnen, waarin het ou- 
derenbeleid van het begin van de jaren tachtig in essentie werd weergegeven. Op één van de eerste bladzijden stond een weegschaal afgebeeld waarop aan de ene kant een stoet ouderen opstapte en aan de andere kant een bescheiden hoeveelheid geld lag dat aanmerkelijk minder woog. Na de vraag 'Waar gaat het om?' werd een 'dilemma' gepresenteerd. Nederland vergrijsde en werd geconfronteerd met een toenemende zorgbehoefte van een sterk groeiende groep ouderen, waarvan de categorie mensen van 90 jaar en ouder tot 2000 waarschijnlijk zelfs zou verdubbelen. Er was echter geen geld genoeg om alle bejaarden de zorg te geven die ze eigenlijk nodig hadden: het aanbod bleef dus achter bij de vraag. 'Dat moet wel tot knelpunten leiden', luidde de onontkoombare conclusie van het ministerie. ${ }^{76}$

Deze knelpunten waren grotendeels andere dan die van de jaren twintig. Werd het toenemende ouderental destijds met een bezadigd volkskarakter geassocieerd, in de jaren veertig concentreerde de zorg zich op een breed scala aan 'acute' noden. In de jaren vijftig werd in deze noden een patroon ontdekt. De kern van het probleem lag in de psychische toestand van bejaarden: hun gevoel van eenzaamheid en overbodigheid. Dat gevoel werd door onvermijdelijke veranderingen van de samenleving veroorzaakt en verergerd doordat bejaarden hun zeldzaamheidswaarde verloren. In de tweede helft van de jaren zestig kwam de nadruk te liggen op het probleem van de marginaliteit van ouderen: niet hun aantal was het grootste probleem, maar hun status als 'minderheid' in een op prestatie gerichte maatschappij. Na het midden van de jaren zeventig kregen getalsverhoudingen weer de volle aandacht, nu via de collectieve lasten die vergrijzing met zich mee zou brengen.

In het wisselende betoog tussen 'tal' en 'last' werden de grenzen van het probleem, althans op papier, steeds opnieuw vastgelegd. In de schetsen van de problematiek werd telkens aangegeven welke moeilijkheden centraal of perifeer moesten worden geacht en welke kwesties binnen en buiten het 'problematische' vielen. Niet het economische of het sociale, maar het psychische was het ware probleem; niet de demografie, maar de discriminatie verdiende de meeste aandacht; niet de wensen inzake, maar 
de kosten van voorzieningen moesten nu eens bestudeerd worden. Wat dit voor de praktijk van de ouderenzorg betekende, komt nog aan de orde. Eén kwestie is hier echter alvast van belang. In de beschouwingen werd niet alleen de aard van de problematiek geanalyseerd, maar werd vaak ook de 'eigenaar' van het probleem aangewezen, dat wil zeggen degene die verantwoordelijk werd geacht voor het oplossen ervan. ${ }^{77}$ Zo werd in een betoog waarin vergrijzing als probleem van collectieve lasten werd gepresenteerd, de overheid als 'penvoerder' van het probleem benoemd. Omgekeerd riep de schets van de vele 'acute' noden van bejaarden een sfeer op, waarin het de hoogste tijd leek de handen van alle betrokkenen ineen te slaan. Wie deze betrokkenen waren, zal hieronder aan de orde komen.

\section{Het ontstaan van instanties}

'In de jaren die achter ons liggen', zo schreef een lid van de Unie van Vrouwelijke Vrijwilligers in I955, 'is het vrijwel onbekende en ternauwernood onderkende vraagstuk van de zorg voor de ouden van dagen tot een probleem gegroeid, dat ik bijna het troetelkind van iedere organisatie (...) zou willen noemen. ${ }^{78} \mathrm{In}$ richtingen, raden, stichtingen en verenigingen van politieke en godsdienstige signatuur, zo was haar stelling, hadden het bejaardenprobleem in hun programma's opgenomen. De oude mens was ontdekt.

Eén van de organisaties waarop de schrijfster doelde was de Nederlandse Vereniging voor Gerontologie, die op initiatief van de al genoemde arts Sleeswijk ontstond. Tijdens de oorlog werkte Sleeswijk aan de redactie van een tweedelig geneeskundig handboek over de ouderdom dat in $1948 / 49$ verscheen. ${ }^{7}$ En al jaren daarvoor speelde hij met de gedachte een gerontologische vereniging in het leven te roepen. Dat plan kreeg echter pas vaart toen bleek dat de Britse Club for Research on Aging zich opmaakte om een internationale organisatie in Londen op te zetten. Sleeswijk vroeg de co-auteurs van zijn ouderdomsboek of zij belangstelling hadden en in juli 1946 kon hij in Londen melding 
maken van de Nederlandse Vereniging voor Gerontologie (NVG) in oprichting. In de anderhalf jaar daarna werden de eerste vergaderingen gehouden, de statuten vastgesteld en goedgekeurd, en het bestuur benoemd. Sleeswijk nam de voorzittershamer ter hand, Muntendam werd secretaris. ${ }^{80}$

De nieuwe vereniging wilde zowel de kennis van het verouderingsproces bevorderen als de kennis van de maatschappelijke vraagstukken die met dat proces verband hielden. Daarom behoorde het 'bestuderen en bevorderen van sociale maatregelen op het gebied van ouderdomszorg' eveneens tot het werk van de vereniging. ${ }^{{ }^{\prime \prime}}$ In de zomer van 1948 riep Muntendam dan ook een klein aantal leden van de vereniging bij elkaar om een voorlopige studiecommissie op dat terrein te vormen. ${ }^{{ }_{2}}$ Everts, de al ter sprake gebrachte bestuurder van zowel Pro Senectute als de Nederlandse Vereniging voor Maatschappelijk Werk, was één van die leden. Hij vond dat de laatstgenoemde organisatie en de gerontologische vereniging samen een kleine, sociaal gerichte commissie met een volledig secretariaat dienden op te zetten. Die commissie moest zich met de bestudering van en informatievoorziening over oudelieden bezighouden. Daarnaast zou ze een organisatie moeten oprichten waarin alle instanties voor oudeliedenzorg werden verenigd. Want hoe nuttig de bestaande wirwar van plaatselijke en landelijke initiatieven ook was, verbrokkeling en verdubbeling lagen op de loer. En dat terwijl, aldus Everts, het vraagstuk der oudeliedenzorg toch overal hetzelfde was. ${ }^{{ }^{3}}$ Uit de aard van de problematiek volgde naar zijn mening de noodzaak tot een gemeenschappelijke aanpak.

Everts' wens werd gedeeltelijk werkelijkheid: rond de jaarwisseling werd de Nationale Commissie voor de Oudeliedenzorg ( $\mathrm{NCO}$ ) geïnstalleerd. Volgens Everts werd het de betrokkenen al snel duidelijk dat een blijvend centrum voor de bestudering van oudedagsproblemen en de stimulering van een verantwoorde bejaardenzorg onmisbaar was. Het bleek echter niet gemakkelijk daarvoor een juiste vorm te vinden: de 'stelselloosheid' van het terrein kostte vele hoofdbrekens. ${ }^{84}$ Bovendien, zo blijkt uit andere bronnen, lagen de confessionelen dwars. Net als op andere terreinen van het maatschappelijk leven, mislukte ook 
hier de 'doorbraak' van het oude zuilensysteem. Van de nieuwe instanties op het gebied van bejaardenzorg en de belangenbehartiging voor bejaarden organiseerden de meeste zich op levensbeschouwelijke basis. Vooral de katholieke instellingen zagen niets in een neutrale bejaardenzorg en keerden zich tegen een voorstel van de $\mathrm{NCO}$ voor een nationale vereniging voor bejaardenzorg. ${ }^{85}$ Ook in het parlement werd erover geklaagd dat in de samenstelling van de NCO de vertegenwoordiging van enkele protestantse organisaties ontbrak. ${ }^{86}$ De Nederlandse Vereniging voor Gerontologie moest van een nationale vereniging voor bejaardenzorg overigens evenmin veel hebben. In die vereniging zou de gerontologische vereniging niet meer als zelfstandige vereniging, maar slechts als geneeskundige sectie voortleven. Bovendien kreeg, aldus de gerontologen, het medisch-biologisch aspect in die opzet onvoldoende aandacht. ${ }^{87}$

Een nationale vereniging was daarmee van de baan. Een dag voor de kerst van 1954 werd de Nationale Commissie voor de Oudeliedenzorg omgevormd tot de Stichting Nationale Federatie voor Bejaardenzorg. Een klein jaar later werd de naam van deze federatie veranderd in de Stichting Nederlandse Federatie voor Bejaardenzorg, dit om verwarring met de Katholieke Nationale Federatie voor Bejaardenzorg te voorkomen. ${ }^{\mathrm{kn}}$ Veel organisaties, waaronder de samenwerkende ouderenbonden, de organisaties voor bejaardentehuizen en de koepels voor maatschappelijk werk, werden vroeger of later lid. ${ }^{89}$ Daarnaast meldde zich de Nederlandse Vereniging van Gemeenten en traden in de loop der tijd ook de kruisorganisaties, verschillende beroepsorganisaties en vrijwilligersorganisaties toe. Bovendien werden vertegenwoordigers van het departement van Wederopbouw en Volkshuisvesting, het in 1952 opgerichte Ministerie van Maatschappelijk Werk en het departement van Sociale Zaken en Volksgezondheid als adviseurs aan het algemeen bestuur toegevoegd. ${ }^{90} \mathrm{~W}$ ant ook de bemoeienis van de Rijksoverheid nam via wetgeving, subsidiëring, nota's en adviezen na 1945 snel toe.

De Nederlandse Federatie voor Bejaardenzorg (NFB) werd met haar vele secties en commissies een belangrijk orgaan voor overleg tussen de verschillende deelnemende groepen, al werd 
intern nogal eens over de Federatie geklaagd en tot verschillende reorganisaties besloten. Zo zou de Federatie geen duidelijk beleid uitstippelen, te weinig daadkracht tonen en onvoldoende contact hebben met de periferie. ${ }^{17}$ Niettemin bood de Federatie voor de top van de vele organisaties rond ouderen gelegenheid tot regelmatig onderling contact. Ook de tijdschriften functioneerden als zodanig. Verschillende onderzoekers combineerden hun werk aan instituten en universiteiten met het leveren van kopij voor dergelijke bladen of accepteerden bestuursfuncties in organisaties voor bejaardenzorg. Anderen wisselden verschillende malen van pet. Muntendam was secretaris van de gerontologen, voorzitter van de nationale oudeliedenzorg-commissie en vanaf I950 staatssecretaris van Volksgezondheid. Als staatssecretaris zorgde hij voor de subsidiëring van de adviescommissie inzake gerontologisch onderzoek van TNO. ${ }^{92}$ De Minister van Maatschappelijk Werk in deze jaren, F.J.F.M van Thiel, werd na zijn ministerschap voorzitter van de Nederlandse Federatie voor Bejaardenzorg. Staatssecretaris van Cultuur, Recreatie en Maatschappelijk Werk C. Egas volgde dezelfde weg. Niet lang na zijn regeringsperiode werd hij voorzitter van de Nederlandse Federatie voor Bejaardenzorg en vervolgens medewerker van de Jong Oud Trust, waarover later meer. Op die manier stond een relatief klein aantal mensen op een hoog niveau met elkaar in contact. $^{.3}$

Daarnaast zorgden congressen, waarvan de grootste al genoemd zijn, voor ontmoetingen tussen praktijkmensen, ambtenaren, bewindslieden en onderzoekers. Het congres over de oudeliedenzorg, georganiseerd in 1950, was een initiatief van de Nederlandse Vereniging voor Maatschappelijk Werk, in samenwerking met de Nederlandse Vereniging voor Gerontologie. Het congres van 1956 was een co-produktie van de Nederlandse Vereniging voor Gerontologie, de Federatie en het Nederlands Congres voor Openbare Gezondheidsregeling. Volgens de organisatoren moest dit congres - dat door zo'n 1300 mensen werd bezocht - een nationale samenbundeling worden, een monument voor het Nederlandse volk waarbij de natie het bejaardenvraagstuk in al zijn facetten voorgehouden kreeg. ${ }^{94}$ 
Bij een veelkoppig probleem hoorde een brede, landelijke samenwerking, zo was de gedachte. Had Everts' stelling dat het oudeliedenvraagstuk overal hetzelfde was en dus een gemeenschappelijke aanpak vereiste, niet tot een nationale vereniging geleid, een federatieve samenwerking was wél haalbaar gebleken. Die samenwerking werd via gezamenlijk georganiseerde congressen onderstreept: een probleem met vele facetten vroeg, zoals gezegd, om de inzet van verschillende instanties. In de loop van de jaren zestig en zeventig raakte deze alle-schouders-eronder-sfeer op de achtergrond en ontstond een grotere variatie aan opvattingen over de aard van de problemen rond ouderen. Voor een deel hing dat samen met de toenemende, maar bepaald niet onomstreden kritiek op 'apartheidstendensen' binnen het bejaardenwerk zelf. Voor een ander deel had dit te maken met de omstandigheid dat zowel wetenschappelijke instanties als de overheid hun verhouding tot de ouderenproblematiek herformuleerden.

Aanvankelijk begaven de Nederlandse Vereniging voor Gerontologie en de Nationale Commissie voor de Oudeliedenzorg zich gedeeltelijk op hetzelfde terrein. Beide organisaties hadden immers het bevorderen van sociale maatregelen en het stimuleren van wetenschappelijk onderzoek in hun vaandel staan. $\mathrm{Al}$ in het prille bestaan van de vereniging voor gerontologie ontstonden hierover moeilijkheden. Volgens Muntendam en A. Kleijn, burgemeester en bestuurslid van de vereniging, probeerde Sleeswijk lezingen over 'sociale onderwerpen' voortdurend aan de kant te schuiven." Ook het voorstel van de nationale commissie om de gerontologische vereniging tot een sectie van de nationale vereniging voor bejaardenzorg te maken, viel $-\mathrm{zo}$ is besproken - geheel verkeerd. Volgens het officiële standpunt van de gerontologen-vereniging moest het bevorderen van bejaardenzorg in haar geval opgevat worden als 'de bestudering van de wijze waarop de resultaten van research in practische toepassing kunnen worden gebracht'. ${ }^{6}$

Maar ook na de opname van maar liefst drie vertegenwoordigers van de Nederlandse Vereniging voor Gerontologie in het 
bestuur van de Nederlandse Federatie voor Bejaardenzorg bleef de taakverdeling spanningen opleveren. Er waren verschillen van mening over de inhoud van het congres van 1956 - specialistisch en theoretisch versus algemeen en praktisch - en er was verwarring over de betekenis van de gerontologie: in- of exclusief bejaardenzorg. Bovendien liet de vereniging de Federatie in 1957 weten dat zij de wetenschappelijke gegevens die voor het bejaardenbeleid nodig waren wilde verzamelen en daaruit conclusies wilde trekken, maar dat 'de "vertaling" van deze conclusies in beleidsbesluiten (...) buiten haar taak en competentie' viel. ${ }^{.7}$

Steeds vaker lieten de gerontologen weten het niveau van de 'praktijk-studies' te willen overstijgen. Zo stelde de ontwikkelingspsycholoog K.J.M. van de Loo in 1957 dat de veel gebezigde opsomming van psychologische ouderdomskenmerken een willekeurige en niet-systematische aangelegenheid was en dat hij empirisch gefundeerd onderzoek node miste. Elf jaar later schreef de socioloog L. Turksma dat sociologisch bejaardenonderzoek van theoretische aard nog vrijwel ontbrak. En Munnichs noteerde in hetzelfde jaar dat het inmiddels verrichte onderzoek voornamelijk beschrijvend van karakter was en nog te weinig hypothesetoetsend en multidisciplinair. Negen jaar later meende hij dat er te weinig tijd was geweest om het gerontologisch onderzoek in alle rust te ontwikkelen. Onderzoekers waren te snel bij praktijkproblemen betrokken geraakt en te vroeg tot deskundigen gebombardeerd. ${ }^{* x}$

Deze inhoudelijke demarcatie werd ook organisatorisch zichtbaar. In de loop van de jaren zestig kreeg de gerontologie een bredere institutionele basis. Zo ontstonden verschillende werkgroepen, waaronder de Werkgroep Gerontologie Nijmegen. ${ }^{.0}$ Deze werkgroep vond in de tweede helft van de jaren zestig onderdak in het Gerontologisch Centrum Nijmegen. Daarin werkten verschillende instituten samen, waaronder het Gemeenschappelijk Instituut voor Toegepaste Psychologie Nijmegen en de afdeling Ontwikkelingspsychologie van de Katholieke Universiteit. Deze instituten hielden zich, vooral in de persoon van J.M.A. Munnichs, al jaren met gerontologisch onderzoek 
bezig en Munnichs werd in 1972 dan ook lector ontwikkelingspsychologie met nadruk op de psychogerontologie. ${ }^{100}$ Vier jaar eerder was J.Th.R. Schreuder in Utrecht de eerste bijzonder hoogleraar medische gerontologie geworden. Daarnaast werden in de loop van de jaren zeventig en tachtig ondermeer het Nederlands Tijdschrift voor Gerontologie, het Nederlands Instituut voor Gerontologie (NIG) en de Interfacultaire Vakgroep Sociale Gerontologie, de 'opvolger' van het Gerontologisch Centrum Nijmegen opgericht. Bovendien werd een landelijke coördinatie en planning van het gerontologisch onderzoek op gang gebracht. ${ }^{101}$ De nieuwe houding ten aanzien van de praktijk bleek in organisatorisch opzicht echter vooral uit het gegeven dat gerontologen en praktijkmensen steeds vaker los van elkaar studiedagen regelden en dat de Federatie een apart Wetenschappelijk Advies College kreeg. ${ }^{1{ }^{202}}$ Onderzoekers en praktijkmensen werkten nog steeds samen. Maar zij schaarden zich niet meer op dezelfde manier - als één man - rond het 'bejaardenprobleem' als in de jaren vijftig het geval was geweest.

Niet alleen de wetenschap veranderde haar verhouding tot de ouderenproblematiek, hetzelfde gold voor de overheid. Zoals in de vorige paragraaf aan de orde kwam, zag de overheid haar financiële verantwoordelijkheid voor de ouderenzorg in de jaren zestig en zeventig sterk toenemen en formuleerde zij de problemen rond ouderen steeds vaker in termen van collectieve lasten. Hoewel deze manier van denken geleidelijk veld won, riep de wijze waarop de overheid het debat naar zich toe trok, ook verzet op. Zo voelde de Nederlandse Federatie voor Bejaardenzorg zich rond de voorbereidingen van de nota's bejaardenbeleid verschillende malen door de overheid gepasseerd.

Bovendien distantieerden zowel onderzoekers als organisaties op het terrein van ouderenzorg en ouderenbelangen zich op bepaalde punten nadrukkelijk van de inhoud van die nota's. Omdat het welzijn van ouderen niet louter 'zorg', maar een 'gezond beleid' vereiste - dat afweek van dat van de overheid -, werd de naam Nederlandse Federatie voor Bejaardenzorg dan ook vervangen door Nederlandse Federatie voor Bejaardenbe- 
leid. ${ }^{103}$ Tegelijkertijd bezorgden de overheidsnota's praktijkmensen en onderzoekers nieuwe aanleidingen om zich, voor het opstellen van kritisch commentaar, om de tafel te scharen. Daarmee is niet gezegd dat de verschillende organisaties het steeds met elkaar eens waren, maar de nota's gaven, net als de congressen van 1950,1956 en 1963 dat hadden gedaan, de discussies rond ouderen een zekere regelmaat. Iedere nieuwe nota werd door besprekingen, commentaren en alternatieve nota's gevolgd. In 1982 organiseerden de NFB, het Centraal Orgaan van de Samenwerkende Bonden van Ouderen (COSBO), het NIG en de NVG (weer) samen een congres: 'Oud in Nederland'. ${ }^{104}$

In de inleiding van de congresbundel werd met een zekere trots vermeld dat voor het eerst verschillen van inzicht en zelfs tegenstellingen duidelijk waren geworden tussen ouderen onderling. Er bleken behoudende, liberale, progressieve en anarchistische ouderen te bestaan. Bovendien werd er in het woord van welkom op gewezen dat het een illusie was om te denken dat degenen die het beleid voor ouderen ontwierpen, zij die het uitvoerden en zij die de consequenties ervan ondergingen, één geheel vormden. In het idee van de jaren vijftig dat een veelkoppig 'bejaardenprobleem' om een landelijke aanpak vroeg, waren verschillende bressen geslagen. Tussen mensen uit de wetenschap, de praktijk, het beleid en de ouderenbeweging, alsook binnen deze groepen, waren verschillen in mening en aanpak duidelijk geworden. Allianties bleven mogelijk. Maar niet meer rond 'de oude mens', als wel rond 'oudere mensen'. Niet alleen de grenzen van het probleem, maar ook de grenzen van de groep waarover de vele instanties zich bogen, waren aan verandering onderhevig.

\section{Een ongrijpbare groep}

Veel van de organisaties en tijdschriften die aanvankelijk de term 'bejaarden' in hun naam droegen, maakten daarvan in de loop van de jaren zeventig vrijwel geruisloos 'ouderen'. Aan het eind van dat decennium en het begin van de jaren tachtig kreeg ook 
de term 'senioren' populariteit. Op dezelfde manier werden in de jaren vijftig de termen 'oudelieden' en 'ouden van dagen' door 'bejaarden' vervangen.

Deze naamsveranderingen hielden voor een deel verband met de reikwijdte van de zorg. Zo liet de eerder genoemde Van der Spek in de jaren twintig weten dat het begrip 'oudelieden' stond voor mensen in tehuizen en gestichten, terwijl de term 'bejaard' gebruikt werd voor mensen van 65 jaar en ouder. Wanneer zijn interpretatie klopt, wordt het begrijpelijk waarom het na de oorlog regel werd om van 'bejaarden' te spreken: bejaardenzorg omvatte volgens de toenmalige opvattingen immers veel meer dan de zorg in gestichten en tehuizen. Op dezelfde manier werd het woord 'ouderen' in de jaren zeventig een betere vlag voor de activiteiten van veel organisaties dan het woord 'bejaarden'. Hun bemoeienis beperkte zich niet meer tot mensen van 65 jaar en ouder, voor wie de term 'bejaarden' was gereserveerd, maar breidde zich - via de introductie van thema's als de voorbereiding op de pensionering, de oudere werknemer, oudere vrouwen en vervroegde uittreding - uit tot mensen van veertig à vijftig jaar en ouder. ${ }^{\text {10s }}$

De naamswijzigingen hadden niet alleen te maken met taakuitbreidingen, maar ook met verschuivingen in de gevoelswaarde van de begrippen. Volgens Lely had de Unie van Vrouwelijke Vrijwilligers in 1952 officieel besloten de benaming 'ouden-vandagen-werk' te vervangen door 'bejaardenwerk'. Het waren de oude mensen zelf die vaak aanmerkingen op de betiteling 'ouden van dagen' hadden gemaakt. Het woord bejaarden klonk 'warmer en vriendelijker', aldus Lely. ${ }^{106}$ Die klank bleef echter niet stabiel. In 1966 liet staatssecretaris Egas weten niet gelukkig te zijn met het etiket 'bejaarde' dat iedere 65-plusser kreeg opgeplakt. Volgens hem werd die term door zeer velen als kwetsend ervaren. Hij zelf sprak dan ook liever van 'gepensioneerden'. ${ }^{107}$ Egas' afkeer van het begrip 'bejaarde' werd in de loop van de jaren zeventig door steeds meer mensen gedeeld. Hoewel aanvankelijk bedoeld als een neutrale term, werd steeds vaker op negatieve associaties met 'afgedankt zijn', 'hulpbehoevend' en 'isolement' gewezen. Mede om reden van die associaties werd het 
woord door deskundigen, overheidsvertegenwoordigers, organisaties rond ouderen en tijdschriften in toenemende mate vermeden. ${ }^{\text {tox }}$

Maar het bleef moeilijk het juiste woord te vinden. 'Wij zijn allemaal op de hoogte van de subtiele strijd die er woedt rond de naamgeving aan bejaarden, pardon ouderen, sorry senioren, oh nee, 65-plussers (...)', schreef de redactie van het tijdschrift Leeftijd in 1977 . 'Iedereen wacht op de ideale, onbesmette naam, het magische woord, waarmee het bejaardenprobleem dan als vanzelf uit de wereld zal worden geholpen. ${ }^{109}$ Zo gemakkelijk bleek het echter niet te zijn.

De verschuiving in de naamgeving van ouderen had niet alleen te maken met de reikwijdte van de zorg en de gevoelswaarde van woorden. De onmogelijkheid een eenduidig begin van de ouderdom aan te wijzen en kritiek op de veronderstelde homogeniteit van de groep bejaarden speelden ook een rol.

Van de jaren twintig tot de jaren tachtig vroegen deskundigen zich af wanneer de ouderdom nu precies begon. Vrijwel niemand kon daarop een eenduidig antwoord leveren. Van der Spek zocht in alle hoeken en gaten, maar vond zelfs de leeftijdsgrens voor pensioenregelingen geen geschikt criterium voor het begin van de ouderdom. Slechts de manier waarop iemand zijn jaren droeg en zijn 'involutie' onderging, bepaalde of iemands oude dag was begonnen. Een proces dat per individu sterk kon verschillen, zo vond Van der Spek. Zijn visie bleef hoogst actueel. Er waren artsen die de grens tussen volwassenheid en ouderdom bij het 'climacterium' legden, maar volledig zeker van hun zaak waren zij doorgaans niet. ${ }^{.10}$

Bovendien werd, vooral door psychologen en artsen, tot in den treure vermeld dat de ouderdom vele gedaanten en typen kende en dat de verschillen tussen oude mensen - mede door hun uiteenlopende levensgeschiedenissen en ervaringen - groot waren. ${ }^{11 t}$ Vaak werd deze constatering gevolgd door een uiting van twijfel over juistheid van een uniforme leeftijdsgrens voor de pensionering. Wanneer oude mensen in hun geestelijke en lichamelijke conditie zo sterk van elkaar verschilden, was de 
alomtegenwoordige 65 -jaren grens dan wel reëel? De meeste deskundigen legden zich dan ook alleen in sociologische zin bij de 65-jaren grens neer. 'Voorshands', schreef Diederich na een uiteenzeting van de beperkingen van die grens, 'zal evenwel de leeftijdsgrens van 65 jaar als begin van bejaard zijn gehandhaafd blijven, temeer daar onze tijd gedwongen is haar sociale voorzieningen met behulp van concreet meetbare criteria in toepassing te brengen. ${ }^{112}$

In het verlengde van de nadruk op het diffuse begin van de ouderdom en de variatie onder bejaarden, lag de bewering dat de ouderdom sterk met andere levensfasen verbonden diende te zijn. Een van de meest consequente verdedigers van dit perspectief was Munnichs. 'Ongetwijfeld is het menselijker en getuigend van meer beleid', zo schreef hij, 'uit sociaal-hygiënisch oogpunt, meer zorg te dragen voor een geleidelijk overgaan van de verschillende levensphasen in elkaar, dan een levensperiode van de andere af te zonderen en dan te bezien. Door de eenheid van de verschillende levensperioden voorop te stellen, wordt de ouderdom beslist eerder als een normaal en naar verkiezing zegenrijk levenstijdperk gewaardeerd dan als een vervelend sluitstuk van een overigens acceptabel verblijf op aarde. ${ }^{\text {"II }}$ Munnichs stond in zijn opvattingen niet alleen. In de jaren zeventig werd deze gedachte zelfs de expliciete doelstelling van een aan Humanitas gerelateerde organisatie: de Jong Oud Trust - 'voor een ononderbroken levensloop'. Aan dergelijke gedachten gaf de Nederlandse Federatie voor Bejaardenzorg in haar publikaties eveneens een centrale plaats. Begrippen als 'proces', 'preventie', 'ouderen', 'de tweede levenshelft' en 'de derde levensfase' sloten bij deze benadering aan. ${ }^{1 / 4}$

Analoog daaraan werd ook de gedachte dat bejaarden een grijpbare, aparte groep vormden zeer vaak ter discussie gesteld. Het begrip 'bejaarde', zo beweerde de sociaal econoom A.A. Wirtz in 1956 , was hoofdzakelijk een modern, sociologisch begrip dat niets zei over biologische veranderingen, capaciteiten, welstand en klasse. "' Zorg voor bejaarden, zo meenden velen in de jaren zestig, was niet afhankelijk van het overschrijden van de 65-jarige leeftijd, maar hing af van de mensen en omstandighe- 
den in kwestie. De toon van dit type beweringen werd in de jaren zeventig stelliger en radicaler. 'De bejaarde bestaat niet!', riep de voorzitter van de samenwerkende ouderenbonden. De aanwezigheid van de groep 'bejaarden' was geen onproblematische werkelijkheid, zo betoogden verschillende auteurs als sociaalconstructivisten avant-la-lettre, maar was een gevolg van bureaucratische maatregelen als pensioenvoorzieningen. ${ }^{116}$

Toch deden deze opmerkingen en overwegingen het spreken in termen van afgebakende categorieën niet verdwijnen. Integendeel: het gebruik van categorieën werd zelfs uitgebreid en verfijnd. Zo werd in het midden van de jaren zestig - naar een buitenlands voorstel-een nieuwe indeling overwogen. De mensen tussen de 45 en 59 jaar zouden 'van middelbare leeftijd' heten. $\mathrm{Zij}$ die tussen de 60 en de 74 jaar oud waren, zouden 'ouderen' genoemd worden. Wie een leeftijd tussen de 75 en 89 had bereikt, zou als 'bejaarde' door het leven gaan, terwijl degenen van 90 jaar en ouder tot de 'hoogbejaarden' zouden worden gerekend. ${ }^{117}$ De precieze grenzen van deze indeling kregen geen 'harde' status, maar het onderscheid tussen ouderen en hoogbejaarden werd in de loop van de jaren zeventig en tachtig steeds gebruikelijker. ${ }^{n k}$

Deze spanning tussen het spreken in termen van een onderscheiden groep en het ter discussie stellen van de grenzen, homogeniteit en het 'werkelijk bestaan' van diezelfde groep, bestond gedurende de gehele besproken periode. De aard van die spanning veranderde: terwijl in de jaren vijftig sprake was van een voorzichtig geuite twijfel over de juistheid van de grenzen en het al te gemakkelijk samenvoegen van uiteenlopende individuen onder één noemer, was in de jaren zeventig iedere afbakening - met bijbehorende 'status aparte' - in principe verdacht. Het verschuiven van de aanduidingen van de groep waar om het ging, van 'oudelieden' en 'ouden van dagen' via 'bejaarden' naar 'ouderen' en 'senioren', loste die spanning niet op. Iedere verschuiving betekende een tijdelijke neutraliteit en een tijdelijk betere lading van de activiteiten die organisaties en deskundigen ondernamen. Maar al zocht iedereen naar het magische woord dat het 
bejaardenprobleem zou doen 'oplossen', de paradox tussen het spreken in termen van categorieën en de kritiek daarop bleef een constante. Niet zonder reden, zo zal in het derde hoofdstuk duidelijk worden.

\section{Een uitgemaakte zaak?}

De grenzen van de groep veranderden, het profiel van het probleem verschoof. Wat aanvankelijk de essentie van de kwestie werd geacht, werd later perifeer. Wat eerst geoorloofd was, werd later verdacht. Maar wat maakte dit alles uit? Wat betekenden de grenzen van het probleem bij voorbeeld voor datgene wat in Nederland ten aanzien van ouderen werd gedaan?

Onderzoekers van andere, maar soortgelijke problemen hebben erop gewezen dat die betekenis vooral ligt in het vastleggen van oorzaak-en-gevolg-relaties en daarmee van het type oplossingen dat in zicht komt. Daarbij maakt een deel van hen een onderscheid tussen sociale en publieke problemen: niet alle sociale problemen zijn immers voorwerp van publieke discussie. ${ }^{199} \mathrm{Zo}$ was ziekteverzuim lange tijd een sociaal, maar geen publiek probleem. Aangezien over 'het vraagstuk der oudeliedenzorg', 'het bejaardenprobleem' en 'het vergrijzingsvraagstuk' wel degelijk een publiek debat werd gevoerd, kan hier van publieke problemen worden gesproken. Inderdaad zijn de daarin gelegde oorzaak-en-gevolg-relaties van belang. Het maakt nogal wat uit of de oorzaak van 'het bejaardenvraagstuk' wordt gezocht in een onvermijdelijk geachte overgang naar een industriële maatschappij, of in een als maakbaar beschouwde mentaliteit en inrichting van een samenleving. In het eerste geval wordt die maatschappij niet, en in het tweede geval wel veranderbaar geacht. Dat geeft op zijn minst aan waar de sleutels tot oplossingen wel en niet te vinden zijn en welke instanties daarvoor verantwoordelijk geacht kunnen worden.

Bovendien liggen - en ook dit is ontleend aan het werk van anderen over publieke problemen - opties voor oplossingen besloten in het gebruik van metaforen, homerische vergelijkingen 
en retorisch idioom. ${ }^{120}$ Het hanteren van metaforen als 'het dichten van de dijk' en het tot stand brengen van 'een gesloten circuit' van zorg, veronderstelt dat alle behoeften van bejaarden gekend kunnen worden en dat bij al deze behoeften aansluitende voorzieningen gezocht of gecreëerd moeten worden. Die manier van denken leidde tot een voortdurende roep om onderzoek naar de werkelijke behoeften van bejaarden. Ook zijn er vele voorstellen gedaan tot nieuwe voorzieningen en coördinerende instanties die het circuit zouden kunnen sluiten. Daarnaast had de homerische vergelijking tussen de eeuw van het kind en 'de eeuw der ouderdom' invloed op het scala van voorgestelde oplossingen. Verschillende ideeën voor voorzieningen - consultatiebureaus, bejaardenconcerten, de medische zorg van een geriater - werden ontleend aan of verdedigd onder verwijzing naar bestaande voorzieningen voor kinderen. Hetzelfde fenomeen deed zich voor bij het spreken in termen van een bepaald idioom. Voorbeelden daarvan waren formuleringen aan de hand van het vocabulair van 'het verlies' (het verlies van een wereld waarin ouderen nog gezag hadden) en 'de ramp' (vergrijzing als ramp). Een gevolg van het betoog met 'een verlies' als kern was, dat bescherming van het object dat onder het verlies te lijden had (de bejaarde) de vanzelfsprekende remedie leek. Een consequentie van het spreken in termen van 'een ramp' of 'acute noden' was, dat daarmee de noodzaak tot onmiddellijke en boven alle partijen staande actie geïmpliceerd werd.

Dit alles neemt niet weg dat de gehanteerde 'probleemprofielen' slechts de richting van mogelijke oplossingen vastlegden en zo de keuze voor concrete oplossingen veelal open lieten. Ook wanneer wel een voorstel tot een concrete oplossing werd gedaan, zei dat nog niets met zekerheid over de uiteindelijke praktijk. Zo schoot de organisatie ('een nationale vereniging') die door Everts uit de aard van het probleem ('het oudeliedenvraagstuk is overal hetzelfde') werd afgeleid, immers geen wortel. Evenmin werden de consultatiebureaus en concerten voor bejaarden werkelijkheid, althans niet in de oorspronkelijk voorgestelde vorm. Tussen de voorstellen voortvloeiend uit het profiel van een probleem en de praktijk van alledag lagen principiële 
meningsverschillen, praktische overwegingen en politieke strategieën die buiten de algemeen gedeelde typeringen van de problemen vielen.

Aan de hand van deze opmerkingen kan - net als in het vorige hoofdstuk - nogmaals worden geconstateerd dat de kracht van bepaalde 'definities' van de ouderdom (of de daarmee verbonden problematiek), anders dan veel van het definitie-onderzoek suggereert, allerminst vanzelfsprekend is. Tussen het in kaart brengen van die definities en de stelling dat daarmee de ouderdom op een bepaalde manier wordt geconstrueerd (geïnstitutionaliseerd, afhankelijk gemaakt, gemedicaliseerd), ontbreekt een schakel. Wat moet worden onderzocht is de mate waarin en de manier waarop de grenzen van de ouderdom als publiek probleem - of als sociale categorie, levensfase etcetera - in een bepaalde praktijk verankerd raken: in organisaties, regelingen en voorzieningen. De verschuivingen in de grenzen van het probleem maken die vraagnog intrigerender: want hoe konden voorzieningen ondanks dergelijke verschuivingen overleven? Tegelijkertijd suggereert het onderzoek naar publieke problemen dat in het gebruik van bepaalde metaforen, vergelijkingen en retorische wendingen constantes aanwezig zijn, die het specifieke van het 'bejaardenprobleem' overstijgen. Juist deze combinatie van bepaalde mechanismen in de ontwikkeling van grenzen en de lokale variaties in de mate waarin en manier waarop die grenzen verankerd raken, is interessant, maar wordt in het huidige definitie-onderzoek niet gethematiseerd. Om dit thema tot haar recht te laten komen, is het nodig om theorieën te zoeken die zijn toegespitst op een bepaald type grens. Bovendien moeten de lotgevallen van een specifieke grens nauwkeurig worden gevolgd.

De vraag naar datgene wat de grenzen van het probleem deed veranderen, kan op basis van dit hoofdstuk evenmin op dezelfde manier beantwoord worden als in het definitie-onderzoek gebeurde. In dat onderzoek wordt de inhoud van definities steeds herleid tot de functie van die definities voor de moderne of kapitalistische samenleving. Het verschuiven van grenzen is in dit hoofdstuk echter met zeer verschillende zaken in verband gebracht. 
Op twee manieren zijn die verbanden in de voorafgaande paragrafen - zij het impliciet - aan de orde geweest. In de eerste plaats is in de bespreking van de naoorlogse periode verschillende keren gewezen op 'achtergronden' die tijdgenoten zelf in hun teksten en redes mobiliseerden. Zo kwam aan de orde dat deskundigen direct na de oorlog de problemen rond ouderen als acuut beschreven onder verwijzing naar de chaos van die jaren. Een ander voorbeeld is de manier waarop auteurs in de jaren zeventig hun verwachtingen omtrent de emancipatie van ouderen ontleenden aan het gedrag van jongeren van die tijd. Weer een ander voorbeeld is de wijze waarop de overheid de veranderde financiële situatie aanhaalde ter verdediging van haar typering van de essentie van het vergrijzingsvraagstuk.

In de tweede plaats is in de bespreking van het interbellum gewezen op kaders waaraan niet door de tijdgenoten zelf werd gerefereerd. Zo is over die periode gezegd dat bevolkingsveroudering - hoewel als verschijnsel al in de jaren twintig bekend juist in de jaren veertig binnen de oudeliedenzorg een relevant gegeven werd, omdat in de jaren daarvoor de oudeliedenzorg zich van de lagere naar de hogere standen uitbreidde en naast armoede 'sociale omstandigheden' en 'validiteit' als criteria voor hulp begon te hanteren. Hier ging aan het leggen van een verband tussen demografie en zorglast dus een interventie, gebaseerd op een ander vermeend probleem, vooraf. Bovendien werd de aandacht voor de mentaliteit van een oude bevolking verbonden met de geest van de tijd: een periode waarin zaken als de kracht van een volk en het voortbestaan der natie veel mensen bezighielden.

De verklarende kracht van een dergelijk kader - de tijdgeest - is echter beperkt. Het maakt de aandacht voor bepaalde zaken in bepaalde perioden weliswaar begrijpelijk, maar verschuift het probleem van de verklaring naar de tijdgeest zelf. De manier waarop problemen rond ouderen getypeerd werden, stond zelden op zichzelf en was veelal niet uniek. Zo vertoonde in de jaren vijftig het betoog over de problemen van leegte die voortvloeiden uit de overgang van een agrarische naar een industriële samenleving, grote verwantschap met de typeringen van de pro- 
blemen van de (massa)jeugd in die jaren. En de stelling dat niet het individu, maar de maatschappij zélf verbeterd moest worden, was in de jaren zeventig niet alleen in de ouderensector populair, maar ook in de geestelijke gezondheidszorg en de huisartsgeneeskunde. ${ }^{121}$ Maar, zoals gezegd, een bespreking van dergelijke parallellen biedt nog geen verklaring.

Ook een - op het eerste gezicht relevant lijkende - verwijzing naar professionele belangen is ter verklaring voor de constanten en verschuivingen in het denken over problemen rond ouderen niet toereikend. Dat in het benoemen van problemen van ouderen voor bepaalde beroepsgroepen ook een zeker eigenbelang besloten lag, zal niemand verbazen. In het debat over de problematiek van ouderen werd daar soms op gewezen. ${ }^{13}$ Maar dat verklaart de verschuivingen in het denken over problemen rond ouderen nog niet. Weliswaar valt soms de oorsprong of verdediging van een gedachte tot een bepaalde professie te herleiden - zo was het transitie-betoog in de eerste plaats een historisch-sociologisch betoog - maar daarmee is de overname en in$z e t$ van die gedachte door anderen nog niet verklaard. Hoe vanzelfsprekend een dergelijke overname - bij voorbeeld op grond van gemeenschappelijke economische belangen - voor een deel van de definitie-onderzoekers ook is, opnieuw is de vraag of, door wie en hoe bepaalde denkbeelden worden overgenomen en in de praktijk worden ingebed, van groot belang. Het 'inbeddingsverloop' van een specifieke probleemschets in een voorziening zal in het zesde hoofdstuk aan de orde komen. Het onderzoeken van de bijzondere ontwikkeling en verankering van andere typen grenzen zal in de hoofdstukken drie tot en met vijf centraal staan.

\section{Slot}

Mensen die beweren dat het probleem van vergrijzing al sinds de jaren twintig op de nationale agenda staat, hebben zowel gelijk als ongelijk. Dat Nederland vergrijst was bij de directeur van het Centraal Bureau voor de Statistiek en vele anderen inderdaad al 
in de jaren twintig bekend. Maar de problemen die in de loop van de decennia aan bevolkingsveroudering werden gekoppeld, waren in het begin van de jaren tachtig voor een belangrijk deel andere dan in de jaren twintig. Vergrijzing hield een prominente plaats in toekomstscenario's. Maar het profiel van het vergrijzingsprobleem kreeg een andere omtrek en inhoud: de grenzen van het publieke probleem van de bevolkingsveroudering verschoven. Tussen het 'tal' en de 'last' van ouderen werden andere schakels gevlochten die aangaven wat binnen en buiten de problematiek van vergrijzing viel.

Er waren kwesties waarvan de aard gedurende de hier behandelde zestig jaar niet wezenlijk veranderde. Vooral de bemoeienis van economen met het probleem van de demografische druk moet hiertoe worden gerekend, al werd het probleem in tijden van economische voorspoed uit de aard der zaak minder nijpend geacht dan in perioden van recessie. Een andere constante was het voortdurend ter discussie stellen van het spreken in termen van categorieën, hoewel dat spreken zelf niet werd afgeschaft. De 'noemers' veranderden - oudelieden, ouden van dagen, bejaarden, ouderen, senioren - onder invloed van veranderende gevoelswaarden en het zich wijzigende takenpakket van de vele instanties. Maar de deler, het afbakenen van een groep, bleef gelijk. Steeds opnieuw werden de grenzen van de groep waarom het ging, aangegeven.

Ondanks deze constanten verschilden de typeringen van de problemen rond ouderen niettemin sterk van elkaar. De aandacht van het interbellum voor datgene wat het aantal oudelieden met de mentaliteit van een natie zou kunnen doen verdween, terwijl de bemoeienis met de tehuizen voor de betere standen en minder validen in de jaren veertig oploste in bredere concepten van zorg voor ouden van dagen. Het 'vraagstuk der oudeliedenzorg' en 'het bejaardenprobleem' van de jaren na I945 stonden in het teken van acute noden waarvan de urgentie onderstreept werd door demografische veranderingen, een vergelijking met het kindervraagstuk en de opsomming van facetten die grotendeels parallel liepen met de bestaande en gewenste voorzieningen. In het 'bejaardenvraagstuk' kwamen deze aspec- 
ten terug, maar werd tevens de hoofdoorzaak van de problemen gedefinieerd: de overgang van een traditionele naar een moderne samenleving. Het isolement en de nutteloosheid van bejaarden, volgens sommigen nog eens versterkt door hun toenemend aantal, werden in deze jaren de meest elementaire noden van bejaarden geacht. De hoofdtherapie voor deze noden bestond uit een aanpassing van de bejaarde aan de gewijzigde omstandigheden. De omstandigheden zelf werden echter ongemoeid gelaten. In de jaren zeventig was het daarentegen juist de maatschappij die het moest ontgelden in haar neiging de bejaarden naar de marge te drukken. In de tweede helft van de jaren zeventig, ten slotte, verschoof de aandacht opnieuw. De hoge aantallen ouderen werden bijna synoniem met collectieve uitgaven en steeds vaker werden de gevolgen van bevolkingsveroudering in economische termen omschreven. Voor of tegen bezuinigingen: zorgen rond financiën werden een belangrijk criterium voor de mate waarin iets problematisch werd geacht.

In de beschouwingen over de problemen die met bevolkingsveroudering gepaard gingen, werd steeds - impliciet of expliciet - aangegeven welke moeilijkheden centraal of perifeer waren en welke kwesties binnen en buiten de grenzen van het probleem vielen. Ook werd via oorzaak-en-gevolg-relaties, metaforen, vergelijkingen en retorisch idioom gesuggereerd wie het probleem moest oplossen en hoe dat moest gebeuren. Daarin bleek het debat rond het 'tal' en 'last' van ouderen niet uniek: de opbouw van publieke problemen kent bepaalde veel voorkomende vormen. Aan de andere kant werd duidelijk dat een bepaald profiel van een probleem niet automatisch tot een bepaalde praktijk leidt. Daarmee kon opnieuw kritiek worden geleverd op de macht die binnen het definitie-onderzoek aan definities van de ouderdom - en de 'ontwerpers' van die definities wordt toegeschreven. Bovendien werd ook wat de achtergronden van het ontstaan en verschuiven van 'probleemprofielen' betreft op een grotere diversiteit gewezen dan in veel van het definitie-onderzoek het geval is.

Bij kritiek op het definitie-onderzoek kan het echter niet blijven. In de drie hoofdstukken hierna zullen de vooralsnog 
ontbrekende schakels tussen het ontstaan van een bepaalde grens en de betekenis van die grens voor de praktijk centraal staan. Daarbij zijn steeds die theoretische perspectieven ingezet die het mogelijk maken om de ontwikkeling van een bepaalde grens nauwkeurig te volgen. Tegelijkertijd kan met behulp van deze perspectieven duidelijk worden gemaakt dat de lotgevallen van de grenzen van de ouderdom op meer dan alleen toevalligheden zijn gebaseerd. Dat gold zeker voor de grenzen van de ouderdom als sociale categorie: het onderwerp van het volgende hoofdstuk. De eerder geciteerde stelling van Diederichs - dat zijn tijd gedwongen was haar sociale voorzieningen in concreet meetbare criteria in toepassing te brengen - vormt daarvoor de ideale opmaat. 


\section{Vrouw, ongehuwd en oud: de verzorgingsstaat en het onderscheid naar sociale categorie ${ }^{\mathrm{I}}$}

I Inleiding

Met zijn opmerking dat de leeftijdsgrens van 65 jaar als begin van het bejaard-zijn gehandhaafd moest blijven omdat zijn tijd nu eenmaal gedwongen was sociale voorzieningen in concreet meetbare criteria toe te passen, zou Diederich niet hebben misstaan tussen de levensloop-sociologen die in het eerste hoofdstuk ter sprake kwamen. Auteurs als Kohli en Chudacoff menen immers dat de standaardisering van de levensloop - en daarmee de pensionering - functioneel is voor de moderne samenleving. Een moderne, complexe maatschappij kan niet zonder dergelijke organisatorische ingrepen, aldus Chudacoff.

Hoewel deze auteurs daarmee een verklaring geven voor het ontstaan van scherpe grenzen tussen levensfasen en het ingeburgerd raken van onderscheiden leeftijdsgroepen, valt op grond van hun functionalisme niet af te leiden waarom bepaalde grenzen vastgelegd worden en andere niet. Hun blik is in de eerste plaats gericht op geslaagde vormen van standaardisering, niet op mislukte pogingen om die standaardisering teniet te doen of om alternatieve standaarden ingang te doen vinden. Ook is, zo kwam in het eerste hoofdstuk al ter sprake, niet duidelijk hoe het gedrag van individuen zich tot die standaardisering verhoudt. Kohli wil uitdrukkelijk aandacht voor de spanning tussen de levensloop als sociaal geordende realiteit en de biografie in termen van individuele perspectieven en handelingen. Maar hoe dat het beste tot zijn recht kan komen, werkt Kohli niet uit. Standaardisering lijkt zich, ook in het werk van veel andere levensloop-sociologen, toch vooral over de hoofden van burgers heen af te spelen. 
In dit hoofdstuk worden een geschiedenis en een perspectief gepresenteerd die het ontstaan en verschuiven van de grenzen van de ouderdom als sociale categorie kunnen verhelderen. Anders dan bij de levensloop-sociologen, bij wie het onderscheid tussen levensfasen en leeftijdscategorieën in één theoretisch kader wordt ondergebracht, gaat het hier uitdrukkelijk om de grenzen tussen sociale categorieën. Anders is ook, dat het hier niet gaat om het louter aandragen van een voorbeeld van standaardisering, maar om het analyseren van een mislukte poging om voor een bepaalde categorie mensen van een standaard af te wijken: de pensioengerechtigde leeftijd van 65 jaar. Tegelijkertijd wordt een perspectief geĭntroduceerd waarmee twee kwesties verhelderd kunnen worden. Aan de ene kant kan dit perspectief inzichtelijk maken waarom het denken in termen van een 'afgebakende' categorie in discussies over ouderen, ondanks jarenlange kritiek op de nadelen van die categorisering, niet werd losgelaten. Aan de andere kant kan duidelijk worden gemaakt dat niet alleen de overheid, maar ook burgers zelf een hand kunnen hebben in het doen ontstaan en verankeren van nieuwe grenzen tussen sociale categorieën.

De geschiedenis waar het om gaat, is het debat over de verlaging van de pensioengerechtigde leeftijd voor ongehuwde vrouwen (paragraaf 3, 4 en 5). Dit debat, waarin de meest belangrijke ontwikkelingen zich voordeden tussen 1955 en 1980 , werd gevoerd binnen en tussen het parlement, adviesraden en belangengroepen. Het theoretisch perspectief dat ingezet zal worden, is ontleend aan de rechtssocioloog C.J.M. Schuyt (paragraaf 2). Zijn stellingen over het rechtskarakter van de verzorgingsstaat verhelderen op welke manier en door wie in de context van de verzorgingsstaat grenzen tussen sociale categorieën worden aangebracht. Juist het door hem aangedragen kader maakt het - zij het in geamendeerde vorm - mogelijk om het trekken van grenzen tussen sociale categorieën en de eventuele verankering van die grenzen in wetgeving te begrijpen zonder 'almacht' aan de overheid toe te schrijven. 


\section{Een moderne tragedie}

Eind jaren zeventig zag Schuyt de toekomst van de verzorgingsstaat somber in. ${ }^{2}$ Het lot ervan zou nog het best te vergelijken zijn met dat van een held in een moderne tragedie. Gedreven door de wens recht te doen, richt deze held zichzelf ten gronde. Met zijn 'verdelende rechtvaardigheid' zou de verzorgingsstaat een oneindige waaier van eisen hebben opgeroepen die niet weerlegd, maar evenmin waargemaakt konden worden.

De verzorgingsstaat, zo luidde het startpunt van Schuyts betoog, neemt de verdeling van goederen en diensten aan individuen over daar waar 'de markt' of 'de charitas' in die verdeling tekortschieten. De manier waarop de verzorgingsstaat verdeelt, verschilt echter wezenlijk van die van de andere twee domeinen. Bij de overheid verloopt de allocatie van goederen en diensten niet via het prijsmechanisme (als op de markt) of naar willekeur (als in de charitas), maar via het toekennen van formele rechten. Die formele rechten roepen via precedentwerking, algemeen geformuleerde regels en de eis tot rechtsgelijkheid per definitie vergelijkingen op. Groepen burgers vergelijken zich met anderen, zien 'onrechtvaardige' verschillen en stellen nieuwe eisen. De stijging van verwachtingen die zo ontstaat wordt versneld doordat wetgeving - met haar scherpe afbakening van rechthebbenden - dwars door traditionele groepen heen 'sociale categorieën' creëert. Die categorisering leidt niet alleen tot een gefragmenteerd mensbeeld en een gefragmenteerd bestuur, maar ook tot nieuwe belangengroepen en een eindeloze 'emancipatie van deelbelangen'.

In de praktijk wordt, aldus Schuyt, een groot deel van de potentiële rechten en claims niet in wetgeving omgezet. Maar wanneer groepen eenmaal hun verlangens ontdekt en geformuleerd hebben, kan de overheid het verdelingsproces niet stopzetten zonder haar eigen principes te verloochenen. Bovendien beschikken beleidsmakers niet over 'interne sleutels' aan de hand waarvan beslist kan worden welke eisen wel of niet gehonoreerd kunnen worden. Daar komt bij dat politici niet graag de steun van groepen kiezers verliezen. Daarom zullen zij eerder beweren 
dat een bepaalde wens door omstandigheden (nog) niet te verwezenlijken is, dan dat die wens niet gerechtvaardigd is.

Zo zou de verzorgingsstaat zijn noodlot tegemoet hollen, meende Schuyt. Die stelling bleek echter niet zondermeer houdbaar. Schuyts gedachte dat burgers zich voortdurend vergelijken met mensen met wie zij wél bepaalde kenmerken maar niet bepaalde rechten gemeen hebben, werd op empirische gronden aangevochten. Categorieën die jarenlang in een slechte positie verkeerden, zoals langdurig werklozen, bleken zich nauwelijks te vergelijken met groepen die het beter hadden, maar zich juist te spiegelen aan groepen die in soortgelijke situaties verkeerden. De neerwaartse spiraal van ontevredenheid trof dus niet iedereen. Dat buurmans gras altijd groener was, leek vooral de preoccupatie van de maatschappelijke middenmoot. ${ }^{3}$

Schuyts veronderstelling dat de verzorgingsstaat, gevangen in rechtsregels zonder interne verdeelsleutels, amper de mogelijkheid zou hebben om de principiële rechtmatigheid van nieuwe eisen te weerleggen, werd echter niet ter discussie gesteld. Hier zal dat, aan de hand van een geschiedenis van een verworpen wens, wél gebeuren. Die geschiedenis betreft het jarenlange debat tussen parlementsleden, belangengroepen en bewindslieden over een eventuele verlaging van de pensioengerechtigde leeftijd voor ongehuwde vrouwen binnen de Algemene Ouderdomswet (AOW). Via een analyse van de argumenten voor en tegen deze verlaging zal duidelijk worden dat sociale vergelijkingen en verwijzingen naar rechtsgelijkheid en precedentwerking niet alleen bij de identificatie en introductic van een eis, maar ook bij de afwijzing ervan een grote rol kunnen spelen. In het debat over de pensioengerechtigde leeftijd werden de vergelijkingen van de 'eisers' door de 'verdedigers' gediskwalificeerd én gepareerd met alternatieve vergelijkingen. Door de relevantie van de oorspronkelijke vergelijkingen te betwijfelen, konden de verdedigers ook de rechtvaardigheid van de bijbehorende claims ontzenuwen.

Schuyts stelling dat juist het juridische karakter van de overheidsallocatie de verzorgingsstaat in een fuik doet lopen, wordt in dat licht minder overtuigend. De wapens van vergelijking, rechtsgelijkheid en precedentwerking staan in principe immers 
zowel de burgers (voor het inkleden van een eis) als de overheid (voor de afwijzing van een eis) ter beschikking. Dat wil niet zeggen dat Schuyts schets van de stijgende verwachtingen niet juist zou zijn. Evenmin betekent dit dat het intrekken van bestaande rechten niet tegen de uitgangspunten van de verzorgingsstaat indruist. Zelfs nu nog - in tijden waarin de gehele sociale verzekeringswetgeving ter discussie staat - stuit het intrekken van bestaande rechten op grote politieke bezwaren. Er is echter geen reden om te veronderstellen dat juist het rechtskarakter van de verzorgingsstaat het moeilijk zou maken om de rechtvaardigheid van nieuwe eisen te weerleggen. Uiteraard zijn er electorale en vele andere overwegingen die politici kunnen doen besluiten een nieuw recht toe te kennen. Maar het rechtskarakter zélf bezorgt - zo zal worden geillustreerd - de staat allesbehalve een zwak afweersysteem.

Aan de hand van de geschiedenis hieronder en de deels geamendeerde stellingen van Schuyt kan bovendien duidelijk worden gemaakt dat het rechtskarakter van de verzorgingsstaat het spreken in termen van categorieën, en daarmee grenzen, weliswaar oproept, maar dat daarmee nog niet gezegd is welke grens wel en welke niet een wettelijke status bereikt. Het rechtskarakter van de verzorgingsstaat verheldert de manier waarop in de context van die verzorgingsstaat grenzen tussen sociale categorieën tot stand komen en laat zien hoe uiteenlopende groepen ook ouderen zelf - daarin hun partij meeblazen. Het lot van de oudere ongehuwde vrouwen illustreert echter tegelijkertijd dat de bakens tussen sociale categorieën zoals wij die nu kennen bakens die door bepaalde sociologen als bewijzen voor een standaardisering van de levensloop worden gezien - niet 'logisch' voortvloeien uit een rationaliseringsproces. Want ook op dit terrein werden politieke keuzen gemaakt.

De geschiedenis van de 'strijd' voor een lagere pensioengerechtigde leeftijd voor ongehuwde vrouwen begon bij de indiening van het wetsvoorstel voor de Algemene Ouderdomsvoorziening in 1955 en eindigde rond 1980 . Dat betekent niet dat de kwestie daarvoor of daarna nooit aan de orde was. Maar de hier besproken periode biedt voldoende informatie om de hoofdstel- 
lingen van dit hoofdstuk te illustreren. Schuyt zélf schreef dat zijn analyse van de verzorgingsstaat door gedetailleerd onderzoek bevestigd of ontkracht diende te worden. Hier volgen de details.

\section{Deelbelang en belangengroep}

\section{Een spel van vergelijkingen}

Het wetsontwerp voor de Algemene Ouderdomsverzekering van 1955 gaf mannen én vrouwen vanaf 65 -jarige leeftijd recht op een zelfstandig ouderdomspensioen. Alleen de gehuwde vrouw kreeg dat recht in principe niet. Voor haar zou gezorgd worden via het 'gehuwdenpensioen' dat de gehuwde man vanaf zijn $65 s t e$ ontving en waarbij de leeftijd van de echtgenote er niet toe deed. Met de voorgestelde AOW-gerechtigde leeftijd van 65 jaar konden vrijwel alle Tweede-Kamerleden instemmen. Slechts enkelen meenden dat het ontwerp onvoldoende rekening hield met het feit dat de pensioengerechtigde leeftijd voor vrouwen 'eigenlijk 60 jaar' was. 'Daarbij doelden de betreffende kamerleden waarschijnlijk op het verschijnsel dat in verschillende bedrijfs- en ondernemingspensioenfondsen de pensioengerechtigde leeftijd van vrouwen lager was dan die van mannen.

Noch dit argument, noch latere argumenten brachten veranderingen in de AOW-gerechtigde leeftijd. Misschien hield dat verband met de grote inhoudelijke verschillen tussen de naar voren gebrachte argumenten. Maar die variatie gold niet voor de vorm van de argumenten. Vrijwel steeds werd, conform Schuyts verwachting, een vergelijking gemaakt tussen twee sociale categorieën die op grond van een bepaald kenmerk aan elkaar gelijk waren, maar niettemin ten aanzien van een bepaalde regeling verschillend behandeld werden (of andersom). Om al deze sociale vergelijkingen in beeld te krijgen én straks duidelijk te kunnen maken welke mogelijkheden de verdedigers hadden om de vergelijkingen van de eisers te diskwalificeren of in een andere richting om te buigen, worden de 'vergelijkende' argumenten aan de hand van een 'standaardvergelijking' in een schema ondergebracht. Die standaardvergelijking heeft de volgende vorm: 
Categorie A verschilt van/is gelijk aan categorie B op grond van kenmerk $X$ en wordt terecht/ten onrechte gelijk/verschillend behandeld ten aanzien van regeling $Y$.

De lettertekens achter ieder argument verwijzen naar de gestandaardiseerde vergelijking in het schema op p. 96/97. De verschillende argumenten worden met kleine letters onderscheiden.

De zojuist genoemde opmerking van de kamerleden werd zes jaar later herhaald. In 196r vroegen verschillende leden van de Tweede Kamer de Minister van Sociale Zaken en Volksgezondheid schriftelijk of hij - in afwachting van een nieuwe invaliditeitsverzekering - overwoog om aan ongehuwde vrouwen, gescheiden vrouwen en weduwen zonder weduwenpensioen vanaf 60 jaar een AOW-uitkering te verstrekken. Het antwoord was kort maar krachtig: zo'n maatregel was niet in overweging." Het kamerlid De Wolf (KVP) liet zich daardoor echter niet van slag brengen. Hij wees erop dat in diverse pensioenregelingen in het bedrijfsleven de pensioengerechtigde leeftijd van vrouwen 60 jaar was of dat binnenkort zou worden. Gezien de groeiende communis opinio over deze verlaging was er volgens De Wolf alle reden om met de uitkeringen van de Aow dezelfde kant op te gaan. Wanneer de Aow als een basisvoorziening werd beschouwd waarop de vrije pensioenregelingen konden voortbouwen, dan was het niet meer dan logisch om voor de ongehuwde vrouw de 60-jarige leeftijd in de wet op te nemen. ${ }^{6}(a)$

In hetzelfde jaar werd in de senaat een totaal ander argument gebruikt. Ongehuwde vrouwen, zo betoogde Eerste-Kamerlid Van Bruggen (CHU), betaalden hun hele leven premie voor een weduwenuitkering. Maar het stond als een paal boven water dat zij voor een weduwenrente nooit in aanmerking zouden komen. Een verlaging van de leeftijd voor het ouderdomspensioen tot 60 jaar zou daarvoor dan ook een redelijke compensatie kunnen zijn.? (b) Die gedachte kreeg een jaar later bij de herziening van de Algemene Weduwen- en Wezenwet ( $A$ Ww) een vervolg. De bewuste herziening hield ondermeer in dat weduwen zonder kinderen voortaan een $\mathrm{Aw}$ w-uitkering zouden krijgen wanneer zij bij het begin van hun weduwstaat 40 jaar of ouder waren. 
Argumenten (sociale vergelijkingen) wobr verlaging vas de $A O W$.gerechtigde leeftijd voor ongehwwde vrouwen

\begin{tabular}{|c|c|c|c|c|c|c|}
\hline Catrgorie A & $\begin{array}{l}\text { verschilt nan' } \\
\text { a grilip aan }\end{array}$ & Calrgorie $B$ & $\begin{array}{l}\text { ep grond van } \\
\text { krmmen } X\end{array}$ & $\begin{array}{l}\text { in wardi } \\
\text { imeche } \\
\text { im onrecher }\end{array}$ & $\begin{array}{l}\text { srlijd/ } \\
\text { wernchiliend } \\
\text { behandrld }\end{array}$ & $\begin{array}{l}\text { tia.v. } \\
\text { regeting } Y\end{array}$ \\
\hline $\begin{array}{l}\text { (a) Vrouwen } \\
\text { in de AOW }\end{array}$ & $\begin{array}{l}\text { ajn getijk } \\
\text { aan }\end{array}$ & $\begin{array}{l}\text { vrouwes in } \\
\text { bedrijfspes- } \\
\text { soenres. }\end{array}$ & $\begin{array}{l}\text { (ogev. } \\
\text { selve) }\end{array}$ & $\begin{array}{l}\text { en worden } \\
\text { ten ontechte }\end{array}$ & $\begin{array}{l}\text { verschillend } \\
\text { behandeld }\end{array}$ & $\begin{array}{l}\text { La.v. } \\
\text { pens. get } \\
\text { lechijd }\end{array}$ \\
\hline $\begin{array}{l}\text { (b) Ongehuwde } \\
\text { vrouwen }\end{array}$ & $\begin{array}{l}\text { verschillen } \\
\text { van }\end{array}$ & weduwen & $\begin{array}{l}\text { o.g.v. } \\
\text { borgerlijke } \\
\text { staat }\end{array}$ & $\begin{array}{l}\text { en worden } \\
\text { ten onrechte }\end{array}$ & $\begin{array}{l}\text { gelijk } \\
\text { behandeld }\end{array}$ & $\begin{array}{l}\text { t.a.v. premie } \\
\text { AWW (comp. } \\
\text { via AOW) }\end{array}$ \\
\hline $\begin{array}{l}\text { (e) Oudete } \\
\text { ongehuwde } \\
\text { voumen }\end{array}$ & $\begin{array}{l}\text { ajin pelijk } \\
\text { aan }\end{array}$ & $\begin{array}{l}\text { weduwen en } \\
\text { gescheiden } \\
\text { vrouwen }\end{array}$ & $\begin{array}{l}\text { a.g.v. proble- } \\
\text { matiek arbeid } \\
\text { buiten gezin }\end{array}$ & $\begin{array}{l}\text { en worden } \\
\text { ten onrechte }\end{array}$ & $\begin{array}{l}\text { verschillend } \\
\text { hehandeld }\end{array}$ & $\begin{array}{l}\text { La.visociale } \\
\text { zekertucid }\end{array}$ \\
\hline $\begin{array}{l}\text { (d) Vrouwen } \\
\text { in Nederiand }\end{array}$ & $\begin{array}{l}\text { zijn gelijk } \\
\text { aan }\end{array}$ & $\begin{array}{l}\text { vrouwen in } \\
\text { builenland }\end{array}$ & $\begin{array}{l}\text { (o.g.v. } \\
\text { sekse) }\end{array}$ & $\begin{array}{l}\text { en wonden } \\
\text { ien onrechte }\end{array}$ & $\begin{array}{l}\text { verschillend } \\
\text { behandeld }\end{array}$ & $\begin{array}{l}\text { tas. } \\
\text { pens.ger. } \\
\text { leefind }\end{array}$ \\
\hline $\begin{array}{l}\text { (e) Vrouwe- } \\
\text { like ambte- } \\
\text { naven }\end{array}$ & $\begin{array}{l}\text { vernchillen } \\
\text { van }\end{array}$ & $\begin{array}{l}\text { mannelijke } \\
\text { ambienaren }\end{array}$ & $\begin{array}{l}\text { o.g. } \\
\text { verhoogde } \\
\text { aanvraat } \\
\text { imv.penvioen }\end{array}$ & $\begin{array}{l}\text { en worden } \\
\text { ten onrechie }\end{array}$ & $\begin{array}{l}\text { gelijk } \\
\text { behandeld }\end{array}$ & $\begin{array}{l}\text { 1.a.v. AOW: } \\
\text { gerechtigde } \\
\text { lecftijd }\end{array}$ \\
\hline $\begin{array}{l}\text { (f) Oudere } \\
\text { ongehuwde } \\
\text { vrouren }\end{array}$ & $\begin{array}{l}\text { verschillen } \\
\text { van }\end{array}$ & $\begin{array}{l}\text { oudere } \\
\text { mannen }\end{array}$ & $\begin{array}{l}\text { o.g. } \\
\text { verhoogule } \\
\text { kans vervr. } \\
\text { pensioen }\end{array}$ & $\begin{array}{l}\text { en worden } \\
\text { ten onrechte }\end{array}$ & $\begin{array}{l}\text { gehjk } \\
\text { behandeld }\end{array}$ & $\begin{array}{l}\text { La.v. AOW: } \\
\text { gerechtigste } \\
\text { Ieftijd }\end{array}$ \\
\hline $\begin{array}{l}\text { (g) Oudere } \\
\text { vrouwen }\end{array}$ & $\begin{array}{l}\text { verschillen } \\
\text { van }\end{array}$ & anderen & $\begin{array}{l}\text { o.g. } \\
\text { verminderde } \\
\text { kans op werk }\end{array}$ & $\begin{array}{l}\text { en worden } \\
\text { ten onrechte }\end{array}$ & $\begin{array}{l}\text { gciijk } \\
\text { behandeld }\end{array}$ & $\begin{array}{l}\text { Lav. AOW- } \\
\text { gercehtigde } \\
\text { Iceftijd }\end{array}$ \\
\hline $\begin{array}{l}\text { (h) (Oudere) } \\
\text { alicenstaande } \\
\text { vrouwen }\end{array}$ & $\begin{array}{l}\text { vernchillen } \\
\text { van }\end{array}$ & (anderen) & $\begin{array}{l}\text { o.gv. } \\
\text { (Iwaarte) } \\
\text { dubbete taak }\end{array}$ & $\begin{array}{l}\text { en worden } \\
\text { ten onrechte }\end{array}$ & $\begin{array}{l}\text { pelijk } \\
\text { behandeld }\end{array}$ & $\begin{array}{l}\text { Lav AOW. } \\
\text { gerschtigde } \\
\text { leefijd }\end{array}$ \\
\hline $\begin{array}{l}\text { (i) Ongehusde } \\
\text { vrouwce }\end{array}$ & $\begin{array}{l}\text { njo getijk } \\
\text { aas }\end{array}$ & $\begin{array}{l}\text { meduwen } \\
\text { (zondet } \\
\text { kinderen) }\end{array}$ & $\begin{array}{l}\text { (o.g. v, status } \\
\text { als alleen- } \\
\text { staande) }\end{array}$ & $\begin{array}{l}\text { en worden } \\
\text { ies onfechte }\end{array}$ & $\begin{array}{l}\text { veruchillend } \\
\text { hehandeld }\end{array}$ & $\begin{array}{l}\text { Lav. } \\
\text { peas ger. } \\
\text { lecfijd }\end{array}$ \\
\hline $\begin{array}{l}\text { (j) Ongehuw: } \\
\text { de vouren }\end{array}$ & $\begin{array}{l}\text { nije gelijk } \\
\text { aan }\end{array}$ & $\begin{array}{l}\text { gehurede } \\
\text { vroumen }\end{array}$ & $\begin{array}{l}\text { (o.g. } \\
\text { sekse) }\end{array}$ & $\begin{array}{l}\text { en worden } \\
\text { ten ourechte }\end{array}$ & $\begin{array}{l}\text { vernchillend } \\
\text { hehandeld }\end{array}$ & $\begin{array}{l}\text { 1.a. AOW: } \\
\text { gerochtigde } \\
\text { leeftijd }\end{array}$ \\
\hline (k) Vrouwes & $\begin{array}{l}\text { vernchillen } \\
\text { van }\end{array}$ & mannen & $\begin{array}{l}\text { o.e. verkop } \\
\text { prestaticcure }\end{array}$ & $\begin{array}{l}\text { en wortlen } \\
\text { ten onrechte }\end{array}$ & $\begin{array}{l}\text { gelijk } \\
\text { hehandeld }\end{array}$ & $\begin{array}{l}\text { Lav. AOW- } \\
\text { gerechtigde } \\
\text { leftijd }\end{array}$ \\
\hline $\begin{array}{l}\text { (1) Verple- } \\
\text { genden die } \\
\text { geen ambte- } \\
\text { nast zijn }\end{array}$ & $\begin{array}{l}\text { sjo getijk } \\
\text { an }\end{array}$ & $\begin{array}{l}\text { verplegenden } \\
\text { die } \\
\text { ambtenaar } \\
\text { ajn }\end{array}$ & $\begin{array}{l}\text { o.g.vi } \\
\text { berocp }\end{array}$ & $\begin{array}{l}\text { en worden } \\
\text { ten onrechte }\end{array}$ & $\begin{array}{l}\text { verschillend } \\
\text { behandeld }\end{array}$ & $\begin{array}{l}\text { La.v. } \\
\text { pens-ger. } \\
\text { leefiijd }\end{array}$ \\
\hline (m) Vrouwen & $\begin{array}{l}\text { veruchillen } \\
\text { van }\end{array}$ & mannen & $\begin{array}{l}\text { o.g v werk. } \\
\text { loonheids } \\
\text { risico }\end{array}$ & $\begin{array}{l}\text { en worden } \\
\text { tes ontechte }\end{array}$ & $\begin{array}{l}\text { gelijk } \\
\text { hehandeld }\end{array}$ & $\begin{array}{l}\text { L.a.v. AOW- } \\
\text { Eerechtipde } \\
\text { Iecitijd }\end{array}$ \\
\hline $\begin{array}{l}\text { (a) Ongehuw: } \\
\text { de vrouwea }\end{array}$ & $\begin{array}{l}\text { verschillen } \\
\text { van }\end{array}$ & (anderen) & $\begin{array}{l}\text { o.ger. type } \\
\text { heroep }\end{array}$ & $\begin{array}{l}\text { en worden } \\
\text { ten onrechte }\end{array}$ & $\begin{array}{l}\text { gelijk } \\
\text { hehandeld }\end{array}$ & $\begin{array}{l}\text { t.a. A. AOW. } \\
\text { gerechtigde } \\
\text { leeftijd }\end{array}$ \\
\hline $\begin{array}{l}\text { (o) Oudere } \\
\text { vrouwen }\end{array}$ & $\begin{array}{l}\text { veruchillen } \\
\text { van }\end{array}$ & $\begin{array}{l}\text { oudere } \\
\text { maneen }\end{array}$ & $\begin{array}{l}\text { o.g. } \\
\text { mogelijkheid } \\
\text { functiever- } \\
\text { andering }\end{array}$ & $\begin{array}{l}\text { en worden } \\
\text { ten onrechte }\end{array}$ & $\begin{array}{l}\text { gelijk } \\
\text { behandeld }\end{array}$ & $\begin{array}{l}\text { t.a.v. AOW: } \\
\text { gerechtigde } \\
\text { lecftijd }\end{array}$ \\
\hline
\end{tabular}




\begin{tabular}{|c|c|c|c|c|c|c|}
\hline Catrgonie A & $\begin{array}{l}\text { werschill van' } \\
\text { is gelith aun }\end{array}$ & Caserune B & $\begin{array}{l}\text { op grond van } \\
\text { Lewimerk } x\end{array}$ & $\begin{array}{l}\text { en wordt } \\
\text { aerechat } \\
\text { ien onrecher } \\
\text { (en hehoren) }\end{array}$ & $\begin{array}{l}\text { schija/ } \\
\text { vmriliend } \\
\text { hehandeld } \\
\text { (ie morden) }\end{array}$ & $\begin{array}{l}\text { ta.r. } \\
\text { regrling } \gamma\end{array}$ \\
\hline $\begin{array}{l}\text { (p) Vrouwen } \\
\text { in de AOW }\end{array}$ & $\begin{array}{l}\text { zijn (groten- } \\
\text { deels) gelijk } \\
\text { aan }\end{array}$ & $\begin{array}{l}\text { vrourwen in } \\
\text { pens.wetef } \\
\text { priv.sector }\end{array}$ & $\begin{array}{l}\text { (o.g. } v \text {. } \\
\text { selse) }\end{array}$ & $\begin{array}{l}\text { en worden } \\
\text { terecht }\end{array}$ & $\begin{array}{l}\text { gelijk } \\
\text { behandeld }\end{array}$ & $\begin{array}{l}\text { t.a.v. } \\
\text { pens.ger. } \\
\text { leeftijd }\end{array}$ \\
\hline $\begin{array}{l}\text { (a) Vrousen } \\
\text { (in private } \\
\text { sector) }\end{array}$ & $\begin{array}{l}\text { xijn gelijk } \\
\text { an }\end{array}$ & $\begin{array}{l}\text { personen is } \\
\text { diverse he- } \\
\text { mepagroepen }\end{array}$ & $\begin{array}{l}\text { (o.g.v, tagere } \\
\text { pens.ger. } \\
\text { leeftijd) }\end{array}$ & $\begin{array}{l}\text { en worden } \\
\text { terecht }\end{array}$ & $\begin{array}{l}\text { gelijk } \\
\text { behandeld }\end{array}$ & $\begin{array}{l}\text { t.a.v. AOW. } \\
\text { gerechtigde } \\
\text { keftijd }\end{array}$ \\
\hline $\begin{array}{l}\text { (r) Vroowen } \\
\text { in Nedertand }\end{array}$ & $\begin{array}{l}\text { ajn gelijk } \\
\text { aan }\end{array}$ & $\begin{array}{l}\text { vrouwen in } \\
\text { West-Europa }\end{array}$ & $\begin{array}{l}\text { (o.g.r. } \\
\text { sckie) }\end{array}$ & $\begin{array}{l}\text { en worden } \\
\text { terecht }\end{array}$ & $\begin{array}{l}\text { (grotendects) } \\
\text { gchijk } \\
\text { behandeid }\end{array}$ & $\begin{array}{l}\text { Lav. } \\
\text { pen_eer. } \\
\text { leefiijd }\end{array}$ \\
\hline $\begin{array}{l}\text { (s) Veouwen } \\
\text { in hedrijfs- } \\
\text { peniocneg. }\end{array}$ & $\begin{array}{l}\text { veruchitien } \\
\text { van }\end{array}$ & $\begin{array}{l}\text { mannen in } \\
\text { bedrijlspen: } \\
\text { sinentes. }\end{array}$ & $\begin{array}{l}\text { o.g.v. pens. } \\
\text { ger. Keeftijd } \\
\text { naar geslacht }\end{array}$ & $\rightarrow$ & $\rightarrow$ & $\rightarrow$ \\
\hline $\begin{array}{l}\text { Ongehuwde } \\
\text { vrauwen }\end{array}$ & $\begin{array}{l}\text { vernchilien } \\
\text { van }\end{array}$ & $\begin{array}{l}\text { (andere } \\
\text { vrouwen) }\end{array}$ & $\begin{array}{l}\text { o.g.v. } \\
\text { burgertijke } \\
\text { staat }\end{array}$ & $\rightarrow$ & $\rightarrow$ & $\rightarrow$ \\
\hline $\begin{array}{l}\text { Ongchurude } \\
\text { vrousen }\end{array}$ & $\rightarrow$ & $\rightarrow$ & $\rightarrow$ & $\begin{array}{l}\text { en worden } \\
\text { terecht }\end{array}$ & $\begin{array}{l}\text { (naar ge- } \\
\text { slache) pelijk } \\
\text { behandeld }\end{array}$ & $\begin{array}{l}\text { tav, AOW. } \\
\text { ectechtigde } \\
\text { lecfujd }\end{array}$ \\
\hline (i) Vroesencen & $\begin{array}{l}\text { ajes ectijk } \\
\text { aan }\end{array}$ & mannen & $\begin{array}{l}\text { o.g.v. } \\
\text { invaliditeits } \\
\text { risico }\end{array}$ & $\begin{array}{l}\text { en wonden } \\
\text { terecht }\end{array}$ & $\begin{array}{l}\text { gelijk } \\
\text { behandeld }\end{array}$ & 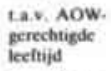 \\
\hline $\begin{array}{l}\text { (a) Vrouwe- } \\
\text { lijke amhe- } \\
\text { naren }\end{array}$ & $\begin{array}{l}\text { ajn (jeroten- } \\
\text { deels) Eelijk } \\
\text { aan }\end{array}$ & $\begin{array}{l}\text { mannchjke } \\
\text { ambtenaren }\end{array}$ & $\begin{array}{l}\text { o.g.v. } \\
\text { invaliditeits- } \\
\text { rinice }\end{array}$ & $\begin{array}{l}\text { en worden } \\
\text { terecht }\end{array}$ & $\begin{array}{l}\text { getijk } \\
\text { techandeld }\end{array}$ & $\begin{array}{l}\text { tav. AOW. } \\
\text { eerechtigde } \\
\text { lecflijd }\end{array}$ \\
\hline $\begin{array}{l}\text { (v) Ohudere } \\
\text { vmusen }\end{array}$ & $\begin{array}{l}\text { zije getijk } \\
\text { an }\end{array}$ & $\begin{array}{l}\text { oodere. } \\
\text { mannen }\end{array}$ & $\begin{array}{l}\text { o.g.v } \\
\text { serkloos- } \\
\text { beidurisios }\end{array}$ & $\begin{array}{l}\text { en worden } \\
\text { terecht }\end{array}$ & $\begin{array}{l}\text { pelijk } \\
\text { behandeld }\end{array}$ & $\begin{array}{l}\text { tav. AOW. } \\
\text { gerechtigde } \\
\text { leeftijd }\end{array}$ \\
\hline $\begin{array}{l}\text { (w) Oudere } \\
\text { vtouwen }\end{array}$ & $\begin{array}{l}\text { ajn (gnoten } \\
\text { decls) gelijk } \\
\text { aan }\end{array}$ & $\begin{array}{l}\text { owedere } \\
\text { manhen }\end{array}$ & $\begin{array}{l}\text { o.gv, nekte- } \\
\text { frequentic }\end{array}$ & $\begin{array}{l}\text { en murden } \\
\text { terecht }\end{array}$ & $\begin{array}{l}\text { gelojk } \\
\text { hehandeld }\end{array}$ & $\begin{array}{l}\text { La.v. AOW. } \\
\text { gerechtigde } \\
\text { keftijd }\end{array}$ \\
\hline $\begin{array}{l}\text { (x) Ongehuw: } \\
\text { \&e wouwen }\end{array}$ & $\begin{array}{l}\text { verschillen } \\
\text { van }\end{array}$ & weduwen & $\begin{array}{l}\text { ogv, kam op } \\
\text { verwerving } \\
\text { inkomen }\end{array}$ & $\begin{array}{l}\text { en worden } \\
\text { terecht }\end{array}$ & $\begin{array}{l}\text { vernchillend } \\
\text { hehandels }\end{array}$ & $\begin{array}{l}\text { 1.av. } \\
\text { pens_ger. } \\
\text { leeftijd }\end{array}$ \\
\hline $\begin{array}{l}\text { (y) Ongehuw:- } \\
\text { de vrouwen }\end{array}$ & $\begin{array}{l}\text { zijn gelijk } \\
\text { an }\end{array}$ & $\begin{array}{l}\text { gehowde } \\
\text { werkende } \\
\text { vrowwen }\end{array}$ & $\begin{array}{l}\text { o.g., dubbele } \\
\text { taak }\end{array}$ & en behoren & $\begin{array}{l}\text { gelijk } \\
\text { hehandeld ie } \\
\text { worden }\end{array}$ & $\begin{array}{l}\text { Lav. AOW. } \\
\text { gerechtigde } \\
\text { keftigd }\end{array}$ \\
\hline $\begin{array}{l}\text { (a) Ongehuw- } \\
\text { de vrouwen }\end{array}$ & $\begin{array}{l}\text { ajn gelojk } \\
\text { wan }\end{array}$ & $\begin{array}{l}\text { telfit won. } \\
\text { ongehurode } \\
\text { manncn }\end{array}$ & $\begin{array}{l}\text { o.g.v, duhtwele } \\
\text { taxk }\end{array}$ & $\begin{array}{l}\text { en worden } \\
\text { terecht }\end{array}$ & $\begin{array}{l}\text { gelijk } \\
\text { hehandeld }\end{array}$ & $\begin{array}{l}\text { t.a. AOW. } \\
\text { ecrechtigde } \\
\text { lecftijd }\end{array}$ \\
\hline $\begin{array}{l}\text { (a') Onge- } \\
\text { hrede vrou- } \\
\text { wen met } \\
\text { werk }\end{array}$ & $\begin{array}{l}\text { verschillen } \\
\text { van }\end{array}$ & $\begin{array}{l}\text { ongehuwde } \\
\text { vrouwen } \\
\text { zonder werk }\end{array}$ & $\begin{array}{l}\text { o.g.v. duhbele } \\
\text { takk }\end{array}$ & en behoren & $\begin{array}{l}\text { niet gelijk } \\
\text { hehandeld te } \\
\text { wordes }\end{array}$ & $\begin{array}{l}\text { I.a. AOW. } \\
\text { gerechtigde } \\
\text { leeftijd }\end{array}$ \\
\hline $\begin{array}{l}\text { (b') Onge- } \\
\text { husede vrou- } \\
\text { wen in } \\
\text { koondienst }\end{array}$ & $\begin{array}{l}\text { verschillen } \\
\text { van }\end{array}$ & $\begin{array}{l}\text { ongehuwde } \\
\text { vrousen niet } \\
\text { in loondienst }\end{array}$ & $\begin{array}{l}\text { o.gv, aan- } \\
\text { spraak Zick. } \\
\text { tewet/WAO }\end{array}$ & en behoren & $\begin{array}{l}\text { niet gelijk } \\
\text { hehandeld te } \\
\text { wonden }\end{array}$ & $\begin{array}{l}\text { La v. AOW. } \\
\text { ecrechtigde } \\
\text { leeftijd }\end{array}$ \\
\hline$\left(c^{*}\right)$ Vrouwes & $\begin{array}{l}\text { zijn gelijk- } \\
\text { (wasrdig) aan }\end{array}$ & mannea & $(\ldots)$ & $\begin{array}{l}\text { en wurden } \\
\text { terecht }\end{array}$ & $\begin{array}{l}\text { gelijk } \\
\text { hehandeld }\end{array}$ & $\begin{array}{l}\text { tav, AOW. } \\
\text { gerechtigde } \\
\text { leeftijd }\end{array}$ \\
\hline $\begin{array}{l}\text { (d') Onge- } \\
\text { huwde vrou: } \\
\text { wen }\end{array}$ & $\begin{array}{l}\text { zijn gelijk } \\
\text { an }\end{array}$ & $\begin{array}{l}\text { alleenstaande } \\
\text { ouden }\end{array}$ & $\begin{array}{l}\text { o.g.V. dubbeic } \\
\text { taak }\end{array}$ & en behoren & $\begin{array}{l}\text { nict ongelijk } \\
\text { behandeld te } \\
\text { worden }\end{array}$ & $\begin{array}{l}\text { t.a.v. AOW. } \\
\text { gerechtigde } \\
\text { lecefijd }\end{array}$ \\
\hline
\end{tabular}


Voorheen lag die grens bij so jaar. Veel parlementsleden hadden hiertegen geen bezwaar, maar vroegen zich wel af of de regering voldoende rekening had gehouden met de relatieve lastenverzwaring die de herziening voor ongehuwden, en met name ongehuwde vrouwen, met zich mee zou brengen. In deze context stelden verschillende fracties voor om ongehuwde vrouwen een compensatie te geven in de vorm van een AOW-uitkering vanaf 60 -jarige leeftijd. Ook werd aangevoerd dat arbeid veel oudere vrouwen zwaar viel, iets wat Van Bruggen eveneens had genoemd. Daar kwam bij dat ongehuwde vrouwen die jarenlang voor familieleden hadden gezorgd er, net als weduwen en gescheiden vrouwen, moeite mee hadden op latere leeftijd werk buiten het gezin te zoeken. ${ }^{*}(c)$

De langste reeks argumenten kwam echter in 1964 tijdens de behandeling van het wetsontwerp voor de invoering van een sociaal minimum in de AOw en de AwW ter sprake. Verschillende kamerleden vonden die verandering een goede aanleiding om nogmaals na te gaan of ongehuwde vrouwen - voor zover zij geen recht hadden op een bepaalde sociale verzekeringsuitkering - niet eerder voor een AOW-uitkering in aanmerking zouden kunnen komen. ${ }^{9}$ Kamerlid Roolvink (ARP) realiseerde zich dat dit een omstreden punt was en dat er vele kanten aan de zaak zaten. Niemand zou daarvoor een redenering kunnen opzetten die door iedereen onderschreven werd. Maar hij wilde er wel op wijzen dat er vele landen in de wereld waren, waar de vrouw op een vroeger tijdstip werd gepensioneerd dan de man. (d) Ook stond naar Roolvinks mening vast dat vrouwelijke ambtenaren veel vaker dan mannelijke ambtenaren voor hun 6sste een aanvraag voor een invaliditeitspensioen indienden ${ }^{10}(e)$ en dat de kans op vervroegd pensioen wegens invaliditeit in de leeftijdsgroep van 60-64 jaar bij ongehuwde vrouwen tweemaal zo hoog was dan bij mannen. (f) Bovendien verliep de arbeidsbemiddeling van vrouwen rond de 60 jaar moeizamer dan die van anderen; deze vrouwen kwamen dus moeilijker aan de slag. (g) Daar kwam volgens Roolvink nog eens bij '(...) dat de alleenstaande vrouw (...) naast haar werk ook de dagelijkse zorg voor haar eigen huishouden heeft. Bij het ouder worden begint deze dubbe- 
le taak zwaar te vallen." (h) Meer argumenten wilde hij niet noemen, maar een nader onderzoek op dit gebied leek hem bepaald gewenst. Hij was dan ook van plan hierover een motie in te dienen waarvoor hij uit bijna alle fracties handtekeningen had verzameld.

Die motie - waarin de regering gevraagd werd over de bewuste kwestie advies aan de Sociaal-Economische Raad (SER) te vragen - zou inderdaad ingediend en aangenomen worden. ${ }^{12}$ Maar dat betekende niet dat alle handtekeningzetters zich vóór een verlaging van de pensioengerechtigde leeftijd van vrouwen uitspraken. Volgens vvvD-kamerlid Corver voelde een aantal vrouwen misschien wél voor een vervroegde Aow-uitkering, maar een andere groep niet. 'Deze laatste groep, die veel prijs stelt op gelijkstelling in rechten met de man, zou - en ik geloof niet helemaal ten onrechte - juist in deze ongelijkstelling weer een zekere onrechtmatige discriminatie kunnen zien. Wanneer men aan de Minister vraagt, of hij dit probleem nog eens wil bestuderen, of hij het aan de SER wil voorleggen en of hij ons zijn bevindingen wil mededelen, geloof ik, dat daarin geen kwaad steekt en daar willen wij dan ook graag aan medewerken. Verder zou ik op dit moment bepaald niet willen gaan. ${ }^{1 / 3}$

\section{Weduwen van koek}

Ondertussen druppelden op het Binnenhof diverse brieven van vrouwen binnen die op persoonlijke titel om een verlaging van de pensioengerechtigde leeftijd voor ongehuwde (en soms gescheiden) vrouwen vroegen. ${ }^{14}$ Bovendien nam de organisatiegraad van de betrokken vrouwen toe.

Eén van die organisaties was het 'Vrouwen-actiecomité voor vervroegde staatspensionering' te Amsterdam. ${ }^{15}$ Dit kleine, politiek ongebonden en actieve comité werd in 1962 opgericht door M. van Saane, een voormalig coupeuse, en I.J.A. Oosterbaan, een oud-secretaresse, beiden ongehuwd. ${ }^{16}$ Aanleiding was de al genoemde wijziging van de $\mathrm{AWW}$. Het comité achtte het uiterst onrechtvaardig dat kinderloze weduwen voortaan al vanaf hun 4 oste jaar recht op een weduwenpensioen zouden krijgen, terwijl ongehuwde vrouwen tot hun 65 ste op hun pensioen moes- 
ten wachten. (i) Want sinds wanneer waren weduwen 'van koek' en ongehuwde vrouwen 'van ijzer'? In emotionele brieven aan politici, in brochures, commentaren, demonstraties, interviews en rapporten eisten de leden een vervroegd AOW-pensioen voor ongehuwde vrouwen. Vaak, maar niet altijd noemden zij daarbij ook de gescheiden vrouwen en een enkele keer de weduwen zonder Aww. Vooral de moeilijke positie van laag geschoolde ongehuwde vrouwen versus de bevoorrechte status van weduwen en gehuwde vrouwen was hen een doorn in het oog. Waarom mocht de gehuwde vrouw - via haar man - vaak al ruim voor haar eigen 65 ste verjaardag van een $\mathrm{AOW}$-pensioen genieten, terwijl de ongehuwde vrouw dat genoegen pas op haar 6sste zou kunnen proeven? (j) Tevens vergeleek het comité de pensioenregelingen in Nederland met die in het buitenland, de dubbele taak van ongehuwde vrouwen met de enkelvoudige taak van anderen en de fysieke gesteldheid van vrouwen met die van mannen. Dat laatste argument werd ook door een andere belangengroep voor ongehuwde werkende vrouwen genoemd. Deze groep, de 'Werkbijen', bepleitten vrijwillige vervroegde pensionering mede op grond van het feit dat de prestatiecurve van vrouwen eerder zou dalen dan die van mannen. ${ }^{17}(k)$

Niet alle belangengroepen opereerden echter op basis van burgerlijke staat. Zo lieten verpleegsters zich horen via de Federatie van Verenigingen die de Verpleging en andere onderdelen van de Gezondheidszorg bevorderen. De aanleiding voor hun bemoeienis lag in de moeilijke financiële omstandigheden waarin veel oud-verpleegsters, met name in de particuliere sector, verkeerden. Het Pensioenfonds Volksgezondheid en Maatschappelijk Werk bood deze verpleegsters weliswaar vanaf het begin van de jaren zestig de mogelijkheid om op hun 6oste met pensioen of op hun 55 ste met vervroegd pensioen te gaan, maar voor het 'gat' van 5 tot ro jaar tussen het moment van pensionering en het recht op een AOW-uitkering bestond geen oplossing.

Dat bracht de Federatie ertoe voor een verlaging van de pensioengerechtigde leeftijd van vrouwen in de AOw te pleiten, al bleek uit de argumenten dat de Federatie daarbij vooral aan ongehuwde vrouwen dacht. Een verhoging van de pensioenge- 
rechtigde leeftijd in de aanvullende pensioenvoorzieningen viel nauwelijks te overwegen, zo meende de Federatie. Daarvoor was het verpleegkundig beroep fysiek te zwaar. In een brief van 20 maart 1968 aan de Minister van Sociale Zaken en Volksgezondheid Roolvink wees zij erop dat de rijksoverheid elders ondermeer via het functioneel leeftijdsontslag in de ambtenarenwetgeving - had erkend dat de verpleging niet tot het 6 sste jaar vol te houden was. (l) Toch beperkte de Federatie zich niet tot argumenten die alleen voor de verpleging golden. In de zojuist vermelde brief noemde zij bij voorbeeld verschillende argumenten die ook door anderen naar voren werden gebracht of daar sterk op leken. Zo schreef de Federatie dat vrouwen eerder dan mannen fysiek en psychisch niet meer tegen hun taak opgewassen zouden zijn, dat gehuwde vrouwen hun AOw-pensioen gemiddeld vanaf hun 63ste kregen en dat het werkloosheidsrisico voor vrouwen groter was dan voor mannen. $(m)$

Daarnaast gebruikte de Federatie verschillende 'eigen' vergelijkingen. Van de ongehuwde vrouwen was een relatief groot aantal werkzaam in een beroep dat sterk gericht was op de intermenselijke verhoudingen, zo werd gezegd, en juist een dergelijk beroep kon op oudere leeftijd bezwaarlijk worden. (n) Bovendien was de mogelijkheid om op latere leeftijd zonder financiële en/of maatschappelijke achteruitgang van functie te veranderen voor vrouwen geringer dan voor mannen. ${ }^{18}(0)$

Kortom, de variatie aan argumenten vóór verlaging van de AOWgerechtigde leeftijd van ongehuwde vrouwen was aanzienlijk. Niet alleen overlapten de argumenten die in de Tweede Kamer werden ingezet slechts gedeeltelijk met de argumenten van de belangengroepen. Ook de belangengroepen zélflegden, afhankelijk van hun invalshoek, het accent op zeer verschillende sociale vergelijkingen. Expliciet of impliciet werden vrouwen met andere vrouwen vergeleken $(\mathrm{a} / \mathrm{d})$, vrouwen met mannen $(\mathrm{e} / \mathrm{k} / \mathrm{m})$, ongehuwde vrouwen met weduwen $(\mathrm{b} / \mathrm{i})$, ongehuwde vrouwen met gehuwde vrouwen (j), ongehuwde vrouwen met anderen $(\mathrm{n})$, oudere ongehuwde vrouwen met weduwen en gescheiden vrouwen (c), oudere ongehuwde vrouwen met oudere mannen 
(f), (oudere) alleenstaande vrouwen met anderen (h), oudere vrouwen met oudere mannen (o), oudere vrouwen met anderen (g) en verplegenden met verplegenden (l). En zelfs wanneer dezelfde sociale categorieën werden vergeleken, was de grond van de vergelijking vaak verschillend. Een overdonderende hoeveelheid argumenten voor een vervroegd AOW-pensioen, zo leek het. Maar de 'verdedigers' wisten er wel raad mee.

\section{Advocaat van de staat}

$\mathrm{Al}$ in 1955 had de toenmalige regering een ferm weerwoord op het argument dat de pensioengerechtigde leeftijd van vrouwen eigenlijk 60 jaar zou zijn. De regering achtte die stelling eenvoudig 'onbewezen'. Noch in de bestaande wetgeving, noch in een groot deel van de private sector was de pensioengerechtigde leeftijd voor vrouwen 60 jaar. $(p)$ En los daarvan zou een afwijkende pensioengerechtigde leeftijd voor vrouwen in de AOw 'even weinig passen als zulks het geval is ten aanzien van personen, wier pensioengerechtigde leeftijd in verband met het door hen uitgeoefende beroep - zoals politiepersoneel, militairen, verplegend personeel, mijnarbeiders - in het algemeen beneden 65 jaar is bepaald'. ${ }^{19}$ Er was, met andere woorden, geen reden om voor vrouwen van de regel af te wijken als dat voor vergelijkbare groepen ook niet werd gedaan. (q)

Precies hetzelfde antwoord gaf staatssecretaris Roolvink zes jaar later. ${ }^{20}$ Maar juist zijn houding zou wisselvallig zijn. Als staatssecretaris (1959-1963) reageerde hij in $196 \mathrm{I}$ in principe afwijzend, maar wilde hij Van Bruggens opmerking over de voor ongehuwden nutteloze weduwenpremie niet tegenspreken. Hij stond de SER, die inmiddels hetzelfde probleem had gesignaleerd, dan ook toe om over de positie van de ongehuwden in de sociale verzekering advies uit te brengen en verwees daar in 1962 naar. ${ }^{21}$ Als kamerlid (196I-1967) deed Roolvink vervolgens in 1964 via zijn motie alle moeite het punt weer op de agenda te krijgen en de SER opnieuw advies te laten uitbrengen, om daarna als minister (1967-1971) zeer met de zaak in zijn maag te zitten. 


\section{Onvoldoende relevant}

Terwijl de elkaar opvolgende bewindslieden meer of minder voorzichtig de boot afhielden, ontpopte de SER zich als de werkelijke 'advocaat van de staat'. In twee adviezen, de eerste over de positie van gehuwden en ongehuwden in de sociale verzekering $(1963)^{23}$ en de tweede over verlaging van de pensioengerechtigde leeftijd van de ongehuwde vrouw $(1966)^{23}$, werd de eis afgewezen.

In het advies van 1963 wilde de SER nagaan wat het cumulatieve effect was van de verschillen in premies en aanspraken tussen ongehuwden en gehuwden in de sociale verzekeringen. De SER stelde uitdrukkelijk dat het advies niet op de maatschappelijke positie van ongehuwden zou ingaan, al was de raad zich ervan bewust dat vele ongehuwden, met name oudere ongehuwde vrouwen, daarmee niet tevreden zouden zijn. De raad wist dat bij vele werkende ongehuwden het gevoel leefde dat met hun specifieke levensstijl en problematiek - huisvesting, sluitingstijden van winkels etcetera - geen rekening werd gehouden. Dat gevoel leefde, zo dacht de SER, sterker onder werkende ongehuwde vrouwen dan ongehuwde mannen, wat mogelijk samenhing met de omstandigheid dat ongehuwde vrouwen, zeker op oudere leeftijd, veelal 'zelfverzorgsters' waren. Bovendien werd dat gevoel volgens de SER nog eens versterkt doordat ongehuwde vrouwen vaak minder verdienden dan hun mannelijke collega's.

Maar los daarvan was het oordeel van de SER dat de verschillen in premies en aanspraken tussen gehuwden en ongehuwden niet onaanvaardbaar waren. De raad baseerde die conclusie ondermeer op de opvatting dat in de volksverzekeringen terecht solidariteitselementen waren ingebouwd. Een compensatie voor ongehuwde vrouwen in de vorm van een verlaging van hun pensioengerechtigde leeftijd wees de SER eveneens van de hand. Die maatregel zou wel eens een averechts effect kunnen hebben. 'Het is immers niet uitgesloten', schreef de SER, 'dat verlaging van de pensioengerechtigde leeftijd zal leiden tot een overeenkomstige verlaging van de leeftijd van ontslag, hetgeen per saldo de financiële positie van de ongehuwde vrouwen eerder zou verslechteren dan verbeteren $(. . .)^{24}$ Bovendien had de raad de in- 
druk dat een verlaging van de pensioengerechtigde leeftijd niet in overeenstemming was met de wensen van de ongehuwde vrouwen zélf.

Het argument dat het voor ongehuwde vrouwen op hogere leeftijd moeilijk zou zijn om aan een baan te komen - een argument dat volgens de SER door een deel van de betrokkenen bestreden werd - achtte de SER in dit geval niet relevant. Een dergelijk pleidooi vond zijn grondslag niet in de verschillen in premielasten en aanspraken tussen ongehuwden en gehuwden, maar ' (...) in de veronderstelling dat de ongehuwde vrouw op een jongere leeftijd dan de man de fysieke en psychische capaciteiten zou gaan missen om zich in het bedrijfs- en beroepsleven te kunnen handhaven (...)' Over die veronderstelling wilde de raad geen uitspraak doen. Dat lag buiten het probleem waarop de adviesaanvraag betrekking had. ${ }^{\text {s }}$

\section{Geen rechtsgrond}

In 1966 lag die veronderstelling niet meer buiten de reikwijdte van de adviesaanvraag. Maar nog steeds was de SER nauwelijks onder de indruk van de argumenten pro verlaging van de pensioengerechtigde leeftijd voor ongehuwde vrouwen. Eén voor één werden de argumenten die in de adviesaanvraag en de parlementaire debatten waren genoemd van tafel geveegd.

Om te beginnen nuanceerde de SER de vergelijkingen met het buitenland en het bedrijfsleven. Een overzicht liet zien dat in veel 'buitenlanden' de pensioengerechtigde leeftijd voor vrouwen lager was dan voor mannen, maar de waarde van dat overzicht achtte de SER beperkt. Over de inhoud van de voorzieningen was immers weinig bekend. Bovendien was het beeld wat West-Europa betreft verdeeld. De pensioengerechtigde leeftijd voor vrouwen was lager in België, de Bondsrepubliek Duitsland, Groot-Brittannië, Italië, Oostenrijk en Zwitserland, maar gelijk in Denemarken, Finland, Frankrijk, Ierland, Luxemburg, Noorwegen, Portugal, Spanje en Zweden. $(r)$ Over de ondernemingspensioenfondsen in Nederland had de SER geen gegevens, maar wat betreft de bedrijfspensioenfondsen - fondsen voor gehele bedrijfstakken in plaats van afzonderlijke ondernemingen - was 
bekend dat van de circa 36.000 deelnemende vrouwen er ongeveer 21.000 een lagere pensioengerechtigde leeftijd kenden. Daarbij vermeldde de SER dat enkele van de betreffende fondsen in belangrijke mate vrouwen in de slijtende beroepen als deelneemster hadden en dat veelal een aanvullende pensioenregeling bestond voor de periode tussen pensionering en de 65 -jarige leeftijd. De conclusie van de SER was dat de pensioengerechtigde leeftijd voor vrouwen weliswaar in een niet te verwaarlozen omvang lager was dan die van mannen, maar dat dit een verschil in geslacht betrof en niet een verschil in burgerlijke staat. (s) Daardoor werd de betekenis ervan als motief voor een maatregel die slechts een deel van de vrouwen zou beslaan '(...) naar het oordeel van de Raad op zijn minst twijfelachtig'. ${ }^{16}$

In de tweede plaats hechtte de raad weinig waarde aan het argument dat de kans op vervroegd pensioen wegens invaliditeit in de leeftijdsgroep van 60 tot 65 jaar bij ongehuwde vrouwen veel hoger zou zijn dan bij mannen. De gegevens van de Sociale Verzekeringsbank over de uitkeringen op grond van de Invaliditeitswet lieten tussen het invaliditeitsrisico van mannen en vrouwen over ongehuwde vrouwen bestonden geen afzonderlijke gegevens - geen verschil zien. ( $t$ ) De cijfers van het Algemeen Burgerlijk Pensioenfonds etaleerden wél een dergelijk verschil. Maar de raad vond het percentage vrouwen dat vanwege invaliditeit haar baan vervroegd opgaf ( 15 à $20 \%$ ) toch niet groot genoeg om daaruit verstrekkende conlusies te trekken, '(...) mede omdat niet bekend is in hoeverre het uiteenlopen van de door mannen en vrouwen uitgeoefende functies de cijfers heeft beïnvloed. ${ }^{27}$ ( $(u)$

Met het derde argument - "het werkloosheidsrisico is voor vrouwen van 60 tot 65 jaar veel groter dan voor mannen in dezelfde leeftijdsklasse' - kon de SER evenmin uit de voeten. Het Ministerie van Sociale Zaken en Volksgezondheid kon wel gegevens verstrekken over de leeftijdscategorie van 50-64 jaar, maar niet over de categorie van 60-65 jaar. Uit die gegevens kon volgens de SER echter niet worden afgeleid dat het werkloosheidsrisico voor oudere vrouwen groter was dan voor mannen uit dezelfde leeftijdscategorie. (v) Verschillende onzekerheden speelden de SER daarbij parten. Zo was niet duidelijk of vrouwen 
van wie de plaatsingskans klein was zich überhaupt wel bij het arbeidsbureau lieten inschrijven. Bovendien hadden de gegevens alweer - niet rechtstreeks betrekking op ongehuwde vrouwen.

Zelfs de redenering dat de ongehuwde werkende vrouw in het algemeen tevens haar eigen huishouden voerde en deze taak haar zwaarder viel naarmate zij ouder werd, kon de SER niet vermurwen. Die zwaardere belasting zou, meende de SER, dan tot uitdrukking moeten komen in een groter invaliditeits- en ziekterisico. Het grotere invaliditeitsrisico was als relevant argument al terzijde geschoven. De ziektefrequentie bleek volgens de Diagnosestatistiek Bedrijfsverenigingen voor vrouwen in de hogere leeftijdscategorieën (vanaf so jaar) gelijk of zelfs lager dan de ziektefrequentie van mannen. (w) Daarbij werd aangetekend dat over ongehuwde vrouwen wederom geen afzonderlijke gegevens beschikbaar waren en dat de lagere ziektefrequentie van vrouwen wellicht het gevolg was van een positief selectieproces: de beroepsdeelname van vrouwen nam met het stijgen van de leeftijd immers sterker af dan de beroepsdeelname van mannen. Dat het voeren van een eigen huishouden naast een functie in het bedrijfsleven een extra belasting betekende stond volgens de raad buiten kijf. Maar de beschikbare gegevens konden niet bewijzen dat deze dubbele last een ongunstige invloed had op de arbeidsgeschiktheid.

En toen restte nog één argument - tevens het enige argument waarover de SER een verdeeld standpunt innam. Het argument luidde dat oudere ongehuwde vrouwen achtergesteld waren bij weduwen van dezelfde leeftijd die in het algemeen aan de Aww een recht op pensioen ontleenden. Volgens de meerderheid van de Raad lag dit motief vooral in de sociaal-psychologische sfeer en kon de waarde ervan dus niet met kwantitatieve gegevens worden ondersteund of ontkracht. Aan het motief lag impliciet de gedachte ten grondslag dat de weduwen en ongehuwde vrouwen wat betreft de inkomensverwerving in dezelfde positie verkeerden. Maar deze vergelijking ging naar het oordeel van de raadsmeerderheid niet op. Het uitgangspunt van de AwW was nu juist dat de weduwe in een ongunstiger positie verkeerde dan de ongehuwde vrouw omdat de weduwe zich na haar hu- 
welijk doorgaans uitsluitend aan haar huishoudelijke taak wijdde. Voor haar was het daarna moeilijker om een baan te vinden dan voor vrouwen die zonder onderbreking in het beroeps- of bedrijfsleven werkzaam waren geweest. $(x)$

Ook al vond een minderheid van de SER de vergelijking met de weduwen wél begrijpelijk, de raad meende toch dat de argumenten pro verlaging van de AOW-gerechtigde leeftijd niet duidelijk bevestigd konden worden. Weliswaar waren er gegevens boven water gekomen die erop wezen dat vrouwen fysiek en psychisch eerder minder geschikt werden om een beroep uit te oefenen dan mannen, maar daarbij ging het meer om een verschil naar geslacht dan naar burgerlijke staat. De snellere vermindering van de arbeidsgeschiktheid, zo schreef de SER, gold dus niet alleen voor oudere ongehuwde vrouwen, maar voor oudere vrouwen in het algemeen. Daarmee herhaalde de raad een argument - vergelijk (s) - dat al eerder was genoemd.

Evenmin achtte de SER de dubbele taak een argument dat hout sneed. Afgezien van het al vermelde gegeven dat die dubbele taak niet tot meer invaliditeit of ziekte leidde, gold de tweevoudige taak óók voor werkende gehuwde vrouwen $(\gamma)$ en zelfstandig wonende ongehuwde mannen. (z) Wél was een belangrijk verschil dat de gehuwde vrouw eerder dan de ongehuwde kon besluiten uit haar baan te stappen als de dubbele taak haar te zwaar werd. Naast haar inkomen stond immers meestal een inkomen van de echtgenoot. Dat nam echter niet weg dat de dubbele taak geen rechtsgrond kon bieden voor een maatregel die alléén ongehuwden zou betreffen.

Daar kwam bij dat de dubbele taak niet gold voor de relatief grote groep ongehuwde vrouwen zonder beroep. ( $\left.a^{*}\right)$ Misschien zou een maatregel om andere redenen (bij voorbeeld een laag inkomen) overwogen kunnen worden. Maar dan nog stond de vraag open of een algemene maatregel op zijn plaats was als niet alle leden van een groep daaraan behoefte hadden. Ten slotte wees de Raad erop dat het overgrote deel van de werkende ongehuwde vrouwen in loondienst was. Voor deze categorie achtte de Raad de dubbele taak als argument voor een verlaging van de pensioengerechtigde leeftijd '(...) van geen of nagenoeg geen be- 
tekenis'. ${ }^{2 s}$ De Ziektewet en de Wet op de Arbeidsongeschiktheidsverzekering (WAO) boden voorzieningen die gunstiger en beter op de individuele situatie afgestemd waren dan een regeling binnen de ouderdomsverzekering. $\left(b^{\star}\right)$

De SER liet zich bij het bepalen van zijn standpunt echter niet uitsluitend leiden door de uitkomsten van het eigen onderzoek. De onzekerheden waarmee de Raad kampte waren reden om het oordeel van een aantal vrouwenorganisaties in te winnen. Daarom werd een hearing georganiseerd. ${ }^{29}$ Het Vrouwen-actiecomité behoorde - de reden daarvoor is onbekend - niet tot de genodigden. De meeste van de wél aanwezige organisaties plaatsten de kwestie van de pensioengerechtigde leeftijd in het bredere kader van de maatschappelijke positie van ongehuwden en ongehuwde vrouwen. Met de specifieke behoeften van ongehuwden zou te weinig rekening worden gehouden en een algemeen 'ongehuwdenbeleid' was gewenst.

De SER interpreteerde deze stellingname zo dat, wanneer aan deze voorwaarden was voldaan, de dubbele taak voor de ongehuwde vrouw niet zoveel problemen meer zou veroorzaken dat daarvoor een verlaging van de pensioengerechtigde leeftijd nodig zou zijn. De organisaties benadrukten echter dat die ongehuwde vrouwen die werkzaam waren in beroepen die fysiek en psychisch hoge eisen stelden, wél eerder met pensioen dienden te kunnen gaan. Bovendien was de meerderheid van de organisaties van mening dat voor de huidige generatie oudere ongehuwde vrouwen - voor wie het ongehuwdenbeleid geen effect meer zou sorteren - een tijdelijke noodmaatregel ontworpen moest worden.

Maar de SER zag in dit alles geen reden om haar visie te wijzigen, noch om alsnog een tijdelijke maatregel in te stellen. Mede met het oog op het gevaar van precedentwerking, wees de meerderheid van de raad een tijdelijke maatregel af. Wel achtte de raad het gewenst een onderzoek te laten instellen naar de levensomstandigheden en maatschappelijke positie van ongehuwden, en met name ongehuwde vrouwen, waarin zowel aan de materiële als aan de psychologische aspecten aandacht zou 
worden besteed. Echte oplossingen voor de problemen van oudere ongehuwde vrouwen zouden volgens de SER slechts in de aanvullende pensioenen of in de ziektewet en de arbeidsongeschiktheidsverzekering gezocht kunnen worden. Een verlaging van de AOW-gerechtigde leeftijd behoorde in ieder geval niet tot de juiste oplossingen.

Zoals al in de inleiding werd aankondigd, stonden de wapens van vergelijking, rechtsgelijkheid en precedentwerking niet alleen de eisers, maar ook de verdedigers ter beschikking. Hoewel de SER en anderen meer pijlen op hun boog hadden dan het strategisch schuiven met gelijkenissen en verschillen, draaiden veel argumenten toch om vergelijkingen. De verdedigers ontkenden de juistheid van 'gelijkenissen' $(t / u / v)$, bogen vergelijkingen om $(\mathrm{p} / \mathrm{q} / \mathrm{r})$, redeneerden verschillen weg $(\mathrm{s})$, introduceerden nieuwe vergelijkingen $\left(\mathrm{w} / \mathrm{x} / \mathrm{y} / \mathrm{z} / \mathrm{a}^{\star} / \mathrm{b}^{\star} / \mathrm{c}^{\star} / \mathrm{d}^{\star}\right)$ en wezen via een deel van deze argumenten op het gevaar van precedentwerking. Niet alle argumenten van de eisers werden onder vuur genomen. Maar toch genoeg om Roolvink van een wetsvoorstel te weerhouden.

\section{De versplintering van een categorie}

Wat de SER merkwaardigerwijs niet in zijn eindverslag vermeldde was dat tijdens de 'hearing' diverse vrouwenorganisaties een vroegere pensionering afwezen omdat vrouwen en mannen gelijk(waardig) waren en dus dezelfde rechten en plichten zouden moeten hebben. $\left.{ }^{30}{ }^{(} c^{*}\right)$ Dit argument - waarover later meer - én het gebrek aan succes brachten steeds meer eisers er na 1966 toe hun claims om te buigen.

Toch werd de eis nog niet begraven. In 1967 vroeg 'mejuffrouw' Van Leeuwen (ARP) of de minister iets kon vertellen over de studie naar de levensomstandigheden van ongehuwde vrouwen waar de SER om had gevraagd. Van Leeuwen was er namelijk niet zeker van of dit onderzoek wel zo noodzakelijk was. Het idee om een studie te laten verrichten was vermoedelijk het ge- 
volg van de 'hearing' van de vrouwenorganisaties. Maar deze vrouwenorganisaties achtte ze '(...) toch niet de eerste aangewezenen om over dit vraagstuk een standpunt in te nemen, omdat de betrokkenen zelf in deze vrouwenorganisaties - want de meest schrijnende nood is namelijk bij de vrouwen uit de laagst bezoldigde groepen - weinig vertegenwoordigd zijn, zeker in de leidinggevende functies'. Van Leeuwen achtte wél een spoedige studie nodig naar de vraag of de vrouw inderdaad op oudere leeftijd fysiek en psychisch eerder ongeschikt was voor een plaats in het arbeidsproces dan de man. Want dat was volgens haar '(...) de enige grond, waarop wij zouden kunnen pleiten voor de verlaging van de pensioengerechtigde leeftijd voor de ongehuwde vrouw $(\ldots)^{311}$

Van Leeuwen, haar fractiegenoten en enkele andere partijen bleven ook in de jaren daarna aandringen op een studie, juist omdat bij velen twijfel heerste over de richting waarin een oplossing voor de problemen van ongehuwde vrouwen moest worden gezocht. Na 1966 wist vrijwel niemand in het parlement meer zeker of die oplossing nu in de AOW of de WAO zou moeten liggen. Slechts CPN'ers waren er heilig van overtuigd dat de pensioengerechtigde leeftijd voor ongehuwde vrouwen verlaagd zou moeten worden, terwijl de PvdA in 1968 als enige zeker was van het tegenovergestelde. ${ }^{3 x}$

PvdA-kamerlid Singer-Dekker tobde in 1967 naar eigen zeggen nog erg met het vraagstuk. 'Enerzijds kan men niet altijd gelijkgerechtigdheid vragen, terwijl men tegelijkertijd een uitzonderingspositie bepleit, maar anderzijds moeten wij heel goed weten dat vrouwen, die op het ogenblik ongeveer vijftig jaar zijn, die gelijkgerechtigdheid nooit hebben gekregen. Zij zijn in alle opzichten gediscrimineerd (...) [en] altijd beschouwd als de zielepieten, die eigenlijk niet in een bedrijf maar in een gezin thuishoorden en die het ongeluk hadden niet getrouwd geraakt te zijn. ${ }^{\text {'3 }}$ Maar een jaar later betoogde Singer-Dekker dat de PvdA zich niet tegen een afwijzing door de minister zou verzetten '(...) omdat de verlaging van de AOW-gerechtigde leeftijd het grote risico meebrengt van alle mogelijke discriminaties ten opzichte van de vrouw in het algemeen en van de ongehuwde vrouw in 
het bijzonder. Verlaging van de AOw-gerechtigde leeftijd zal zeker leiden tot ontslag bij 60 jaar, ook voor die vrouwen die helemaal niet van plan zijn ontslag te nemen. ${ }^{34}$ Bovendien zou het een verslechtering betekenen voor die vrouwen die nu recht hadden op een veelal hogere WAO-uitkering, een uitkering die ze bij pensionering zouden verliezen.

Ook minister Roolvink liet herhaaldelijk weten de knoop voor zichzelf nog niet te hebben doorgehakt. ${ }^{35} \mathrm{Al}$ met al voelde hij zich, mede door de vele brieven die hij kreeg, behoorlijk door de zaak achtervolgd. Hij zag nog steeds wel wat in een verlaging van de pensioengerechtigde leeftijd voor ongehuwde vrouwen, maar wilde de SER niet tegen zich in het harnas jagen. Bovendien schreef hij in een antwoordbrief aan de verplegingsfederatie - die in 1968 in afwachting van een definitieve maatregel binnen de AOW om een tijdelijke maatregel binnen de WAO vroeg - dat het in de gegeven omstandigheden ondoenlijk was om voor de ongehuwde vrouw de pensioengerechtigde leeftijd te verlagen. Dit gold volgens hem temeer omdat de premies voor bijna alle sociale verzekeringen in 1968 sterk moesten stijgen en tegen de hoge premies bij de bevolking in toenemende mate weerstand rees. ${ }^{36}$

Toch wilde Roolvink geen definitieve uitspraak doen en hij beloofde vaart achter de studie te zetten. Nog even zag het ernaar uit dat het Eerste-Kamerlid Vuylsteke (KVP) hem een uitweg zou bieden. In 1969 wees zij erop dat de aanzwellende stroom onvrijwillige vrijgezellen de situatie wel eens drastisch zou kunnen doen veranderen. Trouwen zou voor de ongehuwde vrouwen misschien de oplossing voor de toekomst kunnen zijn. ${ }^{37}$ Roolvink pakte die strohalm dankbaar vast: "Als dit vraagstuk zich vanzelf zou oplossen, doordat de ongehuwde vrouwen, voor zover zij het verlangen hebben nog eens in het huwelijk te treden, daarvoor de gelegenheid krijgen, dan zou ik zeggen: dit is een van de schoonste oplossingen, die voor een vraagstuk als dit is te vinden. ${ }^{3{ }^{38}}$

Wat werkelijk als de schoonste oplossing uit de bus zou rollen, werd echter niet zozeer beïnvloed door aanstormende vrijgezel- 
len, als wel door de lang verwachte studie De Ongehuwde Vrouw. ${ }^{30}$ Deze studie, die in 1970 verscheen, onderzocht de levensomstandigheden van ongehuwde vrouwen van 40-65 jaar en vergeleek die met de situatie van ongehuwde mannen uit dezelfde leeftijdscategorie. Daarbij ging het bij beide groepen om de verhouding tussen hun belasting en belastbaarheid.

Die vraagstelling betekende dat Van Leeuwens rechtsgrond (vrouwen zijn psychisch en fysiek eerder 'aan hun eind' dan mannen) niet werd onderzocht. Maar wat eveneens belangrijke gevolgen zou hebben was dat de studie - door in het eerste deel de schijnwerpers uitsluitend op de ongehuwde vrouwen te richten - ook de verschillen binnen deze groep duidelijk maakte. De bestudeerde ongehuwde vrouwen, zo schreven de onderzoekers, hadden behalve hun burgerlijke staat weinig gemeenschappelijk. Binnen de totale groep (ruim I60.000 vrouwen in 1967) diende dan ook een onderscheid gemaakt te worden naar werkende ongehuwde vrouwen $(67,3 \%)$, ongehuwde vrouwen die niet meer werkten $(20,4 \%)$ en ongehuwde vrouwen die nooit gewerkt hadden $\left(12,3^{\%}\right) 4^{40}$ Tot de diverse probleemgroepen hoorde de laatste categorie, vrijwel de gehele middelste categorie en een deel van de werkende vrouwen.

Anders dan de SER in 1963 verondersteld had, achtte $84 \%$ van de werkende ongehuwde vrouwen het onjuist dat ongehuwde vrouwen pas op 65-jarige leeftijd een AOW-uitkering kregen en vond tweederde deel het onterecht dat de pensioengerechtigde leeftijd van ongehuwde mannen en vrouwen gelijk was. "Waar de SER echter gelijk in had gehad, was de veronderstelling dat ook ongehuwde mannen een dubbele taak hadden. Voor minder dan een vijfde van de ongehuwde mannen gold inderdaad een dubbele of zelfs drievoudige taak (werk, huishouding en zorg voor hulpbehoevende huisgenoot). Daar stond echter tegenover dat hetzelfde voor meer dan de helft van de oudere ongehuwde vrouwen gold. De onderzoekers achtten de belasting van de ongehuwde vrouwen dan ook principieel onvergelijkbaar met die van de ongehuwde mannen, al lag de situatie wat betreft de belastbaarheidgenuanceerder.

Een onthullend rapport, vond Van Leeuwen. Maar ook een 
rapport waaruit duidelijk werd dat de groep oudere ongehuwde vrouwen niet zomaar over één kam kon worden geschoren. Wist de minister, zo vroeg zij samen met een aantal andere kamerleden, al wat zijn antwoord hierop was?+2 Dat antwoord had Roolvink niet. Maar hij zou er een interdepartementale werkgroep voor aan de slag zetten. ${ }^{43}$

Het rapport dat de betreffende werkgroep in 1973 aan de Tweede Kamer zond bevatte een lawine van voorstellen tot maatregelen in de sfeer van de bedrijfsgeneeskundige zorg, de werktijden, de arbeidsongeschiktheidsverzekering, het invaliditeitspensioen, de arbeidsbemiddeling, de om- en bijscholing en de huishoudelijke hulp. ${ }^{44}$ Maar een verlaging van de pensioengerechtigde leeftijd werd onder verwijzing naar de argumenten van de SER afgewezen. En met hetzelfde type argumenten - 'niet alle ongehuwde vrouwen hebben het moeilijk en anderen dan ongehuwde vrouwen hebben het even moeilijk' - keerde de werkgroep zich tegen een categorale regeling binnen de Algemene Bijstandswet. Want bij elke maatregel diende men zich, aldus redeneerde de werkgroep, bewust te zijn van het risico van discriminatie van vergelijkbare groepen én van de kwade kans tot een te ver gaande, en daardoor stigmatiserende bescherming.

Ondanks de zojuist besproken versplintering van de categorie 'ongehuwde vrouwen' en de afkeer die de SER en de ambtenaren van een categorale regeling voor ongehuwde vrouwen tentoonspreidden, was de discussie nog niet afgerond. Door vakcentrales, vrouwenorganisaties, belangengroepen en leden van het parlement werden tot ver in de jaren tachtig regelingen - waaronder een tijdelijke rijksgroepsregeling - voorgesteld, besproken en becommentarieerd die ongehuwde vrouwen uit hun benarde positie zouden moeten bevrijden. Ook de regeringen bleven zich met de kwestie bezighouden. Zo werd ondermeer een voorziening voor ongehuwde mannen én vrouwen binnen de Aanvullende Arbeidsongeschiktheidswet overwogen."

De kans op een verlaging van de pensioengerechtigde leeftijd in de AOw werd na 1977 steeds kleiner. In een brief aan de Tweede Kamer in dat jaar memoreerde minister Boersma de inmiddels 
klassiek geworden argumenten. Ten eerste liepen de aard, ernst en mate van het vóórkomen van problemen bij ongehuwde vrouwen zo uiteen dat maatregelen voor de gehele categorie niet juist zouden zijn. Ten tweede beperkten de problemen van veel oudere ongehuwde vrouwen zich niet specifiek tot deze categorie, maar golden ze ook voor anderen. Zo speelde het probleem van de dubbele taak ook voor alleenstaande ouders. $(d *)$ Ten derde zou een verlaging van de pensioengerechtigde leeftijd niet stroken met het beginsel van gelijke behandeling van vrouwen en mannen. Mede om die reden zagen verschillende vrouwenorganisaties niets in een wijziging van de $\mathrm{AOW}$. $^{40}$

Inderdaad kreeg het gelijkheidsargument aan het eind van de jaren zestig en de eerste helft van de jaren zeventig - met het ontstaan van de tweede feministische golf-voor steeds meer fracties en vrouwenorganisaties extra gewicht, zij het nog niet voor iedereen. Boersma vermeldde in zijn brief van 1977 dat de actiegroep Man/Vrouw-Maatschappij wél voor een verlaging van de pensioengerechtigde leeftijd pleitte. Ook het Vrouwenactiecomité en de Werkbijen bleven volharden. En zelfs de Emancipatiecommissie schreef in 1976 dat-hoewel het op zichzelf juist was dat mannen en vrouwen op gelijke leeftijd pensioengerechtigd werden - als overgangsmaatregel de mogelijkheden voor vervroegde vrijwillige pensionering voor oudere alleenstaande werkende vrouwen verruimd diende te worden. ${ }^{47}$

Toch werd ook de Emancipatiecommissie voorzichtiger. In 1979 bleek de commissie in een algemene verlaging van de pensioengerechtigde leeftijd voor ongehuwde vrouwen te veel gevaren te zien. Daartoe behoorden de risico's tot inkomensachteruitgang en versterking van het isolement waarin een deel van de betrokken vrouwen verkeerde. ${ }^{48}$ Wel stelde de Emancipatiecommissie een tijdelijke uitkeringsregeling voor. Bovendien had de Europese Gemeenschap ondertussen, op 19 december 1978 , de zogenaamde 'derde richtlijn' aangenomen. Die richtlijn bepaalde dat het beginsel van gelijke behandeling van mannen en vrouwen binnen een aantal jaren ook op het gebied van de sociale zekerheid ingevoerd zou moeten zijn. ${ }^{49}$

Daarmee had de regering, althans voorlopig, het tij mee. Het 
debat over eventuele voorzieningen voor ongehuwde werkenden was nog niet afgesloten. ${ }^{50}$ Maar een bijzondere AOW-gerechtigde leeftijd voor ongehuwde vrouwen zat er niet meer in.

\section{Slot}

De verlaging van de AOW-gerechtigde leeftijd voor ongehuwde vrouwen was één van de vele nieuwe eisen waarmee de naoorlogse verzorgingsstaat geconfronteerd werd. Precies zoals Schuyt veronderstelde, speelde het verschijnsel 'sociale vergelijking' bij de ontdekking en formulering van deze eis een belangrijke rol. Oudere ongehuwde vrouwen werden vergeleken met andere categorieën met wie zij wél bepaalde kenmerken maar niet bepaalde rechten gemeen hadden, terwijl ook het omgekeerde voorkwam. In dat geval werd de vergelijking aangevoerd om te wijzen op een kenmerkend verschil waarmee vervolgens het recht op een afzonderlijke behandeling geëist werd.

Anders dan Schuyt verondersteld zou hebben, bleek de overheid wel degelijk in staat de rechtmatigheid van de bewuste eis te betwisten. Ook in dit geval was er geen 'interne sleutel' aan de hand waarvan een snel oordeel geveld kon worden. Maar de SER - en in haar kielzog de bewindslieden en de ambtenaren - zagen gelijkenissen waar de voorstanders op verschillen wezen, en ongelijkheden waar de eisers overeenkomsten constateerden. Dat had niet alleen te maken met andere interpretaties van gegevens, maar vooral met de keuze van de 'vergelijkbare' categorieën en kenmerken. Juist over de mate waarin en de grond waarop bepaalde groepen met elkaar vergelijkbaar waren, was zoveel discussie mogelijk dat rechtvaardigheidsargumenten zowel voor als tegen de verlaging van de AOW-gerechtigde leeftijd ingezet konden worden.

Dat roept de vraag op wat de achterliggende redenen voor de afwijzing geweest kunnen zijn. Weliswaar was de groep ongehuwde vrouwen klein, maar er werden in dezelfde periode wel voor kleinere groepen maatregelen getroffen. De gevraagde regeling kostte geld, maar dat gold ook voor de vele categorale re- 
gelingen die probleemloos een wettelijke status bereikten. Een tekort aan vrouwelijke arbeidskrachten, volgens het Vrouwenactiecomité de reden, kan slechts tijdelijk gespeeld hebben. Misschien waren de ongehuwde vrouwen organisatorisch onvoldoende in staat één vuist te maken en zich als electoraat te laten gelden. Zo is het mogelijk dat het Vrouwen-actiecomité zich naar de maatstaven van de SER onvoldoende 'formeel' opstelde het comité werd in ieder geval niet voor de 'hearing' uitgenodigd. Daar staat tegenover dat de wensen van de ongehuwde vrouwen wel degelijk door de volksvertegenwoordiging werden opgemerkt. De kwestie van hun AOw-gerechtigde leeftijd werd immers door vertegenwoordigers van uiteenlopende partijen op de agenda gehouden.

Zeker is, dat het zichtbaar worden van de onderlinge verschillen tussen ongehuwde vrouwen hun zaak geen goed deed, evenmin als het toenemende gewicht van het gelijkheidsargument. Het belang van dat laatste wordt nog duidelijker bij vergelijking met het buitenland. In de tweede helft van de jaren dertig voerde de National Spinsters Pensions Association in Groot-Brittannie eenzelfde soort strijd als het Vrouwen-actiecomité in Nederland. Ook de Engelse 'spinsters' vroegen om een verlaging van hun pensioengerechtigde leeftijd, in dit geval van 65 naar 55 jaar. Ook zij beargumenteerden hun wens door zich met weduwen te vergelijken. Bovendien wezen zij erop dat het voor ongetrouwde vrouwen rond hun 55 ste moeilijker werd hun werk te behouden of nieuw werk te vinden, omdat werkgevers hen minder efficiënt, flexibel en fysiek aantrekkelijk vonden. Volgens een commissie die de zaak onderzocht, was het voor vrouwen van boven de s5 inderdaad iets moeilijker om werk te vinden of te behouden dan voor jongere vrouwen of mannen van dezelfde leeftijd. De vergelijking tussen ongehuwde vrouwen en weduwen vond de commissie echter niet terecht. Weduwen kregen hun pensioen op grond van hun verweduwing, niet omdat zij op s5-jarige leeftijd 'oud' werden. Wel zag de commissie iets in een verlaging van de pensioengerechtigde leeftijd voor alle vrouwen.

De Britse regering nam dit idee over, mede omdat een dergelijke maatregel een geheel ander probleem kon oplossen: dat van 
de financiële moeilijkheden van echtgenoten die 65 werden, terwijl hun vrouw - en dit kwam vaak voor - dat nog niet was. In dat geval moest het echtpaar van één pensioen leven. Mede met het oog op deze kwestie kondigde de regering in 1940 aan de pensioengerechtigde leeftijd voor alle vrouwen tot 60 te verlagen. Op die manier werden niet alle echtparen geholpen en kregen de 'spinsters' slechts gedeeltelijk hun zin. Niettemin werden twee vliegen in één klap geslagen. Maar wat de 'spinsters' in 1940 gedaan kregen, lukte het Vrouwen-actiecomité veertig jaar later niet meer. De Engelse regering had, anders dan het Nederlandse bewind, voor de maatregel in kwestie meer redenen dan alleen het tegemoet komen aan de problemen van oudere ongehuwde vrouwen. Maar er speelde ook een ander belangrijk verschil: in het Engeland van de jaren veertig was de weerstand tegen een ongelijke behandeling van mannen en vrouwen niet zo groot als in het Nederland van de jaren zeventig en tachtig."

Wat in Nederland de achtergronden voor de afwijzing ook zijn geweest, duidelijk is dat het rechtskarakter zélf voldoende barrières bood tegen claimende burgers. Daarmee laat de geschiedenis van de pensioengerechtigde leeftijd van ongehuwde vrouwen zien hoe het rechtskarakter van de verzorgingsstaat weliswaar het formuleren van grenzen tussen sociale categorieën oproept, maar allesbehalve vastlegt welke grens uiteindelijk in wetgeving verankerd raakt. Nieuwe regels vloeien, met andere woorden, niet 'functioneel' voort uit het rationele karakter van de moderne samenleving, noch uit het rechtskarakter van de verzorgingsstaat. Bovendien maakt deze geschiedenis duidelijk dat in het formuleren en vastleggen van grenzen tussen sociale categorieën niet alleen de staat, maar juist ook burgers zélf - in dit geval oudere ongehuwde vrouwen - de hand hebben gehad of probeerden te hebben. Daar komt bij dat deze geschiedenis niet zondermeer in termen van een lineaire, toenemende standaardisering van de ouderdom geïnterpreteerd kan worden. Weliswaar bleef de AOW-gerechtigde leeftijd van 65 jaar als standaard gehandhaafd, maar via regelingen in de sfeer van de Ziektewet en de wAo konden ongehuwde vrouwen alsnog met werken ophouden op een andere leeftijd dan die van 65 jaar. 
Het rechtssociologisch perspectief maakte het mogelijk om een poging een sociale categorie af te bakenen en als bijzondere groep in de wetgeving bevestigd te zien, in termen van 'sociale vergelijkingen' te volgen. Het liet zien in welke context de grenzen tussen sociale categorieën worden aangebracht of opgeheven en welke mechanismen daarbij een rol spelen. In het afbakenen van de sociale categorie van oudere ongehuwde vrouwen werd ondermeer geprobeerd aan te tonen dat deze vrouwen op jongere leeftijd 'uitgeblust' waren dan andere ouderen: eerder werkloos, ziek of invalide werden en eerder hun prestaties achteruit zagen gaan of hun vele taken niet meer aankonden. Dat zou, samen met het argument dat de ongehuwde vrouwen veel gemeen hadden met allerlei groepen burgers die wél eerder van de sociale zekerheid konden genieten, in een verlaging van de pensioengerechtigde leeftijd moeten resulteren. Die nieuwe leeftijdsregel zou het bestaan van een bijzondere sociale categorie - oudere ongehuwde vrouwen - moeten markeren.

Het verloop en de uitkomst van het debat over deze markering waren echter, zo bleek, allesbehalve kwesties van leeftijd. Die ontwikkeling werd wat de 'grammatica' van het debat aangaat door de juridische regels van de verzorgingsstaat bepaald, en wat de uitkomst betreft door politieke keuzes en ontwikkelingen als de opkomst van het emancipatie-denken. De grenzen van de ouderdom liggen echter niet alleen in het onderscheid naar sociale categorie, maar ook in datgene wat voor de ouderdom als levensfase 'normaal' of 'natuurlijk' wordt geacht. Voor deze laatstgenoemde grenzen waren, zo zal in het volgende hoofdstuk blijken, andere zaken relevant dan voor die van de ouderdom als sociale categorie. 


\section{4 \\ Natuurlijk verouderen: de geriatrie en het karakter van een levensfase ${ }^{1}$}

\section{Inleiding}

De grens tussen wat normaal en abnormaal is voor een bepaalde leeftijd, of tussen verschijnselen die wel en niet tot de natuurlijke veroudering gerekend mogen worden, kan in het dagelijks leven van grote betekenis zijn. Wie meent dat enige vergeetachtigheid op hogere leeftijd normaal is, maakt zich-eenmaal ouder geworden - waarschijnlijk weinig zorgen over wat hem of haar zo nu en dan ontschiet. En wie veronderstelt dat een achteruitgang van bepaalde lichaamsfuncties na een zekere leeftijd natuurlijk is, past zijn of haar sportieve aspiraties vermoedelijk daarbij aan.

Onder medici zijn discussies over wat ten aanzien van de ouderdom als normaal en abnormaal, natuurlijk en onnatuurlijk moest worden beschouwd in ieder geval zeer belangrijk geweest. Het is dan ook begrijpelijk dat historici en sociologen in hun onderzoek naar de typering en waardering van de ouderdom in het verleden ook de geschiedenis van de geneeskunde en het medisch-wetenschappelijk onderzoek hebben bestudeerd. Zo heeft Carole Haber betoogd dat Europese en Amerikaanse artsen in de tweede helft van de negentiende eeuw een groot aandeel hadden in de problematisering van het ouder worden. Dat gebeurde doordat deze artsen, op grond van post mortem onderzoek waarin bij ouderen steeds anatomische afwijkingen werden aangetroffen, ouderdom en het verval van weefsels en organen aan elkaar gelijk gingen stellen. Het ontstaan van deze associatie liep parallel met de opkomst van ouderdomsvoorzieningen die de afhankelijkheid van ouderen onderstreepten. Deze combinatie van ontwikkelingen leidde tot een beeld van de ouderdom als 
een levensfase waarin een terugtrekking uit de samenleving, bij voorbeeld via pensionering en institutionalisering, wenselijk en noodzakelijk was. Zo werd, aldus Haber, de uitsluiting van ouderen uit het maatschappelijk leven zowel door economische en demografische veranderingen - als gevolg waarvan ouderen de controle over hun familie, inkomen en bezittingen verloren - als door de voorschriften van deskundigen een feit. ${ }^{2}$

Hoewel Habers stellingen over de negentiende eeuw overtuigend zijn, hoeft dat uiteraard niet te betekenen dat veranderingen in het denken en doen van artsen steeds parallel liepen met ontwikkelingen op het terrein van de economie, de politiek of het particulier initiatief. Een deel van de 'constructivistisch' werkende geschiedschrijvers neemt dat laatste, zo werd in het eerste hoofdstuk besproken, te gemakkelijk aan. Zij spreken over de standaardisering of 'verafhankelijking' van de ouderdom als grote bewegingen met één grondoorzaak, waaraan vanuit uiteenlopende maatschappelijke domeinen, waaronder de medische wereld, is bijgedragen. Maar of de opvattingen van artsen en onderzoekers, voor zover die onderling al op één lijn lagen, inderdaad spoorden met de gedachten, regels en ontwikkelingen in andere kringen, is wat betreft het naoorlogse Nederland nog maar de vraag. Het antwoord kan per kwestie verschillend zijn.

Bovendien is er geen reden om aan te nemen dat onderzoekers en artsen de bakens rond de ouderdom slechts in één richting hebben verzet. $\mathrm{Zij}$ konden, zo zal nog blijken, binnen één betoog de inhoud of de redelijkheid van een gebruikelijke "begrenzing' van de ouderdom ter discussie stellen én een nieuwe grens, over een andere boeg, verdedigen. Die dubbele inzet kon zowel een problematisering als een de-problematisering van de ouderdom betekenen. Daar komt bij dat de opvattingen en voorstellen van medici niet steeds geruisloos en zonder verschuivingen door anderen zijn overgenomen.

Dit alles kan duidelijk worden gemaakt aan de hand van de lotgevallen van een veelvuldig door artsen besproken grens: die tussen omkeerbare en onomkeerbare verschijnselen in de ouderdom, en daarmee de grens tussen wat aan de ouderdom als levensfase inherent is en wat niet (paragraaf 2). In de beschouwingen over 
deze grens speelde het onderscheid tussen wat ten aanzien van de ouderdom wel en niet 'natuurlijk' dan wel 'normaal' werd geacht een grote rol. Een deel van de betrokkenen stelde de gangbare plaatsbepaling van de grens tussen het omkeerbare en het onomkeerbare ter discussie, maar verbond daaraan tegelijkertijd de noodzaak van een specifieke deskundigheid en een aparte voorziening: de geriatrie en geriatrische afdelingen van ziekenhuizen. Deze poging een uitspraak over de aard van de ouderdom aan een bepaalde praktijk te verbinden, mislukte echter, althans in eerste instantie (paragraaf 3 ). De nieuwe verhouding tussen het omkeerbare en het onomkeerbare kreeg voet aan de grond. Maar de daaraan gekoppelde praktijk haalde voorlopig niet de omvang die de propagandisten ervan wensten. Het lot van het gedachtengoed van deze medici lag voor een belangrijk deel in de handen van anderen.

Dat de toekomst van beweringen van onderzoekers in de handen van anderen ligt, is een stelling die de afgelopen jaren door de Franse wetenschapsonderzoeker Bruno Latour is verdedigd en geillustreerd. Hij betoogt dat in het proces waarin wetenschappelijke beweringen geaccepteerd raken en de status van 'gegevens' krijgen, ook de samenleving verandert. Zo diende Pasteur, om zijn laboratorium-bevindingen ten aanzien van bacteriën zowel binnen als buiten het laboratorium 'waar' te laten zijn, artsen ervan te overtuigen hun praktijk zo te veranderen dat buisjes en soortgelijke instrumenten daarin ondergebracht konden worden. Met de verplaatsing van kennis kreeg de wereld een nieuw gezicht. Voor de manier waarop de beweringen van onderzoekers met andere gedachten, gebruiken en voorwerpen verbonden raken, acht Latour de term 'translatie' dan ook geschikter dan het gebruikelijke begrip 'diffusie'. De laatste term verwijst naar een geruisloze verspreiding van wetenschappelijke kennis over de samenleving. Het woord 'translatie' moet duidelijk maken dat met de verplaatsing van kennis zowel die kennis als de wereld van aanzien verandert.

Daarmee wil Latour niet beweren dat onderzoekers - of artsen en ingenieurs - in dit proces van translatie of (her)ordening 
steeds de eerste viool spelen. Wel laat hij zien dat onderzoekers een omvangrijk retorisch repertoire tot hun beschikking hebben om de wereld naar hun hand te zetten. Daarbij kunnen ze hun stellingen zo versleutelen dat ze in het gedachtengoed passen van degenen die overtuigd dienen te worden. Maar minstens zo belangrijk is het gebruik van wetenschappelijke concepten, apparaten en 'verbanden' door anderen dan de onderzoekers zelf. Gebruikers kunnen de door onderzoekers geïntroduceerde ideeën op een eigenzinnige manier hanteren en 'verslepen'. Ordenende elementen liggen bovendien in het ontstaan van instituten en instrumenten waarin de ideeën van onderzoekers vorm krijgen, en die tot nieuwe vindingen en gedragsregels aanleiding kunnen geven. In de sluiting en uitbreiding van dergelijke 'bondgenootschappen' of 'netwerken' tussen mensen, beweringen en dingen, ligt de essentie van nieuwe ordeningen.

Zo gaan, aldus Latour, de produktie van kennis en de opbouw van een samenleving hand in hand. Wie de ordening van de wereld op het spoor wil komen, doet er dan ook goed aan wetenschappers, artsen of ingenieurs in hun doen en laten te volgen en de netwerken te traceren waarin hun beweringen en ontwerpen een weg vinden. Wetenschapsonderzoekers zouden zich naar de mening van Latour dan ook niet bezig moeten houden met het 'verklaren' van de ontwikkeling van wetenschap of techniek aan de hand van de structuur van de samenleving of het wezen van de natuur, maar met het aanschouwelijk maken van de manier waarop 'de natuur' en 'de samenleving' tegelijkertijd ontstaan.

Een dergelijke werkwijze maakt het mogelijk om de grillige lotgevallen van de door artsen en onderzoekers voorgestelde 'grenzen' tussen wat voor de ouderdom als levensfase karakteristiek is en wat niet, zowel in hun ideële als materiële vorm, zichtbaar te maken. Een dergelijke analyse kent ook beperkingen, zo zal in de loop van dit hoofdstuk duidelijk worden. Want met deze manier van 'volgen' komen niet alle zaken boven tafel die voor een goed begrip van de ontwikkelingen rond deze grenzen nodig zijn (paragraaf 4 ). Maar nu eerst de ouderdom. 


\section{In's mensen erfelijke natuur besloten}

In 1952 omschreef de medicus P.A. Voûte veroudering als een vertraging van het levenstempo. Deze vertraging, hoewel per persoon verschillend, kon niet straffeloos genegeerd worden. Wie zich boven zijn lichamelijke, met zijn ouderdom overeenkomende levenstempo forceerde, had grote kans schade te berokkenen aan zijn gezondheid. Zo waren huwelijken van oude mannen met jonge vrouwen (hij 60 , zij 30 jaar) ongewenst. 'De practijk leert dat de man bij dergelijke huwelijken', zo stelde Voûte, 'in vrij korte tijd te gronde kan gaan, omdat hij uit zijn natuurlijke levenstempo van 60-jarige wordt gewrikt door de omstandigheden waaronder hij zichzelf brengt en waartegen hij niet meer is opgewassen."

Voute's karakterisering van de ouderdom sloot aan bij een eeuwenoude metafoor: die van het lichaam als begrensde bron van vitaliteit. Tijdens de ouderdom kwam de bodem van die bron in zicht en begon het lichaam te vervallen. Maar in een ander opzicht brak Voûte met een traditie. Al sinds de oudheid, zo heeft Haber beschreven, werd door artsen een levensloop geschetst waarin volwassenheid en ouderdom duidelijk van elkaar werden onderscheiden. Tot in de negentiende eeuw was de medische behandeling van ouderen niettemin gelijk aan die van volwassenen. Weliswaar werd verondersteld dat mensen in hun ouderdom minder vitaliteit tot hun beschikking hadden dan in eerdere levensfasen en daardoor vatbaarder waren voor ziekten: zozeer zelfs dat de ouderdom zich als één grote ziekte vertoonde. Maar de manifestatie van ziekten werd bij ouderen niet anders geacht dan bij jongeren. Evenmin gingen artsen ervan uit dat de vermindering van de vitaliteit de lichamelijke constitutie van mensen wezenlijk veranderde. Een leeftijdsspecifieke behandeling was dan ook niet aan de orde.

Dat veranderde toen Franse en Duitse artsen - het is al even genoemd - in het midden van de negentiende eeuw naar aanleiding van post mortem onderzoek gingen beweren dat de ouderdom steeds gepaard ging met anatomische afwijkingen van weef- 
sels en organen. Het verval van het lichaam kon, aldus deze artsen, niet meer louter in termen van een vermindering van vitaliteit worden beschreven. Want ook bij ouderen die op het oog gezond hadden geleken, werden anatomische veranderingen als verkalking en verbening van organen aangetroffen. Het ontstaan van dergelijke afwijkingen en veroudering leken twee loten van dezelfde stam. Bijgevolg moest bij het behandelen van de ziekten van ouderen, gezien deze 'natuurlijke' anatomische veranderingen, rekening worden gehouden met wat voor hun leeftijd 'normaal' was. Die standaard van normaliteit bleek echter moeilijk te ontwikkelen: want waar precies eindigde de normale ouderdom en begon de ziekte of pathologie? De meeste Europese clinici schreven, aldus Haber, een groot deel van de ziekteverschijnselen van ouderen toe aan natuurlijke, onvermijdelijke veranderingen in het organisme. Amerikaanse en Engelse artsen, die deze benadering in het oudere vitaliteitsconcept incorporeerden, veronderstelden daarom dat zelfs een ziekte die zowel bij jongeren als bij ouderen voorkwam, in zijn 'seniele' vorm 'anders' was. De natuurlijke en onvermijdelijke verandering van het bejaarde organisme beperkte echter, zo was de overtuiging van deze negentiende-eeuwse artsen, de therapeutische mogelijkheden. Aan ouderdomsziekten viel bijzonder weinig te doen.

Voûte brak met deze traditie door te beweren dat 'ouderdomsziekten' simpelweg niet bestonden. Bij een toename van de kennis over de oorzaken van ziekten zou de betiteling ouderdomsziekte verdwijnen. ${ }^{5}$ Hoewel dat laatste voorlopig niet gebeurde, waren Voûte's opmerkingen typerend voor de naoorlogse jaren. Artsen plaatsten zeer vaak kanttekeningen bij het bestaan van 'typische' ouderdomsziekten. Veel ziekten van ouderen, zo stelden zij, kwamen ook bij jongeren voor. Bovendien bleken bepaalde verschijnselen bij nader inzien niet 'inherent' aan de ouderdom: verschijnselen die aanvankelijk tot de natuurlijke veroudering waren gerekend, waren inmiddels tot 'ziekten' omgedoopt. Gebleken is, zo schreef de arts J. Groen in 1956, 'dat veel van wat tot nu toe als een "natuurlijke", onafwendbare veroudering bij mens en dier is beschouwd, allerminst natuurlijk is, doch veroorzaakt wordt door een ziekte of beschadiging, die 
weliswaar in de ouderdom frequenter voorkomt, doch allerminst per se daaraan gebonden is'. ${ }^{6}$

Groen zelf noemde de atherosclerose als voorbeeld en was bepaald niet de enige die dat deed. J.Th.R. Schreuder, de eerste bijzonder hoogleraar medische gerontologie in Nederland, meldde in zijn inaugurele rede in 1969 dat het altijd moeilijk was geweest 'de obligaat optredende ouderdomsverschijnselen' duidelijk te onderscheiden van de gevolgen van ziekten. In zijn studietijd werd atherosclerose nog als zo'n obligat ouderdomsverschijnsel opgevat. Maar volgens Schreuder had de '(...) schrikwekkende stijging van de frequentie van hartinfarcten bij mannen na het 4 se jaar (...) ons wel anders geleerd. Wij weten nu, dat milieufactoren hierop een zeer grote invloed hebben." Schreuders opvolger C.F. Hollander gaf bij zijn ambtsaanvaarding hetzelfde voorbeeld. 'Waar nog aan het begin van deze eeuw gesteld werd dat de aderverkalking een typische ouderdomskwaal was, weten wij nu dat wij de vroegste afwijkingen van deze zo gevreesde ziekte reeds bij de jong volwassene kunnen aantreffen, maar dat het geruime tijd duurt voordat de veranderingen aan de vaten van dien aard zijn dat ze tot waarneembare stoornissen aanleiding geven."

Anders dan hun negentiende-eeuwse collega's waren artsen en onderzoekers in naoorlogs Nederland - voor zover zij in ouderdomsvraagstukken geïnteresseerd waren - er dus zeer op gebrand te laten zien dat verschillende verschijnselen uit de sfeer van het 'natuurlijke' konden worden getild.' Velen van hen lieten weten dat het onderscheid tussen natuurlijke of fysiologische veroudering en ziekte of pathologie bijzonder ingewikkeld was. ${ }^{10} \mathrm{Maar}$ dat nam niet weg dat het verschil van groot praktisch belang werd geacht. 'Immers, indien men op het standpunt staat, dat de meeste ouderdomsveranderingen onafwendbaar zijn, daar zij berusten op "ingeboren" eigenschappen van de levende stof, lijkt de kans gering om, hetzij curatief, hetzij preventief in deze gang van zaken in te grijpen. Wanneer evenwel vele zogenaamde ouderdomsveranderingen in werkelijkheid berusten op stoornissen, die voor wetenschappelijk onderzoek toegankelijk zijn, dan openen zich mogelijkheden om deze, evenals ziekten op jeugdiger leeftijd, 
eens te kunnen behandelen en te voorkomen', aldus Groen. "

Voor Groen stonden de termen 'onafwendbaar' en 'natuurlijk' aan elkaar gelijk. 'Natuurlijk' stond daarmee tegenover 'te behandelen', 'te voorkomen' en 'omkeerbaar'. Ook andere artsen associeerden de natuurlijke veroudering met onvermijdelijkheid en onomkeerbaarheid. J.G. Sleeswijk, redacteur van een handboek voor artsen dat geheel aan de ouderdom was gewijd, schreef in 1948 dat onderzoek moest uitwijzen 'welke ouderdomsverschijnselen onverbiddelijk in de natuur liggen, welke door misbruik ontstaan en welke zijn te wijten aan de omstandigheid, dat sommige krachten te veel, andere te weinig zijn ontwikkeld'. ${ }^{2}$ Zo wist hij dat het accommodatievermogen van de ooglens al vanaf het rode levensjaar begon af te nemen. Maar het was de vraag 'of zulks als een in 's mensen erfelijke natuur besloten verschijnsel moet worden beschouwd, dan wel of hier reeds een schadelijke factor van het milieu (de school) een rol speelt'. '3

Aan Sleeswijks roep om onderzoek werd in Nederland, zij het op bescheiden schaal, gevolg gegeven. Medisch-biologisch en sociaal-geneeskundig onderzoek deed de academische opvattingen over de oorzaken van bij ouderen optredende verschijnselen, over de gezondheidsproblemen van ouderen in relatie tot omgevingsfactoren en daarmee tevens over de (on)omkeerbaarheid van bepaalde fenomenen veranderen. ${ }^{4} \mathrm{P} . J$. Thung veronderstelde zelfs, dat aan de manipuleerbaarheid van de natuur in principe geen grenzen waren en dat 'inherente' of 'intrinsieke' levensverschijnselen slechts onvoldoende onderzochte verschijnselen waren. Het begrip 'normale veroudering', dat door veel auteurs in dezelfde betekenis werd gebruikt als 'natuurlijke veroudering', diende naar Thungs mening dan ook gereserveerd te worden voor die veranderingen die in een medisch en sociaal goed geoutilleerde samenleving statistisch overheersten. ${ }^{\text {s }}$ Maar ook buiten de onderzoeksinstituten, in klinieken en tehuizen, deden zich ontwikkelingen voor die de 'natuurlijke' of 'onomkeerbare' veroudering een ander gezicht gaven. Om die laatste veranderingen aanschouwelijk te maken is het goed de man te volgen die later de 'Vader van de Nederlandse Geriatrie' zou worden genoemd: de al geïntroduceerde arts Schreuder. ${ }^{16}$ 


\section{Gevaren van bedrust}

In de eerste helft van de jaren vijftig bezocht Schreuder, toen nog internist in een ziekenhuis in Sneek, een groot aantal verpleegen verzorgingshuizen voor bejaarden in de 'Zuidwesthoek' van Friesland. Zijn verslag daarover was weinig opwekkend. 'Als ik mijn indrukken (...) wil samenvatten, geeft het een treurig beeld van verwaarlozing', zo schreef hij. In de meeste inrichtingen was een groot deel van de patiënten bedlegerig en incontinent. Volgens Schreuder werd aan het voorkómen van doorliggen veel aandacht besteed, maar aan de functie van de spieren en gewrichten te weinig. Ruimte en gelegenheid om te zitten, om aan tafel te eten, om zich te wassen, of om na een periode van bedrust het lopen te oefenen, ontbraken. Ook stoorde Schreuder zich aan de psychische verwaarlozing, de 'typisch bazige sfeer'. Hij had aan een patiënte op een ziekenafdeling gevraagd of zij geregeld ontlasting had. Voordat de patiënte iets kon zeggen, had de verpleegster al een antwoord: 'Dokter, de patiënten hebben hier 2 keer per week ontlasting, op Dinsdag en op Vrijdag. ${ }^{17}$ Bed houden, zo bleek uit het verslag, was in de bezochte tehuizen regel.

Schreuders bezoek aan de inrichtingen was onderdeel van een onderzoek naar het aantal chronisch zieken in het werkgebied van het ziekenhuis, de aard van de afwijkingen van deze zieken en hun behoefte aan behandeling en zorg. Wie precies de aanzet tot dit onderzoek gaf, is op basis van de publikaties hierover niet duidelijk. ${ }^{18}$ Maar in ieder geval bracht dit onderzoek Schreuder definitief op het spoor van de ouderdom. In het jaar waarin ook zijn rapport verscheen, publiceerde Schreuder samen met R.J. van Zonneveld een enthousiast verslag van een studiereis naar Engeland. ${ }^{19}$ Midden jaren dertig was de arts Marjorie Warren daar in een armenverpleeghuis begonnen met de reactiverende behandeling van bejaarden. Het resultaat daarvan was dat 'talrijke bejaarden die waren opgenomen als chronisch zieken en die tevoren nog apathisch (...) in bed lagen, weer redelijk gezond en actief werden'. ${ }^{20} \mathrm{Na}$ thuiskomst begon Schreuder ook in zijn eigen ziekenhuis, aanvankelijk op een gang, met de revalidatie van bejaarde patiënten.

Dat een dergelijke aanpak op dat moment niet vanzelfspre- 
kend was, bleek niet alleen uit Schreuders eigen beschrijving van de verzorgingshuizen en rusthuizen in Friesland, maar ook uit de voorstelling die deskundigen zich in de jaren veertig maakten van de ideale zorg voor zieke ouden van dagen. Een Amsterdams rapport uit 1942 noemde verschillende voordelen van een combinatie van een verzorgingshuis met een afdeling voor chronisch zieke en invalide bejaarden. 'Een verzorgingshuis accepteert a priori de chronische invaliditeit als een verschijnsel, dat bij ouder worden der verpleegden bijkans normaal is te achten. Men tracht er het leven van den invalide zoveel mogelijke te veraangenamen, men biedt hem huiselijkheid, gezelligheid, spel en zoo mogelijk zelfs nog arbeid." Weliswaar kregen de verpleegden dus recht op huiselijkheid en arbeid, maar tegelijkertijd werd hun invaliditeit als 'bijkans normaal' geaccepteerd.

Juist dat laatste zou Schreuder in de jaren na zijn Engelse reis te vuur en te zwaard bestrijden. Daarin was hij niet de eerste of enige. ${ }^{21}$ Maar Schreuder toonde zich in de jaren vijftig en zestig wel een van de meest actieve en bevlogen bestrijders van een defaitistische houding ten aanzien van de ouderdom. In zijn vele lezingen, artikelen, interviews en media-optredens kwamen steeds stellingen terug die de 'omkeerbaarheid' van bij ouderen geconstateerde verschijnselen tot inzet hadden. Zo vereiste de aloude verwarring tussen normale ouderdomsverschijnselen-die Schreuder hier in de betekenis van natuurlijke veroudering gebruikte - en ziekte naar Schreuders mening een grote oplettendheid: 'De symptomen van hypothyreose (...) lijken zeer veel op de verschijnselen van de normale ouderdom of althans op ons verwachtingsbeeld hiervan. Kouwelijkheid, constipatie, apathie en langzaam tempo worden bij bejaarden als min of meer normaal beschouwd, zodat men de hypothyreose gemakkelijk over het hoofd ziet. Een zwarte streep op wit papier valt op, een iets minder zwarte streep op grijs papier niet.' Psychische stoornissen werden volgens Schreuder eveneens vaak verkeerd beoordeeld. Dergelijke stoornissen konden reversibel zijn en op allerlei manieren (infecties, vitaminetekorten, uitdroging etcetera) ontstaan, maar blijvend worden als de juiste oorzaak van het lijden niet werd herkend. 'Vooral de acute en de chronische verward- 
heid worden vaak voor dementie gehouden, terwijl de werkelijke oorzaak niet primair in het cerebrum, maar elders gelokaliseerd is. ${ }^{23}$ Net als anderen dat deden, benadrukte Schreuder dat het vaak moeilijk te achterhalen was in hoeverre bepaalde verschijnselen het gevolg waren van ziekte of tot de normale veroudering behoorden. Maar het was in ieder geval zaak, zo viel uit zijn formuleringen af te leiden, om tijdens de diagnose van wat een bejaarde mankeerde, het hoofd niet te snel in de schoot van de normale veroudering te leggen. Men diende omkeerbaar te houden wat nog omkeerbaar was.

De term 'slijtage' zag Schreuder dan ook het liefst uit het vocabulaire van artsen geschrapt. Voor een dergelijke mechanistische term, zo schreef hij, was in geen enkele verouderingstheorie plaats. In de levende natuur kwam slijtage nauwelijks voor. Wie daarvan niet overtuigd was, zou de Vierdaagse eens moeten lopen. ' $[Z]$ ij zullen zien dat de zolen van hun voeten op sommige plekken dikker worden en de zolen van hun schoenen op sommige plekken dunner. ${ }^{24}$ Niet het gevaar van slijtage, zo meende Schreuder, maar die van totale invaliditeit besloop de bejaarde. Vaak noemde hij ondoelmatige voeding, onnodige ongevallen en het niet herkennen van multipele pathologie bij bejaarden het tegelijkertijd lijden aan meer dan één ziekte - als veel voorkomende oorzaken van invaliditeit. Een zo mogelijk nog grotere bedreiging van de validiteit van bejaarden schuilde echter in het bed. 'Bedrust', schreef Schreuder, 'vormt voor alle bejaarden het grootste gevaar, door het ontstaan van seniele osteoporose, spieratrophie, fixatie van gewrichten, contracturen, snelle psychische achteruitgang, incontinentie en decubitus. Voorts is de kans op overlijden door thrombose en embolie bij bedlegerige bejaarden groot (...)'ss Ook voor jongeren gold dat hun gewrichten, spieren, hart en bloedvaten onder bedrust te lijden hadden. Maar bejaarden hadden meer moeite een dergelijke schade te boven te komen. Daarom moest ook met diagnostische en therapeutische middelen voorzichtig worden omgesprongen - de bejaarde diende er niet te veel door te worden belast. Validiteit woog zwaarder dan levensverlenging. ${ }^{26}$ Validiteit was echter allesbehalve een absoluut begrip. Mensen waren, zo legde Schreuder 
steeds opnieuw uit, niet zonder meer (in)valide, maar valide of invalide ten opzichte van bepaalde handelingen. Die handelingen groepeerde Schreuder in drie concentrische cirkels: handelingen ten aanzien van het eigen lichaam, handelingen in het kader van het huishouden, en handelingen ten behoeve van het beroep. Wat bejaarden betreft ging het vooral om de eerste twee groepen handelingen. Voor het herstel of de preventie van het verlies van deze handelingen gebruikte Schreuder het liefst de term 'reactivering', terwijl het begrip 'revalidatie' betrekking hoorde te hebben op de derde groep van handelingen. Reactivering achtte hij dan ook begrensder dan revalidatie. ${ }^{37}$ In het verlengde van Schreuders nadruk op de relativiteit van invaliditeit lag zijn integrale benadering: een arts die de bejaarde patiënt werkelijk terzijde wilde staan, diende niet alleen diens lichaam, maar ook diens psyche - zoals het tempo en de motivatie van de patiënt - en zijn sociale omgeving in de gaten te houden: een ongeschikte woning kon een gereactiveerde bejaarde opnieuw invalide maken.

Op die manier probeerde Schreuder de grens tussen omkeerbare en het onomkeerbare te verschuiven: het terrein van het eerste werd in de beweringen van Schreuder groter ten koste van het laatste. Wie goed keek, zou - aldus Schreuder - in een verschijnsel dat tot de normale of natuurlijke veroudering leek te behoren een reversibele stoornis kunnen herkennen. Wie een bejaarde serieus nam, zou de term 'versleten' links laten liggen en zijn of haar invaliditeit proberen te voorkomen of te herstellen. En wie de onderlinge relatie tussen het lichamelijke, het psychische en het sociale tot uitgangspunt koos, kon bejaarden mobieler houden dan ooit mogelijk was geacht.

Schreuder verliet Sneek in 1959 om in Hilversum hoofd van de afdeling voor geriatrie en reactivering van het ziekenhuis Zonnestraal te worden. In 1968 werd hij tevens bijzonder hoogleraar medische gerontologie in Utrecht. ${ }^{28}$ Als hoogleraar liet hij studenten per bus uit Utrecht naar Hilversum komen om hen te laten zien wat reactivering betekende. Door bij lezingen dia's te vertonen en bezoekers in het ziekenhuis te ontvangen, gaf hij 
zijn betoog een visuele ondersteuning. Niet alleen met verwijzingen naar - vaak Engelse - literatuur, maar ook met foto's van bejaarden oefenend aan een looprek, in een roeimachine of met hun arm aan een oud stuurrad, probeerde hij anderen van zijn stellingen te overtuigen. ${ }^{29}$

Dat leek te lukken. Schreuders waarschuwingen tegen het te snel 'afdoen' van klachten en stoornissen van bejaarden als 'versletenheid' of 'dementie' werden in de loop der jaren door velen gedeeld en herhaald. ${ }^{30} \mathrm{Al}$ in 1960 werd in een periodiek voor bejaardenzorg geconstateerd dat de tijd waarin chronisch zieken als hopeloze gevallen werden beschouwd voorbij was. Inmiddels hadden artsen in binnen- en buitenland, waaronder Schreuder, bewezen dat behandeling en daarmee een herstel of behoud van een zekere validiteit mogelijk was." Waar de medische zorg voor bejaarden ter sprake kwam, werd het - ten dele onder verwijzing naar het werk van Schreuder - vanzelfsprekend om ook de revalidatie of reactivering van bejaarden aan de orde te stellen. ${ }^{32}$ Ook bewindslieden en kamerleden lieten zich in positieve zin over de revalidatie van bejaarden uit. Velen van hen beschouwden een dergelijke revalidatie als kostenbesparend, al meende een PvdA-kamerlid dat daarbij niet zo ver mocht worden gegaan dat bejaarden léérden vallen: 'Ik zie deze judo-oefeningen toch liever niet. ${ }^{33}$

Maar judo-oefeningen of niet, in verpleeghuizen verschenen apparaten als de loopbrug, de oefentrap en het schouderrad en deden in de loop der tijd fysiotherapeuten, bezigheidstherapeuten, maatschappelijk werkenden, psychologen en logopedisten hun intrede. Waren revalidatie- en reactiveringsruimten in 1950 in bejaardentehuizen nog onbekend, in 1970 beschikte $13 \%$ van de bejaardenoorden over een dergelijke ruimte en in $198638 \%{ }^{34}$ Het onomkeerbare - de typische ouderdomskwaal, de natuurlijke of normale veroudering, de slijtage - kreeg niet alleen in de wereld van Schreuder, maar ook daarbuiten beduidend minder inhoud dan voorheen. 
3 De perken te buiten: de griatrie en de geriatrische afdeling van het ziekenhuis

\section{Meester op vele wapens}

Toch bereikte Schreuder niet wat hij wilde. Want in zijn betogen was de verschuiving van de grens tussen het omkeerbare en het onomkeerbare slechts één kant van de medaille. De andere kant hield in dat juist omdat het onderscheid tussen normale ouderdom en ziekte zo ingewikkeld was, juist omdat het gevaar van onnodige invaliditeit en irreversibiliteit de bejaarde bedreigde en juist omdat bij ouderen het lichamelijke, psychische en sociale zo verweven was, er een speciale deskundigheid en een aparte voorziening nodig was: de geriatrie en de geriatrische afdeling in het ziekenhuis. Daarmee zette Schreuder in één redenering de typering van de ouderdom in twee verschillende richtingen in beweging. Aan de ene kant werd het 'eigene' van de ouderdom - datgene wat voorheen onomkeerbaar was geacht - verkleind, aan de andere kant werd dat 'eigene' verdiept: de aard van de ouderdom bracht met zich mee dat een specifieke deskundigheid en aparte praktijk noodzakelijk was. Een de-problematisering en ont-medicalisering van het ouder worden in het algemeen - want ouderen werden naar Schreuders mening vaak ten onrechte tot het bed veroordeeld - ging zo hand in hand met een problematisering en medicalisering van de ouderdom van een deel van de bevolking. Een bepaalde groep ouderen, zo luidde de boodschap van Schreuder, zou de deskundige blik en behandeling van geriatrisch gespecialiseerde artsen niet kunnen ontberen.

In Schreuders betogen van de jaren vijftig werd het verband tussen de aard van de ouderdom en de noodzaak van geriatrie en geriatrische afdelingen veelal impliciet via een omschrijving van de problemen van 'chronisch zieke bejaarden' gelegd. In de loop van de jaren zestig gebeurde dat echter steeds vaker expliciet door middel van een typering van de 'geriatrische' patiënt. Een waterdichte definitie van het specialisme geriatrie was niet mogelijk, zo stelde Schreuder, maar dat gold ook voor de bestaande specialismen. Wel kon hij de karakteristieke eigenschappen van de geriatrische patiênt noemen, waardoor 'geriatrie als vak zijn 
eigen coloriet' kreeg. ${ }^{35}$ Schreuder groepeerde die karakteristieken niet steeds op dezelfde manier. Maar de volgende kenmerken waren belangrijk: het bereikt hebben van een zekere leeftijd in combinatie met het lijden aan een ziekte die met veroudering samenhing (al was het moeilijk de invloed van leeftijd precies vast te stellen en was niet iedere bejaarde patiënt een geriatrische patiënt); het naast elkaar voorkomen van een verwarrende hoeveelheid verschillende afwijkingen (de multipele pathologie); het gevaar van invaliditeit (bij voorbeeld door bedrust); en de rol van bijzondere psychologische en sociale factoren (zoals een langzamer tempo of de situatie thuis).

Dit alles vereiste binnen de gezondheidszorg een specifieke deskundigheid en organisatie. Juist de geriater had het vermogen om in het 'moeras van symptomen' wegen aan te leggen, oudere patiënten op een adequate manier te benaderen - geduld! - en het besef van een sociale context te kunnen opbrengen: al bij de opname diende met het ontslag, en dus met de sociale omgeving van de patiënt, rekening te worden gehouden. ${ }^{36}$ En alleen geriatrische klinieken of geriatrische afdelingen van ziekenhuizen waren in staat tegemoet te komen aan de bijzonderheden van de geriatrische patiënt. Want anders dan in de rest van het ziekenhuis, was bedrust op een dergelijke afdeling - die overigens over een normale diagnostische en therapeutische uitrusting hoorde te beschikken - geen regel, maar uitzondering. De oefenzaal diende dan ook het hart van de afdeling te zijn. Daar moest een speciaal programma van reactivering worden uitgevoerd, dat onder geen beding onder leiding van de revalidatie-arts of samen met jongeren mocht plaatsvinden. Want in dat geval wist Schreuder van tevoren 'dat de patiënten in een tempo zullen worden gejaagd, dat hen niet ligt'. ${ }^{37}$

De geriater in het ziekenhuis zou met vele specialisten en paramedici moeten samenwerken en de geriatrische afdeling zou bij voorkeur - naar Engels voorbeeld - een centrale plaats in de gezondheidszorg voor ouderen behoren in te nemen. Zo zag Schreuder de verpleeginrichtingen het liefst onder toezicht van de geriater staan, waarbij niemand tot het verpleeghuis zou mogen worden toegelaten, zonder een diagnose en behandeling in 
het ziekenhuis. Dat voorkwam dat mensen onnodig snel in verpleeghuizen werden opgenomen en confronteerde de geriater met de gevolgen van zijn behandelingen. Daarnaast zag Schreuder, vooral in de grote steden, wat betreft de coördinatie van de preventie en nazorg een taak voor geriatrische diensten: afdelingen van de geneeskundige diensten. In ieder geval zouden de banden tussen afzonderlijke voorzieningen versterkt moeten worden.

In een dergelijke opzet kon, aldus Schreuder, het overgrote deel van de patiënten terug naar huis. Daarmee maakte Schreuder zijn stellingen over de ouderdom tot de rode draad van zijn betoog. In zijn redeneringen vloeiden de geriatrie en geriatrische afdelingen 'logisch' voort uit de aard van de ouderdom. Aan de andere kant kon een deel van die aard - het gegeven dat ten aanzien van de ouderdom meer 'omkeerbaar' was dan voorheen werd gedacht - pas werkelijk zichtbaar en hard gemaakt worden binnen een praktijk waarin geriatrie en geriatrische afdelingen een centrale plaats hadden, en waarin de gescheiden ontwikkeling van ziekenhuis en verpleeghuis een halt werd toegeroepen. Het was 'enkele minuten voor twaalf, liet hij in het midden van de jaren zestig weten. ${ }^{38}$ Veranderde er niets in de organisatie van de bejaardenzorg, dan zou Nederland in de nabije tockomst tweemaal zoveel verpleeghuisbedden nodig hebben dan Engeland en met een veel groter aantal bejaarde chronisch zieken geconfronteerd worden dan andere landen. Het odium dat met de stichting van geriatrische afdelingen de segregatie van bejaarden in de hand werd gewerkt, schreef Schreuder in dezelfde tijd, moest maar op de koop toe worden genomen. ${ }^{39}$

Schreuder probeerde een eigen werkterrein voor geriaters af te bakenen door het bijzondere karakter van de ouderdom te verbinden aan het belang van de specifieke kennis en kunde van de geriater. Uniek was die strategie niet. Volgens de professie-socioloog Andrew Abbott hanteren professies die hun plaats onder de zon nog moeten veroveren een zogenaamde retoriek van 'reductie'. Dat wil zeggen dat deze professies-in-opkomst hun bestaansrecht proberen te verzekeren door aan te tonen dat hen een exclusieve taak wacht die niet reduceerbaar is tot de 'jurisdictie' 
van een bestaande professie..$^{\circ}$ Schreuders strategie om de 'typisch' geriatrische patiënt niet zozeer op grond van een nauwkeurige leeftijdsgrens af te bakenen, maar op basis van de bijzondere eigenschappen van oudere patiënten, past in deze retorische strategie. Wanneer Schreuder alleen leeftijd zou hebben ingezet, dan zou de noodzaak van de geriatrie naast andere specialismen immers minder overtuigend zijn geweest. De inzet van het debat - de erkenning van de geriatrie - riep zo een retorisch patroon op: slechts een bepaald type argumenten was relevant. Juist dat patroon maakte dat 'de grenzen van de ouderdom als levensfase' en de 'grenzen van de geriatrie als vak' twee kanten van dezelfde medaille werden. Voor een erkenning van de geriatrie moest de ouderdom als bijzondere levensfase worden afgebakend, terwijl een bepaalde begrenzing van die levensfase in de praktijk van de ouderenzorg verankerd zou raken, wanneer de geriatrie werd erkend.

Schreuder werd in zijn betoog gesteund door de sociaal-geneeskundige R.J. van Zonneveld en de internisten J. Schouten en C. van Proosdij. Net als Schreuder koppelden zij de karakteristieken van de bejaarde en geriatrische patiënt aan de wenselijkheid van geriatrie en geriatrische afdelingen en wezen zij op de gevaren van bedrust, het succes van reactivering en de behoefte aan een integrale geneeskunde." Volgens Van Proosdij dienden geriaters - die ten onrechte als 'stropers in andersmans jachtvelden' werden beschouw $\mathrm{d}^{43}$ - haastige spoed aan engelengeduld te paren, 'een meester te zijn op vele wapens' én zich te realiseren dat juist deze 'onbegrensdheid' beperkingen met zich meebracht. ${ }^{43}$ Schouten deed in 1968 , samen met Schreuder, zelfs mee aan een televisieprogramma met Sonja Barend, waarin fel van leer werd getrokken tegen het tekort aan geriatrische kennis en geriatrische afdelingen in Nederland. Een tekort, zo meende Schouten, waarvan zowel bejaarden als belastingbetalers zwaar de dupe werden. ${ }^{4}$

\section{Van alles wat, van alles te weinig}

Al presenteerde Sonja Barend deze gang van zaken als een maatschappelijke misstand van de eerste orde, anderen gingen daar 
niet in mee. Voor een verwerkelijking van de plannen van Schreuder diende namelijk veel 'verplaatst' te worden: de indeling van specialismen, de muren van ziekenhuizen en de taken van verpleeghuizen. Dat de geriatrie en de geriatrische afdeling bestaande perken te buiten gingen, hadden de voorstanders ervan zelf duidelijk gemaakt. Voorlopig zouden echter niet deze perken, maar de uitgangsstellingen van Schreuder verschoven worden. De kern van zijn opvattingen over de ouderdom werd overgenomen, maar tegelijkertijd van richting veranderd en ingebed in betogen en praktijken waarin van geriatrie en/of geriatrische afdelingen geen sprake was.

In 1960 liet het bestuur van de Nederlandse Vereniging voor Gerontologie weten dat artsen die met de medische zorg voor bejaarden belast waren, een speciale opleiding nodig hadden. Die opleiding zou moeten bestaan uit drie jaar interne geneeskunde, een half jaar revalidatie, een half jaar psychiatrie en neurologie en drie maanden 'geriatrie'. Het voorstel werd gesteund door de Nederlandse Vereniging voor Geriatrie, die een jaar later een officeel verzoek ter instelling van het specialisme geriatrie indiende bij het Centraal College voor de Erkenning en Registratie van Medisch Specialisten. Ter motivering van de speciale opleiding werd verwezen naar de bijzondere kenmerken, diagnostiek en behandeling van - met invaliditeit bedreigde - bejaarden, naar de vergrijzing en behoefte aan kennis van ouderdomsziekten, alsook naar het niemandsland tussen gezondheid en ziekte op hogere leeftijd. ${ }^{45}$

$\mathrm{Al}$ snel bleek over de noodzaak van geriatrie bij andere specialisten grote twijfel te bestaan. Binnen de Nederlandsche Internisten Vereniging was men het erover eens dat reactivering een belangrijke rol zou moeten spelen bij de behandeling van oudere patiënten en sociale hulp voor deze groep zeer wenselijk was. Maar over de medische organisatie die daarbij hoorde, bestond verdeeldheid. Omdat de ontwikkeling van de geriatrie, zowel naar inhoudelijke begrenzing als naar organisatie, nog niet was uitgekristalliseerd, werd - midden jaren zestig - een definitieve beslissing uitgesteld. ${ }^{46}$ Niettemin lieten individuele internisten niets aan duidelijkheid te wensen over. Zo achtte één van hen 
geriatrische afdelingen zeker zinvol, maar dan wel onder leiding van een internist in plaats van een geriater. Volgens hem was dat ook in Engeland het geval en kon dat ook niet anders. Want aan iedere behandeling diende een goede diagnostiek vooraf te gaan en juist die diagnostiek was bij bejaarden, ondermeer door de multipele pathologie, erg ingewikkeld. Het was dan ook volstrekt onverantwoord om deze taak op te dragen aan medici met onvoldoende opleiding op het terrein van de interne geneeskunde. De geriatrie omvatte inderdaad vele werkterreinen, maar het was onmogelijk de deskundigheid op al deze terreinen in één persoon te verenigen. ${ }^{77}$ Daarmee ontkoppelde deze internist wat Schreuder nauwkeurig aan elkaar verbonden had: dat de aard van de ouderdom een eigen, integraal specialisme vereiste. De internist in kwestie meende, juist met het oog op de 'ingewikkelde' aard van de ouderdom, tegen het gevaar van oppervlakkige kennis te moeten waarschuwen.

Opvallend was dat deze internist Engeland als zijn gidsland beschouwde. Ook Schreuder en de zijnen zagen Engeland immers als lichtend voorbeeld. De laatsten wisten wel dat de positie van de Engelse geriatricians of geriatric physicians niet vergelijkbaar was met die van specialisten in Nederland, maar toch stond de organisatie waarin de 'geriatricians' werkten, met de geriatric units van ziekenhuizen als het hart van de gezondheidszorg voor ouderen, model voor hun wensen. ${ }^{48}$ Bovendien benadrukten Schreuder en de zijnen dat de 'geriatricians' geriatrisch opgeleide artsen waren: hun specialisatie in de geriatrie volgde na een specialisatie in de interne geneeskunde. De internist die de geriatrie overbodig vond, zag de Engelse 'geriatricians' echter in de eerste plaats als internisten.

Ook in kringen van revalidatie-artsen werd verontrust op de plannen voor geriatrie gereageerd. Zo liet iemand weten dat de geriatrie de fundamenten gebruikte, waarop de revalidatie al jaren steunde. Geriaters pronkten dus, zo was de impliciete boodschap, met de veren van een ander. Want tussen de ideologie van de geriater en die van de revalidatie-arts bestond naar zijn mening nauwelijks verschil. De revalidatie-arts erkende sinds jaar en dag de verwevenheid van het biologische, het psychische en het 
sociale, stimuleerde de multidisciplinaire aanpak en benadrukte de nog aanwezige-in plaats van afwezige-validiteit. Dat maakte de geriaters heel wat minder origineel en uniek dan zij zichzelf presenteerden. Revalidatie-artsen zagen dan ook meer in samenwerking tussen revalidatie-artsen en de bestaande klinisch specialisten dan in de instelling van een nieuw vak. Een brede benadering was noodzakelijk, maar niet uitsluitend bij bejaarden. Bovendien werd die brede aanpak al toegepast: door de revalidatie-arts die - anders dan de voorstanders van geriatrie deden voorkomen - meer deed dan mensen weer geschikt maken voor beroepsarbeid. ${ }^{49}$ Zo werden Schreuders eigen pionnen in het spel gebracht, maar op een andere manier op het bord geplaatst dan Schreuder lief was.

In de verpleeghuis-wereld gebeurde iets soortgelijks. Ook daar werden de nieuwe grenzen tussen het omkeerbare en onomkeerbare in de ouderdom tot het eigen domein gerekend. Dat het bejaarden-opberg-systeem verleden tijd was en een activerende en multidisciplinaire benadering de toekomst had, behoorde vanaf de jaren zestig tot het credo van de leidende figuren in de organisaties van verpleeghuizen. ${ }^{50}$ Revalidatie zou dan ook niet alleen in geriatrische afdelingen van ziekenhuizen, maar ook in verpleeghuizen aan de orde van de dag moeten zijn en verder horen te gaan dan het behoud van het al bereikte. Ook verpleeghuizen waren in staat werkelijk positieve resultaten te halen - op een relatief goedkope manier, in een rustiger tempo en in een huiselijke sfeer. ${ }^{\text {st }}$ Anderen gingen echter een stap verder en gaven het verpleeghuis een centrale plaats in de medische zorg voor ouderen. ${ }^{s}$ Weer anderen zagen voor verpleeghuizen een belangrijke taak, maar benoemden de geriatrische dienst tot het hart van de gezondheidszorg. ${ }^{53}$ Ook over het specialisme geriatrie dacht niet iedereen in de verpleeghuis-wereld gelijk. Sommigen zagen in het verpleeghuis het voor de hand liggende werkterrein van de geriater. ${ }^{54}$ Anderen wensten geen erkenning van de geriatrie, maar een aparte opleiding voor de verpleeghuisarts. Want juist dit type arts, zo was de gedachte, bracht de geriatrische benadering in de praktijk..$"$ s

Ondertussen boog de ene na de andere commissie zich over 
de erkenningsaanvraag voor de geriatrie, zonder tot een eensluidende uitspraak te komen. Pas in 1968 hakte het Centraal College de knoop door: de instelling van het specialisme geriatrie werd afgewezen. Dat er ten aanzien van bejaarden een noodtoestand bestond en dat vele huisartsen en specialisten onvoldoende op de hoogte waren van de mogelijkheden tot reactivering, zag het College zeker in. Een specialisme geriatrie zou echter van alles wat én van alles te weinig zijn. Wilde de geriater op alle relevante terreinen voldoende deskundig worden, dan zou een opleiding nodig zijn met een lengte, die maatschappelijk onaanvaardbaar was. Het College zag wel mogelijkheden voor een keuzejaar geriatrie binnen bestaande opleidingen en voor een uitbreiding van het geriatrisch onderwijs voor medisch studenten en artsen in tehuizen. Maar de erkenning van de geriatrie was een brug te ver. ${ }^{56}$

Hiermee zijn zeker niet alle redeneringen genoemd waarmee de plannen van Schreuder en de zijnen, voor of achter de schermen, werden bestreden of van richting werden veranderd. Zo zijn in de discussies rond de geriatrie ook de competenties van neurologen, huisartsen en sociaal-geneeskundigen, de kosten van de eventueel langere verpleegduur van geriatrische patiënten, en de mogelijke verlaging van tarieven van bestaande specialisten in de ring gegooid. ${ }^{57}$ Voor een volledig overzicht van deze discussies zou bestudering van de archieven van vele medische verenigingen en van het Centraal College nodig zijn. Niettemin is duidelijk dat de associatie die Schreuder probeerde te leggen tussen - kennis van - de aard van de ouderdom en de noodzaak van geriatrie en geriatrische afdelingen voorlopig allesbehalve vanzelfsprekend was. De elementen uit het betoog van Schreuder die het defaitisme ten aanzien van ouderen ter discussie stelden, werden - zij het in subtiel verschoven configuraties - ook door anderen tot hun uitgangspunten gerekend. Maar velen van hen gaven de nieuwe grens tussen het omkeerbare en onomkeerbare in de ouderdom een andere organisatorische inbedding dan Schreuder wenste. De laatste mocht menen dat de door hem gesignaleerde taken niet tot de expertise en zeggenschap van andere artsen reduceerbaar was; die artsen dachten daar anders over. 
Na 1968 paste Schreuder zijn wensen gedeeltelijk aan. Een nauwe samenwerking tussen ziekenhuizen en verpleeghuizen bleef hoog op zijn verlanglijst staan. Maar steeds vaker positioneerde hij de verpleeghuis-arts, in plaats van de ziekenhuis-geriater, als belangrijke en soms centrale schakel in die samenwerking. ${ }^{58}$ Een commissie uit de gelederen van de artsen in dienstverband en de sociaal-geneeskundigen kwam na de uitspraak van het Centraal College tot de conclusie dat de verticale, op organen gebaseerde indeling van specialismen haaks stond op het horizontale specialisme geriatrie, en dat een herziening van de structuur van specialismen aan de erkenning van de klinische geriatrie vooraf zou moeten gaan. Wel zag deze commissie binnen de sociale geneeskunde mogelijkheden voor de opleiding van sociaal-geriaters ten behoeve van de sociaal-geriatrische diensten - een idee dat al sinds het begin van de jaren zestig speelde. Voor de erkenning van de klinische geriatrie moest echter meer herordend worden dan zij zelf op dat moment voor mogelijk hield. ${ }^{59}$

\section{Voor Koningin en vaderland}

Een decennium later bleek een erkenning van de geriatrie alsnog haalbaar zonder dat aan de structuur van specialismen werd geknaagd. Dat gebeurde nauwelijks via een bekering van de oorspronkelijke tegenstanders. Hoe dan wel?

Twee jaar na de afwijzing van 1968, diende de Nederlandse Vereniging voor Geriatrie opnieuw een verzoek tot erkenning bij het Centraal College in. Dat verzoek leidde in 1974 tot de instelling van een studiecommissie geriatrie. ${ }^{60}$ In de tussenliggende jaren voerde het Centraal College, aldus het rapport van de studiecommissie, overleg met allerlei deskundigen en betrokkenen. Daarbij werd duidelijk dat het verzet tegen erkenning van de geriatrie nog steeds groot was. Zo meenden de internisten dat zij zelf, gezien het hoge percentage bejaarden onder hun patiënten, voldoende deskundigheid bezaten. Het Centraal College vond echter dat er rond 's lands ouderen vele onopgeloste problemen bleven bestaan en dat de problematiek zo complex was, dat een studiecommissie nodig bleek. Om welke problemen het precies ging, valt niet rechtstreeks uit het rapport af te leiden. Wel werd 
verwezen naar een aantal ontwikkelingen, die het Centraal College er blijkbaar toe bracht de zaak in beraad te houden. Zo had een commissie bejaardenzorg binnen de Koninklijke Nederlandse Maatschappij tot bevordering der Geneeskunst (KNMG) inmiddels laten weten aan de instelling van het specialisme geriatrie hoge prioriteit te geven en wilde de Vereniging van Verpleeghuisartsen de verpleeghuisartsen in een apart register laten inschrijven. Bovendien werd melding gemaakt van de internationale trend om oudere patiënten alleen in uiterste noodzaak naar instellingen als het verpleeghuis over te brengen.

Al boden deze ontwikkelingen enige bewegingsruimte voor de geriatrie, ook binnen de studiecommissie bleef de weerstand tegen de erkenning van de geriatrie aanzienlijk. Tot de leden van de commissie behoorden velen die zich al sinds jaar en dag voor de geriatrie uitspraken. Van de overigen liet een enkeling weten de geriatrie het voordeel van de twijfel te willen geven. Maar de revalidatie-arts, de neuroloog en de internist in de commissie hielden voet bij stuk. De inhoud van hun verzet verschilde niet wezenlijk van die van de jaren zestig. Evenmin kwamen de voorstanders met een ander betoog, al werd de multipele pathologie als argument voor de geriatrie minder belangrijk geacht en kreeg de geriatrische aandacht voor de psychische en maatschappelijke kanten van ziekte meer gewicht dan voorheen.

Dat de studiecommissie ondanks deze herhaling van zetten toch vóór de erkenning van de geriatrie adviseerde, is alleen te begrijpen wanneer ook de verwijzingen - zowel in het rapport als geheel als in de formulering van het uiteindelijke besluit naar politieke ontwikkelingen in ogenschouw worden genomen. In de eerste plaats richtten verschillende ouderenbonden zich in de tweede helft van de jaren zeventig tot de KNMG en het parlement met een pleidooi tot de instelling van het klinisch specialisme geriatrie. Mede naar aanleiding daarvan boog ook de Tweede Kamer zich over de kwestie.

Dit laatste betekent niet dat Schreuders voorstellen nooit eerder parlementaire of ambtelijke sympathie hadden gekregen. Plannen in de lijn van Schreuder werden diverse malen naar voren geschoven, vooral door sociaal-democraten. ${ }^{61}$ Maar weer- 
stand was er eveneens. Zoals al aan de orde kwam, werd het belang van reactivering algemeen ingezien. De noodzaak van geriatrische afdelingen in ziekenhuizen werd echter door verschillende kamerleden betwijfeld. Zij zagen in de medische zorg voor bejaarden vooral een taak voor het particulier initiatief, met name voor de kruisverenigingen en de nog te ontwikkelen consultatiebureaus voor ouderen. ${ }^{63}$ Bovendien werd de erkenning van de geriatrie in de eerste plaats gezien als een zaak van de medici onderling. ${ }^{63}$ Daar kwam bij dat de tegenstelling die Schreuder zag tussen een zelfstandige uitbouw van het verpleeghuiswezen en een adequate gezondheidszorg geen wortel schoot. ${ }^{4}$ Integendeel, via een gedeeltelijke ziekenfondsvergoeding van de verpleegprijs van erkende verpleeghuizen in 1961 en de Algemene Wet Bijzondere Ziektekosten in I968, werd die ontwikkeling juist gestimuleerd. ${ }^{65}$

Opvallend was dat in de jaren zeventig zowel in de argumenten van ouderenbonden als in die van de kant van het parlement vele oude 'verbindingen' opnieuw van stal werden gehaald. Zo zagen de ouderenbonden in de figuur van de geriater een belangrijk antwoord op de behoefte aan coördinatie in de medische opvang van ouderen. ${ }^{66}$ In het parlement werd vooral de bijzondere situatie van ouderen naar voren gehaald. In 1977 nam de Tweede Kamer een motie aan, waarin de regering werd gevraagd eraan mee te werken dat de geriatrie als geneeskundig specialisme zou worden ingesteld en dat algemene ziekenhuizen zouden gaan beschikken over geriatrische afdelingen. Volgens het lid van de Partij van de Arbeid dat deze motie indiende, waren deze maatregelen noodzakelijk ondanks de stigmatisering die categorale voorzieningen met zich meebrachten. Bejaarden vormden een risicogroep en vertoonden vaak meer dan één ziektebeeld tegelijk. Die situatie noopte tot een bijzondere aanpak, al diende in die aanpak zeker samenwerking te worden gezocht met de instanties die de verpleging en verzorging van bejaarden al tot hun taak hadden. ${ }^{\text {"7 }}$

Het was alsof Schreuder zelf het woord had genomen, met dit verschil dat de motie effectiever bleek dan Schreuders inspanningen. De staatssecretaris van Volksgezondheid liet zich positief 
uit over het bestaansrecht van de geriatrie, al wilde hij het aantal ziekenhuizen met een geriatrische afdeling in de hand houden vanwege de beperking van het aantal ziekenhuisbedden die op dat moment aan de orde was. ${ }^{68} \mathrm{Naar}$ aanleiding van de motie liet de secretaris-generaal van het Ministerie van Volksgezondheid en Milieuhygiëne nog in hetzelfde jaar aan het Centraal College weten tegen de erkenning van de geriatrie geen bezwaar te hebben. ${ }^{69}$ Twee jaar later vroeg een nieuwe staatssecretaris hoe de stand van zaken met betrekking tot de geriatrie was. Die vraag stelde ze mede naar aanleiding van de belangstelling die de Koningin voor het vraagstuk had getoond.

Niet lang daarna kwam het rapport van de studiecommissie gereed. Deze commissie zag in het ziekenhuis de natuurlijke plaats van de geriater, al was te voorzien dat een aantal directeuren van verpleeghuizen voor erkenning in aanmerking zou komen en dat de grotere verpleeghuizen in de toekomst geriaters aan zouden stellen. Bovendien achtte de commissie de geriater het middelpunt van de zorg voor ouderen. In 1980 werd, conform de aanbevelingen in dat rapport, de geriatrie in principe als klinisch specialisme erkend. Dat principebesluit werd in $1983-$ via een formulering van opleidingseisen - gevolgd door een formele erkenning..$^{70}$ Voorstanders van de geriatrie gingen ervan uit dat afbakenings- en statusproblemen nog niet voorgoed de wereld uit waren. Zo ging de uitbreiding van het aantal Geriatrische Afdelingen van Algemene Ziekenhuizen hen niet snel genoeg. ${ }^{71}$ Maar al was hun positie nog niet zo sterk als ze wensten, het specialisme bestond.

\section{Naar Brits model}

\section{Een groot verschil}

In de vorige paragrafen werd zichtbaar dat de grens tussen het omkeerbare en onomkeerbare van de ouderdom in het naoorlogse Nederland op een ingrijpende manier verschoof. Mede door de inspanningen van Schreuder werd het domein van het onomkeerbare verkleind: de typische ouderdomskwaal, de 'ver- 
sletenheid' en de natuurlijke veroudering kregen minder inhoud dan voorheen. Zijn stellingen over de aard van de ouderdom kregen niet alleen op papier, maar ook in de organisatie en inrichting van de zorg voor ouderen vorm: via nieuwe apparaten, ruimten en deskundigen in verpleeg- en bejaardentehuizen.

Ook is duidelijk geworden dat deze vorm een andere was dan Schreuder voor ogen had, en is in kaart gebracht wat Schreuder moest 'verplaatsen' om zijn plannen alsnog ingang te doen vinden. Schreuder deed immers niet alleen een poging de grens tussen het omkeerbare en onomkeerbare in de ouderdom te verschuiven, maar wilde tevens nieuwe grenzen creëren in de vorm van een specifieke deskundigheid en categorale voorziening voor ouderen. Zijn eerste pogingen om kennis over de aard van de ouderdom en de noodzaak van geriatrie en geriatrische afdelingen 'logisch' aan elkaar te verbinden, mislukten echter. Anderen bevestigden zijn uitspraken over de ouderdom, maar maakten die uitspraken - via kleine verschuivingen in accent en richting ervan - 'waar' binnen voorzieningen die niet des Schreuders waren. Pas in tweede instantie, met de hulp van ouderenbonden, het parlement, bewindslieden en de studiecommissie geriatrie, werden Schreuders wensen realiteit.

Toch heeft deze analyse iets onbevredigends. Want onduidelijk blijft wat de bemoeienis met de geriatrie op parlementair en overheidsniveau deed toenemen en wat de visie op geriatrie en geriatrische afdelingen deed verschuiven. Evenmin is begrijpelijk waarom vooral sociaal-democraten zich over de plannen van Schreuder ontfermden. Waarom vonden de voorstellen van Schreuder juist bij hen begrip? En waarom achtte het parlement het in de jaren zeventig vanzelfsprekend een uitspraak te doen over geriatrie en geriatrische afdelingen, terwijl deze kwesties voorheen aan de medici werden overgelaten? Beantwoording van deze vragen is mogelijk. Maar daarvoor is het nodig terug te keren naar Schreuders eerste schreden op ouderengebied. Bovendien vereist de beantwoording van de vragen een methodologische manoeuvre, die binnen een Latouriaanse benadering niet gebruikelijk is. 
In het verslag dat Schreuder en Van Zonneveld in het midden van de jaren vijftig maakten van hun reis naar Groot-Brittannië, lieten zij weten dat het geheel van voorzieningen voor 'zieke en gebrekkige ouden van dagen' in dat land een 'efficiënte indruk' maakte. Nederland liep daarbij vergeleken achter. Niet vergeten mocht worden dat Engeland eerder met een grote groep bejaarden was geconfronteerd dan Nederland; dat men in Engeland - ondermeer door de vele oorlogsgewonden - al langer vertrouwd was met de mogelijkheden tot revalidatie; en dat het 'systeem van de National Health Service dikwijls tot een eenvoudiger procedure leidde dan hier te lande, waar verschillende instanties zich met zieke en gebrekkige bejaarden bezighouden'. ${ }^{72}$ Toch nam dat niet weg dat Nederland een achterstand in te halen had. Schreuder en Van Zonneveld hoopten dat de instellingen die zich in Nederland met de zorg voor de oudste bevolkingsgroep bezighielden, zich bewust zouden worden van de taak die hen wachtte.

De 'eenvoudiger procedure' van de Britten lag volgens Schreuder en Van Zonneveld in het gegeven dat de National Health Service de taak had zorg te dragen voor alle zieke bejaarden, los van het feit of deze bejaarden thuis, in het ziekenhuis of in een verpleeginrichting verbleven. 'Een groot verschil met Nederland is dus, dat men bij de verzorging van bejaarde patiënten slechts met één instantie te maken heeft. ${ }^{73}$ Wanneer behandeling thuis niet meer mogelijk was, werd een bejaarde in Groot-Brittannië opgenomen in een gewone afdeling van het ziekenhuis, danwel in een geriatrische kliniek. Tot dergelijke geriatrische afdelingen behoorden soms ook een halfway house voor herstellenden, een long stay annex voor bejaarden die ondanks een zorgvuldige behandeling voortdurend enige verpleging nodig hielden, en revalidatie-afdelingen voor bejaarden met bepaalde stoornissen. Aan het hoofd van al deze afdelingen stond steeds, zelfs wanneer de afdelingen in verschillende gebouwen ondergebracht waren en op het platteland soms tientallen kilometers van elkaar af lagen, de 'geriatrician': meestal een arts met een gehele of gedeeltelijke opleiding in de interne geneeskunde en een speciale belangstelling voor bejaarden. Die organisatie 
maakte het mogelijk dat patiënten gemakkelijk van de ene naar de andere afdeling konden worden overgebracht. Bovendien was ook de samenwerking met de plaatselijke autoriteiten vaak goed en werd geen bejaarde opgenomen voordat de geriater of een assistent de bejaarde thuis had bezocht om na te gaan of opname inderdaad nodig was. Op die manier werd bevorderd dat bejaarden de medische zorg ontvingen die in overeenstemming was met hun toestand.

Uit Schreuders stukken uit de jaren vijftig en zestig komt naar voren dat dit Britse systeem voor hem een uiterst belangrijke inspiratiebron vormde. Schreuder maakte echter niet steeds expliciet wat er precies in de Nederlandse gezondheidszorg moest veranderen om een organisatie mogelijk te maken die vergelijkbaar was met de Engelse. Dat hij samenwerking tussen de verschillende ouderenzorg-instellingen in Nederland tot zijn idealen rekende, kwam in de vorige paragraaf aan de orde. Maar wat die samenwerking in de weg stond, gaf hij slechts in algemene bewoordingen aan. Zo mopperde hij aan het eind van de jaren zestig over het ontbreken van een centrale planning in de gezondheidszorg en over de autonomie van zieken- en verpleeghuizen. ${ }^{74}$ Over de basis van die autonomie liet Schreuder zich niet uit. Degenen die de plannen van Schreuder en de zijnen bestreden, deden dit evenmin. Volgens Van Proosdij pleegden deze ' $[t]$ egenstanders van onze opvattingen' op te merken dat de Engelse toestanden niet zo maar te vergelijken waren met de Nederlandse en 'dat een systeem dat in Engeland uitstekend blijkt te voldoen, daarom nog niet geschikt is voor de situatie in Nederland'. ${ }^{75}$ Inderdaad merkte één van hen op, dat hem de Engelse relatie tussen de geriatrische afdeling van het ziekenhuis en de 'long stay annex' in de Nederlandse verhoudingen niet opportuun leek. 'De sociale en maatschappelijke factoren zijn in Nederland', zo meende hij, 'anno 1967 geheel anders dan in Engeland ten tijde van het pionierswerk van Warren. ${ }^{76}$ Maar hij legde niet uit welke sociale en maatschappelijke factoren dat waren. 


\section{In vergelijking met andere landen}

Hoe anders deze 'sociale en maatschappelijke factoren' waren, kan pas duidelijk worden wanneer de Nederlandse en Engelse situatie gedetailleerder met elkaar worden vergeleken dan Schreuder en zijn tijdgenoten deden.

In het eerste hoofdstuk kwam aan de orde hoe de medischhistoricus Armstrong, geïnspireerd door Foucaults normaliseringstheorie, de 'geboorte' van de geriatrie en geriatrische voorzieningen in Groot-Brittannië beschreef. Die geboorte kwam volgens Armstrong voort uit het gebruik van de 'survey'. Op grond van onderzoek naar de levensomstandigheden en lichamelijke toestand van ouderen, constateerden artsen dat de criteria voor ziekte en gezondheid niet voor iedereen gelijk mochten zijn, maar per leeftijdscategorie behoorden te verschillen. Bovendien bracht dit type onderzoek de artsen tot de overtuiging dat chronische ziekte geen statische eenheid, maar een dynamisch proces was; dat veel bejaarden ziek waren zonder dat zij dit wisten of rapporteerden; en dat het functioneren van bejaarden mede afhing van hun omgeving. Dit alles deed hen concluderen dat Groot-Brittannië een veelomvattende organisatie van geriatrische diensten nodig zou hebben, waarin het momentane karakter van de diagnose werd vervangen door een vorm van toezicht die zich over een langere periode en een grotere ruimte uitstrekte. Preventie en de integratie van ziekenhuizen en extramurale dienstverlening - met daghospitalen en huisbezoek - werd door hen dan ook zeer belangrijk geacht. Zo leidde, aldus Armstrong, de 'survey' tot het ontstaan van bepaalde voorzieningen.

Bij Armstrongs versie van de geboorte van de Britse geriatrie werd in het eerste hoofdstuk de kanttekening geplaatst, dat hij het ontstaan van de geriatrie en geriatrische voorzieningen verklaart uit de opvattingen van artsen, terwijl soortgelijke opvattingen elders niet tot een overeenkomstige positie van de geriatrie of tot een vergelijkbaar systeem van voorzieningen leidden. Dat laatste maakt aannemelijk dat Armstrong in zijn betoog een stap heeft overgeslagen. Dat Armstrongs analyse incompleet is, valt bovendien af te leiden uit een studie van David Carboni. Carboni's studie draait om de vraag waarom de geriatrie zich in Groot- 
Brittannië wel en in de Verenigde Staten niet tot een medisch specialisme ontwikkelde." Welke verschillen tussen dit Europese en Amerikaanse land waren zo belangrijk, dat ze de gescheiden wegen van de geriatrie in die landen kunnen verklaren?

Groot-Brittannië en de Verenigde Staten, zo luidt Carboni's antwoord, verschilden in ieder geval niet wezenlijk naar bevolkingsopbouw, morbiditeitspatroon, beleid ten anzien van ouderen of voorzieningen voor langdurige zorg. Wel constateert Carboni verschillen in de plaats van en bevoegdheden verbonden aan de medisch specialismen in beide landen. Zo is specialisatie in Groot-Brittannië gekoppeld aan de ziekenhuispraktijk, terwijl dat in de Verenigde Staten niet het geval hoeft te zijn. In het eerstgenoemde land is iemand pas werkelijk specialist wanneer hij of zij in een ziekenhuis tot consultant benoemd wordt en de verantwoordelijkheid krijgt over een patiëntenpopulatie. In het laatstgenoemde land wordt een arts echter specialist via het behalen van een diploma, waaraan bepaalde privileges - zoals het mogen berekenen van hogere tarieven - verbonden zijn. In de Verenigde Staten is dan ook een veel groter deel van de artsen gespecialiseerd dan in Groot-Brittannië.

Maar het grootste verschil tussen deze twee landen, en het verschil dat de ontwikkeling van de geriatrie in beide landen uiteen deed lopen, ligt naar de mening van Carboni in de rol van de overheid. In Groot-Brittannië kon de geriatrie zich al kort na de Tweede Wereldoorlog in de belangstelling en steun van het Ministerie van Volksgezondheid verheugen. Toevallig was dit niet. Het ministerie zou namelijk op korte termijn de verantwoordelijkheid krijgen over de gemeentelijke zieken- en armenhuizen, waarin van oudsher veel chronisch zieke ouderen werden ondergebracht. Deze tehuizen kwamen onder de hoede van het ministerie op grond van de oprichting van de National Health Service. In deze voorziening werd het overgrote deel van de bevolking ondergebracht en werd - ondermeer middels de nationalisatie van ziekenhuizen - een regionale en lokale planning van de gezondheidszorg geregeld. Zo kreeg de overheid de bevoegdheid het aantal specialisten vast te stellen. Deze veranderingen leidden ertoe dat ambtenaren van het ministerie zich op 
de hoogte gingen stellen van het 'ouderenwerk' van enkele artsen, zich onder de indruk toonden van het hoge ontslagpercentage dat door Warren werd gehaald, en tot de conclusie kwamen dat de geriatrie binnen de National Health Service speciale aandacht verdiende. Kort na de oprichting van de Medical Society for the Care of the Elderly in 1947, de latere British Geriatrics Society, werden de eerste in geriatrie geïnteresseerde artsen als 'consultants' benoemd. Het ging daarbij aanvankelijk om posten, waarin 'algemene geneeskunde' - door Nederlandse artsen, gezien hun opmerkingen, vergelijkbaar geacht met 'interne geneeskunde' - en geriatrische geneeskunde met elkaar werden gecombineerd. Een overschot aan artsen die uit de Tweede Wereldoorlog terugkeerden, vergemakkelijkte de invulling van de eerste vacatures op dit gebied. Rond 1960 nam het Ministerie van Volksgezondheid het officiële besluit om de geriatrie als afzonderlijk specialisme te steunen.

De eerste generatie geriaters had, aldus Carboni, uitgesproken opvattingen over de organisatie van de zorg voor hun patiënten. Carboni's beschrijving komt op dit punt overeen met de observaties van Schreuder en Van Zonneveld. Binnen de per regio functionerende 'geriatric units' wilden de Britse geriaters aan diagnose, revalidatie en langdurige verpleging - ook wanneer die in verschillende gebouwen waren ondergebracht - evenveel aandacht besteden. Bovendien wilden zij de patiënten in hun persoonlijke omgeving 'volgen', zowel via huisbezoek als via de samenwerking met zorgverleners buiten het ziekenhuis: een uiting van hun geloof in de rol van psycho-sociale factoren in ziekte en invaliditeit bij ouderen. Carboni benadrukt dan ook, dat de oorspronkelijke identiteit van de geriatrie in Groot-Brittannië in de eerste plaats lag in een gemeenschappelijk management-ideaal en de uitgangspunten die daaraan ten grondslag lagen. Dat managementideaal was bovendien nauw verweven met de National Health Service, zowel via de invloed die het Ministerie van Volksgezondheid had op de benoeming van en toekenning van bedden aan 'geriatricians', als via de nationale structuur van per regio georganiseerde en geplande gezondheidszorgvoorzieningen.

$\mathrm{Bij}$ afwezigheid van een dergelijke gezondheidszorgstructuur 
heeft zich in de Verenigde Staten onder artsen die zich voor de geriatrie interesseerden, nooit een gemeenschappelijke identiteit kunnen ontwikkelen. Er ontstond wel een geriatric movement, waarin een verbetering van de zorg voor langdurig zieken, een uitbreiding van het geriatrisch onderwijs aan medisch studenten en de uitbouw van fundamenteel en klinisch geriatrisch onderzoek werd voorgestaan. Tot deze geriatrische beweging behoorden echter uiteenlopende groepen - artsen met een eigen praktijk, fundamenteel onderzoekers, verpleeghuisartsen, hoofden van geriatrische klinieken - die zeer van mening verschilden over de manier waarop deze doelen bereikt dienden te worden. Hun opvattingen daarover varieerden - en variëren nog steeds naar gelang hun beroepsbelangen. Slechts een minderheid was vóór de instelling van een klinisch specialisme in de geriatrie. Bovendien, zo stelt Carboni, werkten andere aspecten van de gezondheidszorg in de Verenigde Staten evenmin in het voordeel van de geriatrie. Zo is betaling per dienst niet bevorderlijk voor het ontstaan van aandacht voor-minder snelle - oudere patiënten en is erkenning van een nieuw specialisme in de Verenigde Staten geheel afhankelijk van de bestaande specialisten.

Anders dan in de Verenigde Staten, had in Groot-Brittannië ook de overheid een stem in het creëren van werk voor 'geriatricians'. Binnen de Britse National Health Service werd niet die mate van coördinatie, de-institutionalisering en kwaliteitsverbetering van de zorg voor chronisch zieken gerealiseerd als vele deskundigen wensten. Maar er ontstond wel meer eenheid in de verantwoordelijkheid voor geriatrische zorg. ${ }^{7}$

\section{Overheid en particulier initiatief}

Wanneer de National Health Service inderdaad zo belangrijk is geweest voor de benoeming van geriaters en de totstandkoming van geriatrische eenheden als Carboni stelt - en Carboni's analyse is overtuigend - dan wordt daarmee inzichtelijk, dat Schreuder voor het bereiken van zijn idealen nog veel meer moest 'verplaatsen' dan hij zelf of zijn tegenstanders expliciteerden.

Schreuders omschrijving van de ideale geriatrische zorg lag dicht bij die van de Engelsen en veronderstelde daarmee, gezien 
de verwevenheid van de Britse geriatrische praktijk met de $\mathrm{Na}-$ tional Health Service, een systeem van gezondheidszorg dat sterk van het Nederlandse verschilde. Nederland kende geen genationaliseerde ziekenhuizen, maar een geheel van voorzieningen waarin het primaat lag bij het particulier initiatief. De Nederlandse gezondheidszorg was niet georganiseerd naar regio, maar naar zuil. In de jaren zeventig liet Schreuder weten een regionalisatie en deconfessionalisatie van de gezondheidszorg voor te staan, zodat ziekenhuizen, verpleeghuizen, verzorgingstehuizen en het open bejaardenwerk gezamenlijk de verantwoordelijkheid zouden krijgen over zowel de ouderen die zij onder hun hoede namen als over hen die zij weigerden. Naar Schreuders mening hoefde de Nederlandse gezondheidszorg niet genationaliseerd te worden. Maar een reorganisatie was hoogst noodzakelijk. ${ }^{79}$

In de jaren vijftig en zestig liet Schreuder zich nog niet in deze zin uit over de gezondheidszorg als geheel. Wel verwees hij naar de efficiëntie van het Engelse systeem en gaf hij aan de autonomie van de verschillende instellingen voor gezondheidszorg in Nederland te betreuren. Maar hij ging niet zo ver om de consequenties van zijn streven volledig duidelijk te maken. Zijn gedachte om de geriater - in samenwerking met anderen - ook buiten de muren van het ziekenhuis een stem te geven in de zorg voor bejaarden, betekende immers een doorbreking van een systeem van gezondheidszorg waarin verantwoordelijkheden naar werkvorm en zuil gescheiden waren. Dat wil niet zeggen dat Schreuder Nederland volledig naar Brits voorbeeld wilde omvormen. Wel dat hij en anderen voor het vorm geven van hun opvattingen over integrale zorg meer moesten 'verplaatsen' dan zij in het openbaar aangaven. Het kan zijn dat Schreuder dit achter de schermen heeft gedaan. Ook is mogelijk, dat deze consequenties voor alle betrokkenen zo vanzelfsprekend waren, dat ze niet hoefden te worden genoemd. Wellicht heeft Schreuder er niet al te veel aandacht aan besteed, om zijn plannen niet nog controversiëler te maken dan ze toch al waren.

In ieder geval maakt de vergelijking tussen de Britse en Nederlandse situatie begrijpelijk waarom sociaal-democraten zich 
vaker achter de plannen van Schreuder schaarden dan anderen. Vermoedelijk hadden de eersten er minder moeite mee aan de autonomie van het verzuilde particulier initiatief te knagen dan de laatsten. Bovendien plaatst de vergelijking het oorspronkelijk parlementaire verzet tegen geriatrische afdelingen - de medische zorg voor bejaarden zou een taak zijn van het particulier initiatief - in een breder perspectief. En ten slotte maakt de vergelijking duidelijk waarom Schreuders plannen in de jaren zeventig meer steun kregen dan in de jaren vijftig en zestig. Vanaf de jaren zeventig ontwikkelde de Nederlandse gezondheidszorg zich immers - zoals Paul Schnabel het formuleerde - van 'immuniteit' tot publiek domein. ${ }^{8 \circ}$ Terwijl de gezondheidszorg zich voorheen had gekenmerkt door een hoge mate van autonomie, probeerde de overheid na 1970 met het oog op kostenbeheersing een grotere greep op de gezondheidszorg te krijgen via regionalisering en echelonnering. In deze context werd parlementaire bemoeienis met de geriatrie en geriatrische afdelingen minder 'ongepast' dan in de jaren vijftig en zestig.

\section{Een onzichtbaar 'netwerk'}

Een internationale vergelijking met als doel 'structurele' verschillen in de context van medisch-wetenschappelijke ontwikkelingen op te sporen, is binnen een Latouriaanse benadering niet gebruikelijk. Het 'volgen' van de activiteiten van onderzoekers, artsen of ingenieurs en het in kaart brengen van de 'netwerken' waarin de beweringen en ontwerpen van dergelijke deskundigen een weg vinden, is immers bedoeld om het gemeenschappelijk ontstaan van wetenschap en samenleving op het spoor te komen. 'Structuur' kan wel aan de orde komen, maar alleen in de vorm van - stabiele - netwerken waarin de beweringen van onderzoekers ingebed dan wel verstrikt raken.

Het is de vraag of het 'volgen' van onderzoekers en hun beweringen altijd de meest geschikte manier is om dergelijke netwerken op het spoor te komen. Dat Schreuder niet alleen de indeling van specialismen, de muren van ziekenhuizen en de taken van verpleeghuizen, maar ook de structuur van de Nederlandse gezondheidszorg moest 'verplaatsen' om zijn idealen vorm te ge- 
ven, werd pas duidelijk nadat de Nederlandse situatie gedetailleerd met de Engelse was vergeleken. Schreuder en zijn tegenstanders gaven immers wel aan dat er een vergelijking tussen Groot-Brittannië en Nederland in het spel was, maar niet wat precies de consequenties van die vergelijking waren. Uit hun openbare optreden werd, om in Latours termen te spreken, wel de aanwezigheid van het bewuste 'netwerk' duidelijk, maar niet de aard of stabiliteit ervan.

Het kan zijn dat Schreuder en de zijnen daarvoor niet ver genoeg gevolgd zijn en dat zij-achter de schermen - de consequenties van hun streven voor de structuur van de gezondheidszorg wel degelijk besproken hebben. Mogelijk is ook, zoals eerder werd opgemerkt, dat deze consequenties te gevoelig lagen, ofwel te vanzelfsprekend waren. Juist in deze twee laatste gevallen kan het verradelijk zijn de 'follow-the-actors'-strategie te volgen. Want kan de publieke onzichtbaarheid van wat gevoelig ligt of vanzelfsprekend is, niet juist een indicatie zijn voor de stabiliteit van een netwerk? Zonder de 'omweg' van Carboni's vergelijkende studie, zou - althans met het beschikbare bronnenmateriaal - de plaats van de structuur van de gezondheidszorg in de geschiedenis van de geriatrie en geriatrische afdelingen in $\mathrm{Ne}-$ derland in ieder geval minder zichtbaar geworden zijn.

\section{Slot}

In de jaren na de Tweede Wereldoorlog werd in Nederland de grens tussen het omkeerbare en het onomkeerbare in de ouderdom-en daarmee de grenzen van wat aan de ouderdom als levensfase 'eigen' werd geacht - verschoven. Ouderdomsverschijnselen die lange tijd voor 'natuurlijk', en daarmee onafwendbaar waren gehouden, werden tot behandelbare ziekten benoemd. Slijtage werd een omstreden begrip en bedlegerigheid van bejaarden werd niet meer tot het gebruikelijke gerekend. In bejaarden- en verpleeghuizen verschenen nieuwe apparaten, nieuwe ruimten en nieuwe deskundigen die tot doel hadden ouderen te 'mobiliseren' die voorheen 'te ruste' waren gelegd. 
In deze ideële en materiële verschuivingen had de arts Schreuder een belangrijk aandeel. Op uiteenlopende manieren verkondigde hij dat de validiteit van bejaarden veelal voor verbetering vatbaar was. Daarin was hij zeker niet de enige. Maar Schreuder behoorde in Nederland wel tot de eersten die de revalidatie van bejaarde patiënten daadwerkelijk ter hand namen. Schreuders stellingen over het omkeerbare in de ouderdom werden echter op een andere manier in de organisatie van de ouderenzorg 'ingebouwd' dan hij wenste. Naar zijn mening noopten het ingewikkelde onderscheid tussen normale ouderdom en ziekte, het gevaar van onnodige invaliditeit van bejaarden en de verwevenheid van het lichamelijke, psychische en sociale tot de inzet van erkende geriaters en de oprichting van geriatrische afdelingen binnen ziekenhuizen. Die 'associatie' werd echter door andere deskundigen doorbroken. Zij deelden Schreuders opvattingen over de karakteristieken van de ouderdom, maar verbonden die aan een andere organisatie van de zorg voor bejaarde patiënten. Pas aan het begin van de jaren tachtig werden de idealen van Schreuder in een andere politieke constellatie en op bescheiden schaal praktijk.

Het voorbeeld van Schreuders pogingen om de zorg voor ouderen in Nederland een ander aanzien te geven, maakt zichtbaar dat aan wetenschap en geneeskunde niet zondermeer de standaardiserende, problematiserende, medicaliserende of disciplinerende rol kan worden toegeschreven, die 'constructivisten' hen vaak in de schoenen hebben geschoven.

In de eerste plaats laat het werk van Schreuder en de zijnen zien, dat artsen binnen één betoog zowel bestaande grenzen kunnen verschuiven als nieuwe grenzen kunnen trekken. Schreuder probeerde de traditionele grens tussen het omkeerbare en het onomkeerbare zo te verplaatsen, dat de 'natuurlijke' ouderdom minder inhoud kreeg. Tegelijkertijd echter deed hij pogingen om zijn stellingen over de ouderdom op zo'n manier aan een specifieke deskundigheid en praktijk te verbinden, dat daarmee de ouderdom ten dele - via de definitie van de geriatrische patiënt - op een nieuwe manier van andere levensfasen 
werd onderscheiden. Schreuders pogingen tot het instellen van nieuwe grenzen kregen aanvankelijk onvoldoende aanhang. Maar ze laten wel zien, dat afbakening van de ouderdom geen ontwikkeling hoeft te zijn die slechts één richting kent. Op eenzelfde manier kunnen de activiteiten van Schreuder en de zijnen niet zondermeer als een vorm van problematisering of medicalisering van de ouderdom worden omschreven. $\mathrm{Zij}$ stelden dat onnodig veel ouderen in instellingen voor gezondheidszorg verbleven. Tegelijkertijd probeerden zij echter aan te tonen dat een geriatrisch regime voor een specifiek deel van de ouderen broodnodig was.

In de tweede plaats maakt het voorbeeld van Schreuder duidelijk, dat aan medici - of zij het onderling nu wel of niet eens zijn - niet vanzelfsprekend 'almacht' kan worden toegeschreven. Een uiteenzetting van hun standpunten is niet genoeg om het ontstaan van een bepaalde aanpak of maatschappelijke houding ten aanzien van de ouderdom te verklaren, zoals Armstrong suggereert. Veel van Schreuders stellingen over de ouderdom werden door anderen, binnen en buiten de medische wereld gedeeld, maar verbonden aan en 'waargemaakt' binnen voorzieningen die in Schreuders wereldbeeld een bescheidener rol kregen dan in het wereldbeeld van deze anderen. Voor hetgeen met de denkbeelden van Schreuder en de zijnen gebeurde, is Latours 'translatie' dan ook zeker toepaslijker dan het begrip 'diffusie'. Schreuders denkbeelden verspreidden zich niet over de samenleving, zij 'translateerden' die samenleving ondermeer via een nieuwe inrichting van bejaarden- en verpleegtehuizen. Omgekeerd werd Schreuders gedachtengoed 'getranslateerd' door degenen die sceptisch stonden tegenover de geriatrie en/of geriatrische afdelingen.

Deze verplaatsingen konden via de Latouriaanse methodologie van het 'volgen' van de historische actoren en hun beweringen niet voldoende worden achterhaald. Latour wees de weg naar het belang van 'associaties' tussen 'netwerken'. Met behulp van zijn perspectief kon worden nagegaan of en hoe de nieuwe grenzen van het 'eigene' van de ouderdom aan een andere organisatie van de ouderenzorg werden verbonden. Dat in het be- 
toog over de geriatrie een bepaalde organisatie van de gezondheidszorg besloten lag die niet in de politieke verhoudingen van de jaren vijftig en zestig paste, werd echter pas bij vergelijking met de Britse situatie zichtbaar. Misschien behoren de meest uitgebreide en stabiele netwerken ook tot de meest vanzelfsprekende. Dat kan hun zichtbaarheid in het bronnenmateriaal zo klein maken, dat andere methoden - zoals die van de internationale vergelijking - nodig zijn om een dergelijk netwerk allsnog op het spoor te komen. 


\section{Ommuurde ouderdom:de ruimtelijke orde van verzorgingshuizen $^{I}$}

\section{Inleiding}

Sanjib Datta Chowdhury, een antropoloog uit India, deed aan het eind van de jaren tachtig etnografisch onderzoek in een $\mathrm{Ne}$ derlands verzorgingshuis. Als culturele buitenstaander, gewend aan de Indiase situatie waarin kinderen voor hun bejaarde ouders zorgen, verwachtte hij in het tehuis veel eenzaamheid en ongeluk aan te treffen. Deze gedachte deed hem, in combinatie met zijn kennis van het werk van Goffman over het leven in grote instellingen, op zoek gaan naar verschijnselen als 'het sterven van het zelf en het bestaan van een 'onderwereld' van bewoners onder elkaar. ${ }^{2}$

Maar hoe hij ook zocht of keek, sporen van een dergelijk schaduwleven kon Chowdhury niet vinden. Wel viel het hem op dat de bewoners op een voor hem ongewone wijze omgingen met de ruimten binnen en buiten het tehuis. Bewoners ontmoetten elkaar aan tafel in de eetzaal, maar betraden tot zijn ontsteltenis elkaars kamers zelden of nooit. Familie werd daarentegen altijd - na afspraak - op de eigen kamer ontvangen. Bovendien gingen sommige bewoners met elkaar uit en zorgden bij ziekte of afwezigheid voor elkaars planten, post of boodschappen. Opvallend was ook, dat de onderlinge ontmoetingen buiten de kamers met bijzondere codes omgeven waren. Vrouwen waren erop gebrand bij hun bezoek aan de eetzaal verzorgd gekleed te zijn. Chowdhury noteerde bij deze observatie het woord 'bloemetjesjurk'. In de eetzaal had iedereen een vaste plaats aan tafel. Aan die tafel mocht niet over de persoonlijke gezondheid worden geklaagd. Het met nadruk aankondigen van familiebezoek, dat niettemin buiten het zicht van de andere be- 
woners ontvangen werd, was een steeds terugkerend ritueel. Bewoners hadden onderling dus wel contact, maar op een andere manier dan de antropoloog op grond van zijn theoretische en culturele bagage had verwacht.

In eerste instantie begreep Chowdhury niets van deze vormen van in- en uitsluiting. Na verloop van tijd ontwikkelde hij echter de veronderstelling dat deze gewoonten een voortzetting waren van de betekenis van 'privacy' en het gebruik van de ruimte in Nederlandse eengezinswoningen. In deze eengezinshuizen is de hal zo geplaatst dat alle ruimten onafhankelijk van elkaar bereikbaar zijn. Deze ruimtelijke structuur maakt het mogelijk om mensen van 'buiten' op verschillende plaatsen te ontmoeten. Gaat het om iemand die bij de gehele familie bekend is, dan wordt hij of zij in de 'publieke' woonkamer ontvangen. Betreft het een persoonlijke vriend, dan wordt die, vooral wanneer het om een vriend van één van de kinderen gaat, in de 'eigen' kamer onthaald. Deze mogelijkheid om via ruimten onderscheid aan te brengen in de aard van relaties werd, aldus de antropoloog, in het tehuis voortgezet. Daarbij gold de kamer als privé-domein en werden de overige ruimten in het tehuis - de gang, de eetzaal, de recreatiezaal - openbaar gebied geacht. Omdat binnen de eigen kamer, anders dan in eengezinshuizen, niet meer gedifferentieerd kon worden, werd de mogelijkheid om onderscheid aan te brengen verplaatst naar andere ruimten: bewoners zagen hun vrienden aan tafel, hun kennissen in de koffiehoek. Door aan bepaalde ruimten 'privacy' toe te kennen, zo begreep Chowdhury, handhaafden de bewoners een element van keuze in hun betrokkenheid of distantie ten aanzien van andere mensen. Op die manier probeerden zij de beperkingen van het wonen in een tehuis te overstijgen. Het belang dat zij aan 'privacy' hechtten was constant, maar ruimten bleken niet in zichzelf 'privé' of 'openbaar'. Dat hing af van de manier waarop deze ruimten gebruikt en benoemd werden.

De Indiase antropoloog raakte in de loop van zijn onderzoek geinnteresseerd in de manier waarop de bewoners van het tehuis betekenis gaven aan de rumtelijke grenzen in hun omgeving. Naar het ontstaan van deze grenzen deed hij geen onderzoek. 
Toch suggereerde Chowdhury dat niet alleen in het dagelijks gebruik van de ruimte continuïteit werd gecreëerd tussen de gemiddelde wooncultuur en het wonen in verzorgingshuizen, maar dat dit ook bij het ontwerp van die ruimten het geval was geweest. Volgens de antropoloog waren de Nederlandse verzorgingshuizen ontworpen voor relatief gezonde ouderen die in het tehuis zo gewoon mogelijk, zij het in een beschutte omgeving, door zouden moeten kunnen leven. In die opzet werd het wonen in een tehuis als een praktisch en gesubsidieerd alternatief voor het alleenwonen in een doorsnee woning beschouwd. Daarbij paste een ontwerp met eigen kamers, lange gangen - voor valide ouderen geen probleem - en voorzieningen als de bibliotheek en de winkel: replica van de wereld buiten het tehuis.

Deze nadruk op continuĩteit in het ontwerp van de 'ruimtelijke orde' van doorsnee-woningen en verzorgingshuizen is noch in het huidige ouderenbeleid, noch in de geschiedschrijving van de ouderdom gebruikelijk. In het huidige ouderenbeleid wordt tussen het wonen in een verzorgingshuis en het wonen in een afzonderlijke woning - een eengezins- of eenpersoonswoning - een duidelijk onderscheid aangebracht. Met dat onderscheid zijn belangrijke begrippentegenstellingen als die tussen 'intramuraal en extramuraal', 'afhankelijkheid en zelfstandigheid', 'segregatie en integratie' verbonden. Ook in de geschiedschrijving van de ouderdom is de toenemende institutionalisering van ouderen in de negentiende en twintigste eeuw doorgaans als een belangrijke caesuur beschouwd. Juist de groei van het aantal tehuizen voor ouderen wordt als een belangrijk voorbeeld van de standaardisering en verafhankelijking van de ouderdom gezien.

Dit hoofdstuk heeft tot doel te laten zien dat de naoorlogse ontwikkelingen in de huisvesting voor ouderen beter te volgen zijn, wanneer de scherpe begrippentegenstellingen van vandaag even tussen haakjes worden geplaatst en de aandacht meer gericht wordt op geleidelijke verschuivingen in de betekenis van de ruimte. In terugblikken op de bejaardenhuisvesting in Nederland wordt vaak verondersteld dat de naoorlogse bouw van tehuizen werd geïnspireerd door de woningnood en de gedachte 
dat veel bejaarden zich niet meer zelf konden redden. In de jaren waarin de bouw van bejaardenwoningen extra aandacht kreeg na 1970 - zouden 'zelfstandigheid' en 'integratie' van bejaarden uitgangspunten geworden zijn. Verwijzingen van deskundigen, parlementsleden of bewindslieden naar het belang van zelfstandigheid en integratie vóór 1970 worden in dergelijke terugblikken genegeerd óf beschouwd als vroege voorbereidingen op de 'grote omslag'. ' Chowdhury's observaties inspireren echter tot een interpretatie waarin de bezorgdheid over bejaarden, de 'vroege' verwijzingen naar zelfstandigheid en de 'omslag' in één traditie te plaatsen zijn. Steeds draaide de discussie over tehuizen, zo zal duidelijk worden gemaakt, om de verhouding tussen het 'publieke' en het 'private' en de ruimtelijke vormgeving daarvan. Juist subtiele verbindingen en verschuivingen in de betekenis van ruimten en ruimtelijke grenzen maken begrijpelijk waarom in de jaren vijftig en zestig de bouw van tehuizen 'logisch' leek en vanaf de jaren zeventig niet meer. Aanvankelijk pasten de ruimtelijke orde van tehuizen, de 'symbolische orde' van betekenissen die met die ruimtelijke structuur verbonden waren en de wettelijke orde van overheidsbemoeienis bij elkaar. Maar de symbolische orde bleef niet dezelfde en maakte dat het tehuis in een totaal ander licht kwam te staan dan voorheen.

Hieronder zal dan ook, geïnspireerd door Chowdhury's oog voor de culturele betekenis van ruimtelijke grenzen, nagegaan worden waar de wortels van de ruimtelijke orde van pension-, bejaarden- en verzorgings(te)huizen lagen. ${ }^{4}$ Hoe ontstonden deze tehuizen en waarop waren de ruimtelijke grenzen - indeling en ligging - van deze instellingen gebaseerd? Wat deed de waardering van die grenzen veranderen? Welke ruimtelijke concepten circuleerden in de overwegingen van degenen die bij de bouw van tehuizen betrokken waren - overheidsinstanties, particuliere organisaties, deskundigen en architecten? Tot welke gebouwen leidden deze concepten en wat betekenden eenmaal gemetselde muren voor nieuwe opvattingen over de juiste huisvesting en zorg voor ouderen? De ouderdom werd niet alleen als probleem, sociale categorie en levensfase afgebakend, zij kreeg als object van zorg ook een geografisch begrensde plaats. 
2 'Classificeering' en het ontstaan van het pensiontehuis

Institutionele zorg voor ouderen is zeker geen uitvinding van deze eeuw. Voor Nederland geldt dat de opvang van ouderen in speciaal voor hen bedoelde instellingen al voor 1800 bestond.' De zorg voor ouderen in hofjes gaat zelfs terug tot het eind van de middeleeuwen. ${ }^{6}$ De aard van deze institutionele zorg was echter wezenlijk anders dan die van de huidige zorg in instellingen. Huisvesting van 'oudelieden' vond in de vorige eeuw voor het overgrote deel plaats in het kader van de burgerlijke, kerkelijke en particuliere armenzorg. Door gemeenten, diaconieën en stichtingen werden ouderen verzorgd in armenhuizen, oude mannen-en vrouwenhuizen, liefdegestichten, gasthuizen en hofjes. Met name de kerken toonden zich wat betreft de opvang van ouderen zeeractief?

In de jaren twintig van deze eeuw werd in de wereld van de armenzorg echter tot een bezinning op deze traditionele instellingen opgeroepen. Zoals in het tweede hoofdstuk werd besproken, ontstond deze onrust naar aanleiding van nieuwe wetgeving die een deel van de ouderen een bescheiden ouderdomsrente bood. Volgens armenzorg-deskundigen had dit tot gevolg dat zij met een ander type cliënt werden geconfronteerd dan voorheen het geval was geweest. De hulpvraag van oudere mensen uit de onderste lagen van de bevolking nam af, terwijl het aantal verzoeken om ondersteuning van personen uit de hogere klassen toenam. De oorzaken van de laatstgenoemde ontwikkeling lagen naar de mening van de armenzorg-deskundigen in een waardevermindering van vermogens, een tekort aan huishoudelijke hulp, het kleiner worden van de woningen van de jongere generatie - waardoor ouderen niet meer in die woningen konden worden opgenomen - en de sloop van oude woningen. De verschuiving in het cliëntenbestand die dit alles met zich meebracht, riep bij de armenzorg-elite de vraag op of de bestaande oudeliedenzorg nog wel aan de eisen des tijds voldeed.

Nee, luidde het antwoord van deze mensen - een 'nee' dat in de eerste plaats de oudeliedengestichten betrof. Het type zorg dat daar geboden werd, was naar hun mening volstrekt ongeschikt 
voor de ondersteuning-vragende burgers waarmee zij sinds kort te maken hadden. Deze waardige oudelieden verdienden veel meer vrijheid dan de traditionele gestichten met hun aparte zalen voor mannen en vrouwen en strenge regels konden bieden. Tehuizen zouden dan ook gelegenheid moeten gaan bieden tot 'classificeering': verzorging voor mensen van verschillende standen. Bovendien diende er wat betreft de leiding, inrichting en sfeer van de tehuizen het nodige verbeterd te worden. Zo werden kamers voor een klein aantal personen, slaapzalen met chambrettes - door schotten of gordijnen afgescheiden nissen en gezellig ingerichte ruimten met heel wat meer sympathie beschreven dan de massale verzorging in kale slaap-, eet- en conversatiezalen. ${ }^{*}$

Op zichzelf was het idee van een naar stand gescheiden oudeliedenzorg niet nieuw. In bepaalde (gast)huizen werd door alle of een deel van de bewoners een soort lijfrente betaald. ${ }^{9}$ In andere instellingen, zoals de katholieke liefdegestichten, kende men de bijzondere klasse van betalende kostdames en-heren. ${ }^{10} \mathrm{Maar}$ met het oog op de nieuwe vraag uit de middenstand werden, aldus degenen die over de oudeliedenzorg schreven, steeds vaker inrichtingen met classificatie gebouwd of uitgebreid. Daarbij ging het doorgaans om verhoudingsgewijs grote, door kerken geïnitieerde tehuizen. Een deel van de tachtig tot honderdveertig bewoners werd door de diaconie ondersteund, een ander deel betaalde gedifferentieerde prijzen. Hoe hoger de klasse waarbinnen iemand ingedeeld werd, des te hoger de prijs en des te groter de privacy: minder mensen per kamer, afzonderlijke chambrettes of een eigen kamer. De omvang en mate van beslotenheid van de persoonlijke nimte werd dus uitdrukkelijk aan inkomen en stand gekoppeld." Tegelijkertijd werden speciale afdelingen voor echtparen gebouwd. Overigens speelden bij de beslissing tot de bouw en uitbreiding van deze tehuizen niet alleen de gewijzigde omstandigheden van ouderen uit de burgerij een rol. Door een enkele deskundige werd erop gewezen dat de protestanten in het stichten van tehuizen vergeleken met de katholieken een achterstand hadden. ${ }^{12}$ Dat wijst erop dat, althans voor een deel van de betrokkenen, ook de concurrentie tussen de zuilen in het geding was. 
Het klassenstelsel van de grote kerkelijke tehuizen was, zoals gezegd, niet volkomen nieuw. Wel werden aan het eind van de jaren tien en in de loop van de jaren twintig verschillende semifilantropische verenigingen en stichtingen opgericht, die speciaal aan mensen uit de 'beteren stand', 'beschaafden kring' en 'den middenstand' kleine tehuizen beschikbaar stelden. Tot die verenigingen en stichtingen behoorden Pro Senectute, Vredeheim en Ons Thuis. "' Zo bouwde en verbouwde Pro Senectute relatief kleine tehuizen of pensions voor vijfentwintig à dertig personen, vaak in voormalige herenhuizen, villa's en hotels, met voor iedere bewoner een zit-slaapkamer. Daarbij diende elk gestichtskarakter, zo liet de vereniging weten, vermeden te worden en stond het behoud van de 'ongerepte zelfstandigheid' voorop. ${ }^{4}$ Een sluitende exploitatie werd verkregen via een systeem van pensionprijzen naar draagkracht en een steunfonds voor diegenen die de prijzen niet konden opbrengen. J. Everts, secretaris van de Armenraad te Amsterdam en één van de oprichters van Pro Senectute, noemde de nieuwe tehuizen voor de beter gesitueerden in de jaren veertig 'pension-tehuizen', omdat ze naar zijn mening de karakteristieken van een gewoon pension combineerden met de voordelen van een tehuis. ${ }^{15}$

In armenzorg-tijdschriften werd met ontroering melding gemaakt van de gezelligheid, huiselijkheid, beschaving en uitnemende geest die dergelijke tehuizen uitstraalden. Aantrekkelijke foto's van gebouwen in parkachtige omgevingen en van eet- en conversatiezalen met zacht gefilterd zonlicht begeleidden de enthousiaste beschrijvingen ervan in de tijdschriften (zie illustratie 1 $t / m$ 7). Soms werd de rust van de tehuizen als het contrapunt van de instabiliteit van de jaren twintig en dertig gezien en werden de oorden getypeerd als oasen in de woestijn van het maatschappelijk leven. Gedetailleerd en bijna dichterlijk werden de rondleidingen door de nieuwe instellingen beschreven: 'Ik heb aan de verzoeking geen weerstand kunnen bieden om, zonder dat ik kon opgemerkt worden, even een blik in de eetzaal te slaan. Ik wou dat ik een schilder was om u den indruk, die dit tafereeltje op mij maakte, weer te kunnen geven. Want het was voornamelijk de kleur, de toon, die mij trof en zoo diep ontroerde. Een neergestreken 
vlucht vogels, bijkans uniform van kleur: zwart, grijs, zilver-wit, een kleur, die gedachten wekte aan herfst-en wintertij, aan leven, dat ten einde spoedt, aan strijd en smart doorleden en doorstaan. En daarachter het felrood der serre-gordijnen ver-af genoeg om niet te hinderen, dichtbij genoeg om over het geheel te spreiden dien zeldzaam mooien, warmen gloed, als een streeling van warmte en stil geluk, een belofte van vrede. ${ }^{16}$

Zo werden in de armenzorg-literatuur, via de beschrijving van de uitgangspunten en verbeelding van de sfeer in oude en nieuwe instellingen, de traditionele oudeliedengestichten en de tehuizen en afdelingen voor de burgerij op twee verschillende manieren tegenover elkaar gezet. De massale, gereglementeerde zaalverpleging in oudeliedengestichten werd niet alleen gecontrasteerd met de vijheid en zelfstandigheid die de nieuwe tehuizen boden, maar ook met de huiselijkheid en gezelligheid ervan. De nieuwe en verbouwde instellingen verschaften net als de oude instituten onderdak en verzorging, maar aan een ander type bewoners en met de eigen kamer en een warme aankleding van de nuimten als nieuwe ijkpunten.

Het bleef in de jaren twintig overigens niet bij juichkreten over de nieuwe voorzieningen voor beschaafde burgers. Ook over de complexen van bejaardenwoningen die vanaf dat decennium werden gebouwd, waren de deskundigen zeer te spreken. Dergelijke woningen maakten het de bewoners mogelijk om '(...) nog eenigen tijd zelfstandig te blijven onder het wakend oog der kinderen (...)', zonder dat de ouderen last hadden van het drukke gezin, de kleinkinderen en de 'gramophoon'. '7 Daarnaast werd in armenzorg-kringen om afzonderlijke tehuizen voor invaliden en chronisch zieken gevraagd - tehuizen die hier en daar inderdaad werden gebouwd. De achtergrond daarvan was dat de nieuwere tehuizen doorgaans alleen gezonde mensen wilden opnemen, terwijl in de traditionele gestichten het aantal invaliden toenam. Ook dat laatste werd aan de invoering van de ouderdomsrente toegeschreven. Die rente maakte het velen mogelijk om langer een zelfstandig leven te leiden, waardoor in de gestichten steeds meer 'afgeleefde stakkers' arriveerden en de gemiddelde leeftijd steeg. ${ }^{18}$ 
Maar in de periode tussen de beide wereldoorlogen groeide ook een tak van huisvesting die door vele armenzorg-deskundigen minder gewenst werd geacht: die van de winstbeogende tehuizen. Zo kende Amsterdam aan het begin van de jaren veertig ruim vier keer zoveel kleine commerciële inrichtingen als nietwinstbeogende tehuizen. Deze explosie van commerciële zorgverlening weet men in Amsterdam aan een tekort aan moderne tehuizen. Weliswaar werd Amsterdam tussen 1920 en 1940 met negen nieuwe inrichtingen voor 'personen uit meer beschaafd milieu' verrijkt, maar de oude gestichten verlaagden - vanwege het toenemend aantal chronisch zieken en invaliden - hun capaciteit. Als geheel steeg de capaciteit daardoor nauwelijks. En dat terwijl in dezelfde periode het totaal aantal bejaarden, ook landelijk, met ruim de helft toenam."

Ook Everts, die in 1944 de situatie in de bejaardenhuisvesting de revue liet passeren, wilde uit de gelijkblijvende capaciteit in Amsterdam niet de conclusie trekken dat in de behoefte was voorzien. Hij was ervan overtuigd dat in alle maatschappelijke lagen van de bevolking gezocht werd '(...) naar moderne inrichtingen, waar zij goede huisvesting kunnen vinden, zooveel mogelijk een eigen kamer of kamers, passende verzorging, zo noodig (...) eenige verpleging, en waar zij hun vrijheid en zelfstandigheid volkomen behouden, zoo lang dit wegens hun lichamelijken toestand mogelijk is'. ${ }^{20}$ Juist de toename van het aantal winstbeogende 'rusthuizen' achtte hij het bewijs voor zijn stelling. Het bestaan van deze inrichtingen maakte volgens hem duidelijk, dat de zorg voor ouden van dagen niet uitsluitend een armenzorg-belang was, maar mede een zaak van volkshuisvesting was geworden - vooral waar het ging om bejaardenwoningen en (flat)gebouwen met huurwoningen voor 'rentetrekkers' en gepensioneerden. Dergelijke voorzieningen waren nodig met het oog op de veroudering van de bevolking. Bovendien kon op die manier, zo meende Everts, de gewone woningmarkt worden ontlast. $^{2 t}$ 
3 Het verlangen naar individualiteit: de 'massa der bejaarden' en burgerlijk wonen

\section{Twee tegengestelde elementen}

De hoofdinspecteur van Volkshuisvesting van die jaren voelde zich blijkbaar door het betoog van Everts aangesproken, want Everts' publikatie van 1944 was voor de persoon in kwestie aanleiding om de huisvesting van bejaarden in studie te nemen. ${ }^{22}$ Tot dan toe had de overheid zich nauwelijks met de huisvesting van ouderen ingelaten. Dergelijke bemoeienis was beperkt gebleven tot een gemeentelijke toezichtsverordening op tehuizen in Amsterdam en financiële steun van gemeenten aan de bouw van bejaardenwoningen. ${ }^{33}$ Tijdens en in de jaren na de oorlog werd op het departement van Volkshuisvesting echter een rapport over de huisvesting van bejaarden voorbereid, dat uiteindelijk in 1949 zou worden gepubliceerd. ${ }^{24}$

In de secundaire literatuur wordt deze belangstelling van de landelijke overheid voor de huisvesting van bejaarden - waarbij de aandacht van de overheid voor pensiontehuizen het meest voor het voetlicht wordt gehaald - vaak verklaard door op de grote naoorlogse woningnood te wijzen. Veel auteurs stellen dat de overheid de bouw van pensiontehuizen ondersteunde om op die manier de grotere woningen voor gewone gezinnen vrij te maken. ${ }^{35}$ Inderdaad speelde dit motief op centraal niveau een aanzienlijke rol. Net als Everts had gedaan, wees ook het volkshuisvestingsdepartement ambtenaren en kamerleden op het voordeel van doorstroming. ${ }^{26}$ Ook degenen die lokaal het initiatief namen tot de bouw van tehuizen lieten zich mede leiden door de woningnood. ${ }^{27}$ Toch meende het departement enigzins een 'domper' te moeten zetten op de verwachte doorstroming: veel van de vrij te komen woningen zouden van slechte kwaliteit zijn en een deel van de bejaarden verliet een particulier rusthuis of beëindigde inwoning. ${ }^{2 \pi}$ Bovendien werd de doorstroming niet alleen ingezet als argument voor pensiontehuizen, maar ook voor speciale woningen voor bejaarden. ${ }^{29}$

Voor de rijksoverheid was de woningnood dan ook niet de enige reden om zich over de bejaardenhuisvesting te buigen. 
Volgens verschillende publikaties van de Centrale Directie van de Wederopbouw en de Volkshuisvesting - waaronder het rapport van 1949 - en van ambtenaren werkzaam op het terrein van de volkshuisvesting, was de huisvesting van bejaarden in een nieuwe fase beland. Het ging niet meer in de eerste plaats om armenzorg en weldadigheid, maar om gespecialiseerde huisvesting voor mensen die daar op grond van hun leeftijd en validiteit voor in aanmerking kwamen. Ook de visie op volkshuisvesting was veranderd. Het verbeteren van 'in het oog lopende slechte woningtoestanden' was niet meer voldoende. Voortaan was volkshuisvesting een 'sociale werkzaamheid' die de bevolking de materiele omgeving voor een harmonieus gezinsleven moest verschaffen. De woningvooraad als geheel diende passend te worden voor iedere bevolkingsgroep - ook voor bejaarden. ${ }^{30}$

Juist die laatstgenoemde groep nam sterk in antal toe. Op grond daarvan werd een stijgende behoefte aan speciale huisvesting verwacht: bejaardenwoningen, pensiontehuizen en invalidentehuizen. ${ }^{31}$ In vergelijking met het percentage 65 -plussers dat an het begin van de jaren tachtig in verzorgingshuizen woonde - zeven tot acht procent - veronderstelde de Centrale Directie in 1949 een bijzonder grote vraag naar pensiontehuizen, waaronder alle vormen van huisvesting werden verstaan waarbij inwoners profiteerden van centrale voorzieningen en/of een zekere verzorging. Zo zou ruim zeventien procent van de gehuwde mannen van 65 tot en met 75 jaar, samen met hun deels jongere vrouwen, behoefte hebben aan een kamer in een pensiontehuis. ${ }^{12}$ Er werd niet uitgelegd waar deze schattingen precies vandaan kwamen. Gepensioneerden, zo was de gedachte, woonden liever in een kleiner dan een groter huis, ondermeer vanwege het vertrek van de kinderen. Ook werd ervan uitgegaan dat de behoefte aan verzorging bij ouderen - vooral bij mannen - toenam naarmate de leeftijd steeg. Verder zouden bejaarden, al gold dat minder voor de beter gesitueerden, zo min mogelijk veranderingen willen en prijs stellen op een vertrouwde omgeving. Bovendien maakte de Centrale Directie tussen de regels door duidelijk voor de bewoning van pensiontehuizen vooral aan 'valide bejaarden' te denken. Maar over het ontstaan van de per- 
centages liet zij zich louter in algemene termen uit. Volgens het rapport van 1949 ging het om zeer globale schattingen, die voornamelijk steunden op 'het evenwicht' tussen de verschillende huisvestingsvormen, 'zoals zich dat ons inziens in de maatschappij voordoet'. ${ }^{33}$

Opvallend was de plaats die maatschappelijke veranderingen innamen in de verwachtingen van de Centrale Directie. Uitspraken over de woningnood, de volkshuisvesting, de demografie en de preferenties van bejaarden werden omgeven door stellingen over de maatschappij van de toekomst. Verwachtingen over de huisvestingswensen van bejaarden werden dan ook mede door dat maatschappijbeeld gevoed. Tijdens de oorlogsjaren, zo werd gesteld, was duidelijk geworden dat met name ouderen moeite hadden met het bijhouden van de bonnenadministratie voor de voedseldistributie. Voor velen bleek dit zowel geestelijk (het tijdig inleveren van de bonnen) als lichamelijk (het wachten in rijen) te zwaar. Er was dan ook een verhoogde vraag naar opname in tehuizen ontstaan. Ook na de afschaffing van de distributie zou voor bejaarden de rust niet terugkeren. Een tijdperk van overheidsinmenging brak aan. Het invullen van papieren en geloop naar bureaus zou voor bejaarden, naarmate de leeftijd steeg, steeds moeilijker worden. Ook de toenemende neiging te profiteren van de mogelijkheden die de techniek bood, zou tot grotere belangstelling voor pensiontehuizen leiden. Met opmerkelijke stelligheid noteerde de Centrale Directie '(...) dat het tijdperk der eeuwig stofafnemende en poetsende huisvrouw ten einde loopt'. Het type vrouw dat zich uitsluitend op de woning en de huishouding zou concentreren zou geleidelijk verdwijnen. 'En hiermee zal voor dezen, ouder geworden, de behoefte aan opname in een tehuis met service en zonder particuliere belemmeringen toenemen. ${ }^{34}$ Overigens voegde de Directie daaraan toe dat de behoefte aan een vermindering van het huishoudelijk werk voor de beter gesitueerden meer gold dan voor de minder gesitueerden.

'Zoo gaat zich steeds duidelijker afteekenen', schreef een ambtenaar, 'dat twee tegengestelde elementen het leven der bejaarden zullen gaan beheerschen: eenerzijds een zoo ongestoord 
mogelijk gebruik van de woning voortkomende uit een verlangen naar ongeschonden individualiteit en anderzijds de behoefte aan een groote mate van service en verzorging, de behoefte om huiselijke beslommeringen, waar het kan, terzijde te stellen." ${ }^{3 s}$ Het verlangen naar individualiteit mocht bij bejaarden, aldus het departement van Volkshuisvesting, echter niet synoniem worden geacht met afzondering of afgeslotenheid. Want bij bejaarden, zo was de gedachte, nam de 'gezelligheidsdrang' toe naarmate de fysieke en psychische capaciteiten afnamen..$^{36}$

De bestaande huisvestingsvormen konden, zo lieten de autoriteiten zien, veelal niet aan deze wensen voldoen. Onverbloemd werd gewezen op de weerzin die vooral de gemeentelijke (armen)tehuizen, met hun slaapzalen vol paupers, bij bejaarden opriepen. Ook de vaak gedwongen inwoning van ouders bij hun kinderen werd ongewenst en impopulair geacht. ${ }^{37}$ ' $\mathrm{Bij}$ de bejaarden zelf leeft het verlangen om zo lang zulks mogelijk is zelfstandig te blijven', liet een ambtenaar nog eens weten. Ouderen weerden inwoning en oudeliedentehuizen dan ook af. ${ }^{36}$ Over de particuliere rusthuizen werd evenmin veel goeds vermeld. De zorg zou er overwegend beneden peil zijn en de bejaarde kon de dupe worden van het winstbejag van de exploitant.

Mede gezien de lange wachtlijsten voor de pensiontehuizen achtte de Centrale Directie het zonneklaar dat de vraag naar kamers in deze tehuizen groot was. ${ }^{39} \mathrm{Zij}$ meende dan ook 'de wenselijkheid van pensiontehuizen te hebben aangetoond'. Het pensiontehuis bood vele mogelijkheden om bejaarden een 'gelukkige oude dag' te bezorgen, al was het zeker niet de enige woonvorm die in aanmerking kwam. Eén oplossing kon niet voldoen..$^{40} \mathrm{Het}$ toegestane bouwvolume was bovendien nog onvoldoende, zo schreef een ambtenaar, om op grote schaal tehuizen te bouwen. ${ }^{4}$

\section{Niet stand, maar toestand}

Net als in de jaren twintig het geval was geweest, werden de traditionele oudeliedentehuizen met het tegendeel van zelfstandigheid geassocieerd. Inwoning kreeg dezelfde connotatie. Daartegenover stond het pensiontehuis, dat de moderne bejaarde kon 
bieden wat de oudere huisvestingsvormen goeddeels misten: zowel ongeschonden individualiteit als service en gezelligheid. Niet alleen het wonen in bejaardenwoningen, maar ook het verblijf in pensiontehuizen werd met vrijheid en zelfstandigheid verbonden. Tegen de achtergrond van de gedeelde ruimten in oudeliedentehuizen en huizen-met-inwoning, werd het leven in het moderne tehuis als een 'ongestoord' bestaan gepresenteerd.

Nieuw was ook dat het pensiontehuis in de overheidsstukken van na de oorlog niet meer als een tehuis voor de "beter gesitueerden' figureerde, maar als een tehuis voor bejaarden van alle klassen. Niet de stand, maar de toestand van de bejaarde zou bepalend moeten zijn voor zijn of haar keuze voor een bepaalde huisvestingsvorm. Dat nam natuurlijk niet weg, zo werd in het rapport van I 949 vermeld, dat tussen de verlangens van bejaarden en de vervulling ervan vaak financiële bezwaren stonden. Het werd dan ook wenselijk geacht daaraan van overheidswege aandacht te geven.

Het Ministerie van Volkshuisvesting zelf deed dit door de bouw van bejaardenwoningen en -tehuizen financieel te steunen op grond van de Woningwet en-sinds 1950-de Wederopbouwwet. De voorzieningen op basis van de Woningwet golden alleen voor instellingen die in het belang van de volkshuisvesting werkten. De regelingen voorzagen ondermeer in leningen voor grond-, bouw- en installatiekosten en in jaarlijkse bijdragen aan de exploitatielasten over een bepaalde periode. De subsidies in het kader van de Wederopbouwwet richtten zich op de particuliere woningbouw en betroffen een premie-uitkering ineens bij het gereedkomen van bejaardenwoningen - en vanaf 1954 van bejaardentehuizen. Ondanks deze subsidies kwam aan het begin van de jaren vijftig in het parlement aan de orde, dat de huren van kamers in tehuizen de draagkracht van vele bejaarden te boven gingen. Door kamerleden van verschillende partijen werd met grote volharding om maatregelen gevraagd die de 'tehuizen voor de grote massa der bejaarden beschikbaar [konden doen] komen'. ${ }^{42}$ Aan die wens werd in zoverre voldaan dat zowel binnen de Woningwet als de Wederopbouwwet de mogelijkheid werd geopend tot een extra bijdrage aan de huur van kamers in 
bejaardentehuizen, althans voor bejaarden met een inkomen beneden een bepaalde grens. Overigens werd dezelfde mogelijkheid voor bejaardenwoningen in het leven geroepen. ${ }^{43}$

Toch bleef volgens veel parlementsleden het gevaar bestaan dat een verblijf in een bejaardentehuis alleen voor bemiddelde bejaarden bereikbaar was. Ook bejaardenbonden maakten zich daar zorgen over, ${ }^{44}$ De praktijk liet vele voorbeelden zien. Zo werd over het Maastrichtse Calvariënberg gezegd, dat het oorspronkelijk bedoeld was voor de gewone man, maar dat de inmiddels onvermijdelijke gang van zaken bekend was: de kamers werden bezet door de gegoede middenstand. ${ }^{\text {ts }}$ De Nederlandse Federatie voor Bejaardenzorg was er zelfs van overtuigd dat de opname van bejaarden in tehuizen door financiële problemen vaak langer werd uitgesteld dan in overeenstemming was met een goede bejaardenzorg. ${ }^{46}$ Dat alles maakte het beleid ten aanzien van tehuizen tevens een zaak van het in 1952 opgerichte Ministerie van Maatschappelijk Werk. Maar maatregelen rond het kostenvraagstuk werden zowel door minister Van Thiel als zijn opvolgster Klompé uitgesteld, ondermeer vanwege een bestedingsbeperking en twijfel over de koers ten aanzien van tehuizen - waarover later meer. ${ }^{47}$ Uiteindelijk bracht de Algemene Bijstandswet het soelaas waarom het parlement steeds had gevraagd. Met de inwerkingtreding van die wet in 1965 werd de opname van bejaarden in tehuizen gemakkelijker gemaakt, omdat voortaan de kosten van opname, voor zover een bejaarde die niet zelf kon opbrengen, door het Rijk werden vergoed en het tot dan toe geldende verhaalsrecht geheel werd afgeschaft. ${ }^{48}$

In dezelfde periode werd, via de invoering van de Wet op de Bejaardenoorden in 1963, ook het toezicht op de kwaliteit geregeld. Verhalen over wantoestanden in winstbeogende tehuizen gaven daartoe aanleiding. Verschillende gemeenten en provincies kenden toezichtsregelingen en er bestond controle via de Gezondheidswet. ${ }^{49}$ Maar ondanks dat werd in de Tweede Kamer onder verwijzing naar tirannieke directrices en andere onverkwikkelijkheden voortdurend om landelijk toezicht op het verzorgingsniveau gevraagd. ${ }^{50}$ Dat toezicht werd in de Wet op de Bejaardenoorden geregeld. Deze 'raamwet' schreef voor dat de 
provincies richtlijnen voor toezicht op en inspectie van de bejaardenoorden moesten opstellen. ${ }^{\text {st }}$ Die richtlijnen dienden betrekking te hebben op de vrijheid van bejaarden hun leven naar eigen inzicht in te richten, de hygiëne, de gezondheid, de veiligheid, het personeel, de inrichting van het gebouw en de boekhouding. Verder dienden de provinciale besturen erop toe te zien dat er een redelijke verhouding bestond tussen de prijs en de geboden verzorging en huisvesting..$^{\text {s2 }}$ Een bejaardenoord werd omschreven als een inrichting waarin aan ten minste vijf bejaarden duurzame huisvesting, gepaard met gehele of gedeeltelijke verzorging, werd verschaft. Overigens was niemand erg gelukkig met het woord 'bejaardenoord'. Maar op overheidsniveau werd de term 'bejaardenoord' geschikter bevonden dan het begrip 'bejaardentehuis', dat geen betrekking had op de kleine pensions, terwijl ook daar toezicht nodig was. ${ }^{33}$

Naast de provinciale richtlijnen voor alle soorten tehuizen, bestond er overheidstoezicht in de vorm van bouwvoorschriften voor de gesubsidieerde sector. Zo werden de richtlijnen voor tehuizen uit de woningwetsector vermeld in de Voorschriften en Wenken voor het Ontwerpen van Woningen uit 1951. Aanvankelijk waren deze voorschriften, meer dan in de premiebouw, bijzonder sober. Jarenlang was er geen geld voor liften of centrale verwarming. ${ }^{54}$ Vanaf 1966 golden aparte voorschriften en wenken voor verzorgingstehuizen waarin de mogelijkheden werden verruimd. Zo werd de minimum-oppervlakte van een eenpersoons zitslaapkamer vergroot van ruim tien tot vijftien vierkante meter, en diende per wooneenheid een eigen portaal en wc aangebracht te worden. Bovendien werd aanbevolen de zelfstandigheid van bejaarden te accentueren door 'elke wooneenheid van een brievenbus en een deurbel te voorzien'. ss Verplichte onderdelen waren de badgelegenheden, de telefooncel, de recreatiezaal en - bij één of meer gemeenschappelijke maaltijden - een eetzaal. De eetzaal kon met de recreatiezaal gecombineerd worden. Ruimten als zieken- en logeerkamers, een winkel-kapsalon, een hobbyruimte en een reactiveringszaal werden in overweging gegeven.

Opvallend was dat in de nieuwe voorschriften de tehuizen 
voornamelijk werden onderscheiden naar de wijze waarop hun bouw werd gefinancierd, maar niet meer naar de klasse van hun bewoners, hetgeen in de eerdere regeling nog wel het geval was geweest. ${ }^{56}$ Het klasse-onderscheid dat ooit aan de basis van het pensiontehuis had gelegen, was niet meer het vermelden waard. Het oorspronkelijk burgerlijk ideaal van de 'eigen' kamer was tot norm geworden voor al die bejaarden die 'om medische en/of sociale redenen verzorging nodig hebben of wensen'. ${ }^{57}$

Waar deze laatste omschrijving vandaan kwam, komt nog aan de orde. Hier is van belang dat de overheid onder invloed van nieuwe opvattingen over volkshuisvesting en bejaardenzorg, met het oog op de bevolkingsveroudering, de woningnood en de veronderstelde hang van bejaarden naar 'individualiteit' en service het pensiontehuis via financiële steun voor de 'massa der bejaarden' bereikbaar maakte. Wellicht werd in het licht daarvan in de loop van de jaren vijftig steeds vaker van 'bejaardentehuis' gesproken. Die 'massa' der bejaarden diende in de nieuwe tehuizen haar vrijheid en zelfstandigheid waar mogelijk te behouden. Dat betekende niet dat na de oorlog geen tehuizen meer werden gebouwd met afdelingen voor verschillende klassen. ${ }^{58}$ Het betekende wel, dat een afzonderlijke zitslaapkamer een vereiste werd. Aan het begin van de jaren zestig uitte een lid van een onafhankelijke studiecommissie over dat laatste nog zijn twijfel. Volgens hem bestond in de oude delen van de grote steden een categorie bejaarden, die meer 'communaal' gericht was en voor wie de burgerlijke stijl van leven een verschraling betekende. Het commissielid in kwestie werd door de rest van de commissie teruggefloten: de drang tot privacy werd algemeen geacht. ${ }^{59}$ Deze opvatting zou, samen met andere uitgangspunten, een belangrijk stempel drukken op de ruimtelijke orde van tehuizen.

4 Publieke en private ruimten: het tehuis als gezin, hotel, dorp en voorstad

Tehuizen behoorden naar de mening van overheidsvertegenwoordigers zowel te zorgen voor het behoud van de zelfstandig- 
heid en vrijheid van ouderen als voor service, huiselijkheid en gezelligheid. Deze uitgangspunten werden zij aan zij naar voren gebracht, al lag bij de eerste twee het accent op het oudere indivi$d u$, terwijl bij de laatste drie het collectief van ouderen centraal stond. Dezelfde 'grondslagen' kwamen in de formulering van wensen, keuzen en dilemma's ten aanzien van de ruimtelijke orde van tehuizen terug. Afhankelijk van de geplaatste accenten mondde dat, bij zowel de overheid als andere instanties, uit in conceptualiseringen - expliciet of impliciet - van het tehuis als gezin, hotel, dorp en voorstad, met bijbehorende ideeën voor de indeling van de ruimte. De meeste van deze concepten leidden, vermengd met andere overwegingen, tot tehuizen die relatief groot waren en veel voorzieningen onder hun dak hadden. Met kamers gedacht als woningen, gangen als straten, afdelingen als wijken, en centrale ruimten als pleinen kreeg het tehuis van de jaren zestig het karakter van een woonkern binnen de grenzen van een grotere gemeente. Aanvankelijk paste deze ruimtelijke orde uitstekend bij de 'horizon' die met oud zijn werd verbonden. Maar mede doordat die horizon in de loop van de jaren zestig werd verlegd, en begrippen als 'zelfstandigheid' en 'integratie' met andere ruimten werden geassocieerd, werd de bouw van tehuizen minder vanzelfsprekend dan voorheen.

Wat de daadwerkelijke bouw van tehuizen betreft, lag het initiatief overigens niet bij de landelijke overheid. Dat initiatief werd genomen door particuliere instellingen - veelal stichtingen uitgaande van kerkelijke en levensbeschouwelijke instanties - door woningbouwverenigingen of door gemeenten. Zij overwogen de noodzaak tot bejaardenhuisvesting in hun dorp, stad of regio. $\mathrm{Zij}$ besloten geld te verzamelen voor de bouw van bejaardenwoningen, bejaardentehuizen of andere huisvestingsvormen. $\mathrm{Zij}$ gaven architecten de opdracht tot het ontwerp. Opdrachtgevers en architecten stonden er echter niet alleen voor. Tijdens de voorbereidingen voor de bouw konden zij hun voordeel doen met rapporten en adviezen van de overheid, tehuizenorganisaties, bouwcorporaties, onderzoekers en het Bouwcentrum. Het laatstgenoemde - Rotterdamse - instituut publiceerde, met behulp van breed samengestelde studiecommissies, ver- 
schillende veel geciteerde rapporten over de bejaardenhuisvesing. ${ }^{50}$

De beschikbaarheid van adviezen van experts, onderzoekers en tehuizenorganisaties betekende niet, dat de opdrachtgevers en bouwers van de tehuizen een eenduidig antwoord kregen op al hun vragen. Integendeel. In bepaalde opzichten waren de adviezen - zoals de oppervlakte van de kamers - mede door de overheidsvoorschriften tamelijk homogeen (zie illustratie 8). Ten aanzien van de grootte van de tehuizen, de indeling ervan en de behoefte aan tehuizen liepen de meningen van de adviserende instanties echter nogal uiteen - meningsverschillen die doorgaans een reflectie waren van uiteenlopende ideeën in de wereld van de bejaardenhuisvesting als geheel.

\section{Gezin en hotel}

Waar het ging om de opzet van de tehuizen, toonde de overheid zich in het eerste decennium na de oorlog evenmin eenkennig. In rapporten en verslagen van het volkshuisvestingsdepartement, in uitspraken van bewindslieden en in artikelen van ambtenaren werd vaak meer dan één mogelijkheid geopperd. Die werkwijze werd gemotiveerd door erop te wijzen dat niet alleen de plaatselijke omstandigheden, maar ook de bejaarden zélf sterk van elkaar konden verschillen. Maar de variatie in suggesties voor de vormgeving van de tehuizen hing eveneens samen met het naast elkaar propageren van principes waarin afwisselend de individuele oudere dan wel het collectief tot uitgangspunt werd genomen.

Zo werden voor de omvang van het pensiontehuis twee uiteenlopende opties redelijk geacht. Een klein tehuis met ongeveer dertig bewoners had als voordeel, zo werd gezegd, dat het 'karakter van een groot gezin' gehandhaafd kon blijven en het gestichtsidee vermeden kon worden. ${ }^{61}$ In een groot tehuis waarbij de Centrale Directie dacht aan tehuizen met honderd tot driehonderd bewoners, met verschillende klassen en met eetzalen voor de minst bemiddelden - verdween dat gezinskarakter onherroepelijk. Een dergelijk tehuis was eerder verwant aan een bedrijfsmatig georganiseerd hotel. Daar stond tegenover dat in 
een groot tehuis een ziekenkamer mogelijk was, zodat ziekenhuisopname van bewoners kon worden uitgesteld. Ook de conversatiezaal met biljart, de schouwburgzaal en de kapsalon waren alleen mogelijk in grotere tehuizen, wat zowel een gezelligheidselement bracht als de service ten goede kwam. Bovendien zouden echtparen in de meer omvangrijke tehuizen een grotere zelfstandigheid kunnen bereiken en betere contacten met andere bejaarde echtparen kunnen onderhouden. Daarnaast konden bejaarden die weliswaar verzorging wensten, maar verder een leven zonder veel bindingen, zich in het grote tehuis eveneens gelukkig voelen. ${ }^{62}$

In ieder geval zou de sprong tussen het kleine en het grote tehuis omvangrijk moeten zijn. Dat had ondermeer economische en organisatorische achtergronden. Maar de sprong diende ook groot te zijn, omdat 'de tussenvorm noch de intieme sfeer geeft van een klein tehuis, door sommigen zo gewaardeerd, noch de mogelijkheid biedt zo ongestoord en onopgemerkt te leven te midden van een kleine kring van zelf gekozen kennissen, als door weer anderen wordt gewenst' ${ }^{\prime}{ }_{3}$ De intieme huiselijkheid van het gezin en de vrijheid van keuze in het hotel - meer mogelijkheden tot service, gezelschapsleven of juist alleen-zijn - waren binnen de varianten van de Centrale Directie niet tegelijkertijd mogelijk. Er behoorde voor het een óf het ander gekozen te worden. Een middenweg verloor het goede van beide mogelijkheden.

Aanvankelijk voelde het Bouwcentrum het meest voor een klein tehuis: een tehuis met een capaciteit van vijftig tot vijfenzeventig bejaarden. Een tehuis van een dergelijke omvang bleef onderdeel van een wijk; voor grotere tehuizen waren concentraties bejaarden uit grotere stadsdelen of gebieden nodig. Ook werd - analoog aan de opmerkingen van de overheid - benadrukt dat in het kleine tehuis een persoonlijk contact tussen leiding en bejaarde mogelijk bleef, terwijl het grote tehuis snel 'als gesticht' werd gekwalificeerd. ${ }^{64}$ Een capaciteit van ongeveer vijftig bejaarden was bovendien financieel verantwoord. Bij kleinere en grotere tehuizen stegen de kosten; bij zeer grote tehuizen lagen de kosten op hetzelfde niveau. 
Enkele jaren later meldde het Bouwcentrum echter, dat ook de middelgrote tehuizen exploitatie-technisch aanvaardbaar waren. Tegelijkertijd verliet het Bouwcentrum de uitgesproken voorkeur voor een bepaalde omvang en meldde - terecht - dat de meningen daarover verdeeld waren. Zo werd in de wereld van de bejaardenhuisvesting tegen de eerder genoemde voordelen van het kleine tehuis ingebracht, dat het gezichtsveld van de bewoners van het kleine tehuis te beperkt zou zijn. Wat de voordelen van het grote tehuis betreft, werd - net als op overheidsniveau was gedaan - op de vrijheid in keuze ten aanzien van contacten en centrale voorzieningen gewezen. Bovendien zagen sommigen in de grote tehuizen stedebouwkundige waarde. Het verlies van verbondenheid met de wijk en de kans dat bejaarden zich er verloren gingen voelen, werden tot de nadelen gerekend. $^{\text {os }}$

Het Bouwcentrum achtte de kwestie zo onduidelijk, dat het een onderzoek wenselijk vond. Dat onderzoek werd, in opdracht van de overheid, in de eerste helft van de jaren zestig inderdaad uitgevoerd. Het betrof een participerend-observerend onderzoek in zes tehuizen. Een van de conclusies van het onderzoek was dat sociale homogeniteit op de 'gang' voor de onderlinge contacten zeer belangrijk was. Wat de grootte betreft kon, tot teleurstelling van een medewerker van het Bouwcentrum, geen sociaal optimum worden aangegeven. In ieder geval was, aldus de onderzoekers, niet gebleken dat het welzijn in de gemeenschap van een groot tehuis minder goed zou zijn dan in een klein tehuis. ${ }^{60}$

\section{Dorp en voorstad}

Ook in de beargumentering van voorzieningen binnen het tehuis schemerden de conceptualisering van het tehuis als gezin, waarbij het gehele tehuis als 'thuis' werd beschouwd, en als hotel, waarbij de eigen kamer als 'thuis' werd opgevat, afwisselend door. Binnen het eerste concept werd het tehuis gedacht als een hechte gemeenschap, binnen de tweede als een relatieflosse verzameling individuen.

Over vele aspecten van de indeling van bejaardentehuizen 
bestond in de wereld van de bejaardenzorg weinig onenigheid. Zo werd vanaf de tweede helft van de jaren vijftig algemeen aanbevolen binnen de wooneenheden een eenvoudige kook- en afwascombinatie aan te brengen, zodat bejaarden zelf hun koffie en thee konden zetten en op die manier een deel van hun zelfstandigheid konden behouden. Ook het advies om de wooneenheden van bejaarden, dienstruimten als de keuken en de linnenkamer, en de afdeling voor het personeel ruimtelijk van elkaar te scheiden, werd breed gedragen. Evenmin werden kanttekeningen geplaatst bij de aanbeveling om het mortuarium en de uitvaartweg uit het zicht van de bewoners te plaatsen, al werd in de praktijk wel eens anders gebouwd. Bovendien vermeldde een directrice van een tehuis in Joure dat de begrafenisstoeten bij het kerkhof tegenover het tehuis allerminst een sombere sfeer brachten. De bejaarden zagen de stoeten eerder als de 'evenementen van de dag'. ${ }^{.7}$

Wat het belang van de verschillende ruimten betreft, bestonden wel belangrijke accentverschillen, die samenhingen met de mate waarin het tehuis als een gemeenschap werd opgevat. In katholieke kring werd aan dat laatste meer waarde gehecht dan in het protestantse milieu, waar aan de individuele ruimte meer gewicht werd toegekend. Zo meldde een protestantse organisatie dat bejaarden, ondanks de aanwezigheid van prettige recreatieruimten, veelal in hun eigen kamer vertoefden. 'Daar worden herinneringen doorleefd, brieven van de kinderen gelezen en herlezen, voorts gestudeerd en bezoek van familie, vrienden en kennissen ontvangen. ${ }^{6 \%}$

Ook in discussies over de eetzaal stonden argumenten van individuele vrijheid en gemeenschapsvorming tegenover elkaar. Een eetzaal werd veelal efficiënt bevonden en de gemeenschappelijke maaltijd kon, zo werd gesteld, het isolement van bewoners doorbreken of gewaardeerd worden in relatie tot de levensbeschouwelijke identiteit van een tehuis. Daar stond tegenover dat het gezamenlijk eten de bejaarden aan de klok bond en een achteruitgang van de tafelmanieren van sommige bejaarden de disgenoten kon storen, terwijl het eten op de eigen kamer het gevoel van zelfstandigheid kon versterken en ook trage bejaar- 
den aan hun trekken deed komen. In verschillende tehuizen werd dan ook in het geheel geen eetzaal aangelegd, wat bovendien in de bouwkosten scheelde. ${ }^{\sigma}$ Vaak werden de maaltijden via luikjes - die bij sommige mensen in de bejaardenzorg onaangename associaties met een ruif opleverden - in de afzonderlijke kamers van de bewoners afgeleverd. ${ }^{\circ}$

De visies van katholieken en protestanten stonden het meest pregnant tegenover elkaar waar het ging om de noodzaak en omvang van een ziekenzaal, al deden zich hierover ook op andere niveaus meningsverschillen voor. Zo was de Centrale Directie van de Wederopbouw en de Volkshuisvesting ervan overtuigd dat bewoners van pensiontehuizen bij ziekte graag in hetzelfde tehuis werden verpleegd. Zo konden zij onder de mensen blijven die zij al kenden: ' $\mathrm{Zij}$ gevoelen zich dus als het ware thuis $\left(\right.$ (...) ${ }^{\text {'7t }}$ Een ziekenafdeling was dan ook wenselijk, al zou dit - het kwam al ter sprake - exploitatie-technisch alleen in grote tehuizen mogelijk zijn. Een ambtenaar liet echter weten de ziekenafdeling zo klein mogelijk te willen houden. Volgens hem gaven bewoners er de voorkeur aan zo lang mogelijk op de eigen kamer te worden verpleegd, 'op dezelfde wijze als dit in een normaal gezin zou geschieden'. ${ }^{72}$ De ziekenafdeling in het pensiontehuis zou dan ook slechts berekend hoeven te zijn op de opname van een betrekkelijk klein aantal patiënten. Ook andere gemeenschappelijke ruimten konden naar zijn mening tot een minimum worden beperkt, omdat het gezelschapsleven zich voor een belangrijk deel op de kamers zou afspelen. Dat nam overigens niet weg dat de ziekenafdeling - met ondermeer een of meer ziekenkamer(s), een isoleerkamer, een kamer voor de verpleegster, een dienkeuken en een onderzoekkamer - voor grote tehuizen algemeen werd aanbevolen. Over de wenselijkheid ervan bij kleinere tehuizen waren de meningen echter verdeeld.

Onder katholieken werd de ziekenzaal als een verlichting van de taak van het personeel gezien, en als een mogelijkheid om te voorkomen dat bejaarden verplaatst moesten worden. Zo behoorde volgens de directeur van de Katholieke Vereniging van Bejaardentehuizen de bejaarde tot zijn dood in het bejaardentehuis te kunnen worden verzorgd, met uitzondering van die be- 
jaarden die in een ziekenhuis of revalidatiecentrum moesten worden opgenomen. Centraal in deze redenering stond dat het tehuis een waarlijke 'gemeenschap' van gezonden en zieken diende te zijn. In de visie van de directeur, en in die van veel andere katholieken, diende het tehuis als het ware het karakter van een dorp te hebben, waarbinnen bejaarden naar het ziekenhuis, de huisarts, het toneel of de kerk konden gaan. De bejaarde zou er zo veel mogelijk van zijn gading moeten kunnen vinden, zodat hij of zij daar in verschillende stadia van (in)validiteit zou kunnen wonen. Het tehuis behoorde dan ook 'een zo volledig mogelijke woon- en leefgemeenschap' te zijn, waar bejaarden die zich niet in de gewone samenleving wisten te handhaven een 'permanent' verblijf konden vinden. ${ }^{73}$

Niet iedereen geloofde in de mogelijkheid binnen het tehuis een ware gemeenschap te creëren. Besturen van tehuizen mochten dan laaiend enthousiast zijn over mooie eet- en recreatiezalen, zo schreef iemand uit de wereld van de bejaardenzorg, zij zouden zich echter eens voor ogen moeten halen hoe het was om in een tehuis te wonen: 'Stelt u het zich maar eens voor dat de straat waar $u$ woont een eetzaal had op de hoek, prachtig gelegen, waar $u$ allemaal elke dag driemaal heen moest gaan. $U$ zat dan als het ware altijd met die mensen uit dat huis aan de overkant aan één tafel. Niet om wat op die mensen van de overkant aan te merken (...), maar alle dagen mee aan tafel... Neen, niet veertien dagen in de vakantie, maar een, vijf, misschien wel tien jaar of langer. ${ }^{174}$ Met sardonisch genoegen legde deze commentator de vinger op een naar zijn mening gevoelige plek: het gebrek aan keuzevrijheid. Impliciet stelde hij de kamer in het tehuis voor als huis, de gangen als straten en het tehuis als dorp. Maar een 'echt' dorp was het tehuis niet, zo wilde deze auteur via zijn gedachtenexperiment laten zien. Er viel voor de 'burgers' immers weinig te kiezen.

In protestantse kringen werd juist de keuzevrijheid als belangrijk goed gepresenteerd. Hun houding ten aanzien van de ziekenzaal was dan ook gereserveerder dan die van de katholieken. Wie ziek werd, kon doorgaans op de kamer worden verpleegd of - als dat echt niet meer ging - op een verpleegzaaltje. 
Maar chronisch zieken behoorden in principe niet in een pensiontehuis te worden verpleegd, al was die verzorging zolang er onvoldoende verpleeghuizen waren noodzaak. ${ }^{75}$ In het tijdschrift De Bejaarden, ondermeer orgaan van de Protestantse Vereniging van Instellingen voor Bejaardenzorg, verdedigde een arts de opvatting dat binnen het tehuis de extramurale situatie zo goed mogelijk moest worden benaderd en bejaarden dus op hun kamer verpleegd dienden te worden. Daarbij kon de wijkverpleging ingeschakeld worden en behoorden bewoners hun eigen huisarts te kunnen kiezen. De arts zag het tehuis als een 'conglomeraat van woningen', als een 'wijk met straten'. Het was goed wanneer het tehuis gelegenheid bood voor gemeenschappelijke bezigheden, maar aan de vrijheid van de bewoners mocht niet worden getornd. ${ }^{76}$ In een dergelijke conceptualisering van het tehuis werd de kamer dus beschouwd als eigen woning, van waaruit de bejaarde zo onafhankelijk mogelijk zou moeten kunnen opereren. Op deze manier werd het tehuis impliciet voorgesteld als een voorstad: een deel van de stad met een specifieke functie - in dit geval het zo 'normaal' mogelijk doen wonen van ouderen.

\section{Veel voorzieningen, hoge gebouwen}

Toch werden in de praktijk steeds vaker grote tehuizen gebouwd die binnen hun muren een breed scala aan voorzieningen herbergden. Van de sinds 1959 tot en met 1962 met financiële steun van de overheid gebouwde tehuizen viel $11 \%$ in de grootte-klasse van minder dan 50 bedden, $53 \%$ in de klasse van 51 tot 100 bedden en $36 \%$ in de klasse van meer dan roo bedden, waarvan vier in de omvang van 250 tot 400 bedden. ${ }^{77}$ Dergelijke grote tehuizen, zo noteerde een ambtenaar in het midden van de jaren zestig, werden verder alleen in de Verenigde Staten aanvaardbaar geacht. In andere landen varieerden de aanbevelingen van minimaal dertig tot maximaal tachtig bedden, hoewel de aangeprezen capaciteit wel eens werd overschreden. ${ }^{78}$ Bovendien werden de Nederlandse tehuizen, zoals gezegd, geleidelijk met steeds meer service-ruimten uitgebreid. Zo deden in de loop van de tijd de knutselkamer, het sigarenwinkeltje, de kapsalon, de bibliotheek, 
de televisiezaal, de kapel/aula, de biljart-(rook)kamer en de toko hun intrede.

Gedacht vanuit de opvatting dat het tehuis een ware 'gemeenschap' van gezonden en zieken zou moeten zijn, was deze ontwikkeling begrijpelijk. Wie ouderen zo lang mogelijk in dezelfde omgeving wilde houden, moest veel voorzieningen in het tehuis onderbrengen - voorzieningen die op hun beurt slechts rendabel waren wanneer het tehuis groots werd opgezet. Met het tehuis-als-verzameling-zo-gewoon-mogelijk-wonende-individuen als vertrekpunt was het tehuis met vele voorzieningen een veel minder logische opzet. In dat geval zou een deel van die voorzieningen immers ook buiten het tehuis gelokaliseerd kunnen zijn. Het bieden van service-in-huis was echter niet alleen met de gemeenschapsgedachte verbonden, maar ook met het al langer bestaande hotel-concept, waarin service ook een zekere vrijheid impliceerde. Ouderen zouden op die manier binnen de muren van het tehuis een zo normaal mogelijk leven - zelf een boodschap bij de toko doen - kunnen leiden. Bovendien sloot het 'inbouwen' van allerlei voorzieningen aan bij de veronderstelling dat ouderen een zekere beschutting op prijs stelden. Een bibliotheek binnen het tehuis had bij voorbeeld het voordeel, zo legde iemand uit, dat bejaarden op een gure dag niet naar buiten hoefden.

Dat neemt niet weg dat in het ontstaan van de voorkeur voor grote tehuizen ook andere overwegingen een rol speelden. Zo verklaarde een Bouwcentrum-medewerker deze ontwikkeling ondermeer op grond van de bevolkingsdichtheid en economische motieven. Ook kwam het voor dat een nieuw tehuis een groot oud gesticht moest vervangen, zodat alleen al om die reden voor een tehuis met veel kamers werd gekozen. ${ }^{79}$ Daar komt bij dat in Nederland al vroeg in de jaren vijftig grote belangstelling voor het zogenaamde 'all-round'-systeem ontstond: de combinatie van pensiontehuis of verzorgingspaviljoen met bejaardenwoningen - een enkele keer ook met verpleegafdeling. In een dergelijke combinatie, waarbij bewoners van bejaardenwoningen op een deel van het personeel en de voorzieningen van het tehuis een beroep mochten doen, konden bejaarden - zo werd 
gezegd - tot het eind in een vertrouwde sfeer blijven en hun vrijheid en zelfstandigheid volkomen behouden. ${ }^{\circ 0}$ Aanvankelijk was het Bouwcentrum over deze vorm van bejaardenhuisvesting om exploitatie-technische redenen weinig enthousiast. Het ministerie zag echter grote voordelen in de handhaving van de zelfstandigheid. Een dergelijke differentiatie van huisvestingsvormen, waarbij zich in de tweede helft van de jaren vijftig ook de verzorgingsflat (later serviceflat) en in de jaren zestig groepen bejaardenwoningen met dienstverleningscentrum voegden, voorkwam een te duidelijke 'indicatie' van de groep bejaarden en voorzag in hun uiteenlopende behoeften. ${ }^{81}$

Opvallend was ook dat dergelijke grote complexen zodanig werden onderverdeeld, dat over 'wijken' werd gesproken. Zo schreef iemand over een groot verzorgingstehuis met verzorgingsflats, dat een etage met flatwoningen als het ware een eigen wijk met burenhulp vormde. ${ }^{k 2}$ En een architect vermeldde over 'zijn' tehuis dat per verdieping de kamers weer onderverdeeld waren tot een 'eigen wereldje' van zestien bejaarden. ${ }^{{ }^{3}}$ Die ontwikkeling werd uiteraard in de hand gewerkt doordat aan de kamers - via eigen portaal, brievenbus en voordeurbel - steeds meer het aanzien van een woning werd gegeven. Nederland ging daarin, samen met de Scandinavische landen, verder dan veel andere landen: elders waren kamers voor alleenstaanden veelal als slaapkamers te beschouwen. ${ }^{4}$ Architecten bevestigden de ontwikkeling naar wijkjes door de kamers op een bepaalde afdeling of gang in groepen onder te verdelen. Dit gebeurde bij voorbeeld door verschillende kleuren te gebruiken of kamers op 'pleintjes' te laten uitkomen. . $^{\text {s }}$

Vanaf de tweede helft van de jaren vijftig werd bovendien vaker voor hoogbouw gekozen, bij voorbeeld wanneer het ging om een verzorgingstehuis in combinatie met verzorgingsflats. Over die hoogbouw werd genoteerd, dat de verbondenheid van de hoog gehuisveste bejaarden met de maatschappij beneden waarschijnlijk veel inniger zou zijn dan bij conventionele huisvestingsvormen. '[D]e bewoner heeft een wijds panorama op alle mogelijke facetten van het actieve leven. Het verkeer, de ontwikkeling van de stad, hij kan alles nauwkeurig en in haar samen- 
hang volgen, zonder er zelf al te direct bij betrokken te zijn of er hinder van te ondervinden. ${ }^{86}$ Een architect schreef over een hoog woongebouw met flats, dat dit uitstekend paste bij de bejaarde (zie illustratie 9): 'Hij blijft verbonden met zijn stad, met het leven, doch beziet dit allemaal zo bekende uit een hoger standpunt. $^{\text {"37 }}$

\section{Een beschutte verbinding met buiten}

De verbondenheid met de omgeving, zonder van die omgeving hinder te ondervinden, was ook een belangrijk thema in de gedachten over de juiste ligging van de tehuizen. Ook daaraan, en daarmee op de grenzen tussen het tehuis en zijn omgeving, lagen twee verschillende uitgangspunten ten grondslag. In dit geval werden de betreffende opvattingen echter niet onafhankelijk van elkaar naar voren geschoven, maar met elkaar verbonden: zowel de behoefte van bejaarden aan contact met de omgeving, als het belang van een zekere beschutting werden in de beschouwingen opgenomen.

Zo was het Ministerie van Volkshuisvesting fervent voorstander van de wijkgedachte: huisvesting voor bejaarden diende zoveel mogelijk over de verschillende stadsgedeelten verdeeld te zijn en gemakkelijke verbindingen te hebben met de buurt: kerken, winkels en plantsoenen. Dat voorkwam dat bejaarden bij het verhuizen naar een bejaardenwoning of -tehuis hun vertrouwde wijk voor een vreemde omgeving moesten inruilen." Op die manier bleef het contact tussen ouderen en hun familieleden zo natuurlijk mogelijk. Want bij grotere afstanden kon het familiecontact ontaarden in sleurbezoeken, waardoor bejaarden het gevoel kregen 'er buiten' te staan. 'Zij zijn zich bewust, dat men gelegenheidsverhalen afsteekt in een krampachtige poging het contact te bestendigen tussen twee groepen, die niet meer gebonden zijn door de dagelijkse gang van het leven zelf. ${ }^{,{ }_{9}} \mathrm{Het}$ Ministerie van Maatschappelijk Werk zag dezelfde gevaren. Zo stelde de bewindsman van dat departement in 1953 dat er aandacht moest worden besteed aan de '(...) wenselijkheid en mogelijkheid om de bewoners van de bejaarden-tehuizen in staat te stellen zoveel mogelijk verbindingen te onderhouden met de sa- 
menleving van de plaats van vestiging. Wordt hierop geen acht geslagen, dan bestaat het gevaar, dat de tehuizen een vreemd element gaan vormen in deze samenleving. ${ }^{90}$ Niet lang daarna gebruikte dezelfde minister in dit verband het woord 'integratie'.

Uit de publikaties van die jaren valt echter af te leiden, dat bij de integratie van bejaarden in de samenleving aan een betrekkelijk kleine wereld werd gedacht: die van de familie en de naaste omgeving. Juist in het geven van gezelligheid aan hun (klein)kinderen lag de taak van de bejaarden, terwijl andersom de ouderen 'liefde, begrip en eerbied' nodig hadden..$^{92}$ En hoewel variatie in de ligging van tehuizen - in het centrum van stad en dorp, of juist aan de rand - op grond van de verschillen tussen bejaarden werd gepropageerd, ${ }^{93}$ sprak uit veel passages in teksten van zowel de overheid als van andere instanties, de wenselijkheid van een combinatie van contact met de omgeving en een zekere beslotenheid. 'Erbij zijn, zonder er last van te hebben wordt in het algemeen prettig gevonden', liet de Centrale Directie weten."

Tehuizen dienden dan ook met zicht op de wereld én rustig gelegen te zijn. 'Oude mensen', zo schreef een ambtenaar, 'willen graag nog "meedoen" in de maatschappij, al ware het slechts als critische toeschouwer en commentator. (...) Over het algemeen hebben ze nog liever, dat er vanuit hun venster veel te zien is (veel verkeer) dan dat ze van een bijzonder fraai doch enigszins verlaten uitzicht kunnen genieten. De hinder van het straatverkeer (...) moet echter (...) zo veel mogelijk geëlimineerd worden $(\ldots)^{\text {ys }}$ Dergelijke formuleringen deden sterk denken aan de vele psychologische - vaak fenomenologische - beschouwingen van die jaren waarin de ouderdom werd getypeerd als een periode waarin afstand werd genomen. Rümke's metafoor van de ouderdom als 'badplaats waar het seizoen gesloten is', kwam in het tweede hoofdstuk al ter sprake. ${ }^{96}$ Een andere, nog vaker gebruikte metafoor was die van de bejaarde als 'toeschouwer'. In dit verband werd F.J.J. Buytendijk veel geciteerd. 'Oud zijn', zo schreef hij, "is een verzadigd zijn van ervaring en daad, der jaren zat; is op een besliste distantie staan tot bewogenheid en beweging, is een rust (...) Van deze positie der distantie en rust uit leeft de oude mens "in-en-met-de-wereld", die thans voor hem een tafereel 
geworden is, (...) een comédie humaine, objectief aanschouwd en als in een theater op afstand meegeleefd. ${ }^{197}$ Vergelijkbare gedachten speelden een rol in de opvattingen over de tuin. De aanwezigheid van een tuin rond het tehuis werd van groot belang geacht. Die tuin moest echter worden aangelegd op het gebruik van bejaarden, hetgeen inhield 'dat er meer naar gekeken zal worden dan in gewandeld. Zitten in de tuin zal weinig voorkomen, tenzij speciale glazen windschermen dit op een mooie dag zeer aanlokkelijk maken. ${ }^{, 98}$

Met een dergelijke combinatie van openheid en geslotenheid konden veel architecten goed uit de voeten. Veel problematischer was de verbinding van 'privacy' met 'huiselijkheid'. Bovendien worstelden veel architecten met de vraag hoe zij ondanks de forse omvang van de tehuizen konden voorkomen dat de tehuizen te massaal en monumentaal werden en te veel het karakter van een instituut zouden krijgen. Vermoedelijk reflecteerden opmerkingen over die worsteling de zorgen van de opdrachtgevers. Maar de architecten spraken erover.

Dat laatste bleek ondermeer uit de beschrijvingen die architecten in bejaardenzorg- en bouwtijdschriften gaven van zojuist gereed gekomen tehuizen. Eén van hen meldde gezocht te hebben naar een architectonische verschijningsvorm die nog een 'woonsfeer' ademde en niet die van 'kazerne, hotel of ziekenhuis' ${ }^{99}$ Anderen lieten weten massaliteit te vermijden door de inhoud van het gebouw, via de toepassing van gangen met aan weerszijden kamers, zo klein mogelijk te houden en anonimiteit te voorkomen door eentonige gangen te 'breken'. ${ }^{100} \mathrm{Al}$ ging het om een bejaardencomplex met vierhonderd bewoners: grootsheid en monumentaliteit waren taboe. ${ }^{101}$ Enkele architecten hadden zich - naar eigen zeggen - laten leiden door de overtuiging dat de massale huisvesting 'architectonisch zo niet ontkend, dan toch zoveel mogelijk verzacht' moest worden, in dit geval door een sterk horizontalisme in hun ontwerp, ${ }^{102}$ Eén ontwerper probeerde de massaliteit van zijn tehuis te verdoezelen door een genoeglijke entree op papier te zetten: 'Ze komt de bewoners bij wijze van spreken handreikend tegemoet. ${ }^{103}$ 
Tegelijkertijd maakten architecten er melding van de bewoners een zo groot mogelijke vrijheid te willen geven. Zo ontwierp iemand een rechtsstreekse verbinding vanuit elke wooneenheid naar buiten, zodat bewoners konden gaan en komen wanneer zij wilden, ongecontroleerd bezoek konden ontvangen en geen gebruik hoefden te maken van de gemeenschappelijke gangen. ${ }^{104}$ Een ander schreef dat in het ontwerp een maximum an privacy voor de individuele bewoners was bereikt door de toegangen naar de kamers als echte voordeuren uit te voeren, compleet met bel, naamplaat en brievenbus. ${ }^{105}$ Met het oog op de privacy en het contact met de buitenwereld stelden veel architecten overigens voor om eenzijdig bewoonde, en daarmee lange gangen, te bouwen. ${ }^{106}$

Het belang van privacy viel echter niet altijd even gemakkelijk met dat van huiselijkheid te verenigen. Op dit probleem wezen twee deskundigen in een bespreking van een Zweeds ontwerp (zie illustratie 10). In dat ontwerp werden steeds tien eenpersoonskamers en één tweepersoons-suite informeel gegroepeerd rond een korte gang met twee open, gemeenschappelijke (eet)ruimten. Een dergelijk tehuis leek in niets meer op een oud gesticht. Maar werden de mensen die er woonden niet te veel gedwongen op elkaars lip te leven? De bewoners van de kamers die aan de open ruimten grensden konden hun kamers immers niet verlaten zonder gezien te worden door de mensen die in de gemeenschappelijke ruimten verbleven. Bovendien zou iedereen die naar een ander deel van het tehuis of naar buiten wilde, hoe dan ook één van de open gebieden moeten passeren. ${ }^{107}$

Veel architecten hadden oog voor openheid én geslotenheid. 'De situering, enerzijds dicht bij bos en park, anderzijds in de onmiddellijke omgeving van winkels en dorpskern, is vooral voor bejaarden bijzonder gunstig te noemen', schreef een architect over het door hem ontworpen tehuis. ${ }^{108}$ In een programma van eisen voor een ander tehuis werd vermeld, dat het gebouw de bejaarden nog zoveel mogelijk de gelegenheid moest bieden met de maatschappij in contact te komen, terwijl toch een zekere rust gewaarborgd moest worden. Het eerste werd geprobeerd door in het tehuis een sociëteit te situeren, het tweede door de vleu- 
gels van het gebouw rond een binnentuin aan te leggen. ${ }^{109}$ Anderen wilden via glazen wanden en recreatiezalen-met-uitzicht het contact met de buitenwereld vergroten. 'Om de bejaarde', zo stond ergens vermeld, 'die soms een groot gedeelte van het jaar het tehuis niet verlaat toch het gevoel te geven er even uit te zijn (...) is getracht door toepassing van veel glas de relatie met buiten te versterken." ${ }^{\prime \prime}$ Tegelijkertijd wilden architecten datgene wat buiten was naar binnen halen. Zo werd de conversatiezaal met uitzicht gezien als een comfortabele vervanging van de bankjes langs de weg en wilde men gangen als straten laten functioneren door schoon metselwerk aan te brengen."

In de tehuizen van de jaren vijftig en zestig werd het contact met 'buiten' dan ook op twee manieren inhoudelijk en ruimtelijk afgebakend. In de eerste plaats werd de integratie tussen de bewoners en hun omgeving voorgesteld als die binnen de beperkte 'kring' van familie en wijk. In de tweede plaats werd het contact met de omgeving ruimtelijk zo vorm gegeven, dat bejaarden van de omgeving 'niet te veel last hadden'. Het ging om het 'gevoel' er even uit te zijn, om een blik op de wereld van bovenaf of vanachter het glas dat zicht gaf én beschermde. Binnen het tehuis had de oudere zijn eigen 'woning' en 'wijk', het bankje waarop hij met zijn buren kon spreken en alles - een eigen winkel, kerk en dokter - bij de hand. Dergelijke voorzieningen werden zowel gemotiveerd vanuit de gemeenschapsgedachte als vanuit de gedachte dat binnen het tehuis zo gewoon mogelijk moest kunnen worden geleefd. Maar terwijl de tehuizen werden gebouwd, vaak vijf tot tien jaar na de eerste voorstellen, begon bij vele betrokkenen de twijfel te knagen.

5 Een nieuwe horizon: tehuizen ter discussie

In 1950 woonde $6 \%$ van de Nederlandse bejaarden in inrichtingen en instellingen van allerlei aard, waarvan $3,8 \%$ in nietwinstbeogende tehuizen. ${ }^{112}$ Vijfentwintig jaar later was het percentage 65-plussers in bejaardentehuizen gestegen tot zo'n ro\% (zie tabel I). ${ }^{13}$ In I950 was nog bijna de helft van het aantal ver- 
zorgden in niet-winstbeogende tehuizen aangewezen op kamers met meer dan vijf bedden. In 1986 was nog geen $I, 5$ promille van de appartementen in bejaardenoorden bestemd voor meer dan twee personen. ${ }^{114}$

Bij degenen die lokaal het initiatief namen tot de bouw van deze tehuizen speelde, zo is ter sprake gekomen, ondermeer de woningnood een rol. Verzuiling heeft de bouw van tehuizen versneld, menen J. Baars en C.P.M. Knipscheer: iedere zuil zag zich per dorp, stad of regio graag in de bejaardenzorg vertegenwoordigd." ${ }^{\text {"s }}$ En waar lokale bestuurders bij de bouw betrokken waren, sprak misschien ook het prestige van voorzieningen een woordje mee. Zo is uit bestuurssociologisch onderzoek gebleken dat bij wisselingen in de bezetting van burgemeesters- en wethoudersposten het aantal gemeentelijke initiatieven tot het opzetten van bejaardentehuizen, industrieterreinen en zwembaden toeneemt. ${ }^{16}$ Bovendien is de activiteit van lokale initiatiefnemers vermoedelijk zowel door de vele publikaties over de toekomstige behoefte aan tehuizen als door de lange wachtlijsten voor de bestaande tehuizen gestimuleerd.

\section{Een zelfstandige woning}

Juist bij die lange wachtlijsten begon men in de loop van de jaren vijftig en zestig kanttekeningen te plaatsen, zowel in kringen van de overheid als in die van de bejaardenzorg zelf. Eén van de achtergronden daarvan was dat deskundigen andere opvattingen over de woonwensen van bejaarden ontwikkelden. Rond het midden van de jaren vijftig formuleerden zij, mede op grond van nieuw onderzoek, de stelling dat de meeste bejaarden best tot zelfstandig wonen in staat waren en dat ook wilden blijven doen. Zelfstandige huisvesting hield hen in hun vertrouwde omgeving, kwam hun lichamelijke en geestelijke validiteit ten goede doordat zij hun eigen huishouding voerden - en bood bovendien economische voordelen. Zelfverzorging hield de bestaanskosten laag, zodat bejaarden minder of geen financiële steun nodig hadden van anderen en hun inkomen vrij konden besteden. Het zou dan ook het streven moeten zijn hen zo lang mogelijk in zelfstandige woningen te handhaven. Dat bood bovendien een 
oplossing voor het tekort aan personeel in de tehuizen. ${ }^{17}$ Dat betekende niet dat institutionele zorg voortaan overbodig werd geacht, maar wel dat deskundigen zich afvroegen of de grote bouwactiviteit ten aanzien van bejaardentehuizen wel juist was. 'Men is het er nu immers over eens, dat huisvesting in kleine zelfstandige woninkjes (...) verre de voorkeur verdient. ${ }^{\text {'us }}$

Opvallend was dat in dergelijke betogen 'zelfstandigheid' steeds vaker exclusief met het wonen in een afzonderlijke woning werd geassocieerd. Werd tot het midden van de jaren vijftig het pensiontehuis geroemd om de zelfstandigheid die het de bewoner in vergelijking met het oudeliedentehuis bood, daarna werd het geleidelijk vanzelfsprekend om zelfstandigheid met het wonen in een bejaarden- of eengezinswoning te verbinden. Weliswaar werd verondersteld dat bejaarden ook binnen het tehuis behoefte hadden aan een zo groot mogelijke vrijheid van handelen. Maar wanneer geschreven werd dat bejaarden zelfstandigheid nastreefden, dan werd daarmee in de eerste plaats het zelfstandig wonen bedoeld, waarmee niet alleen een grotere financiele vrijheid werd verbonden, maar ook een vertrouwde omgeving en - impliciet - een grotere actieradius. Zelfstandigheid werd op die manier aan een andere nimte gekoppeld.

Dat laatste werd ondermeer duidelijk in de formuleringen die het Ministerie van Volkshuisvesting in de jaarverslagen van haar Centrale Directie koos. Zo werd in 1956 geconstateerd dat de '(...) verworven inzichten in de grote betekenis van de uiterste handhaving van de zelfstandigheid van de bejaarden (...) niet tot gevolg [hebben] gehad dat de (...) nieuwe pensiontehuizen uit hun dominerende positie zijn verdrongen, doch wel dat de initiatiefnemers zich afvragen, of er niet van een zekere overwaardering ten aanzien van het pensiontehuis sprake is'. ${ }^{19}$ Het standpunt dat de Centrale Directie wat dit betreft zélf innam was overigens tweeslachtig. Op de gestage groei van het aantal tehuizen werd zowel verheugd als verontrust gereageerd. In 1959 werd vermeld dat de uitbreiding van het aantal woningen en tehuizen recht deed aan de moeilijke huisvestingssituatie van bejaarden. ${ }^{120}$ Maar het jaar daarop was het 'de vraag of de aandacht van de initiatiefnemers niet te veel is gericht op de pensiontehuizen' en in 
I965 moest het feit dat de bouw van verzorgingstehuizen nog steeds de boventoon voerde 'voor een evenwichtig beleid op dit terrein eigenlijk als onwenselijk (...) worden beschouwd'. ${ }^{12}$

Ook het Ministerie van Maatschappelijk Werk hechtte vanaf het midden van de jaren vijftig een toenemend belang aan zelfstandige huisvesting. Van Thiel stelde zich in 1955 ten doel het maatschappelijk werk ten behoeve van bejaarden - sociale hulpdiensten, sociëteiten - uit te bouwen, aangezien 'de grote meerderheid der bejaarden niet in tehuizen woonachtig is en het in het algemeen juist wordt geacht, dat de bejaarde zo lang mogelijk in zijn oude milieu blijft (... $)^{1,22} \mathrm{Klompé,} \mathrm{die} \mathrm{Van} \mathrm{Thiel} \mathrm{in} 1956$ opvolgde, nam deze doelstelling over. $\mathrm{Zij}$ wenste die activiteiten te bevorderen 'die er op gericht zijn de bejaarden zolang mogelijk in de hun vertrouwde omgeving te laten leven', al bleven de begrotingsbedragen voor deze activiteiten jarenlang bescheiden. ${ }^{123} \mathrm{Ka}-$ merleden betuigden eveneens hun instemming met de nieuwe denkbeelden. Het belang van zelfstandige huisvesting werd door vrijwel alle partijen onderschreven. Niettemin bleven veel parlementariërs erop hameren dat bejaardentehuizen voor veel bejaarden niet betaalbaar waren en dat daar iets aan gedaan diende te worden. ${ }^{124}$

Uiteraard deed de constatering dat de meeste bejaarden huisvesting in een afzonderlijke woning prefereerden de vraag ontstaan hoe de lange wachtlijsten uitgelegd moesten worden. Daarvoor werden in de loop der tijd verschillende verklaringen aangedragen. Sommigen beschouwden de lange wachtlijsten in de eerste plaats als een indicatie van de woningnood. ${ }^{125}$ Anderen wezen op de toename van het aantal hoogbejaarden, op een tekort aan verzorging via gezinshulp, wijkverpleging en verpleeghuizen en op de verbeterde kwaliteit van de tehuizen. Ook werd opgemerkt dat veel tehuizen bij voorkeur gezonde en vitale bejaarden opnamen. Dat stimuleerde bejaarden zich 'op tijd' op te laten nemen. Ook de wachtlijsten zélf hadden dat effect, zo meenden velen. Ouderen gaven zich, uit angst dat er voor hen geen plaats zou zijn als het nodig was, op relatief jonge leeftijd op voor één of zelfs meerdere tehuizen. Daar namen zij dan jarenlang een kamer in beslag, wat de wachtlijsten weer langer maak- 
te. ${ }^{126}$ Munnichs heeft bovendien gewezen op de toename van het aantal alleenwonende ouderen in de jaren zestig. Deze toename hing samen met de verbetering van de financiële positie van bejaarden en het beschikbaar komen van bejaardenwoningen. Bij het ouder worden zochten juist deze alleenwonenden hun heil in tehuizen, zo redeneerde Munnichs. ${ }^{127}$

Maar verklaringen voor de wachtlijsten boden nog geen antwoord op de vraag hoeveel procent van de bejaarden werkelijk behoefte had aan een onderkomen in een tehuis. In 1953 schatte het Bouwcentrum dat percentage op grond van enkele plaatselijke steekproeven op tien. Maar aan het eind van de jaren vijftig toonde het centrum zich daarover onzeker. Uit onderzoek bleek steeds weer dat bejaarden een 'sterke drang tot het handhaven van de zelfstandigheid' vertoonden. ${ }^{128}$ Daarbij tekende het Bouwcentrum aan dat bejaarden niet altijd een juist beeld van het moderne tehuis hadden en dat het verhaalsrecht de opname nogal eens in de weg stond. Aan de andere kant verbleven in de tehuizen nog veel bejaarden die eigenlijk in - onvoldoende gebouwde - verpleegtehuizen thuishoorden. Niettemin zou voor 80 tot 90 procent van de bejaarden geen noodzaak tot opname in een tehuis bestaan. Voor hoeveel bejaarden die noodzaak of behoefte dan wél bestond, durfde het Bouwcentrum niet te zeggen. Wat dat betreft liepen de schattingen van onderzoekers uiteen van vier tot zestien procent en vermoedde een ambtenaar in 1961 een behoefte van acht procent in plaats van de oude vuistregel van tien procent. ${ }^{120}$ Die variatie hing samen met plaatselijke omstandigheden, maar ook met de manier waarop de behoefte aan tehuizen werd gedefinieerd. Zo nam een deel van de onderzoekers de wensen van bejaarden tot uitgangspunt, terwijl anderen een onderscheid maakten tussen 'subjectief verzorgingwensenden en 'objectief' verzorgingbehoevenden. ${ }^{130}$

\section{Het ware verzorgingstehuis}

Juist in dat laatste onderscheid lag een verschuiving die het denken over bejaardentehuizen belangrijk zou doen veranderen. In de loop van de jaren zestig werd het tehuis-als-hotel door steeds meer mensen in de beklaagdenbank gezet en werd een discussie 
in gang gezet die uiteindelijk een nieuw concept van het tehuis naar voren zou duwen: het verzorgingstehuis. In een dergelijk tehuis hoorden niet alleen andere bejaarden, maar - op den duur ook andere ruimten.

In november 1959 verscheen in een tijdschrift voor sociale zorg een artikeltje onder de kop 'Voor wie bouwen wij bejaarden-tehuizen?' De schrijfster ervan verzette zich in dat artikel tegen wat volgens haar de gangbare selectiemethode van tehuizen was. Vooral de kerkelijke tehuizen lieten tot haar ergernis vaak alleen gezonde en valide bejaarden toe. De minder validen werden naar particuliere, commerciële tehuizen of naar gemeentelijke instellingen verwezen. De reden daarvoor lag in de kosten: het zou de exploitatie te duur maken. Een gevolg was dat ouder wordende mensen die nog heel goed in staat waren hun zelfstandigheid te handhaven, voor de zekerheid alvast naar een pensiontehuis gingen. In een tijd waarin zelfstandigheid bij velen hoog in het vaandel stond, waarin verzorging in een pensiontehuis duurder was dan een verblijf in een eigen woning, en waarin tehuizen diaconaal- en overheidsgeld kregen, kon deze vorm van selectie niet juist zijn, zo meende de auteur. Een bejaardentehuis was geen verpleeginrichting. Maar het was noch verantwoord noch sociaal om een 80-jarige man met 'suiker' of een 82jarige vrouw die zich na een gebroken heupbeen niet helemaal had hersteld, te weigeren. ${ }^{3 \prime}$

De vrouw stond in haar aanklacht niet alleen. Veel tehuizen, zo stond in het vaktijdschrift De Bejaarden, prefereerden niet alleen gezonde ouderen, maar ook kandidaten die voldoende draagkrachtig waren en wat hun maatschappelijke achtergrond betreft in het karakter van het tehuis pasten. En dat terwijl de tehuizen verzorgingstehuizen in de ware zin des woords moesten worden. ${ }^{132}$ De achtergrond van de bestaande praktijk lag, aldus een commentator van katholieke huize, zowel in onmacht - een gebrek aan personeelskrachten - als in onwil. Tehuizen hielden storende gedachten aan ziekte en dood, aan gebrekkigheid en de kwalen van de oude dag liever buiten de deur. ${ }^{133}$ Vermanende woorden kwamen ook van de top van de Katholieke Vereniging van Bejaardentehuizen. Een bejaardentehuis was geen hotel 
voor pensiongasten, maar een tehuis voor bejaarde mensen die in de laatste fase van hun leven waren. Opname mocht dan ook niet zo maar op grond van lichamelijke gebreken geweigerd worden. Uiteraard maakte een lange wachtlijst het gemakkelijk om aan gezonden voorrang te geven. En uiteraard scheelde dat laatste in de kosten van de exploitatie, de belasting van het personeel en de inrichting van een ziekenkamer. Maar het was passender om voor revalidatie-mogelijkheden, een verpleegafdeling en een kwaliteitsverbetering van het personeel te zorgen. ${ }^{134}$ Bovendien sloot dat beter aan bij de realiteit, zo was de gedachte. Uit een onderzoek onder de eigen tehuizen, gepubliceerd in 1963 , bleek dat het aantal bejaarden dat intensieve verzorging en/of verpleging nodig had veel groter was dan gedacht. ${ }^{135}$ Mede door de toename van zelfstandige woonvormen voor bejaarden, zo liet bovendien het Ministerie van Volkshuisvesting in I96 I weten, veranderde het type bewoner van het bejaardentehuis - de gemiddelde leeftijd steeg. ${ }^{136}$

Maar niet iedereen wilde de bestaande selectiepraktijk veranderen. Zo werd die praktijk ondermeer verdedigd door op standsverschillen tussen de tehuizen te wijzen. ${ }^{137}$ Ook het belang van een goede sfeer werd naar voren geschoven. Voor een 'levende gemeenschap' was het, aldus één van de verdedigers, noodzakelijk dat nieuwe bewoners nog redelijk konden bewegen, zien en horen. Slechts in die toestand waren zij in staat mensen te leren kennen en deel te nemen aan het gemeenschapsleven. ${ }^{1{ }^{k}}$ Anderen ontkenden dat veel van de opgenomen bejaarden nog echt valide waren. Die validiteit was slechts schijn: bewoners konden vlak vóór de opname door verwaarlozing op instorten staan, maar ná opname geheel opbloeien. ${ }^{139}$ Bovendien zou van de kandidaten niet zozeer een volledige gezondheid mogen worden geëist, als wel een bepaalde minimum-prestatie. $^{140}$

Toch werd in de loop van de jaren zestig de roep om een nieuw selectiebeleid steeds sterker. Het tehuis hoorde niet voor mobiele, sterke en verzorgingwensende bejaarden bedoeld te zijn, zo was de gedachte, maar voor minder valide en hulp- of verzorgingbehoevende bejaarden die slechts op grond van een 
deugdelijke medische en/of sociale indicatie mochten worden opgenomen. ${ }^{14}$ Dergelijke indicatie-criteria werden vanaf het midden van de jaren zestig door verschillende instellingen ontwikkeld, waaronder de Nederlandse Federatie voor Bejaardenbeleid en de Katholieke Vereniging voor Bejaardenzorg. ${ }^{143}$ In 1967 publiceerden beide instellingen een gezamenlijk rapport, waarin zowel het werken met een opname-commissie als met opname-criteria werd anbevolen. ${ }^{143}$ In de opname-criteria werd verwerkt dat een bejaarde nog niet voor opname in aanmerking kwam wanneer een familielid of het open bejaardenwerk in regelmatige en continue zorg kon voorzien. Iemands validiteit werd aan huishoudelijke, lichamelijke en psychische criteria getoetst - waarin een bepaalde rangorde werd aangebracht. Dit betekende niet dat met het type huis geen rekening meer hoefde te worden gehouden, maar dat kon buiten de eigenlijke opnemingscriteria blijven. Overigens bleven onderzoekers en instellingen aan deze opname-criteria werken, ondermeer aan de hand van het Angelsaksische begrip Activities of Daily Living - Algemeen Dagelijkse Levensverrichtingen (ADL) - oftewel activiteiten die nodig waren voor de verzorging van het eigen lichaam. Omdat in het verlies van de zogenaamde ADL-functies volgens onderzoekers een zeker systeem zat, konden ouderen naar hun ADL-niveau en daarmee naar hun verzorgingsbehoefte worden gemeten en ingedeeld. ${ }^{44}$

Het rapport van 1967 en andere voorstellen voor een gestandaardiseerde opneming ontmoetten veel, zij het weinig nieuwe, kritiek. Gezien de uitkomst van een onderzoek onder katholieke tehuizen was dat niet verwonderlijk. Bij ruim een kwart van de onderzochte tehuizen besliste uitsluitend de directrice over de toelating, bij iets meer dan de helft de directrice samen met iemand anders of enkele anderen. $\mathrm{Na}$ de aanvraag ondernam $38 \%$ van de tehuizen niets anders dan het op de wachtlijst plaatsen van de gegadigden. Van de $4 \mathrm{I} \%$ die inlichtingen inwon, vroeg meer dan de helft naar de gezondheidstoestand van de bejaarden en minder dan een kwart naar maatschappelijke en sociale omstandigheden. Slechts een derde gaf voorrang aan urgente gevallen. ${ }^{45}$ Tegen een opname-beleid op grond van validiteit werd onder- 
meer ingebracht dat de indeling en vorm van de bejaardentehuizen niet op de opvang van verzorgingbehoevende ouderen waren afgestemd. Anders dan de kritici achtten de voorstanders van een nieuw opname-beleid aanpassingen echter mogelijk. ${ }^{146}$

Dat ondanks dergelijke discussiepunten de opvattingen over de taak van het tehuis toch in brede kring aan verandering onderhevig waren, bleek ondermeer uit de veelvuldig gebruikte Nomenclatuur van bejaardenvoorzieningen van de Nederlandse Federatie voor Bejaardenzorg. In de eerste helft van de jaren zestig werden zowel 'het bejaardenpension' als 'het verzorgingstehuis' in deze nomenclatuur besproken en werd het verzorgingstehuis omschreven als een voorziening die huisvesting bood aan bejaarden die om medische en/of sociale redenen verzorging nodig hadden of wensten. De term 'pensiontehuis' kwam alleen in de inleiding voor. Aan het begin van de jaren zeventig werd de term 'bejaardenpension' uit de nomenclatuur geschrapt - over het pensiontehuis werd zelfs niet meer gerept - en kwam in de definitie van het verzorgingstehuis alleen de uitdrukking 'verzorging nodig hebben' nog voor. ${ }^{147}$

\section{De blik gewend}

Met het ontstaan van een nieuwe invulling van zelfstandigheid en een andere kijk op wat het tehuis te doen stond, werden de indeling en ligging van de tehuizen opnieuw geëvalueerd. Het nieuwe ideaal van zelfstandigheid werd met een andere ruimte verbonden dan voorheen: de eigen woning. De nieuwe verontrusting over vergeten groepen betrof dit keer niet de beter gesitueerde oudelieden of de massa der niet bemiddelde bejaarden, maar de 'ware' verzorgingbehoevenden, waarvoor sommige ruimten te klein en andere te groot bemeten waren.

Maar ook op een andere manier veranderde de betekenis en waardering van de ruimte. Waar de integratie van de bejaarde nog werd voorgesteld als een geregeld contact met familieleden en de wijk en het bekijken van de omgeving zonder er zelf last van te hebben, waren kamers-met-balkon, een recreatiezaal met glazen uitbouw en een ligging met uitzicht op enig verkeer adequaat. Maar in de loop van de jaren zestig en zeventig kreeg 'in- 
tegratie', zo kwam in het tweede hoofdstuk aan de orde, zowel in de publikaties van de overheid als in die van de zorginstellingen de betekenis van 'participatie'. En terwijl 'meedoen' belangrijker werd dan 'toekijken' en integratie eerder het 'maatschappelijk leven' dan de 'nabije omgeving' ging betreffen, stond het tehuis zélf opeens te kijk.

Het was alsof de blik van commentatoren als overheidsvertegenwoordigers, parlementariërs, mensen uit de bejaardenzorg en architecten van richting veranderde. Aanvankelijk keken zijmet de bejaarde mee - van binnen naar buiten. $\mathrm{Zij}$ stelden zich voor wie en wat de bejaarde bewoners zagen dan wel tegenkwamen wanneer zij uit hun raam keken of hun kamers verlieten. $\mathrm{Zij}$ waren erop gespitst bejaarden elkaar te laten ontmoeten - bij de zitjes, in de recreatiezaal, in de hal - en hen uitzicht te geven: op de tuin, de buurt, het verkeer. Maar ergens in de jaren zestig en zeventig leek die blik van richting te veranderen. Meer en meer werd het tehuis gezien als een afzijdig liggende enclave die bij het maatschappelijk leven betrokken moest worden door er delen van die maatschappij bij en in te bouwen. Met het volle leven in stad en dorp als referentiepunt, viel het velen op dat voor het tehuis, hoe groot en massief ook, slechts een verloren hoekje was gereserveerd. Voor sommigen werd het zelfs een 'ding, dat indrukwekkend staat te wezen', een 'grotesk monument van onze nog niet gevallenen', een 'bejaardengetto'. ${ }^{48}$

Uiteraard gebeurde dat niet van de ene op de andere dag. Een eerste teken van deze verschuiving werd al besproken: architecten toonden zich bewust van het gevaar dat hun ontwerpen monumentaliteit en massaliteit zouden uitstralen, waarbij zij hun ogen in gedachten van buitenaf over het bejaardentehuis lieten dwalen. Ook schreven zij en anderen steeds vaker over de noodzaak van contact tussen het tehuis en de maatschappij, in plaats van het tehuis en zijn omgeving. Daarbij werd de cirkel rond het tehuis wijder en het contact actiever voorgesteld. ${ }^{149}$ Zo maakte architect $G$. Feenstra aan het eind van de jaren vijftig via ingezonden brieven en tekeningen duidelijk hoe zijn ideale tehuis er uit zou moeten zien (zie illustratie 11). Dat tehuis werd met woningen, winkels, werkplaatsen en een speeltuin gecombineerd 
om op die manier bejaarden midden in het leven te houden. ${ }^{190}$ Bovendien schaarde Feenstra zich met groot enthousiasme achter een utopisch ontwerp van een bejaarde dame, waarin woongebouwen met meer dan tweeduizend bewoners werden voorgesteld. Daarbij zou het niet meer alleen gaan om ouderen, maar om iedereen van boven de twintig die een beknopte kamer en verzorging kon gebruiken. Net als in Feenstra's ontwerp, werden woningen met andere voorzieningen gecombineerd: winkels, horeca-gelegenheden, een bibliotheek en hulppostkantoor. Dit om te voorkomen dat er een 'categorie' gepensioneerden ontstond. ${ }^{\text {st }}$

Feenstra was een van de eersten die in deze termen over het bejaardentehuis spraken, maar vanaf de tweede helft van de jaren zestig schreven ook andere architecten nadrukkelijker over het doorbreken van het vermeende isolement van de bewoners. Dat gebeurde bij voorbeeld door een kleuterspeelplaats op het terrein te projecteren of het terrein publiek toegankelijk te maken. ${ }^{152}$ Verschillende architecten stoorden zich bovendien aan de beperkingen die de overheid hen, vooral in de woningwetsector, oplegde. De verplichte soberheid leidde, zo klaagde één van hen, tot een architectonisch uitgemergelde huisvesting en monotone gevels. ${ }^{133}$ Een directeur van een woningstichting liet weten dat de Voorschriften en Wenken het gevaar van verstarring herbergden: het zou moeilijk worden 'om het boekje heen te lopen', al wilde het er bij hem niet in dat een bel aan iedere deur de zelfstandigheid van de bewoners zou bevorderen. ${ }^{154}$

Radicaler was echter een ontstaan van een kritische beweging binnen de bejaardenzorg zelf, die zich genoodzaakt zag om de manier waarop bejaarden maatschappelijk op een zijspoor werden gezet, aan de kaak te stellen. Aanvankelijk draaide die kritiek nog vooral om 'misstanden' binnen de tehuizen, zoals een bazige houding van het personeel en een gebrek aan inspraak van de bewoners. Dergelijke problemen werden door velen opgemerkt - in 1970 wijdde de varA-Ombudsman zelfs twee dramatische televisie-uitzendingen aan paternalisme, vrijheidsbeperking, verwaarlozing en mishandeling in vooral commerciële inrichtingen - en leidden uiteindelijk tot de verplichte instelling 
van bewonerscommissies. ${ }^{155}$ Maar na verloop van tijd werd het tehuis, door een kleinere groep commentatoren, onder vuur genomen als onderdeel van een verderfelijk maatschappelijk bestel. 'Iemand wórdt oud, bejaard wordt hij gemáákt', luidde in het midden van de jaren zeventig een stelling in een brochure van de Nederlandse Federatie voor Bejaardenbeleid. ${ }^{156}$ De maatschappelijke bejegening en behandeling van ouderen, zo werd in de brochure beweerd, dwong ouderen in een positie van apartheid. De samenleving zag ouderen als hulpeloze stakkers en nutteloze wezens, zette hen van de ene dag op de andere via pensionering op een zijspoor en borg hen netjes op in bejaardentehuizen. Cartoons in de brochure onderstreepten dit: één ervan portretteerde ouderen als garnering op verjaardagstaarten omringd door een traliewerk van kaarsjes. Een ander stelde het bejaardentehuis voor als een stapel blokken met inhoud. Veel ouderen gedroegen zich zoals dat van hen werd verwacht, aldus de samenstellers van de brochure. Maar protest was er eveneens - protest dat volgens de makers aangewakkerd diende te worden.

Tot grote verontrusting van directeuren van tehuizen en een deel van de bewoners, wilde Annie Romein-Verschoor van bejaardenhuizen af. Het waren 'stapeldoosjes' waarin bewoners amper inspraak hadden. Ook de leden van de uit Humanitas voortgekomen Jong Oud Trust gooiden olie op het vuur. Deze organisatie publiceerde in de loop van de jaren zeventig verschillende pamfletten die tot doel hadden het 'apartheidsdenken' en het 'in (...) polderen' van ouderen in instituten tegen te gaan. De belangrijkste dijkdoorbraak die de Jong Oud Trust wilde forceren - een reductie van het aantal bejaarden in tehuizen tot $5 \%$ werd niet bereikt. Een andere dijkdoorbraak werd, met steun van de overheid, echter wel doorgezet: het doen vervagen van de 'grenzen tussen binnen en buiten' het tehuis. ${ }^{157}$

\section{Afremmen, de wijk nemen en groepsverzorging}

Ook op overheidsniveau begon de visie op het bejaardentehuis te schuiven. Dat had niet alleen ideële gronden. Zo bleek het moeilijk om voldoende personeel voor de tehuizen aan te trekken. ${ }^{158}$ Ook stegen de kosten van de bouw en exploitatie zeer 
snel. Samen met de steeds hoger wordende subsidies maakte de Algemene Bijstandswet de kosten van de bejaardentehuizen, aanvankelijk vooral een probleem voor de bejaarde zelf, in toenemende mate tot een probleem van de overheid.

Het was dan ook geen toeval dat politici en ambtenaren in de loop van de jaren zestig, mede onder verwijzing naar de kosten van de tehuizen, steeds vaker bepleitten alleen de werkelijk hulpbehoevende bejaarden op te nemen en op zoek te gaan naar goedkopere alternatieven. ${ }^{159}$ Jarenlang toonden zowel het Ministerie van Maatschappelijk Werk als dat van Volkshuisvesting een zekere ambivalentie ten aanzien van de tehuizen. Een leven buiten de verzorgingssfeer van een bejaardentehuis, zo schreef Klompé in 1960, laat 'ongetwijfeld ruimer mogelijkheid om bij te blijven in en deel te nemen aan de maatschappelijke ontwikkeling ${ }^{\prime}{ }^{160}$ Het departement vond het aantal tehuizen een jaar later verhoudingsgewijs hoog genoeg en wilde de zelfstandigheid en integratie van bejaarden bevorderen door ondermeer de gezinszorg en de dienstencentra te subsidiëren. ${ }^{161}$ Weer twee jaar daarna toonden ambtenaren van het ministerie zich niettemin trots op het 'uitmuntende figuur' dat Nederland wat betreft het aantal bejaardenoorden sloeg. ${ }^{162} \mathrm{Op}$ een soortgelijke manier werd op het departement van Volkshuisvesting de dominante positie van de tehuizen betreurd, maar werden in 1966 de subsidiemogelijkheden voor zowel bejaardenwoningen als tehuizen verhoogd. ${ }^{\text {'t3 }}$

Aan deze ambivalentie kwam in 1968 een eind. In dat jaar bepaalde het ministerie dat voortaan twee in plaats van vier bedden in verzorgingstehuizen als contingentseenheid gerekend zouden worden, wat tot voorzichtigheid zou manen bij het stichten van tehuizen. ${ }^{164}$ Een jaar later kondigde minister Schut aan dat de bouw van bejaardentehuizen gefaseerd zou worden: de afgifte van subsidiebeschikkingen werd voortaan beperkt. ${ }^{165}$ Zou dat niet gebeuren dan zou op korte termijn, gezien de stijgende stroom aanvragen, voor meer dan ro\% van de bejaarden een bed beschikbaar zijn. Dat percentage lag, aldus de minister, aanzienlijk hoger dan de behoefte-percentages op grond van lokaal onderzoek. ${ }^{166}$ Daarnaast zou de bouw van bejaardenwoningen 
worden versneld. De schattingen van de behoefte aan zelfstandige huisvesting liepen uiteen van 7 à 8 tot $30 \%$. Het Ministerie van Volkshuisvesting hield $15 \%$ als richtlijn aan. ${ }^{167}$ Deze huisvestingspolitiek werd gekoppeld aan een reeks andere beleidsvoornemens, waaronder een versnelde uitbreiding van de maatschappelijke dienstverlening - gezinszorg, wijkverpleging, dienstencentra - aan bejaarden en de uitbouw van het aantal verpleeghuizen. ${ }^{168}$ In toelichtingen op deze prioriteitsverschuivingen werd ondermeer gewezen op de zelfstandigheidsbehoefte van bejaarden, op de hoge exploitatiekosten van de tehuizen en op de personeelstekorten: geen nieuwe overwegingen. ${ }^{169}$ Maar nieuw was wel dat bij de begrotingsbehandeling ook de hoge bijstandslasten openlijk op tafel kwamen. ${ }^{170}$ Alleen al om die reden is het waarschijnlijk, dat juist dit argument de weegschaal van voor- en nadelen van tehuizen naar de negatieve kant deed doorslaan. ${ }^{171}$

In de jaren die volgden bleven wat betreft de huisvesting, los van de wisselende politieke signatuur van kabinetten en los van kritiek van het parlement en de wereld van de zorg, de uitbouw van het aantal bejaardenwoningen en de afremming van de bouw van tehuizen de pijlers van het beleid. ${ }^{172}$ Daarnaast werd in 1972 de Wet op de Bejaardenoorden gewijzigd. Die verandering hield in dat voortaan regels konden worden opgesteld met betrekking tot de provinciale planning van bejaardenoorden, de opname van bejaarden en het prijstoezicht. ${ }^{173}$ Voortaan zou een breed samengestelde Centrale Commissie voor de Bejaardenoorden (ССв) de minister over dergelijke zaken van advies dienen. Daarnaast zouden in gemeenten commissies worden ingesteld, die aan bejaarden die opname in een tehuis wensten, alsmede aan de houder van een bejaardenoord, schriftelijk advies uit zouden brengen over de aard en mate van verzorging die een bejaarde nodig had. De wetsartikelen die de opname preciezer regelden traden echter pas vijf jaar later, op I januari 1977, in werking. Voortaan zou een bejaardenoord een bejaarde slechts mogen opnemen wannneer een indicatiecommissie daarover schriftelijk had geadviseerd. Zonder een dergelijk advies was opname uitgesloten, al hielden bejaardenoorden in principe de vrij- 
heid zich niet aan de strekking van het advies te houden. Tegelijkertijd werd het Besluit Opneming Bejaardenoorden ingevoerd. Daarin werden bij algemene maatregelen van bestuur urgentiecriteria opgesteld aan de hand waarvan de indicatiecommissies hun beslissingen dienden te nemen. ${ }^{174} \mathrm{Na} 1977$ werd de autonomie van de tehuizen steeds verder beperkt en werden de urgentie-klassen steeds verder verscherpt. Vanaf 1984 mochten bejaardenoorden uitsluitend positief geïndiceerde bejaarden opnemen.

In de Wet op de Bejaardenoorden van 1972 werd eveneens vastgelegd, dat voortaan geen enkel bejaardenoord meer opgericht, uitgebreid of verbouwd zou mogen worden zonder een door Gedeputeerde Staten afgegeven verklaring van geen bezwaar. Planning zou immers een provinciale taak worden. Voorlopig trad dit deel van de wet echter niet in werking en nam het Rijk, via de aankondiging van de $7 \%$-regel in de Nota Bejaardenbeleid van 1975 , zelf de touwtjes in handen. ${ }^{175}$ Die regel hield in dat voortaan slechts toestemming zou worden verleend aan de bouw of uitbreiding van een bejaardenoord, wanneer het aantal plaatsen in bejaardenoorden niet uitkwam boven $7 \%$ van het aantal bejaarden in de regio. Een overgangsartikel bepaalde dat er slechts met toestemming van het Rijk gebouwd of gerenoveerd mocht worden. ${ }^{176}$ Vanaf 1976 werd de bouw van bejaardenoorden dan ook met $10 \%$ beperkt tot 4500 bedden per jaar. Ook dit keer stond de afremming van het bouwtempo niet los van de hoge kosten van de tehuizen - kosten die gezien de verslechterende economische situatie van Nederland een extra belasting betekenden. ${ }^{17}$ Maar nog vóór dat de 7\%-norm in 1977 formeel door de Tweede Kamer bekrachtigd werd, was de regel al verscherpt. In 1976 bepaalde het kabinet-Den Uyl dat zelfs provincies waar de $7 \%$ nog niet was gehaald geen toestemming meer kregen tot nieuw- of verbouw van tehuizen. En via een 'inleveringsbeleid' werden de 'overbezette' regio's aangepakt: bij renovatie van een tehuis in een dergelijke regio moest een deel van de capaciteit van dat tehuis worden opgeheven. ${ }^{178}$ Zoals tabel 2 laat zien, steeg die capaciteit na 1977 dan ook niet of nauwelijks meer.

Tegelijkertijd had de overheid nieuwe taken voor de bejaar- 
denoorden in petto. $\mathrm{Al}$ jaren verleenden veel bejaardenoorden aan zelfstandig wonende bejaarden diensten als maaltijden, tijdelijke opname in de ziekenboeg en bewaking via alarmsystemen. In de nota Bouwstenen voor een ouderenbeleid van 1982 werd aanbevolen deze 'wijkfunctie' te verbreden. Diensten als kortdurende opname, dag- of nachtopvang en sociaal-culturele activiteiten konden, zo was de gedachte binnen de ouderenzorg, ervoor zorgen dat ouderen langer zelfstandig functioneerden en op die manier een kostenbesparing opleveren. Tegelijkertijd kon deze transmurale dienstverlening ertoe bijdragen dat ouderen een reeel beeld van het tehuis ontwikkelden. Bovendien hielden de verzorgingstehuizen zo een levendiger klimaat. ${ }^{179}$

Zo werd alsnog een dijkdoorbraak bewerkstelligd - die tussen de bewoners van het tehuis en de 'wijkbejaarden' - iets wat overigens niet zonder een debat over de privacy van de tehuisbewoners verliep. Die privacy stond overigens ook op een andere manier ter discussie. De strakke planning van het aantal bejaardenoorden en het stringenter opname-beleid in de jaren zeventig deden de bevolking van de tehuizen veranderen. De verzorgingsbehoefte van de vaak hoogbejaarden nam sterk toe en stelde nieuwe eisen aan het personeel. ${ }^{1{ }^{8} \mathrm{O}}$ Met het oog op die ontwikkeling werd vanaf het eind van de jaren zestig door verschillende instanties, waaronder de Contactcommissie van de Landelijke Organisaties van Bejaardentehuizen, voorgesteld om meer-persoons-slaapkamers en dagverblijven voor groepsverzorging te bouwen. Maar de Centrale Commissie voor de Bejaardenoorden en de Interdepartementale Stuurgroep Bejaardenbeleid waren daarover weinig enthousiast. Groepsverzorging mocht, gezien de aantasting van de privacy en onafhankelijkheid, slechts een laatste redmiddel zijn. Er hoorden dan ook geen blijvende ruimten en aparte afdelingen voor te worden ingericht; accomodaties moesten weer gemakkelijk omgebouwd kunnen worden tot gewone kamers. In die geest werden de Voorschriften en Wenken gewijzigd. Slechts de 'mogelijkheid' werd geopend een aantal bij elkaar gelegen wooneenheden samen te voegen voor bejaarden die uitgebreidere persoonlijke verzorging nodig hadden. ${ }^{\text {'st }}$ Hoe logisch groepsverzorging gezien het nieuwe type te- 
huisbewoner ook leek, zij paste niet vanzelfsprekend in de plattegrond van het verzorgingshuis, waarin vanaf de jaren twintig de eigen kamer als paradepaardje had gefigureerd.

\section{Slot}

Sanjib Datta Chowdhury, de antropoloog uit India, veronderstelde dat de Nederlandse verzorgingshuizen ontworpen waren voor verhoudingsgewijs gezonde ouderen die binnen de beschermende muren van het tehuis een leven zouden moeten leiden dat zoveel mogelijk het 'normale' leven spiegelde. Hij had ten dele gelijk. In de wereld van degenen die zich na de oorlog over de bejaardenhuisvesting bogen, circuleerden verschillende concepten voor het tehuis, waarbij voor velen meer dan één optie acceptabel was. In die concepten ging het steeds om de verhouding - en daarmee de grenzen - tussen private en publieke ruimten. Niettemin vielen de mogelijkheden op papier in twee groepen uiteen: die waarbij de nadruk lag op het tehuis als gemeenschap en die waarin het accent lag op het tehuis als verzameling van individuele bewoners.

In het eerste geval stonden, expliciet of impliciet, het 'gezin' of het 'dorp' model voor het ideale tehuis; in het tweede geval het 'hotel' of de 'voorstad'. Bij het tehuis-als-gezin werd gedacht aan een klein tehuis waarin gezamenlijk aan tafel werd gegaan, de recreatiezaal het karakter van een huiskamer had en iedereen elkaar kende. Aan de andere kant van het spectrum stond het grote tehuis waarin de bewoners op hun kamers leefden als in een gewone woning met enige service en bijgevolg hun maaltijd op de kamer gebruikten, hun eigen huisarts kozen, de wijkverpleegster lieten komen als dat nodig was, bij ernstige ziekte in het ziekenhuis werden opgenomen en hun eigen kerk bezochten. In de praktijk werden echter, vooral in de jaren zestig, tehuizen gebouwd die zowel elementen van het 'hotel' als het 'dorp' in zich hadden. In deze tehuizen werd de keuzevrijheid van het hotel - naar eigen believen gezelligheid zoeken en banden met andere bewoners aangaan, naar keuze op de eigen kamer of in de eetzaal eten - gecombineerd 
met de overzichtelijkheid, vertrouwdheid en knusheid van het dorp: de zitjes, het winkeltje en ziekenzaal boden de bejaarden een 'thuis' tot de dood hen haalde. Juist deze vermenging van modellen en uitgangspunten, gecombineerd met de economie van de exploitatie en de demografie van het land, maakte het Nederlandse tehuis tot wat het was. Wat Chowdhury wegliet, was de preoccupatie met gezelligheid, huiselijkheid en verzorging in een vertrouwde omgeving - niet alleen op het niveau van de bewoners, maar ook op dat van de bouwers.

De toenemende institutionalisering van ouderen in de negentiende en twintigste eeuw is vaak geïnterpreteerd als een teken van de 'standaardisering' en 'verafhankelijking' van de ouderdom. Daarbij is de standaardisering, zo kwam in het eerste hoofdstuk ter sprake, ondermeer als een functie van de rationalisering van moderne naties beschreven, en de verafhankelijking als een functie van de kapitalistische economieën van het Westen. De institutionalisering van ouderen is - door historici - bovendien in verband gebracht met demografische veranderingen, de woningnood en de nadruk op de zwakke constitutie van bejaarden. Maar al lijken een besef van de zwakte van ouderen en het bouwen van tehuizen vanzelfsprekend in elkaars verlengde te liggen, in de Nederlandse situatie kan met een verwijzing naar dat besef niet worden volstaan. De eerste tehuizen-nieuwe-stijl die in de jaren twintig werden gebouwd waren immers niet alleen bedoeld om ouderen die zich niet meer in hun oude woning konden handhaven een helpende hand in een aangename omgeving te bieden, maar ook om hen een zelfstandigheid en vrijheid toe te staan die in de oudeliedentehuizen ver te zoeken was. Bovendien werd met deze tehuizen niet in eerste instantie een standaardisering van de ouderdom ingezet, maar juist het tegenovergestelde. Weliswaar werd voor méér ouderen gezorgd, maar de pensiontehuizen van de jaren twintig en dertig onderstreepten het onderscheid tussen de standen. Pas in tweede instantie, toen parlement en regering het tehuis na de oorlog voor de massa der bejaarden - mede met de vergrijzing en de woningnood voor ogen - bereikbaar wilde maken, verdween dat specifieke onderscheid. 
Deze redenering zou er gemakkelijk toe kunnen leiden de ontwikkelingen rond tehuizen te omschrijven als een geschiedenis van de onbedoelde consequenties van 'goede' intenties. Hoewel de 'bouwers' een zelfstandig bestaan in gedachten hadden, ontstonden grote oorden waarin ouderen in afzondering en afhankelijkheid leefden. Toch is een dergelijke voorstelling van zaken evenmin juist. Wat van gedaante verwisselde, waren de ruimtelijke voorstellingen van 'zelfstandigheid', de symbolische verbindingen tussen de horizon van ouderen en de ruimtelijke orde van de tehuizen, en de opvattingen over de juiste bewoners van degenen die bij de bouw van de tehuizen betrokken waren. Net als Chowdhury voor de dagelijkse gang van zaken in een tehuis constateerde, bleken in de verbindingen tussen waarden en ruimten subtiele, maar belangrijke verschuivingen mogelijk. Dat alles leidde tot een perspectiefwisseling, waarin het tehuis niet langer een vanzelfsprekende huisvestingsvorm was.

Zelfstandigheid was ook in de jaren twintig en dertig een preoccupatie van degenen die zich met ouderen bezighielden. Maar in hun wereld ging het om de zelfstandigheid van ouderen uit de betere standen, verwees zelfstandigheid naar een zekere vrijheid van handelen, het behoud van een persoonlijke sfeer en het onaangetast laten van de 'individualiteit', en werd zelfstandigheid verzilverd in de vorm van een eigen ruimte. Die persoonlijke ruimte stond in een gunstig licht in vergelijking met de afwezigheid van een dergelijke ruimte bij 'inwoning' in een gewoon huis en opname in een traditioneel oudeliedentehuis. In de loop van de jaren vijftig kreeg zelfstandigheid een andere connotatie: financiële onafhankelijkheid en zelfverzorging kwamen centraler te staan en zelfstandigheid raakte in de context van de huisvesting steeds exclusiever verbonden met zelfstandige woonruimte. Bovendien werd het, mede met het oog op de kosten van de tehuizen, niet langer redelijk geacht dat tehuizen vooral valide bejaarden opnamen. Het tehuis moest de omgeving worden waar juist degenen die zich niet meer zelfstandig konden redden, een onderkomen konden vinden. Tegelijkertijd werd de vermeende horizon van ouderen ter discussie gesteld. $\mathrm{Al}$ in de jaren vijftig bestond zorg over de ligging van de tehuizen: contact met de 
omgeving diende gewaarborgd te worden. Maar die omgeving kreeg in de loop van de jaren zestig en zeventig een andere invulling. Niet alleen werd in de latere jaren gedoeld op integratie in het maatschappelijk leven als geheel, waar eerder aan integratie in de wijk en het familieleven was gedacht, maar het ging nu ook om meedoen in plaats van toekijken. Het 'gebied' van de bejaarde werd niet alleen weidser voorgesteld, er moest ook anders in 'bewogen' worden. Daarmee kreeg het tehuis een andere ideale plattegrond en inrichting. Bovendien leek de blik van een deel van de betrokkenen van richting te veranderen. $\mathrm{Z}_{\mathrm{ij}}$ keken niet meer over de schouder van de bejaarde mee 'naar buiten', maar zagen het tehuis als een terzijde liggende kolos in een ondeugdelijk maatschappelijk bestel. De grens tussen 'binnen' en 'buiten' het tehuis leek daarmee 'absoluter'.

Op dat moment, in de eerste helft van de jaren zeventig, was het overheidsbeleid ten aanzien van de tehuizen al dusdanig gewijzigd, dat het tehuis ook om die reden een ander karakter kreeg. De bouw werd vertraagd, de opneming aan criteria onderworpen en de bewoner veranderde van type. $\mathrm{Zijn}$ toenemende verzorgingsbehoefte deed de vraag ontstaan of de muren binnen het tehuis niet opnieuw verplaatst dienden te worden. Op de verzorging van zwaar hulpbehoevenden waren de tehuizen immers niet gebouwd. Maar aan die muren bleek het niet eenvoudig beitelen. Niet zozeer omdat hun stenen weerstand boden, maar omdat die muren in een lange traditie van privacy waren gefundeerd. 
Tabel 1: Het aantal in Nederlandse bejaardentehuizen/bejaardenoorden wonende personen van 65 jaar en ouder, uitgedrukt als percentage van de totale bevolking van 65 jaar en ouder in Nederland, $1950-86 / 89^{1}$

\begin{tabular}{lllllll} 
Jaar & $\%$ & Jaar & $\%$ & Jaar & $\%$ \\
\hline & & & & & & \\
1950 & $3,8^{2}$ & 1964 & $(6,2)$ & 1977 & 8,6 \\
1951 & $(3,9)^{3}$ & 1965 & $6,0^{4}$ & 1978 & 8,4 \\
1952 & $(4,1)$ & 1966 & 7,0 & 1979 & 8,2 \\
1953 & $(4,1)$ & 1967 & 7,0 & 1980 & 8,1 \\
1954 & $(4,2)$ & 1968 & 7,1 & 1981 & 7,9 \\
1955 & $(4,3)$ & 1969 & 7,3 & 1982 & 7,9 \\
1956 & $(4,5)$ & 1970 & 7,8 & 1983 & 7,8 \\
1957 & $(4,7)$ & 1971 & 8,2 & 1984 & 7,7 \\
1958 & $(4,9)$ & 1972 & 8,7 & 1985 & $8,0^{5}$ \\
1959 & $(5,1)$ & 1973 & 8,8 & 1986 & 8,0 \\
1960 & $(5,3)$ & 1974 & 8,7 & 1987 & 7,0 \\
1961 & $(5,4)$ & 1975 & 8,9 & 1988 & $\ldots$ \\
1962 & $(5,5)$ & 1976 & 8,8 & 1989 & $(6,9)^{6}$ \\
1963 & $(5,8)$ & & & & \\
\hline
\end{tabular}

1 Omdat bij het samenstellen van deze tabel gebruik moest worden gemaakt van verschillende statistieken en overzichten zijn de gegevens niet volledig vergelijkbaar. In de noten staat aangegeven op welke bronnen de gegevens zijn gebaseerd. De tussen haakjes geplaatste getallen betreffen gegevens die niet direct aan het Centraal Bureau voor de Statistiek (cas) zijn ontleend en die om verschillende redenen minder betrouwbaar worden geacht. Voor 1988 waren (nog) geen cijfers beschikbaar.

2 Bron: Verzorging van bejaarden in tehuizen naar de toestand op 1 October 1950. 's-Gravenhage: cas, 1951. In deze cBs-publikatie werden alleen gegevens opgenomen met betrekking tot de niet-winstbeogende huizen (toestand per 1 oktober 1950). 3 Bronnen: Jaarverslag van de Centrale Directie van Volkshuisvesting en Ruimtelijke Ordening 1968. ('s-Gravenhage): Centrale Directie van Volkshuisvesting en Ruimtelijke Ordening, [1969] en 1889-1989. Negentig jaren statistiek in tijdreeksen. 's-Gravenhage: sDu-uitgeverij/cBs-publikaties, 1989. De percentages over de jaren 1951-1964 betreffen schattingen aan de hand van de bovengenoemde bronnen. 4 Bron: Cas-Statistiek van de bejaardenoorden 1965-1987. 's-Gravenhage: Staatsuitgeverij/cBs, 1968-1990. De gegevens over 1965 waren nog niet volledig. Wanneer daarmee rekening zou zijn gehouden, zou het percentage op 7\% kunnen zijn gesteld. De cijfers (naar de toestand van 31 december) hebben betrekking op 'bejaardenoorden' (waartoe ook commerciêle tehuizen behoorden).

5 Vanaf 1985 inclusief kloosterbejaardenoorden.

6 cas-cijfers volgens Volkskrant-bericht dd. 7 augustus 1990.

Uit: Bijsterveld, K. De geschiedenis van het beleid met betrekking tot verzorgingshuizen in Nederland van 1945-1990. In: Handboek 'Wonen en werken in een verzorgingshuis'. Amersfoort: Academische Uitgeverij, 1991: (par. 1.3) I-31 (pp. 25-26) 
Tabel 2: Aantal, capaciteit, bewoners, personeel en indexcijfers (van) bejaardentehuizen/bejaardenoorden 1950, 1965-1985 ${ }^{1}$

\begin{tabular}{|c|c|c|c|c|c|c|c|c|}
\hline \multirow[t]{2}{*}{ Jaar } & \multicolumn{2}{|c|}{$\begin{array}{l}\text { Bejaardentehuizen/ } \\
\text { bejaardenoorden }\end{array}$} & \multicolumn{2}{|c|}{ Capaciteir $^{2}$} & \multicolumn{2}{|c|}{ Bewoners } & \multicolumn{2}{|c|}{ Personeel $^{3}$} \\
\hline & abs. & $1980=100$ & abs. & $1980=100$ & $a b s$. & $1980=100$ & abs. 198 & $=100$ \\
\hline 1950 & 812 & (52) & 38235 & (26) & 36274 & (27) & 9195 & (19) \\
\hline 1965 & 1528 & 99 & 78188 & 54 & 73344 & 54 & 20737 & 43 \\
\hline 1966 & 1782 & 115 & 93112 & 64 & 84899 & 63 & 25011 & 52 \\
\hline 1967 & 1852 & 120 & 99995 & 69 & 91713 & 68 & 27239 & 57 \\
\hline 1968 & 1863 & 120 & 103928 & 72 & 95429 & 71 & 28226 & 59 \\
\hline 1969 & 1878 & 121 & 108543 & 75 & 100350 & 74 & 30187 & 63 \\
\hline 1970 & 1880 & 122 & 117901 & 81 & 108875 & 81 & 32781 & 69 \\
\hline 1971 & 1865 & 121 & 124588 & 86 & 115083 & 85 & 34985 & 73 \\
\hline 1972 & 1858 & 120 & 134652 & 93 & 124533 & 92 & 38905 & 81 \\
\hline 1973 & 1801 & 116 & 138277 & 95 & 129132 & 95 & 40547 & 85 \\
\hline 1974 & 1730 & 112 & 139020 & 96 & 129987 & 96 & 42880 & 90 \\
\hline 1975 & 1709 & 110 & 144383 & 100 & 134680 & 100 & 45277 & 95 \\
\hline 1976 & 1662 & 107 & 146281 & 101 & 136086 & 101 & 46385 & 97 \\
\hline 1977 & 1633 & 106 & 145997 & 101 & 136297 & 101 & 47074 & 99 \\
\hline 1978 & 1574 & 102 & 144323 & 100 & 134638 & 100 & 46972 & 98 \\
\hline 1979 & 1554 & 100 & 143869 & 99 & 134076 & 99 & 49402 & 103 \\
\hline 1980 & 1547 & 100 & 144798 & 100 & 135242 & 100 & 47778 & 100 \\
\hline 1981 & 1510 & 98 & 143782 & 99 & 133715 & 99 & 50772 & 106 \\
\hline 1982 & 1506 & 97 & 144428 & 100 & 134701 & 100 & 51752 & 108 \\
\hline 1983 & 1499 & 97 & 144624 & 100 & 134733 & 100 & 52183 & 109 \\
\hline 1984 & 1489 & 96 & 143697 & 99 & 133804 & 99 & 51779 & 108 \\
\hline $1985^{4}$ & 1575 & 102 & 148738 & 103 & 137527 & 102 & 52649 & 110 \\
\hline 1986 & 1567 & 101 & 147773 & 102 & 136440 & 101 & 53004 & 111 \\
\hline
\end{tabular}

1 Bronnen: Verzorging van bejaarden in tehuizen naar de toestand op I October 1950. 's-Gravenhage: cas, 1951; CBs-Statistiek van de bejaardenoorden 1986. 's-Gravenhage: sDu-uitgeverij/cas-publikaties, 1989. Zie voor commentaar op deze bronnen tabel 1.

2 Aantal verzorgingsplaatsen + ziekenbedden + bedden in niet-erkende verpleegafdelingen.

3 Omgerekend tot hele formatieplaatsen.

4 Vanaf 1985 inclusief kloosterbejaardenoorden.

Uit: Bijsterveld, K. De geschiedenis van het beleid met betrekking tot verzorgingshuizen in Nederland van 1945-1990. In: Handboek 'Wonen en werken in een verzorgingshuis'. Amersfoort: Academische Uitgeverij, 1991: (par. 1.3) 1-31 (p. 26) 


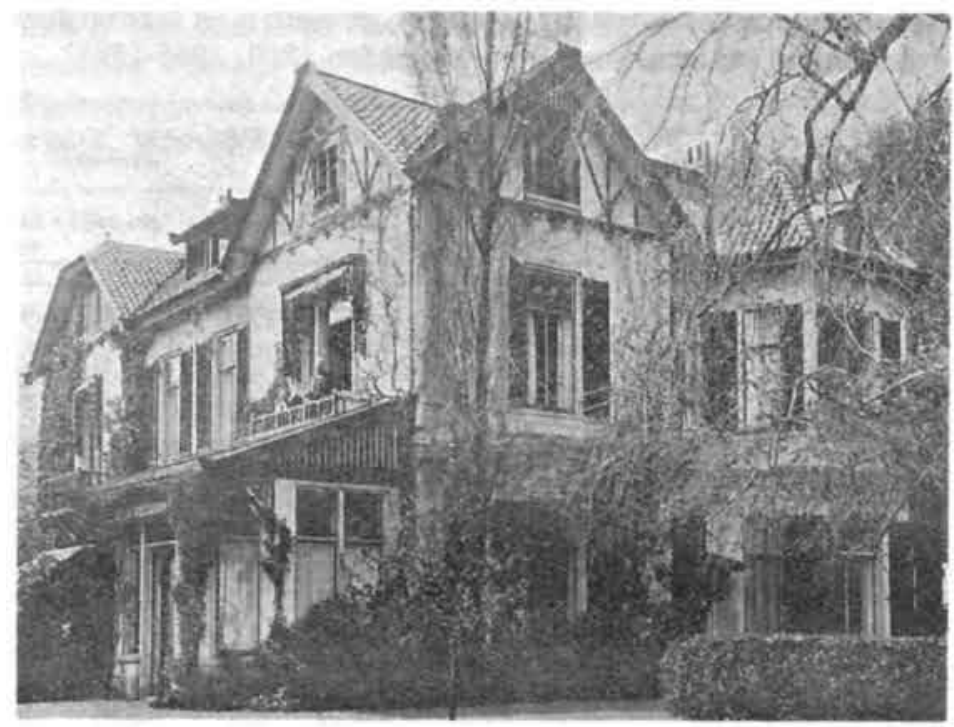

I Berghof van Pro Senectute. Uit: De Vereeniging 'Pro Senectute' (Voor den Ouderdom). TAMK 4 (1925) 87, 612-615 (p. 613) 


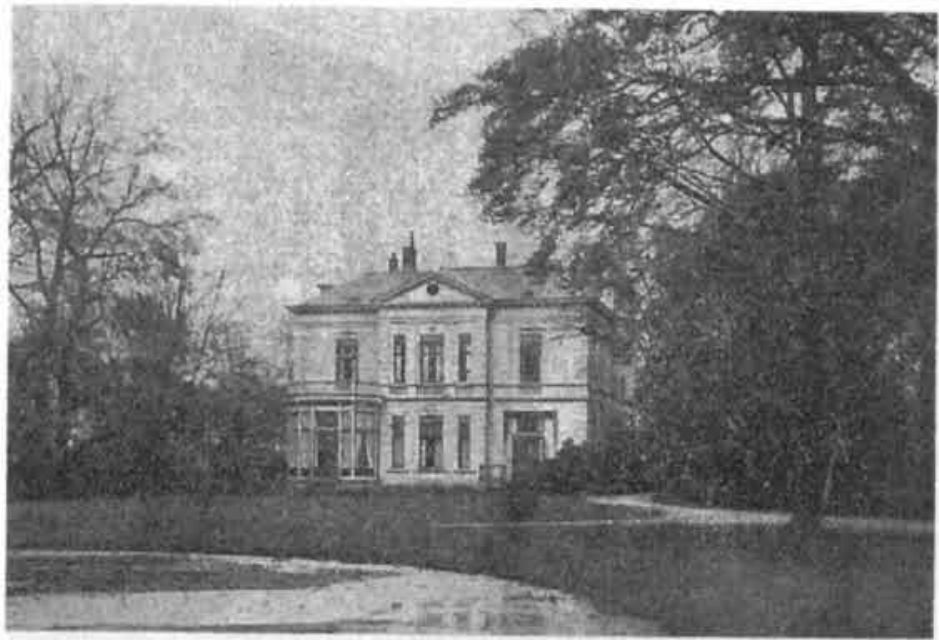

2 'Huize Westhoff' van 'Ons Thuis', Uit: Rooseboom, M.P. 'Ons Thuis'. TAMK 7 (1928) 164, 1829-1832 (p. 1831) 


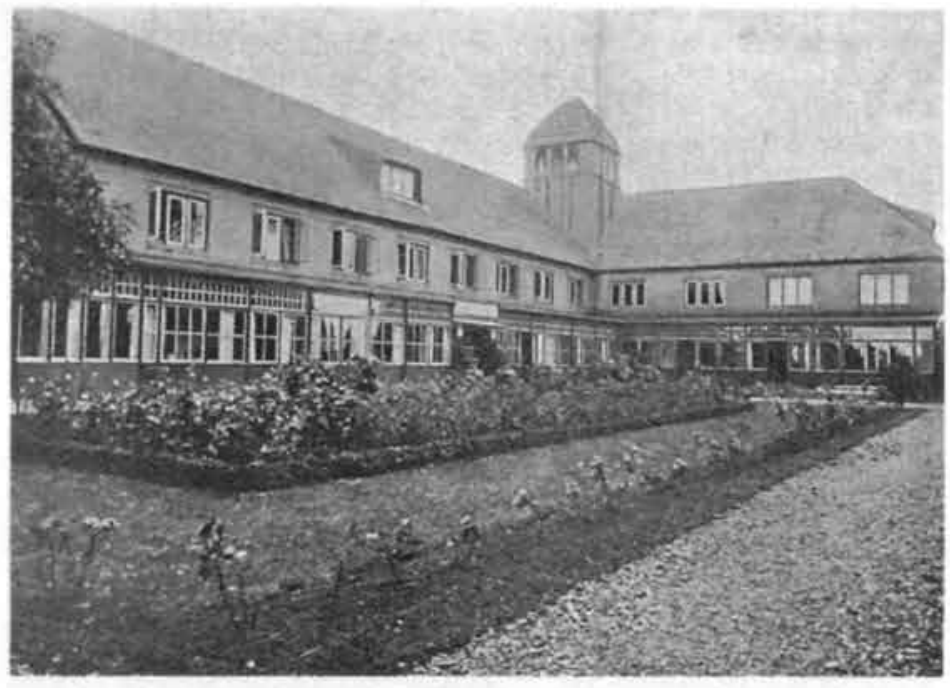

3 'Vredeheim' te Rockanje. Uit: [Adriani], J.H. De Stichting

'Vredeheim' te Rockanje. TAMK 4 (r925) 88, 63 I-634 (p. 632) 


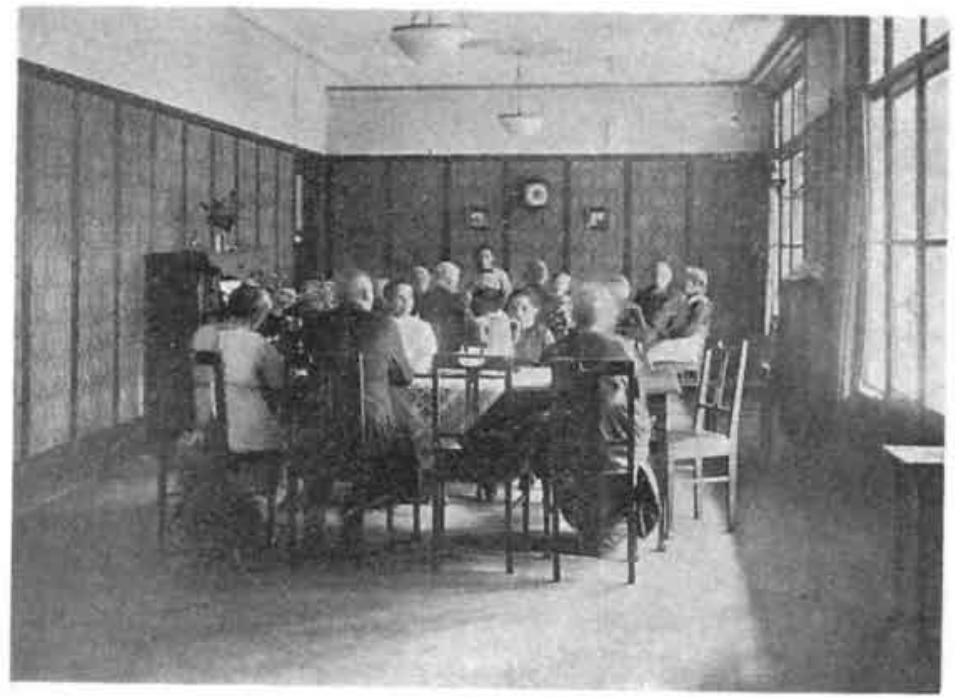

De cetzaal van .Vredeheim“ te Rockanje

4 Uit: Adriani (1925) op. cit. p. 634 


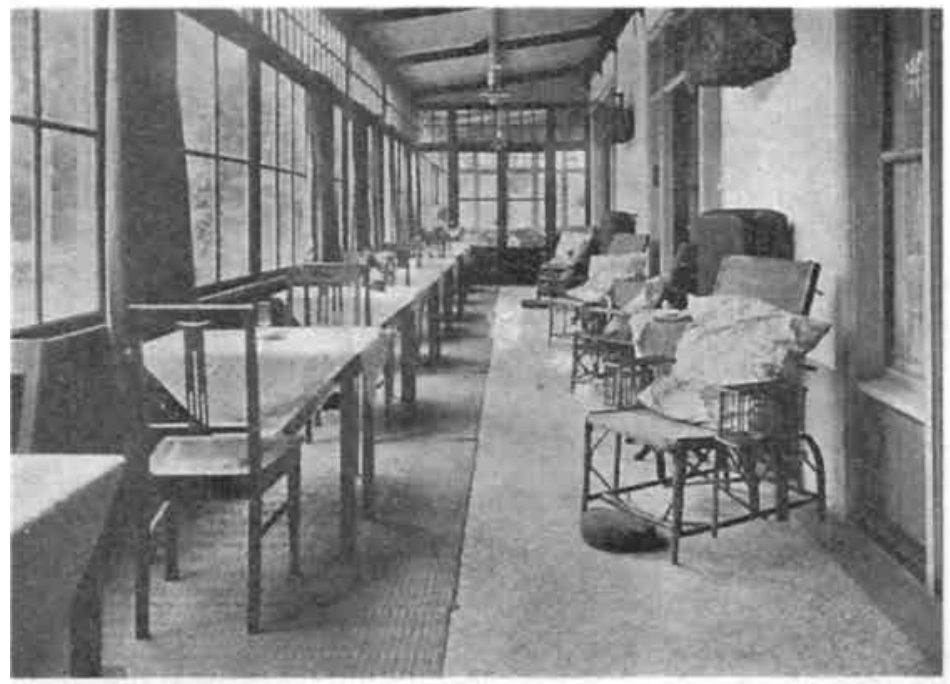

De serre van „.Vredeheim" te Rockanje

5 Uit: Adriani (1925) op. cit. p. 633 


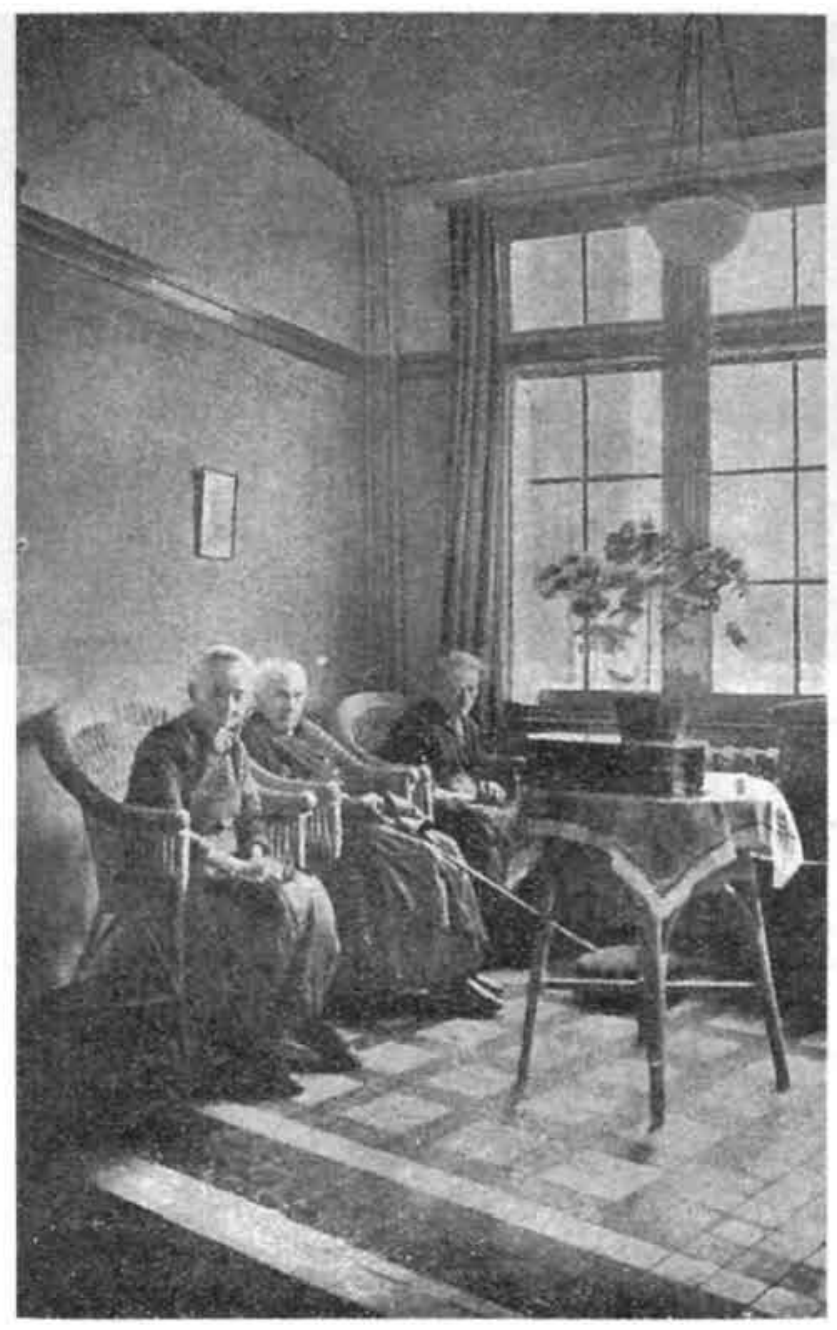

EEN GEZELLIG ZITJE.

6 Uit: Welling, J. Het protestantsch tehuis 'Levensavond', Nijmegen. TAMK 6 (1927) 125, 1205-1207 (p. 1207) 


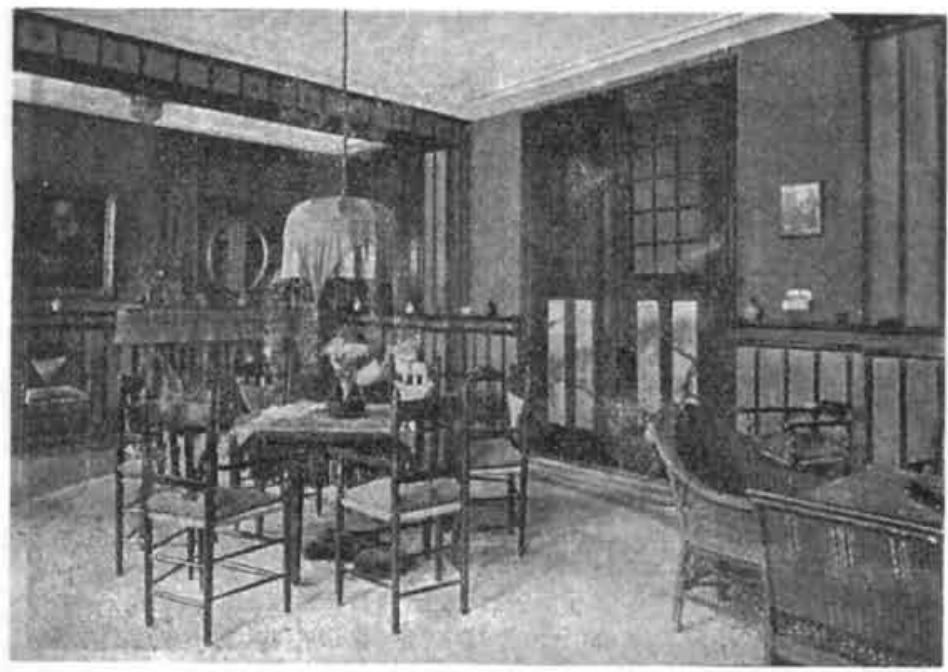

CONVERSATIEZAAL IN ,HUIZE ROYAL"

7 Uit: Rooseboom (1928) op. cit. p. 1830 

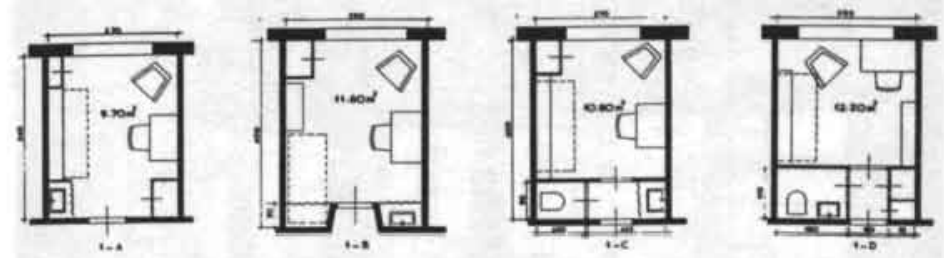

TWEEPERSOONSKAMERS
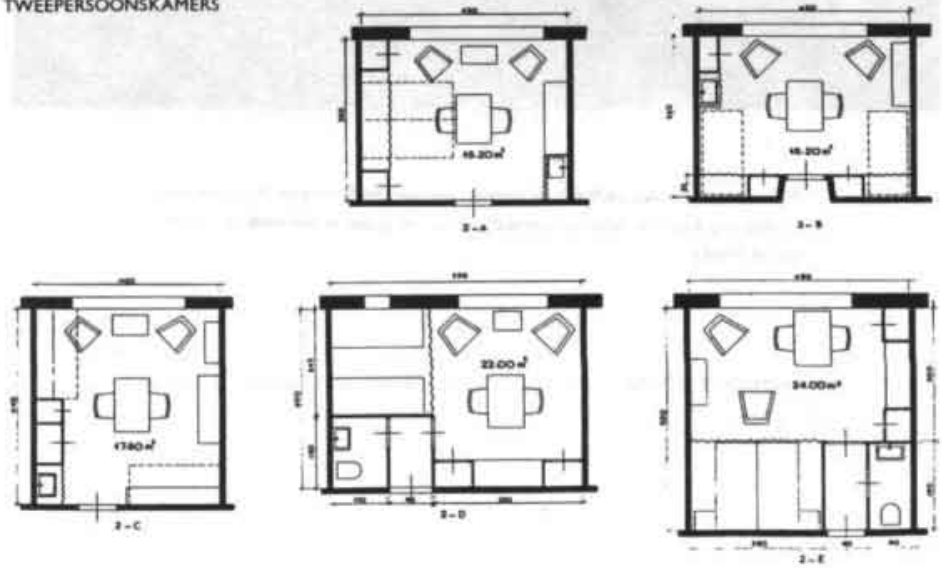

8 Uit: Huisvesting voor bejaarden. Richtijnen voor de bouw en de exploitatic van zelfstandige woningen en pensiontehuizen. Rotterdam: Bouwcentrum, 1953. Gepubliceerd in Bouw 8 (1953) 17,301-320(p.315) 


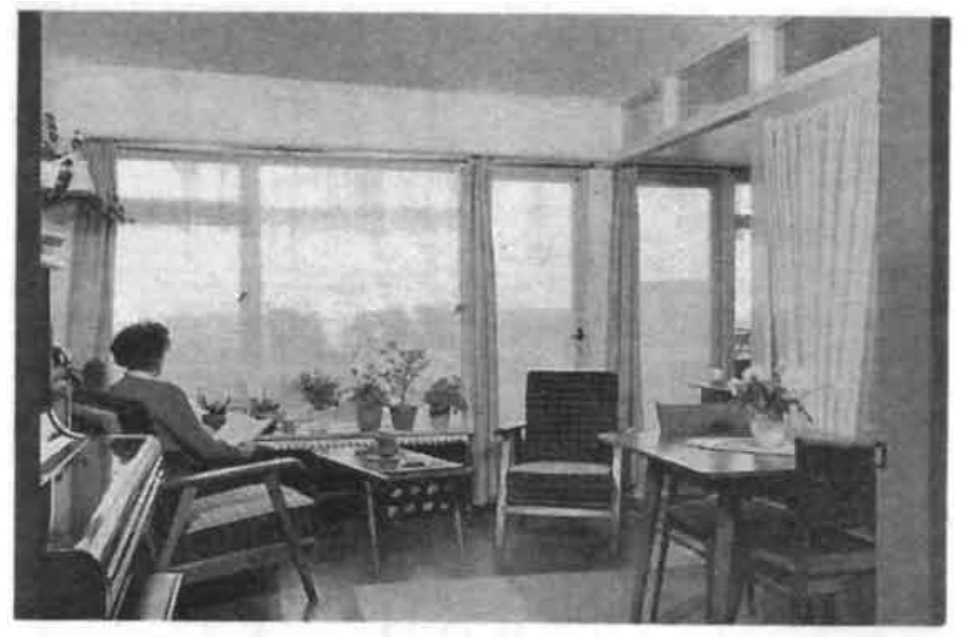

Woonkamer wan en individuele woning van het smallen type: bij intelligente meubilering kan ecn zithock, ecn eethoek en een piano in het vertrekje worden ondencebradu.

9 Bejardencentrum Vlaardingen. Boutw 10 (1955) 1049-1053

(p. 1050$)$ 

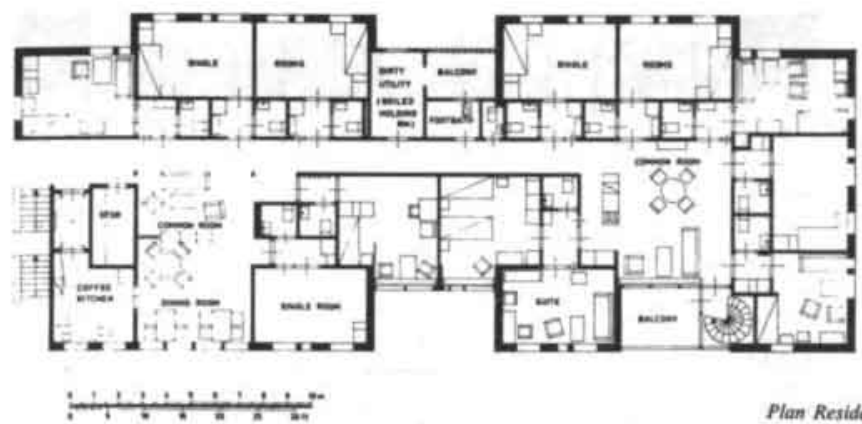

Plan Residence Unit

10 Bejaardentehuis Norrkőping, Zweden: plattegrond begane grond. Uit: Beyer, G.H. en Nierstrasz, F.H.J. Housing the Aged in Westem Countries. Prognams, Duellings, Homes and Geriatric Facilities. Amsterdam [etc.]: Elsevier, 1967 (p. 123) 


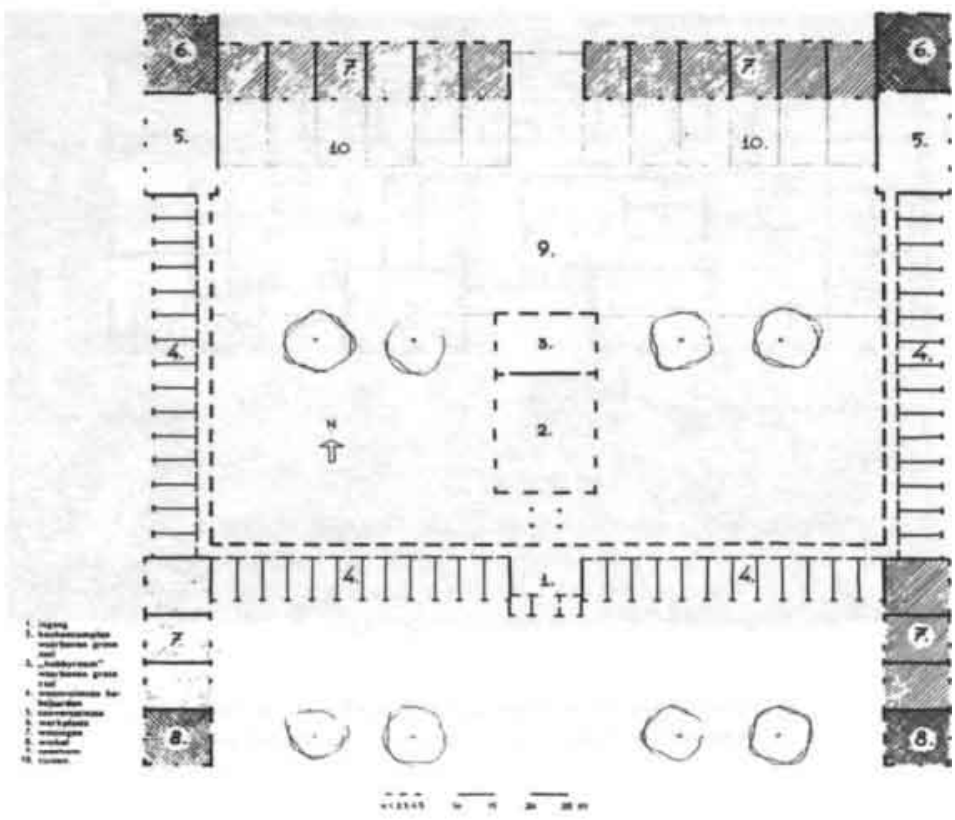

i1 Het ontwerp van Feenstra. Uit: Lezers schrijven ons. 'Geef bejaardentehuis meer contact met buitenwereld'. Boun I $_{4}$ (1959) 17,471 


\section{6 \\ De dynamiek van grenzen}

\section{Inleiding}

Toen H.J.A. Hofland in 1982 zijn toekomstvisie op de positie van ouderen in het jaar 2000 gaf - een visie waarmee dit boek opende - karakteriseerde hij die positie, zo was de interpretatie, door grenzen te trekken. Tegelijkertijd gaf hij aan welk onderscheid het meeste gewicht had. Het criterium voor bejaard-zijn lag bij vijftig jaar, het moment waarop mensen 'arbeidsvrij' werden gemaakt. Die 'arbeidsvrijheid' en de daaraan gekoppelde, verplichte onderwerping aan de Gerontopol van uitkeringen en huisvestingsvoorzieningen behoorde tot de kern van de ouderdomsproblematiek. In de toekomst zouden ouderen echter niet meer braaf naar de pijpen van de gerontologische diensten dansen. In Hoflands schets van de gebeurtenissen op 3 januari 2000 overschreden ouderen de grens van wat voor hen 'normaal' gedrag werd geacht: zij gedroegen zich ongekend brutaal en verrassend onbeheerst door tijdens een demonstratie in Amsterdam een rel uit te lokken. Niettemin zou deze grensoverschrijding de werkelijke machtsverhoudingen - de grens tussen de onvrijheid van de ouderen en de vrijheid van de jongeren - niet wezenlijk aantasten.

Hofland was in staat een hiërarchie van grenzen aan te brengen, omdat hem duidelijk voor ogen stond wat de kern van het ouderenprobleem was. Deze kern lag in het verschijnsel dat ouderen het recht op arbeid werd ontzegd, terwijl jongeren mochten werken. Aan dat onderscheid waren de bijzondere voorzieningen voor ouderen gekoppeld. De essentie van het ouderenprobleem legde bovendien vast welke toekomstige grensoverschrijdingen of -verschuivingen er wel of niet toe deden. Slechts 
een omwenteling in het systeem van de 'arbeidsvrijheid', zo was de impliciete boodschap, zou het bestaan van ouderen werkelijk veranderen. De overschrijding van de grens tussen normaal en abnormaal gedrag kon dit niet bewerkstelligen: dat nieuwe verschijnsel zou de machtsverhoudingen tussen ouderen en anderen niet in beweging brengen.

Dat de grenzen aan de hand waarvan de ouderdom wordt afgebakend in een bepaalde verhouding tot elkaar staan, is ook de suggestie die uitgaat van de structuur van de vele congressen en rapporten die aan ouderen zijn gewijd. Aan lezingen en hoofdstukken over de pensionering of de huisvesting van ouderen gingen en gaan veelal inleidingen over het 'bejaardenvraagstuk' of 'de vergrijzingsproblematiek' vooraf. Daarin worden zaken als de positie van ouderen, hun aantal en de problematiek die daarmee samenhangt in algemene zin gepresenteerd. Op het eerste gezicht is dat logisch. Het omlijnen van het bejaarden- of vergrijzingsprobleem lijkt immers een groter domein te beslaan dan het afbakenen van een sociale categorie of het ruimtelijk bijeenbrengen van degenen waarvoor gezorgd moet worden. Aangezien de grenzen van het vergrijzingsprobleem de indruk maken het 'geheel' te vormen, waarvan de grenzen van een sociale categorie of object van zorg 'delen' zijn, liggen de laatstgenoemde grenzen als het ware in het verlengde van de eerste grens. Uit het profiel van het probleem, zo suggereert de gebruikelijke opbouw van rapporten en congressen, vloeien de overige 'grenzen rond de ouderdom' voort.

Dit hoofdstuk zet hier een vraagteken bij. Uit een bepaalde typering van de problematiek rond ouderen kunnen zeker andere grenzen voortvloeien. Maar die grenzen kennen vaak een $d y$ namiek die het oorspronkelijke probleemprofiel overstijgt. In de voorafgaande hoofdstukken werd duidelijk dat de grenzen van de ouderdom als publiek probleem, sociale categorie, levensfase en ruimtelijk gesitueerd object van zorg ieder een eigen geschiedenis hebben. Juist het begrip 'grenzen' maakte het mogelijk om deze uiteenlopende kwesties op eenzelfde manier te bestuderen en te laten zien dat de geschiedenis van de ouderdom niet zondermeer in termen van een toenemende standaardisering en ver- 
afhankelijking van de ouderdom kan worden beschreven. Onder de grenzen die werden opgeworpen waren er zowel die verschoven, verdwenen, als verankerden. Bovendien, zo zal hieronder duidelijk worden, riepen grenzen nieuwe problemen en daarmee nieuwe grenzen op of deden zij oude grenzen vervagen.

Deze dynamiek van grenzen zal worden geillustreerd aan de hand van een nieuw voorbeeld: de geschiedenis van de voorbereiding op de pensionering (paragraaf 2). Vervolgens zullen de oorspronkelijke vragen naar het ontstaan en de betekenis van grenzen nogmaals worden gesteld, om zo-mede aan de hand van de voorafgaande hoofdstukken - de oogst van de aanpak binnen deze studie te kunnen bepalen (paragraaf 3 ). Dat mondt uit in een pleidooi voor een bepaalde heuristiek voor het doen van onderzoek naar de geschiedenis van de ouderdom. Die heuristiek is een alternatief voor de bestaande geschiedschrijving over 'de maatschappelijke definitie van de ouderdom'. Tot slot wordt (in paragraaf 4 ) beargumenteerd waarom juist deze studie duidelijk maakt dat de geschiedenis van de ouderdom niet als een kwestie van leeftijd kan worden afgedaan.

2 Een grens gepasseerd: voorbereiding op de pensionering'

Een slagboom in het bestaan

In de jaren vijftig was de pensionering in de ogen van veel artsen eerder een gevaar dan een goede zaak voor bejaarden. Groen rekende de pensionering tot de 'psychische traumata' die bij bejaarden, met hun verminderd aanpassingsvermogen, tot lichamelijke en geestelijke klachten konden leiden. ${ }^{2}$ Volgens G.C.E. Burger gaf de plotselinge overgang van regelmatige arbeid tot een leven van niets doen "een psychische druk, die zich al gauw in een gebrek aan vitaliteit manifesteert en zodoende duidelijk invloed heeft op geestelijk en lichamelijk welbevinden. Hier is de uitspraak van de volksmond, waarin gezegd wordt, dat een pensionnering vaak het begin van het einde is, zeker niet helemaal mis., ${ }^{3}$ Van Zonneveld had hier zijn twijfels over. Hem scheen het statistisch niet bewezen dat gedwongen pensionering 
leidde tot eventuele lichamelijke en geestelijke achteruitgang en zelfs een vroegere dood. Toch zag ook hij problemen. Vele ouden van dagen zouden zich na hun pensioen goed kunnen redden. '[G]root blijft echter de massa, die al direct of na enige tijd niet weet, wat met haar dagen aan te vangen." En dat terwijl nietsdoen voor de meeste bejaarden, zo meenden artsen, mede met het oog op 'inactiviteitsatrofie' bijzonder ongunstig was."

Artsen als Groen, Burger en Van Zonneveld doelden niet steeds op dezelfde problemen. Wanneer zij en andere deskundigen hun zorg over de pensionering uitspraken, had die zorg doorgaans betrekking op twee verschillende kwesties. De eerste kwestie betrof het abrupte, allesomvattende en algemene karakter van de pensionering. De pensionering kwam van de ene op de andere dag, maakte een einde aan het hele werkende bestaan en trof 'iedereen' - waaronder doorgaans 'mannen' werden verstaan - op dezelfde leeftijd. De juistheid van die laatste regel, zo kwam in het tweede hoofdstuk al aan de orde, werd door velen betwijfeld. Een dergelijke uniformiteit hield geen rekening met de grote verschillen tussen ouderen onderling, noch met de geleidelijkheid van het ouder worden zelf, noch met de vermeende vitaliteit van ouderen of de economische voordelen van hun produktiviteit. Van de jaren vijftig tot de jaren tachtig werd dan ook met de regelmaat van de klok voorgesteld om uitzonderingen en alternatieven als flexibele en geleidelijke pensionering mogelijk te maken. ${ }^{6}$ Ook de nadelen van dergelijke regelingen werden besproken. Het langer aanblijven van ouderen betekende, vooral in tijden van werkloosheid, minder kans op werk en promotie van jongeren. Bovendien konden keuzevrijheid en medische keuringen, zo schreven deskundigen, psychisch belastend zijn. Het viel mensen nu eenmaal niet gemakkelijk te erkennen dat zij niet meer tot een behoorlijke prestatie in staat waren. ${ }^{7}$ Niettemin bleven flexibele en geleidelijke pensionering veelvuldig geopperde regelingen in de naoorlogse literatuur over ouderen.

Deze opties werden geen economische en politieke werkelijkheid. Weliswaar werd flexibele pensionering binnen een enkel bedrijf mogelijk en ontstond in de loop der tijd aandacht voor 
de problematiek van de oudere werknemers. Maar flexibele en geleidelijke pensionering werden niet in wettelijke regelingen vastgelegd, althans niet in de bestudeerde periode. ${ }^{8} \mathrm{Op}$ de achtergronden daarvan zal niet worden ingegaan. Hier gaat het vooral om de verwikkelingen rond de tweede kwestie waarover ouderdomsdeskundigen zich zorgen maakten: de inhoud van het gepensioneerde bestaan. Velen beschreven in de jaren vijftig en zestig de grote veranderingen waarmee een nieuw gepensioneerde in zijn dagelijks leven werd geconfronteerd: de achteruitgang in het inkomen, het ontbreken van een strak dagritme, de confrontatie met de echtgenote, het gevoel van overbodigheid, en het verlies van sociale contacten, bezigheden en status. In boeken en artikelen voor vakgenoten en het grote publiek, ruimden artsen, psychologen, sociologen en mensen uit het maatschappelijk werk een groot aantal bladzijden in voor de behandeling van deze 'heilloze leegte' in het bestaan van gepensioneerden en de problemen van aanpassing die daarmee gepaard gingen."

Sociologen en mensen uit de wereld van het maatschappelijk werk zagen in dit type problematiek, zo werd in het tweede hoofdstuk besproken, de kern van het bejaardenvraagstuk. In hun betogen figureerde de pensionering als treurig element in een al even zwaarmoedig beeld van de maatschappelijke positie van bejaarden. De overgang van een agrarische, statische samenleving naar een dynamische stedelijk-industriële maatschappij was naar hun mening samengegaan met een afnemend gezag en toenemend isolement van bejaarden. De uit drie generaties opgebouwde familie was vervangen door het kleine gezin, waarin geen plaats meer was voor grootouders. Bood de boerderij, ook voor oude mensen, nog allerlei soorten arbeid, in moderne industrieën heerste uniformiteit in werksoort- en tempo en waren traditie en ervaring minder relevant. "[D]e inkrimping van de rol der bejaarden in onze tijd', stelde J.M.G. Thurlings, 'bestaat hierin dat zij normaliter geen functie meer te vervullen hebben in het sociaal systeem - noch waar dit de arbeidswereld, noch waar dit de gezinswereld betreft. Hun rol wordt ingeperkt tot die van de stille, teruggetrokken wachter op de dood. ${ }^{10}$ R.A. de Moor ver- 
wachtte dat de pensionering in de toekomst uit kon groeien tot een nieuwe status met een positieve inhoud. Hij had echter de indruk dat in het huidige cultuurpatroon aan de pensionering nog geen heldere rollen verbonden waren. "In veel publikaties werd een verband verondersteld tussen deze rolloosheid van bejaarden en hun geestelijk en lichamelijk welzijn. ${ }^{13}$ De pensionering was lang niet iedereen noodlottig, meende Van Dam. 'Maar ons allen (...) zijn velen bekend aan wie het uitgerangeerd-zijn een enorme slag heeft toegebracht en hen gemaakt heeft tot cliënten van de maatschappelijke zorg. ${ }^{13}$ De slagboom tussen het werkende en rustende bestaan kon, zo schreef een ander, 'fatale' gevolgen hebben. ${ }^{14}$

Bij praktisch iedereen die zijn of haar licht over ouderen liet schijnen, stonden vervangende activiteiten en contacten - een nuttige tijdsbesteding - hoog genoteerd als mogelijk antwoord op het problematisch bestaan van bejaarden in het algemeen en het pensioendrama in het bijzonder. Zo werden creatieve bezigheden, werkplaatsen en sociëteiten voor bejaarden, mits daar meer gebeurde dan klaverjassen alleen, bijzonder zinvol bevonden. 's Bovendien werd niet alleen de opvang ná de pensionering, maar ook een tijdige 'opvoeding tot de ouderdom' door velen noodzakelijk geacht. Wilde iemand tijdens zijn oude dag kunnen teren op 'geestelijke bagage' in de sfeer van liefhebberijen en belangstellingen, dan zou de verwerving daarvan tijdig moeten beginnen. ${ }^{\text {th }}$

De bejaarde moest de kans krijgen zijn plaats en taak in het leven te ontdekken, zo meende de psycholoogJ.M.A. Munnichs. ${ }^{17}$ In de Verenigde Staten zagen bepaalde bedrijven het als hun taak arbeiders tijdig voor te bereiden op de jaren na hun pensioen. Er werden gesprekken met aanstaande gepensioneerden georganiseerd om hen aan te sporen na te denken over hun pensioentijd en groepscursussen gegeven in 'de kunst van het oud worden'. Volgens Munnichsschonk deze laatste methode de beste mogelijkheden voor een adequate aanpassing. Het programma was erop gericht informatie te geven over de pensioen-periode, een positieve instelling te ontwikkelen ten opzichte van de ouderdom en de deelnemers aan te moedigen tot het maken van plannen voor hun 
vele vrije tijd. Het voornaamste doel was een bewuste confrontatie met de realiteit van de gepensioneerde staat. Op die manier zou de ouderdom misschien minder een schrikbeeld zijn. ${ }^{18}$ Want hoewel sommige mensen - aldus Munnichs - de kans moesten krijgen te blijven werken, ging het er vooral om bejaarden te leren dat pensionering 'normaal' was: een te grote nadruk op arbeid betekende een ontkenning van ziekte en dood. Naar zijn mening lag het probleem dan ook niet in de pensionering op zich, maar in het ontbreken van een levensplan daarna. ${ }^{19}$

Dat nam niet weg dat ook Munnichs de pensionering, zij het impliciet, als een slagboom tussen het werkende en het rustende bestaan beschouwde. Na die slagboom lag voor vele gepensioneerden een leegte. Die leegte vereiste invulling en aanpassing. Net als vele andere deskundigen meende hij dat de inmiddels massale passage van de grens tussen het arbeidsleven en het gepensioneerde leven een nieuw probleem opleverde: dat van de moeizame overgang naar een inhoudelijk 'lege' levensfase.

\section{Een overschat probleem?}

Enige jaren later kreeg Munnichs twijfel over de omvang van de aanpassingsproblematiek. In 1963 publiceerde hij een artikel onder de titel 'Pensionering, een overschat probleem?'. Daarin kon hij rapporteren over Angelsaksisch longitudinaal onderzoek naar deze kwestie. ${ }^{20}$ Hield het wegvallen van werk voor de meesten inderdaad in dat men zich nutteloos, waardeloos, uitgerangeerd en eenzaam ging voelen? Het onderzoek bevestigde dat niet. De betrokkenen hadden vaak een gunstige houding ten aanzien van de pensionering en driekwart kon zijn draai wél vinden. Voor zover de aanpassing mislukte was dat volgens een andere, Duitse studie te wijten aan geestelijke verstarring, onvolgroeidheid en een te sterke werkidentificatie. Ook Nederlandse publikaties van de jaren zestig en zeventig gaven - deels op basis van eigen sociaal-wetenschappelijk onderzoek, deels op grond van literatuuronderzoek - een minder dramatisch beeld van de pensionering dan voorheen. Al had ongeveer de helft van de onderzochte gepensioneerden aanpassingsproblemen, ${ }^{21}$ dit aanpassingsproces zou na ongeveer een jaar voltooid zijn. ${ }^{23}$ 
Toch vloeide deze omslag in het denken over de pensioneringsproblematiek niet alleen voort uit het beschikbaar komen van nieuwe onderzoeksresultaten. Voor enkele onderzoekers gold dat aan deze verandering ook een theoretische wending ten grondslag lag. G.P.A. Braam constateerde dat men in naoorlogse sociologische beschouwingen steeds was uitgegaan van een min of meer vanzelfsprekende relatie tussen de sociale positie van bejaarden - de 'uitstoting' uit het arbeidsproces - en hun persoonlijk welzijn. Maar Braam kon op basis van eigen empirisch onderzoek onder Utrechtse bejaarden niet hard maken dat pensionering inderdaad vrij algemeen ongunstige gevolgen had. De invloed van de pensionering was in ieder geval niet groter dan die van andere factoren. Braam bracht dit resultaat in verband met een nieuwe, door E. Cumming en anderen in de Verenigde Staten geïntroduceerde theorie over het oud worden. ${ }^{23}$ Deze zogenaamde 'disengagement-theory', waaraan in hoofdstuk twee al even werd gerefereerd, had relatief veel aandacht voor individueel-psychologische factoren. Volgens Cumming en de zijnen was het niet alleen de maatschappij die bejaarden uit haar midden stootte, maar trokken bejaarden zich ook zelf, op eigen initiatief, uit sociale verbanden terug. Deze 'onvermijdelijke' terugtrekking ging gepaard met een verminderde emotionele betrokkenheid bij en een grotere psychologische afstand tot activiteiten en sociale relaties. ${ }^{24}$ Braam liet de uitstotingstheorie gedeeltelijk overeind: hij nam aan dat in de meldingen over bejaarden die door hun pensionering werden getroffen, een kern van waarheid zat. Hij veronderstelde dan ook dat bij een 'natuurlijke' ontwikkeling naar bejaard-zijn de tendens tot werken constant bleef en de tendens tot losmaking toenam. Op deze manier incorporeerde Braam de disengagement-theorie in oudere sociologische opvattingen - een aanpak die ook bij anderen voorkwam. ${ }^{25}$

Op zichzelf was het 'disengagement'-denken in Nederland niet helemaal nieuw. In de jaren vijftig werd in veel verhandelingen over de psyche van de oude mens - waarin een fenomenologische benadering overheerste - de ouderdom gekarakteriseerd als een periode van 'distantiëring', als een levensfase waarin afstand werd genomen. Dit kwam in het vijfde hoofdstuk al ter 
sprake. Maar al vormde de 'disengagement'-theorie in Nederland een minder grote breuk met het verleden dan in Amerika, aan de pensionering kon toch een andere betekenis gegeven worden. In de 'disengagement'-theorie werden de sociologische en de psychologische benadering onder één noemer gebracht. De theorie maakte het mogelijk de pensionering niet louter meer te zien als een van buitenaf opgelegde ingreep, maar ook als een gebeurtenis die op een haast natuurlijke manier bij het ouder worden hoorde, al gebruikte alleen Braam werkelijk de term 'natuurlijk'. Volgens Munnichs bereidde de distantiëring - die naar zijn mening samenging met een hernieuwd engagement ${ }^{26}-$ de 'uittrede uit het arbeidsveld' voor en hield het verschijnsel verband met de afname van de kracht van ouderen en hun confrontatie met 'eindigheid'. ${ }^{27}$ De fase van het oud worden en de ouderdom, zo zei hij, waren er blijkbaar niet voor een rusteloze activiteit, wel voor het uitwerken en afronden van een eenmaal ontwikkelde beroepslijn. Aan de latere levensfasen werd een andere opdracht aangereikt dan te moeten werken. 'Misschien is de pensionering, in onze tijd zo vaak verkeerd begrepen, daarvan een zeer gezonde uiting. ${ }^{28}$ Anderen noemden de gedwongen pensionering een "duidelijk moment in het "disengagement"proces' ${ }^{29}$ Pensionering werd in deze benadering dus niet meer uitsluitend geïnterpreteerd als een externe, door de samenleving opgelegde regel, maar als een gebeurtenis die ook vanuit de interne beleving van het ouder worden begrijpelijk was.

In de loop van de jaren zestig en zeventig ontmoette de 'disengagement'-theorie zowel in binnen- als buitenland veel kritiek, ondermeer door aanhangers van de 'activity'-theorie. Bovendien verschoof in het internationale debat de aandacht naar een nieuw type studie, waarin onderzoekers wat betreft het aanpassingsvermogen van ouderen een onderscheid maakten naar verschillende typen ouderen, verschillende adaptatie-fasen en verschillende 'coping-styles'. ${ }^{\circ}$ Niettemin bleef de relativering van de aanpassingsproblematiek overeind en verbond een deel van de onderzoekers aan die relativering consequenties voor de cursussen voorbereiding op de pensionering. Zo vond Munnichs dat deze cursussen, aangenomen 'dat de pensionering min- 
der desastreuze effecten' had dan veelal was verondersteld, zich voortaan moesten richten op praktische en concrete informatie over zaken als het inkomen. ${ }^{31}$ Anderen waarschuwden tegen de problematiserende kant van de cursussen. ${ }^{32}$ En Braam vroeg zich zelfs af of de voorbereiding niet op een 'schijnfenomeen' gericht was. Hij zag de pensionering dan ook liever als een aanknopingspunt voor de voorbereiding op de ouderdom dan als een 'plotseling inwerkende gebeurtenis'. ${ }^{33}$

Noch Braam, noch Munnichs of anderen gingen zo ver het bestaan van pensioneringsproblemen volledig te ontkennen. Dat de aanpassingsproblemen overschat waren, stond echter voor hen vast en werd door anderen bevestigd ${ }^{34}$ Nog steeds waren er auteurs die veronderstelden dat vele pas gepensioneerden in moeilijkheden waren. ${ }^{35}$ Maar 'het trauma van de pensionering', in de jaren vijftig nog breed onderschreven, raakte in de jaren zestig en zeventig omstreden. Zo leidde de bestudering van het probleem dat volgens deskundigen door een grens - de overgang van werken naar gepensioneerd-zijn - was opgeroepen, tot een nieuwe grens. Voortaan werd een onderscheid gemaakt tussen mensen die zich zonder veel problemen aan de pensionering aanpasten, en de ex-werknemers die niet aan hun pensionering konden wennen.

\section{Nieuwe grenzen - een oude voorziening}

Het zou in de loop der dingen hebben gelegen, wanneer de relativering van de pensioneringsproblematiek zou zijn gevolgd door een vermindering van de aandacht van ouderdomsdeskundigen voor de voorbereidingscursussen. Ook op andere gronden viel te verwachten dat het nut van dergelijke voorzieningen serieus ter discussie zou worden gesteld. Het trauma van de pensionering paste bij de opvatting dat de essentie van het bejaardenvraagstuk gezocht moest worden in de leegte van het bejaarde bestaan. Die leegte werd veroorzaakt door de overgang van een agrarische naar een stedelijk-industriële samenleving en kon opgevangen worden door de bejaarde te leren de leegte te vullen. Die typering, zo werd in het tweede hoofdstuk besproken, werd in de loop van de jaren zestig en zeventig 'weggedrukt' door een 
andere karakterisering. Daarin werd het normen- en waardenpatroon van Westerse maatschappijen als dé oorzaak van de moeilijke positie van bejaarden aangewezen en werd de oplossing in een herziening van dat collectieve patroon gezocht. Gezien die ontwikkeling zou het niet vreemd zijn geweest wanneer de-op opvoeding van de bejaarde gerichte - voorbereidingscursussen uit de gratie zouden zijn geraakt.

Dat gebeurde niet. De voorstellen voor een voorbereiding op de pensionering werden wel degelijk praktijk. Binnen die praktijk werd de relativering van de pensioneringsproblematiek niet volledig genegeerd. Maar die relativering kreeg nieuwe accenten: de schijnwerpers werden vooral gericht op de mensen die de confrontatie met het gepensioneerde bestaan niet aandurfden of aankonden. Bovendien werd de problematiek nieuw omschreven en de oplossing iets verlegd. Tijdens die herformulering verschoven de doelstelling en doelgroep van de cursussen zodanig, dat een oude praktijk op een nieuwe problematiek, en op een andere typering van het ouderenvraagstuk in het algemeen, werd 'aangesloten'. Daardoor verdween de oorspronkelijke grens - die tussen werkenden en gepensioneerden - uit zicht en doemden nieuwe grenzen op: die van de nieuwe sociale categorieën waarvoor de cursussen nodig werden geacht.

$\mathrm{Al}$ in 1958 werd in het vormingscentrum De Haaf in NoordHolland een cursus 'Met pensioen' gegeven. Daarin kregen ouderen voorlichting, hadden gesprekken met elkaar, maakten kennis met cultuur, en brachten een bezoek aan een bejaardencentrum. ${ }^{36}$ Bovendien raakte het vormingscentrum in de eerste helft van de jaren zestig op initiatief van Hoogovens betrokken bij de organisatie van enkele werkweken voor pas gepensioneerden. ${ }^{37}$ Omvangrijker werden echter de internaatscursussen die De Haaf vanaf 1967 op verzoek van de vormingswereld en in overleg met het bedrijfsleven ontwikkelde. Tijdens meerdaagse bijeenkomsten op het vormingscentrum werden aanstaande gepensioneerden en hun echtgenotes op de jaren na het pensioen voorbereid. De cursus zette de veranderingen die de gepensioneerde te wachten stonden op een rijtje en bood de gepensioneerde handvatten - een gezonde levensstijl, ideeën voor activi- 
teiten - om die veranderingen op te vangen. Dit type voorbereiding op de pensionering, dat later de naam 'Pensioen-in-zicht' kreeg, werd door andere vormingscentra overgenomen. In de eerste helft van de jaren zeventig volgde de oprichting van een landelijk samenwerkingsverband en breidde het cursuswerk zich, ook buiten het samenwerkingsverband, gestaag over het land uit. De totale omvang van de cursussen bleef bescheiden: in I975 namen ongeveer 2300 personen deel aan circa 100 cursussen. ${ }^{3 \mathrm{x}} \mathrm{Het}$ cursuswerk was niet de enige vorm van voorbereiding, maar de cursussen vormden zondermeer de kern van het voorbereidingswerk. ${ }^{39}$

In publikaties van de leidende figuren in het voorbereidingswerk, onder wie W. van Gelder en Th. Wehkamp, werd benadrukt dat de pensionering een diep in het persoonlijk leven ingrijpende gebeurtenis was. ${ }^{40}$ Toch kwamen zij hoogstwaarschijnlijk wel met de relativering van de pensioneringsproblematiek in aanraking. Zo was tijdens de eerste conferentie van mensen uit het voorbereidingswerk de psycholoog J.F.J. Janmaat aanwezig." Deze deskundige erkende dat de pensionering voor velen niet problematisch was en dat de problematiek in kwestie voor zover ze wel bestond - voor een belangrijk deel generatieen milieu-bepaald was. De bereidheid om na het 65 ste jaar te werken, nam namelijk af, wat zowel teruggevoerd kon worden op betere pensioenvoorzieningen en ervaring met vrije tijd, als op afkeer van de bestaande werksituatie. Dat betekende echter niet dat de overgang van werken naar niet-werken vanzelfsprekend was. Voorbereiding bleef nodig. Bovendien waren er volgens Janmaat aanwijzingen dat voorbereiding op de pensionering de tevredenheid met de pensionering gunstig kon beïnvloeden. $^{42}$

Binnen de Nederlandse Federatie voor Bejaardenzorg werden soortgelijke opvattingen verdedigd. Ook daar wist men dat de pensionering door een deel van de gerontologen als een overschat probleem werd gezien. Niettemin meenden de samenstellers van een nota over voorbereiding dat tijdige bezinning op de pensionering moeilijkheden kon voorkomen. Weliswaar, zo stond in een toelichting op een NFB-film over de financiële pro- 
blematiek na de pensionering, groeide 'een deel van de mensen als het ware op natuurlijke wijze naar hun pensionering toe'. ${ }^{3}$ Een flinke groep mensen had echter de neiging de kop in het zand te steken. En dat terwijl bekend was dat een reëel beeld van het gepensioneerde bestaan de aanpassing vergemakkelijkte.

Janmaat behoorde, samen met enkele mensen van de Nederlandse Federatie voor Bejaardenzorg, tot de organisatoren van een 'beraadsdag' in 1974 over de voorbereiding op de pensionering, waarvoor een breed scala aan betrokkenen - onder wie onderzoekers en vormingsleiders - werd uitgenodigd. Ook tijdens deze dag was de omvang van de pensioneringsproblematiek een belangrijk thema. '[F]ingeren wij zelf de hele problematiek rond de pensionering', zo was de vraag, 'of is zij reëel. En als ze dan bestaat, wat kunnen we er aan doen, hoe, en wie moeten dat doen?"4t De beantwoording van de eerste vraag verliep via een herformulering, in dit geval een verbreding, van het probleem. De realiteit van de problematiek lag namelijk, aldus het verslag van de beraadsdag, in het ouder worden in de Westerse samenleving - met haar gerichtheid op jeugd en vitaliteit - in het algemeen, alsook in veranderingen in het produktieproces als fusies, opheffingen, overplaatsingen en vervroegde pensionering. Ook het antwoord op de vraag wat er aan de problematiek te doen viel, lag in het verlengde van deze probleemverschuiving: éducation permanente. Volgens die gedachte zou de houding van allen, dus ook van jongeren, ten aanzien van de ouderdom veranderd dienen te worden. $\mathrm{Na}$ een discussie over behoudend 'incidenteel lapwerk' versus 'fundamentele maatschappij-kritiek' via 'éducation permanente', werd besloten dat het voortaan zowel moest gaan om voorbereiding op de pensionering, als om veranderingen in de arbeidssituatie en maatschappij-vernieuwing. Vakbonden, politieke partijen, de regering en ouderen zelf dienden tot bemoeienis met deze kwesties te worden aangezet. Flexibele pensionering, betaald vormingsverlof, werktijdverkorting, democratisering, onderzoek en experimenten met vorming dienden gestimuleerd te worden. ${ }^{45}$ Commentaar op het pensioentrauma en nieuwe opvattingen over de ouderenproblematiek leidden in deze context dus niet tot het aan de kant schuiven van 
de oorspronkelijke voorziening, maar tot incorporatie ervan in een breder scala aan beleidsvoorstellen.

Deze perspectief-verbreding bleef niet beperkt tot de 'beraadsdag'. Ook in de wereld van het vormingswerk werd een dergelijke verbreding zichtbaar, zowel in de manier waarop de grenzen van de doelgroep werden verlegd, als in de uitbreiding van de doelstellingen van het voorbereidingswerk. Zo liet Van Gelder in 1972 weten dat de voorlichting eigenlijk veel te laat begon. Omstreeks het 55 ste jaar begon de periode van afstandnemen van het werk en het zoeken naar nieuwe waarden. Aan de oude generatie ouderen dienden dergelijke waarden tijdig te worden bijgebracht. Wanneer de cursussen eerder zouden starten, zou het vormingswerk niet meer de functie hebben om mensen over de schok van hun pensionering heen te helpen, maar om hen bewust te maken van de mogelijkheden om anders ouder te worden.$^{46}$ Bovendien werd er van de kant van De Haaf op gewezen dat ook de bewustwording van en bevordering van de weerbaarheid in de bedrijfssituatie van wezenlijk belang was. ${ }^{47}$ Anderen, onder wie Wehkamp, vonden dat de bestaande cursussen te weinig inhoud hadden en te veel op recreatie waren gericht. ${ }^{4}$ Van Gelder zelf zag bovendien gevaren in de therapeutische sfeer van cursussen. Ook hij meende dat de voorbereiding eigenlijk onderdeel zou moeten zijn van permanente educatie en educatief verlof. ${ }^{49}$ Volgens Van Gelders handboek uit 1978 moest het daarbij om méér gaan dan het aanleren van hobbies. Ouderen hadden recht op zinvolle functies en de voorbereiding op de pensionering moest hen dan ook 'tot emancipatie stimuleren'..$^{50}$

Dergelijke uitspraken sloten aan bij het politieke klimaat van die jaren. $\mathrm{Al}$ was door eerdere bewindslieden eveneens aandacht besteed aan de voorbereiding op de pensionering, de politieke agenda van het kabinet-Den Uyl bood extra aanknopingspunten. ${ }^{51}$ Voor dat kabinet stond spreiding van inkomen, kennis en macht centraal en kregen permanente educatie en bijscholing van lager opgeleiden hoge prioriteit. Een regeling voor Betaald Edukatief Verlof werd overwogen. In dat licht boog de Commissie Open School zich over de voorbereiding op de pensionering, 
waarvan het uiteindelijke resultaat was dat begin jaren tachtig een ontwikkelingsprojekt prépensionering werd gestart. Dat projekt zou vooral aandacht moeten besteden aan de ontwikkeling van geschikte methodes voor het voorbereidingswerk. Daarnaast werd het recht op voorbereiding op de pensionering in het kader van betaald educatief verlof door de vakbonden bepleit en werd dat recht in een toenemend aantal collectieve arbeidsovereenkomsten vastgelegd..$^{52}$

Onder onderzoekers was de discussie over de zin en onzin van de cursussen echter nog niet afgerond. Al bleek uit buitenlandse studies dat goede informatie een geslaagde aanpassing bevorderde, de resultaten van kleinschalig Nederlands onderzoek wezen erop dat de behoefte aan de cursussen beperkt was. Bovendien werden vormende activiteiten als rollenspelen door cursisten achteraf vaak niet gewaardeerd en hadden de onderzochte cursussen - hoewel door velen met plezier gevolgd - geen effect op de tijdsbesteding, aldus evaluatie-onderzoekers. Mede op basis van buitenlandse literatuur stelden deze mensen dat het merendeel van de werknemers het probleem van de pensionering zonder hulp van professionals tot een goede oplossing wist te brengen. Afschaffing van de cursussen ging hen echter te ver. De manier waarop mensen zich op hun pensionering voorbereidden, zo beweerde onderzoeker Bart van der Zee, verschilde van individu tot individu. De cursussen zouden dan ook meer differentiatie naar vorm, inhoud en deelnemers moeten bieden. Bovendien zou de bekendheid met vorming vergroot kunnen worden door de voorbereidingscursus onderdeel te laten zijn van een reeks vormingscursussen gedurende de gehele loopbaan. Daar kwam bij dat mensen meer moeite hadden met onvoorspelbare zaken als arbeidsongeschiktheid of werkloosheid dan met voorspelbare zaken als de pensionering. Daarom was eerder aandacht nodig voor WAO'ers dan voor AOW'ers. ${ }^{33}$

In die lijn wilden de leden van het ontwikkelingsprojekt prépensionering de cursussen inderdaad anpassen. De doelgroep van hun voorziening vervloog niet, maar werd verbreed: ook WAO'ers en werklozen behoorden voor de cursussen in aanmerking te komen. ${ }^{54}$ Vormingswerkers en andere betrokkenen wil- 
den de cursus voortaan integreren in een langdurig proces van permanente educatie en voorbereiding op de 'derde levensfase'. Daarbij ging het niet meer alleen om opvoeding van ouderen tot een betere tijdsbesteding, maar om bewustwording van hun eigen marginale positie en emancipatie. Sommigen wilden ouderen zelfs omvormen tot een avant-garde voor een nieuwe maatschappelijke orde, waarin de kwaliteit van het leven centraal stond.ss

Op die manier kreeg de voorbereiding op de pensionering in de Nederlandse samenleving een bescheiden plaats. De stelling waarop de noodzaak van de voorziening aanvankelijk was gebaseerd - dat de pensionering een slagboom in het bestaan van ouderen betekende en dramatische gevolgen had -, was in de wereld van het onderzoek gerelativeerd. En ook de karakterisering van het bejaardenvraagstuk, waarbinnen de gedachte aan 'opvoeding' tot de ouderdom was opgekomen, was inmiddels door een maatschappijkritische variant vervangen. Dit alles betekende allerminst dat de voorbereiding op de pensionering in de kiem werd gesmoord. De eenmaal ontstane cursuspraktijk verzorgde haar eigen voortzetting, waarin de relativering van de pensioneringsproblematiek werd geminimaliseerd en tegelijkertijd de problematiek, de doelgroep en doelstellingen van de voorbereiding werden verruimd. Bovendien had het cursuswerk de politieke wind in de rug: het kreeg een plaats in een brede beweging voor permanente educatie.

Het is zonneklaar dat de geschiedenis van de voorbereiding op de pensionering niet gezien kan worden als een voorbeeld van een 'gegeven' probleem waarop gerontologen en praktijkmensen slechts 'reageerden'. Het probleem bleek immers allesbehalve vanzelfsprekend. Juist dit voorbeeld kan duidelijk maken wat een benadering in termen van 'grenzen' aan inzichten in de geschiedenis van de ouderdom oplevert. Om aan de hand van de voorbereiding op de pensionering aan te kunnen geven wat die benadering precies zichtbaar maakt, is het echter goed om nog enkele andere interpretaties van de geschiedenis van het voorbereidingswerk de revu te laten passeren. 
Zo vond Hans Achterhuis de - in zijn ogen merkwaardige overleving van de voorbereidingscursussen een sprekend voorbeeld van de manier waarop het arbeidsethos de Nederlandse burgers werd opgedrongen en welzijnswerkers zichzelf aan banen hielpen: wie niet werkte, zo meenden deskundigen, had een probleem. Aan de discriminatie op de arbeidsmarkt en de scheve verdeling van arbeid werd op deze manier echter, aldus Achterhuis, niets gedaan. ${ }^{36}$ De interpretatie van Achterhuis heeft als nadeel dat daarin de wens van vormingsleiders om de cursisten tot een kritische houding ten aanzien van hun werk aan te sporen en hen zelfs tot de avant-garde van maatschappij-vernieuwing om te vormen, niet passen.

Een soortgelijk probleem speelt bij de interpretatie van de politiek econoom Phillipson. In ontwikkelingen rond de voorbereiding op de pensionering in Groot-Brittannië zag Phillipson het economisch klimaat van dat land weerspiegeld. In een tijd waarin de behoefte aan arbeidskrachten groot was - de jaren vijftig en zestig-werd de pensionering door gerontologen en anderen als een probleem gezien. Aan de voorbereiding op de pensionering, al gingen daartoe enkele stemmen op, werd echter nog niet veel gedaan. Economisch gezien werd het immers belangrijker geacht om mensen aan het werk te houden dan om hen te leren van hun baan afstand te nemen, zo luidde Phillipsons verklaring. Toen in de loop van de jaren zeventig de werkloosheid toesloeg, veranderde ook de ideologie rond pensionering: voortaan dienden burgers overtolligheid, massa-ontslagen en vervroegde pensionering te accepteren. ${ }^{77}$ Phillipson ging nauwelijks op de praktijk van de Engelse voorbereidingscursussen in. Voor de Nederlandse situatie kan Phillipsons lezing echter niet worden gevolgd. Hier riepen de cursusleiders immers niet alleen op tot waardering van een bestaan zonder werk, maar ook tot emancipatie, bewustwording van de eigen marginaliteit, democratisering en weerbaarheid in de bedrijfssituatie: zaken die eerder tegen dan ter ondersteuning van het maatschappelijk establishment werden geformuleerd. De politiek-economische benadering kent dus ook hier haar beperkingen.

De levensloop-sociologen zouden, hadden $z i j$ de geschiede- 
nis van de voorbereiding op de pensionering geschreven, evenmin een bruikbaar perspectief aangedragen hebben. Naar aanleiding van de verbreding van de doelstellingen van de voorbereidingscursussen zouden zij zich vermoedelijk hebben afgevraagd of dit een vorm van institutionalisering of de-institutionalisering van de levensloop is. En juist die vraag bleek moeilijk te beantwoorden.

Het levert meer op om de gang van zaken rond de voorbereiding als een uitdrukking van de dynamiek van grenzen en problemen te zien. Omdat grenzen niet automatisch problemen oproepen en problemen niet automatisch grenzen, moet die dynamiek zo gedetailleerd mogelijk beschreven worden. Zo maakt het rechtskarakter van de verzorgingsstaat het noodzakelijk om de sociale categorieën die voor een bepaalde voorziening in aanmerking komen, nauwkeurig te omschrijven (zie hoofdstuk drie). Maar daar komt nog iets bij. Het (voort)bestaan van een voorziening zelf dient gelegitimeerd te worden onder verwijzing naar een exclusief probleem of karakteristiek van een specifieke groep burgers (zie hoofdstuk vier). Deze combinatie van procedurele rechtvaardigheid (de eis tot rechtsgelijkheid) en substantiele rechtvaardigheid (het tegemoet willen komen aan verschillende noden en wensen) leidt altijd tot een zekere spanning. ${ }^{5 *}$ Dat wil zeggen: iedere regel kent zijn uitzonderingen en roept overgangsproblemen op.

Op die manier vloeide uit de pensionering ondermeer het probleem voort van de mensen die al eerder of nog niet aan pensionering toe waren, alsook het probleem van de aanpassing aan die pensionering. Vervolgens riep de noodzaak tot een nauwkeurige benoeming van dat laatste probleem een nieuw onderscheid op: dat tussen de mensen die zich gemakkelijk aan hun nieuwe status konden aanpassen en zij die daar (grote) moeite mee hadden. De uit het oorspronkelijke probleem voortgevloeide praktijk negeerde die relativering niet, maar concentreerde haar legitimatie aanvankelijk op de categorie van gepensioneerden die de overgang moeilijk viel. De 'professionals' van de voorbereiding versterkten hun legitimatie echter door de problematiek waarop hun voorziening betrekking moest hebben, te 
verbreden. Die verbreding deed de oorspronkelijke grens - die van de pensionering - vervagen, maar deed ook nieuwe grenzen ontstaan: het onderscheid tussen de mensen die wel en niet hun derde levensfase (van niet-meer-werken) ingingen. Welke nieuwe grenzen precies werden opgeworpen, werd niet door de bovenbedoelde dynamiek, maar door andere ontwikkelingen zoals die op de arbeidsmarkt en het politieke klimaat - bepaald. Niettemin riepen problemen en voorzieningen, in de context van de verzorgingsstaat en de legitimatie van specifieke interventies, steeds andere grenzen op.

Juist een benadering die oog heeft voor de verschillende manieren waarop de ouderdom wordt afgebakend - manieren verbonden met het soort grens dat in het geding is - kan deze dynamiek zichtbaar maken. Het afbakenen van de ouderdom als probleem, sociale categorie of levensfase gebeurt niet steeds binnen één kader, maar is via een bepaalde context met specifieke mechanismen en achtergronden verbonden. In de discussie rond de voorbereiding op de pensionering werd de ouderdom afwisselend in verschillende 'gedaanten' begrensd: van probleem naar categorie, van categorie naar levensfase. Daarbij werd de overgang van de ene naar de andere gedaante gedeeltelijk door de context van de voorafgaande gedaante opgeroepen. Precies deze dynamiek kon in het bestaande onderzoek naar de maatschappelijke definitie van de ouderdom niet worden gethematiseerd.

\section{De oogst van het onderzoek naar grenzen}

Betekent de nadruk op de 'eigen geschiedenis' en 'dynamiek' van grenzen dat het niet meer mogelijk is iets algemeens te zeggen over de wijze waarop de ouderdom van andere problemen, categorieën en levensfasen werd onderscheiden en hoe dergelijke grenzen doorwerkten in de praktijk van de zorg voor ouderen? Leidt de aanval op het onderzoek naar de 'maatschappelijke definitie van de ouderdom' louter tot een vergruizing van het beeld dat door het definitie-onderzoek werd geproduceerd? Toch niet. Op grond van de voorafgaande paragraaf en hoofd- 
stukken kan een alternatief voor het definitie-onderzoek worden gepresenteerd. Dat alternatief heeft de vorm van een heuristiek die via vergelijkingen alsnog generaliserende opmerkingen mogelijk maakt. Voordat dit antwoord beargumenteerd kan worden, is het echter nodig de problemen en vragen waarmee deze studie begon, nogmaals in herinnering te roepen.

In het eerste hoofdstuk van deze studie werd het onderzoek naar 'de maatschappelijke definitie van de ouderdom' besproken omdat veel van dit onderzoek - zij het in andere termen - de geschiedenis van grenzen rond de ouderdom bespreekt. In de loop van de jaren zeventig ontstond binnen de historiografie van de ouderdom een type geschiedschrijving dat de ouderdom als een sociale constructie of definitie typeerde en bijzondere aandacht besteedde aan het ontstaan van de ouderdom als duidelijk afgebakende levensfase en afzonderlijke sociale categorie. Terwijl andere geschiedschrijvers het ontstaan van voorzieningen voor ouderen in de eerste plaats beschreven als een reactie van overheden en deskundigen op problemen en behoeften van ouderen, schrijven de 'definitie-onderzoekers' aan de staat, de wetenschap en de economie een groot ordenend vermogen ten aanzien van de ouderdom toe. In hun onderzoek zijn ouderdom en ouderdomsproblemen geen onafhankelijke variabelen, maar zijn ze cultureel en maatschappelijk bepaald.

Een deel van dit 'definitie-onderzoek' heeft een kritische toon ten aanzien van de (contemporaine) positie van ouderen. Zo zien onderzoekers uit de politiek-economische hoek in het ontstaan van pensioenregelingen, tehuizen en andere voorzieningen voor ouderen vooral een 'verafhankelijking' en 'problematisering' van de ouderdom, een situatie die voortkomt uit de kapitalistische structuur van Westerse economieën. Het werk van de - eveneens in het eerste hoofdstuk besproken - levensloop-sociologen is meer analytisch van aard, al geeft het evenzeer een diagnose van de moderne tijd. In hun betogen is de standaardisering van de levensloop in duidelijk van elkaar afgebakende fasen een noodzakelijk produkt van een gerationaliseerde samenleving. Historici, ten slotte, plaatsen de 'ontdekking' van 
de ouderdom doorgaans niet in dergelijke functionalistische kaders, maar hebben voor ontwikkelingen als de 'medicalisering' en 'institutionalisering' van de ouderdom uiteenlopende, al dan niet theoretisch geïnspireerde, achtergronden gezocht. Volgens hen zijn typeringen van de ouderdom veelal door een combinatie van demografische, politieke en medisch-wetenschappelijke veranderingen ontstaan.

Hoewel de geschiedschrijving over de definitie van de ouderdom het bestaan van de sociale categorie 'ouderen' en 'typische' ouderdomsproblemen terecht heeft gehistoriseerd en geproblematiseerd, kleven aan de genoemde benaderingen - zo kwam in het eerste hoofdstuk ter sprake - verschillende haken en ogen. Veel van die geschiedenissen kenmerken zich door een grote mate van lineariteit. De ontwikkeling naar een afhankelijke ouderdom, een gemedicaliseerde ouderdom of een gestandaardiseerde levensloop kent slechts één richting; verschijnselen die daarvan afwijken passen niet of slechts moeizaam in de geschetste lijnen.

Bovendien wordt in dergelijke betogen aan de economie, de staat en de (medische) wetenschap een grote macht toegekend. Zo legt een deel van de literatuur wel uit welke ideeën over de ouderdom binnen de wetenschappen werden ontwikkeld, maar niet hoe dat gedachtengoed vervolgens tot een bepaalde politiek of tot bepaalde voorzieningen leidde: de macht van de wetenschap wordt eerder verondersteld dan aangetoond. Ook komt het voor dat de invoering van pensioenvoorzieningen als bewijs van het 'regime van de klok' naar voren wordt geschoven, zonder dat de verhouding tussen dergelijke regels en de manier waarop individuen hun levensloop vorm geven, wordt uitgewerkt. Daarnaast is vaak geen of weinig aandacht voor de vraag wat een bepaalde definitie, zoals de definitie van de problematiek van vergrijzing, er precies toe deed - wat die definitie nou eigenlijk uitmaakte.

De gang van een definitie die in de context van de verzorgingsstaat, het bedrijfsleven of de wetenschap is ontstaan naar andere domeinen van de samenleving wordt daarmee voorgesteld als een weg van louter verspreiding - een diffusie van conceptua- 
liseringen, waarbij deze conceptualiseringen in de loop van de rit niet wezenlijk veranderen. Met het ontstaan van een definitie, wordt de stabiliteit en de 'werking' ervan als het ware gegeven verondersteld: eenmaal geformuleerde definities ordenen als vanzelf de praktijk van de ouderenzorg, de positie van ouderen en - in bepaalde versies - zelfs het gedrag van ouderen. Daar komt bij dat de herkomst van definities er in functionalistische benaderingen niet toe doet. Of de bron nu de overheid of de wetenschap is, beiden liggen in een functionele relatie tot een diepere achtergrond: de structuur van de economie of die van de moderne, gerationaliseerde samenleving. Het is dan ook geen toeval dat het onderscheid tussen het produkt en het proces van definitie in dergelijke betogen nauwelijks een rol speelt: in de termen 'definitie', 'constructie' en 'constitutie' liggen zowel het proces als het produkt besloten. Dat onderscheid is immers pas van belang, wanneer verondersteld wordt dat een definitie niet stabiel hoeft te zijn, dat de formulering van een definitie nog niets zegt over hetgeen het teweegbrengt, en dat het voor de manier waarop een definitie verankerd raakt misschien uitmaakt van waaruit of door wie er is gedefinieerd.

In de hoofdstukken twee tot en met vijf is steeds geprobeerd om deze problemen van lineariteit, (al)macht en diffusie te voorkomen en juist wél na te gaan via welke wegen een bepaalde typering van de ouderdom tot een bepaalde praktijk leidt. Dat is in de eerste plaats gedaan door andere termen te gebruiken en andere vragen te stellen. In deze studie stond niet de vraag naar 'de maatschappelijke definitie van de ouderdom' centraal, maar de vraag naar 'de geschiedenis van de verschillende grenzen die de ouderdom een bepaalde vorm gaven'. Met die grenzen werd gedoeld op datgene aan de hand waarvan de ouderdom in het verleden is afgebakend, omlijnd, gekarakteriseerd en getypeerd. Voor de term 'grens' werd gekozen omdat het woord betrekking heeft op datgene wat de ouderdom van 'niet-ouderdom' onderscheidt, maar tegelijkertijd het probleem van het ontbreken van een onderscheid tussen het proces en produkt van 'definitie' oplost. Met een grens wordt immers naar een produkt verwezen (datgene aan de hand waarvan de ouderdom wordt afgebakend), 
terwijl de vraag naar het ontstaan, verschuiven, verdwijnen en verankeren van die grenzen naar processen verwijst. Bovendien houdt de laatste vraag de richting van die processen nog open.

Daarnaast werd verondersteld dat het onderzoek naar het verleden van de ouderdom aan specificiteit zou kunnen winnen, wanneer het ontstaan van de ouderdom als afzonderlijk probleem, als aparte levensfase en als sociale categorie niet als onderdelen van één beweging zou worden beschouwd, maar als een zaak van verschillende grenzen die ieder een eigen onderzoeksaanpak verdienen. Door steeds naar het ontstaan, verschuiven, verdwijnen en verankeren van grenzen rond de ouderdom te vragen, werd niet alleen de mogelijkheid van discontinuïteit ingebouwd, ook werd op die manier de weg geopend om tussen verschillende soorten grenzen te differentiëren. Vervolgens zijn in de hoofdstukken twee, drie, vier en vijf-over de grenzen van bevolkingsveroudering als publiek probleem, over de grenzen van oudere ongehuwde vrouwen als sociale categorie, over de grens tussen het natuurlijke en het onnatuurlijke van de ouderdom als levensfase, en over de ruimtelijke situering van ouderen als object van zorg - steeds die perspectieven ingezet die aansloten bij het type grens waarover werd gesproken. Daarbij had het tweede hoofdstuk zowel de functie een 'tableau' van de historische deelnemers aan de te bespreken debatten te presenteren, als om enkele bezwaren die in het eerste hoofdstuk op logische gronden of naar aanleiding van secundaire studies tegen de 'definitie-benadering' waren geformuleerd, met eigen empirisch onderzoek te staven. In de drie hoofdstukken daarna werd het alternatief van het 'grenzen-onderzoek' nader uitgewerkt door die perspectieven te kiezen die inzicht konden geven in de achtergronden van de ontwikkeling en 'werking' van grenzen, zonder een groot ordenend vermogen van economie, staat of wetenschap te vooronderstellen. Wat levert deze aanpak nu uiteindelijk op?

Van de grenzen die besproken werden, waren de meeste in beweging en verdween een enkele. Vanaf het moment dat de vergrijzing in Nederland als publiek probleem werd geïdentificeerd, 
veranderde het profiel ervan voortdurend. Hoewel sommige kwesties, zoals de gevolgen van de vergrijzing voor de 'demografische last' tussen de jaren twintig en de jaren tachtig steeds opnieuw werden opgeworpen, werd de essentie van het probleem van de vergrijzing in de loop der tijd op heel verschillende manieren verwoord. Terwijl de problematiek van vergrijzing - om een deel van hoofdstuk twee in herinnering te roepen - in de jaren twintig en dertig ondermeer gezocht werd in de mentaliteit van een oud volk, werd bevolkingsveroudering in de jaren tachtig vooral gezien als een probleem van collectieve lasten. Hoewel het dus mogelijk is over het ontstaan van vergrijzing als afzonderlijk publiek probleem te spreken, is het profiel van dat probleem verschillende keren ingrijpend verschoven.

In de discussie over de pensioengerechtigde leeftijd van ongehuwde vrouwen werd eveneens veelvuldig aan grenzen gemorreld: terwijl de AOW-gerechtigde leeftijd van 65 jaar als maatregel overeind bleef, werd in dit geval aan de grenzen van de sociale categorie van ongehuwde vrouwen gesleuteld. Voorstanders van een verlaging van de pensioengerechtigde leeftijd voor ongehuwde vrouwen vergeleken de laatsten met andere sociale categorieën om via overeenkomsten en verschillen een bijzondere of juist vergelijkbare behandeling aannemelijk te maken. Tegenstanders deden hetzelfde, maar met het omgekeerde doel. Op die manier werden aan oudere ongehuwde vrouwen kenmerken toegeschreven - net als weduwen het alleen moeten rooien, anders dan gehuwde mannen een dubbele taak van werk en huishouding hebben - die de categorie in kwestie een bijzonder gezicht gaf dan wel 'gelijk' maakte aan anderen. In de context van deze discussies en het rechtskarakter van de verzorgingsstaat, waarin nieuwe rechten gewoonlijk via sociale vergelijkingen worden geclaimd, verdween echter de grens tussen oudere ongehuwde vrouwen en verschillende andere sociale categorieën. Verschillen tussen oudere ongehuwde vrouwen onderling werden geaccentueerd, terwijl er tegelijkertijd op gewezen werd dat deze vrouwen veel met andere groepen gemeen hadden. Daarmee werd de rechtvaardiging van een bijzondere behandeling ondermijnd en werden de pogingen om de categorie van oudere 
ongehuwde vrouwen nauwkeurig ten opzichte van andere categorieën te positioneren, effectief tegengewerkt.

Ook de grens tussen natuurlijk en onnatuurlijk verouderen lag allesbehalve vast - en daarmee evenmin het 'eigene' van de ouderdom als levensfase. In de periode na de oorlog werden steeds meer verschijnselen die aanvankelijk tot het domein van de natuurlijke ouderdom waren gerekend tot ziekten bestempeld. Op die manier verschoof gestaag de grens tussen datgene wat als onvermijdelijk en onomkeerbaar werd gezien en datgene wat als principieel behandelbaar werd beschouwd. In vergelijking daarmee leken de ruimtelijke grenzen binnen en rond het verzorgingshuis nog het meest stabiel. Hoewel het tehuis van de jaren tachtig ruimten kende die in het tehuis van de jaren veertig nog niet waren opgenomen, werd na de geboorte van het 'pensiontehuis' niet meer wezenlijk aan de 'eigen' kamer getornd. De grenzen van de eenheid voor iedere bewoner bleken stevig verankerd in de ruimtelijke orde van het tehuis.

De meeste voorbeelden duiden echter op het voortdurend verschuiven van grenzen, en doorbreken de 'definitie-schema's' van voortgaande standaardisering, verafhankelijking of medicalisering van de ouderdom. Het voorbeeld van de oudere ongehuwde vrouwen laat aan de ene kant zien dat de pogingen om de AOW-gerechtigde leeftijd speciaal voor deze groep van de algemene standaard te laten afwijken mislukte, maar maakt aan de andere kant duidelijk dat het amalgaam van regelingen dat als alternatief werd voorgesteld - waaronder de wAO - juist een grotere variatie aan 'vertrek-leeftijden' mogelijk maakte dan een algehele verlaging van de pensioengerechtigde leeftijd voor ongehuwde vrouwen. Terwijl de bereikte 'institutionalisering' van de levensloop als het ware met de rechterhand werd vastgehouden, werd deze met de linkerhand losgelaten. Van de grote categorie van Aow'ers werden de oudere ongehuwde vrouwen niet 'losgekoppeld', maar de categorie van niet-meer-werkenden die niet gepensioneerd waren, werd er door vergroot. Evenmin is de geschiedenis van de grens tussen natuurlijk en onnatuurlijk verouderen zondermeer als een vorm van voortgaande medicalisering van de ouderdom te interpreteren. Het werk van Schreuder, 
die met zijn beweringen het domein van het natuurlijke en daarmee van het onvermijdelijke 'bed-houden' verkleinde, ontmedicaliseerde het ouder worden in het algemeen, maar problematiseerde en medicaliseerde de ouderdom van een deel van de bevolking: namelijk dat deel dat naar zijn oordeel onder geriatrisch toezicht moest worden geplaatst. En zelfs de invoering van het pensiontehuis, alhoewel de voorganger van het massale bejaardentehuis, kan niet zomaar als een vorm van standaardisering worden begrepen. Het pensiontehuis, bedoeld voor de betere standen, verscherpte immers in eerste instantie het onderscheid tussen de klassen.

Deze geschiedenissen maken duidelijk dat grenzen zich niet steeds in één richting bewegen. Ook blijkt dat het ontstaan, verschuiven, verdwijnen en verankeren van grenzen niet willekeurig tot de 'activiteiten' van staat, bedrijfsleven en wetenschap te herleiden is. Dit werd zichtbaar door steeds die perspectieven in te zetten die een analyse mogelijk maakten op een niveau tussen dat van de macro-verklaringen van de politiek economen en levensloop-sociologen en de micro-verklaringen van veel van het historisch definitie-onderzoek in. Het ging om perspectieven die het 'louter contingente' overstegen zonder zich te beroepen op grote functionalistische schema's: zo konden de schijnwerpers worden gericht op een bepaald 'kader', een zekere 'as' of een gegeven 'netwerk' waarbinnen of waarlangs de conceptualisatie van een grens (al dan niet) tot een bepaalde praktijk leidde. Daarbij ging het om regels, verhoudingen en patronen die de aard van de discussies en de 'bandbreedte' van de ontwikkelingen rond een bepaalde grens bepaalden en zo de speelruimte van verschillende deelnemers beperkten.

Door in het derde hoofdstuk de aandacht te richten op het juridische kader waarin grenzen tussen sociale categorieën tot stand komen, werd duidelijk dat burgers ook zelf een groot aandeel kunnen hebben in het formuleren van dergelijke grenzen. In dit geval boden Schuyts stellingen over het rechtskarakter van de verzorgingsstaat het perspectief waarmee dit kader voor het voetlicht kon worden gehaald. Wat zichtbaar werd, was het spel 
van vergelijkingen waarmee sociale categorieën ten opzichte van elkaar werden afgebakend. Het rechtskarakter van de verzorgingsstaat legde zo de regels vast aan de hand waarvan de discussie over de pensioengerechtigde leeftijd en andere rechten van ouderen moest worden gevoerd. Die regels stuurden de 'taal' en beperkten de ruimte van alle deelnemers aan het debat, maar legden niet bij voorbaat de uitkomst van de discussie vast. Dat de ongehuwde vrouwen van het Vrouwen-actiecomité voor Vervroegde Staatspensionering niet in staat bleken de algemene regel van pensionering op 65 -jarige leeftijd te doorbreken, kan niet aan de 'macht' van de staat op zichzelf of de 'rationaliteit' van de moderne samenleving - het functionele kader van de levensloop-sociologen - worden toegeschreven. Het verlies van het actiecomité had ondermeer te maken met de periode waarin de meest cruciale beslissingen vielen: de jaren zeventig waarin vrouwenemancipatie en gelijkheids-streven verhoudingsgewijs hoog op de politieke agenda stonden.

Ook het ontstaan en de ontwikkeling van verzorgingshuizen, een voorbeeld van ruimtelijke begrenzing van de ouderdom, kan niet worden gereduceerd tot een kwestie van standaardisering in een rationale samenleving of verafhankelijking in een kapitalistische samenleving. Door met de ogen van de niet-Westerse antropoloog Chowdhury naar het Nederlandse verzorgingshuis te kijken werd duidelijk, dat de verhouding tussen het private en het openbare en de ruimtelijke vormgeving daarvan een belangrijke as bleek in de ontwikkeling van het verzorgingshuis. Tegenwoordig wordt het verzorgingshuis doorgaans geassocieerd met afhankelijkheid en segregatie, terwijl het wonen in afzonderlijke woningen voor zelfstandigheid en integratie staat. In terugblikken op de ontwikkeling van de ouderenhuisvesting wordt het afremmen van de bouw van bejaardenoorden en het stimuleren van de bouw van bejaardenwoningen in de jaren zeventig dan ook als een ingrijpende wending in het denken over ouderen gezien. Chowdhury's oog voor de cruciale plaats van privacy in de Nederlandse wooncultuur en voor de manier waarop mensen aan ruimten privacy toekennen, wees de weg naar een beter begrip van die geschiedenis. 
De eerste 'pensiontehuizen' waren zowel bedoeld om ouderen een helpende hand te reiken als om hen - via een eigen kamer - een zekere vrijheid en zelfstandigheid ('individualiteit') te geven die het oudeliedenhuis met slaapzalen niet kon bieden. $\mathrm{Na}$ de oorlog werd de discussie over het ideale tehuis door twee verschillende concepten gedomineerd: die van het tehuis als gemeenschap (het tehuis als gezin of dorp) en die van het tehuis als verzameling alleenwonende individuen (het tehuis als hotel of voorstad). In het eerste geval lag de nadruk op gezelligheid en huiselijkheid (met veel gemeenschappelijke ruimten en zitjes), in het tweede geval op keuzevrijheid (het eigen keukentje om eventueel zo min mogelijk van de eetzaal gebruik te hoeven maken). In de praktijk werden tehuizen gebouwd die op een combinatie van beide 'modellen' waren gebaseerd - grote tehuizen met mini-woningen én veel collectieve voorzieningen - hetgeen zowel economische als demografische achtergronden had.

Wat in de loop van de jaren zestig en zeventig veranderde was niet zozeer het ontstaan van belangstelling voor zelfstandigheid, want die bestond immers al lang, maar wel een subtiele verschuiving van de inhoud van het begrip 'zelfstandigheid' en een koppeling van dat begrip aan andere ruimten. Onder invloed van de discussie over de kosten van de ouderenhuisvesting ging zelfstandigheid naast 'behoud van de individualiteit' vooral ook 'financiële onafhankelijkheid' en 'zelfverzorging' betekenen en werd zelfstandigheid mede daardoor steeds exclusiever aan huisvesting in een afzonderlijke woning verbonden. Tegelijkertijd werd de toelating van ouderen tot tehuizen gereglementeerd en werden deze tehuizen in toenemende mate juist voor de nietzelfstandigen bedoeld. Toch ging die nadruk op verzorgingbehoevenden niet zover dat massaal tot groepsverzorging werd overgegaan: daarvoor bleek de notie van privacy - continu aanwezig in de geschiedenis van het tehuis - te stevig verankerd in de muren van het tehuis.

Nog nauwkeuriger kon de weg tussen het formuleren van grenzen en de praktijk van de ouderenzorg worden gevolgd in het vierde hoofdstuk: over de grens tussen natuurlijk en onnatuurlijk verouderen en het ontstaan van de geriatrie. In dat 
hoofdstuk werd de wetenschapssociologie van Latour ingezet om een alternatief te bieden voor 'definitie-onderzoek' waarin de definities van wetenschappers 'als vanzelf de praktijk van de ouderenzorg lijken te bepalen. Door Latours concept van 'translatie' te gebruiken, werd de aandacht gericht op de manier waarop onderzoekers hun beweringen aan andere beweringen en praktijken koppelen (en anderen op hun beurt datzelfde doen), waarbij in de loop van dat proces van 'associatie' zowel de oorspronkelijke beweringen als de praktijk kunnen veranderen. Dat maakte het mogelijk om de lotgevallen van de stellingen van arts-onderzoekers over natuurlijke en onnatuurlijke veroudering precies te volgen.

Daarbij werd duidelijk dat de stelling van de arts Schreuder, dat veel fysieke problemen van ouderen niet zo 'natuurlijk' en dus 'onvermijdelijk' waren als lang was aangenomen, door velen werd overgenomen en verankerd raakte in revalidatie-apparaten, -ruimten en -deskundigen in verpleeg- en bejaardentehuizen. Tegelijkertijd bleek dat Schreuder probeerde zijn stellingen over het 'vermijdelijke' aan de noodzaak van een erkenning van de geriatrie te verbinden - een 'associatie' die pas aan het begin van de jaren tachtig succes had. Schreuders strategie om een eigen domein van zeggenschap voor de geriatrie af te bakenen door de eigen aard van de ouderdom aan de noodzaak van een specifieke expertise en behandeling te verbinden, volgde een door de professie-socioloog Abbott als gebruikelijk getypeerd retorisch patroon van reductie. Die reductie houdt in dat de 'aanvallende' professie - de professie die bestaansrecht en erkenning zoekt - een nieuwe exclusieve taak voor zichzelf ziet weggelegd die niet reduceerbaar is tot de 'jurisdictie' van een bestaande professie. Schreuders pogingen om de zeggenschap van de geriatrie niet primair op grond van de leeftijd van oudere patiënten af te bakenen, maar via de specifieke eigenschappen van hun levensfase (die een bijzondere expertise, diagnose, behandeling en preventie vereisten), past in dat patroon.

Op deze manier kwam in alle hoofdstukken, zij het soms tussen de regels door, aan de orde wat grenzen doen, wat ze voor de ouderenzorg uitmaken. In het tweede en zesde hoofdstuk werd 
gesteld dat een bepaalde typering van het bejaardenvraagstuk soms richting geeft aan de te kiezen oplossingen (en dus aan de praktijk), maar deze niet determineert. Niet alleen omdat voorzieningen soms aan een probleemprofiel voorafgaan: pas toen bedacht was dat ook voor ouderen van de betere standen speciale voorzieningen nodig waren, kon over een 'oudeliedenvraagstuk' gesproken worden. Maar ook omdat grenzen - in de context van de verzorgingsstaat - een eigen dynamiek kunnen hebben, zoals in de vorige paragraaf is geillustreerd. Grenzen kunnen daarnaast ook worden ingezet om iets anders (een nieuw recht, een nieuw vak) te bewerkstelligen, zo kwam in verschillende hoofdstukken naar voren. Bovendien bleken zelfs de meeste versteende grenzen - de muren van het moderne tehuis - van symboliek te kunnen veranderen. $\mathrm{Zij}$ konden zowel het symbool van zelfstandigheid als van afhankelijkheid zijn.

Het gebruik van de term 'grenzen' stelt in staat om uiteenlopende geschiedenissen onder één noemer te bestuderen, zonder een probleem te reproduceren dat veel onderzoek naar de definitie van de ouderdom parten speelt: het probleem dat de 'definitie' van de ouderdom zowel op het proces als op het produkt van definitie slaat. Daarmee wordt het mogelijk de ontwikkeling van een bepaalde grens te volgen en de betekenis van die grens voor de praktijk te onderzoeken. Bovendien laat de terminologie van grenzen de richting van ontwikkelingen open en biedt deze woordkeus ruimte voor het maken van onderscheid tussen soorten grenzen.

Deze aandacht voor de eigen geschiedenis van de verschillende grenzen impliceert dat deze studie niet met een overkoepelende theorie kan worden afgesloten. Maar dat betekent niet dat over de weg tussen de conceptualisering van grenzen en het ontstaan of veranderen van voorzieningen niets algemeens gezegd zou kunnen worden, noch dat het onderzoek naar grenzen slechts tot een vergruizing leidt van het beeld dat door het definitie-onderzoek is gegenereerd. Juist door te veronderstellen dat het afbakenen van de ouderdom als sociale categorie iets anders is dan het begrenzen van de ouderdom als levensfase, konden verschillende theorieën 
het betoog worden binnengehaald. Aan de hand van de sociaalwetenschappelijke perspectieven van Schuyt, Latour/Abbott en Chowdhury kon - ondanks kritiek op deze perspectieven - verwezen worden naar kaders waarbinnen grenzen zich ontwikkelden. Dat waren bepaalde regels (het rechtskarakter van de verzorgingsstaat), bepaalde patronen (de retoriek rond het ontstaan van wetenschappelijke kennis en nieuwe specialismen) of verhoudingen (die tussen het private en het openbare).

Bovendien bracht een internationale vergelijking in veel hoofdstukken 'lokale achtergronden' voor het voetlicht, die de uitkomst van de discussies voor een belangrijk deel konden verklaren of een alternatieve interpretatie van een bepaalde ontwikkeling opleverden. Dat Schreuders pogingen om de geriatrie in Nederland wortel te laten schieten pas aan het begin van de jaren tachtig succes hadden, lag niet alleen an verzet van bestaande specialisaties, maar ook aan de structuur van de Nederlandse gezondheidszorg. Dit werd echter pas duidelijk nadat de Nederlandse situatie met de Engelse en Amerikaanse vergeleken was; Latours wetenschapssociologie alleen is niet voldoende om het belang daarvan te achterhalen. Ook de verwikkelingen rond de verzorgingshuizen van ouderen kregen reliëf door een vergelijking met het, in dit geval niet-Westerse, buitenland. De voor ons zo vanzelfsprekende en daardoor 'onzichtbare' Nederlandse preoccupatie met privacy werd zichtbaar doordat Chowdhury 'onze' omgang met private en publieke ruimten als bijzonder ervoer. En zelfs in het hoofdstuk over de ongehuwde vrouwen kon een vergelijking met het buitenland nog iets verhelderen. In Engeland lukte de National Spinsters Association in 1940 datgene - een verlaging van de pensioengerechtigde leeftijd - wat het Nederlandse Vrouwen-actiecomité niet voor elkaar kreeg. De Spinsters hoefden in hun tijd echter, zo bleek na vergelijking, nog niet op te boksen tegen het emancipatoire gelijkheidsdenken waarmee het Vrouwen-actiecomité te maken kreeg.

Juist dergelijke vergelijkingen kunnen duidelijk maken waarom bepaalde grenzen in het ene land tot een andere praktijk leidden dan in een ander land. Zeker waar het om vormen van 'zorg' gaat, die sterk met de institutionele en politieke organisatie van 
een land verbonden zijn, heeft internationaal vergelijkend onderzoek veel te bieden. Hoewel dergelijk onderzoek in de geschiedschrijving van de ouderdom niet volledig ontbreekt - zo werd ondermeer vergelijkend onderzoek naar de geschiedenis van de pensionering verricht-, verschijnen vooralsnog vooral landen-monografieën en bundels waarin ontwikkelingen in verschillende landen in afzonderlijke hoofdstukken worden beschreven. Verrassend is dat niet. Onderzoekers die op zoek zijn naar functionalistische verklaringen die toepasbaar zijn op de Westerse wereld als geheel, hebben wel oog voor ontwikkelingen in verschillende landen, maar zij zijn niet primair geïnteresseerd in het opsporen van allerlei verschillen. Het gaat hen om het demonstreren van globale overeenkomsten. Aan de andere kant missen de meer op contingentie gerichte historici vaak de instrumenten - zoals het instrument van 'grenzen' - om hun gevalstudies met elkaar te vergelijken. Toch kan vergelijkend onderzoek naar verschillen, zoals gezegd, veel verhelderen. Bovendien is dergelijk onderzoek op meso-niveau, nu de historiografie van de ouderdom in verschillende landen door een kleine, maar 'stabiele' groep mensen wordt beoefend, inmiddels ook in 'logistiek' opzicht mogelijk.

Aan de hand van de voorafgaande hoofdstukken wordt hier dus geen samenvattende theorie van grenzen voorgesteld, maar een bepaalde heuristiek van onderzoek: een aanpak die het mogelijk maakt om beter zicht te krijgen op datgene wat er gebeurt tussen een karakterisering van de ouderdom als probleem, sociale categorie, levensfase of object van zorg-de conceptualisering van een bepaalde grens - en de ontwikkeling van voorzieningen voor ouderen. Voor een juist begrip van de weg die daartussen wordt afgelegd, is het zinvol om zowel op zoek te gaan naar 'meso-perspectieven' die aansluiten bij het type grens in kwestie - en een onderzoeker kan in die zoektocht in disciplinair opzicht niet liberaal genoeg zijn - als in combinatie daarmee internationaal vergelijkend onderzoek te doen. In het eerste geval worden verschillende kwesties binnen één land met elkaar vergele$\mathrm{ken}$; in het tweede geval dezelfde kwesties in verschillende landen. De laatstbedoelde vergelijking hoeft bovendien niet tot 
Westerse landen beperkt te blijven. Een vergelijking met een niet-Westers land kan juist een manier zijn om de meest vanzelfsprekende gebruiken en achtergronden op te laten lichten.

4 Slot: geen kwestie van leeftijd

Aan leeftijd werden en worden regels, wetten, eigenschappen, waarden, ruimten en voorzieningen verbonden. De weg tussen een aan leeftijd gekoppeld probleem of karakteristiek en het ontstaan van voorzieningen wordt, zo maakt deze studie duidelijk, echter niet door leeftijd bepaald. Discussies rond ouderen en de lotgevallen van de grenzen van de ouderdom als publiek probleem, sociale categorie, levensfase en object van zorg kregen reliëf in uiteenlopende contexten: het rechtskarakter van de verzorgingsstaat, de emancipatie van vrouwen, de retoriek rond de erkenning van specialisaties, de structuur van de Nederlandse gezondheidszorg en de verhouding tussen private en openbare ruimten. Dat betekent dat de geschiedenis van de ouderdom in ieder geval niet als 'een kwestie van leeftijd' kan worden afgedaan. 


\section{Noten}

I Het verleden van de ouderdom

I. Hofland, H.J.A. Het kale grijze tuig. In: Ewijk, T. van (Red.) In het jaar 2000. Utrecht/Antwerpen: Het Spectrum, 1982: 48-52 (p. 48)

2. Hofland (1982) op. cit. p. 52

3. Historiografische overzichten zijn ondermeer geschreven door: Conrad, C. Altwerden und Altsein in historischer Perspektive. Zur neueren Literatur. Zeitschrift fur Sozialisationsforschung und Erziehungssoziologie 2 (1982) 1, 73-90; Conrad, C. Geschichte des Alterns: Lebensverhältnisse und sozialpolitische Regulierung. Zur neueren Forschung. Zeitschrift fur Sozialisationsforschung und Erziehungssoziologie 4 (1984) I, 143-1 56; Conrad, C. Old Age in the Modern and Postmodern Western World. In: Cole, Th.R., Van Tassel, D.D. en Kastenbaum, R. (Eds.) Handbook of the Humanities and Aging. New York: Springer, 1992: 62-95; Conrad, C. en Kondratowitz, H.-J. von. Einleitung: Repräsentationen des Alters vor und nach der Moderne. In: Conrad, C. en Kondratowitz, H.-J. von (Hg.) Zur Kulturgeschichte des Altems. Berlin: Deutsches Zentrum für Altersfragen, 1993: 1-16; Ehmer, J. Sozialgeschichte des Alters. Frankfurt am Main: Suhrkamp Verlag, 1990; Fennell, G., Phillipson, C. en Evers, H. The history of old age/Social theory and old age. In: The Sociology of Old Age. Milton Keynes: Open University Press, 1988: 27-40/41-55; Gratton, B. The New History of the Aged: A Critique. In: Tassel, D. van en Stearns, P.N. (Eds.) Old Age in a Bureaucratic Society. New York [etc.]: Greenwood Press, 1986: 3-29; Haber, C. en Gratton, B. Aging in America: The Perspective of History. In: Cole, Van Tassel en Kastenbaum (1992) op. cit. pp. 352-370; Knipscheer, C.P.M. Bouwstenen voor een geschiedenis van de ouderdom en van de positie van de oudere mens binnen het familieverband. In: Knipscheer, C.P.M. (Red.) Ouder worden, een uitdaging voor het familieverband. Nijmegen: NVG/NIG, I984: 8-53; Laslett, P. The Significance of the Past in the Study of Ageing. 
Introduction to the Special Issue on History and Ageing. Ageing and Society 4 (1984) 4, 379-389; Moody, H.R. en Cole, T.R. Aging and Meaning: A Bibliographical Essay (and) A Select Bibliography. In: Cole, T.R. en Gadow, S.A. What Does It Mean to Grow Old? Reflections from the Humanities. Durham N.C.: Duke University Press, 1986: 247273; Pelling, M. en Smith, R.M. Introduction. In: Pelling, M. en Smith, R.M. (Eds.) Life, death, and the elderly. Historical perspectives. London/New York: Routledge, 1991: 1-38; Stavenuiter, M. Ouderen en ouderdom na 1750: een historiografisch overzicht. Tijdschnift voor Sociale Geschiedenis 16 (1990) 3, 217-243; Stavenuiter, M. Verzorgd of zelfstandig. Ouderen en de levensloop in Amsterdam in de tweede helft van de negentiende eeuw. Groningen: proefschrift, 1993

4. Dit betekent niet dat degenen die de definitie van de ouderdom onderzoeken zich niet met andere onderwerpen bezighouden. Zo is ook over de geschiedenis van het maatschappelijk werk veel geschreven en doet een deel van de onderzoekers eveneens uitspraken over de huidige - financiële en politicke - positie van ouderen. Niettemin nemen de genoemde thema's in veel van de definitie-literatuur een belangrijke plaats in.

5. Zie ondermeer: Estes, C.L. Austerity and Aging in the United States: 1980 and Beyond. In: Guillemard, A.-M. (Ed.) Old Age and the Welfare State. Londen/Beverly Hills, Cal.: Sage, 1983: 169-185; Estes, C.L. The Social Construction of Reality: A Framework for Inquiry. In: Estes, C.L. The Aging Enterprise. San Francisco, CA: Jossey-Bass Publisher, 1979: 1-15; Fennell e.a. (1988) op. cit. pp. 52-54; Guillemard, A.-M. Preface/Introduction/The Making of Old Age Policy in France: Points of Debate, Issues at Stake, Underlying Social Relations. In: Guillemard (1983) op. cit. pp. 1-I 5/75-99;Johnson, P., Conrad, C. en Thomson, D. Introduction. In: Workers versus Pensioners: Intergenerational Justice in an Ageing World. Manchester: University of Manchester Press, 1989: I-16; Means, R. The Development of Social Services for Elderly People: Historical Perspectives. In: Phillipson, C. en Walker, A. Ageing and social policy. A Critical Assessment. Aldershot [etc.]: Gower, I986: 87-106; Myles, J. Introduction/The Aged in the Welfare State. In: Old Age in the Welfare State. The Political Economy of Public Pensions. Boston [etc.]: Little, Brown and Company, 1984: 1-27. Myles baseert zich daarbij ondermeer op de volgende historische studie: Graebner, W. A history of retirement. The meaning and function of an American institution 1885-1978. New Haven, C.T.: Yale University Press, 1980; Phillipson, C. Capitalism and the Construction of Old Age. 
London [etc.]: Macmillan, 1982 (met name het eerste hoofdstuk en de historisch georiënteerde hoofdstukken 3, 6, 7 en 9); Phillipson, C. The state, the economy and retirement. In: Guillemard (1983) op. cit. pp. 127-139; Townsend, P. The Structured Dependency of the Elderly: A Creation of Social Policy in the Twentieth Century. Ageing and Society I (1981) I, 5-28; Walker, A. The Social Creation of Poverty and Dependency in Old Age. Joumal of Social Policy 9 (1980) 1, 49-75; Walker, A. Social policy and elderly people in Great Britain: The Construction of Dependent Social and Economic Status in Old Age. In: Guillemard (1983) op. cit. pp. 143-167; Walker, A. The Economic 'Burden' of Intergenerational Conflict. Ageing and Society 1o (1990) 4 , 377-396. Hoewel de 'politieke economie van het ouder worden' de gangbare term is voor de benadering die hier beschreven wordt, is ook wel van een 'politieke sociologie' gesproken. David, H. Review. Guillemard A.-M. Le Déclin du Social, Formation et Crise des Politiques de la Vieilesse. Paris: Presses Universitaires de France, 1986. Ageing and Society 9 (1989) [4], 441-444. De meeste van de genoemde auteurs beperken hun analyse van de structurele afhankelijkheid van ouderen tot de kapitalistische landen van het Westen. De inmiddels overleden onderzoeker Peter Townsend doet daarnaast uitspraken over de voormalige - socialistische landen. Dat neemt echter niet weg dat ook Townsend de structurele afhankelijkheid van ouderen verklaart uit economische verhoudingen en ontwikkelingen.

6. Cole, T.R. The 'enlightened' view of aging. Hastings Center Report (1983) 13, 34-40 (p. 38); Cole, T.R. The Prophecy of Senescence: G. Stanley Hall and the Reconstruction of Old Age in America. The Gerontologist 24 (1984) 4, 360-366; Cole, Th.R. Introduction/Toward the scientific management of aging: the formative literature of gerontology and geriatrics, 1890-1930/The prophecy of Senescence: G. Stanley Hall and the reconstruction of old age. In: The Joumey of Life: A Cultural History of Aging in America. Cambridge: Cambridge University Press, 1992: xv-xxxv/191-21 I/212-226; Cole, Th.R. en Holstein, M. Interpreting the Formative Literature of Gerontology and Geriatrics: A View From American Cultural History, 1890-1930. In: Conrad en Kondratowitz (1993) op. cit. pp. 135-153. Zie voor soortgelijke gedachten: Gruman, G.J. Cultural origins of present-day 'age-ism': the modernization of the life cycle. In: Spicker, S., Woodward, K. en Tassel, D. van (Eds.) Aging and the Elderly: Humanistic Perspectives in Gerontology. Atlantic Highlands, N.J.: Humanities Press, 1978: 359387 ; Knipscheer, C.P.M. Uitzicht op ouder worden. Golfbewegingen 
in de gerontologie. In: Knipscheer, C.P.M., Baars, J., Severijns, M. (Red.) Uitzicht op ouder worden. Een verkenning van nieuwe rollen. Assen/Maastricht: Van Gorcum, 1988: I-20. Hoewel de historicus Cole niet tot de kern van de 'politiek economen' gerekend kan worden, vertoont zijn gedachtengoed - wat de rol van de gerontologie en de geriatrie betreft - overeenkomsten met dat van hen. Bovendien heeft hij zich, via een bijdrage aan een nog te bespreken studie, achter een gematigde versie ('moral economy') van de politiek-economische benadering geschaard. Cole's aandacht voor de betekenis van spiritualiteit en religie in de geschiedenis van het ouder worden, is de politiek economen echter vreemd.

7. Zie ondermeer: Knipscheer, C.P.M. Uitzicht op ouder worden. Golfbewegingen in de gerontologie. In: Knipscheer, Baars en Severijns (1988) op. cit. pp. 1-20; Knipscheer, C.P.M. Gerontologie en concepties over het ouder worden. In: Schroots, J.J.F. e.a. (Red.) Gezond zijn is ouder worden. Assen/Maastricht: Van Gorcum, 1989: 307-314; Munnichs, J.M.A. Integratie of Gerontotheek. NTG 6 (1975) 3, 130-1 37

8. Phillipson (1983) op. cit.; Means (1986) op. cit.

9. Estes (1979) op. cit.; Estes, C.L. en Binney, E.A. The Biomedicalization of Aging: Dangers and Dilemma's. The Gerontologist 29 (1989) 5, 587-596; Estes, C.L., Swan, J.H. en Gerard, L.E. Dominant and competing paradigms in gerontology: towards a political economy of ageing. Ageing and Society 2 (1982) 2, 151-164; Fennell e.a. (1988) op. cit.; Kart, C.S. Review Essay: The end of conventional gerontology? Sociology of Health and Illness 9 (1987) 1, 76-87; Phillipson (1983) op. cit.; Phillipson, C. The development of european social gerontology. Ageing and Society 6 (1986) 1, 91-98; Walker, A. Ageing and the social sciences: the north american way. Ageing and society 7 (1987) 235-24I

10. In dergelijke publikaties wordt de introductie van de term 'geriatrie' doorgaans toegeschreven aan de arts I.L. Nasher. Deze Amerikaan zou het woord in 1909 voor het eerst hebben gebruikt. Zie ondermeer: Fennell e.a. (1988) op. cit. p. 39; Haber, C. Geriatrics: A Specialty in Search of Specialists. In: Van Tassel en Stearns (1986) op. cit. p. 66. Over het ontstaan van de term 'gerontologie' bestaat minder eenstemmigheid. Pouw gaat ervan uit dat het woord 'gerontologie' in 1929 door de Russische onderzoeker N.A. Rybnikow ten doop werd gehouden. Achenbaum en Levin schrijven dezelfde daad echter toe aan E. Metchnikoff die de term in 1905 zou hebben geïntroduceerd. Volgens Polisar en anderen zou R.N. Butler Metchnikoffs introductie van 
het begrip 'gerontologie' echter in I901 gedateerd hebben. Zie: Pouw, A. Oud, maar wijs genoeg? De Nederlandse Vereniging voor Gerontologie 1947-1987. Lochem [etc.]: De Tijdstroom, 1987 (p. 13); Polisar, D. e.a. Where Do We Come From? What Are We? Where Are We Going? An Annotated Bibliography of Aging and the Humanities. Washington, DC: The Gerontological Society of America, 1988 (p. I09); Achenbaum, W.A. en Levin, J.S. What Does Gerontology Mean? The Gerontologist 29 (1989) 3, 393-400.

Het begrip 'geriatrie' verwijst in deze publikaties meestal naar het klinisch specialisme geriatrie, maar wordt ook wel omschreven als een wetenschap die zich bezighoudt met de bestudering van (de behandeling van) ziekten die op hogere leeftijd vaker voorkomen. De term 'gerontologie' staat vandaag de dag voor een multidisciplinair vakgebied waarbinnen zowel verouderingprocessen als vraagstukken rond ouderen worden bestudeerd en waarin verschillende takken worden onderscheiden: de biologische en biomedische of 'experimentele' gerontologie, de medische of 'klinische' gerontologie en de sociale gerontologie. Onder het kopje 'sociale gerontologie' valt een brede waaier van onderzoek. Er worden zowel psychologische, pedagogische, andragogische, sociologische, sociaal-geneeskundige, epidemiologische, demografische, antropologische, sociaal-geografische en planologische studies als economische, juridische, historische en architectonische publikaties toe gerekend. De hoofdmoot van de sociale gerontologie bestaat niettemin uit de psycho-gerontologie, de sociogerontologie en de sociale geneeskunde. Zie ook: Bezooijen, C.F.A. Biomedical gerontology in the Netherlands. TGG I8 (1987) 2a, 139146; Bok, P. de. Gerontologie, wat is dat? S.l.: NFB/NIG, 1984; Fockert, J.A. De klinische geriatrie, quo vadis? Voorzichtige overwegingen bij de toekomst van een nieuw specialisme. TGG 15 (1984) 35-39; Haaijman, J.J. en Van den Borne, H.W. Gerontological Research in the Netherlands. An Inventory. NTG 9 (1978) 3, 157-164; Hellemans, J. en Kammen-Wijnmalen, E.H.W. van. De ontwikkeling van de geriatrie tot een medisch specialisme. TGG ${ }_{3}$ (1982) 2, 53-59; Hollander, C.F. Experimental gerontological research. NTG 9 (1978) 3, 125-128; Munnichs, J.M.A. en Diesfeldt, H.F.A. Psychology of aging. An overview of research in the Netherlands. TGG 18 (1987) 2a, I17-I29; Ringoir, D.J.B. en Zonneveld, R.J. van. Aspecten van gezondheidsvoorzieningen voor ouderen. In: Schouten, J., Leerling, C. en Bender, J. (Red.) Leerboek geriatrie. Utrecht/Antwerpen: Bohn, Scheltema en Holkema, 1985: 44-53; Santvoort, M.M. van. Gerontologie in Neder- 
land. Een momentopname van het gerontologisch onderzoek in Nederland. Nijmegen: NIG, 1988; Santvoort, M.M. van en Zanden, G.H. van der. Het wetenschappelijk onderzoek. In: Aakster, C.W. (Red.) Oud. Beeld van ouderen en ouderenzorg. Groningen: Wolters-Noordhoff, 1987: 244248.

Veel auteurs situeren de start van een meer systematische bestudering van verouderingsvraagstukken in ieder geval in de jaren twintig en dertig van deze eeuw. De institutionalisering van de gerontologie en geriatrie via (inter)nationale organisaties en vaktijdschriften heeft zich echter overwegend vlak vóór en vlak ná de Tweede Wereldoor$\log$ afgespeeld. De instelling van leerstoelen volgde veelal later. Zie ondermeer: Adler, M. History of Gerontological Society, Inc. Joumal of Gerontology (1958) 13, 94-100; Beauvoir, S. de. Ouderdom en biologie. In: De ouderdom. Maatschappelijke situatie van bejaarden en persoonlijke zingeving in de laatste levensfase. Utrecht: Erven J. Bijleveld, 1987 (oorspr. 1970): 19-33; Behrend, C., Dieck, M. en Kondratowitz, H.-J. von. Notes on the development of socio-gerontological research in de Federal Republic of Germany (FRG) and on selected findings and theories. In: Amann, A. (Ed.) Social-Gerontological Research in European Countries - History and Current Trends. Berlin/Vienna: German Centre of Gerontology, 1984; Bezooijen (1987) op. cit.; Birren, J.E. A brief history of the psychology of aging. Part 1/II. The Gerontologist I (I96I) 1, 69-77/127-134; Falck, 1. Die Geschichte der Deutschen Gesellschaft für Gerontologie. Zeitschnift für Gerontologie 20 (1987) 163-167; Fennell e.a. (1988) op. cit.; Freeman, J.T. Aging. Its history and literature. New York [etc.]: Human Sciences Press, 1979; Goedhard, W.J.A. Research and development in geriatrics in the Netherlands. TGG 18 (1987) 2a, 147-157; Kooy, C. van der. Van oude mensen vroeger en nu. Over de geschiedenis van de ouderdom en de zorg voor oude mensen. Deventer: van Loghum Slaterus, 1987; Munnichs, J.M.A. Psychogerontologie: een jonge discipline. Nederlands Tijdschrift voor de Psychologie 42 (1987) 3-10; Munnichs, J. De oudere mens en de wetenschap. In: Voorzieningen voor ouderen: visie op ouderdom. Deventer: Van Loghum Staterus, 1984: $71-76$ (oorspr. 1978); Paillat, P. Development of social-gerontological research in France. In: Amann (1984) op. cit. pp. 179-200; Pouw (1987) op. cit.; Proosdij, C. van. Klinische geriatrie - 'un peu d'histoire'. NTvG (1977) I2I, 152-56; Sheldon, J.H. A History of British Geriatrics. Modem Geriatrics (1971) 1, 457-464; Sipsma, D.H. Klinische geriatrie, een medische odyssee. Rede uitgesproken bij de aanvaarding van het ambt van hoogleraar in de Klinische Geriatrie aan de Rijksuniversiteit te Groningen 
op dinsdag 9 febnuari 1993. Groningen, 1993

II. Zie ondermeer: Amann (1984) op. cit. pp. 3-14; Behrend e.a. (1984) op. cit.; Philibert, M.A. The Emergence of Social Gerontology. Joumal of Social Issues 21 (1965) 4-12

12. Pouw (1987) op. cit. (p. 14); Munnichs,J.M.A., Nies, H.L.G.R., Lako, C.J. en Zonneveld, R.J. van. The state of the art in psycho-and social gerontology in the Netherlands. In: Amann (1984) op. cit. pp. 261298

13. Kohli, M. The World We Forgot: A Historical Review of the Life Course. In Marshall, W.V. (Ed.) Later Life: The Social Psychology of Aging. London: Sagè, 1986: 271-303; Kohli, M. Thesen zur geschichte des Lebenslaufs als sozialer Institution. In: Conrad, C. en Kondratowitz (1983) op. cit. pp. 133-147; Kohli, M. en Meyer, J.W. Social Structure and Social Construction of Life Stages. Human Development 29 (1986) 145-180. Zie ook Chudacoff over Kohli in: Chudacoff, H.P. Introduction/Conclusion. In: How old are you? Age Consciousness in American Culture. Princeton, N.J.: Princeton University Press, 1989: 3-8/183190

14. Kohli (1986) op. cit.

I5. Chudacoff (1989) op. cit. Ook het werk van J. Baars is verwant aan dat van Kohli: Baars, J. De sociale constitutie van de ouderdom. In: Knipscheer, Baars en Severijns (1988) op. cit. pp. $21-36$ (Baars laat zich hierin echter (mede) theoretisch inspireren door het werk van Jürgen Habermas); Baars, J. Het regime van de klok. Over de chronologisering van de moderne levensloop. Amsterdams Sociologisch Tijdschrift I8 (1991) 2, 100-120

16. Zo stelt Tamara Hareven dat in de sociale constructie van de levensloop zowel demografische veranderingen als sociaal-economische veranderingen - die ondermeer tot de introductie van wetgeving ten aanzien van kinderarbeid en pensionering hebben geleid - een rol speelden. Hareven, T.K. Historical Changes in the Social Construction of the Life Course. Human Development 29 (1986) 3, 171-180; Hareven, T.K. The last stage: historical adulthood and old age. In: Tassel, D.D. van (Ed.) Aging, death and the completion of being. Philadelphia: University of Pennsylvania Press, 1979

17. Zie ondermeer: Conrad, C. Die Entstehung des modernen Ruhestandes. Deutschland im internationalen Vergleich I850-1960. Geschichte und Gesellschaft 14 (1988) 4, 417-447; Conrad (1984) op. cit; Conrad, C. Zur Konstitution einer Lebensphase als Gegenstand von Sozialpolitiek. In: Conrad, C. en Kondratowitz, H.-J. von (Hg.) Ge- 
rontologie und Sozialgeschichte. Wege zu einer Historischen Betrachtung des Alters. Berlin: Deutsches Zentrum fur Altersfragen, r983: 365-378; Conrad, C. Vorgeschichte und Verwirklichung staatlicher Alterssicherung/Lebensverhältnisse und Sozialleistungen (1880-1933). In: Vom Greis zum Rentner. Der Struktunvandel des Alters in Deutschland zwischen 1830 und 1930. Göttingen: Vandenhoeck \& Ruprecht, 1994: 207261/289-346; Ehmer (1990) op. cit.; Thane. P. Old Age in English History. In: Conrad en Kondratowitz (1993) op. cit. pp. 17-37; Winters, W. Die staatshulp wenschen wij... Pensioenstrijd in Nederland. 's-Gravenhage: SDU uitgeverij, 1990.

Uiteraard hebben niet alle historici die zich met het ontstaan van pensioenvoorzieningen bezighielden deze geschiedenis in termen van een sociale constructie van de ouderdom beschreven. Ook los van dat perspectief is veel gepubliceerd over de achtergronden van pensioenregelingen en de leeftijdsgrenzen binnen die regelingen. Veel van deze publikaties, met name die over Nederland, concentreren zich op de politieke debatten over pensioenwetgeving en sociale zekerheid. Dat geldt ondermeer voor: Mannoury, J. Een gouden nap voor iedereen? Achtergronden van de totstandkoming van de Algemene Ouderdomswet. De Gids I52 (1989) 6, 446-460; Roebroek, J.M. The (political) history of the Dutch Pensions. In: The 'Silent' Revolution. Structure, Development and Future of the Dutch pensions. Tilburg: Studierichting Sociale Zekerheidswetenschap, Katholieke Universiteit Brabant, 1991: 13-22; Royers, T. en Winters, W. 100 jaar pensioenstrijd in Nederland 1884-1984. S.l: s.n., 1984; Velema, W. De oudedagsvoorziening in Nederland: toen, nu en in de toekomst. In: Krop, M. e.a. (Red.) Het achtste jaarboek voor het democratisch socialisme. Amsterdam: De Arbeiderspers, 1987: 57-89; Winters, W. ANBo bestaat 85 jaar. 'Ik ga op voor hen wier levenszon ondergaat'. $L$ (1986) $4,23-25$. Daarnaast bestaan verschillende publikaties die de geschiedenis van pensioenregelingen in een breder (historisch en/of theoretisch) perspectief plaatsen: Dumons, B. en Pollet, G. Les combats pour l'assurance-vieillesse en europe au tournant du xxe siècle. Gérontologie et Société. Cahier de la Fondation nationale de Gérontologie 49 (1989) 70-84; Hannah, L. Accident and design in the evolution of pensions/Retirement: age discrimination or the fruits of prosperity? In: Inventing retirement. The Development of Occupational Pensions in Britain. Cambridge: Cambridge University Press, 1986: 85-90/122-137; Göckenjan, G. 'Solange uns die Sonne leuchtet, ist Zeit des Wirkens'. Zum Wandel des Motivs: Leistung im Alter. In: Göckenjan, G. en Kondratowitz, H.-J. von ( $\mathrm{Hg})$ Alter und 
Alltag. Frankfurt am Main: Suhrkamp Verlag, 1988: 67-99; Quadagno, J.S. Work and retirement. In: Aging in early industrial society. Work, Family, and Social Policy in Nineteenth-Century England. New York [etc.] Academic Press, 1982: 139-169; Stearns, P. Old Age in French Working-Class Culture/Toward a New Style of Life. In: Stearns, P. Old age in European Society. London: Croom Helm, 1977: 42-79/1 $38-155$. Bovendien geven enkele Nederlandse publikaties over de geschiedenis van de armenzorg en werklozenzorg eveneens enige aandacht aan de historie van pensioenregelingen: Loo, L.F. van. 'Den arme gegeven...' Een beschrijving van armoede, armenzorg en sociale zekerheid in Nederland, 1784-1965. Meppel [etc.]: Boom, 1981; Rooy, P. de. Werklozenzory en werkloosheidsbestrijding 1917-1940. Landelijk en Amsterdams beleid. Amsterdam: Van Gennep, 1979; Valk, L. van der. Van pauperzorg tot bestaanszekerheid. Ammenzorg in Nederland 1912-1965. Proefschrift Rotterdam, 1986

18. Haber, C. Mandatory retirement in nineteenth century America: The conceptual basis for a new work cycle. Joumal of Social History 12 (1978/79) 77-96; Haber, C. Beyond Sixty-Five: The Dilemma of Old Age in America's Past. Cambridge: England, r983; Haber, C. From senescence to senility: the transformation of senile old age in the nineteenth century. International Joumal of Aging and Human Development i9 (1984) I, 41-45. Zie ook: Gratton, B. The infant geriatrics. International Joumal of Aging and Human Development 19 (1984) 3, 253-256

19. Harper, S. en Thane, P. The Consolidation of 'Old Age' as a Phase of Life, 1945-1965. In: Jefferys, M. (Ed.) Growing Old in the Twentieth Century. London [etc.]: Routledge, 1989: 43-6r; Roebuck (1979) op. cit.; Roebuck, J. en Slaughter, J. Ladies and pensioners: stereotypes and public policy affecting old women in England, 1880I940. Joumal of Social History 13 (1979) ro5-114; Thane, P. The muddled history of retiring at 60 and 65. New Society (1978) 234-236; Winters, W. De dalende ondergrens van de ouderdom. Spiegel Historiael. Maanblad voor geschiedenis en archeologie 9 (1990) 406-410

20. Conrad, C. (1988) op. cit. Op eenzelfde manier waakt ook Hans-Joachim von Kondratowitz ervoor 'institutionele macht' een te dominante rol in zijn geschiedschrijving te laten spelen. Kondratowitz, H.-J. von. Zum historischen Konstitutionsprozess von 'Altersgrenzen'. In Conrad en Kondratowitz (1983) op. cit. pp. 379-4II

21. Kirk, H. Geriatric Medicine and the Categorisation of Old Age - the Historical Linkage. Ageing and Society 12 (1992) 4, 483-497 
22. Achenbaum, W.A. Reconstructing GsA's History, The Gerontologist 27 (1987) 1, 21-29; Calhoun, R.B. Biological and Social Scientists and the Problem of Aging Stereotypes/Social Scientists and Images of the Aged: Providing the Basis for Action. In: In search of the new old: redefining old age in America, 1945-1970. New York [etc.]: Elsevier, 1978: $67-127$

23. Armstrong, D. Disciplines of the survey: 4- geriatrics. In: Political anatomy of the body. Medical knowledge in Britain in the twentieth century. Cambridge [etc.]: Cambridge University Press, 1983: 85-92 (p. 88)

24. Brakel, W.P. van en Bommel, J. van. Zes eeuwen bejaard Rotterdam. Verzorging en huisvesting van bejaarden te Rotterdam. Rotterdam: Dienst van Volkshuisvesting Rotterdam, 1971; Haber, C. Institutionalizing the Elderly. In: Haber (1983) op. cit. pp. 82-107; Leeden, C.B. van der. De ontuikkeling van diaconiehuis tot gemeentelijk tehuis voor ouden van dagen te Rotterdam 1906-1956. Rotterdam: s.n., 1956; Pley, G. Liefdewerk en bejaardenzorg. Verkenningen in de historie van de R.K. Stichting Verzorgings- en Verpleegtehuis Bemardus te Amsterdam, 1839-1989. Amsterdam: R.K. Stichting Verzorgings- en Verpleegtehuis Bernardus, 1989; Veen, W.K. van der. 'Ten tijde des avonds...'. Vijftig jaren bejaardentehuis 'Avondlicht' en wat daaraan voorafging: diakonale bejaardenhuisvesting te Groningen. Groningen: Diakonie Hervormde Gemeente, 1984; Veen, W.J. van der en Poppel, F. van. Institutionele zorg voor ouderen in de tweede helft van de r9e eeuw. Een case-study. TGG 23 (1992) 2, 60-66; Veen, W.J. van der en Poppel, F. van. Institutional Care for the Elderly in the roth Century: Old People in The Hague and their Institutions. Ageing and Society 12 (1992) 2, 185-212; Vlodrop, J. van. Van gasthuisbed tot verzorgingsflat. $O L$ (1975) 3, 14-16; Wolf, H.C. de. 58 miljoen Nederlanders en hun bejaarden. Amsterdam: Uitgeverij Amsterdam Boek, 1977

25. Stearns (1977) op. cit. (p. 12); Ehmer (1990) op. cit. (p. 193). Historici zijn het erover eens dat, voor zover bekend, steeds slechts een minderheid -3 tot $5 \%$ - van de ouderen in instituten heeft geleefd. Wat betreft Amsterdam is in de negentiende eeuw echter een stijging geconstateerd, terwijl voor Engeland tussen de pre-industriële periode en de jaren tachtig van deze eeuw een daling is gedocumenteerd. Ehmer (1990) op. cit.; Stavenuiter (1993) op. cit.; Wall, R. Residential Isolation of the Elderly: A Comparison over Time. Ageing and Society 4 (1984) 4, 483-503

26. Kondratowitz, H.-J. von. Allen zur Last, niemandem zur Freu- 
de. Die institutionelle Prägung des Alterserlebens als historischer Prozeß. In Göckenjan en Von Kondratowitz (1988) op. cit pp. 100-136. Een soortgelijke redenering is te vinden bij Ehmer. Ehmer (r990) op. cit.

27. Dat geldt ondermeer voor een aantal studies dat de formulering van problemen en oplossingen op overheidsniveau tot onderwerp heeft. Blommestijn, P.J. Ouderenbeleid in Nederland van 1955 tot 1985. Een beleidshistorisch evaluatie-onderzoek. [Bewerkt door prof. dr. A. Hoogerwerf]. Enschedé: Universiteit Twente, Faculteit der Bestuurskunde, 1990; Winters, W. 'Hoort regeerders van het land...' Uit de geschiedenis van het ouderenbeleid. Leiden: Stichting Burgerschapskunde [etc.], 1988; Zwier, J. Het overheidsbeleid ten aanzien van ouderen. Ars Aequi 37 (1988) 1o, 633-642. Slechts Naafs spreekt van de 'veronderstelde negatieve aspecten van de vergrijzing'. Naafs, J. Maatschappelijke beeldvorming over ouderen en ouderenbeleid. In: Blom, M.M., Kuin, Y., Hendriks, H.F.J. (Red.) Ouder worden '93. Voordrachten gehouden tijdens het gerontologisch symposium 'Ouder worden' op 18 en 19 november 1993 in het Beurs-World Trade Center te Rotterdam. Utrecht: Nederlands Instituut voor Zorg en Welzijn, 1993: pp. 291-294 (p. 292)

28. Bourdelais, P. Vieillissement de la population ou artefact statistique? In: Paillat, P. (Ed.) L'age à travers les ages. Gérontologie et société (1989) 4, 22-32; Ehmer (1990) op. cit.; Macintyre, S. Old age as a social problem. Historical Notes on the English Experience. In: Dingwall, R. e.a. (Eds.) Health care and health knowledge. London [etc.]: Croom Helm/New York: Prodist, 1977: 41-63; Means (1986) op. cit.; Means, R. en Smith, R. Introduction. In: The development of welfare services for elderly people. London [etc.]: Croom Helm, 1985: 1-16; Praag, $\mathrm{Ph}$. van. De Crisisjaren. Veranderende leeftijdsstructuur. In: Het bevolkingsvraagstuk in Nederland. Ontwikkeling van standpunten en opvattingen (19181940). Deventer: Van Loghum Slaterus, 1976: 79-83; Thane, P.M. The debate on the declining birth-rate in Britain: the 'menace' of an ageing population, 19205-1950s. Continuity and change s (1990) 2, I-23

29. Heuvel, W.J.A. van den. Zelfstandigheid van ouderen en de bijdrage van de wetenschap. In: Brouwer, W.H. e.a. (Red.) Grijze cellen, wijze cellen? Groningen: Interfacultaire Werkgroep Gerontologie [etc.], 1989: 69-77; Timmermans, J.M. Overheid en ouderenprobleem in Nederland. In: Borghardt, M.B. e.a. (Red.) Sociale problemen in België en Nederland. [Amsterdam]: sıswo, 1988: IOI-I I I

30. Kohli (1986) op. cit.; Kohli, M. en Wolf, J. Altersgrenzen im Schnittpunkt von betrieblichen Interessen und Individueller Lebens- 
planung. Das Beispiel des Vorruhestands. Soziale Welt 38 (1987) 92109; Kohli, M. en Rein, M. The changing balance of work and retirement. In: Kohli, M. e.a. (Eds.) Time for retirement. Comparative Studies of Early Exit from the Labour Force. Cambridge: Cambridge University Press, 1991: 1-35

3I. Guillemard, A.M. The Trend Towards Early Labour Force Withdrawal and the Reoganisation of the Life Course: A Cross-national Analysis. In: Johnson, Conrad en Thomson (1989) op. cit. pp. 164-180; Guillemard, A.-M. en Gunsteren, H. van. Pathways and their prospects: A comparative interpretation of the meaning of early exit. In: Kohli e.a. (1991) op. cit. pp. 362-387. Zie voor een beargumentering van verschijnselen van de-institutionalisering ook: Held, Th. Institutionalization and Deinstitutionalization of the Life Course. Human Development 29 (1986) 157-162

32. Smolenaars, E. Rustgeld of roestgeld - pensioen en de doorbreking van leeftijdsgrenzen. In: Blom, Kuin en Hendriks (1993) op. cit. pp. 519-524. Smolenaars verwijst daarbij naar: Henretta, J.C. Uniformity and Diversity: Life Course Institutionalization and Late-life Work Exit. The Sociological Quarterly 33 (1992) 2, 265-279

33. Smolenaars, E. (1993) op. cit. Smolenaars schrijft bovendien darbij verwijzend naar andere auteurs - dat ook de levensloop van zelfstandigen, werknemers van kleine bedrijven en werknemers met niet-traditionele arbeidscontracten buiten beschouwing is gebleven. Bovendien zouden de studies meer op de Europese dan op de Amerikaanse en Japanse situatie zijn gericht.

34. Kohli en Rein (1991) op. cit.; Minkler, M. Overview. In: Minkler, M. en Estes, C.L. (Eds.) Critical Perspectives on Aging. The Political and Moral Economy of Growing Old. Amityville, New York: Baywood Publishing Company, 1991: 3-17

35. Thane, P. Geriatrics. In: Bynum, W.F. en Porter, R. (Eds.) Companion Encyclopedia of the History of Medicine. Londen: Routledge, 1993: vol. II, 1092-I I I 5; Kondratowitz, H.-J. von. The medicalization of old age. Continuity and change in Germany from the late eighteenth to the early twentieth century. In: Pelling en Smith (199I) op. cit. pp. 134-164; Kondratowitz, H.-J. von. Die Medikalisierung des höheren Lebensalters. Kontinuität und Wandlungen vom ausgehenden $\mathrm{I} 8$. bis zum frühen 20. Jahrhundert. In: Labisch, A. und Spree, R. (Hg.) Medizinische Deutungsmacht im sozialen Wandel des 19. und frühen 20. Jahrhunderts. Bonn: Psychiatrie-Verlag, 1989: 207-222. Kondratowitz liet zich bij zijn onderzoek mede inspireren door het werk van Lepe- 
nies en Koselleck.

36. Smith, R.M. The Structured Dependence of the Elderly as a Recent Development: Some Sceptical Historical Thoughts. Ageing and Society 4 (r984) 4, 409-428

37. Zie voor een discussie van deze kritiek ondermeer: Hunt, E.H. Abstract. In: Hunt, E.H. Paupers and Pensioners: Past and Present. Ageing and Society 9 (1989) 4, 407-430; Pelling, M. en Smith, R.M. Introduction. In: Pelling en Smith (1991) op. cit. pp. I-38; Thomson, D. The welfare of the elderly in the past: a family or community responsibility? In: Pelling en Smith (I99I) op. cit. pp. 194-217; Bulder, E. The responsibility assumed by the collectivity/The role of the collectivity. In: Bulder, E. The social economics of old age. Strategies to maintain income in later life in the Netherlands 1880-1940. Rotterdam: Thesis $\mathrm{Pu}-$ blishers/Tinbergen Institute, 1993: 46-52/103-1 16. Thomson vergeleek de 'moderne' ouderdomspensioenen met invaliditeitspensioenen voor mannen en weduwenpensioenen voor vrouwen. Daarmee zou hij, aldus één van de kritiekpunten op zijn werk, appels met peren hebben vergeleken.

De term 'whiggish history' werd in 1965 door Georg Stocking geïntroduceerd. Een 'whiggish' werkende historicus '(..) seeks out in the past phenomena which seem to resemble those of concern in the present, and then moves forward in time by tracing lineages up to the present in simple sequential movement. When this abridging procedure is charged with a normative commitment to the phenomena whose origins are sought, the linear movement is "progress" and those who seem to abet it are "progressive". The result is whiggish history. Because it is informed by a normative commitment, its characteristic interpretive mode is judgement rather than understanding, and history becomes the field for a dramatic struggle between children of light and children of darkness. Because it wrenches the individual historical phenomenon from the complex network of its contemporary context in order to see it in abstracted relationship to analogues in the present, it is prone to anachronistic misinterpretation. Because it assumes in advance the progressive character of historical change, it is less interested in the complex processes by which change emerges than in agencies which direct it, whether they be great men, specific deterministic forces, or the "logic" of historical development itself.' Stocking, G.W. On the Limits of 'Presentism' and 'Historicism' in the Historiography of the Behavioral Sciences. Joumal of the History of the Behavioral Sciences I (1965) 2II-218. Herdrukt in: Stocking, G.W. Race, Culture, and 
Evolution: Essays in the History of Anthropology. New York: Free Press, 1968: I-12 (p. 3-4). Geciteerd in: Jones, R.A. On Merton's 'History' and 'Systematics' of Sociological Theory. In: Graham, L., Lepenies, W. en Weingart, P. (Eds.) Functions and Uses of Disciplinary Histories. Dordrecht [etc.]: D. Reidel Publishing Company, 1983: 121-142 (pp. 122-123)

38. Blaikie, A. The Emerging Political Power of the Elderly in Britain 1908-1948. Ageing and Society 10 (1990) 17-39: Jefferys (1989) op. cit.; Kohli, M. Ageing as a Challenge for Sociological Theory, Ageing and Society 8 (1988) 367-394

39. Walker (1983) op. cit. Verschillende historici menen echter, dat - hoewel voor de Eerste Wereldoorlog arbeiders veelal een ambivalente houding ten aanzien van de pensionering innamen - de acceptatie van de pensionering vanaf het eind van de jaren vijftig van deze eeuw onder de meeste groepen werknemers is toegenomen. King, G.B. en Stearns, P.N. The retirement experience as a policy factor: an applied history approach. Joumal of Social History 14 (1980-8I) 589-615; zie ook Ehmer (1990) op. cit. John Macnicol en Andrew Blaikie benadrukken, in de lijn van Walker, dat de Engelse vak- en ouderenbeweging de pensionering - en daarmee een positie van geïnstitutionaliseerde afhankelijkheid - weliswaar aanvaardde, maar niet zonder verzet en alleen omdat zij niet anders kon. Het was de prijs die zij noodgedwongen moest betalen voor haar streven naar een waardige ouderdom en beloning van langdurige arbeid an de ene kant en bescherming van jongere werknemers aan de andere kant. Macnicol, J. en Blaikie, A. The Politics of Retirement, 1908-1948. In: Jefferys (1989) op. cit. pp. 21-41. Graham Fennell, eveneens van politiek-economische huize, wil pensioenregelingen echter niet uitsluitend zien als voorzieningen die afhankelijkheid construeren. Pensioenregelingen creëren weliswaar een levensfase van gedwongen terugtrekking uit arbeid, maar functioneren ook als voorzieningen om verlies van zelfstandigheid op andere vlakken te compenseren. Fennell, G. Structured dependency revisited. In: Phillipson, C., Bernard, M. en Strang, P. (Eds.) Dependency and Interdependency in Old Age: Theoretical Perspectives and Policy Altematives. London: Croom Helm, 1986

40. Munnichs, J.M.A. Reflexies over gerontologisch onderzoek en belemmeringen daarbij. De Psycholoog 12 (1977) 3, 109-116

41. Borne, H.W. van den en Snellen, I.Th.M. Welzijnsconcepties in het bejaardenbeleid. Verslag van een onderzoek. TGG $\left.\mathrm{I}_{4}\left(\mathrm{I}_{98}\right)_{3}\right)_{3}$, II5-I19; Heuvel, W.J.A. van den. Het gebruik van gerontologisch 
onderzoek bij beleidsvoornemens gericht op ouderen. In: Knipscheer, C.P.M. (red.) Sociologie van het ouder worden sinds 1970. Onderzoek en beleid. Krimpen aan de IJssel/Nijmegen: NVG/NIG, 1985: 86-98; Heuvel, W. van den. Onderzoek over het ouder worden: Enkele ontwikkelingen en het belang ervan. Trefpunt Speciaal (1984) 46-48; Houben, P.P.J. Toepassing van onderzoek in beleidsnota's inzake ouderenhuisvesting. TGG 16 (1985) 2, 45-50; Kraan, J.R. Interactie tussen onderzoek en beleid beschouwd vanuit het Stafbureau Onderzoek van het Departement van Welzijn, Volksgezondheid en Cultuur: Enige ervaringen in de afgelopen tien jaar. In: Knipscheer (1985) op. cit. pp. 69-85; Kronjee, G.J. De invloed van de wetenschap op het beleid voor ouderen. TGG 13 (1982) I, 2-7

42. Minkler, M. Overview. In: Minkler en Estes (1991) op. cit. pp. 3-17; Minkler, M. en Cole, Th.R. Political and Moral Economy. Not Such Strange Bedfellows. In: Minkler en Estes (1991) op. cit. pp. 37-49; Myles, J. Postwar capitalism and the extension of social security into a retirement wage. In: Minkler en Estes (I991) op. cit. pp. 293309; Pampel, F.C. Review of Minkler en Estes (1991) op. cit. Ageing and Society 12 (1992) I, 125-126; Warren, L. Moral Economy and Old Age. Ageing and Society 13 (1993) I, 107-112

43. Hudson, R.B. Misunderstood, critical, and new: divergent views of contemporary aging policy. The Gerontologist 32 (1992) 5 . 708-711; Kohli, M. Retirement and the moral economy: An historical interpretation of the german case. In: Minkler en Estes (1991) op. cit. pp. 273-29I

44. Zonneveld, R.J. van. Forty years of gerontological research in the Netherlands. A comment on some topics. TGG 18 (1987) 5. 298-99

45. Veldhuijzen van Zanten-Hyllner, M. De geschiedenis van de verpleeghuisgeneeskunde. Vox Hospitii 12 (1988) 2, 41-43

46. Avorn, J.L. Medicine, health and the geriatric transformation. Daedalus (1986) I15, 211-225; Fox, D.M. The perception of chronic illness in health policy: Britain and America, 1930s-1960s. In: Program, Papers and Abtstracts for the Joint Conference Manchester, England, 11-15 July 1988 , British Society for the history of science and the history of science society, Proosdij, C. van en Sipsma, D.H. Dertig jaar vaderlandse geschiedenis. De lijdensweg van de klinische geriatrie in Nederland. Tijdschrift voor Gerontologie en Geriatrie 15 (1984) 3-5; Rosenberg, C.E. The Aged in a Structured Social Context: Medicine as a Case Study. In: Van Tassel en Stearns (1986) op. cit. pp. 231-245; Sipsma (1993) op. cit. 
47. Munnichs, Nies, Lako en Van Zonneveld (1984) op. cit.

48. Knipscheer, K. Sociological research on age, aging and the aged in the Netherlands. Tijdschrift voor Gerontologie en Geriatrie 18 (1987) 2a, 130-137

2 Bevolkingsveroudering: het profiel van een publiek probleem

I. Een deel van dit hoofdstuk werd eerder gepubliceerd als lezing. Bijsterveld, K. Het 'bejaardenvraagstuk': het denken over problemen rond ouderen in Nederland, 1945-1982. In: Blom, M.M., Kuin, Y. en Hendriks, H.F.J. Ouder worden '93. Voordrachten gehouden tijdens het gerontologisch symposium 'Ouder worden' op 18 en 19 november 1993 in het Beurs-World Trade Center te Rotterdam. Utrecht: Nederlands Instituut voor Zorg en Welzijn, 1993: 179-187. 'Bevolkingsveroudering' heeft zowel betrekking op 'ontgroening' (het kleiner worden van het aandeel van jongeren in de bevolking als geheel) als op 'vergrijzing' (het groter worden van het aandeel van ouderen in de totale bevolking). Bevolkingsveroudering en vergrijzing betekenen strikt genomen dus niet hezelfde, maar ten behoeve van de leesbaarheid en de afwisseling zijn de termen in dit hoofdstuk door elkaar gebruikt, al is bij de parafrasering van de teksten van historische actoren altijd de woordkeus van die actoren gevolgd. Wanneer in de noten hieronder naar meer dan één tekst wordt verwezen, dan worden de teksten waaruit is geciteerd het eerst genoemd, waarna de overige titels - eventueel naar thema onderverdeeld - in chronologische volgorde volgen.

2. Nederland wordt ouder maar wil het niet weten. De Groene Amsterdammer. Weekblad voor Nederland 27 september 1947

3. Maas, P. van der. Mythen over vergrijzing en volksgezondheid. TSG 60 (1982) 23, $711-721$ (p. 711 )

4. Praag, Ph. van. Het bevolkingsvraagstuk in Nederland. Ontuikkeling van standpunten en opvattingen (1918-1940). Deventer: Van Loghum Slaterus, 1976

5. Methorst, H.W. Enkele belangrijke demografische feiten. Mensch en Maatschappij 2 (1926) 407-429 (p. 429)

6. Van Praag (1976) op. cit. en Zanten, J.H. van. De toeneming v.h. aantal oudelieden. De Sociale Verzekeningsgids 18 (1938) 9, 135-137

7. Zie voor literatuur hierover: noot 17 van hoofdstuk 1.

8. Sleeswijk, J.G. Alt werden und jung bleiben. Wiener Medizinische Wochenschnift (1925) 25, 1496-I 500 en idem (1925) 26, I555-1 563 
9. Boeke, J. Problemen der onsterfelijkheid. Leven, dood, levensduur en onsterfelijkheid, biologisch beschouwd. Amsterdam: J.M. Meulenhoff, 1941

10. Verrijn Stuart, C.A. De wetenschap der volkshuishoudkunde en de grondslagen der volkshuishouding. Haarlem: 1930 (3 de druk) (p. 306) geciteerd in Idenburg, Ph.J. De statistiek van de levensduur. In: Sleeswijk, J.G. (Red.) De ouderdom van geneeskundig standpunt beschouwd. Een handboek voor artsen. Deel 1. Algemeen Gedeelte. Amsterdam/Antwerpen: Uitgeverij Kosmos, 1948: 22-63 (p. 37)

11. Spek, J. van der. De psychologie van den Ouden dag. (Overdruk uit Ons godsdienstondenvijs, No. 6, Mei 1925) Zalt-Bommel: Uitg. Mij en Boekh. v.h. P.M. Wink, [1925]

12. Rümke, H.C. Levenstijdperken van den man. Amsterdam: De Arbeiderspers, 1938 (p. 83)

13. Idenburg (1948) op. cit.

14. Behoort een nieuwe richting te worden gegeven aan onze oudeliedenzorg? (Inleiding gehouden op de Vergadering van de Algemeene Armencommissie met Voorzitters en Secretarissen van Armenraden op 8 Januari 1920.) Tijdschrift voor Ammenzorg en Kinderbescherming (1920) 970, 28-31; Rapport van de commissie, door het dagelijksch bestuur benoemd om een onderzoek in te stellen naar den toestand van de zorg voor ouden van dagen in Nederland. [Geschriften van de Nederlandsche Vereeniging voor Armenzorg en Weldadigheid te Amsterdam.] Haarlem: H.D. Tjeenk Willink \& Zoon, 1923 (p. 3, p. I9); De oudeliedenzorg te Amsterdam. Amsterdam: Centraal bureau voor maatschappelijk hulpbetoon te Amsterdam. [Geschriften van den armenraad te Amsterdam No. viII], 1924 (p. 13)

15. Zon-Soete, C. van. Vier en een half jaar practijk. Maandblad voor kerkelijke armenzorg 18 (I927) I, 3-9; Jong, A.A. de. Pro Senectute. De nieuwe Tehuizen te Sneek, Den Haag en Amsterdam. TAMK 6 (1927) 122, 1160-1163; [Kiers], G.F.E. Huisvesting van ouden van dagen. Maandblad voor kerkelijke armenzorg 19 (1928) I, 1-9; Rooseboom, M.P. 'Ons Thuis'. TAMK 7 (1928) 164, I829-1832

16. De vereeniging 'Pro Senectute'. (Voor den ouderdom). TAMK 4 (1925) 87, 612-615 (p. 612); Jaarverslagen - Pro Senectute in 1935. TAMK Is (1936) 355, 287-88; Opening van het tweede tehuis van Vredeheim. Maandblad voor kerkelijke ammenzorg I3 (1922) I2, 186I89, I9I; [Adriani], J.H. De Stichting 'Vredeheim' te Rockanje. TAMK $_{4}$ (1925) 88, 631-34; Everts, [J.] De verzorging in pensiontehuizen van ouden van dagen uit eenvoudigen kring. TAMK 19 (I940) $445,172-173$ 
17. Zie ondermeer: [Adriani], J.H. Het tehuis voor ouden van dagen 'Vredeveld' te Amstelveen. Maandblad voor kerkelijke anmenzorg I3 (1922) 8, I13-I2I en De oudeliedenzorg te Amsterdam. Rapport van de commissie tot het instellen van een onderzoek naar de oudeliedenzorg te Amsterdam. Amsterdam: Centraal Bureau van Maatschappelijk Hulpbetoon te Amsterdam, 1942

18. Rapport van de commissie (1923) op. cit. p. I8-19; Benner, J.B. Oudeliedenzorg - Nieuw leven. TAMK 5 (1926) 100, 817-8 19; Benner, J.B. Rekenen zonder cijfers. Maandblad voor kerkelijke armenzorg 18 (1927) 2, 17-23; Adriani, J.H. Voorlezingen over anmenzorg en maatschappelijk werk. Zutphen: Ruys, 1940 (3e dr.) (p. 180); De oudeliedenzorg te Amsterdam (1942) op. cit.

19. Rapport van de Commissie van onderzoek in zake de gemeentelijke armenverzorging over de oudeliedenverzorging in gestichten. Gemeenteblad [Amsterdam] Afdeeling I (1918) Bijlage H (p. 4, p. 6); De oudeliedenzorg te Amsterdam (1924) op. cit. p. 13; De oudeliedenzorg te Amsterdam (1942) op. cit. p. 5-8

20. Beyerman, Th. De geestelijke hygiëne van het oud-worden. $M V_{3}$ (1948) 419-424 (p. 419). Beyerman was ook degene die schreef dat de 'onvermurwbare niet over 't hoofd te ziene cijfers van de statistiek (..) 't onmogelijk [maken] nog langer problemen, welke het ouder worden der mensen meebrengt, te negeren'. (p. 4I9)

21. Meyer, J.A.J. Tijdsbesteding der bejaarden. In: De oudeliedenzorg. Prae-adviezen uitgebracht door Prof. Dr Ir H.G. van Beusekom, Drs J. Diederich, Dr Mr F.M. Havermans en Mr J.A.J. Meyer. Haarlem: H.D. Tjeenk Willink \& Zoon, I950: $84-132$ (p. 88). De rol van bejaarden als politieke belangengroep werd in de periode $1945-55$ overigens slechts door enkelen aan de orde gesteld. Zie: Zonneveld, R.J. van. Enkele beschouwingen over het ouderdomsvraagstuk en in het bijzonder over de bejaarde werkers. Mens en ondememing 7 (1953) 182-197 en Rubbens-Franken, E. De invloed van een groeiend aantal bejaarden op de samenleving. In: Rubbens-Franken, E. De ouder wordende mens in onze samenleving. Bussum: A. Voorhoeve, 1953: 19-25

22. Sleeswijk, J.G. Een woord vooraf. In: Sleeswijk (1948) op. cit. pp. v-viii (p. vi). Deel II (Clinisch Gedeelte) van dit handboek verscheen in 1949 .

23. Tuntler, J.H. Sociaal-geneeskundige kroniek. TAMK 20 (I94I) $458,24-26$ (p. 26). Een 'engeltjesmaakster' is volgens Van Dale (1984, p. 723) een 'vrouw die voor geld de verzorging van zeer jonge kinderen, vooral buiten huwelijk verwekt, op zich neemt en ze daarna door stelsel- 
matige verwaarlozing of verkeerde voeding langzaam laat sterven'. Met een engeltjesmaakster kan ook op een aborteuse worden gedoeld, maar gezien de vergelijking met tehuizen voor oude mensen, ligt de eerstgenoemde betekenis hier meer voor de hand. Dat de sociaal-geneeskundige kroniek van Tuntlers hand was, stond overigens niet bij de kroniek zelf vermeld, maar wel in de inhoudsopgave van het tijdschriftnummer in kwestie.

24. Muntendam, P. Ouderdomszorg. TSG 24 (1946) 9, 205-209; Tuntler, J.H. Oudeliedenzorg. $T M W_{\text {I }}$ (1947) 6, 93-94; De oudeliedenzorg. Verslag van het op 9 juni 1950 te Amhem gehouden congres ter behandeling van de prae-adviezen van Prof. Dr Ir H.G. van Beusekom, Drs J. Diederich, Dr Mr F.M. Havermans en Mr J.A.J. Meyer. Haarlem: H.D. Tjeenk Willink \& Zoon, 1950 (pp. 21-22); Dekhuyzen-Zeehuisen, I. Geriatrie. De Gemeente 6 (1951) 4, 40-42; Lely, R. Overzicht van het Bejaardenwerk van 1948 tot 1955. Raad en Daad [10] (1955) 12-14. Zie wat betreft de adviesbureaus, waarvan de taken overigens verschillend werden omschreven: Muntendam (1946) op. cit; Muntendam, P. De sociale betekenis van de ouderdom. In: Sleeswijk (1948) op. cit.: 65-9I; Beyerman (1948) op. cit.; Havermans, F.M. De adviesbureaux voor bejaarden. In: De oudeliedenzorg. Verslag (I950) op. cit.: 69-83; Semistatisch Archief Ministerie van Sociale Zaken en Werkgelegenheid, Departementaal Archief (hierna: Archief szw), dossiernr. 1.842.6, Nationaal Comité Oudeliedenzorg Amsterdam (hierna: NCO), Studiecommissie inzake Adviesbureaux voor Ouden van Dagen; Wartena, B. Bejaardenzorg in Friesland. TMW 10 (1956) 4, 52-56; Archief Ministerie van Volksgezondheid, Welzijn en Sport (hierna: Archief wvs), Archief Ministerie van Maatschappelijk Werk, inventarisnr. 351.842 .6 (hierna: Archief Mw), dossiernr. 1092, Werkconferentie van de Nederlandse Federatie voor Bejaardenzorg te Woudschoten op 13 en 14 November I956, stuk vi (p. 4), stuk viI (p. 4), stuk IX (p. 7), stuk XI (p. 1). Hoewel verschillende artsen, onder wie $T$. Beyerman, met advisering begonnen en er in verschillende steden plannen en experimenten hebben bestaan, is het adviesbureau in de vorm die Muntendam zich voorstelde nooit systematisch van de grond gekomen. Wel is op verschillende plaatsen ambulante hulpverlening ontstaan, die zich in de loop der tijd vooral in de richting van de geestelijke gezondheidszorg ontwikkeld heeft. Zie voor deze ontwikkeling: Robben, P. Ambulante geestelijke gezondheidszorg voor bejaarden, 1945-1992. MGV (1992) 11, 1209-1223. Zie wat betreft de bejaardenconcerter: Archief wvs, Archief Mw, dossiernr. 1092, Werkconferentie van de Neder- 
landse Federatie voor Bejaardenzorg te Woudschoten op I3 en I4 November 1956, stuk ma, Inleiding door A.J. Gijsbers (p. 6), stuk rv, stuk vIII (p. s). Een deel van de deelnemers aan deze werkconferentie meende overigens dat speciale voorstellingen voor bejaarden het groepsstigma zouden versterken. Zie wat betreft de toekomst van de ouderdomsgeneeskunde Nederlandse Vereniging voor Gerontologie. Vergadering gehouden in het Rijksinstituut voor de Volksgezondheid te Utrecht, op 14 juni 1947 . NTvG 92 (1948) 1, 70-76 en Nederlandsche Internisten Vereeniging. Vergadering op 26 november 1949 in het Stads- en Academisch Ziekenhuis te Utrecht. NTvG 94 (1950) 28, 2040-2052

25. Blokhuis, W.B.P.J. Sociale zekerheid en pensioenfondsen. ESB 30 (1945) 1493, 304-306; Campagne, C. De financiering van de sociale pensioenverzekering op het $13 \mathrm{e}$ Internationale Congres van Actuarissen. ESB 36 (1951) 1790, 663-665; Meerdink, J. Aspecten van de veroudering der Nederlandse bevolking. De Economist roo (1952) 495-524. Overigens wezen verschillende economen erop dat de economische druk in de eerste jaren na de oorlog niet hoger, maar lager werd en ging hun zorg tot ver in de jaren zeventig meer uit naar bevolkingsgroei dan naar bevolkingsveroudering. En voor zover de gevolgen van vergrijzing wel werden bestudeerd, was er niet alleen aandacht voor de economische druk, maar ook voor de consumptie, de produktie, de promotiekansen voor de jeugd en de emigratie. Zie voor de ontwikkelingen rond de Algemene Ouderdomswet: Sociale Zekerheid. Rapport van de commissie ingesteld bij beschikking van de Minister van Sociale Zaken van 26 maart 1943, met de opdracht algemeene richtlijnen vast te stellen voor de toekomstige ontwikkeling der sociale verzekering in Nederland. (3 delen) S.1.: s.n., 1945-1946; Nota inzake de toekomstige ouderdomsvoorziening van de Ministervan Sociale Zaken en Volksgezondheid en van de Staatssecretanis van Sociale Zaken. 's-Gravenhage: Staatsdrukkerij en -Uitgeverij, I952; Advies inzake de wettelijke ouderdomsverzekering uitgebracht aan de Minister van Sociale Zaken en Volksgezondheid en aan de Staatssecretaris van Sociale Zaken. 's-Gravenhage: Sociaal-Economische Raad, 1954; Verslag der handelingen der Staten-Generaal (hierna: Handelingen) 11 B I954-1955 4009 (Algemene Ouderdomsverzekering) MVT (nr. 3) 34. Zie voor de Noodwet Ouderdomsvoorziening: Handelingen Iв 1946-1947 362 (Noodwet Ouderdomsvoorziening)

26. Algemeen Rijksarchief Den Haag (hierna: ARA), Archief van de Nationale Raad voor Maatschappelijk Welzijn, lijstnummer 2.19.99 (hierna: Archief NRMw), inventarisnr. 89, Verslag van de Algemene 
Ledenvergadering van de Nederlandse Vereniging voor Maatschappe lijk Werk op 22 april 1949, punt sa (p. 73)

27. Zie ondermeer Muntendam, P. Ouderdomszorg. TSG 24 (1947) 18, 296; Muntendam, P. Arts en ouderdom. TMW I (1947) II, 161-162; Leopold Siemens, J. Een vergeten rubriek in het rappon inzake reorganisatie van de volksgezondheidszorg. $M C_{2}$ (1947) 281282; Muntendam, P. Maatschappelijke vraagstukken in verband met de ouderdom. $T M W_{3}$ (1949) 99-102; Beyerman, T. Enige opmerkingen over ouderdomszorg Raad en Daad [4] (1949) 7, 10-13, 17; Smit, J. Het vraagstuk der Ouden van Dagen. Katholiek Sociaal Tijdschrift 2 (1949/50) 5, 114-119; Berg, J.H. van den. De veroudering van de Bevolking. TSG 28 (I950) 5, 77-79; Rapport van de commissie ter bestudening van het vraagstuk van de oude dag. Amsterdam: Sociale Raad, 1950; Wat doelmatige bejaardenzorg zoal meebrengt ( $\mathrm{I})-(4)$. Onze Bejaar denzorg 1 (1950/5I) 3, 4 en 4, 3-4 en 6/7, 6 en 8, 1-2. Zie voor samenvattingen van het lokale levensomstandigheden-onderzoek: $R_{\ell}$. gister van Sociaal-Gerontologisch onderzoek, 1945-1964. Amsterdam: Noord-Hollandsche Uitgevers Maatschappij, 1966. Een van de daarin besproken rapporten was: Diederich, J. Levensomstandigheden van bejaarden in de provincie Utrecht. Utrecht: Stichting voor Maatschappelijk Werk in de provincie Utrecht, 1953

28. Everts, J. Onze instelling tegenover de ouden van dagen. In: De oudeliedenzorg. Verslag (1950) op cit.: 3-16 (p. 3). In hetzelfde jaar werd overigens ook in Rotterdam een studie-conferentie gehouden. Zie: Snoek, M.A.H. Studieconferentic over het oudeliedenvraagstuk. Gehouden Is en I6 April r95o in het conferenticoord 'De Tempel' bij Rotterdam. TMW 4 (1950) 11, 168-170

29. Zie voor het gebruik van de term 'noden' o.a. Meyer, J.A.J. Groei aan inzichten in de vraagstukken van ouderdom en bejaardenzorg. TMW s (1951) I29-133 (p. 132) en Everts (1950) op. cit. p. 5. Zie voor het uitdijen van het scala van noden, waaronder de kwesties 'voeding' en 'revalidatie': Rede van Dr P. Muntendam, Staatssecretaris van Sociale Zaken. In: De Oudeliedenzorg. Verslag (1950) op. cit. pp. 75-78; Rhijn, A.A. van. Bejaardenzorg. Diakonia [1953] 183-184; De ontwikkeling van de bejaardenzorg in verband met het maatschappelijk werk der burgerlijke overheid. Prae-adviezen, uitgebracht door de Vereniging van Openbare Diensten en Instellingen voor Sociale Zorg. Amsterdam [etc.]: Vereniging van Openbare Diensten en Instellingen voor Sociale Zorg, 1955; Riem Vis, W.C.A. De ontwikkeling van de bejaardenzorg in verband met het maatschappelijk werk der burgerlijke overheid. Sociale 
Zorg 17 (1955) 16, 249-255; Wartena, B. Bejaardenzorg 1. TSG 33 (I955) I8, 552-553

30. Havermans (1950) op. cit.

31. Tuntler (1947) op. cit.; Beyerman (1948) op. cit.; Querido, A. De geestelijke hygiëne van de ouderdom. MGV 3 (I948) 300-304; Meyers, F.S. Psycho-hygie̋nische beschouwingen over de Ouderdom. $T_{M W}$ (1949) 8, 1 16-I I9; Archief szw, dossiernr. 1.842.6, NCO. Studiecommissie inzake Adviesbureaux voor Ouden van Dagen, 'Concept-punten voor samenstelling van het advies van de Studiecommissie inzake Adviesbureaux voor Bejaarden' (I951) en 'Rapport over de adviesbureaux voor bejaarden' (1952)

32. Zie ondermeer Michielsen, A.B. Jonge mensen boven de 60. Onze Bejaardenzorg 2 (1951/52) I, 2-4; Onze Bejaardenzorg aan het werk! Ons Bejaardencentrum 3 (1952) 1, 2-3; Handelingen II 1952-1953 3507, Ів 1953-19543200 н XIIA vV (nr. 78) 12; Snelder, M.A. Bejaarden jonger dan U denkt! DB 4 (1958) I I I-112

33. Diederich (1953) op. cit. p. 37; Rapport van de commissie (1950) op. cit.; Loon, P. De 'Nederlandse Vereniging' congresseert. Katholiek Sociaal Tijdschrift 3 (1950/5I) 1, 8-1 I; Redactie. Aspecten van bejaardenzorg. Onze Bejaardenzorg 2 (1951/1952) 4, I-2; Handelingen IB 1952-1953 2800 н XIIA VV (nr. 131) 12, MVA (nr. 131a) 12, II I9531954 3070-3071; Diederich, J. Bevolkingsveroudering als sociologisch probleem. Sociologisch Jaarboek vIII (1954) 97-115; Tilanus, A.D.W. Bejaardenzorg in Gelderland. TMW 9 (1955) 193-196. Het bittere karakter van deze analyses riep echter ook weerstand op. Zo werden Meyers stellingen over het - gedwongen - onnuttige en parasiterende bestaan van bejaarden in katholieke kringen niet gewaardeerd of misschien verkeerd begrepen. De uitdrukking 'parasiterend' werd daar als ongelukkig, onwaardig en onjuist ervaren. Bejaarden hadden recht op een onbezorgde levensavond. Varia [over een prae-advies]. Onze Bejaardenzorg 1 (1950/5I) 5, 6

34. Bouman, P.J. Enige historische beschouwingen. In: Andel, J.C. van en Andel-Ripke, O, van. Oud worden in deze tijd. Man en vrouw rondom en boven de zestig. Utrecht: Erven J. Bijleveld, 1953; Bouman, P.J. De ouderdom in ons maatschappelijk bestel. In: Andel (1953) op. cit. Eerder - op 14 april I95I - hield Bouman onder de titel 'De Sociologie van de Ouderdom' een voordracht voor de Nederlandse Vereniging voor Gerontologie met global dezelfde strekking. Archief Nederlandse Vereniging voor Gerontologie (Archief NVG), inventarisnr. 40. 100 (Klinische sectie: Voordrachten 1947-1968); Loon, P.C.J. 
van. Industrialisatie en marginale groepen. $M G V 8$ (I953) 276-8I; Romein-Verschoor, A. Jeugd en Ouderdom. Overdruk uit: Sociologisch Jaarboek vIII (1954) 51-84; Verslag der discussie gevolgd op de inleiding van dr A. Romein-Verschoor. Sociologisch Jaarboek vIII (1954) 95-96. P.C.J. van Loon was hoofd van de afdeling Studie, Planning en Documentatie van het Ministerie van Maatschappelijk Werk.

35. Zie ondermeer Groen, J. Gerontologie, een nieuw veld van activiteit der Gezondheidsorganisatie TNO. TNO Nieuus (1953) 8, 403409; Beekman-Eggink, J. Bejaarden in de samenleving. Congres georganiseerd door de Nederlandse Federatie voor bejaardenzorg. TMW I7 (1963) 19, 435-440

36. Verschillende auteurs vonden bij voorbeeld dat er een onderscheid moest worden gemaakt tussen de situatie op het platteland en in de stad. Zie ondermeer: De oudeliedenzory. Verslag (1950) op. cit. p. 24 (e.v.). Elementen van het bedoelde type betoog verschenen ondermeer in: Leusen, A.J. van. De maatschappelijke positie. In: Ouder worden en ... gelukkig zijn! Amsterdam: G.J.A. Ruys Uitgeversmaatschappij, [1952]: 59-66; Rubbens-Franken, E. Méér bejaarden in een veranderende samenleving. In: Rubbens-Franken (1953) op. cit. pp. I I-I 8; Berg. J.D.J.E. van den. De bejaarden onder ons. Sociaal Maandblad Arbeid to (1955) 9, 475-480; Inleiding. In: Onderzoek naar de levensomstandigheden, behoeften en wensen der bejaarden in de Watergraafsmeer. Amsterdam: Economisch en Sociaal Instituut, Vrije Universiteit, 1954: I-7; Wirtz, A.A. De bejaarde in de huidige samenleving. Katholieke Gezondheidszorg 25 (I956) 4, 114-I 16

37. Wirtz (1956) op. cit. p. 116

38. Het bejaardenvraagstuk. Prae-adviezen en handelingen van het congres inzake het bejaardenvraagstuk. Scheveningen 1956. Assen: Van Gorcum, 1957; Groenman, S. Ouderdom naar jaren, constitutie en sociale rol. In: Het bejaardenvraagstuk (1957) op. cit. pp. 5-I4. Cloeck, H.P. Een vergeten aspect? (Een nabetrachting) TSG 34 (I956) 25, 859; Leeden, C.B. van der. Nabeschouwingen over een Congres... TSG 35 (1957) $16,385-388$. Tijdens een werkconferentie van de Nederlandse Federatie voor Bejaardenzorg die kort na het grote congres werd gehouden, stond ondermeer de vraag centraal in hoeverre dergelijke structuurwijzigingen invloed zouden hebben op de zelfstandigheid van bejaarden. Archief vws, Archief Mw, dossiernr. I092, Werkconferentie van de Nederlandse Federatie voor Bejaardenzorg te Woudschoten op 13 en 14 November 1956, stuk 111a, Inleiding door A.J. Gijsbers. Zie wat betreft de (grond)oorzaak van het bejaardenvraagstuk: Munnichs, J.M.A., 
Moor, R.A. de en Maltha O.P., A.H. Herfttij van de levensloop. Beschouwingen over de ouderdom. Utrecht [etc.]: Het Spectrum, 1956; Wirtz (1956) op. cit.; Thurlings, J.M.G. Het bejaardenvraagstuk vanuit psycho-sociologisch oogpunt beschouwd. Maandschrift Economie 21 (1956/57) 4, 173-191; Klinken, J. van. Het gezin en het bejaardenprobleem. AR-Staatkunde 27 (1957) 112-120; Haas van Dorsser, S.C. de. Het bejaardenvraagstuk en de diensten van sociale zaken. Sociale Zorg 20 (1958) 8, 120-121; Rubbens-Franken, E. Het bejaardenvraagstuk. Nogmaals: een visie op de oorzaken. Sociale Zorg 20 (1958) 9, I29-132; Archief NVG, inventarisnr. 40.1 10 (Sociale Gerontologie: Voordrachten), Research en het Bejaardenprobleem. Samenvatting van de lezing gehouden door Drs. M.G. van der Geld voor de sociaal-wetenschappelijke sectie van de Nederlandse Vereniging voor Gerontologie op zaterdag ${ }_{13}$ december 1958 Utrecht. Zie wat betreft de paragrafen over de bejaarde in de samenleving ondermeer: Nieuwe wegen in de bejaardenzorg. TMW Io (1956) 22, 356; Diederich, J. Levensomstandigheden van bejaarden in kleinere en middelgrote gemeenten in Nederland. Amsterdam/'s-Gravenhage: Nationale Raad voor Maatschappelijk Werk, 1958; Algemeen oriënterend vooronderzoek naar de levensomstandigheden van de bejaarden in de gemeente Voorburg. Utrecht: Sociologisch Instituut, Rijksuniversiteit Utrecht, 1960; Een verkenning op het terrein van de tijdsbesteding voor bejaarden. 's-Gravenhage: NFB, [1960]; Als de amandelboom blocit. Rapporten opgesteld in opdracht van het Comité Centrale Diaconale Conferentie over de hulpverlening aan bejaarden door de sectie Bejaardenzorg van de Raad voor Gereformeerde Sociale Arbeid, en van een sociologisch onderzoek naar de vereenzaming bij bejaarden, ingesteld door het Gereformeerde Sociologisch Instituut. Utrecht: Stichting Raad voor Gereformeerde Sociale Arbeid, [1962]. Zie voor beschoutvingen over en onderzoek naar eenzaamheid (en/of sociaal isolement) ondermeer: Horlings, M. Het dagelijks leven van bejaarden en hun houding tegenover de oude dag. Middelburg: Stichting Zeeland voor Maatschappelijk en Cultureel Werk, 1959; Schreuder, J.Th.R. De vereenzaming van bejaarden. MC 17 (I962) 2, 22; Als de amandelboom bloeit (1962) op. cit.; Bejaarden en bejaardenbeleid. In: Bejaard-zijn in Amsterdam. Verkenningen omtrent de bejaarde medemens in Amsterdam. Gemeenteblad (1962) Bijlage H: 93-ro9

39. Handelingen пв 1956-1957 4500 н хпи мVт (nr. 12) 3: пв 1954-1955 3700 H хнл MVt (nr. 2) 13. Uit stukken van het Ministerie van Maatschappelijk Werk blijkt overigens dat men op het Ministerie op de hoogte was van het betoog van A. Romein-Verschoor. Zie: 
Archief vws, Archief Mw, dossiernr. 1080, Stukken betreffende instelling en verslagen van de Werkgroep Bejaardenzorg 1952-1954, Discussiegroep Bejaarden. Verslag van de eerste bijeenkomst op I Maar 1954, p. 6. Een dergelijke visie werd niet alleen door de Katholieks Volkspartij-die op dat moment de Minister van Maatschappelijk werk leverde - maar ook door de Partij van de Arbeid gedragen. Zie Program voor bejaardenzorg. Amsterdam: dr. Wiardi Beckmanstichting, 1958

40. Handelingen II 1958-1959 3386; 118 1960-1961 6100 н XI1 MVt (nr. 2) 8; Die Bejahrtenfürsorge in den Niederlanden. Kurze Zusammenfassung einer Auseinandersetzung von Dr. H.J.P.J. Goedmakers, chef det Unterabteilung für Bejahrtenfürsorge des Ministeriums, I960; Problemen van de bejaardenzorg in hun veelzijdige samenhang. Studie van he Katholiek Sociaal-Kerkelijk Instituut. Den Haag: Katholiek Sociaal-Kerkelijk Instituut, 196 I; Zelfstandig wonende bejaarden. Leeuwarden: Stichting Friesland voor Maatschappelijk Werk, 1960; Goedmakers, H.J.P.J. Vanwaar onze zorg voor de bejaarde mens? In: Apartheid of integratie van de bejaarde in de samenleving. Diocesane charitasdag 6 november 1962, Kurhaus Scheveningen. 's-Gravenhage: [Diocesaan Sociaal Charitatief Centrum in het Bisdom Rotterdam], 1962: 9-19: Oostvogel, F.J.G. Hoe kan het leven van de bejaarde zinvol blijven? In: Apartheid of integratie (1962) op. cit. pp. 20-32; Thuiswonende bejaarden. Bijdrage ter stimulering van het bejaardenwerk in de wijk. 's-Hertogenbosch: Katholieke Nationale Federatie voor Bejaardenzorg/Sectie van het Landelijk Sociaal Charitatief Centrum, 1964 (zie voor de term 'open bejaardenwerk' ondermeer p. 73); Wentholt, R. Bejaarden thuis. 's-Gravenhage Minister van Maatschappelijk Werk, 1964

4I. Deze beeldspraak werd gebruikt door Hombergh, $\mathrm{H}$, van den. Geneeskunde, de vierde pijler in de hedendaagse bejaardenzorg. Katholieke Gezondheidszorg 25 (1956) 4, roo-109. Iemand van de Bond voor Staatspensionering sprak van de noodzaak van een 'deltaplan' voor de problemen rond de vergrijzing: Er bestaat geen deltaplan voot problemen rond de vergrijzing. $\mathrm{OL}_{2}$ (1965) 3,62. Zie wat betreft de ontdekking van nieuwe gaten ondermeer: Geestelijk gestoorde bejaarden worden nog primitief verzorgd. In: Jongedijk, J.W. Het einde van het leven is ook leven. De ouder wordende mens in de samenleving. Overdruk uit Het Vaderland 1957/1958, 1959: De Bejaardenzorg in Nederland. Rapport uitgebracht door de Ministeries van Volkshuisvesting en Bouunijverheid, Maatschappelijk Werk en Sociale Zaken en Volksgezondheid aan het Comité voor het Openbaar bestuur, van de West-Europese Unie. 
Den Haag, I958; Zonneveld, R.J. van. De bejaarden in onze veranderende samenleving. In: Banning, W. e.a. Motief en functie. Bewogenheid en beweging in het maatschappelijk werk, 1908-1958. Haarlem: Tjeenk Willink, [1958]: 251-264: Algemeen oriënterend vooronderzoek (1960) op. cit.; Bejaarden in Schiedam. Uitkomsten van een onderzoek naar de woon- en leefomstandigheden van de bejaarden in deze gemeente. Rotterdam: Economisch-Technologisch Instituut voor Zuid-Holland, 1962; Proosdij, A.C.G. van. De bejaarden en de moderne bejaardenzorg. TSG $_{42}$ (1964) 25, 963-964

42. Brink, T. van den. Enkele statistische aspecten van het bejaardenvraagstuk. TSG 36 (1958) 4, 10I-106; Munnichs, J.M.A. Noodzaak van institutioneel samenspel. $B W_{12}$ (1966) 3,6I-62; Verslag over de periode 1962-1965. Den Haag: Nederlandse Federatie voor Bejaardenzorg, [1966]; Staatssecretaris CRM: 'Samenwerking belangrijk voor goede opzet bejaardenwerk.' $O L$ (1969) 3, I4 1-142; Bejaardenwerk: potpourri van gemiste aansluitingen. $O L 6$ (1969) 3, 157. Zie voor opmerkingen over het gesloten circuit van zorg ondermeer: Oostvogel, F.J.G. Bejaarden opnemen in gesloten circuit van zorg. In: Bejaarden in de Samenleving. Scheveningen, 1963. ['s-Gravenhage]: NFB, 1963: 22-28; Na-conferentie Lunteren 1963. 's-Gravenhage: Nederlandse Federatic voor Bejaardenzorg, 1963; Eekelen, J.A.H. van. Organisatie en vormgeving van bejaardenwerk. In: Thuiswonende bejaarden (1964) op. cit. pp. 73-76. Zie voor kritiek op het onderzoek: Zonneveld, R.J. van. Speurwerk met betrekking tot het ouderdomsvraagstuk. DB S (1959) 3. 33-34; Zonneveld, R.J. van. Er is gecoördineerd sociaal-medisch onderzoek nodig. $D B_{12}$ (1966) I1, 283. Zie voor commentaar op het beleid: Handelingen II 1960-1961 3241, II 1961-62 3201, 3246; II 19641965 C431-432, C443-444; Overheid en bejaardenbeleid. $\mathrm{OL}_{4}$ (1967) $6,262-263$

43. Munnichs, J.M.A. De bejaarden in deze tijd. Enkele Aspecten van het Bejaardenvraagstuk. S.I.: Unie van Katholieke Diocesane Bonden van Bejaarden en Gepensioneerden in Nederland, [1962] (p. 2); Beeks, A.F. Oud(er) worden.... en dan? Een gelukkige ouderdom. DB 6 (1960) 4, 59-61; Bejaarden in de Samenleving (1963) op. cit.

44. Zo waarschuwden sociologen en anderen tegen een romantisering van het verleden en nuanceerden zij de gedachte dat in een moderne samenleving familieleden niet of nauwelijks meer voor bejaarden zorgden. Beusekom, H.G. van. Bejaarden en hun familie. DB $5(1959)$ 4, 47-48/61; Braam, G.P.A. Bejaarden in Utrecht. Rapport naar aanleiding van een enquête onder bejaarden in de stad Utrecht, 1962. Utrecht: 
Sociologisch Instituut van de Rijksuniversiteit Utrecht, 1964; Braam G.P.A. De micro-structuur van de bejaarde en een macro-sociale invloed hierop. Mens en maatschappij 39 (1964) 437-444; Moor, R.A. de. Sociologische aspecten van het bejaardenwerk. $B W$ Io (I964) 4, 95IOO; Eekelen, J.A.H. van. Hedendaags onderzoek bij bejaarden. BW II (1965) 1, 16-17; Sande, F. van de. De maatschappij en de oude bevolking. Visies en theorieën van Amerikaanse sociologen. NTG (1970) 2, 93-III; Sande, F. van de. Leefbare ouderdom in een veranderende samenleving. NTG 2 (1971) 3a, 225-236; Asten-Kuipers, E van en Groenestijn, M. van. Bejaarden en bejaardenwerk I. Intermediait 9 (1973) 28, 15-23. Zie voor de doonverking van het transitiebetoog ondermeer: Eerste diakenenconferentie over bejaardenzorg. $\mathrm{OL}_{2}$ (I965) 3 , 64-65; Kooy, G.A. Adequate bejaardenzorg. In: Buytendijk, F.J.J. c.2. De derde levensfase. Voordrachten over geestelijke gezondheid en ouderdom at eindrapport van een werkgroep 'Psychohygiëne en ouderdom'. Utrecht/ Antwerpen: Het Spectrum, 1966: 15-27; Grinten, T. van der. Notitic over maatschappelijke deprivatie van bejaarden. Maatschappelijk Wel. zijn 25 (1973) 9, 251-253: Peters, T. Oud(er) worden. Enkele notities. TBKZ 9 (1976) I9I-197

45. Zie ondermeer: Verhagen, C.M. Sociale revalidatie en het bejaardenvraagstuk. Onze Bejaarden 3 (1957) 30-31. Volgens Verhagen werd over bejaarden nog te veel gesproken in de geest van 'kinderen'; Algemeen oriënterend vooronderzoek ( 1960 ) op. cit.

46. Bustochtverslagen onverwoestbaar optimistisch/Er wordt gebedeld bij winkeliers om jaarlijkse bejaardenbustocht. $O L_{\text {I }}(1963 / 64)$ 2, 26

47. Velden, P.A. van de. Enige kritische kanttekeningen bij het bejaardenwerk in Nederland. KB 8 (1962) 5, 105; Handelingen 1 196219633114 ; Lezen houdt geest actief. Geen aparte bejaardenlectuur. $O L$ I (1963/64) 3, 48; Michels, J.J.M. Maatschappelijke aspecten van het verouderen. In: Het ouder worden. Symposion voor studenten van de faculteit der geneeskunde der katholieke universiteit. Nijmegen: Thoben Offset, 1965: 29-33; Verslag over de periode 1962-1965 (r966) op. cit.; ARA, Archief NFB, inventarisnr. 3, stuk 143, Samenvattend verslag van het gesprek van de Structuurcommissie van de Nederlandse Federatie voor Bejaardenzorg met Mejuffrouw Dr. M.A.M. Klompé op 11 maart I 966 te 's-Gravenhage; Lucas Luycks, J.H. Bejaardenprobleem of probleembejaarden. $B W_{14}$ (1968) 5, 117-1 19; Zorgen voor de bejaarden. $B W 16$ (1970) 5, $134-136$ 
48. Bejaarden behoeven niet steeds rust. TSG 40 (1962) 15, 445; Handelingen пв 1962-I963 6900 н XVI MVT (nr. 2) 8; 1B 1962-1963 6900 H XVI MVA (nr. 53a) 3

49. De plaats van oude mensen in onze samenleving. Rede van de staatssecretaris van Cultuur, Recreatie en Maatschappelijk Werk, dhr. C. Egas ter gelegenheid van de opening van een bejaardentehuis te Workum op 27 oktober, 1966. $B W_{12}$ (1966) 6, 160-162

5o. Verslag over de periode $1962-1965$ (1966) op. cit.

5I. Zie ondermeer: Kooy (I966) op. cit.; ARA, Archief van het Studie- en Informatiecentrum voor Ouderenbeleid N.F.B., vroeger Nederlandse Federatie voor Bejaardenbeleid (1954-1989), lijstnummer 2.19.098 (hierna: Archief NFB), inventarisnr. 157, Werkgroep Fundamentele Problematiek, Vergadering dd. 15-10-'70 (p. 6); Handelingen IIв 1974-75 13463 nr. 2 (Nota bejaardenbeleid 1975) II; Stalpers, J.A. Illusie-bejaarde of werkelijke bejaarde? In: Zilverdraden. Een terugblik op de manifestatie 'Dag ouwe dag'. Den Haag: NFB, [1976]: 8-18. Zie voor de disengagement-theorie ook hoofdstuk 6 .

52. Zie voor de waarschuwingen: Kanttekeningen van congresbezoekers. $B W_{9}$ (1963) 6, 171-173; Kroniek. Bejaarden moeten oud mogen zijn. $D B$ ro (r964) 4, 86-87; Mohr, F.R. Twee fundamentele uitgangspunten I-II. $\mathrm{DB}_{\mathrm{I} 3}$ (1967) 5, 103-105/8, 176-178; Mohr, F.R. Kanttekeningen bij 'De wortels van het bejaardenbeleid' van $L$. van der Meer. DB I9 (1973) I0, 276-277; Mohr, F.R. De plaats van de bejaarde in onze maatschappij I-11. DB I9 (1973) I1, 306-307/12, 331-333: Mohr, F.R. Bejaardenzorg: menselijke begrip of fanatisme? $D B$ i9 (1973) 3, 62-63; Dijkers, L.J. Maatschappelijk welzijn van bejaarden. DB 20 (1974) 4, 84-85/5, I1 2-I 13; MGS [M.G. Schenk] Ja vader, nee vader. $D B 20$ (1974) 16, 428-429; A.B. We willen niet altijd betutteld worden. DB 20 (I974) 2, 36

53. Hattinga Verschure, J.C.M. Inleiding. In: Hattinga Verschure, J.C.M. e.a. (Red.) De toekomst van het oud worden. [Amsterdam]: Agon Elsevier, 1971: 7-8 (p. 8); Rutten, F.J.Th. Over zelfstandigheid en onafhankelijkheid van bejaarden I. $B W_{14}(1968) 4,77-82$. Zie voor andere verwijzingen naar een parallel tussen de inspraak-wensen van de jeugd en die van bejaarden: Janssen, A.M.A.J. Nemen wij de bejaarden serieus? BW is (1969) S, ro9-III; Turksma, L. Autonomie of medezeggenschap van bejaarden. $D B$ I6 (1970) 18, 502-503

54. Brautigam, G. Het nut van de bejaarden in onze samenleving. S.I.: Bond voor Staatspensionering, 1965; Leenaerts, W.A.F. De bejaarden kunnen het. [Openingswoord Mr. M. van Thiel, voorzitter Unie van 
Katholieke Diocesane Bonden van Bejaarden en Gepensioneerden] $D B$ 2I (1975) 2I, 566-567; 25 jaar Unie. $L$ I4 (1977) 6/7, 24-25, Keune, C. en Zanden, G.H. van der. Belangenbehartiging in Nederland. In: Beeld van ouderen. Een overzichtsstudie naar kennis inzake het beeld in de samenleving van oudere mensen. Rijswijk: Ministerie van wvc, 1980. 6-7. Vanaf het midden van de jaren zeventig waren de ouderenbonden ook meer dan voorheen in staat om hun stem te laten gelden. Zo kreeg het COSBO in 1975 een eigen bureau en beleidsmedewerker en stelden in die jaren ook de andere bonden beleidsmedewerkers aan. Korteweg, H. Het cosBo jubileert. DB 23 (1977) 4, 69. Toch werd zowel binnen als buiten de bonden geregeld geklaagd over een gebrek aan geschoold kader en een te grote aandacht voor ontspanningsaktiviteiten. Zit ondermeer: De ouderenbeweging. Leeftijd-specifiek 4. Overdrukken uit het maandblad LEEFTIJD gebundeld naar ondenverp. Den Haag: NFB, s.2. Zie ook: 25 jaar Algemene Bond van Bejaarden. Amsterdam: [Algemene Bond van Bejaarden, 1970]; 25 jaar Protestants Christelijke Ouderen Bond. Rijssen: PCOB, 1985 ; Baan, P. van der. Voor ons en door ons. De geschivdenis van de Unie van Katholieke Bonden van Ouderen. 's-Hertogenbosch: Unie van Katholieke Bonden van Ouderen, 1989: Winters, W. Het domein van de ouderdom: uit de geschiedenis van de Nederlandse ouderenbeweging. In: Handboek 'Wonen en werken in een verzorgingshuis'. Amersfoort: Academische Uitgeverij, 1991: (par. I.2) pp. I-23

55. Munnichs, J.M.A. Onderzoek onderzocht: Emancipatie in het register van sociaal-gerontologisch onderzoek. NTG 7 (1976) [7], 203214: Emancipatie als leidraad in onderzoek en beleid. Gerontologische Dagen 1976. Programma/werkcahier. Nijmegen: Katholieke Universiteit/Gerontologisch Centrum, 1976. Dat betekent niet dat nooit eerder tot 'emancipatie' van bejaarden was opgeroepen. In een rapport geproduceerd door onderzoekers van de Vrije Universiteit gebeurde dit bij voorbeeld al in 1954. Zie: Dijk, R. van. Slotbeschouwingen en conclusies. In: Onderzoek naar de levensomstandigheden (..) in de Watergraafsmeer (1954) op. cit. pp. 79-95 (p. 86)

s6. Oudjes kijken. Den Haag: NFB, 1974; Tielens, J. Twee jart 'oudjes kijken'. OL II (1974) 5, 26-27. De praat-platenstrip bestond uit een aantal platen aan de hand warvan in groepjes - bij voorbeeld in het vormingswerk - gediscussieerd kon worden.

57. Vanouds. Den Haag: NFB, [1975] (p. 2); 'Bejaarden mogen levend dood zijn!' [Interview met C. Egas]. OL 6 (I969) 5, 25I-255: Romein-Verschoor, A. Boutade over het bejaardenwezen. $O L$ ? (1970) 3, 98-99; Staps, A.C.J. Verslag 'Oud of out'. Symposium geor- 
ganiseerd door het Instituut voor Experimentele Gerontologie TNO op 22 maart 1972, te Rijswijk. NTG 3 (1972) 2, 130-131; Egas, C. De duivel is oud. Niet meer jong zijn als maatschappelijk probleem. Amsterdam: Contact, [1974] (p. 66); Tielens, G. Oud zit fout. Bilthoven: Ambo, 1974

58. M.H. Bespreking van C. Egas. De duivel is oud. TBKZ 8 (1975) 2, 52; Turksma, L. Lang leven en niet oud worden volgens Egas. $D B 21$ (1975) I, 9-1 I

59. Milikowski, H.Ph. Bejaardenprobleem een klassenprobleem. NTG 3 (1972) 3a, 273-277; Winters, W. en Winters, A. Klasseprobleem moet worden aangepakt. $O L$ II $(1974)$ 12, 23. Zie voor een kritische bespreking van Milikowski's stellingen: Turksma, L. Milikowski en de bejaarden. DB 19 (1973) 3, 63-64

6o. Heuvel, W.J.A. van den. Beleid beleden; onderzoek als toetssteen. NTG 7 (1976) 4, 21 5-227; Schreuder, J.Th.R. Het gesloten circuit. DB I8 (1972) 4, 97-100; Schreuder, J.Th.R. Mensen die een vraagstuk worden. In: Bekkum, D.W, van e.a. Oud worden, oud zijn. Deventer: Van Loghum Slaterus, 1974: 4I-5I. Zie voor de nadruk op de achterstand, deprivatie en discriminatie van bejaarden: Sande, A. van de. Is er een bejaardenprobleem? $B W$ I6 (1970) 4, 97-99; Kruisinga, R.J.H. Toenemende diskriminatie van ouderen. $D B 20$ (I974) 12 , 314-315; Dr. Kruizinga [sic] voorzitter NVG. OL II (1974) 6/7, 35; Ackermans, M. Geruisloze diskriminatie. [Interview met F. van de Sande]. OL 8 (I97I) 2, 58-6I; Vaarten, H.J.M. De positie van de bejaarde in de samenleving. $L_{14}$ (1977) 12, 34-37/39. Braam, Coolen en Naafs noemden bejaarden weliswaar een 'minderheidscategorie', maar geen 'minderheid'. Volgens hen kon wat betreft de positie van bejaarden zeker van 'segregatie' en van een relatief 'lage positie' worden gesproken. De vraag of bejaarden ook gediscrimineerd werden en daarmee een 'minderheid' vormden - onderzochten zij echter niet. Braam, G.P.A., Coolen, J.A.I. en Naafs, J. Bejaarden in de samenleving: hun sociale positie, hun acties en invloed. In: Ouderen in Nederland. Sociologie van bejaarden, bejaardenzorg en -beleid. Alphen aan den Rijn/Brussel: Samson, 1981: 203-253; Braam, G.P.A., Coolen, J.A.I. en Naafs, J. Ouderen. Een vergeten bevolkingsgroep. Natuur en Techniek 50 (1982) II, 814-829. Zie daarover ook: Turksma, L. Ouderen in Nederland. [Recensie]. Senior 28 (1982) 5, I14-IIS

61. Handelingen I1в 1974-1975 13463 nr. 2 (Nota Bejaardenbeleid 1975) (p. 14)

62. Janssen, A.M.A.J. Samenwerking tussen bejaardentehuizen en 
bejaardenbonden. $B W_{14}$ (1968) I, I-7; Commentaar van de Neder. landse Federatie voor Bejaardenzorg op de Regeringsnota Bejaarden. beleid 1970. BW I6 (1970) 5, 127; Dr. G.M.J. Veldkamp: meer inspraak voor bejaarden. $O L$ S (1968) S, 203

63. Groenman (1957) op. cit. Zie voor verwante opmerkinger Hijmans, L. en Wetering de Rooy, J.V.D. Bejaarden....zorg. $T M W_{9}$ (1955) 12, 196-200

64. Psychologisch Laboratorium Nijmegen, Archief Gerontologisch Centrum, 2. Algemeen, Notitie dd. 5 september 1974; Dam,J.C van. Het bejaardenvraagstuk. Sociale Zorg 25 (1963) 2-8. Zie ook Turksma, L. De positie van de bejaarden en de maatschappijkritick DB 17 (1971) 10, 296-298; Korteweg, H. Bejaardenproblematick openbaring van maatschappelijke strukturen. [Interview met $\mathrm{M}$. Hoekstra, Humanistisch Verbond] DB I9 (1973) I6, 459; Het gaat om een maatschappijprobleem, niet om bejaarden in nood. $D B$ I9 (1973) $19,518-520 / 20,552-553$

65. Protestants beraad 'Oud worden, en toch...' DB I6 (1970) $n$, 332-333; Meer, L. van der. De wortels van het bejaardenbeleid. $D B 19$ (1973) 3, 52-54; Van harte gefeliciteerd met uw 65ste verjaardag. OL 10 (1973) Io, 12-13: Ja vader, nee vader. [Interview met dr. A. Romein-Verschoor]. $O L$ II (I974) 2, 8-10; Schreuder, W.A. Welvaart, het paard van Troje. DB 20 (1974) 5, 104-IO6; Roos, S.P. Bejaardenproblemen. MGV 30 (1975) 344-35I; De toekomst voor bejaarden. DB 23 (1977) 20, 438-440; Turksma, L. Hoe past de maatschappij de bejaarde in? DB 23 (1977) 16, 339; Gelijkwaardigheid. DB 24 (1978) 22, 56r; Aalsma, P.R.A.J. Maatschappelijk werk voor bejaarden? $T B K Z_{12}$ (1979) [februari], 37-4I. Deze gedachten werden ook in de eerste helft van de jaren zestig al door enkelen verdedigd: Dokter Tilanus, voorzitter Nederlandse Federatie voor Bejaardenzorg: "ons congres moet een wapenschouw worden voor allen die bij het bejardenwerk zijn betrokken.' $B W 9$ (1963) 4, 87-89. Zie wat betreff beeldvorming ondermeer: Ackermans, M. Op toernee naar Koekange [Interview met C. Tempelman]. OL 12 (1975) 5, 6-7; Remmerswad, P.W.M. Het zelfbeeld van ouderen, een psychologische bijdrage NTG 6 (1975) 3, 190-201; Heuvelmans-Hoppenbrouwers, P.J.M. Beeldvorming ten aanzien van ouderen, een sociologische bijdrage NTG 6 (1975) 3, I8I-189; Haanstra, B. Bejaard? Dat zou je hem ook niet geven. Over beeldvorming en de positie van bejaarden. Tijdschrff voor maatschappijvraagstukken en welzijnswerk 31 (1977) 7/8, 248-53

66 . Zo lang ouderen nog niet als volwaardig en gelijkwaardig lid 
van de maatschappij werden aanvaard, zo meende de Nederlandse Federatie voor Bejaardenbeleid (NFB), waren belangenorganisaties nodig. En wat de Pas 65 betreft was - volgens de Federatie - uit een enquête duidelijk geworden dat bejaarden een dergelijk paspoort niet als discriminatie ervaarden. Bovendien waren de ervaringen in verschillende gemeenten positief. De algemene beleidsontwikkeling in het tijdperk van twee nota's bejaardenbeleid. Bij wijze van Jaanverslag van de Nederlandse Federatie voor Bejaardenbeleid over de periode $1973 \mathrm{t} / \mathrm{m} 1977$. [Den Haag]: NFB, 1978. Ook Schreuder meende dat zo lang de positie van bejaarden nog niet gelijk was aan die van anderen, aparte maatregelen en voorzieningen verdedigbaar waren. Schreuder (Het gesloten circuit, 1972) op. cit. Anderen maakten zich echter zorgen over het isolerende effect van bejaardenpaspoorten: Handelingen II I972-73 78I, II 1974-1975 3344. Zie voor dergelijke discussies ook: ARA, Archief $\mathrm{NFB}$, inventarisnur. 205. Vergaderingen Algemeen Bestuur (hierna: $\mathrm{AB}$ ) dd. 5-6-1970 (pp. 2-3); Probleeminventarisatie bejaarden en bejaardenvraagstuk. Onderzoek uitgevoerd door de afdeling Research van het Gemeenschappelijk Instituut voor Toegepaste Psychologie te Nijmegen, in opdracht van het Ministerie van Cultuur, Recreatie en Maatschappelijk Werk. Rijswijk: Ministerie van CRM, 1973. Vanaf het eind van de jaren zestig verschenen aparte bejaardenpartijen op het lokale en landelijke toneel. Op die ontwikkeling werd in de wereld van de ouderenzorg en ouderenbonden voorzichtig tot afwijzend gereageerd. Zo werden de doelstellingen van dergelijke partijen te beperkt geacht. Bij de gemeenteraadsverkiezingen van 1970 werden enkele successen gehaald, maar bij de TweedeKamerverkiezingen van $197 \mathrm{I}$ behaalde geen van de bejaardenpartijen een zetel. Partij voor bejaarden is er! OL6 (1969) 3, 140; Red. Politieke bejaardenpartijen. DB 16 (1970) 7,216; Wel in een BOND, niet in een PARTIJ. DB I6 (1970) I4, 41 I; Turksma, L. Na de verkiezingen. DB I7 (1971) 11, 336-338; MGS [Schenk, M.G.] Anderhalf miljoen stemmen. DB 22 (1976) 20, 421; Putten, J. van. Lijsttrekker Van der Min: Zeg maar ja tegen een bejaardenpartij. $L_{\text {I }} 4$ (1977) 5, I5-I6; Bejaardenorganisaties tegen politieke partijen bejaarden. $L_{14}$ (1977) 5, 17. Staatssecretaris Van Veenendaal-Van Meggelen was van mening dat de - in de jaren zeventig door velen bepleitte - Raad voor het Bejaardenbeleid (waarvoor overigens ook veel andere benamingen in omloop waren) het isolement van ouderen in de hand zou werken. Zie: MGs. Ouderen moeten geïntegreerd blijven zegt mevrouw van Veenendaal. $D B$ i 8 (1972) I, 5-7. Zie voor de tehuizen: hoofdstuk 5.

67. Moeten we echt alles zelf uitzoeken? In: Tielens (1974) op. cit. 
pp. 55-61; Ouderen willen nieuw beleid. Utrecht: cosвo Nederland 1979; Pleeggrootouders. OL II (1974) 4, 14-15. Zie wat betreft de vermelding van de traditionele 'deugden' wijsheid en nust (in de jarte zestig, zeventig én tachtig): Sleeswijk, J.G. Oud worden ... Waaroni DB 8 (1962) 3, 39-40; Leenaerts, W.A.F. De waarde van het leven van de oudere mens. [Rede Mr. M. van Thiel tijdens Studiedagen vand Unie.] DB 24 (1978) 24, 608; Ouderen willen nieuw beleid (1979) op cit.; Verschure, P. Wordt de oudere mens onderschat? Senior 26 (1980) 4, 63-65: Melsen, A.G.M. De betekenis van de derde levensfase. $\mathrm{G}_{\mathrm{.}}$ rontologie II (1980) 2, 118-123. Zie wat betreft de politieke machtsfatto en het marktsegment: Optimisme voor het jaar 2000. DB I6 (I970) 23, $67 \mathrm{I}$; Blommestijn, P.J. Oudere mens vraagt nieuwe plaats. OL6 (1969) 4. $194-198$

68. ARA, Archief NFB, inventarisnr. I57, Werkgroep Fundamentek Problematiek, Vergadering dd. 11-6-1970 (p. 9); Vergadering dd. 15 10-1970; Concept-brief M. Smeets aan leden werkgroep dd. 10-121970; Brief M. Smeets aan leden werkgroep dd. 24-10-1970; Brief M. Smeets aan voorzitter en leden werkgroep dd. 9-2-1971; Konsep selektie van vragen die in de vergaderingen van de werkgroep Fundsmentele Problematiek aan de orde zijn geweest; Brief M. Smeets aan J. Munnichs dd. I2-3-1971. De leden van de werkgroep waren: J.M.A Munnichs (voorzitter), M. Smeets (secretaris), B. Korstanje, J. Matse, A.A.J.M, van de Sande en L. Turksma. Aanleiding tot de instelling van de werkgroep was de noodzaak tot het ontwikkelen van commentar op de in voorbereiding zijnde Nota Bejaardenbeleid van de regering Die nota verscheen echter sneller dan verwacht, zodat de NFB commentaar moest geven voordat de werkgroep klaar was. Ook daarom werd de nota niet meer afgemaakt. Zie voor andere opmerkingen over de zoektocht naar een nieuwe visie op de ouderdom: Munnichs, J.M.A. Vergrijzing van de bevolking. Een actuele problematiek. BW 6 (1970) 2, 47-48; Droste, B. Dag dag ouwe dag. In: Zilverdraden (1966) op. cit. pp. 37-52. Volgens Munnichs had de samenleving geen helder beeld omtrent de plaats van de ouderdom in die samenleving Volgens Droste was de NFB-manifestatie 'Dag ouwe dag' bedoeld geweest om een nieuwe toekomst van de ouderdom te schilderen, mast bleek dit te hoog gegrepen.

69. NTvG. $B W$ I6 (1970) I, I9-2I; Kuiper, H.J. Vergrijzing in Nederland. DB 24 (1978) 6, 121; NFB Kritiek. OL 9 (1972) 4, 6-9

70. Wentholt (1964) op. cit. p. 8; Gijsbers, A.J. Mogelijkheden en moeilijkheden bij de financiering van de hulpverlening aan bejaarden. 
In: Verslag van de Provinciale voorlichtingsdag over bejaardenhulp in het kader van de gezinsverzorging. Gehouden in het Huis der Provincie te Arnhem op 9 april 1965. Maar ook anderen wezen op het belang van zo laag mogelijke produktiekosten in de bejaardenzorg en aanvaardbare bezuinigingen. Fijlstra, W.J. Vormen de bejaarden een last? DB 12 (1966) 10, 246-247. Volgens D. Dolman, medewerker van de Dr. Wiardi Beckman-Stichting, namen ouderen in tal en last toe en moest de samenleving 'racen' om achterstanden in te lopen en 'remmen' om overdreven luxe en verspilling - het gevolg van een slechte coördinatie van voorzieningen - tegen te gaan. Dolman, D. Op het gesloten circuit: Racen en remmen. $D B$ is (1969) 7, 162-166

71. Memorandum betreffende enige belangrijke punten inzake het bejaardenbeleid. Rijswijk: Ministerie van CRM/ISB, 1969; Handelingen $11 \mathrm{~B}$ 1970-1971 10934 nr. 2 (Nota bejaardenbeleid 1970); IIB 1974-1975 13463 nr. 2 (Nota bejaardenbeleid 1975); пв 198I-1982 $17393 \mathrm{nr} .2$ (Bouwstenen voor een ouderenbeleid); ІІВ 198 I-82 I6625 nr. 54 (Heroverwegingen Bejaardenbeleid); Handelingen I1в 1976-1977 14100 HXVI MVT (nr. 2) 58; 11 B I977-I 978 14800 H XVI nr. 43, I-4. Wat betreft de extramurale zorg werd ondermeer bezuinigd op het 'gecoördineerd bejaardenwerk': II 1977-78 1763. Zie voor het afremmen van de intramurale zorg ook hoofdstuk 5 .

72. Redactioneel. NTG io (1979) 4, 185 ; Redactioneel. Vergrijzing. NTG 8 (1977) 4, 199; W.L. [Leenaerts, W.] Vergrijzing. Senior 26 (1980) I, 4; Iedere tijd is leeftijd. $\mathrm{OL}_{13}$ (1976) 7/8, 27-28; Gillissen, M. en Fonk, M. Ouder worden onderzocht. [Met daarin: Klinken, J. van. Grijs boven de prijs?]. $L$ I8 (1981) 12, 31-33; Ouderen en sociale zekerheid [Bijdragen Van Thiel en Braam]. L 19 (1982) 12, 2-5; Berg, H. van den. De voorzieningen. In: Oud in Nederland. Verslag. Den Haag: NFB, 1982: 12-15 (Van den Berg vond het spreken in termen van marktbegrippen als vraag en aanbod met betrekking tot ouderenzorg misleidend.) Daar kwam bij dat de bezuinigingen een stroom van protesten opriepen en dat zowel de organisaties voor bejaardenzorg als de ouderenbonden zich verontwaardigd uitlieten over de geringe inspraak die zij in het beleid kregen. De NFB valt CRM aan. DB 22 (1976) 22, 484; Brief van Cosbo-voorziter aan kabinetsformateur. $D B 23$ (1977) 15, 314; Landelijke aktiegroep bejaardenwerk. $L$ Is (1978) II, 2I-[22]; Ouderen willen nieuw beleid (1979) op. cit.; Het werk van de ouderenbonden in Nederland. Utrecht: ANBO, 1980; Voor ouderen is de maat vol. Utrecht: cosBo, 1982. Ook werd door onderzoekers kritiek geuit op bepaalde vooronderstellingen in het overheidsbeleid, zoals de ge- 
dachte dat het percentage bejaarden in bejaardentehuizen af zou kunnen nemen wanneer het aantal aangepaste woningen voor bejaarden uitgebreid zou worden. Zie: Coolen, J.A.I. Samenhang van voorzieningen voor bejaarden. Sociologische Gids 27 (1980) 1, 47-66

73. Hattinga Verschure, J.C.M. Zelfzorg, mantelzorg en verzorging van ouderen. Senior 27 (198I) 4, 78-8I; Mr. Van Thiel over toekomstig beleid Unie кво. Senior 28 (1982) 23, 517-519; MGs [Schenk, M.G.] Zelfzorg of thuiszorg. DB 25 (1979) 12, 23

74. Franssen, B. Ik hoop dat we de proffesionele [sic] hulp niet meer betalen kunnen. [Interview met Hattinga Verschure, J.C.M.] $L$ 19 (1982) 3, 28-31; Vlodrop, J. Symposium Beverwijk. Gaan wij te vet met de professionalisering van het welzijnswerk voor ouderen? [Met daarin: Verhaar, P. Solidariteit, want het geld is op.] L I4 (I977) I, IO-I3; Gijsbers, A.J. Het rijksbejaardenbeleid. Senior 26 (I980) 17. 326-327

75. Zo vroeg H. Verwey-Jonker zich af of de toekomstige beroepsbevolking de verzorging van ouderen - gezien de grote financiële last die deze verzorging met zich mee zou brengen - wel op het bestaande peil zou kunnen houden. Verwey-Jonker, H. De bejaarden, slachtoffers van de geboortenbeperking? Socialisme en democratie 35 (1978) 9, 415-420. Zie voor andere beschouwingen waarin naar economische kwesties werd verwezen of die in economische termen waren geschreven: Ritzen, J.M.M. Toekomstverwachtingen: een reaktie. DB 22 (1976) 19, 415 ; Bremer, J.J.C.B. Vraag en aanbod in de gezondheidszorg voor bejaarden. TSG 55 (1977) 356-361; Oosterwijk Bruijn, J]. van. De veranderende leeftijdsopbouw van de Nederlandse bevolking. NTvG 121 (1977) 42, 1634-1638; Assen, J.G.M. Demografische ontwikkelingen in de bejaarde bevolking en de consequenties voor de benodigde voorzieningen. Tijdschrift voor Agologie 7 (1978) [5] 287-302; Oosterwijk Bruyn, J.J. van. Ontwikkeling en vooruitberekening van het aantal bejaarden in Nederland van 1946 tot 2000 . NTG 9 (1978) I, 2-12; Heuvel, F.G. van den en Siegers, J.J. Economische ontwikkeling, demografische structuur en de omvang van de overheidsuitgaven. ESB 65 (1980) 14-16; Heyden, R. van der. Symposium 'zorg om de verzorging' [met daarin: Zijderveld, A.C. Sociologische kanttekeningen bij het verschijnsel verzorging.] $L$ I7 (1980) 2, 43-45; Hollander, C.F. en Veldkamp, G.M.J. Het volumebeleid en het daarmede samenhangende belang van verouderingsonderzoek voor de kosten van gezondheidszorg voor ouderen. Sociaal Maandblad Arbeid 35 (1980) 1724; Turksma, L. Bejaarden: toekomst en kosten. Senior 26 (I980) 6 , 
104; Trommel, J. [Brieven aan de Redactie.] Advies gerontologisch onderzoek. NTvG 125 (1981) 22, 889; Albeda, W. De wankelende verzorgingsstaat; sociaal-economische gevolgen van een oudere bevolking. TSG 60 (1982) 23, 724-728 (p. 724); Een oudere bevolking; een andere sociale gezondheidszorg? TSG 59 (1981) 24, 923-924; Kamps, H. De grijze sector. ESB 67 (1982) 841; Koesoebjono, S. Demografische ontwikkeling en enige kenmerken van alleenstaande bejaarden in Nederland. Bevolking en Gezin (1982) 1, 85-104; Matse, J. Pleidooi voor een nieuw realisme in de hulpverlening aan bejaarden. TSG 60 (1982) 6, 109; Ouderen en sociale zekerheid. [Bijdrage De Kam]. L 19 (1982) 12, 2-5; Philipsen, H. Een oudere bevolking; een andere sociale gezondheidszorg? TSG 60 (1982) 23, 705-710

76. Ouder worden ... zelfstandig blijven. Een brochure over 'flankerend bejaardenbeleid'. Rijswijk: Ministerie van wvc, I984 (pp. 4-5)

77. Deze gedachte en de uitwerking van de voorbeelden hieronder is ontleend aan het werk van Gusfield, Schön, Miller en Holstein (zie noot 119).

78. Lely (1955) op. cit. pp. $12-13$

79. Sleeswijk, J.G. (Red.) De ouderdom van geneeskundig standpunt beschouwd. Een handboek voor artsen. Deel 1. Algemeen Gedeelte. Deel II. Clinisch gedeelte. Amsterdam/Antwerpen: Uitgeverij Kosmos, I948/I949

80. ARA, Archief NFB, inventarisnr. 152, 1.1.2.26 (Nederlandse Vereniging voor Gerontologie 1948-1973) en Archief NVG, inventarisnr. 50.130 (Jaarverslagen 1947-1987): Muntendam, P. Nederlandse Vereniging voor Gerontologie. Ie Jaarverslag (1946-1948). Zie ook Ouderdomswetenschap (gerontologie) TSG 25 (1947) i 1, 165. De statuten van de NVG werden op 14 juni 1947 vastgesteld en bij Koninklijk Besluit van 2 januari 1948 , no. I4 goedgekeurd.

8I. Statuten Nederlandse Vereniging voor Gerontologie. Bijvoegsel tot de Nederlandse Staatscourant van Donderdag 25 Maart 1948, No. $60, v_{48}$

82. Muntendam, P. Nederlandse Vereniging voor Gerontologie. Ie Jaarverslag (1946-1948) op. cit.; Archief NVG, inventarisnr. 20.120, bestuursvergadering NVG dd. 11 oktober 1947, punt 9; ibidem dd. 13 december I947; ibidem dd. Io april $194^{8}$

83. Everts, J. Opleving van de belangstelling voor de ouderdomszorg. TMW 2 (1948) 149-151; Everts, J. De nationale commissie voor de oudeliedenzorg. TMW 3 (1949) 321-22; Everts, J. Een nationale commissie voor de Oudeliedenzorg. Katholiek Sociaal Tijdschrift 2 
(1949/50) 3, 63-66; Everts, J. Een nationale commissie voor de oudeliedenzorg. Sociale Zorg 12 (1950) 5, 86-88; ARA, Archief NRMw, inventarisnummer 89, Verslag van de Algemene Ledenvergadering (hierna; Al.v) van de Nederlandse Vereniging voor Maatschappelijk Werk (hierna: NVMw) op 22 april 1949, punt sa

84. ARA, Archief NRMW, inventarisnr. 89, Verslag ALV van de NVMW op I december I950 (p. I55)

85. Redactie. O, die hokjes! Onze Bejaardenzorg I (I950/195I) 2,4; Redactie. Wat anderen zeggen. Onze Bejaardenzorg I (1950/5I) 5, 1-3; De 'Nederlandse vereniging' congresseert (Red.) Onze Bejaardenzong 1 (1950/51) 6/7, 2-4; Van der Baan (1989) op. cit. pp. 2I-24. In 1952 werd de NCO omgezet in de Nationale Vereniging voor Bejaardenzorg. De NCO ontwierp de statuten. Het bestuur van de NVMw ging met de statuten van de NVB accoord, maar in later stadium bleek het Landelijk Sociaal-Charitatief Centrum niet accoord te gaan. Zie: ARA, Archief NRMW, inventarisnr. 89, Verslag ALV NVMW dd. 26 november I953 (p. 2I9)

86. Handelingen II 1950-1951 993

87. Pouw, A. Oud, maar wijs genoeg? De Nederlandse Vereniging vor Gerontologie 1947-1987. Lochem/Gent: Uitgeversmaatschappij De Tijdstroom, 1987

88. ARA, Archief NFB, inventarisnr. I86, Vergaderingen Dagelijks Bestuur (hierna: DB), dd. 23-6-1955, punt VIII, p. 6

89. Tot de ouderenbonden behoorden de Bond voor Staatspensionneering (opgericht in 1900), de Algemene Bond van Ouden van Dagen (1945) en de Unie van Diocesane Katholieke Bonden van Bejaarden en Gepensioneerden (1952). Deze bonden werkten samen in het Centraal Orgaan Samenwerkende Organisaties (1954). Deze organisatie, waartoe ook de Protestantse Christelijke Ouderen Bond (1960) toetrad, werd later omgedoopt tot het Centraal Orgaan van de Samenwerkende Bonden van Ouderen (CosBo). De Bond voor Statspensionneering en de Algemene Bond van Ouden van Dagen werkten vanaf 1978 samen in de Algemene Nederlandse Bond van Ouderen (ANBO). Tot de organisaties op het gebied van de tehuizen behoorden ondermeer de in 1957 opgerichte Katholieke Vereniging van Bejardentehuizen (KVB), de in 1960 tot stand gekomen Protestantse Vereniging van Inrichtingen voor Bejaardenzorg (PVIB) en de Algemene Vereniging van Instellingen voor Bejaardenzorg (AviB). Deze organisaties zochten in 1972 samenwerking in de Federatie Landelijke Samenwerkende Bejaardentehuizenorganisaties (LSB). 
90. Verslag 1955-1959 (1960) op. cit.; ARA, Archief NFB, inventarisnr. 186, DB dd. 13-12-1956, punt vIII

9I. Zie ondermeer: ARA, Archief NFB, inventarisnr. I86, DB dd. 8-II-196I (p. 3); ibidem, inventarisnr. 205, Vergaderingen Algemeen Bestuur (hierna: AB) AB dd. I5-2-1957 (p. 2); AB dd. II-6-1965 (p. 2 e.v.); $A B$ dd. 3-3-1967 (pp. 3-6); ibidem, inventarisnr. 4, stuknr. 310, Structuur en functionering van de NFB.

92. Pouw (1987) op. cit. p. 36-38; Groen (1953) op. cit. Andere voorbeelden zijn de onderzoekers R.J. van Zonneveld en J.M.A. Munnichs, die beiden ondermeer actief waren binnen de NFB en geregeld in bejaardenzorg-tijdschriften publiceerden. Zo schreef Munnichs voor Katholieke Bejaardenzorg.

93. C. Egas was van 1952 tot 1965 lid van de Tweede Kamer voor de Partij van de Arbeid, in 1965 en 1966 Staatssecretaris en vanaf 1967 weer lid van de Tweede Kamer. In 1968 volgde hij A.D.W. Tilanus op als voorzitter van de NFB: Commandowisseling. OL 5 (1968) 6 , 250-251

94. Verslag 1955-59 (1960) op. cit. p. I2; Fabrianus, O.F.M. Algemene ouderdomsverzekering en algemeen verzekerde oude dag vanuit katholiek standpunt. 's-Hertogenbosch: Geert Groote Genootschap, 1958 (p. s); Bejaardenzorg voor de microfoon. TSG 34 (1956) 10, 267; [Redactioneel]. Katholieke Gezondheidszorg 25 (1956) 4. 95; ARA, Archief NFB, inventarisnr. 205, AB dd. 28-4-1955, punt 8 (p. 5) en dd. 17-5-1955. punt 6-7 (p. 3-4)

95. Archief NVG, Privé-archief A. Kleijn, brief dd. 17-8-1950 van Mr. A. Kleijn aan [dr. P.] Muntendam en brief dd. 23-8-1950 van dr. P. Muntendam aan Mr. A. Kleijn

96. Geciteerd in: Pouw (1987) op. cit. p. 41-42

97. ARA, Archief NFB, inventaris nr. I 52 (Nederlandse Vereniging voor Gerontologie 1948-1973), stuk 145, brief NVG aan bestuur NFB dd. 28-2-1957. Zie voor de discussies over het congres van 1956: ARA, Archief NFB, inventarisnr. 205, AB dd. 28-4-1955, punt 8 (p. 5), dd. 23-6-1955, punt 7 (p. 5), dd. 14-12-1955, punt 7 (pp. 4-6); ibidem, inventarisnr. 186, DB dd. 9-12-1955 (p. 7)

98. Studiedag 'De Bezigheidstherapie voor Bejaarden' op 26 October te Utrecht gehouden. MC 12 (I957) 814-818; Turksma, L. De theoretische sociologie van bejaarden en ouderdom. Enkele problemen en mogelijkheden. Mens en Maatschappij 43 (1968) 415-424; Munnichs, J.M.A. Sociale gerontologie en sociaal-geontologisch onderzoek in Nederland. Nederlands Tijdschnift voor de Psychologie en haar 
grensgebieden 23 (1968) 458-473; Munnichs, J.M.A. Gerontologisch onderzoek in Nederland. NTG 2 (1971) 4, 281-284; Munnichs, J.M.A. Reflexies over gerontologisch onderzoek en belemmeringen daarbij. De Psycholoog 12 (1977) 3, I09-1 16. Zie ook: Moeniralam-Van Wel, B. Onderzoek onderzocht. Analyse, evaluatie en perspektief van het sociaal-gerontologisch onderzoek in Nederland. N.a.v. het Register van Sociaal-Gerontologisch Onderzoek Deel II, 1965-1973. Amsterdam: Noord-Hollandsche Uitgevers Maatschappij, 1977; Verwey-Jonker, H. Pleidooi voor een volwassen geronto-sociologie. NTG 9 (1978) 4, 191-195; Naafs, J. Aanzetten tot een bejaardensociologie. Een terreinverkenning naar aanleiding van verschenen literatuur. Sociologische Gids 28 (198r) S, 445-458; Turksma, L. Enquêteren en rapporteren moeilijke zaak. Van Smilde tot Heerlen. Enige recente rapporten betreffende bejaardenzorg. DB 12 (1966) 1 1, 284-285; Turksma, L. Bejaardensociologie: een terugblik en momentopname. Mens en Maatschappij 56 (1981) 398-416; Ms [Munnichs, J.M.A.] Commentaar. Zakelijk en beleidsdenken. BW 11 (1965) 6, 138; Leering, A. Gerontologie in Nederland. Enkele kritische opmerkingen, $B W$ is (1969) 4, 84-85; J.M.A. Reflexies over gerontologisch onderzoek en belemmeringen daarbij. De Psycholoog 12 (1977) 3, 109-116; Munnichs, J.M.A. Integratie of gerontotheek. NTG 6 (1975) 3, 130-137

99. Tot de andere werkgroepen behoorden de Werkgroep Experimentele Gerontologie en de Contact Werkgroep Psychologen. De eerste werkgroep was verbonden aan TNO, biologisch georiënteerd en 'voorloper' van het latere Instituut voor Experimentele Gerontologie TNO. De laatstgenoemde werd in de jaren zestig ondergebracht bij het Gerontologisch Centrum Nijmegen.

100. Jaarverslagen Gerontologisch Centrum 1968, 1969 en 1970; Gerontologisch Centrum anno 1974. Nijmegen: Gerontologisch Centrum, [s.a.]; Tien jaar Gerontologisch Centrum Nijmegen 1967-1977. Nijmegen: Interfacultaire Vakgroep Sociale Gerontologie i.o., 1978

I01. Advies inzake gerontologie. Advies uitgebracht 8 maart 1971 door de Gezondheidsraad aan Zijne Excellentie de Staatssecretaris van Sociale Zaken en Volksgezondheid. 's-Gravenhage: Staatsuitgeverij, 1973; Advies inzake programma en instrumentarium voor gerontologisch onderzoek. 's-Gravenhage: Staatsuitgeverij/Planninggroep voor wetenschappelijk onderzoek op het gebied van de ouder wordende mens, 1981. Mede naar aanleiding van dit laatste advies werd in 1982 de Stuurgoep Onderzoek op het terrein van de Ouder wordende Mens (sоom) ingesteld. Zie: Ringoir, D.J.B. Gerontologie, is dat misschien oude wijn in nieuwe zak- 
ken? TNO-Project (1984) 6, 240-243; Wegwijzer SOOM 1982-1987. Nijmegen: NIG, 1987

102. ARA, Archief NFB, AB dd. 31-1-1969 (p. s); Wetenschappelijk Advies College. OL 8 (1971) 9, 8-10; Zilverdraden (1976) op. cit.; Dag ouwe dag. $D B 2$ I (1975) 23, 603-605; 'Een echte manifestatie was het niet.' Impressies van een bezoeker. OL 12 (1975) 11, 10-11; Turksma, L. Het beleidsprogramma van de NFB en het onderzoek. DB 22 (1976) 9, 173. De NVG organiseerde in 1971, 1972 en 1973 achtereenvolgens het Eerste, Tweede en Derde Nederlandse Congres voor Gerontologie. Het Gerontologisch Centrum organiseerde in de jaren 1975,1976 en I977 de Gerontologische Dagen in samenwerking met de NVG (zie bijlage).

103. Verslag over 1971 en 1972. Den Haag: Nederlandse Federatie voor Bejaardenbeleid, 1973 (p. 12); NFB richt zich tot Kamercommissies met brief en werkprogramma. DB 16 (1970) 2, 44; S.-r. Kritiek op en verdediging van het regeringsbeleid. $D B$ I6 (1970) 8, 233-234: Aspekten van een integraal bejaardenbeleid. Den Haag: NFB, 1971; Hoorzitting. Bejaardenbonden. OL 8 (1971) I, 24-27; Viif jaar welzijnszorg voor ouderen. Den Haag: NFB, I971; MGs [Schenk, M.G.] Er is geen bejaardenbeleid. DB 19 (1973) 20, 554; Overzicht van reacties en commentaren op de Nota Bejaardenbeleid 1975. Rijswijk: 1SB, 1976; De kamer hoort. $O L$ (1976) 2, 4-8; MGs [Schenk, M.G.] Kommentaar op de Nota Bejardenbeleid. DB 22 (1976) 3, 4I-45; De algemene beleidsontwikkeling (1978) op. cit.. De naamswijziging ging in per 1 juni 1972 . Zie wat betreft de knitiek van onderzockers: Turksma, L. Sociologische visie op de nota '75. DB 2 I (1975) 18, 465-467/19, 505-507

104. Oud in Nederland (1982) op. cit.

105. Red. De bejaardenzorg na vijftien jaar. DB 16 (1970) I, 5; Nederlands Tijdschrift voor Gerontologie ten doop gehouden. MC 25 (1970) II, 258-260; MGs. [Schenk, M.G.] Ouderen moeten geïntegreerd blijven zegt mevrouw van Veenendaal. $D B$ i 8 (1972) I, 5-7. De afbakening van de groep 'ouderen' naar leeftijd verschilde per instantie. Zowel de leeftijden 40 en 45 , als so kwamen voor.

106. Lely (1955) op. cit. p. 14. Zie ook: Bejaarden of ouden van dagen. Is er werkelijk iets veranderd? Ons Bejaardencentnum 3 (1952) 5 , I-2

107. De plaats van oude mensen (Rede C. Egas) (1966) op. cit.

108. 'Ik spreek over een thematiek die niet aantrekkelijk is. Daarom sluit men maar liever de oren.' [Interview met J.M.A. Munnichs]. OL 6 (1969) 6, 330-333; J. de B.-v. S. [J. de Boer-van Strien]. De uvv 
en oud worden in de samenleving van nu. DB I6 (1970) I2, 364-366; MGS [Schenk, M.G.] Seniores priores. DB 25 (1979) 19/20, 365; W.A.F.L. [Leenaerts, W.A.F] en MGs [Schenk, M.G] Staatssekretaris Wallis de Vries aan het woord. $D B 25$ (1979) $19 / 20,73-74$. Nieuwe namen hadden andere associaties. Zo werd de term 'senior' met emancipatie en eigenheid verbonden. MGs [Schenk, M.G.] De waarde van Senioren. Senior 26 (1980) I, I; Naamsveranderingen Gerontologie II (1980) 3, 227-228

109. Op leeftijd Leef tijd. L I 4 (1977) I, 2

1 10. Zie ondermeer: Sleeswijk, J.G. Inleiding. In: Sleeswijk (1948) op. cit. pp. I-20. Met 'climacterium' werd gedoeld op de overgangjaren van de vrouw, met 'climacterium virile' op de - overigens omstreden - overgangsjaren van de man.

111. Zie ondermeer: Zonneveld (1953) op. cit.; Diederich (1954) op. cit.; Munnichs, J.M.A. De oude mens is het beeld van zijn leven. Katholieke Gezondheidszorg 25 (1956) 4, 117/120-121

112. Diederich, J. Enkele sociologische aspecten van het vraagstuk der bejaarden. In: De oudeliedenzorg (1950) op. cit. pp. 35-68 (p. $4^{8-50)}$

113. Munnichs (Katholieke Gezondheidszorg, 1956) op. cit. p. 121

114. Het jot-Handvest. $O L 12$ (1975) I2, I4-I5; MGS [M.G. Schenk] Jong Oud Trust. De Bejaarden 21 (1975) 8, 208; ARA, Archief $\mathrm{NFB}$, inventarisnr. 205, AB dd. 26-9-1969 (p. 5); Egas, C. Algemene beschouwing. In: Vijf jaar welzijnszorg (197I) op. cit. pp. 5-I0; Vershag over 1971 en 1972 (1973) op. cit.; De algemene beleidsontwikkeling (1978) op. cit.; Het gaat om een maatschappijprobleem, (1973) op. cit: Redactioneel. NTG to (1979) 4, 185; Egas, C. Levensloop ideologic en welzijnswerk. TBMK I3 (1980) I, 3-1 I; Heuvel, W.J.A. van den. Kanttekeningen bij 'Bouwstenen voor een ouderenbeleid'. TGG 13 (I982) 4, 155-I59. Ook Turksma legde nadruk op de continuïteit van het bestaan. Turksma, L. De continuïteit van het bestaan. DB I4 (1968) 5, 95-96. Turksma verzette zich echter tegen het uitbreiden van de bemoeienis van de gerontologie tot mensen jonger dan 65 jaar. Turksma, L. DB 25 (1979) 15. 302-303

115. Wirtz (1956) op. cit. (p. I I5). Zie voor vergelijkbare beweringen ondermeer: Zorg voor bejaarden. [Rapport uitgebracht doorde Studie- en Adviescommissie inzake het bejaardenvraagstuk te Enschede] TSG 35 (I957) 3, 54; Diederich, J. Bejaard zijn in de Westerse samenleving. In: Dekhuijzen-Zeehuisen, J. e.a. Zorgen van en voor bejaarden. Zaltbommel/Antwerpen: Jan van Tuyl, 1957: 9-24 
II6. Sytema, S. 'De bejaarde bestaat niet!' DB 20 (1974) 7, 170172; 'De' bejaarde bestaat niet. [Rede S. Sytema] OL II (I974) 2, II-12; Goedmakers, H.J.P.J. Inleiding: In: Goedmakers, H.J.P.J. e.a. Ouderdom en samenleving. Een overzicht van de gehele problematiek van de ouderdom in de gegeven maatschappelijke verhoudingen. Alphen aan de Rijn: Samson, 1970: $11-17$

117. Tonino, F.M.J. Bejaarden vormen geen homogene groep. Een sociaal-medische bijdrage. $B W$ II (I965) ros-109. Van Zonneveld beschreef hoe deze indeling tijdens een seminar in Kiev was voorgesteld. Zonneveld, R.J. van. Gezondheidsbescherming bij ouderen en bejaarden en voorkoming van vroegtijdige veroudering I. TSG 43 (1965) 5, $171-174$

118. Krol, B. Medische rubriek. $\mathrm{OL}_{2}$ (1965) 3, 59; Thiel, M. van. Knelpunten welke ouderen ervaren in de maatschappij. DB 25 (1979) 19-20, 368-371; Egas (1980) op. cit.; Egas, C. Ouder worden als maatschappelijk probleem. Wending (198I) 665-673

119. Miller, G. and Holstein, J.A. (Eds.) Constructivist Controversies. Issues in Social Problems Theory. New York: Aldine de Gruyter, 1993; Veen, R.J. van der. Retoriek, symboliek en beleid. Beleid en Maatschappij 18 (1991) 6, 303-311; Gusfield, J.R. The Culture of Public Problems. Drinking-Driving and the Symbolic Order. Chicago/Londen: The University of Chicago Press, 1981; Schön, D.A. Generative Metaphor: A Perspective on Problem-Setting in Social Policy. In: Ortony, A. (Ed.) Metaphor and Thought. Cambridge [etc.]: Cambridge University Press, 1982

120. Zo zijn de term 'rhetorisch idioom' en ideeën voor voorbeelden daarvan ontleend aan: Ibarra, P.R. en Kitsuse, J.I. Vernacular Constituents of Moral Discourse: An Interactionist Proposal for the Study of Social Problems. In: Miller en Holstein (1993) op. cit. pp. 2I- 54

121. Weijers, L. Tenig naar het behouden huis. Romanschnivers en wetenschappers in de jaren vijftig. Amsterdam: sUA, 1991; Mol, A. en Lieshout, P, van. Ziek is het woord niet; medicalisering, normalisering en de veranderende taal van huisartsgeneeskunde en geestelijke gezondheidszorg, 1945-1985. Nijmegen: SUN, 1989

122. Zie ondermeer: Munnichs, J.M.A. Als daar muziek voor is... [Boekbespreking]. $B W_{11}$ (1965) 116-117 
3 Vrouw, ongehuwd en oud: de verzorgingsstaat en het onderscheid naar sociale categorie

I. Een groot deel van dit hoofdstuk werd eerder als artikel gepubliceerd, met Klasien Horstman en Jessica Mesman als co-auteur: Bijsterveld, K.Th., Horstman, K. en Mesman, J. De versplintering van een categorie. De pensioengerechtigde leeftijd van ongehuwde vrouwen en het rechtskarakter van de verzorgingsstaat. Beleid en Maatschap. pij 19 (1992) 1, 16-30. Aanvullend onderzoek werd gepresenteerd in: Bijsterveld, K.Th., Horstman, K. en Mesman, J. Huilen als de maandag aanbreekt. Oudere ongehuwde vrouwen in Nederland en het spel van vergelijkingen, 1955-1980. In: Stavenuiter, M., Bijsterveld, K. en Jansens, S. (Red.) Lange levens, stille getuigen. Oudere vrouwen in het verleden. Zutphen: Walburg Pers, 1995: 162-180

2. Schuyt, C.J.M. De fragmentering van bestuar en beleid in de verzorgingsstaat. In: Boekaflevering Mens en Maatschappij. Deventer: Van Loghum Slaterus, 1979. Zie ook Schuyt, C.J.M. Het rechtskarakter van de verzorgingsstaat. In: Doorn, J.A.A. van en Schuyt, C.J.M. (Red.) De stagnerende verzorgingsstaat. Meppel/Amsterdam: Boom, 1978. Beide artikelen werden later opgenomen in: Schuyt, C.J.M. Tussen macht en moraal. Over de plaats van het recht in de verzorgingsstaat en de democratie. Alphen aan de Rijn/Brussel: Samson Uitgeverij, 1983

3. Engbersen, G. en Van der Veen, R. De tragiek van de verzorgingsstaat. In: Schuyt, K. en Van der Veen, R. De verdeelde samenleving. Een inleiding in de ontwikkeling van de Nederlandse verzorgingsstaat. Leiden (2de druk): Stenfert Kroese, 1990

4. Handelingen $\mathrm{IB}$ I955-1956 $4900 \mathrm{Vv}$ (nr. 6) 8

5. Handelingen нв 1960-1961 6100 н XII vV (nr.13) 9; MVA (nr. I5) 17

6. Handelingen II 1960-1961 3700, 3714-3715

7. Handelingen 1 1960-1961 3352

8. Handelingen Iв I96I-I962 6540 Mvт (nr. 3) 5-6, vV (nr. 5) I-2, VMO (nr. 9) 2, II 196I-I962 379I, 3793-95, 3798-99, 3808, 1B 1961$19626540 \mathrm{EV}$ (nr. 132) I

9. Handelingen I1в 1964-1965 $7762 \mathrm{vV}$ (nr. 5) 4

Io. Deze gegevens had Roolvink opgediept uit een rapport van een subcommissie van de Staatscommissie voor de Pensioenwetgeving uit 1951. Die subcommissie kwam mede op grond van de invaliditeitscijers tot de conclusie dat de pensioengerechtigde leeftijd voor vrouwelijke ambtenaren verlaagd zou moeten worden tot 60 jaar. Maar noch de 
Statscommissie, noch de regering nam dit advies over. Zie voor de aanbevelingen van de subcommissie: Rapport van de subcommissie voor de bestudering van het vraagstuk van de pensioengerechtigde leeftijden. 's-Gravenhage: Staatsdrukkerij/Staatscommissie voor de pensioenwetgeving, I95 I

11. Handelingen II 1964-1965 364

12. Handelingen II 1964-1965 395, 398

13. Handelingen 11 1964-1965 366

14. Handelingen II 1968-1969 694; II 1974-1975 3735

15. Intemationaal Informatiecentrum en Archief voor de Vrouwenbeweging. Archief Vrouwen-actiecomité voor vervroegde staatspensionering

16. Interview met M. van Saane, Amsterdam dd. 12-6-199I; Privé-archief M. van Saane, brief I.J.A. Oosterbaan aan Emmy van Overeem, dd. 18-3-1974

17. De positie van de oudere, alleenstaande, werkende vrouw. Rijswijk: Ministerie van Welzijn, Volksgezondheid en Cultuur, 1988 (p. 26-27). Over de Werkbijen kon helaas geen extra informatie worden achterhaald.

18. Tijdschnift voor Ziekenverpleging 21 (1968) 9. 387

19. Handelingen II I955-1956 MVA (nr. 7) 8

20. Handelingen IB 1960-1961 6100 H. XII MVA (nr. 90a) IO

21. Handelingen 1 I960-196 I 3397, І1в 1961-1962 6540 MVA (nr. 6) 2-3, II 196I-1962 3805-06

22. Advies inzake de positie van de gehuwden en de ongehuwden in de sociale verzekering. 's-Gravenhage: Sociaal-Economische Raad, 1963

23. Advies inzake verlaging van de pensioengerechtigde leeftijd voor de ongehuude vrouw in de Algemene Ouderdomswet. 's-Gravenhage: SociaalEconomische Raad, 1966

24. Advies (1963) op. cit. p. 14-15

25. Advies (1963) op. cit. p. 15

26. Advies (1966) op. cit. p. 5

27. Advies (1966) op. cit. p. 7

28. Advies (1966) op. cit. p. 12

29. De Christelijke Plattelandsvrouwen- en meisjesbond, de Commissie van Advies voor de Arbeid van Vrouwen en Meisjes (Ministerie van Sociale Zaken en Volksgezondheid), de 'Federatie', de Katholieke Nederlandse Boerinnenbond, de Nederlandse Bond van Plattelandsvrouwen, de Nederlandse Bond van Vrouwen werkzaam in Bedrijf en Beroep, de Nederlandse Unie van Vrouwelijke Bedrijfshoofden, de Nederlandse Vereniging van Vrouwen met Academische Opleiding, 
de Nederlandse Verening voor Vrouwenbelangen, Vrouwenarbeid en Gelijk Staatsburgerschap, de Nederlandse Vrijgezellenbond, de Stichting Nederlandse Vrouwelijke Religieuzen en enkele vrouwenorganisaties uit de vakbeweging.

30. Archief Sociaal-Economische Raad, stuknr. sv/266: Verslag van de tweeënzeventigste vergadering van de Commissie Sociale Verzekeringen, gehouden op 11 maart 1966 te 's-Gravenhage.

31. Handelingen II 1967-1968 s8

32. Handelingen 11 1967-1968 s8-510, 514, 778, 792, 795, 800, 820; II I968-1969 T34-37, T42, I304, I3 I 5-I6, 132 I-22; 1 1968-1969 105, 593, 616

33. Handelingen II $1967-1968$ S9

34. Handelingen $\mathrm{n}$ 1968-1969 $\mathrm{T}_{34}$

35. Handelingen II 1967-1968 S11-12, S1 5, 810, 814, 825; II 19681969 r $35-37$, T42, 1369; 1 1968-1969 633-34

36. Tijdschrift voor Ziekenverpleging 21 (1968) 19, 798

37. Handelingen 1 1968-1969 641

38. Handelingen 1 1968-1969 645

39. De Ongehuwde Vrouw. Onderzoek naar de levensomstandigheden van de ongehuude vrouwen van 40 tot 65 jaar. Nijmegen: Instituut voor Toegepaste Sociologie, 1970. Een samenvatting verscheen in Handelingen ив 1970-1971 11074. Zie voor kamervragen over dit en ander onderzoek (ondermeer van P.G.M. Schrama): Minister beantwoordt vragen over de problematiek van de oudere, werkende vrouw. $M C_{23}$ (1968) 23, 653-654. Zie voor het onderzoek van Schrama: Schrama, P.G.M. Arbeidsgeschiktheid van oudere werknemers. TSG 39 (1961) 12, 379-385; Schrama, P.G.M. De prepensioneringsfase in het arbeidsproces. Commentaar: Orgaan van de Centrale van Hogere Ambtenaren (I968) 39-44

40. De ongehuwde vrouw (1970) op. cit. p. 5-6

4 I. De ongehuwde urouw (1970) op. cit. p. II

42. Handelingen 11 1970-197I 2135, $2143,2145,210 \mathrm{I}-02$

43. Handelingen II 1970-1971 2212

44. Handelingen 118 1972-1973 12330

45. Advies oudere ongehuwde werkenden. 's-Gravenhage: SociaalEconomische Raad, 1982 (par. 1-3). Zie voor een overzicht van de uitgebrachte rapporten tot en met 1973: Beleidsrapporten. NTG 5 (1974) 2, 107-108

46. Brief dd. 18 januari 1977 aan de Voorzitter van de Tweede Kamer van de Staten-Generaal. Staatscourant 20 januari 1977, nr. 14 
47. Aanzet voor een viiffarenplan. Rijswijk: Emancipatiekommissie, 1976

48. Advies verbetering levensomstandigheden oudere ongehuwde vrouw. Rijswijk: Emancipatiekommissie, 1979. Zie daarover ook: Kloppenburg, L. Veel gepraat maar geen enkel besluit over de positie van de oudere ongetrouwde werkende vrouw. L I6 (1979) 9, 25-26. In dit artikel werd de bedrijfsarts $M$. Kloosterhuis-Duinker geïnterviewd, die op grond van onderzoek meende dat de overbelasting van oudere ongehuwde vrouwen vooral ontstond doordat zij een geringer prestatievermogen en kleinere reserves hadden dan mannen. Volgens Kloosterhuis had de Emancipatiecommissie meer oog voor de psychologische en sociologische oorzaken van de vermoeidheid van de oudere ongehuwde vrouwen. Dat kwam, zo dacht ze, omdat het impopulair was om bij het streven naar gelijke kansen voor mannen en vrouwen te beweren dat vrouwen fysiek tot minder in staat waren dan mannen. Overigens besprak ook Munnichs het advies van de Emancipatiekommissie kritisch. Zo meende hij ondermeer dat in het advies te weinig stil werd gestaan bij de tragedie die schuilging achter het hoge percentage 'WAO-genietsters' onder de oudere ongehuwde vrouwen. Munnichs, J.M.A. Advies inzake verbetering levensomstandigheden oudere ongehuwde vrouw. NTG io (1979) 4, 223-224

49. Knopper, E.V. Gelijke behandeling in de AOw. In: LeveltOvermars, W.M. (Red.) Gelijke behandeling van vrouw en man ten aanzien van pensioenen. Deventer: Kluwer, 1988: 11-21 (p. 13)

50. Zie hierover ondermeer: Royers, Th. De oudere ongehuwde werkende. $L 19$ (1982) 11, 38-40

5I. Roebuck, J. When Does Old Age Begin?: The Evolution of the English Definition. Joumal of Social History 12 (1979) 416-428; Roebuck, J. en Slaughter, J. Ladies and Pensioners: Stereotypes and Public Policy affecting Old Women in England 1880-1940. Joumal of Social History I 3 (1979) I, IOS-114; Thane, P. Een onvermoeibare levenslust. Beeld en zelfbeeld van oude vrouwen in Engeland. In: Stavenuiter, M., Bijsterveld, K. en Jansens, S. (Red.) Lange levens, stille getuigen. Oudere vrouwen in het verleden. Zutphen: Walburg Pers, r995: I8I-196 
4 Natuurlijk verouderen: de geriatrie en het karakter van een levensfase

r. Dit hoofdstuk is een op belangrijke punten gewijzigde bewerking van: Bijsterveld, K. De natuurlijke ouderdom: een grenzeloze geschiedenis. Kennis en Methode Is (I99I) 1, 62-86

2. Haber, C. Medical Models of Growing Old/Treating the Postclimacteric Stage. In: Beyond Sixty-Five: The Dilemma of Old Age in America's Past. Cambridge: England, 1983: 47-81

3. Latour, B. The Pasteurization of France. Cambridge [etc.]: Harvard University Press, 1988. Oorspronkelijk gepubliceerd als Les Microbes: guerre et paix suivi de irréductions. Paris: Editions A.M. Métailié, 1984; Latour, B. Science in Action: How to Follow Scientists and Engineers through Society. Milton Keynes: Open University Press, 1987

4. Voûte, P.A. Levenstempo. Een studie over veroudering. Leiden: H.E. Stenvert Kroese, 1952 (pp. 82-83)

5. Voûte (I952) op. cit. p. I 8

6. Groen, J. Medische en medisch-sociale grondslagen van de bejaardenzorg. In: Het bejaardenvraagstuk. Prae-adviezen en handelingen van het congres inzake het bejaardenvraagstuk. Scheveningen, 1956. Assen: Van Gorcum, 1957: 15-32 (p. 15)

7. Schreuder, J.Th.R. Oorzaken en gevolgen van veroudering. [Rede uitgesproken bij de aanvaarding van het ambt van bijzonder hoogleraar in de medische gerontologie aan de Rijksuniversiteit te Utrecht op maandag 28 april r969] Leiden: Stafleu's wetenschappelijke uitgeversmaatschappij, 1969 (p. 8)

8. Hollander, C.F. Ouderdom, spiegelbeeld der jeugd. [Rede uitgesproken bij de aanvaarding van het ambt van bijzonder hoogleraar in de medische gerontologie aan de Rijksuniversiteit te Utrecht op dinsdag 5 october 1976] [Utrecht], 1976 (p. I2). Zie ook: Hollander, C.F. Biologische aspecten van veroudering en ouderdom. In: Zonneveld, R.J. van (Red.) Medische gerontologie. Assen: Van Gorcum, 1970: pp. I5-30; Hijmans, W.. Knook. D.L. en Hollander, C.F. De experimentele basis van de gerontologie. NTG 119 (1975), 30, 1181-1 187; Zonneveld, R.J. van. Het medisch aspect van het ouderdomsvraagstuk. Onze Bejaarden I (I955) 2, I3-I5; Knook, D.L. Oud worden, een natuurlijke zaak? Lochem: De Tijdstroom, 1978

9. R.J. van Zonneveld benadrukte echter dat de belangstelling voor ouderdomskwesties onder artsen in het algemeen nog gering was, juist omdat artsen veronderstelden dat er aan vele ouderdomskwalen 
en -gebreken weinig of niets te doen viel. Dat kwam, aldus Van Zonneveld, zowel door een gebrekkige kennis van de mogelijkheden van preventie en behandeling, als door de overtuiging dat alle of zeer veel ouderdomsverschijnselen van fysiologische en niet van pathologische aard waren. Ingrijpen werd daarom door veel artsen nutteloos en ongewenst geacht. Zonneveld, R.J. van. De arts en de zorg voor bejaarden. $M C_{14}$ (1959) 8, 100-103

10. Dit problematische onderscheid heeft ook in de geschiedenis van de ziekte van Alzheimer een cruciale rol gespeeld. Het bleek bijzonder moeilijk het verschil tussen de 'ziekte van Alzheimer', Seniele Dementie en normale veroudering vast te leggen. Zie daarvoor: Dillmann, R. Alzheimer's disease. The concept of disease and the constnuction of medical knowledge. Amsterdam: Thesis Publishers, 1990; Bijsterveld, K. en Ponds, R. De wankele status van een ziekte. Bespreking van Rob Dillmann, Alzheimer's disease. The concept of disease and the construction of medical knowledge. Psychologie en maatschappij I5 (I99I) 3 , 298-300

11. Groen (1957) op. cit. p. 20. Zie ook: Groen, J. en Zonneveld, R.J. van. Veroudering, ouderdom en ouderdomsziekten. In: Zonneveld, R.J. van (Red.) Geriatnie. Aspecten van de gezondheidszorg voor bejaarden. Assen: Van Gorcum, 1961: 1-38. Hierna aangeduid als Van Zonneveld (196ra)

12. Sleeswijk, J.G. Inleiding, In: Sleeswijk, J.G. (red.) De ouderdom van geneeskundig standpunt beschouwd. Een handboek voor artsen Deel 1. Amsterdam/Antwerpen: Uitgeversmij. Kosmos, 1948: 1-20 (p. 10)

13. Sleeswijk (1948) op. cit. p. I

14. Zonneveld, R.J. van. Gezondheidsproblemen bij bejaarden. Resultaten van een sociaal-geneeskundig onderzoek bij 3000 personen van 65 jaar en ouder in de stad Groningen. Assen: Van Gorcum, 1954; Zonneveld, R.J. van. The health of the aged. Assen: Van Gorcum, 1961 (hierna aangeduid als Van Zonneveld (196 Ib); Zonneveld, R.J. van. Sociale geriatrie. In: Zonneveld, R.J. van (Red.) Sociale geneeskunde. Een algemene inleiding. Utrecht: Oosthoek, 1970: 319-336; Knook, D.L. De betekenis van medisch-biologisch onderzoek voor een leefbare ouderdom. NTG 2 (1971) 3a, 220-223

15. Thung, P.J. Over de zogenaamde normale ouderdom. Huisarts en wetenschap 8 (1965) 19-27

16. [RF]. Prof. dr. J.Th.R. Schreuder. Senior (1989) 11, 239

17. Schreuder, J.Th.R. De verpleging van chronisch zieke bejaarden. [Naar een rapport, uitgebracht aan de afdeling Frieslands Zuidwest- 
hoek van de Koninklijke Nederlandse Maatschappij tot bevordering der Geneeskunst en aan de Stichting Friesland voor Maatschappelijk Werk, over de verpleging van chronisch zieke bejaarden door dr. J.Th.R. Schreuder Internist te Sneek] ['s-Gravenhage]: Vereniging van Nederlandse Gemeenten, 195s (p. 32-33). Hierna aangeduid als Schreuder (1955a)

18. Schreuder zelf vermeldde in zijn rapport (Schreuder (1955a) op. cit.) dat de toename van het aantal bejaarden in het ziekenhuis van Sneek en de daarbij ontstane problemen steeds nadrukkelijker onder de aandacht van de staf van het ziekenhuis en het bestuur van de afdeling Frieslands Zuidwesthoek van de Koninklijke Nederlandse Maatschappij tot bevordering der Geneeskunst (KMNG) waren gekomen, en dat het bestuur van de KNMG-afdeling in samenwerking met de Stichting Friesland voor Maatschappelijk Werk daarop had besloten tot het instellen van een onderzoek. In andere publicaties werd de staf van het ziekenhuis echter niet meer genoemd en werd bovendien vermeld dat de gezondheidsorganisatie TNO steun had verleend aan het onderoek. Volgens Van Proosdij en Sipsma ontstond het idee voor het onderzoek echter nadat de inspecteur van volksgezondheid Schreuder had gevraagd hoeveel chronisch zieke bejaarden de regio kende. Zie: Schreuder, J.Th.R. Internistische Aspecten der Geriatrie. $M C 10$ (1955) 6, 92-96. Hierna aangeduid als Schreuder (1955b); Schreuder. J.Th.R. Chronische ziekten bij bejaarden. TSG 33 (I955) 5, II9-13I. Hierna aangeduid als Schreuder (1955c); Proosdij, C. van. Klinische geriatrie - 'un peu d'histoire'. NTvG I2I (1977) 4, I 52-156; Proosdij, C. van en Sipsma, D.H. Dertig jaar vaderlandse geschiedenis. De lijdensweg van de klinische geriatrie in Nederland. TGG 15 (1984) I, 3-5

19. Schreuder, J.Th.R. en Zonneveld, R.J. van. Geriatrische klinieken in Engeland. NTvG 99 (1955) 23, 1676-78

20. Van Proosdij (1977) op. cit. p. 153

21. De oudeliedenzorg te Amsterdam. Rapport van de commissie tot het instellen van een onderzoek naar de oudeliedenzorg te Amsterdam. Amsterdam: Centraal Bureau van Maatschappelijk Hulpbetoon te Amsterdam, 1942 (p. 40)

22. Zie bij voorbeeld: Rapport van de Studiecommissie voor Verplegingsinrichtingen voor Chronisch Zieken en Invalide Ouden van Dagen. Nationale Commissie voor de Oudeliedenzorg, 1951; Semi-statisch Archief Ministerie van Sociale Zaken en Werkgelegenheid, Departementaal Archief, dossiernr. 1.842.6, Nationaal Comité Oudeliedenzorg Amsterdam, Studiecommissie Verpleeginrichtingen voor Chronisch Zieken en 
Invalide Ouden van Dagen, brief dd. 25 mei 1951 van de Studiecommissie aan de Nationale Commissie voor de Oudeliedenzorg; Red. Activiteit op vergevorderde leeftijd. Onze Bejaardenzorg 2 (1951/52) 2, I-3; Meer, M.D.J. van der. Geriatrie in Nederland. TSG 32 (1954) 9, 162166; Huisvesting van bejaarden. Verpleegtehuizen. Rotterdam: Bouwcentrum, 1955

23. Schreuder (1969) op. cit. p. 14 en p. 16

24. Schreuder, J.Th. R. De geriatrische patiënt. NTvG IIo (1966) 4I, $1825-1828$ (p. I 825). Hierna aangeduid als Schreuder (1966a). Zie ook: Schreuder, J.Th.R. Lichamelijke aspecten bij het ouder worden. In: De ouder wordende mens. Vijfde provinciale gezondheidsdag op 25 mei 1966. [S.1.]: Provinciale Raad voor de Volksgezondheid in de provincie Drenthe, [5.a.]: 17-25. Hierna aangeduid als Schreuder (1966b)

25. Schreuder, J.Th.R. Revalidatie van bejaarden in algemene ziekenhuizen. TSG 37 (1959) 2, 49-52 (p. 50). Zie ook: Schreuder (1955b) op. cit.; Schreuder (I955c) op. cit.; Schreuder, J.Th.R. Invaliditeit en reactivering. In: Van Zonneveld (196ra) op. cit. pp. 39-59; Schreuder, J.Th.R. Gevaren voor bejaarden bij ziekenhuis-opneming. NTvG 107 (1963), 9, 410-412; Schouten, J. en Schreuder, J.Th.R. Gevaren van bedrust. NTvG 112 (1968) 29, 1337-1341; Schreuder, J.Th.R. Hulpbehoevendheid en reactivering. In: Van Zonneveld (1970) op. cit. pp. 258-30 I; Schouten, J. en Schreuder, J.Th.R. Gevaren van bedrust. In: Schouten, J. (Red.) Geriatrische lessen voor verpleegkundigen. Lochem: De Tijdstroom, 1978: pp. $71-80$; Verslag van een themadag over de ouder wordende mens en zijn opname in het ziekenhuis. Gerontologie 12 (1981) 3, 169-170

26. Schreuder, J.Th.R. De bejaarde patiënt; diagnose, therapie en prognose. Huisarts en wetenschap 8 (1965) 193-196. Hierna aangeduid als Schreuder (1965a); Als je een bepaalde leeftijd hebt bereikt is het niet meer zo belangrijk of je dood gaat. [Interview met Prof. Dr. J.Th.R. Schreuder] TBKZ 10 (1977) 1, 36

27. Schreuder (1966a) op. cit. p. 1827; J.Th.R. Revalidatie en geriatric in het Algemeen Ziekenhuis. NTvG 112 (1968) 40, 17871790 (p. 1788). Hierna aangeduid als Schreuder (r968a); De term 'reactivering' kon, aldus Schreuder, echter ook tot misverstanden aanleiding geven. Zie: Schreuder, J.Th.R. De verpleging en de revalidatie van chronisch zieke bejaarden. $M C$ is (1960) 37, 534-538

28. Dr. J.Th.R. Schreuder hoogleraar te Utrecht in de gerontologie. MC 23 (1968) 47, 1270; Pouw, A. Oud, maar wijs genoeg? De Nederlandse Vereniging voor Gerontologie 1947-1987. Lochem/Gent: De 
Tijdstroom, 1987 (p. 82)

29. Dat Schreuder zijn studenten per bus uit Utrecht naar Hilversum haalde om daar demonstratie-colleges te geven wordt vermeld door J.M.A. Munnichs in een brief aan mij dd. 26 juli r991. Dat Schreuder in Hilversum geregeld bezoek ontving en in zijn lezingen plaatjes en dia's gebruikte, blijkt ondermeer uit: Meesen, K. Verwaarlozing van bejaarden verkort het leven niet, maar verlengt het sterven. $K B_{3}$ (1957) 4, 54-57; Schreuder, J.Th.R. Het voorkomen van invaliditeit van bejaarden. $K B$ S (1959) 2, 38-45; Schreuder, J.Th.R. Verpleging en revalidatie van chronisch zieke bejaarden. $K B \quad 6$ (1960) s, 109- II I / 6, 135- 142

30. Zie daarvoor ondermeer Verschure, J.C.M. Ouderdomsziekten. Katholieke Gezondheidszorg 25 (1956) 4, 132-135; Niemeijer, J. Bijdrage tot de diagnostiek der dementiële syndromen. NTG I (1970) I, 17-22; Haar, H.W. ter. Decorumverlies. TSG 4S (1967) 772-774; Sipsma, D.H. Het wankele evenwicht. Een praktisch model ten behoeve van preventie, vroegdiagnostiek en behandeling van geestelijke stoornissen bij bejaarden. NTG 4 (1973) I, 13-22; Verkade, W.J. Oude mensen en ziekenhuizen. $M C_{32}$ (1977) 1478-1480; Aparte gezondheidszorg voor bejaarden. DB 22 (1976) 12, 24I; Diatlowicki-Tobi, A. Over ouderdom en verouderingsverschijnselen. DB 24 (1978) 19, 490492

31. Wartena, B. en Visser, D.S. Verpleegtehuizen. DB $6(1960) 4$. $5 \mathrm{I}-54$

32. Zie daarvoor ondermeer Zonneveld, R.J. van. De huisvesting ten behoeve van bejaarden. Medische en sociale aspecten. In: Het bejaardenvraagstuk (1957) op. cit. pp. 72-82; Miedema, J.J. Revalidatic van bejaarden. TSG 35 (1957) 2I, 535-538; Munnichs, J. Psychologie van de bejaarden x. Revalidatie. KB 3 (1957) 6, I14-115; Querido, A. Revalidatie van bejaarde zieken. NTvG 102 (1958) 5, 209-211; Gorter, $K$. De revalidatie van bejaarden met neurologische aandoeningen. TSG 37 (1959) 2, 52-54; Oosterhuis, J. Rapport Verpleegtehuizen. TSG 39 (196I) 7, 233-24I; Meuwese, C. Reactivering en revalidatic van bejaarden in algemene ziekenhuizen. TSG 43 (1965) 8, 302-303: Verkuyl, A. Revalidatie en geriatrie. TSG 43 (1965) 8, 298-301; Het bejaardenvraagstuk in Nederland. Toelichting op een aantal panelen. [S.1.]: Ministerie van Cultuur, Recreatie en Maatschappelijk Werk, [1966]; Akkerman, H.P. Geriatrie. Leiden: Spruyt, Van Mantgem \& De Does, I973; Faassen, F. van. Reactivering van bejaarden. In: Schouten (1978) op. cit. pp. 92-102 
33. Handelingen II 1957-1958 3181. Zie ook: Handelingen 118 I95619574500 H XII MVA (nr. 9) 31; II 1956-1957 3037, I 1956-1957 3268, Il 1957-1958 3198, II 1958-1959 3313, I 1959-1960 3212, II 1960-196I 3240, Ів 1961-1962 6500 н XV vV (nr. 77) 9, 1 1961-1962 3136; De sociale betekenis van de geriatrie. [samenvatting rede Minister van Sociale Zaken en Volksgezondheid dr. G.M.J. Veldkamp] TSG 39 (1961) 22, 695-696

34. CBS-Verzorging van bejaarden in tehuizen naar de toestand op 1 October 1950 Utrecht: Uitgeversmaatschappij W. de Haan, I95I; CBSStatistiek van de bejaardenoorden 1970. 's-Gravenhage: Staatsuitgeverij, 1973 (p. 21); CBS-Statistiek van de bejaardenoorden 1986. 's-Gravenhage: sDU-uitgeverij/CBS-publikaties, 1989 (p. 21). Zie voor de eerste revalidatie-afdeling in een bejaardencentrum: Rubbens-Franken, E. Hebben revalidatie-afdelingen in verzorgingstehuizen zin? Den Haag geeft het antwoord! DB 7 (1961) 5, 75-77. Zie voor de personele ontwikkelingen in verpleeghuizen ondermeer: Advies verpleeghuizen. Uitgebracht op 25 oktober 1972 aan Zijne Excellentie de Minister van Volksgezondheid en Milieuhygiëne door de Centrale Raad voor de Volksgezondheid. 's-Gravenhage: Staatsuitgeverij, 1972; Interim-advies inzake het functioneren van verpleeghuizen. Uitgebracht aan de Minister van Volksgezondheid en Milieuhygiëne. Rijswijk: Centrale Raad voor de Volksgezondheid, 1982; Oostvogel, F.J.G. Historische ontwikkeling van verpleeghuizen in Nederland. $M C_{39}(1984)$ 2, 45-46

35. Schreuder (r966a) op. cit. p. 1825. Zie voor een opsomming van deze karakteristieken ondermeer ook: Schreuder (1968a) op. cit.; Schreuder, J.Th.R. Geriatrie en reactivering. TSG 43 (I965) 8, 289293. Hierna aangeduid als Schreuder (1965b)

36. Schreuder (1966a) op. cit. p. 1826

37. Schreuder (1968a) op. cit. p. I790. Zie ook: Schreuder, J.Th.R. De geriatrie in het algemeen ziekenhuis. $M C_{17}(1962){ }_{13}, 207$

38. Schreuder (1966a) op. cit. p. 1828

39. Schreuder (1965b) op. cit. p. 290

40. Abbott, A. Introduction/The System of Professions. In: The System of Professions. An Essay on the Division of Expert Labor. Chicago/London: The University of Chicago Press, 1988: 1-31/86-113

41. Zonneveld, R.J. van. De opleiding van artsen, belast met de medische zorg van bejaarden. $M C$ is (1960) 14, 182-183; Schreuder, J.Th.R. en Zonneveld, R.J. van. De cirkelgang van het perfectionisme. TSG 38 (1960) 17, 46r; Zonneveld, R.J. van. Sociale geriatrie. In: Van Zonneveld (1961) op. cit. pp. 117-149; Zonneveld, R.J. van. 
Vraagstukken rondom de gezondheidszorg voor bejaarden. Huisartsen wetenschap 8 (1965), 132-137; Zonneveld, R.J. van. Sociale geriatric. In: Van Zonneveld (1970) op. cit. pp. 328-379; Zonneveld, R.J. van. Geriatrie: omstreden werkelijkheid. Medicinae Scientia Donat 3 (1970) 10, 43-47; Proosdij, C. van. Beschouwingen over de geriatrische kijniek. NTVG III (1967) 44, 1984-1985. Hierna angeduid als Van Proosdij (1967a); Proosdij, C. van. Nogmaals de geriatrische kliniek. NTvG III (1967) 48, 2194-2195. Hierna aangeduid als Van Proosdij (1967b); Proosdij, C. van. Beschouwingen over de geriatrische klinick NTvG 112 (1968) I, 53-54; Proosdij, C. van. Bejaarde patiënten. Genatrie in theorie en praktijk. Leiden: Stafleu, 1972; Proosdij, C. van. Doen of laten in de geriatrie. NTVG 120 (1976) 29, 1237-124I; Schouten,J. Gebreken van de ouderdom. In: Bekkum, D.J. van e.a. Oud worden, oud zijn. Deventer: Van Loghum Slaterus, 1974: 23-29; Schouten, J. Verslag over een geriatrische afdeling in een algemeen ziekenhuis. NTVG I20 (1976) 11, 481-87; Schouten, J. De werkwijze van de geriatrische afdeling van het gemeenteziekenhuis Slotervaart te Amsterdam. TSG 55 (1977) 11, 4I6-4 I9; Beschouwingen over geriatrie (i) en (II). NTG 9 (1978) 1, 35-41/2, 72-79; Schouten, J. De resultaten van de afdeling voor somatische en psychiatrische geriatrie van het Slotervaartziekenhuis te Amsterdam. NTvG 123 (1979) 16, 653-657. Schouten, J. Mobiliteit. In: Schouten, J. (Red.) Gerontologische problemen. Een inleiding. Alphen aan den Rijn/Brussel: Samson, 1980: 50-6r; Braadbaart, S. Inleiding en probleemstelling. In: Ouder worden. Rotterdam: Studium Generale, 1980: 14-17

42. Van Proosdij (1968) op. cit. p. 54

43. Van Proosdij (1972) op. cit. p. 11

44. ARA, Archief NFB, inventarisnr. 8, stuk 449: 'Afschrift Documentatieblad van de Afdeling Voorlichting, Ministerie van Sociale Zaken en Volksgezondheid. (..) varA "Dagje ouder extra", presentatie Sonja Barend, 17 oktober 1968 (..)' en stuk 462: 'Afschrift Medisch Contact 23 (1968) 44, v.M., Kwalijke voorlichting'

45. Van Zonneveld (1960) op. cit.; Braadbaart, S., Schreuder, J.Th.R. en Zonneveld, R.J. van. Geriatrie als specialisme. $M C 17$ (I962) 23, 368-369

46. Verslag van de bespreking over geriatrie en interne geneeskunde. $M C 10$ (1965) 37, 758-759. Eerder had de Commisie van Beroepsbelangen van de Nederlandsche Internisten Vereniging een preadvies geformuleerd, waarin de boodschap was dat binnen het algemeen ziekenhuis geen behoefte bestond aan het specialisme geriatrie, maar 
dat er wel behoefte was aan een geriatrische leiding in de verpleeghuizen. Preadvies over de geriatrie. NTvG 106 (1962) 47, 2396

47. Ottolander, G.J.H. den. Geriatrie als specialisme. $M_{17}$ (1962) 28, 460-46I. Ottolander zelf had ervaring met een afdeling voor bejarden - voor diagnostiek en interne behandeling - van het Rotterdamse Dijkzigt ziekenhuis. Zie: Ottolander, G.J.H. den. Ervaringen met een interne geriatrische unit. NTvG 109 (I965) 47, 2244-2247

48. Zonneveld, R.J. van. Internationale aspecten van de lichamelijke gezondheidszorg voor bejaarden. TSG 37 (1959) 4, 123-130; Van Zonneveld (1965) op. cit.

49. Bruijel, L.P. Revalidatie en geriatrie. MC 23 (1968) 45, I I991200; Rapport van de Commissie voor Revalidatie en Geriatrie. MC 22 (1967) 46, I097-1 100

5o. Zie ondermeer: Rapport over de ontwikkeling van verpleegtehuizen. MC 22 (1967) 52,1252

5I. Wartena, B. Geriatrie n. Sociale Bejaardenzorg. MC Io (I955) 7. 110-116; R[ubbens]-F[ranken], E. De medische kant van het verpleegtehuis. De twee meningen daarover. $D B 8$ (1962) 7, 109-110; Oostvogel, F.J.G. Het probleem van de bejaarden en de Nederlandse oplossing. Medicinae Scientia Donat 3 (1970) 10, 48-50

52. Lelie, L.H. Beschouwingen over de geriatrische kliniek. NTvG 111 (1967) 37, 1609-161 3; Diepersloot, J. Altematief van de geriatrische afdeling van een ziekenhuis. TSG 48 (1970) 17, 572-73; Leering, C. Gezondheidszorg en gezondheidsbescherming bij bejaarden. $B W$ 14 (1968) 6, 140-142; Leering. C. Over verpleegtehuizen en geriatrie; beschouwingen, soms à la perte de vue. $M C_{24}$ (1969) 45, 1279-1283; Leering, C. Een model voor geriatrische hulpverlening in de regio. MC 27 (1972) 16, 432-434

53. Zie ondermeer: Van der Meer (1954) op. cit.; Meer, M.D.J. van der. Een geriatrische dienst. TSG 35 (1957) 2I, 545; Meer, M.D.J. van der. De geriatrische patiënt. NTvG I10 (1966) 46, 2062-2063: Meer, M.D.J. van der. Beschouwingen over de geriatrische kliniek. NTvG 111 (1967) 48, 2192-2193

54. Zie ondermeer: Leering (1969) op. cit.; Leering (1972) op. cit.; Leering, C. Het wetenschappelijk model van de geriatrie als specialisme. $M C_{23}$ (1968) 34, 887-891

55. Post, H.J.W. Verpleeghuisarts en geriatrie. $M C_{3} \mathrm{I}(1976){ }_{3}, 82$; Lokhorst, W. Verpleeghuisartsen vergaderden. DB 19 (1973) 12, 334335

56. Colenbrander, M.C. Moet de geriatrie een erkend specialisme 
worden? $M C_{23}$ (1968) 39, 1025-1026

57. Zie ondermeer: [Redactie]. De geriater. $M C$ is (1960) It $_{4}$ 181-182; [Redactie] Geriatrie. MC I6 (1961) 46, 725-726; Anbeek, A.J. Problemen en aanrakingspunten van de ziekenfondsen bij de revalidatie en reactivering van bejaarden. TSG 43 (1965) 8, 294-298; Diepersloot (1970) op. cit.; Geriatrie een klinisch specialisme. Wat nu? Tekst van de rede, op 6 januari 1983 gehouden door Prof. Dr. C.L.C. van Nieuwenhuizen op de Algemene Ledenvergadering van de Nederlandse Vereniging voor Geriatrie.

58. Schreuder, J.Th.R. Heeft erkenning van geriatrie als specialisme nog zin? Ja! DB I5 (1979) 19/20, 383-384; Ackermans, M. 'Je moet aantonen dat de bejaardenzorg een chaos wordt als het zo doorgaat'. [Interview met J.Th.R. Schreuder]. OL 7 (1970) 3. 84-87. Ook nam Schreuder zitting in een commissie van de Geneeskundige Vereniging tot bevordering van het ziekenhuiswezen, die zich over de samenwerking tussen ziekenhuis en verpleeghuis boog. Zie daarvoor: Privé-archief P.J. Thung, Samenwerking Ziekenhuis-verpleegtehuis. Mogelijkheden en concretisering in de praktijk. [Overdruk uit Ons Zieken. huis februari 1970]; Samenwerking ziekenhuis-verpleegtehuis. Rapport van de Geneeskundige Vereniging tot bevordering van het Ziekenhuiswezen. MC 24 (1969) 34, 957-959; Post, H.J.W. Samenwerking ziekenhuizen-verpleegtehuizen. $M C_{25}$ (1970) 5, 98-99

59. Privé-archief P.J. Thung, Nota 'Geriatrie'. Commissie geriatric van de Landelijke Vereniging van Artsen in Dienstverband en van de Algemene Nederlandse Vereniging voor Sociale Geneeskunde, Oktober 1970 . Deze nota werd niet openbaar gemaakt. De leden van de commissie waren H.W. ter Haar (rapporteur), S. Braadbaart, J.J.M. Michels, F.J.G. Oostvogel en R.J. van Zonneveld. Zie voor gedachten over de sociale geriatrie ook: Braadbaart, Schreuder en Van Zonneveld (1962) op. cit.

60. Geriatrie, een klinisch specialisme? Rapport van een door het Centraal College ingestelde studiecommisie geriatrie. Rapporteur: Prof. Dr. C.L.C. van Nieuwenhuizen. Redactie: Prof. Dr. M.C. Colenbrander. [S.1.]: [s.n.], 1980. Dit interne rapport werd mij ter beschikking gesteld door het Centraal College, KNMG, Utrecht.

61. Zie ondermeer: Muntendam, P. [Directeur-Generaal van de Volksgezondheid] Woord vooraf. In: Schreuder (1955a) op. cit. p. 5; Handelingen IB 1956-1957 4500 HXII MVA (nr. 65a) 23. Minister Suufhoff achtte geriatrische afdelingen aan algemene ziekenhuizen nodig om bejaarden met veelal chronische aandoeningen te revalideren, zo- 
dat zij het ziekenhuis weer zo snel mogelijk konden verlaten. Daarnaast konden consultatiebureaus voor bejaarden - via sociale en geneeskundige adviezen - een waardevolle bijdrage leveren. Zie voor sociaal-democratische steun aan Schreuders plannen ook: Program voor bejaardenzorg. Amsterdam: dr. Wiardi Beckmanstichting 1958; Handelingen II 1967-1968 T21; Anders Ouder Worden. Nota over het bejaardenbeleid. [S.1.]: Tweede Kamerfractie Partij van de Arbeid, [1970]. Het waren echter niet uitsluitend sociaal-democraten die zich voor geriatrische afdelingen uitspraken. Aan het begin van de jaren zestig meende ook kvp-minister Veldkamp dat de totstandkoming van geriatrische afdelingen in de grotere ziekenhuizen - in het belang van de revalidatie van bejarden - bevorderd diende te worden. Ook binnen verpleeginrichtingen moest echter, aldus Veldkamp, meer aandacht aan revalidatie worden besteed. Handelingen 1B 1961-1962 6500 н XV MVA (nr. 77a) 15

\section{Handelingen IB 1956-57 $4500 \mathrm{H}$ Xn VV (nr. 65) 14}

63. 'Geriatrie wordt niet en bagatelle genomen.' MC 21 (1966) 24 , 553; Vraag naar leerstoel voor geriatrie en erkenning als specialisme. MC 22 (1967) 47, I1 17-1118; Handelingen II 1967-1968 T20, T22; II 1975-1976 819; In 1977-78 2946. Volgens Geriatrie, een klinisch specialisme? (1980) op. cit. bestond bij de overheid bovendien enige aarzeling ten aanzien van de erkenning van nieuwe specialismen, omdat men bang was dat artsen als generatoren van kosten ook op nieuwe gebieden kostenverhogend zouden werken. Wanneer het Centraal College een specialisme erkende, werd dit ook steeds door de organen van de sociale zekerheid erkend. Dat was geen wettelijk vastgestelde regeling, maar een 'gentlemen's agreement'.

64. Verpleeghuis en revalidatie. Uit de rede van Prof. Dr. P. Muntendam, uitgesproken ter gelegenheid van de opening van het verpleeghuis 'Bertilla' te Drachten op 6 oktober 1962. MC 17 (1962) 694

65. Michels, J.J.M. Verpleeghuizen voor langdurig zieken. In: Santema, S. (Red.) Intramurale gezondheidszorg. Beschrijving van de verschillende soorten van inrichtingen. Alphen aan de Rijn: Samson, 1970: 37-52

66. Bejaardenbond vraagt erkenning geriatrie als specialisme. $M C$ 3I (1976) 21, 655; Leenaerts, W.A.F. Onrustmakers. DB 25 (1979) 7 , 137; Ouderen willen nieuw beleid. Utrecht: cosBo Nederland, 1979; Het werk van de ouderenbonden in Nederland. Utrecht: ANBO, 1980

67. Fockert, J.A. de en Dillmann, E.B.M. Een geriatrische afdeling in een algemeen ziekenhuis. TSG 60 (1982) 23, 733-738; Handelingen II 1975 -I976, I 3463 , Bijzondere Commissie voor de Nota Bejaarden- 
beleid 1975, Openbare commissievergadering 29 maart 1976, 857-8 58 ; II 1975-1976 I3463 (nr. 14). Ook door een kamerlid van Ds'70 werd voor geriatrische afdelingen gepleit: Handelingen II 1976-1977 I257

68. Handelingen ПІв 1976-1977 13463 (nr. 30)

69. Geriatrie, een klinisch specialisme? (1980) op. cit. p. 6

70. Geriatrie als klinisch specialisme. Discussienota NZR-sectie Verpleeghuizen. $M C 36$ (1981) 28, 852-854; Interim-advies inzake geriatrie in algemene ziekenhuizen. Uitgebracht aan de Minister van Volksgezondheid en Milieuhygiëne. Rijswijk: Centrale Raad voor de Volksgezondheid, 1982; Geriatrie een klinisch specialisme (1983) op. cit.

7I. Schouten, J. Moet geriatrie verdwijnen vóór ze zelfs maar een kans heeft gehad? Senior 28 (1982) 19, 448-449; Bijdragen over het specialisme geriatrie en de opleiding tot geriater. Gerontologie 12 (1981) 4, 224-232; Ringoir, D.J.B. De Geriater - geduld of gewaardeerd? TGG 13 (1982) I, I2-I5; Hellemans, J. en Kammen-Wijnmalen, E.H.W. van. De ontwikkeling van de geriatrie tot een medisch specialisme. TGG 13 (1982) 2, 53-59

72. Schreuder en Van Zonneveld (1955) op. cit. p. 1678

73. Schreuder en Van Zonneveld (1955) op. cit. p. 1676

74. Schreuder (1968a) op. cit.; ARA, Archief NFB, inventarisnr. 8, stuk 449 '(..) VARA "Dagje ouder extra" (..)' (zie noot 44)

75. Van Proosdij (1967b) op. cit. p. 2194

76. Lelie (1967) op. cit. p. 1612

77. Carboni, D.K. Geriatric mediaine in the United States and Grat Britain. Greenwood Press: Westport, Connecticut/London, 1982

78. Webster, C. The elderly and the early National Health Service. In: Pelling, M. en Smith, R.M. (Eds.) Life, death, and the elderly. Historical perspectives. London/New York: Routledge, 1991: 165-193

79. Schreuder, J.Th.R. Het gesloten circuit II. DB 18 (1972) 5. 127-129; Schreuder, J.Th.R. De organisatie van de bejaardenzorg. In: Cahn, L.A. e.a (Red.) 20 jaar geriatrie: een keuze uit het werk van prof. J.Th.R. Schreuder. Deventer: Van Loghum Slaterus, 1973: 275-282 (Oorspronkelijk verschenen in MC 27 (1972) 8, 199-202); Schreuder, J.Th.R. (Dis)continuîteit in de gezondheidszorg voor bejaarden. Tijdschrift voor Sociale Gezondheidszory 55 (1977) 362-366, 375

80. Schabel, P. De gezondheidszorg: van immuniteit tot publiek domein. In: Kreukels, A.M.J. en Simonis, J.B.D. (Red.) Publiek domein. De veranderende balans tussen staat en samenleving. Amsterdam/Meppel: Boom, 1988: pp. 172-200. Met 'immuniteit' doelde Schnabel op het volgende: 'De plaats en de functie van de gezondheidszorg in de samenle- 
ving herinnert aan die van de middeleeuwse immuniteit: als religieuze institutie van een algemeen belang, als autonoom systeem en ruimtelijke enclave in de stad zeker geen openbaar gebied en maar tot op zekere hoogte publiek domein.' (pp. 178-179) Zo was het naar zijn mening traditioneel gezien ook met de gezondheidszorg in Nederland gesteld.
5 Ommuurde ouderdom: de ruimtelijke orde van de verzorgingshuizen

I. Delen van dit hoofdstuk werden eerder gepubliceerd in: Bijsterveld, K. De geschiedenis van het beleid met betrekking tot verzorgingshuizen in Nederland van 1945-1990. In: Handboek 'Wonen en werken in een verzorgingshuis'. Amersfoort: Academische Uitgeverij, 1991: (par. 1.3) 1-31. Zie ook: Bijsterveld, K. Rozenperken, rust en avondrood. Veranderingen in de taak van het verzorgingshuis. Denkbeeld. Tijdschnift voor Psychogeriatrie 4 (1992) 2, 5-7

2. Chowdhury, S.D. Privacy, Space and the Person in a Home for the Aged. Etnofoor 3 (1990) 2, 32-47; Chowdhury, S.D. Lange levens, kleine kamers. Privacy en afhankelijkheid in een Nederlands verzorgingshuis. In: Stavenuiter, M., Bijsterveld, K. en Jansens, S. (Red.) Lange levens, stille getuigen. Oudere vrouwen in het verleden. Zutphen: Walburg Pers, I995: I48-16I

3. Zie ondermeer: Egas, C. De duivel is oud. Niet meer jong zijn als maatschappelijk probleem. Amsterdam: Contact, [1974]; Zwier, J. Het overheidsbeleid ten aanzien van ouderen. Ars Aequi 37 (1988) 1o, 633-642. Opvallend is dat in terugblikken van vóór 1970 de 'omslag' weliswaar eerder in de tijd wordt gesitueerd, maar dat ook daar pensiontehuizen louter met 'verzorging' en bejaardenwoningen met 'zelfstandigheid' worden geassocieerd. Dat blijkt bij voorbeeld uit het volgende citaat: "Hoewel na de oorlog de "verzorgende" factor nog een grote rol heeft gespeeld, hetgeen blijkt uit het grote aantal rusthuizen dat overal in Nederland is gebouwd, begon hierin kentering te komen, doordat men telkens in aanraking kwam met het verlangen der bejaarden om zolang mogelijk zelfstandig te kunnen blijven. Om hieraan tegemoet te komen zijn aparte bejaardenwoningen gebouwd (..).' Zie: Zelfstandig wonende bejaarden. Leeuwarden: Stichting Friesland voor Maatschappelijk Werk, I960 (p. 1). Zie voor een versie van de 'vroege voorbereidingen op de grote omslag: Blommestijn, P.J. Ouderenbeleid in Nederland van 1955 tot 1985 . Een beleidshistorisch evaluatie-onderzoek. 
[Bewerkt door prof. dr. A. Hoogerwerf]. Enschedé: Universitêt Twente, Faculteit der Bestuurskunde, 1990 (pp. 24-25). Blommestijn schreef dat de verschuiving van intramurale naar extramurale zorg al een 'betrekkelijk oud onderwerp' was en dat bewindslieden reeds in de jaren vijftig en zestig op het belang van het behoud van zelfstandig. heid wezen. Vervolgens merkte Blommestijn op dat de verschuiving van intramurale naar extramurale zorg in de Nota Bejaardenbeleid 1970 'fundamenteel' tot actiepunt werd genomen.

4. De benaming van tehuizen voor ouderen is in de bestudeerde periode verschillende malen veranderd en is binnen de wereld van de ouderenzorg vaak een bron van verwarring geweest. De achtergronden daarvan komen nog aan de orde. In navolging van het huidige spraakgebruik van praktijkmensen en beleidsmakers wordt hierna van verzorgingshuizen gesproken, wanneer de tekst een 'tijdloze' noemet vereist.

5. Stavenuiter, M. Verzorgd of zelfstandig. Ouderen en de levensloop in Amsterdam in de tweede helft van de negentiende eeuw. Groningen: Proefschrift, 1993 (p. I4)

6. Beyer, G.H. en Nierstrasz, F.H.J. Housing the Aged in Westem Countries. Programs, Dwellings, Homes and Geriatric Facilities. Amsterdam [etc.]: Elsevier, 1967 (p. I6)

7. Armenzorg in Nederland fin opdracht der Vereeniging voor de Staathuishoudkunde en de Statistiek bewerkt door Mr. Ph. Falkenburg] it deel: Gemeente Amsterdam. Amsterdam: Johannes Müller, 1893

8. Rapport van de commissie, door het dagelijksch bestuur benoemd om een onderzoek in te stellen naar den toestand van den zorg voor ouden van dagen in Nederland. [Geschriften van de Nederlandsche Vereeniging voor Armenzorg en Weldadigheid te Amsterdam] Haarlem: H.D. Tjeenk Willink \& Zoon, 1923. Zie voor het begrip 'classificeering' p. 16.

9. Smissaert, H. Overzicht van het Nederlandsch Anmwezen. Haarlem: H.D. Tjeenk Willink \& Zoon, 1901 (p. 121); Rapport van de commissi (1923) op. cit.

10. Rapport van de commissie (1923) op. cit.; Pley, G. Liefdewerk an bejaardenzorg. Verkenningen in de historie van de R.K. Stichting Verzorgings- en Verpleegtehuis Bemardus te Amsterdam, 1839-1989. Amsterdam: R.K. Stichting Verzorgings- en Verpleegtehuis Bernardus, 1989

II. Een enkele keer werd geen onderscheid gemaakt tussen de kamers van bewoners die de verzorgingsprijs wel of niet zelf opbrachten. Zie: Welling, J. Het Protestantsch tehuis 'Levensavond', Nijmegen. TAMK 6 (1927) 125, 1205-1207 
12. Zie ondermeer: [Adriani], J.H. Het tehuis voor ouden van dagen 'Vredeveld' te Amstelveen. Maandblad voor kerkelijke ammenzorg $\mathrm{I}_{3}(\mathrm{I} 922) 8, \mathrm{II} 3-\mathrm{I} 2 \mathrm{I}$

I3. [Adriani], J.H. De Stichting 'Vredeheim' te Rockanje. TAMK 4 (1925) 88, 63 I-634 (p. 632); De Vereeniging 'Pro Senectute' (Voor den Ouderdom). TAMK 4 (1925) 87, 612-615 (p. 612); Everts, U.] De verzorging in pensiontehuizen van ouden van dagen uit eenvoudigen kring. TAMK 19 (1940) 445, 172-173 (p. 172); Jong, A.A. de. Pro Senectute. TAMK 6 (1927) 122, 1160-1163; Rooseboom, M.P. 'Ons Thuis'. TAMK 7 (1928) 164, 1829-1832. Zie ook: Winters, W. 'Hoort regeerders van het land...' Uit de geschiedenis van het ouderenbeleid. Leiden: Stichting Burgerschapskunde [etc.], I988 (p. II)

14. De vereeniging 'Pro Senectute' (Voor den ouderdom). TAMK 4 (1925) 87, 612-615 (p. 612)

Is. Everts, J. De huisvesting en verzorging van bejaarden. Economisch-Statistische Berichten 29 (1944) 1442, 77-80 (p. 78). Zie voor de term 'pensiontehuizen' ook: Everts, [J.] De verzorging in pensiontehuizen van ouden van dagen uit eenvoudigen kring. TAMK 19 (I940) 445, $172-173$

16. [Muller-Lulofs, M.G.] Oranjestein te Amerongen. Pro Senectute (Voor den Ouderdom). Amenzorg. Orgaan van de Vereeniging tot Verbetening van Amenzorg te Utrecht [3 I] (1923) 27, I-4 (p. 3). Vergelijk ook de commentaren bij de opening van 'Avondlicht', een tehuis van de Hervormde diaconie in Haren, waarin aanvankelijk iedereen, door de diaconie ondersteund of niet, een kamer met aangebouwde slaapkamer tot zijn of haar beschikking kreeg. Zie: Veen, W.K. van der. 'Ten tijde des avonds...' Vijftig jaren bejaardentehuis 'Avondlicht' en wat daaraan vooraf ging: diakonale bejaardenhuisvesting te Groningen. Groningen: Diakonie Hervormde Gemeente, 1984

17. Benner, J.B. Oudeliedenzorg - Nieuw leven. TAMK S (1926) 100, 817-8 I9 (p. 819). Zie voor opmerkingen over de bejaardenwoningen ook: De oudeliedenzorg te Amsterdam. Rapport van de commissie tot het instellen van een onderzoek naar de oudeliedenzorg te Amsterdam. Amsterdam: Centraal Bureau van Maatschappelijk Hulpbetoon te Amsterdam, 1942 en Tijdschrift voor Volkshuisvesting 8 (I927) p. I 53 en Io (1929) p. 162

18. Rapport van de commissie (1923) op. cit. pp. 18-19; Benner (1926) op. cit.; Benner, J.B. Rekenen zonder cijfers. Maandblad voor kerkelijke annenzorg 18 (1927) 2, 17-23

19. Zie voor deze gegevens: De oudeliedenzorg te Amsterdam (1942) op. cit. pp. 5-6, pp. $17-19$, p. 24 , p. 29 , p. 47 
20. Everts (1944) op. cit. p. 78

21. Everts (1944) op. cit. p. 80

22. Beusekom, H.G. van. Een kwart eeuw bejaardenhuisvesting Bouw 25 (1970) 1, 10-13

23. De oudeliedenzorg te Amsterdam (1942) op. cit.; Beusekom, H.G. van. Huisvesting van bejaarden in het kader der practische mogelijkheden. Bouw 3 (1948) 52, 405-412. Hierna aangeduid als Van Beusekom (1948a)

24. 'Huisvesting van bejaarden'. [Concept-rapport] november I945. Mij toegezonden door mr. J. Everts junior, zoon van mr. J. Everts.

25. Bakker, J.C. Huisvestingsbeleid van bejaarden. In: Schouten,]. (Red.) Geriatrische lessen voor verpleegkundigen. Lochem: De Tijdstroom, 1978: 189-196; Blommestijn (1990) op. cit. p. 44; Bosch, J.G.J. en Sul, H.D. Inleiding. In: Zorg en dienstverlening. Deel II: ouderenbeleid. Tekstuitgave. Deventer: Kluwer, 1990; Kastelein, M., Dijkstra, A. en Schouten, C.C. Care of the elderly in the Netherlands. A review of policies and senvices 1950-1990. Leiden: Nederlands Instituut voor Praeventieve Gezondheidszorg/TNO, 1989; Munnichs, J.M.A. Oude mensen, hun familie en het gebruik van algemene voorzieningen. NTG 5 (1974) t, 6-23: Munnichs, J.M.A. Voorzieningen voor ouderen: visie op ouderdom. Deventer: Van Loghum Slaterus, 1987; Winters op. cit.; Zwier (1988) op. cit.

26. Huisvesting van bejaarden. ['s-Gravenhage]: Centrale Directie van de Wederopbouw en de Volkshuisvesting, 1949; Van Beusekom (1948a) op. cit.; Beusekom, H.G. van. Mogelijkheden voor de Huis vesting van Bejaarden. $T M W_{2}$ (1948) 200-202. Hierna aangeduid als Van Beusekom (1948b); Beusekom, H.G. van. De zorg voor de huisvesting van bejaarden. TSG 26 (1948) 14, 24I-245. Hierna aangeduid als Van Beusekom (1948c); Beusekom, H.G. van. De huisvesting van bejaarden. In: De oudeliedenzorg. Prae-adviezen uitgebracht door Prof. Drit H.G. van Beusekom, Drs. J. Diederich, Dr Mr F.M. Havennans en Mr J.A.J. Meyer. Haarlem: H.D. Tjeenk Willink \& Zoon, 1950: 1-34. Van Beusekom was hoofd van de afdeling Onderzoek van de Centrale Directie van de Wederopbouw en de Volkshuisvesting. Zie wat betreft het parlement ondermeer: Handelingen II I952-I953 3123, I 1953-1954 3079

27. Jaanverslag van de Centrale Directie van de Wederopbouw en de Volkshuisvesting 1948. 's-Gravenhage: Staatsuitgeverij, I949. De jaarverslagen van de Centrale Directie van de Wederopbouw en de Volks- 
huisvesting (die later van naam veranderden) zullen hierna aangeduid worden als Jaanverslag Volkshuisvesting. Zie ook Jaanverslag Volkshuisvesting 1949; Red[actie]. Bouwperikelen. Onze Bejaarden 2 (1951-52) 6/7. 3-4; Neesen, K. Een interessant gemeentelijk Bejaardencomplex. KB 3 (1957) $5,78-82 / 96$

28. Huisvesting van bejaarden (1949) op. cit. p. $\$ 2$ en p. 74

29. Zie ondermeer Handelingen II I952-1953 3123; De huisvesting van bejaarden in Nederland. Rapport van een studie, in opdracht van de Landelijke Katholieke Stichting voor Behuizing van Bejaarden, verricht door de architecten ir. N. van der Laan, ir. F.P.J. Peutz en G.J.M. Sarlemijn, in overleg met de bouwcommissie van voomoemde Stichting. Utrecht: Landelijke Katholieke Stichting voor Behuizing van Bejaarden, 1948

30. Huisvesting van bejaarden (1949) op. cit. pp. 3-5, pp. 72-73, p. 81; Van Beusekom (1948a) op. cit.; Van Beusekom (1948b) op. cit.; Van Beusekom (1948c) op. cit.; Van Beusekom (1950) op. cit.; Jaarverslag Volkshuisvesting 1950; Reyers, J.G. Huisvesting van bejaarden. Een sociaal vraagstuk voor de geheele bevolking. Bouw 1 (1946) 15, 372-79. Reyers werkte als ingenieur bij de Dienst der Volkshuisvesting van het Ministerie van Openbare Werken en Wederopbouw. Zie: Nederlandsche Staatsalmanak voor iedereen 45 (1946) p. 7I 4

31. Huisvesting van bejaarden (1949) op. cit. p. 9-33 en p. 79; Van Beusekom op. cit. (1950) p. 2 en p. 12-23: Jaanverslag Volkshuisvesting 1950, p. 23

32. Huisvesting van bejaarden ( 1949 ) op. cit. p. 21 , p. 33 en p. 82 . Uit de globale schattingen die de Centrale Directie met betrekking tot de theoretische behoefte aan bejaardenhuisvesting - voor het jaar r950 maakte, bleek dat men een behoefte veronderstelde aan 194.925 speciale woningen voor bejaarden, 313.215 kamers in pensiontehuizen, en 32.600 bedden in invalidentehuizen. Het percentage van ruim $17 \%$ is een afgeleide van de cijfers die het rapport in tabel x op p. 33 geeft. Zie voor de definitie van pensiontehuizen (of 'rusthuis of welke naam men wil kiezen'): Huisvesting van bejaarden (1949) op. cit. p. 16

33. Huisvesting van bejaarden (1949) op. cit. p. 17. Dat de Centrale Directie wat betreft de pensiontehuizen vooral aan valide bejaarden dacht, bleek - indirect - ondermeer uit de volgende passage uit het rapport van 1949: 'Er zijn ouden van dagen, die meer verzorging nodig hebben dan een tehuis, ingesteld op de nog valide bejaarden kan geven. Die zoeken zich een (..) invalidentehuis (..). Deze vorm van huisvesting ligt tussen het tehuis voor valide bejaarden en een ziekenhuis in.' (p. 38) 
34. Huisvesting van bejaarden (1949) op. cit. pp. 36-37

35. Reyers (1946) op. cit. p. 376

36. Huisvesting van bejaarden (1949) op. cit. p. 7 en p. 37

37. Huisvesting van bejaarden op. cit.; Van Beusekom (1950) op. cit; Reyers (1946) op. cit.; Jaanverslag Volkshuisvesting 1955. Winters (1988) op. cit. (p. 18) vermeldt dat in Leeuwarden zelfs een 'Vereniging en comité ouden van dagen tegen verplichte inwoning' werd opgericht. Daarnaast wezen ook vele deskundigen inwoning af. Zie o.a. Kleyn, A. Huisvestingsmoeilijkheden voor ouden van dagen. TSG 26 (1948) 14, 245-248; Berg, J.H. van den. Woongelegenheid voor ouden van dagen. TSG 27 (1949) 19. 372-76; Red[actie]. De bejaarden op hun eigen plaats. Onze Bejaardenzorg 2 (1951-52) 2, 5-7; Brunet de Rochebrune, W.F.H. Over enige problemen van de ouderdom. Leiden: Nederlandse Uitgeversmaatschappij, 1954; Tilanus, A.D.W. De situatie in Gelderland op het gebied van de bejaardenzorg. In: Lezingencyclus ove bejaardenzorg. Arnhem: Stichting Gelderland voor Maatschappelijk Werk, 1955: 3-7; Rapport van het College van Advies der Anti-Revolutionaire Partij inzake de huisvesting van bejaarden met name in verzorgings- en verpleegtehuizen. 's-Gravenhage: [ARP], 1959. De gevaren van inwoning lagen volgens deskundigen ondermeer in de mogelijkheid van onderlinge onenigheid, een te grote drukte voor de grootouders en een ongewenste bemoeienis van bejaarden met de opvoeding van kleinkinderen. Bovendien werd inwoning ook technisch gezien moeilijker: de nieuwe woningen waren gemiddeld veel kleiner dan de vooroorlogse woningen (zie ondermeer Handelingen II 1952-1953 3078 ). Inwoning van bejaarden bij alleenstaande kinderen werd overigens minder problematisch geacht. Zie voor een bespreking van door anderen opgemerkte nadelen aan het samenwonen van bejaarden en hun kinderen: Meijer, J.A.J. De huisvesting van bejaarden. Socialismt en Democratie 10 (1953) 322-332

38. Van Beusekom (1948b) op. cit. p. 200. Zie ook: Van Beuskom (1948c) op. cit.

39. Huisvesting van bejaarden (1949) op. cit. p. 52 en p. 58

40. Huisvesting van bejaarden (1949) op. cit. pp. 58-59 en p. 8

41. Van Beusekom (1948b) op. cit.; Van Beusekom (1948c) op. cit.

42. Handelingen IB 1952-1953 2800 н xIIA vV (nr. I3 I) 12. Zie ook ив I951-I952 2300 н IXA VV (nr. 16) 8, пв 195I-1952 2300 н XII VV (nr. 8) 29, пв 1952-1953 2800 н IXA VV (nr. Is) 5, II I952-53 3078-79, 3097, IB I952-1953 2800 н IXA vV (nr. 66) 9, Il 1953-1954 3163, 3172 Overigens stelden veel kamerieden eveneens aan de orde dat de huren 


\section{van bejaardenwoningen voor veel bejaarden te hoog waren.}

43. De subsidies op basis van de Woningwet vielen onder de Beschikking Bijdragen Woningwetbouw, de regelingen in het kader van de Wederopbouwwet onder het Premie- en Bijdragebesluit Woningbouw. Zowel binnen de Woningwet (Besluit van II November 1953 houdende nadere wijziging van het Woningbesluit, Stbl. 517) als de Wederopbouwwet (Besluit van 5 Juni 1954 tot wijziging van het Premie- en Bijdragebesluit Woningbouw, Stbl. 242) bestond vanaf respectievelijk 1953 en 1954 de mogelijkheid tot een extra bijdrage aan de huur van bejaardenwoningen en kamers in tehuizen voor bejaarden met een inkomen beneden een bepaalde grens. Voorwaarde was dat de gemeenten per kamer per jaar eveneens een extra bijdrage zouden leveren. Zie ondermeer: Huisvesting van bejaarden. Richtlijnen voor de bouw en exploitatie van zelfstandige woningen en pensiontehuizen. Bouwcentrum: Rotterdam, 1953. Gepubliceerd in: Bouw 8 (1953) 17, 301320 (p. 3 16); Premies en bijdragen voor bejaardentehuizen en -woningen Bouw 9 (1954) 53; Huisvesting van bejaarden, Zelfstandige woningen en pensiontehuizen. Rotterdam: Bouwcentrum, 1959 (p. 9); De huisvesting van bejaarden in Nederland. 's-Gravenhage: Ministerie van Volkshuisvesting en Ruimtelijke Ordening, 1965 (p. 38-42); Jansen, P.J.M. en Peeters, E.M. Volkshuisvesting geregeld. Analyse van overheidssturing met wetgeving vanaf 1945. Leiden: Onderzoekscentrum Sturing en Samenleving, 1989

44. Winters, W. Het domein van de ouderdom: uit de geschiedenis van de Nederlandse ouderenbeweging. In: Handboek 'Wonen en werken in een verzorgingshuis'. Amersfoort: Academische Uitgeverij, 1991: (par. 1.2) 1-23. De katholieke bonden hielden zich tot het midden van de jaren zestig weinig met de tehuizen bezig. Klachten van leden over de tehuizen gaven zij door aan de Katholieke Vereniging van Bejaardentehuizen, Zie: Baan, P. van der. Voor ons en door ons. De geschiedenis van de Unie van Katholieke Bonden van Ouderen. 's-Hertogenbosch: Unie van Katholieke Bonden van Ouderen, 1989

45. Neesen, K. Calvariënberg te Maastricht. $K B_{4}$ (1958) 6, I37146

46. De Federatie stelde daarom in 1956 een nationale financieringsregeling voor, die per persoon een aanvulling op de verzorgingsprijs zou bieden tot een bedrag dat nodig was voor een sluitende exploitatie van het tehuis. Zie: Verslag 1955-1959. 's-Gravenhage: Nederlandse Federatie voor Bejaardenzorg, [1960]. Zie voor oproepen vanuit de praktijk van de bejaardenzorg om de discrepantie tussen de inkomens 
van bejaarden en de reële kosten van het tehuis te doen vermindeten ook: S[treur, J.F.]. De onaangepastheid van de overheid. Rooms-Ko tholieke Bejaardenzorg 2 (1956) 2, 30-31; Hogere subsidie voor nieure bejaardentehuizen bepleit. Bouw Is (1960) 29, 875

47. Handelingen IIB I955-1956 4100 н XIIA MVT (nr. 2) $8 /{ }_{1} 3$ en MVI (nr. Io) I1, II I955-1956 3130, IB I955-1956 4100 н XIIA MVA (nr. 90A) IO, Iв I956-1957 4500 H XIIA MVA (nr. I2) 3, II 1956-I957 3049, L 1956-1957 4500 н XIIA MVA (nr. 52a) 10, I 1956-1957 3080, шв 1957. I958 4900 н XIIA MVA (nr. 14) 14, IIB 1958-1959 5300 н XIIA MVt (nt. 2) Io, 11 1960-1961 3274. Wel werd vanaf 1961 een post op de begroting opgenomen om de opleiding van bejaardenverzorgsters en -help. sters financieel te steunen. Zie ив 1960-1961 6100 н XII MVT (nr. 2) I I

48. Het verhaalsrecht hield in dat een armenzorg-uitkering aan een bejaarde verhaald kon worden op diens familieleden. Dat remde bi een deel van de bejaarden de bereidheid om in een tehuis te gan wonen (zie o.a. Huisvesting van bejaarden (Bouwcentrum, 1959) op. at p. 5 en Handelingen in 1960-1961 3241). Het verhaalsrecht werd in $196 \mathrm{r}$ gedeeltelijk en met de invoering van de Algemene Bijstandswet gehed afgeschaft.

49. Gijsbers, A.J. en Goedmakers, H.J.P.J. Wet op de Bejaardenowden. Alphen aan de Rijn: Samson, 1963 . Overigens hadden de provinciale verordeningen vaak tegelijkertijd betrekking op andersoortigt inrichtingen (b.v. voor zwakzinnigen). Zie wat betreft de Gezondheidswet: De bejaardenzorg in Nederland. Rapport uitgebracht door de Ministeries van Volkshuisvesting en Bouwnijverheid, Maatschappelijk Werk en Sociale Zaken en Volksgezondheid aan het Comité voor het Openbaar Bestuur, van de West-Europese Unie. Den Haag, 1958

50. Zie ondermeer Handelingen 1 I954-1955 35I4-15, $11 \mathrm{~B} 4100 \mathrm{H}$ XIIA vV (nr. 8) 8-9, II 1956-1957 3024, 3038, II 1957-1958 3168-69, 3175, Il I958-1959 3299. Zie voor de voorgeschiedenis van de Wet op de Bejaardenoorden ondermeer: Gijsbers en Goedmakers (1963) op. cit.; Bijsterveld (I991) op. cit.

51. Zie Wet van 10 januari 1963 , Staatsblad nr. 18, houdende bepalingen aangaande de bejaardenoorden (Wet op de bejaardenoorden). Bij de uitvoering van de wet zouden de provincies geholpen en geadviseerd door een breed samengestelde commissie voor de bejaardenoorden. Deze provinciale commissies kregen bovendien de taak zich op de hoogte te houden van de regionale behoefte ann opname in tehuizen. Overigens konden onder bepaalde voorwarden 
ook gemeenten de bevoegdheid krijgen de richtlijnen op te stellen.

52. Dat hield verband met een lange geschiedenis van klachten over de hoogte van de verzorgingsprijzen. Vanaf 1957 werden deze klachten door een Prijzenadviescommissie (waarin de Ministeries van Economische Zaken, van Maatschappelijk Werk, van Volkshuisvesting en de Nederlandse Federatie voor Bejaardenzorg samenwerkten) beoordecld en in 1964 stelde Economische Zaken een tijdelijke prijsstop in (op 21 januari ingevoerd en op 29 september van dat jaar weer ingetrokken) om de enorme stijging van verzorgingsprijzen af te remmen. Zie Gijsbers en Goedmakers op. cit. pp. 62-65 en Jaanverslag Volkshuisvesting 1964, p. 123

\section{Handelingen II 196I-1962 6621 (WBO) MVT (nr. 3) 6}

54. Jaanverslag Volkshuisvesting 1948, p. 90; idem I949, p. 2 I; idem 1950, p. 23; Huisvesting van bejaarden (1949) op. cit. pp. 79-80

55. Voorschriften en wenken voor het ontwerpen van verzorgingstehuizen voor bejaarden (1965) 's-Gravenhage: Ministerie van Volkshuisvesting en Ruimtelijke Ordening, 1966 (p. 15)

56. Zo zouden in tehuizen voor minder draagkrachtigen verhoudingsgewijs minder kamers voor echtparen nodig zijn dan in andere tehuizen. Bijlage 3 (hoofdstukken inzake pensiontehuizen voor bejaarden voorkomende in 'Voorschriften en wenken voor het ontwerpen van woningen (I95I)') van: Modemisering van oude bejaardentehuizen. Rotterdam: Bouwcentrum, 1962: 29-30. Zie ook: Bijlage A (hoofdstukken betrekking hebbende op pensiontehuizen voor bejaarden uit 'Voorschriften en wenken voor het ontwerpen van woningen, 195I' van: Richtlijnen voor de bouw en exploitatie van pensiontehuizen voor bejaarden. Utrecht: Sectie Bejaardenzorg van de Stichting Vrijzinnig Protestantse Centrale voor Maatschappelijk Werk, 1959: 59-62. De 'standaard-verhouding' tussen één- en tweepersoonskamers was 10:1.

57. Voorschriften en wenken (1966) op. cit. p. 9

58. De Klokkenbelt. Tehuis voor bejaarden te Almelo. (Architect: A. Komter) Bouw 8 (1953) 12, 204-209

59. Modermisering van oude bejaardentehuizen (I962) op. cit. p. 3

60. Huisvesting van bejaarden (Bouwcentrum, 1953) op. cit.; Huisvesting van bejaarden (Bouwcentrum, 1959); Modemisering van oude bejaardentehuizen (1962) op. cit.; Huisvesting van bejaarden. Serviceflats en groepen woningen met dienstencentrum. Rotterdam: Bouwcentrum, 1967

61. Huisvesting van bejaarden (1949) op. cit. p. 53 (Cursivering van de auteur); Van Beusekom (1948a) op. cit.

62. Huisvesting van bejaarden (1949) op. cit, p. 54; Van Beusekom 
(1948a) op. cit.; Van Beusekom (1948c) op. cit.

63. Huisvesting van bejaarden (1949) op. cit. p. 59

64. Huisvesting van bejaarden (Bouwcentrum, 1953) op. cit. p. 309

65. Zie ondermeer: Huisvesting van bejaarden (1959) op. cit.; Ridh. lijnen (1959) op. cit.

66. Nierstrasz, F.H.J. Het grote verzorgingstehuis voor bejaarden en het welzijn der bewoners. Bouw 21 (1966) 45, 1779-1782; Het grote verzorgingstehuis voor bejaarden in zijn relatie tot het welzijn der bewoner. Den Haag: Centrale Directie van de Volkshuisvesting en de Bouwnijverheid, 1965; Jaanverslag Volkshuisvesting 1963 (pp. 153-160)

67. Rubbens-Franken, E. Vegelinshof te Joure. Onze Bejaarden 3 (1957) 9, 120-121 (p. 120)

68. Richtlijnen (1959) op. cit. p. 17

69. Neesen, K. Rekenmeesters en durvers bouwden St. Jozefszorg te Helmond. $K B_{3}$ (1957) 1, 2-4/9; Neesen (Een interessant gemeentelijk Bejaardencomplex, 1957) op. cit.; Biemond, H. 'Huize Beatrix' in Doorn. DB ro (1964) 2, 28-29

70. Flatgebouw voor bejaarden te Maastricht. Bouw I6 (I96I) 12, 350-355; Richtlijnen (1959) op. cit.

71. Huisvesting van bejaarden (1949) op. cit. p. 37, vergelijk ook p. 42

72. Van Beusekom (1948a) op. cit. p. 407

73. Rede van de directeur der Katholieke Vereniging van Bejaardentehuizen, uitgesproken ter gelegenheid van de plechtige opening van het bejaardencentrum 'Ten Anker' te Den Helder. KB 7 (I96I) 3 , 62-66 (p. 63); [A.J.] Twee visies pensiontehuis of verzorgingstehuis] $B W_{11}$ (1965) 69; ledere kerk een bejaardenhuis? $B W I_{3}$ (1967) 3. 70; Janssen, A.M.A.J. Samenwerking tussen bejaardentehuizen en bejarrdenbonden. $B W_{\text {I } 4}(1968)$ I, I-7

74. Bouman, M. Wat kiest U? DB 8 (1962) 3, 37-38

75. Richtlijnen (1959) op. cit.; Als de amandelboom bloeit. Utrecht: Stichting Raad voor Gereformeerde Sociale Arbeid, [1962]

76. Wartena, B. In geval van ziekte. DB ro (1964) 5, 99-102 (p. 99): Wartena, B. In geval van ziekte. $D B 9\left(I_{96}\right) 2,26-28$. Wartena was waarnemend inspecteur van de volksgezondheid voor Overijssel. Het tijdschrift De Bejaarden was ook het officiële orgaan van de Vereniging van Directies van Tehuizen voor Bejaarden in Nederland en van de Stichting voor Huisvesting van Ouderen. De redactie vermeldde dat over de verzorging van zieke tehuisbewoners verschillend werd gedacht. Wartena, die de discussie opende en sloot, kreeg zowel instem- 
mende als afkeurende reacties. Principiële tegenstanders zagen het tehuis als een groot gezin, waarop wijkverpleegsters een inbreuk vormden.

77. Nierstrasz (1966) op. cit. p. 1779

78. Borselen, J.W. van. De bejaardenhuisvesting in internationaal verband. Bouw 20 (1965) 49, 1891-1895

79. Gebouw voor ouden van dagen te Tilburg (Architect: J. Bedaux). Bouw 9 (1954) 5, 80-86

80. Onderzoek naar de levensomstandigheden, behoeften en wensen der bejaarden in de Watergraafsmeer. Amsterdam: Economisch en Sociaal Instituut, Vrije Universiteit, 1954 (pp. 74-75, 88); Verzorgingshuizen 'in serie'? Onze Bejaardenzong I (1950/I95I) 2, 2-4; Rapport inzake huisvesting voor ouden van dagen. Deel I. Leeuwarden: Stichting Friesland voor Maatschappelijk Werk, I95I; Red[actie]. De bejaarden op hun cigen plaats. Onze Bejaardenzong 2 (1951/1952) 2, 5-7; Sm. Tijdsbesteding door bejaarden. Onze Bejaardenzorg 2 (1951/52) 3, 3; Borselen, J.W. van. Hofjes, armhuizen en dienstencentra. $\mathrm{OL}_{4}$ (1967) 3, 114118

81. Jaanverslag Volkshuisvesting 1963, p. 151 en Jaanverslag Volkshuisvesting 1966, p. 80. Zie voor verzorgingsflats: Tak, C.B. van der. Verzorgingsflats voor bejaarden. Onze Bejaarden I (1955) 5. 53-54; Burgersdijk, J.A. Verzorgingsflat. Onze Bejaarden 3 (1957) 53-54

82. Neesen (Een interessant gemeentelijk Bejaardencomplex, 1957) op. cit.

83. Gemeentelijk verzorgingshuis Amsterdam (architect: B. Odink). Bouw 20 (1965) 19,693. In de jaren zeventig werd ook in de Tweede Kamer op deze ontwikkeling gewezen: Handelingen 11 1972-1973 793

84. Van Borselen (1965) op. cit.

85. Bejaardentehuis dr. Alphons Ariëns te Utrecht [Architect ir. G.M. Leeuwenberg]. Bouw 22 (1967) 25, 966-971; Korteweg, H. In gesprek met de heer C.M. Verhagen. Het Amsterdamse Flevohuis. DB 18 (1972) 1, 8-10

86. Neesen (Een interessant gemeentelijk Bejaardencomplex, 1957) op. cit. p. 96

87. Bejaardencentrum Vlaardingen (Architectenbureau: Spruyt en Den Butter). Bouw Io (1955) ro49-1053 (p. 1053)

88. Huisvesting van bejaarden (1949) op. cit.; Van Beusekom (1950) op. cit.; Reyers (1946) op. cit.

89. Huisvesting van bejaarden (1949) op. cit. p. 34. Overigens ging men ervan uit, dat dit bezwaar minder opging voor de beter gesitueer- 
den die zich doorgaans op een ruimer terrein begaven en voor wie het familiecontact relatief minder belangrijk was. Zie ook Reyers (1946) op. cit.

90. Handelingen IIB I952-I953 2800 н XIIA MVA (nr. 2) 7

91. Handelingen II 1953-1954 3100

92. Huisvesting van bejaarden (1949) op. cit. p. 4; Reyers (1946) op. cit.; Bezoek van Hare Majesteit de Koningin aan enkele inrichtingen voor ouden van dagen te Arnhem (Rede van de Minister van Maatschappelijk Werk) $T M W_{7}$ (1953) 4, 54-56

93. Huisvesting van bejaarden (1949) op. cit.

94. Huisvesting van bejaarden (1949) op. cit. p. 45. Zie ook: Dekhuyzen-Zeehuisen, I. Huisvesting van bejaarden in Nederland. De Ge. meente 6 (195I) I, 2-3; Froger, J.H. en Meijsing, H.J. Het stedebouwkundig en bouwkundig aspect van de huisvesting van bejaarden. In: Het bejaardenvraagstuk. Prae-adviezen en handelingen van het congres inzake het bejaardenvraagstuk. Scheveningen 1956. Assen: Van Gorcum, 1957: 33-40; Hoe denken bejaarden over de voor hen ontworpen huisvesting? [Groningen: Stichting Groningen voor Sociaal en Cultureel Werk, 1957]

95. Van Beusekom (1950) op. cit. p. 24

96. Rümke, H.C. Levenstijdperken van den man. Amsterdam: $\mathrm{De}$ Arbeiderspers, 1938; Rümke, H.C. Het seizoen is gesloten. In: Bejaarden in de samenleving. Scheveningen, 1963. ['s-Gravenhage]: NFB, 1963: 8-12. Deze beschrijving, die Rümke ook in de jaren zestig nog adequaat achtte, werd in navolging van Rümke ondermeer gebruikt door Drift, $H$. van der. De psyche van de chronisch zieken en de ouden van dagen. $M G V 9$ (1954) 361-368; Munnichs, J.M.A. Enige beschouwingen over de psychologie van de ouderdom. In: Munnichs, J.M.A., Moor, R.A. de en Maltha O.P., A.H. Herfsttij van de levensloop. Beschowwingen over de ouderdom. Utrecht [etc.]: Het Spectrum, 1956: 7-33i Groot, J. de. Productieve arbeid van bejaarden. Het medisch aspect. In: Het bejaardenvraagstuk (1957) op. cit. pp. 102-1 IO

97. Buytendijk, F.J.J. Algemene theorie der menselijke houding en bewe. ging. Utrecht [etc.]: Het Spectrum, 1974 (p. 539). De eerste druk van dit boek verscheen in 1948 . Zie voor verwijzingen naar Buytendijk en soortgelijke beschrijvingen van de ouderdom: Querido, A. De geestelijke hygiëne van de ouderdom. $M G V_{3}$ (1948) 300-304; Meyers, F.S. Psychologische en Psycho-hygiënische beschouwingen over de Ouderdom. $T M W_{3}$ (1949) 8, 1 16-119; Rubbens-Franken, E. Veranderingen in het innerlijk wezen. In: De ouder wordende mens in onzt samenleving. Bussum: A. Voorhoeve, 1953: 94-100; Van der Drift 
(1954) op. cit.; Raalte, C.R. van. Psychologie van de bejaarde mens III. Onze Bejaarden I (1955) 5, 51-52; Munnichs, J.M.A. Enkele aspecten van de psychologie van de bejaarden. Maatschappijbelangen 120 (1956) 9. 344-345; Munnichs, J.M.A. De oude mens is het beeld van zijn leven. Katholieke Gezondheidszorg 25 (1956) 4, 117/120-121; Munnichs, J. Psychologie van de bejaarden vil. Enige kenmerken van de bejaarden. $\mathrm{KB}_{3}$ (1957) 3, 45-46

98. Huisvesting van bejaarden (1949) op. cit. p. 54-55

99. Gemeentelijk verzorgingshuis Amsterdam (1965) op. cit. p. 693 100. Gebouw voor ouden van dagen te Tilburg (1954) op. cit.; Centrum voor bejaarden in Slotermeer (Architect: B.B. Westerhuis). Bouv ro (1955) 925-929; Verzorgingscentrum voor bejaarden te Hoofddorp (Architecten Abma en Hazewinkel). Bouw 26 (r971) 14801482

101. Bejaardencentrum Crabbehoff te Dordrecht. (Architecten- en ingenieursbureau G. Gerritse) Bouw 22 (I967) 9, 334-343

102. Prot. Chr. bejaardencentrum 'De Nudehof te Wageningen (Architectenbureau Rietveld, Van Dillen en Van Tricht). Bouw 22 (1967) t, 28-32 (p. 28)

103. Bejaardencentrum 'Vreedenhoff' te Arnhem (Architect H. Geels). Bouw 23 (1968) I1 42-1146 (p. I143)

104. Gebouw voor ouden van dagen te Tilburg (1954) op. cit.

I05. Bejaardentehuis dr. Alphons Ariěns te Utrecht (Architect ir. G.M. Leeuwenberg). Bouw 22 (1967) 25, 966-971; Bejaardencentrum te Barneveld [Architect J. van der Weerd]. Bouw 24 (1969) 45. 17841788

106. Gemeentelijk verzorgingshuis Amsterdam (1965) op. cit.

107. Beyer en Nierstrasz (1967) op. cit.

108. Bejaardencentrum 'Braamhage' (Architect: J.J. Tuynenburg). Bouw 12 (1957) 20, 494-502

109. Hervormd bejaardencentrum 'De Loohof' te Apeldoorn (Architecten: S. van Woerden en H.J. Schneider). Bouw 20 (1965) 451-454

110. Bejaardencentrum 'Het Bornhof' te Zutphen (Architectenbureau G.K. Vreeze en F.J. Twijnstra). Bouw 22 (1967) 1939-1943

II I. Bejaardencentrum 'Het Bornhof' (1967) op. cit.; Bejaardencentrum 'Vreedenhoff' (1968) op. cit.; Verzorgingstehuis voor bejaarden Hospice Wallon te Amsterdam [Architectenbureau Zanstra, Gmelig Meyling en De Clercq Zubli]. Bouw 25 (1970) 49, 1884-1885

112. CBS-Verzorging van bejaarden in tehuizen naar de toestand op 1 Ottober 1950. Utrecht: Uitgeversmaatschappij W. de Haan, I95I (p. 7) 
113. De bouw en verbouw van de meeste van deze tehuizen gebeurde met financiële steun van de rijksoverheid. In de periode I95a1968 kwamen met financiële steun van het Rijk $\$ 6267$ bedden in tehuizen via nieuwbouw en 7056 bedden via uitbreiding en verbete. ring (totaal 63323) tot stand (Jaarverslag Volkshuisvesting 1968 (p. 67). Volgens CBS-gegevens (zie tabel 2) steeg het totale aantal bedden in bejaardenoorden in die periode van 38235 naar 103928 bedden, wat een toename betekende van 65693 bedden. Daaruit volgt dat $96 \%$ van de toegevoegde bedden in tehuizen door het Rijk werd gefinancierd. Tussen 1950 en 1968 verleende de rijksoverheid financiële steun aan de bouw van 37073 bejaardenwoningen met 78445 bedden (Jaanverslag Volkshuisvesting 1968, p, 67),

114. Verzorging van bejaarden (CBS, 1950) op. cit. p. Is en Statistick van de bejaardenoorden 1986. 's-Gravenhage: SDU-uitgeverij/CBS-publikaties, 1989 (p. 21)

II 5. Baars, J. en Knipscheer, C.P.M. Ageing in the Netherlands: Structural and cultural characteristics. Joumal of Cross-Cultural Geronto$\log \gamma 4(1989) 129-142$

116. Goor, H. van. Democratie of bureaucratie? Een empirische studie naar verschillen in invloed tussen politieke en ambtelijke topposities in Nede. landse gemeenten. Assen/Maastricht: Van Gorcum, 1988. Zie ook: Oostvogel, F.J.G. Veel voorzieningen, geen gesloten keten. In: Bekkum, D.J. van e.a. Oud worden, oud zijn. Deventer: Van Loghum Slaterus, 1974

117. Huisvesting van bejaarden (Bouwcentrum, 1953) op. cit: Zonneveld, R.J. van. Gezondheidsproblemen bij bejaarden. Resultaten van een sociaal-geneeskundig onderzoek bij 3000 personen van 65 jaar en ouder in de stad Groningen. Assen: Van Gorcum, 1954; Zonneveld, R.J. van. Het bejaardentehuis. Onze Bejaarden I (1955) 12, 137-139; ARA Achief NFB, inventarisnummer 186, Vergadering Dagelijks Bestuur dd. 8- I I-1955. punt 6; dd. 23-5-1956, punt 5; dd. 12-11-1958, punt 3; Geerts, W. Zelfstandigheid en isolement. Onze Bejaarden 3 (1957) 79; Palmen, P.M.M.C. De financieel-economische aspecten van de huisvesting van bejaarden. In: Het bejaardenvraagstuk (1957) op. cit. pp. 41-71; Zonneveld, R.J. van. De huisvesting ten behoeve van bejaarden. Medische en sociale aspecten. In: Het bejaardenvraagstuk (1957) op. cit. pp. 72-82

I18. Zonneveld, R.J. van. De bejaarden in onze veranderende samenleving. In: Banning, W. e.a. Motief en functie. Bewogenheid en beweging in het maatschappelijk werk 1908-1958. Haarlem: Tjeenk Willink, 
$\left[195^{8}\right]: 251-264$ (p. 260)

I19. Jaarverlag Volkshuisvesting 1956, p. 33

120. Jaanverslag Volkshuisvesting 1959, p. $\mathrm{II}_{4}$

121 Jaarverslag Volkshuisvesting 1960 , p. 141 ; Jaanverslag Volkshuisvesting 1965, p. 97

122. Handelingen $\mathrm{Iв} 1955-19564100 \mathrm{н} \mathrm{Xाи} \mathrm{MVT} \mathrm{(nr.} \mathrm{2)} 13$

123. Handelingen пв г956-1957 4500 н хін мva (nr. 12) 3. Zie daarnaast ondermeer IB 1956-1957 4500 H XIIA MVA (nr. 52a) 13, I 1956-1957 3079, нв 1957-1958 4900 н XIIA MVA (nr. 14) 14 en II 1958-1959 3386-87. Zie ook: Braam, G.P.A., Coolen, J.A.I. en Naafs, J. Ouderen in Nederland. Sociologie van bejaarden, bejaardenzorg en beleid. Alphen aan de Rijn/Brussel: Samson, 1981; Braam, G.P.A. Vernieuwingen in de zorg: de groepsverbanden van ouderen. In: Coolen, J.A.I. (Red.) Verschuivingen in de ouderenzorg. Lochem [etc.]: De Tijdstroom, 1985: 43-53

124. Zie wat betreft het zelfstandigheidsstreven ondermeer Handelingen II 1956-1957 3037-38, 1в 1956-1957 4500 н хIIA VV (nr. 52) го-I I, шв 1957-1958 4900 н Хін vv (nr. 12) 9, ІІ 1957-1958 3168-69, 3185 , 3198, Iв 1957-I958 4900 н XIIA VV (nr. 88) 8, 1 1957-1958 3020, ІІ 1958-1959 3303, 3392, 3397-98; Iв 1958-1959 5300 н XIIA VV (nr. 85) 7. Zie wat betreft de betaalbaarheid ondermeer: II 1956-1957 3015 , 3027, Iв 1956-1957 4500 н Xila vV (nr. 52) 10, II 1957-1958 3175, 3180, 3206, I 1957-1958 3055, 3137, IIB I958-1959 5300 H IXA V (nr. 8) $12-13$, II 1958-1959 3299, 3313, 3317, II 1960-1961 3241, 3249, $3260-61$

125. Semi-statisch Archief Ministerie van Sociale Zaken en Werkgelegenheid, Departementaal Archief, dossiernr. 1.842.6, Nationaal Comité Oudeliedenzorg, Subcommissie voor Verpleeginrichtingen voor Chronisch Zieke en Invalide Ouden van Dagen, vergadering dd. $1-5-195 \mathrm{I}$

126. Handelingen ив 1965-1966 8300 н XVI MVT (nr. 2) 20-2I; Bejaardenzorg [Interview met J.J. van Muijen van de NFB]. Bouw 21 (1966) 36, 1381; De huisvesting van bejaarden in Nederland. [Den Haag]: Ministerie van Volkshuisvesting en Ruimtelijke Ordening, 1970 (p. 39); Advies inzake taak en functie van het verzorgingstehuis voor bejaarden. 's-Gravenhage: Staatsuitgeverij/CCB, 1979

127. Munnichs (1974) op. cit.

128. Huisvesting van bejaarden (Bouwcentrum, 1959) op. cit. p. 5 .

129. Huisvesting van bejaarden (Bouwcentrum, 1959) op. cit. p. 6; De ontwikkeling van de huisvesting van bejaarden. Voordracht van de 
heer J.W. van Borselen op de jaarvergadering van de Katholieke Veteniging van Bejaardentehuizen 28 juni I96I. $K B 7$ (I96I) 4, 90-93. De ro\%-regel wordt ook genoemd in Oosterhuis, J.P. Tien jaar bejaardenhuisvesting. Bouw 2 I (1966) 27, 1037-104I

130. Zie voor en over de verschillende behoefte-schattingen ondermeer: Financieel-economische aspecten van de huisvesting van bejaarden I. Inleiding en algemene oriëntatie. Rooms-Katholieke Bejaardenzorg 2 (1956) 4, 63-66; Zonneveld, R.J. van. De huisvesting ten behoeve van bejaarden. Medische en sociale aspecten. In: Het bejaardenvraagstuk (1957) op. cit. pp. 72-82; Behoefte aan bejaardenhuis. vesting. Onderzoek naar de behoefte aan bejaardenhuisvesting en naar de levensomstandigheden van de bejaarden te Sittard. Roermond: Provincial Opbouworgaan Limburg, 1958; Puister, T.E. De behoefte an bejaardentehuizen. TMW I5 (1961) 21, 4 I6-417; De behoefte aan tehuisnuimte voor bejaarden in Alkmaar. Den Haag: Katholiek Sociaal-Kerkelijk Instituut, 196I; Modemisering van oude tehuizen (1962) op. cit. p. z; Jansen, H.W. Het woonmilieu van de oudere mens. In: De ouda wordende mens. Viifde provinciale gezondheidsdag op 25 mei 1966. [S.L.] Provinciale Raad voor de Volksgezondheid in de provincie Drenthe, [s.a.]: 26-42; Oostvogel, F.J.G. Verzorgingsbehoeften van bejaarden. Een sociaal-geneeskundig onderzoek naar de behoeften van gegadigden voor en verzorgingstehuis. Nijmegen/Utrecht: Dekker \& Van de Vegt, 1968

131. Fukkink-Wetter, M. Voor wie bouwen wij bejaarden-tehuizen? Diakonia 26 (1959) 11, 247-250

132. Rubbens-Franken, E. Voor wie bouwen wij bejaardentehuizen? Zijn wij op de goede weg? DB 6 (I960) 5, 67-69. Dit ontleende Rubbens-Franken aan een herzien rapport over de huisvesting van bejaarden van de Stichting Friesland voor Maatschappelijk Werk, geschreven door B. Wartena en D.S. Visser. Ook de laatsten meenden dat het tehuis ieder moest opnemen die daar op medische of sociale indicatie aanspraak op kon maken. Op dit probleem werd eveneens in de senaat gewezen: Handelingen IB 1960-196 г 6100 н Xпи vv (nr. 68) 9 en MVA (nr. 68a) 7, 1 1960-1961 3123

133. Nijsten, A.J. Het bejaardentehuis. $K B_{4}$ (1958) 2, 29-34: Munnichs, J.M.A. Bejaarden-hulp. Enige psychologische kanttekeningen. $\mathrm{x}$. Voor wie is het tehuis bestemd? $K B 6$ (1960) 6, 145-146

134. Openingsrede van de Voorzitter ter gelegenheid van de tweede jaarvergadering van de Katholieke Vereniging van Bejaardentehuizen. $K B$ 5 (1959) 4, 83-85; Rede van de directeur der Katholicke Vereniging van Bejaardentehuizen, uitgesproken ter gelegenheid van 
de plechtige opening van het bejaardencentrum 'Ten Anker' te Den Helder. $K B 7$ (1961) 3, 62-66. Zie ook: Toekomst verzorgingstehuis ligt in totale zorg met daarin wonende bejaarden [Lezing J.B.V. Welten, lid Dagelijks Bestuur Katholieke Vereniging van Bejaardentehuizen]. OL 2 (1965) 1, 10-13

135. Het ging om ruim $28 \%$ van de bewoners. Verzorgingsbehoefte van bejaarden in bejaardentehuizen 1963 . Beleidsnota en rapport. Den Haag: Gerontologische Commissie Katholieke Vereniging van Bejaardentehuizen, 1964 (p. 36)

136. Jaanverslag Volkshuisvesting 1961 , p. 125

137. Haveman, J. Menselijke verhoudingen in bejaardentehuizen. Groningen: Rijksuniversiteit Groningen, Sociologisch Instituut, 1967

138. Zie ondermeer Bijleveld, J. Het opnamebeleid van bejaardentehuizen ten aanzien van lichamelijk minder validen. $D B 7$ (1961) 8 , 138; Jelles, W. Nogmaals: Het opnamebeleid. DB I (1965) 9, I8 5186; Hoeven, H.G. van. Interne en externe bejaardenzorg zijn beide nodig. $D B 12$ (1966) 2, 36-37. Dit probleem van de leefbaarheid werd tot in de jaren tachtig opgeworpen. Zie: Houben, P.P.J. Waarheen koersen we met de huisvesting van bejaarden? Bouw 36 (1981) 14/15, $35-36$

139. Smit, W. Opnemingsbeleid en leeftijd. Validiteitsopbloei na opneming in een tehuis. $D B 11$ (1965) 7, 142; Ketwich Verschuur, F.W. van. Op de tweesprong in het tehuisbeleid. $D B$ I $_{3}$ (1967) 12 , 295-297

140. Braadbaart, S. Ervaringen uit een bejaardentehuis. TSG 38 (1960) $319-320$

141. Suggesties voor een beter opnemingssysteem in tehuizen. $D B$ 6 (1960) [12], 174-175; Meer planning bij de bouw van bejaardentehuizen. DB 6 (1960) [12], 184; Poel, D.C. van der. Het pensiontehuis op de helling? Bouw 16 (I96I) 21, 652-654: Verhagen, C.M. Onderontwikkelde gebieden in de zorg voor de bejaarden. $D B 7$ (1961) 2, 2I-23; Paans, J.C. Het opnamebeleid van bejaardentehuizen ten aanzien van lichamelijk minder validen. $D B 7$ (1961) 9, I 50; Meer, M.D.J. van der. Opnemingsbeleid en indicaties. Commentaar (nr. 3) op gehoord, gezien, gelezen. $D B 9$ (1963) I1, 213-215; Meer, M.J.D. [sic] van der. Verpleging en verzorging. Commentaar (nr. 4) op gehoord, gezien, gelezen. $D B 9$ (1963) I2, 243; Alleen plaats voor sterke bejaarden? DB 16 (1970) 7, 221. Zie voor deze verschuiving ook de beschrijvingen van de 'bestemming' van het verzorgingstehuis in de overheidsrapporten De huisvesting van bejaarden in Nederland (1965) op. cit. 
1965 (p. 19) en De huisvesting van bejaarden in Nederland. [Den Haag]: Ministerie van Volkshuisvesting en Ruimtelijke Ordening, 1970 ( $p$. 23); Dokters protesteren tegen het opname(wan)beleid. DB I 8 (1972) $3,65-66$

142. Zie ondermeer: ARA, archief $\mathrm{NFB}$, inventarisnummer 173. Werkgroep Indicatie-stelling (I962-I964); Verzorgingsbehoefte (1964) op. cit.; Het opnamebeleid in de verzorgingstehuizen voor bejaarden. $B W_{\text {II }}$ (1965) [s] IOI-I03/104; Rapport K.v.B. over: opnemingsbeleid $\mathrm{OL}_{2}$ (1965) 5, I21. Zie voor de discussie over opnemingscriteria ook: $\mathrm{De}$ opneming van bejaarden in joodse tehuizen. $D B$ S (1959) [3], 4I; Rubbens-Franken (1960) op. cit.; Munnichs (1960) op. cit.; Nijsten, A. . Taakbewustzijn van de bejaardentehuizen. $K B 6$ (1960) 5, 97-99; Rapport Opneming bejaarden in tehuizen. $D B$ II (1965) 7, 145; Opnemingsbeleid kardinaal vraagstuk van de bejaardenzorg. $O L_{1}$ (1963/64) 8, 184-1 86; Utrecht voert opnemingsbeleid met puntenwaarderingsstelsel. $\mathrm{OL} 2$ (1965) 2, 48-49; Computer ingeschakeld bij opneming in bejaardentehuis. $\mathrm{OL}_{2}(1965) 4,82$

143. Opneming in verzorgingstehuizen voor bejaarden. Procedure on samenwerking. Den Haag: NFB, 1967

144. Oostvogel (1968) op. cit.; Proefschrift Dr. F.J.G. Oostvogel. Verzorgingsbehoeften van bejaarden. $O L_{5}$ (1968) 6, 266; Leering, $C$. De verzorgende en de algemeen dagelijkse levensverrichtingen ( $A D \mathrm{DL}$ ) TBKZ 2 (1969) 9, 180-182; Oostvogel, F.J.G. Verzorgingsbehoeften van bejaarden I/II. TSG 47 (1969) 78-783/814-822; Werkwijze en normen voor opneming en verzorging van bejaarden. TSG 49 (1971) II, 354-36I

145. Het opnemingsbeleid in de praktijk; resultaten van een enquête. In: Opneming (I967) op. cit. pp. 43-53

146. Zie ondermeer: Jelles (1965) op. cit; Ketwich Verschuur (1967) op. cit.

147. Nomenclatuur van vormen van accommodatie voor bejaarden in Nederland. 's-Gravenhage: Stichting NFB, z.j.: Nieuwe 'Nomenclatuur van accommodaties voor bejaarden'. $D B 16$ (1970) 4, 11 5-117; Nogmaals: Nomenclatuur van accommodaties $D B$ I6 (1970) 5, 163. Zie voor deze verschuiving ook: Verzongingstehuizen voor bejaarden. Rotterdam: Bouwcentrum, 1970; Discussierapport. Vragen omtrent huisvestingsvoorzieningen voor bejaarden. 's-Gravenhage: Staatsuitgeverij/СCB, 1976

I48. Vrolijk, J. Architecten, alternatieven, bejaarden. $\mathrm{OL}_{7}$ (1970) II, 322-325 (p. 323); Handelingen II 1972-1973 664; Handelingen II 1972-1973 794 
149. Geìsoleerd tehuis. $O L$ I $(1963 / 1964) 3,53$; Oostindie, A. Waar moeten bejaardenhuizen staan? ESB so (1965) 171; Bejaardentehuizen niet aan rand van de stad bouwen. OL 2 (1965) 5, 11 ; Verzorgingstehuis De Klepperwei in Rhoon. $D B_{17}$ (1971) 6, 171-172

I50. Lezers schrijven ons. Geef bejaardentehuis meer contact met de buitenwereld. Bouw I4 (1959) 17, 47 I en Bouw I4 (1959) 24, 680-68 I. Zie ook: Rubbens-Franken, E. Meer contact tussen bejaardentehuizen en de 'vrije' samenleving. $D B$ S (1959) 5, 69-70; [S-r.] Meer contact tussen bejaardentehuizen en de vrije samenleving. $D B_{5}$ (1959) 7,97

I51. G. Feenstra. Opmerkingen over huisvesting van bejaarden. Het beeld van een bejaarde zèlf. Bouw I6 (I961) 9, 262-263

I52. Bejaardencentrum Crabbehof (1967) op. cit.; Vrolijk (1970) op. cit.

153. Mulder, P. Bejaardentehuizen en architectuur. Bouw 24 (1969) $52,2090-2091$

I54. Pelikaan, J.C. Voorschriften en wenken voor bejaardentehuizen. Bouw 22 (1967) 5, 161-162. Zie voor het gebrek aan speelruimte voor de architecten ook: Enige bedenkingen tegen de voorschriften en wenken voor verzorgingstehuizen. $D B_{13}$ (1967) 10, 237

155. Brieven aan de VARA-Ombudsman. Analyse van schriftelijke klachten over de intramurale verzorging van bejaarden. 's-Gravenhage: NIMAWO, 1971. Zie voor de bewonerscommissies ondermeer: Handelingen IIB I978-1979 15599, nrs. I-3

156. Oudjes kijken. Den Haag: NFB, 1974

157. Ja vader, nee vader [Interview met A. Romein-Verschoor]. $\mathrm{OL}$ II (1974) 2, 8-10 (p. 8); Mensen horen niet in instituten - bejaarden zijn mensen. $O L_{11}$ (1974) 6/7,4-8 (pp. 6, 4 en 7). De volledige naam van de Jong Oud Trust was: Jong Oud Trust ter bevordering van een ononderbroken levensloop. Zie voor kritiek op de tehuizen ook: Egas, C. Bejaardentehuizen in diskussie. DB 20 (1974) 10, 254-255; Egas, C. Nog één keer: de kwestie verzorgingstehuizen. DB 20 (1974) 20, 560-561; Bennekom, D. van. De situatie van de bejaarde in het verzorgingstehuis. TMW 30 (1976) 10, 196-198; Open huis over het tehuis. Amsterdam: Humanitas, 1976; Voet tussen de deur. De toekomst van het verzorgingstehuis. Amsterdam: Humanitas, 1977; Rechten en welzijn van mensen in instituten. Amsterdam: Humanitas, 1978. Zie voor de verontruste reacties op deze kritische stroming: Kerckhoffs, H. Dank u wel, meneer Egas. DB 20 (1974) 9, 234; Mohr, F.R. Bejaardentehuizen in diskussie. $D B 20$ (1974) I1, 284-286; Bruin, C. de. Huize Swerf-rust, Middelburg. $D B 20$ (1974) 13, 335-336; Leven in een 
bejaardentehuis is vierkant ROT. $O L$ II (1974) 3, 6-II; Reakties. DB 20 (1974) 17, 470-471; Mensen horen niet in instituten. OL II (I974) 9, 23-24; Pauw, C. Wonen in een bejaardentehuis. Bouw 30 (1975) 3 , $4 \mathrm{I}-44$. In die reacties werd er ondermeer op gewezen dat tehuizen nu eenmaal nodig waren en er geen zinnig alternatief was, dat het hardwerkend personeel onrecht werd aangedaan en dat de bejaarde bewoners zelf overwegend tevreden waren.

I 58. Handelingen I1B I96 I-1962 662 I (Wet op de Bejaardenoorden) MVT (nr. 3) 4

159. Gijsbers en Goedmakers (1963) op. cit.; Buskens, H.M. Bejaarde behoort niet aangewezen te zijn op de uithoeken en overschotten van het woningbezit. In: Bejaarden in de samenleving (1963) op. cit. pp. I4-20; Handelingen IB I96 I-1962 $6500 \mathrm{H} \mathrm{XVI} \mathrm{MVA} \mathrm{(nr.} \mathrm{78a)} \mathrm{6,} \mathrm{m}$ I965-1966 8300 H XVI MVT (nr. 2) 20, MVA (nr. 10) 33; Niet bang zjjn voor de problematiek. $D B 12$ (1966) 10, 263; Gijsbers, A.J. Het funktioneren van het bejaardentehuis. $B W$ I4 (1968) 2, 38-4I; Het kostenvraagstuk van intra-murale zorg [Toespraak A.J. Gijsbers]. OL 5 (1968) 2, 74-75; Kommers, W. Bejaardentehuizen: De grote schuldigen. DB I 4 (1968) 5, 96-98; Staatssecretaris Van de Poel geeft visic op ontwikkeling bejaardenwerk. OL s (I968) 5, 212-2I3

160. Handelingen пв 1960-1961 6100 н XIIA мVт (nr. 2) 8. Zie ook: Handelingen ив г962-1963 6900 н XV1 мVт (nr. 2) 8, пв г963-1964 7400 н XVI MVT (nr. 2) 1о, пв 1967-1968 9300 н XVI мVT (nr. 2) 20. IIв 1969-1970 го300 н XVI MVT (nr. 2) 24

161. Handelingen Iв 1960-1961 6100 н хІІа vмо (nr. 15) 5

I62. Gijsbers en Goedmakers (1963) op. cit. p. 8

r63. Beschikking geldelijke steun toegelaten instellingen (Staatscourant 1965, 253-in werkingtreding dd. I januari 1966) en Beschikking geldelijke steun particuliere huurwoningen (Staatscourant 1965, 253 - in werkingtreding dd. I januari 1966 en Staatscourant 1966, 194 - in werkingtreding dd. I oktober I966). Zie ook: Jaarverslag Volkshuisvesting 1965. p. 98; Brakel, W.P. van en Bommel, J. van. Zes eeuwen bejaand Rotterdam. Verzorging en huisvesting van bejaarden te Rotterdam. Rotterdam: Dienst van Volkshuisvesting Rotterdam, 1971 (pp. IOI-I02)

I64. Handelingen II 1968-1969 L96. De rijksoverheid wees lagere overheden een bepaald toegestaan bouwvolume toe, hetgeen werd uitgedrukt in 'contingenten'.

165. Handelingen гів 1969-1970 гозо0 н ХІ мVT (nr. 2) 12-13, II r $969-1970$ 1 565 . Het ging om een beperking tot 5600 bedden per jaar, een getal dat later onder druk van een interpellatie van het pvdA-ka- 
merlid Egas tot 7600 werd verhoogd. Handelingen il 1969-1970 27882806 (interpellatie dd. 17 maart 1970). Zie ook Jaanverlag Volkshuisvesting 1969, p. 55

166. Handelingen IIB 1969-1970 10300 H XI Brief dd. 6 september 1969 (nr. 7) 3. Schut verwees naar een onderzoek uitgevoerd in Rotterdam. Volgens de Centrale Directie van Volkshuisvesting werd 10\% door de meeste deskundigen als een hoge maatstaf gezien. Het gebruikelijke percentage lag zelden boven de acht. Zie Jaarverslag Volkshuisvesting 1969 , p. 54

167. Jaanverslag Volkshuisvesting 1969, p. 55; Handelingen II 19691970 10300 н XI MVT (nr. 2) 12-13, IIB I969-1970 10300 Brief (nr. 7) 3-4

168. Handelingen 11 1969-1970 1563-68. Deze maatregelen waren voorbereid door een in 1968 ingestelde Interdepartementale Stuurgroep Bejaardenbeleid.

169. Handelingen шв 1969-1970 10300 н ХІ мVт (nr. 2) 12-13, ив 1969-1970 10300 н х1 Brief (nr. 7) 3-4

170. Handelingen II 1969-1970 I 564-65

171. Ook Munnichs ziet in de sterke stijging van bijstandsuitkeringen aan bejaarden in tehuizen een belangrijke oorzaak van de beleidswijziging: Munnichs (1974) op. cit. p. I6 en Munnichs (1987) op. cit. pp. 36-37

172. Handelingen 11в 1969-1970 I0934 (nr. 2) Nota Bejaardenbeleid 1970; I1В 1974-1975 13463 (nr. 2) Nota Bejaardenbeleid 1975. Zie voor kritiek vanuit de bejaardenzorg ondermeer: Reactie op bouwbeleid. $B W_{16}$ (1970) 2, 41; Viif jaar welzijnszong voor ouderen. Den Haag: Nederlandse Federatie voor Bejaardenzorg, 1971; Integraal bejaardenbeleid. Aspekten van een integraal bejaardenbeleid in verband met de nota 'Bejaardenbeleid 1970' van de regering. Den Haag: NFB, 1971; Tehuizen niet duurder dan woningen. $D B_{1} 8$ (1972) 8, 237. Zie voor de parlementaire kritiek ondermeer: Handelingen II 1969-1970 1459-61, 1463-64, I $471,1477-78,1487,1492-93$, I 563-68; II 1971-1972 2881-2953 en $2960-68$

173. Handelingen 11 1970-1971 10986 (Wijziging wBo) ovw (nr. 2) en MVt (nr. 3); Staatsblad 1972, 344

174. Staatsblad 1976, 637 en 1976, 619. Hoewel de bejaardenoorden in principe vrij bleven de inhoud van het advies te negeren, opende de wet voor de provinciale staten wél de mogelijkheid gedurende een bepaalde termijn vast te leggen dat opneming alleen zou mogen plaatsvinden wanneer de commissie tot opneming adviseerde. 
175. Op verschillende plaatsen in de nota werd de keuze voor de $7 \%$-norm gemotiveerd. CBS-prognoses wezen op een langzaam afnemende groei van de bejaarde bevolking. Ook zouden er aantrekkelijke huisvestingsalternatieven beschikbaar komen. Bovendien zou in de toekomst een stringenter opnemingsbeleid gehanteerd worden. Daarnaast werd gewezen op een onderzoek naar de validiteit van Rotterdamse bejaarden. Zie Nota Bejaardenbeleid 1975 op. cit. p. 67 en pp. 147-148; Bom, J.A. van der. Leefsituatie van oudere Rotterdammers in 1965. Berg en Dal/Nijmegen: Stichting Gerontologisch Centrum, 1976; De Rotterdamse Bejaarden. Een onderzoek naar hun levensomstandigheden en behoeften. Deel 2. Rotterdam: Gemeente Rotterdam, 1970. Parlementsleden, de сCв, de NFB en de Federatie Landelijke Samenwerking Bejaardentehuizenorganisaties (LSB) haastten zich het getal van $7 \%$ te kraken: het berustte op drijfzand. Volgens de NFB paste een rigide normstelling überhaupt niet in een flexibel beleid. Zie: NFBKommentaar op de Nota Bejaardenbeleid 1975 [Den Haag: NFB, 1975] (p. 23); Overzicht van reacties en commentaren op de Nota Bejaardenbeleid 1975 Rijswijk: ISB, 1976: punt 8 (commentaar CCB), punt 26 en 39 (commentaar LSB); De Federatie LSB: geen overheidsbeleid. DB 25 (1979) 1, $12-15$

176. Zie ondermeer Handelingen uв 1981-1982 16625 (nr. 54) Herovenvegingen Bejaardenbeleid 7

177. Nota Bejaardenbeleid 1975 op. cit. pp. 65-71

178. Slechts drie grote gemeenten en enkele kloosterbejaardentehuizen werden gespaard, Handelingen $11 \mathrm{~B} 1976-1977$ г4 $100 \mathrm{H} \mathrm{XI} \mathrm{nr.} \mathrm{I}_{4}$, 22 en nr. 31, 52; Herovenvegingen Bejaardenbeleid op. cit. p. 7 en pp. 17-18; Handelingen шв 1981-1982 17393 (nr. 2) Bouwstenen voor een Ouderenbeleid 90-91

179. Bouwstenen voor een ouderenbeleid (1982) op. cit. p. I05; Verzorgingstehuizen voor bejaarden. $O L 9$ (1972) I-II; Dresselhuys, C. Nieuw-Vredenburgh. L I 4 (1977) S, 1 8-2 I; Verzorgingstehuizen open naar de wijk? DB 24 (1978) 14, 377; Wijkfunktie voor verzorgingstehuizen? TBKZ II (1978) juni, 251; Muskee, H.A. Een voorbeeld van open bejaardenwerk vanuit een bejaardenoord. $T B K Z_{12}$ (1979) oktober, 350-354; De wijkfunktie. Advies inzake de samenwerking tussen het verzorgingstehuis en de wijk. Den Haag: NFB, $198 \mathrm{I}$; Contouren voor ent toekomstig beleid. Den Haag: Federatie ISB, I98I. Onder transmurale dienstverlening werd ook extramurale hulp vanuit de wijk (algemeen maatschappelijk werk, recreatieve en educatieve diensten) aan het tohuis verstaan. Het ontwikkelen van die dienstverlening werd echter 
moeilijker geacht dan de dienstverlening vanuit het tehuis.

I 80 . In 1950 was $8,3 \%$ van de bewoners van de niet-winstbeogende tehuizen (van 65 jaar of ouder) 'voortdurend bedlegerig', terwijl $28,4 \%$ 'min of meer hulpbehoevend' en $63.5 \%$ 'niet hulpbehoevend' was (CBS-Verzorging van bejaarden (195I) op. cit. p. 9). Twintig jaar later was $3,2 \%$ van de bewoners (van 65 jaar en ouder) van de bejaardenoorden (waaronder ook de commerciële) 'praktisch voortdurend bedlegerig'. Daarnaast was $9,2 \%$ 'niet bedlegerig doch volledig hulpbehoevend', $22 \%$ 'niet bedlegerig doch gedeeltelijk hulpbehoevend en kon $65,6 \%$ 'zich met enige huishoudelijke verzorging' redden. In 1986 waren de percentages voor dezelfde categorieẽn respectievelijk $3 \%$, $18,5 \%, 37,8 \%$ en $40,7 \%$ (Statistiek van de Bejaardenoorden 1970 (p, 12) en $1986($ p. 15))

18r. Premieregeling en verzorgingsbehoefte. $D B 16$ (1970) S, I6r; Bakker, J.C. De toekomst van de verzorgingstehuizen. DB I6 (I970) 3 , 78-79; Advies over de noodzakelijkheid van groepsverzorging in bejaardenoorden. 's-Gravenhage: Staatsuitgeverij/ССв, 1976; Overbeek, H.L. Groepsverzorging van bejaarden. $D B 23$ (1977) 23,498- 501; Akkerman, H.P. Groepsverzorging voor bejaarden in bejaardenoorden? $M_{33}$ (1978) 34, 1059-106r; Voorschriften en wenken voor het ontwerpen van verzorgingstehuizen voor bejaarden. $L$ is (1978) 9, 34-35; Handelingen шв 1978-1979 15300 н XV1 MVT (nr. 2) 97 en пв I978-1979 15300 нX1 MVT (nr. 2) 32; Advies inzake taak en functie van het verzorgingstehuis voor bejaarden (I979) op. cit.

6 De dynamiek van grenzen

1. Delen van deze paragraaf werden eerder verwerkt in: Bijsterveld, K. De natuurlijke ouderdom: een grenzeloze geschiedenis. Kennis en Methode Is (1991) I, 62-86

2. Groen, J. Medische en medisch-sociale grondslagen van de bejaardenzorg. In: Het bejaardenvraagstuk. Prae-adviezen en handelingen van het congres inzake het bejaardenvraagstuk. Scheveningen 1956. Assen: Van Gorcum, 1957: 15-32

3. Burger, G.C.E. De oudere mens en zijn arbeid. Mens en ondememing 9 (1955) 281-299 (p. 293). Zie ook Muntendam, P. Arts en ouderdom. TMW I (1947) 11, I6I-162

4. Zonneveld, R.J. van. Enkele beschouwingen over het ouderdomsvraagstuk en in het bijzonder over de bejaarde werkers. Mens en 
ondememing 7 (1953) 182-197 (p. 192)

5. Groot, J. de. Productieve arbeid van bejaarden. Het medisch aspect. In: Het bejaardenvraagstuk (1957) op. cit. pp. 102-1 10 (p. 109); Rapport inzake arbeidsmogelijkheden voor ouden van dagen. Leeuwarden: Stichting Friesland voor Maatschappelijk Werk, I95I

6. In plaats van flexibele pensionering werd aanvankelijk ook van 'elastische' of 'variabele' pensionering gesproken. In geval van flexibele pensionering kregen mensen enige keuzevrijheid met betrekking tot het moment van pensionering; bij geleidelijke pensionering konden mensen stukje bij beetje minder gaan werken. Sleeswijk, J.G. Een woord vooraf: In: Sleeswijk, J.G. (Red.) De ouderdom van geneeskundig standpunt beschouwd. Een handboek voor artsen. Deel I. Algemeen gedeclte. Amsterdam/Antwerpen: Uitgeverij Kosmos, I948: V-vm; Berg, J.H. van den. De veroudering van de bevolking. TSG 28 (1950) 5, 77-79; Diederich, J. Enkele sociologische aspecten van het vraagstuk der bejaarden. In: De Oudeliedenzorg. Prae-adviezen uitgebracht door Prof. Dr Ir H.G. van Beusekom, Drs. J. Diederich, Dr Mr F.M. Havermans en MrJ.A.J. Meijer. Haarlem: H.D. Tjeenk Willink \& Zoon, I950: 35-68; Groen, J. Gerontologie, een nieuw veld van activiteiten der Gezondheidsorganisatie TNO. T.N.O. Nieuus (1953) 8, 403-409; Groenman, S. Ouderdom naar jaren, constitutie en sociale rol. In: Het Bejaardenvraagstuk (1957) op. cit. pp. 5-14; Van Zonneveld (1953) op. cit; Forum. [Vragen voorgelegd aan H.C. Rümke en J.Th.R. Schreuder]. In: De ouder wordende mens. Vijfde provinciale gezondheidsdag op 25 mei 1966. [S.1.]: Provinciale Raad voor de Volksgezondheid in de provincie Drenthe, [s.a.]: 53-74; Oostvogel, F.J.G. Een 65-jarige is geen probleemgeval. $\mathrm{OL}_{3}$ (r 966 ) 3, 90-9 1; Mulders, W.J.M. Op welke leeftijd met pensioen gaan? $D B 17$ (I97I) 1, s-7; Milikowski, H. Ph. Bejaardenprobleem een klasseprobleem. NTG 3 (1972) 3a, 273-277, Zonneveld, R.J. van. Oud zijn in onze maatschappij. In: Bekkum, D.W. van e.a. Oud worden, oud zijn. Deventer: Van Loghum Slaterus, 1974: I7-2I; 'Magische, tragische grens'. $D B 22$ (1976) 4, 70; 65 jaar volslagen arbitrair. DB 24 (1978) 5, 98; M.H.L.S. Eugeria [Samenvatting van voordracht J.J. Groen] Senior 28 (1982) 12, 264-265

7. Mulders (197I) op. cit. sprak zich uit voor een flexibele pensionering in tijden van volledige werkgelegenheid en een vaste pensioneringsleeftijd in perioden van niet-volledige werkgelegenheid. Zie voor (andere) nadelen van flexibele pensionering: Muntendam, P. Ouderdomszorg. TSG 24 (1946) 9, 205-209; Diederich (I950) op. cit.; Burger (1955) op. cit.; Munnichs, J.M.A. Oudere werknemers: een verkennen- 
de studie. ['s-Gravenhage]: SER, 1966; Forum (1966) op, cit.; Turksma, L. Multimorbiditeit, pensioengrenzen en nog veel meer. DB 23 (r977) 20,434-435; Turksma, L. Senioren in de samenleving. Utrecht: Het Spectrum, 1982

8. Flexibele pensionering werd bij voorbeeld ingevoerd bij de PTT. Zie: Nie, H. de. Flex-uit-foetsie. $L$ I6 (1979) 11, 27; Handelingen II 1981-82 I7393 (nrs. I-2) Nota Bouustenen voor een ouderenbeleid 47

9. Loo, K.J.M. van de. Bejaard zijn en bezig zijn. $B W_{9}(1963) 4$, II0-1Is (p. II I); Munnichs, J.M.A. Enkele aspecten van de psychologie van de bejaarden. Maatschappijbelangen 120 (1956) 9, 344-345; Rubbens-Franken, E. Mogelijkheden voor tijdsbesteding door bejaarden. Utrecht: Stichting Vrijzinnig Protestantse Centrale voor Maatschappelijk Werk, 1956; Diederich, J. Bejaard zijn in de Westerse samenleving. In: Dekhuyzen-Zeehuisen, J. e.a. Zorgen van en voor bejaarden. Zaltbommel [etc.]: Jan van Tuyl, 1957: 9-24; Rümke, H.C. Geestelijk-hygiënische aspecten van het ouder worden. In: De ouder wordende mens (1966) op. cit. pp. 9-16

10. Thurlings, J.M.G. Het bejaardenvraagstuk vanuit psycho-sociologisch oogpunt beschouwd. Maandschrift Economie 21 (I956/57) 4 . 173-191 (pp. 182-183). Zie ook Bouman, P.J. De ouderdom in ons maatschappelijke bestel. In: Andel, J.C. van en Andel-Ripke, G. van. Oud worden in deze tijd. Man en vrouw rondom en boven de zestig. Utrecht: Erven J. Bijleveld, 1953: 6I-69; Bouman, P.J. Enige historische beschouwingen. In: Van Andel (1953) op. cit pp. 52-60; Groenman (1957) op. cit.

II. Moor, R.A. de. Oud worden als sociaal verschijnsel. In: Munnichs, J.M.A., Moor, R.A. de en Maltha O.P., A.H. Herfsttij van de levensloop. Beschouvingen over de ouderdom. Utrecht [etc.]: Het Spectrum, 1956: 34-57

12. Iemand die hier later op wees was Braam (Braam, G.P.A. Pensionering: verstoorde arbeid of lokkende rust? Sociologische Gids $I 1$ (1964) $125-138$ (p. 120)). Overigens legde niet iedereen automatisch dit verband. Volgens Thurlings kon bij gebrek aan feitenstudies slechts gespeculeerd worden over het antwoord op de vraag wat de pensionering voor diverse categorieën mensen betekende. Zie Thurlings $(1956 / 57)$ op. cit. p. 182

13. Dam, J.C. van. Wat is de grondoorzaak van het bejaardenvraagstuk? Sociale Zorg 20 (1958) 2, 17-24 (p. 20)

14. Diederich, J. Bevolkingsveroudering als sociologisch probleem. Sociologisch Jaarboek 8 (1954) 97-IIs (p. 98). Zie voor het rol- 
verlies ook: Diederich, J. Levensomstandigheden van bejaarden in kleinere en middelgrote gemeenten in Nederland. Amsterdam/'s-Gravenhage: $\mathrm{Na-}$ tionale Raad voor Maatschappelijk Werk, 1958

15. [Redactie]. Enige gedachten betreffende de taak, die de moderne katholieke bejaardenzorg aan de gemeenschap, respectievelijk aan organen daaruit gevormd oplegt. Onze Bejaardenzorg 2 (I95I) 4 , 5-8; Leenaerts, W.A.F. Hoe Den Bosch zijn bejaarden helpt bij hun tijdsbesteding. Onze Bejaarden I (1955) 6, 63-64; Tijdsbesteding van bejaarden. Leiden: Commissie voor het Oudeliedenvraagstuk, Subcommissie Tijdsbesteding, 1955; Nuyl, M.J. te. Tijdsbesteding voor bejaarden. Onze Bejaarden 2 (1956) 12, I64; [Rubbens-Franken], E. Wat verschillende Gemeenten voor Bejaarden doen. Op cultureel gebied. Onze Bejaarden 2 (1956) 5, 68; Klinkenberg, F. Tijdsbesteding. Onze Bejaarden 3 (1957) 88; Meyer, J.A.J. Tijdsbesteding der bejaarden. In: De Oudeliedenzorg (1950) op. cit. pp. 84-132; Program voor bejaarden. zorg. Amsterdam: dr. Wiardi Beckmanstichting, 1958; Klinkenberg, $\mathrm{F}$. Zinvolle vrijetijdsbesteding door bejaarden. DB S (1959) februari, 26; Beeks, A.F. Otium cum dignitate? $T M W_{14}$ (1960) 4, 63-67; Kweksilber, W. Wat bejaarden nog kunnen doen. Creatieve tijdsbesteding. DB 9 (r963) 5, 84-85; [H.B.] Meer creatieve arbeid. Vrije expressie houdt de geest wakker. uvv hield studiedag. $D B_{\text {II }}$ (1965) 8, I64-165

In de jaren vijftig en zestig werd veel geschreven over het naat Engels voorbeeld opzetten van speciale werkplaatsen voor bejaarden. In verschillende gemeenten, ondermeer bij Philips in Eindhoven, kwam het inderdaad tot oprichting van dergelijke, vaak coöperatieve werkplaatsen. Gepensioneerden konden er voor een bescheiden loon een deel van de dag werken en op die manier, zo vertelden de oprichters met groot enthousiasme, nuttig bezig zijn en contacten onderhouden. In de tweede helft van de jaren zestig zagen de meeste werkplaatsen zich echter gedwongen hun deuren te sluiten, zowel wegens gebrek aan orders, als door onvoldoende belangstelling van geschoolde gepensioneerden. Bovendien werd van regeringszijde meegedeeld dat het verstrekken van produktieve arbeid aan bejaarden in perioden van beperkte werkgelegenheid grote spanningen kon oproepen. Daarmee kwam een einde aan een inmiddels in de vergetelheid geraakte pargraaf in de geschiedenis van voorzieningen voor ouderen. Zie voor de gedachten over en ontwikkelingen rond de werkplaatsen ondermeer: Dekhuyzen-Zeehuisen, I. Werkgelegenheid voor bejaarden. De Gemeente 7 (1952) 8, 86-87; Rubbens-Franken, E. De ouder wordende mens in onze samenleving. Bussum: A. Voorhoeve, 1953; Rendabel werk 
voor ouderen. Onze Bejaarden 3 (1957) 9, 123-124; Interim-rapport inzake de arbeid van bejaarden uitgebracht door een departementale werkgroep. 's-Gravenhage: [Ministerie van Sociale Zaken en Volksgezondheid], 1958; Rapport Arbeid voor Bejaarden. 's-Gravenhage: Nederlandse Federatie voor Bejaardenzorg, [1960]; Schreuder, J.Th.R. De vereenzaming van bejaarden. $M C_{17}$ (1962) 2, 22; Werkgelegenheid voor gepensioneerden: Pro of CONTRA? OL I (1963/1964) 3, 54-55; Biemond, $\mathrm{H}$. Werkgemeenschap in Rotterdam. Er is zeer veel belangstelling! $D B$ II (1965) 2, 34-35; Werkplaatsen voor bejaarden I. Gaatjes boren in Woerden. OL 2 (1965) 5, 116-117; Werkplaatsen voor bejaarden II. In Alblasserdam loopt alles gesmeerd máár ... er is weinig belangstelling. $\mathrm{OL}_{2}$ (1965) 6, 146-147; Sterk door werk? BW 12 (1966) 4, 112; Werkplaatsen geen oplossing! [Toespraak staatssecretaris C. Egas] $O L$ 3 (1966) 45, 156-I 57; ARA, Archief NFB, inventarisnr. 5, stuk nr. 135, De werkplaatsen voor bejaarden. O. en P., 14-2-'67, P.V. en inventarisnr. 3, stuk nr. 219, Werkplaatsen voor bejaarden. Inleiding, I8-5'66, v.V.; Linden-Nijdam, E.J. van der. Werk voor gepensioneerden. DB 19 (1973) ro, 278-280

16. Diederich (1958) op. cit. p. 155. Zie ook: Sleeswijk, J.G. Gezondheidsleer voor de oude dag. In: Sleeswijk, J.G. (Red.) De ouderdom van geneeskundig standpunt beschouwd. Een handboek voor artsen. Deel II. Amsterdam/Antwerpen: Uitgeversmij. Kosmos, 1949: 775-793; Van Zonneveld (1953) op. cit.; Rubbens-Franken (1953) op. cit.; Rubbens-Franken, E. De 6s-jarigen. Pensioen, arbeid, vrije-tijdsbesteding. Maatschappij-belangen 120 (1956) 4, 127-133; Thurlings (1956/57) op. cit.

17. Munnichs, J.M.A. Enige beschouwingen over de psychologie van de ouderdom. In: Munnichs, De Moor en Maltha (1956) op. cit. pp. 7-33; Munnichs, J.M.A. Wat is aanpassing aan de ouderdom? TSG 35 (1957) 21, 539-544

18. Munnichs, J.M.A. Voorbereiding op de pensionering. Jaanerslag Gemeenschappelijk Instituut voor Toegepaste Psychologie 1958. Nijmegen: Gemeenschappelijk Instituut voor Toegpaste Psychologie, I958: 36-4I; Munnichs, J.M.A. Bejaarden-hulp. Enige psychologische kanttekeningen. III. Concreet plan ter voorbereiding op de pensionering. $K B_{5}$ (1959) I, I3-I4

I9. Munnichs, J.M.A. Het uno-Seminar te Königswinter. II. De pensioeneringsleeftijd. KB S (1959) I, I-2 (p. 2); Munnichs (Enige beschouwingen, 1956) op. cit.; Munnichs, J. Psychologie van de bejaarden 1. Inleiding. Rooms-Katholieke Bejaardenzorg 2 (1956) I, 10-11; 
Munnichs (Wat is aanpassing, 1957) op. cit.; Munnichs, J. Psychologic van de bejaarden v. Enige algemene opmerkingen. $K B_{3}$ (1957) $10-11 /$ I6; Munnichs, J. Psychologie van de bejaarden vi. De zin van de ouderdom. $K B_{3}$ (1957) 2, 25-26; Munnichs, J. Psychologie van de bejaarden xIv. Besluit. $\mathrm{KB}_{4}$ (1958) 4, 90-91; Munnichs, J.M.A. Het uno-Seminar te Königswinter Iv. Bezigheden voor bejaarden. $K B_{\text {s }}$ (1959) 3, 49-50

20. Munnichs, J.M.A. Pensionering: Een overschat probleem? Mens en ondememing 17 (1963) 5, 272-281

21. Pensioneringsproblematiek. Onderzoekingen in twee Nederlandse Bedrijuen. DB Io (1964) 6, 127-128; Sandt, M.A. van de. Onderzoekingen betreffende oudere werknemers en het pensioneringvraagstuk. Sociale Wetenschappen 7 (1964) 123-134

22. Zie ondermeer Van de Sandt (1964) op, cit; Pensioneringsproblematiek (1964) op. cit.; Munnichs, J.M.A. Ouder worden en bejaard zijn. Sociaal-gerontologische opstellen. Nijmegen: Dekker en Van der Vegt, 1969; Goewie, R. Voorbereiding op de pensionering. 's-Gravenhage: Nimawo, 1977; Goewie, R. Aanpassing aan de pensionering. NTG 1o (1979) I, I 8-24; Santvoort, M.M. van. Nederlands onderzock naar de oudere werknemer en de pensionering: Een overzicht. TGG 13 (1982) 5, 186-192

23. Braam (1964) op. cit.

24. Cumming, E. en Henry, W.E. Growing old. The process of disengagement. New York: Basic Books Inc., 1961

25. Zie ondermeer Mulders, W.J.M. Noden van de bejaarden; en problemen rondom dit vraagstuk sociaal-economisch beschouvd. Nijmegen: Thoben Offset, 1966

26. Munnichs' theorie over het 'hernieuwd engagement in distantie' was een aanvulling op de disengagement-theorie. Zie ondermeer Munnichs, J.M.A. Het einde in. Psychologische beschouwingen over dood en eindigheid. In: Munnichs, J.M.A., Kwant, R.C. en Thung, P.J. Leven en eindigheid. Een psychogerontologische studie. Utrecht [etc.]: Het Spectrum, 1965: 9-25 en Munnichs, J.M.A. Ouderdom en eindigheid. Een bijdrage tot de psychogerontologie. Assen: Van Gorcum [etc.]. 1964: Munnichs, J.M.A. Role-patterns among ageing and aged teachers and steel-workers in the Netherlands. In: Havighurst, R.J. Munnichs, J.M.A., Neugarten, B. en Thomae, H. (Eds.) Adjustment to retirement. A crossnational study. Assen: Van Gorcum, 1969: 95-115. In de laatste studie constateerde Munnichs naar aanleiding van een onderzoek naar ondermeer groepen ex-staalarbeiders en ex-onderwijzers 
van 70-75 jaar, dat waar de pensionering tot problemen aanleiding gaf, dit te wijten leek aan een sterke identificatie met het beroep, wat 'disengagement' tegenging.

27. Munnichs, J.M.A. De bestaanswijze van de oudere mens. In: Thuiswonende bejaarden. Bijdrage ter stimulening van het bejaardenwerk in de wijk. 's-Hertogenbosch: Katholieke Nationale Federatie voor Bejaardenzorg/Sectie van het Landelijk Sociaal Charitatief Centrum, 1964: $14^{-19}$ (p. 17)

28. Munnichs, J.M.A. Ouder worden en ouderdom. Typering vanuit de psychologie. In: Het ouder worden. Symposion voor studenten van de Faculteit der Geneeskunde der Katholieke Universiteit. Nijmegen: Thoben Offset, 1965 : p. 24-29 (p. 28)

29. Psychohygiëne en ouderdom. Eindrapport van een werkgroep. In: Buytendijk, F.J.J. e.a. De derde levensfase. Voordrachten over geestelijke gezondheid en ouderdom en eindrapport van een werkgroep 'Psychohygiëne en ouderdom'. Utrecht [etc.]: Het Spectrum, 1966: 53-83 (p. 71)

30. Zie voor de kritick op de disengagement-theorie in Nederland ondermeer: Kooy, G.A. Adequate bejaardenzorg. In: Buytendijk (1966) op. cit. pp. 15-27; Schreuder, J.Th.R. De bejaarden patiënt. In: Cahn, L.A. e.a. (Red.) 20 jaar geriatrie. Een keuze uit het werk van prof. J.Th.R. Schreuder. Deventer: Van Loghum Slaterus, 1973: 50-83; Tempelman, C.J.J. Identiteitsprobleem. DB 24 (1978) 14, 384-386. Zie over de verschuivingen in het internationale debat: Turksma (1982) op. cit.; Houtepen, R. Op zoek naar een goede ouderdom. Liberalisme, communitarisme en gerontologie. Kampen: Kok Agora, I993

31. Voorbereiding op de pensionering. Een overschat probleem? [samenvatting inleiding J.M.A. Munnichs] DB 10 (1964) 1, 9; Munnichs (1963) op. cit. en Munnichs (1969) op. cit.

32. Psychohygiëne en ouderdom (1966) op. cit. p. 69

33. Braam, G.P.A. Bejaarden. Sociologische Gids 12 (1965) 384-389 (p. 388)

34. Zie ondermeer: Fuldauer, A. Bejaardenonderzoek in een huisartspraktijk. Hengelo: Drukkerij Insulinde, I966; Michels, J.J.M. Over chronisch zieken en bejaarden. Nijmegen: Dekker en Van de Vegt, 1974: Leenaerts, W.A.F. Het wezenlijke mens-zijn na de pensionering. [Samenvatting lezing J. Matse] $D B 25$ (r979) 4, 72-74

35. Schrama, P.G.M. 'Als ik op mijn 65ste had geweten dat ik nog 25 jaar zo vitaal en gezond zou blijven.' $O L_{2}$ (1966) I, 20-24; Meerloo, J.A.M. Pensioendepressie: een psychologisch probleem. OL 8 (1971) 7/8, 22-24; Vrolijk, J. Gedenk gepensioneerd te worden. OL 9 (1972) 
I2, 8-10; Peters, Th. Oud(er) worden. Enkele notities. I Een sociopsycho-somatisch gebeuren. TBKZ 9 (1976) juni, I9I-197; Picard, J.A. Geestelijke aspekten van ouder worden. $L_{\text {I }} 8$ (I981) 6, 28-29/4244

36. Klinkenberg, F. De cursus 'Met pensioen'. $D B_{4}$ (1958) 42

37. Vermey, A.G.J. Leren pensioneren. $O L_{5}$ (1968) 5, 209-210; Ackermans, M. Het zwarte gat. OL 9 (1972) 12, 20-22

38. Jong, N. de. Ontwikkelingen rond voorbereiding op pensionering. $O L$ ro (I973) Io, 8-IO; Vlodrop, J. van. Je situatie niet als een onontkoombare gegevenheid aanvaarden. [Interview met W. van Gelder] L 14 (1977) I0, 12-22; Gelder, W. van e.a. (Red.) Voorbereiding op de pensionering. Alphen aan de Rijn [etc.]: Samson, 1979. Wat betreff het aantal deelnemers: Zesde advies Commissie Open School. Educative voorzieningen ter voorbereiding op de pensionering. Den Haag: Staatsuitgeverij, 1978 (p. 25); ARA II, Archief NFB, Stuurgroep Derde Levensfase, dossier nr. 266, Gelder, W. van. Vormingskursussen in verband met de voorbereiding op de pensionering (p. 4)

39. Zo bestonden er in de jaren zestig ontmoetingsweken voor gepensioneerden en bood een enkel bedrijf werknemers de mogelijkheid een creatieve cursus te doen ter voorbereiding op de pensionering. In de jaren zeventig kwam daar een schriftelijke cursus ter voorbereiding op de pensionering bij. Zie daarvoor ondermeer: Hafkamp, H.J.A.M. Ontmoetingsweek voor gepensioneerden. DB 12 (I966) II, 275/282; Jacobs, C.H. Voorbereiding op pensioen, een bedrijfsexperiment. $B W_{13}$ (1967) I, 22-24; Erselina, C. Schriftelijke kursus. $O L$ Io (1973) I, 16-17

40. Zie ondermeer: Gelder, W. van. Pensionering en de noodzaak van voorbereiding daarvan. Sociaal Maandblad Arbeid 25 (1970) 3, 173185

4I. De Jong (I973) op. cit.

42. Janmaat, J.F.J. Weiterbildung im Alter: Vorbereitung auf die Pensionierung - Erfahrungen und Perspektiven in den Niederlanden. Aktuelle Gerontologie 2 (1972) 73 1-736; Lokhorst, W. Ervaringen met kursussen ter voorbereiding op de pensionering. $D B$ I 8 (1972) 23, 69ri Janmaat, J.F.J. Ervaring met vorming. $O L_{9}$ (1972) 12, 18-19; Janmaat, J.F.J. Pensionering, bevrijding of isolement. $O L_{9}$ (1972) 12, 12-15; Janmaat, J.F.J. De sociaal-psychologische betekenis van de pensionering. In: Schouten, J. (Red.) Geriatrische lessen voor verpleegkundigen. Lochem: De Tijdstroom, 1978: 210-223

43. ARA, Archief NFB, inventarisnr. 7, stuk nr. 287, Voorbereiding 
op de pensionering. Leidraad voor de diskussieleider bij de vertoning van de film 'Als we dàt geweten hadden...' NFB, Den Haag, 1968 (p. 2); ibidem, inventarisnr. 3, stuknr. 209, Advies over de vervaardiging van een film van de filmcommissie aan het bestuur der N.F.B. Den Haag, io mei 1966. Zie wat betreft de nota: ARA, Archief NFB, inventarisnr. 4, stuk nr. 305, brief dd. I I-8-'66 J. Visser aan diverse instellingen; inventarisnr. 5, stuk nr. 126, Bijlage mi Vergadering Sectie Maatschappelijk Werk dd. 3-3-'67, punt 6; inventarisnr. 7, stuk nr. 326, Smeets, M. Nota voorbereiding op de pensionering (dd. 16-8-'68)

44. Ontwikkelingen rond de voorbereiding op de pensionering. [Den Haag]: NFB, 1974 (p. 20). Ook leverden sommige gerontologen bijdragen aan cursussen 'voorbereiding op de pensionering en ouder worden'. Zie ondermeer: Gerontologisch Centrum anno 1974. [Nijmegen]: Gerontologisch Centrum, [s.a.] (p. I I)

45. Ontwikkelingen (1974) op. cit. pp. $21-23$. Naar aanleiding van de beraadsdag werd in de tweede helft van de jaren zeventig binnen de NFB een Stuurgroep Voorbereiding op de Derde Levensfase ingesteld. ARA, Archief NFB, inventarisnr. 268, stuknr. s3l 78-2I, Notitic omtrent de prioriteitenstelling ten behoeve van de werkzaamheden van de Stuurgroep Voorbereiding op de $3 \mathrm{e}$ Levensfase.

46. Ackermans, M. Recht op vorming. [Interview met ds. W. van Gelder]. $O L 9$ (1972) 12, 16-17; ARA Archief NFB, inventarisnr. 164, 46.2 Voorbereiding Pensionering 1971-1974, brief A. Albers aan J.M.A. Munnichs dd. I-9-'72 [Verslag van een gesprek met Van Gelder]

47. ARA, Archief NFB, inventarisnr. 266, Stuurgroep Derde Levensfase, [N. de Jong] Verslag bijwoning van de conferentie met cursusleiders 'die zich bezighouden met cursussen pensioen in zicht', I3-17 mei '74, Vormingscentrum Oud Poelgeest (Oegstgeest)

48. Ackermans, M. en Vlodrop, J. van. Mensen helpen hun eigen bekwaamheden te ontdekken. [Interview met drs. Th.F. W. Wehkamp, ondermeer staffunctionaris van de Federatie voor Vormingscentra] $L_{14}$ (1977) 9, 30-35

49. Van Vlodrop (1977, interview met Van Gelder) op. cit.

50. Egas, C. Het recht op pensioen in historisch verband. In: Van Gelder (1979) op. cit.: 15-32 (p. 31)

51. Handelingen Iв 1964-65 7800 н XVI MVT (nr. 2) II-12; Zelvelder-Van der Laan, C.Tj. Pensioen in zicht. Bedrijfsvoorbereiding van werknemers op de pensionering. 's-Gravenhage: Staatsdrukkerij- en uitgeverij/Ministerie van Maatschappelijk Werk, 1964; пв 1966-678800 H 
XVI MVT (nr. 2), 27; Staatssecretaris mr. H.J. van de Poel: Sociaal-cultureel werk met bejaarden bijzonder belangrijk. $\mathrm{OL}_{4}$ (1967) 4, 154I5s; Vrolijk, J. Gedenk gepensioneerd te worden. $O L 9$ (1972) 12, 8-10; Handelingen 11 1975-76 1589, 1623; 11в 1976-77 г4100 н XV мVT (nr. 2) 25-26

52. Zesde advies Commissie Open School (1978) op. cit. Den Haag. Staatsuitgeverij, 1978. Zie voor deze ontwikkelingen ook: Ackermans, $M$. De vakbeweging over het welzijnsbeleid voor ouderen. $\mathrm{OL}_{13}$ (1976) 5, 21-23; Edukatief voorbereid ter pensionering. $L_{\text {Is }}$ (1978) 11 , 31-35; Betaald Edukatief verlof. $L$ 16 (1979) 6, 13-14; ARA, Archief NFB, inventarisnr. 268 (Stuurgroep Voorbereiding op de Derde Levensfase), P. Waanders en W. van Doornik. Voorbereiding op de pensionering in collectieve arbeidsovereenkomsten. Amsterdam, I98o; ibidem, inventarisnr. 266, brief Ministerie van Sociale Zaken aan de NFB/COsBo dd. 28-9-'79; Voorbereiding op de derde levensfase en het pensioneringssys. teem. Deelrapport (1). Den Haag: Stuurgroep voorbereiding op de derde levensfase van de Nederlandse Federatie voor Bejaardenbeleid, 1979; M. van den Dungen. Prepensionering ontwikkelingsprojekt. $L$ 19 (1982) $2,37-38$

53. Behoefte aan voorbereiding op de pensionering in kaart gebracht. $L$ is (1978) I9, 34-35 (dit betrof een samenvatting van de volgende scriptie: E. Tempelman-Bröls. Anticipatie van de pensionering); Zee, B. van der. Het bedrijf en aktiviteiten ter voorbereiding op de pensionering. $L$ I6 (1979) 12, 9-1 I; Zee, B. van der. Voorbereiding op de pensionering: maatwerk. $L 17$ (1980) $1,11-12$; Zee, B. van der. De waardering van internaatscursussen ter voorbereiding op de pensionering door oudere werknemers. Een evaluatief onderzoek. Gerontologie 12 (1981) 3, 1 58-163: Zee, B. van der. Overwegingen naar aanleiding van een onderzoek naar de waardering van kursussen pensioen in zicht. L I9 (1982) 2, 38-40; Royers, Th. Bart van der Zeepensionering is een heel individuele zaak. $L 19$ (1982) 2, 44-45. Zie ook: Santvoort, M.M. van. Onderzoek onderzocht. Deel II. Analyse, evaluatic en perspektief van het sociaal-gerontologisch onderzoek in Nederland. Amsterdam: Noord-Hollandsche Uitgevers Maatschappij, 1983.

54. ARA, Archief NFB, inventarisnr. 266 (Stuurgroep Voorbereiding op de Derde Levensfase), Werkplan ontwikkelingsproject prépensionering voor de jaren $1981-1983$. Zie voor de verbreding van de doelgroep ook: Derks, Y. Pensioen in zicht. DB 23 (1977) 20, 426-427, Wehkamp, T. Voorbereiding op het ouder worden. Suggesta (no. 2). Amersfoort: De Horstink, I980 
55. Egas, C. Psychische aspekten van de pensionering. $T B K Z_{7}$ (1974) november, 261-267/270 (p. 263); Waarom edukatief werk voor ouderen? - inleiding ten behoeve van een beraadsdag omtrent edukatieve aktiviteiten voor ouderen dd. 4 oktober 1979 te Utrecht. $L_{17}$ (1980) 2, 47-50; Godding, H. Cursuswerk problematiseert 'Pensioen in Zicht'. Voming 31 (1982) 235-248

56. Achterhuis, H. Arbeid, een eigenaardig medicijn. Baarn: Amboboeken, 1984

57. Phillipson, C. The Emergence of Retirement. In: Capitalism and the Constuction of Old Age. Londen [etc.]: Macmillan, 1982: 16-38

58. Veen, R.J. van der. De sociale grenzen van beleid. Een onderzoek naar de uitvoering en effecten van het stelsel van sociale zekerheid. Leiden/Antwerpen: Stenfert Kroese, 1990 


\section{Lijst van afkortingen}

Algemeen

ADL Algemene Dagelijkse Levensverrichtingen

ANBO Algemene Nederlandse Bond van Ouderen

AOW Algemene Ouderdomswet

ARA Algemeen Rijksarchief

ARP Anti-Revolutionaire Partij

AVIB Algemene Vereniging van Instellingen voor Bejaardenzorg

Aww Algemene Weduwen- en Wezenwet

CBS Centraal Bureau voor de Statistiek

CCB Centrale Commissie voor de Bejaardenoorden

CHU Christelijk-Historische Unie

cosbo Centraal Orgaan Samenwerkende Bonden van Ouderen

CPN Communistische Partij Nederland

CRM Ministerie van Cultuur, Recreatie en Maatschappelijk Werk

Ds'70 Democratisch Socialisten '70

ISB Interdepartementale Stuurgroep Bejaardenbeleid

JOT Jong Oud Trust

KNMG Koninklijke Nederlandse Maatschappij tot bevordering der Geneeskunst

KVB Katholieke Vereniging van Bejaardentehuizen

KVP Katholicke Volkspartij

LSB Federatie Landelijke Samenwerkende Bejaardentehuizenorganisaties

Mw Ministerie van Maatschappelijk Werk

NCO Nationale Commissie voor de Oudeliedenzorg

NFB Nederlandse Federatie voor Bejaardenzorg

NIG Nederlands Instituut voor Gerontologie

NRMW Nationale Raad voor Maatschappelijk Welzijn

NVG Nederlandse Vereniging voor Gerontologie

NVMW Nederlandse Vereniging voor Maatschappelijk Werk

PCOB Protestants Christelijke Ouderen Bond 
pvda Partij van de Arbeid

pVIB Protestantse Vereniging van Inrichtingen voor Bejaardenzorg

SER Sociaal-Economische Raad

szw Ministerie van Sociale Zaken en Werkgelegenheid

soom Stuurgroep Onderzoek op het terrein van de Ouder wordende Mens

TNO Nederlandse Organisatie voor Toegepast Natuurwetenschappelijk Onderzoek

Unie Kво Unie van Katholieke Bonden van Ouderen

uvv Unie van Vrouwelijke Vrijwilligers

vVD Volkspartij voor Vrijheid en Democratie

vws Ministerie van Volksgezondheid, Welzijn en Sport

wao Wet op de Arbeidsongeschiktheidsverzekering

wBo Wet op de Bejaardenoorden

Tijdschriften

BW Bejaardenwerk

DB De Bejaarden

ESB Economisch-Statistische Berichten

кв Katholieke Bejaardenzorg

L Leeftijd

MC Medisch Contact

MGV Maandblad voor de Geestelijke Volksgezondheid

NTG Nederlands Tijdschrift voor Gerontologie

NTvG Nederlands Tijdschrift voor Geneeskunde

ol Op Leeftijd

тммк Tijdschrift voor Armwezen, Maatschappelijke Hulp en

Kinderbescherming

TBKZ Tijdschrift voor Bejaarden-, Kraam- en Ziekenverzorging

TMW Tijdschrift voor Maatschappelijk Werk

TSG Tijdschrift voor Sociale Geneeskunde

Verslag der Handelingen der Staten-Generaal

EV Eindverslag

MVA Memorie van Antwoord

MVt Memorie van Toelichting

vмo Verslag Mondeling Overleg

vv Voorlopig Verslag 


\section{Verantwoording van geraadpleegde bronnen en geïnterviewde personen}

I Tijdschriften

De hieronder genoemde tijdschriften zijn systematisch onderzocht op - voor de thema's van de verschillende hoofdstukken relevante artikelen en vaak ook op boekbesprekingen en mededelingen. Het gaat om tijdschriften op het gebied van de demografie, de economie, de sociologie, de agologie, de psychologie, de geneeskunde, de (geestelijke) gezondheidszorg, het maatschappelijk werk, het vormingswerk, de woningbouw, de gerontologic, de geriatrie, ouderen en ouderenzorg. Wat de laatstgenoemde categorie betreft zijn alleen de meer algemene tijdschriften systematisch bestudeerd. De afzonderlijke 'huisorganen' van de ouderenbonden, de bonden van gepensioneerden en de organisaties op het terrein van de ouderenhuisvesting zijn niet in het systematisch deel van het onderzoek betrokken.

Bevolking en Gezin, I (1972) - I I (1982)

Bouw, I (1946) - 37 (1982)

De Economist, 93 (1944/45) - 130 (1982)

De Psycholoog, I (1966) - I7 (1982)

Economisch-Statistische Berichten, 31 (1946) - 67 (1982)

Gawein. Tijdschrift voor Psychologie, 6 (1957/58) - 20 (1972),

I (1973) - io (1982)

(Vanaf 1969 (nr. 2) voortgezet als Nijmeegs Tijdschrift voor

Psychologie. Samengegaan met Hypothese en vanaf 1973 voortgezet als Gedrag)

Gezondheid en Samenleving, I (1980) - 63 (1982)

Huisarts en Wetenschap, I (1957/58) - 26 (1982) 
Katholiek Sociaal Tijdschrift, I (1948/49) - 28 (1976),

1 (1977) - 6 (1982)

(Vanaf 1965/66 voortgezet als Maatschappelijk Welzijn. Vanaf 1977 samengegaan met Opbouturverk en voortgezet als Marge) Maandblad voor de Geestelijke Volksgezondheid,

1 (1946) - 37 (1982)

Maandschrift Economie, $10(1945 / 46)-47(1982 / 83)$

Medisch Contact, I (1945/46) - 37 (1982)

Mensch en Maatschappij, 20 (1945) - 57 (1982)

Mens en Ondermeming, I (1947/48) - 36 (1982)

Nederlands Tijdschrift voor Geneeskunde, 89 (1945) - 126 (1982)

Nederlands Tijdschrift voor Gerontologie, I (1970) - 13 (1982)

(Vanaf 1980 voortgezet als Gerontologie en vanaf 1982 voortgezet als

Tijdschnift voor Gerontologie en Geriatrie)

Nederlands Tijdschrift voor Psychologie, I (1946) - 37 (1982)

Nieuusbrief Psychologie en Maatschappij, nr. I-5 (1977/78),

3 (1979) - 6 (1982)

(Vanaf 1979 voortgezet als Tijdschrift Psychologie en Maatschappij)

Onze Bejaarden, I (1955) - 28 (1982)

(Vanaf 1958 voortgezet als De Bejaarden en vanaf $\mathrm{I} 980$ voortgezet als Senior)

Onze Bejaardenzorg, I (1950/51) - 3 (1952)

(Vanaf 1952 voortgezet als Ons Bejaardencentrum)

Op Leeftijd, [1] (1963/64) - [19] (1982)

(In 1971 samengevoegd met Bejaardenwerk en voortgezet als $O p$

Leeftijd. Per november 1977 uitgegeven als Leef-tijd)

Rooms-Katholieke Bejaardenzorg, 1 (1955/56) - 16 (1970)

(Eerste jaargang onvolledig. Vanaf 1957 voortgezet als Katholieke Bejaardenzorg en vanaf 1963 voortgezet als Bejaardenwerk. In 1971 samengevoegd met Op Leeftijd en voortgezet als Op Leeftijd) Sociaal Maandblad/Arbeid, I (1946) - 37 (1982)

(Sociaal Maandblad en Arbeid gingen vanaf 1954 samen op in Sociaal Maandblad Arbeid)

Sociale Wetenschappen, I (1957) - 25 (1982)

Sociale Zaken, 7 (1945) - 30 (1968)

(Vanaf 1947 voortgezet als Sociale Zorg en vanaf 1969 voortgezet als Sociaal Bestek)

Sociologisch Jaarboek, 1 (1947) - [14] (1960)

(Na 1960 losse delen) 
Sociologische Gids, I (1953/54) - 29 (1982)

Tijdschrift voor Agologie, I (1972) - II (1982)

Tijdschrift voor Ammezen, Maatschappelijke Hulp

en Kinderbescherming, I (1922) - 20 (194I)

Tijdschrift voor Bejaarden-, Kraam- en Ziekenverzorging,

I (1968) - is (1982)

(Jaargang $198 \mathrm{I}$ onvolledig)

Tijdschrift voor Maatschappelijk Werk, I (1947) - 36 (1982)

(Vanaf 1972 (nr. 6) voortgezet als Tijdschrift Mens en Welzijn, vanaf 1973 als Tijdschrift voor Maatschappijvraagstukken en

Welzijnswerk $T M W$, vanaf 1979 als $T M W$-Welzijnsmaandblad, vanaf 1981 als Welzijnsmaandblad, vanaf $\mathrm{I} 982$ als TMW-Kwartaal, een gedeeltelijke samensmelting van Welzijnsmaandblad en

$T M W$-welzijnsweekblad)

Tijdschrift voor Sociale Geneeskunde, 23 (1945) - 59 (1982)

Vorming, 22 (1973) - 31 (1982)

2 Publicaties opgenomen in het Register van Sociaal-Gerontologisch onderzoek 1945-1979

Onderzoeks- en beleidsrapporten, geselecteerd naar relevante thematiek en - bij veelvoorkomend onderzoek naar levensomstandigheden en huisvesting - naar geografie (uitsluitend landelijk onderzoek). Scripties zijn niet in het onderzoek opgenomen. Van het lokale, regionale en provinciale onderzoek zijn die studies geselecteerd waarvan in de loop van het onderzoek duidelijk werd, dat ze in de discussies een belangrijke rol speelden. Overige publicaties, waaronder populair-wetenschappelijke, zijn via boekbesprekingen in de onderzochte tijdschriften en de sneeuwbalmethode achterhaald. In het Nederlands vertaalde buitenlandse publicaties zijn niet onderzocht. Buitenlandse publicaties van Nederlandse deskundigen zijn evenmin systematisch onderzocht. 
3 Congressen, conferenties, symposia, studiedagen

Daarbij is geselecteerd naar beleids- en onderzoeksbijeenkomsten waarvan de thematiek breed was. Bijdragen van Nederlandse onderzoekers en ambtenaren aan buitenlandse congressen zijn niet systematisch onderzocht. De volgende bijeenkomsten zijn in het onderzoek betrokken (de organiserende instanties staan tussen haakjes vermeld):

\section{Congres De Oudeliedenzorg I950}

(Nationale Commissie voor de Oudeliedenzorg en Nederlandse Vereniging voor Maatschappelijk Werk)

Congres De ontwikkeling van de bejaardenzorg in verband met het maatschappelijk werk der burgerlijke overheid 1955

(Vereniging van Openbare Diensten en Instellingen voor Sociale Zorg)

Congres Het Bejaardenvraagstuk 1956

(Nederlands Congres voor Openbare Gezondheidsregeling,

Nederlandse Federatie voor Bejaardenzorg, Nederlandse

Vereniging voor Gerontologie)

Na-conferentie Woudschoten 1956

(Nederlandse Federatie voor Bejaardenzorg)

Volksgezondheidsweek De zorg voor de oudere mens 1956

(Katholieke Nationale Federatie voor Bejaardenzorg en het

Wit-Gele Kruis)

Studiedag Apartheid of integratie van de bejaarden in de samenleving 1962

(Diocesane charitas)

Congres De Bejaarden in de Samenleving 1963

(Nederlandse Federatie voor Bejaardenzorg)

$\mathrm{Na}$-conferentie Lunteren 1963

(Nederlandse Federatie voor Bejaardenzorg)

Symposium Ouderdom en ontwikkeling 1963

(Katholiek Nationaal Bureau voor Geestelijke Gezondheidszorg) Studieconferentie Bejaardenwerk 1970

(samenwerkende Protestantse landelijke organen voor het bejaardenwerk) 
Symposium De toekomst van het oud worden 1970

(Verpleegtehuis Vreugdehof Amsterdam)

Congres Leefbare Ouderdom. Eerste Nederlandse Congres voor

Gerontologie 1971

(Nederlandse Vereniging voor Gerontologie)

Congres Gestoorde Ouderdom. Tweede Nederlandse Congres voor

Gerontologie 1972

(Nederlandse Vereniging voor Gerontologie)

Congres Gezonde Ouderdom. Derde Nederlandse Congres voor

Gerontologie 1973

(Nederlandse Vereniging voor Gerontologie)

Congres Dag Ouwe Dag 1975

(Nederlandse Federatie voor Bejaardenbeleid)

Gerontologische Dagen Integratie of Gerontotheek 1975

(Gerontologisch Centrum, Nederlandse Vereniging voor

Gerontologic)

Congres Gezondheidszorg en Bejaarden 1976

(Nederlands Congres voor Openbare Gezondheidsregeling)

Gerontologische Dagen Emancipatie als leidraad in onderzoek en beleid 1976

(Gerontologisch Centrum, Nederlandse Vereniging voor Gerontologie)

Gerontologische Dagen Het verpleeghuis na de ontwikkeling 1977

(Gerontologisch Centrum, Nederlandse Vereniging voor Gerontologie)

Ledencongres Verouderend Nederland 1977

(Koninklijke Nederlandse Maatschappij tot bevordering der Geneeskunst)

Congres Ouderen willen nieuw beleid 1979

(Centraal Orgaan Samenwerkende Bonden van Ouderen)

Seminar Onturikkelingen in psychogerontologisch onderzoek $198 \mathrm{I}$

(Nederlands Instituut van Psychologen, Raad voor

Wetenschappelijk Onderzoek in de Psychologie en de

Nederlandse Stichting voor Psychonomie)

Studiedag Sociogerontologie!? I98 I

(Nederlandse Vereniging voor Gerontologie) 
Symposium Ouder worden onderzocht 1981

(Dienst Wetenschapsvoorlichting Amsterdam)

Congres Oud in Nederland 1982

(Centraal Orgaan Samenwerkende Bonden van Ouderen,

Nederlandse Federatie voor Bejaardenbeleid, Nederlands Instituut voor Gerontologie, Nederlandse Vereniging voor Gerontologie) Symposium Een oudere bevolking; een andere sociale gezondheidszorg 1982

(Algemene Vereniging voor Sociale Geneeskunde) Voorjaarsconferentie Psychologie en Gerontologie 1982

(Nederlands Instituut van Psychologen)

4 Verslagen der Handelingen en Bijlagen Eerste en Tweede Kamer der Staten-Generaal, I945-1982

Daarbij is geselecteerd naar stukken die betrekking hadden op het bejaardenbeleid in het algemeen, de pensionering (pensioengerechtigde leeftijd en voorbereiding op de pensionering), de geriatrie en verpleeghuizen, en huisvesting (met name verzorgingshuizen).

5 Jaarverslagen van instellingen rond ouderen

Jarverslagen van de Nationale Commissie voor de Oudeliedenzorg, 1949-1952

(opgenomen in de stukken van de jaarvergaderingen van de Nederlandse Vereniging voor Maatschappelijk Werk (Algemeen Rijksarchief, Archief Nationale Raad voor Maatschappelijk Welzijn))

Jaarverslagen van de Nederlandse Federatie voor Bejaardenzorg, I955-1977

Jaarverslagen van de Nederlandse Vereniging voor Gerontologie, I950-1982

(incompleet, Archief Nederlandse Vereniging voor Gerontologie) 
Jaarverslagen van het Nederlands Instituut voor Gerontologie, 1976-1982

(Jaar)verslagen van het Gerontologisch Centrum, 1968-1971, 1974 en $1967-1977$

Jaarverslagen Centrale Directie van de Volkshuisvesting, 1945-1969 en 1981

6 Geraadpleegde archieven van instellingen rond ouderen

Ministerie van Maatschappelijk Werk

(Archief Ministerie van Volksgezondheid, Welzijn en Sport Rijswijk, inventarisnummer 351.842 .6 )

Nationale Commissie voor de Oudeliedenzorg

(Archief Ministerie van Sociale Zaken en Werkgelegenheid, Departementaal Archief)

Nederlandse Federatie voor Bejaardenzorg

(Algemeen Rijksarchief Den Haag, lijstnummer 2.19.098)

Nederlandse Vereniging voor Gerontologie

(Nederlands Instituut voor Gerontologie)

Vrouwen-actiecomité voor vervroegde staatspensionering

(Internationaal Informatiecentrum en Archief voor de

Vrouwenbeweging Amsterdam)

Ter beschikking gestelde delen privé-archief J.M.A. Munnichs Ter beschikking gestelde delen privé-archief M. van Saane Ter beschikking gestelde delen privé-archief P.J. Thung

Het archief van het Centraal Orgaan Samenwerkende Bonden van Ouderen was ten tijde van het onderzoek helaas niet toegankelijk. 
7 Interviews

G.P.A.Braam dd. $28-05-1990$

C.P.M. Knipscheer dd. 22-03-1990

J.M.A.Munnichs dd. 07-05-1990

dd. $14-12-1990$

dd. 24-06-199I

F.H.J. Nierstrasz dd. 26-1 I-I990 (telefonisch)

M. van Saane dd. I I-06-199I

R.J.van Zonneveld dd. 06-06-1990 dd. 22-02-I99I 


\section{Literatuur}

In deze lijst van geraadpleegde literatuur zijn - naast secundaire literatuur, studies en rapporten over ouderen - alleen die artikelen opgenomen die niet voorkomen in de tijdschriften die systematisch werden onderzocht. Artikelen uit de systematisch onderzochte tijdschriften (zie 'Verantwoording van geraadpleegde bronnen en geïnterviewde personen') zijn wel in de noten genoemd.

Aakster, C.W. (Red.) Oud. Beeld van ouderen en ouderenzorg. Groningen: Wolters-Noordhoff, 1987.

Aanzet voor een viifiarenplan. Rijswijk: Emancipatiekommissic, 1976.

Abbott, A. The System of Professions. An Essay on the Division of Expert Labour. Chicago/London: The University of Chicago Press, 1988. Achenbaum, W.A. Reconstructing GSA's History. The Gerontologist 27 (1987) I, 2I-29.

Achenbaum, W.A. en Levin, J.S. What Does Gerontology Mean? The Gerontologist 29 (1989) 3, 393-400.

Achterhuis, H. Arbeid, een eigenaardig mediajn. Baarn: Amboboeken, 1984 .

Adler, M. History of Gerontological Society, Inc. Jourmal of Gerontology (1958) 13, 94-100.

[Adriani], J.H. Het tehuis voor ouden van dagen 'Vredeveld' te Amstelveen. Maandblad voor kerkelijke armenzorg 13 (1922) 8, 11 3-121.

Adriani, J.H. Voorlezingen over armenzong en maatschappelijk werk. Zutphen: Ruys, 1940.

Advies inzake de positie van de gehuwden en de ongehuwden in de sociale verzekering. 's-Gravenhage: Sociaal-Economische Raad, 1963.

Advies inzake de wettelijke ouderdomsverzekering uitgebracht aan de Minister van Sociale Zaken en Volksgezondheid en aan de Staatssecretanis van Sociale Zaken. 's-Gravenhage: Sociaal-Economische Raad, 1954. Advies inzake gerontologie. Advies uitgebracht 8 maart 1971 door de Gezondheidsraad aan zijne Excellentie de Staatssecretaris van Sociale Zaken en 
Volksgezondheid. 's-Gravenhage: Staatsuitgeverij, 1973.

Advies inzake programma en instrumentarium voor gerontologisch onderzoek. 's-Gravenhage: Staatsuitgeverij/Planninggroep voor wetenschappelijk onderzoek op het gebied van de ouder wordende mens, I98I. Advies inzake taak en functie van het verzorgingstehuis voor bejaarden. 'sGravenhage: Staatsuitgeverij/Centrale Commissie voor de Bejaardenoorden, 1979.

Advies inzake verlaging van de pensioengerechtigde leeftijd voor de ongehuwde vrouw in de Algemene Ouderdomswet. 's-Gravenhage: Sociaal-Economische Raad, 1966.

Advies oudere ongehuwde werkenden. 's-Gravenhage: Sociaal-Economische Raad, 1982.

Advies over de noodzakelijkheid van groepsverzorging in bejaardenoorden. 's-Gravenhage: Staatsuitgeverij/Centrale Commissie voor de Bejaardenoorden, 1976.

Advies verbetering levensomstandigheden oudere ongehuwde vrouw. Rijswijk: Emancipatiekommissie, 1979.

Advies verpleeghuizen. Uitgebracht op 25 oktober 1972 aan Zijne Excellentie de Minister van Volksgezondheid en Milieuhygiëne door de Centrale Raad voor de Volksgezondheid. 's-Gravenhage: Staatsuitgeverij, 1972.

Akkerman, H.P. Geriatrie. Leiden: Spruyt, Van Mantgem \& De Does, I973.

Algemeen oriënterend vooronderzoek naar de levensomstandigheden van de bejaarden in de gemeente Voorburg. Utrecht: Sociologisch Instituut, Rijksuniversiteit Utrecht, 1960.

Allema, J. Gezondheidszorg en veroudering. Tijdschnift voor Sociale Geneeskunde 60 (1982) 23, 729-731.

Als de amandelboom bloeit. Rapporten opgesteld in opdracht van het Comité Centrale Diaconale Conferentie over de hulpverlening aan bejaarden door de sectie Bejaardenzorg van de Raad voor Gereformeerde Sociale Arbeid, en van een sociologisch onderzoek naar de vereenzaming bij bejaarden, ingesteld door het Gereformeerde Sociologisch Instituut. Utrecht: Stichting Raad voor Gereformeerde Sociale Arbeid, [1962].

Amann, A. (Ed.) Social-Gerontological Research in European Countries History and Current Trends, Berlin/Vienna: German Centre of Gerontology, 1984 .

Andel, J.C. van en Andel-Ripke, O. van. Oud worden in deze tijd. Man en vrouw rondom en boven de zestig. Utrecht: Erven J. Bijleveld, I953. Anders Ouder Worden. Nota over het bejaardenbeleid. [S.1.]: Tweede Ka- 
merfractie Partij van de Arbeid, [1970].

Apartheid of integratie van de bejaarde in de samenleving. Diocesane charitasdag 6 november 1962, Kurhaus Scheveningen. 's-Gravenhage: [Diocesaan Sociaal Charitatief Centrum in het bisdom Rotterdam], 1962.

Amenzorg in Nederland [in opdracht der Vereeniging voor de Staathuishoudkunde en de Statistiek bewerkt door Mr. Ph. Falkenburg] 1e deel: Gemeente Amsterdam. Amsterdam: Johannes Müller, 1893.

Armstrong, D. Political anatomy of the body. Medical knowledge in Britain in the twentieth century. Cambridge [etc.]: Cambridge University Press, 1983.

Aspekten van een integraal bejaardenbeleid. Den Haag: Nederlandse Federatie voor Bejaardenzorg, 1971.

Asten-Kuipers, E. van en Groenestijn, M. van. Bejaarden en bejaardenwerk I. Intennediair 9 (1973) 28, I5-23.

Avorn, J.L. Medicine, health and the geriatric transformation. Daedalus (1986) $115,211-225$.

Baan, P. van der. Voor ons en door ons. De geschiedenis van de Unie van Katholieke Bonden van Ouderen. 's-Hertogenbosch: Unie van Katholieke Bonden van Ouderen, 1989.

Baars, J. Het regime van de klok. Over de chronologisering van de moderne levensloop. Amsterdams Sociologisch Tijdschrift 18 (I991) 2, 100-120.

Baars, J. en Knipscheer, C.P.M. Ageing in the Netherlands: Structural en cultural characteristics. Joumal of Cross-Cultural Gerontology 4 (1989) 129-142.

Beauvoir, S. de. De ouderdom. Maatschappelijke situatie van bejaarden en persoonlijke zingeving in de laatste levensfase. Utrecht: Erven J. Bijleveld, 1987.

Behoefte aan bejaardenhuisvesting. Onderzoek naar de behoefte aan bejaardenhuisvesting en naar de levensomstandigheden van de bejaarden te Sittard. Roermond: Provinciaal Opbouworgaan Limburg, 1958.

Behoort een nieuwe richting te worden gegeven aan onze oudeliedenzorg? (Inleiding gehouden op de Vergadering van de Algemeene Armencommissie met Voorzitters en Secretarissen van Armenraden op 8 Januari 1920.) Tijdschrift voor Armenzorg en Kinderbescherming (1920) 970, 28-31.

Bejaarden in de Samenleving. Scheveningen, 1963 ['s-Gravenhage]: NFB, 1963.

Bejaarden in Schiedam. Uitkomsten van een onderzoek naar de woon-en leefomstandigheden van de bejaarden in deze gemeente. Rotterdam: Eco- 
nomisch-Technologisch Instituut voor Zuid-Holland, 1962.

Bejaard-zijn in Amsterdam. Verkenningen omtrent de bejaarde medemens in Amsterdam. Gemeenteblad (1962) Bijlage H: 93-109.

Bekkum, D.J. van e.a. Oud worden, oud zijn. Deventer: Van Loghum Slaterus, 1974.

Benner, J.B. Rekenen zonder cijfers. Maandblad voor kerkelijke anmenzorg I 8 (1927) 2, 17-23.

Beyer, G.H. en Nierstrasz, F.H.J. Housing the Aged in Westem Countries. Programs, Dwellings, Homes and Geriatric Facilities. Amsterdam [etc.]: Elsevier, 1967.

Beyerman, T. Enige opmerkingen over ouderdomszorg. Raad en Daad [4] (1949) 7, 10-13, 17.

Bezooijen, C.F.A. Biomedical gerontology in the Netherlands. Tijdschnift voor Gerontologie en Geriatrie I 8 (1987) 2a, 139-146.

Bijsterveld, K. De geschiedenis van het beleid met betrekking tot verzorgingshuizen in Nederland van 1945-1990. In: Handboek 'Wonen en werken in een verzorgingshuis'. Amersfoort: Academische Uitgeverij, 1991: (par. 1.3) 1-31.

Bijsterveld, K. De natuurlijke ouderdom: een grenzeloze geschiedenis. Kennis en Methode I 5 (1991) 1, 62-86.

Bijsterveld, K. Rozenperken, rust en avondrood. Veranderingen in de taak van het verzorgingshuis. Denkbeeld. Tijdschrift voor Psychogeriatrie 4 (r992) 2, 5-7.

Bijsterveld, K. Het 'bejaardenvraagstuk': het denken over problemen rond ouderen in Nederland, 1945-1982. In: Blom, M.M., Kuin, Y. en Hendriks, H.F.J. Ouder worden '93. Voordrachten gehouden tijdens het gerontologisch symposium 'Ouder worden' op 18 en 19 november 1993 in het Beurs-World Trade Center te Rotterdam. Utrecht: Nederlands Instituut voor Zorg en Welzijn, 1993: 179-187.

Bijsterveld, K., Horstman, K. en Mesman, J. Huilen als de maandag aanbreekt. Oudere ongehuwde vrouwen in Nederland en het spel van vergelijkingen, 1955-1980. In: Stavenuiter, M., Bijsterveld, K. en Jansens, S. (Red.) Lange levens, stille getuigen. Oudere vrouwen in het verleden. Zutphen: Walburg Pers, 1995: 162-180.

Bijsterveld, K. en Ponds, R. De wankele status van een ziekte. Bespreking van Rob Dillmann, Alzheimer's disease. The concept of disease and the construction of medical knowledge. Psychologie en maatschappij Is (1991) 3, 298-300.

Bijsterveld, K.Th., Horstman, K. en Mesman, J. De versplintering van een categorie. De pensioengerechtigde leeftijd van ongehuwde 
vrouwen en het rechtskarakter van de verzorgingsstaat. Beleid en Maatschappij 19 (1992) I, I6-30.

Birren, J.E. A brief history of the psychology of aging. Part $1 / 11$. The Gerontologist I (1961) I, 69-77/127-1 34 .

Blaikie, A. The Emerging Political Power of the Elderly in Britain 1908-1948. Ageing and Society 10 (1990) 17-39.

Blokhuis, W.B.P.J. Sociale zekerheid en pensioenfondsen. EconomischStatistische Berichten 30 (1945) 1493, 304-306.

Blom, M.M., Kuin, Y., Hendriks, H.F.J. (Red.) Ouderworden' 93 . Voordrachten gehouden tijdens het gerontologisch symposium 'Ouder worden' op 18 en 19 november 1993 in het Beurs-World Trade Center te Rotterdam. Utrecht: Nederlands Instituut voor Zorg en Welzijn, 1993.

Blommestijn, P.J. Ouderenbeleid in Nederland van 1955 tot 1985. Een beleidshistorisch evaluatie-onderzoek. [Bewerkt door prof. dr. A. Hoogerwerf]. Enschedé: Universiteit Twente, Faculteit der Bestuurskunde, 1990.

Boeke, J. Problemen der onsterfelijkheid. Leven, dood, levensduur en onsterfelijkheid, biologisch beschouwd. Amsterdam: J.M. Meulenhoff, 1941.

Bok, P. de. Gerontologie, wat is dat? S.1.: NFB/NIG, 1984 .

Bom, J.A. van der. Leefsituatie van oudere Rotterdammers in 1965. Berg en Dal/Nijmegen: Stichting Gerontologsich Centrum, 1976.

Borne, H.W. van den en Snellen, I.Th.M. Welzijnsconcepties in het bejaardenbeleid. Verslag van een onderzoek. Tijdschrift voor Gerontologie en Geriatrie 14 (1983) 3, 11 5-119.

Bosch, J.G.J. en Sul, H.D. Inleiding. In: Zorg en dienstverlening. Deel II: ouderenbeleid. Tekstuitgave. Deventer: Kluwer, r990.

Braam, G.P.A. Bejaarden in Utrecht. Rapport naar aanleiding van een enquête onder bejaarden in de stad Utrecht, 1962. Utrecht: Sociologisch Instituut van de Rijksuniversiteit Utrecht, 1964.

Braam, G.P.A., Coolen, J.A.I. en Naafs, J. Ouderen in Nederland. Sociologie van bejaarden, bejaardenzorg en -beleid. Alphen aan de $\mathrm{Rijn} / \mathrm{Brus}-$ sel: Samson, 1981.

Braam, G.P.A., Coolen, J.A.I. en Naafs, J. Ouderen. Een vergeten bevolkingsgroep. Natuur en Techniek so (1982) 11, 814-829.

Brakel, W.P. van en Bommel, J. van. Zes eeuwen bejaard Rotterdam. Verzorging en huisvesting van bejaarden te Rotterdam. Rotterdam: Dienst van Volkshuisvesting Rotterdam, 1971.

Brautigam, G. Het nut van de bejaarden in onze samenleving. S.1.: Bond voor Staatspensionering, 1965.

Brieven aan de VARA-Ombudsman. Analyse van schriftelijke klachten over 
de intramurale verzorging van bejaarden. 's-Gravenhage: Nimawo, 1971.

Brouwer, W.H. e.a. (Red.) Grijze cellen, wijze cellen? Groningen: Interfacultaire Werkgroep Gerontologie [etc.], 1989.

Brunet de Rochebrune, W.F.H. Over enige problemen van de ouderdom. Leiden: Nederlandse Uitgeversmaatschappij, 1954.

Bulder, E. The social economics of old age. Strategies to maintain income in later life in the Netherlands 1880-1940. Rotterdam: Thesis Publishers/Tinbergen Institute, 1993.

Buytendijk, F.J.J. Algemene theorie der menselijke houding en beweging. Utrecht [etc.]: Het Spectrum, 1974.

Buytendijk, F.J.J. e.a. De derde levensfase. Voordrachten over geestelijke gezondheid en ouderdom en eindrapport van een werkgroep 'Psychohygiëne en ouderdom'. Utrecht [etc.]: Het Spectrum, 1966.

Cahn, L.A. e.a. (Red.) 20 jaar geriatrie: een keuze uit het werk van prof. J.Th.R. Schreuder. Deventer: Van Loghum Slaterus, 1973.

Calhoun, R.B. In search of the new old: redefining old age in America, 1945-1970. New York [etc.]: Elsevier, 1978.

Carboni, D.K. Geriatric mediane in the United States and Great Britain.

Greenwood Press: Westport, Connecticut/London, 1982.

CBS-Statistiek van de bejaardenoorden.

CBS-Verzorging van bejaarden in tehuizen naar de toestand op 1 October 1950. Utrecht: Uitgeversmaatschappij W. de Haan, I95I.

Chowdhury, S.D. Privacy, Space and the Person in a Home for the Aged. Etnofoor 3 (1990) 2, 32-47.

Chowdhury, S.D. Lange levens, kleine kamers. Privacy en afhankelijkheid in een Nederlands verzorgingshuis. In: Stavenuiter, M., Bijsterveld, K. en Jansens, S. (Red.) Lange levens, stille getuigen. Oudere vrouwen in het verleden. Zutphen: Walburg Pers, 1995: 148-16I. Chudacoff, H.P. How old are you? Age Consciousness in American Culture. Princeton, N.J.: Princeton University Press, 1989.

Cole, T.R. The 'enlightened' view of aging. Hastings Center Report (1983) 1 3, 34-40.

Cole, T.R. The Prophecy of Senescence: G. Stanley Hall and the Reconstruction of Old Age in America. The Gerontologist 24 (1984) 4. 360-366.

Cole, T.R. en Gadow, S.A. What Does It Mean to Grow Old? Reflections from the Humanities. Durham N.C.: Duke University Press, 1986. Cole, Th.R. The Joumey of Life: A Cultural History of Aging in America. Cambridge: Cambridge University Press, 1992. 
Cole, Th.R., Van Tassel, D.D. en Kastenbaum, R. (Eds.) Handbook of the Humanities and Aging. New York: Springer, 1992.

Conrad, C. Altwerden und Altsein in historischer Perspektive. Zur neueren Literatur. Zeitschrift fur Sozialisationsforschung und Erziehungssoziologie 2 (1982) 1, 73-90.

Conrad, C. Geschichte des Alterns: Lebensverhältnisse und sozialpolitische Regulierung. Zur neueren Forschung. Zeitschrift fur Sozialisationsforschung und Erziehungssoziologie 4 (1984) I, 143-1 56.

Conrad, C. Die Entstehung des modernen Ruhestandes. Deutschland im internationalen Vergleich 1850-1960. Geschichte und Gesellschaft I4 (1988) 4, 417-447.

Conrad, C. Vom Greis zum Rentner. Der Struktunvandel des Alters in Deutschland zwischen 1830 und 1930. Göttingen: Vandenhoeck \& Ruprecht, 1994.

Conrad, C. en Kondratowitz, H.-J. von (Hg.) Gerontologie und Sozialgeschichte. Wege zu einer Historischen Betrachtung des Alters. Berlin: Deutsches Zentrum fur Altersfragen, 1983.

Conrad, C. en Kondratowitz, H.-J. von (Hg.) Zur Kulturgeschichte des Altems. Berlin: Deutsches Zentrum für Altersfragen, 1993.

Contouren voor een toekomstig beleid. Den Haag: Federatie LSB, I98I.

Coolen, J.A.I. (Red.) Verschuivingen in de ouderenzorg. Lochem [etc.]: De Tijdstroom, 1985 .

Curmming, E. en Henry, W.E. Growing old. The process of disengagement. New York: Basic Books Inc., I96I.

David, H. Review. Guillemard A.-M. Le Déclin du Social, Formation et Crise des Politiques de la Vieilesse. Paris: Presses Universitaires de France, 1986. Ageing and Society 9 (1989) 4, 441-444.

De algemene beleidsontwikkeling in het tijdperk van twee nota's bejaardenbeleid. Bij wijze van Jaanverslag van de Nederlandse Federatie voor Bejaardenbeleid over de periode $1973 \mathrm{t} / \mathrm{m}$ 1977. [Den Haag]: Nederlandse Federatie voor Bejaardenbeleid, 1978.

De behoefte aan tehuisnuimte voor bejaarden in Alkmaar. Den Haag: Katholiek Sociaal-Kerkelijk Instituut, 1961.

De bejaardenzorg in Nederland. Rapport uitgebracht door de Ministeries van Volkshuisvesting en Bouwnijverheid, Maatschappelijk Werk en Sociale Zaken en Volksgezondheid aan het Comité voor het Openbaar Bestuur, van de West-Europese Unie. Den Haag, 1958.

De huisvesting van bejaarden in Nederland. 's-Gravenhage: Ministerie van Volkshuisvesting en Ruimtelijke Ordening, 1965.

De huisvesting van bejaarden in Nederland. [Den Haag]: Ministerie van 
Volkshuisvesting en Ruimtelijke Ordening, 1970.

De huisvesting van bejaarden in Nederland. Rapport van een studie, in opdracht van de Landelijke Katholieke Stichting voor Behuizing van Bejaarden, verricht door de architecten ir. N. van der Laan, ir. F.P.J. Peutz en G.J.M. Sarlemijn, in overleg met de bouwcommissie van voomoemde Stichting. Utrecht: Landelijke Katholieke Stichting voor Behuizing van Bejaarden, 1948.

De Ongehuwde Vrouw. Onderzoek naar de levensomstandigheden van de ongehuwde vrouven van 40 tot 65 jaar. Nijmegen: Instituut voor Toegepaste Sociologie, 1970.

De onturikkeling van de bejaardenzorg in verband met het maatschappelijk werk der burgerlijke overheid. Prae-adviezen, uitgebracht door de Vereniging van Openbare Diensten en Instellingen voor Sociale Zorg. Amsterdam [etc.]: Vereniging van Openbare Diensten en Instellingen voor Sociale Zorg, 1955.

De oudeliedenzorg te Amsterdam. Amsterdam: Centraal bureau voor maatschappelijk hulpbetoon te Amsterdam. [Geschriften van den armenraad te Amsterdam No. viII], 1924.

De oudeliedenzorg te Amsterdam. Rapport van de commissie tot het instellen van een onderzoek naar de oudeliedenzorg te Amsterdam. Amsterdam: Centraal Bureau van Maatschappelijk Hulpbetoon te Amsterdam, 1942.

De oudeliedenzorg. Prae-adviezen uitgebracht door Prof. Dr Ir H.G. van Beusekom, Drs. J. Diederich, Dr Mr F.M. Havermans en Mr J.A.J. Meyer. Haarlem: H.D. Tjeenk Willink \& Zoon, 1950.

De oudeliedenzorg. Verslag van het op 9 juni 1950 te Amhem gehouden congres ter behandeling van de prae-adviezen van Prof. Dr Ir H.G. van Beusekom, Drs J. Diederich, Dr Mr F.M. Havermans en MrJ.A.J. Meyer. Haarlem: H.D. Tjeenk Willink \& Zoon, r9so.

De ouder wordende mens. Vijfde provinciale gezondheidsdag op 25 mei 1966. S.l.: Provinciale Raad voor de Volksgezondheid in de provincie Drenthe, [s.a.].

De ouderenbeweging. Leeftijd-specifiek 4. Overdrukken uit het maandblad LEEFTIJD gebundeld naar ondenverp. Den Haag: Nederlandse Federatie voor Bejaardenbeleid, z.j.

De positie van de oudere, alleenstaande, werkende vrouw. Rijswijk: Ministerie van Welzijn, Volksgezondheid en Cultuur, 1988.

De Rotterdamse Bejaarden. Een onderzoek naar hun levensomstandigheden en behoeften. Deel 2. Rotterdam: Gemeente Rotterdam, 1970.

De wijkfunktie. Advies inzake de samenverking tussen het verzorgingstehuis 
en de wijk. Den Haag: NFB, I98I.

Dekhuijzen-Zeehuisen, J. e.a. Zorgen van en voor bejaarden. Zaltbommel/Antwerpen: Jan van Tuyl, 1957.

Dekhuyzen-Zeehuisen, I. Geriatrie. De Gemeente 6 (I95I) 4, 40-42.

Dekhuyzen-Zeehuisen, I. Huisvesting van bejaarden in Nederland. $D_{\ell}$ Gemeente 6 (I95I) I, 2-3.

Dekhuyzen-Zeehuisen, I. Werkgelegenheid voor bejaarden. De Gemeente 7 (1952) 8, 86-87.

Die Bejahrtenfürsorge in den Niederlanden. Kurze Zusammenfassung einer Auseinandersetzung von Dr. H.J.P.J. Goedmakers, Chef der Unterabteilung für Bejahrtenfürsorge des Ministeriums, 1960.

Diederich, J. Levensomstandigheden van bejaarden in de provincie Utrecht. Utrecht: Stichting voor Maatschappelijk Werk in de provincie Utrecht, 1953.

Diederich, J. Levensomstandigheden van bejaarden in kleinere en middelgrote gemeenten in Nederland. Amsterdam/'s-Gravenhage: Nationale Raad voor Maatschappelijk Werk, 1958 .

Dillmann, R. Alzheimer's disease. The concept of disease and the construction of medical knowledge. Amsterdam: Thesis Publishers, 1990.

Discussierapport. Vragen omtrent huisvestingsvoorzieningen voor bejaarden 's-Gravenhage: Staatsuitgeverij/Centrale Commissie voor de Bejaardenoorden, 1976.

Dumons, B. en Pollet, G. Les combats pour l'assurance-vieillesse en europe au tournant du xxe siècle. Gérontologie et Société. Cahiers de la Fondation Nationale de Gérontologie 49 (1989) 70-84.

Een verkenning op het terrein van de tijdsbesteding voor bejaarden. 's-Gravenhage: $\mathrm{NFB},[1960]$.

Egas, C. De duivel is oud. Niet meer jong zijn als maatschappelijk probleem. Amsterdam: Contact, [1974].

Egas, C. Ouder worden als maatschappelijk probleem. Wending ( $\mathrm{I} 98 \mathrm{I})$ $665-673$.

Ehmer, J. Sozialgeschichte des Alters. Frankfurt am Main: Suhrkamp Verlag, 1990.

Emanaipatie als leidraad in onderzoek en beleid. Gerontologische Dagen 1976. Programma/werkcahier. Nijmegen: Katholieke Universiteit/Gerontologisch Centrum, 1976.

Engbersen, G. en Van der Veen, R. De tragiek van de verzorgingsstaat. In: Schuyt, K. en Van der Veen, R. De verdeelde samenleving. Een inleiding in de ontwikkeling van de Nederlandse verzorgingsstaat. Leiden (2de druk): Stenfert Kroese, 1990. 
Estes, C.L. The Aging Enterprise. San Francisco, CA: Jossey-Bass Publisher, 1979.

Estes, C.L. en Binney, E.A. The Biomedicalization of Aging: Dangers and Dilemma's. The Gerontologist 29 (1989) 5, 587-596.

Estes, C.L., Swan, J.H. en Gerard, L.E. Dominant and competing paradigms in gerontology: towards a political economy of ageing. Ageing and Society 2 (1982) 2, 151-164.

Fabrianus, O.F.M. Algemene ouderdomsverzekering en algemeen verzekerde oude dag vanuit katholiek standpunt. 's-Hertogenbosch: Geert Groote Genootschap, 1958 .

Falck, I. Die Geschichte der Deutschen Gesellschaft für Gerontologie. Zeitschnift für Gerontologie 20 (1987) 163-167.

Fennell, G., Phillipson, C. en Evers, H. The Sociology of Old Age. Milton Keynes: Open University Press, 1988.

Fockert, J.A. De klinische geriatrie, quo vadis? Voorzichtige overwegingen bij de toekomst van een nieuw specialisme. Tijdschrift voor Gerontologie en Geriatrie is (1984) 35-39.

Fox, D.M. The perception of chronic illness in health policy: Britain and America, 1930s-1960s. In: Program, Papers and Abstracts for the Joint Conference Manchester, England, 11-15 July 1988, British Society for the history of science and the history of science society.

Freeman, J.T. Aging. Its history and literature. New York [etc.]: Human Sciences Press, 1979.

Fukkink-Wetter, M. Voor wie bouwen wij bejaarden-tehuizen? Diakonia 26 (1959) 11, 247-250.

Fuldauer, A. Bejaardenonderzoek in een huisartspraktijk. Hengelo: Drukkerij Insulinde, 1966.

Gelder, W. van e.a. (Red.) Voorbereiding op de pensionering. Alphen aan de Rijn [etc.]: Samson, 1979.

Geriatrie een klinisch specialisme. Wat mu? Tekst van de rede, op 6 januari 1983 gehouden door Prof. Dr. C.L.C. van Nieuwenhuizen op de Algemene Ledenvergadering van de Nederlandse Vereniging voor Geriatrie.

Gerontologisch Centnum anno 1974. [Nijmegen]: Gerontologisch Centrum, [s.a.].

Gijsbers, A.J. Mogelijkheden en moeilijkheden bij de financiering van de hulpverlening aan bejaarden. In: Verslag van de Provinciale voorlichtingsdag over bejaardenhulp in het kader van de gezinsverzorging. Gehouden in het Huis der Provincie te Amhem op 9 april 1965.

Gijsbers, A.J. en Goedmakers, H.J.P.J. Wet op de Bejaardenoorden. Al- 
phen aan de Rijn: Samson, 1963.

Göckenjan, G. en Kondratowitz, H.-J. von (Hg.) Alter und Alltag. Frankfurt am Main: Suhrkamp Verlag, 1988.

Goedhard, W.J.A. Research and development in geriatrics in the Netherlands. Tijdschrift voor Gerontologie en Geriatrie 18 (1987) 2a, 147I57.

Goedmakers, H.J.P.J. e.a. Ouderdom en samenleving. Een overzicht van de gehele problematiek van de ouderdom in de gegeven maatschappelijke ver. houdingen. Alphen aan de Rijn: Samson, 1970.

Goewie, R. Voorbereiding op de pensionering. 's-Gravenhage: Nimawo, 1977.

Goor, H. van. Democratie of bureaucratie? Een empinische studie naar verschillen in invloed tussen politieke en ambtelijke topposities in Nederlandse gemeenten. Assen/Maastricht: Van Gorcum, 1988.

Graebner, W. A history of retirement. The meaning and function of an American institution 1885-1978. New Haven, C.T.: Yale University Press, 1980 .

Gratton, B. The infant geriatrics. Intemational Joumal of Aging and Human Development I9 (1984) 253-256.

Groen, J. Gerontologie, een nieuw veld van activiteit der Gezondheidsorganisatie TNO. TNO Nieuws (1953) 8, 403-409.

Gruman, G.J. Cultural origins of present-day 'age-ism': the modernization of the life cycle. In: Spicker, S., Woodward, K. en Tassel, D. van (Eds.) Aging and the Elderly: Humanistic Perspectives in Gerontology. Atlantic Highlands, N.J.: Humanisties Press, 1978: 359-387.

Guillemard, A-M. (Ed.) Old Age and the Welfare State. Londen/Beverly Hills, Cal: Sage, 1983 .

Gusfield, J.R. The Culture of Public Problems. Drinking-Driving and the Symbolic Order. Chicago/Londen: The University of Chicago Press, I981.

Haber, C. Mandatory retirement in nineteenth century America: The conceptual basis for a new work cycle. Joumal of Social History 12 (1978/79) 77-96.

Haber, C. Beyond Sixty-Five: The Dilemma of Old Age in America's Past. Cambridge: England, 1983.

Haber, C. From senescence to senility: the transformation of senile old age in the nineteenth century. Intermational Joumal of Aging and Human Development 19 (1984) I, 4I-45.

Hannah, L. Inventing Retirement. The Development of Occupational Pensions in Britain. Cambridge: Cambridge University Press, 1986. 
Hareven, T.K. The last stage: historical adulthood and old age. In: Tassel, D.D. van (Ed.) Aging, death and the completion of being. Philadelphia: University of Pennsylvania Press, 1979.

Hareven, T.K. Historical Changes in the Social Construction of the Life Course. Human Development 29 (1986) 3, $171-180$.

Hattinga Verschure, J.C.M. e.a. (Red.) De toekomst van het oud worden. [Amsterdam]: Agon Elsevier, 1971.

Haveman, J. Menselijke verhoudingen in bejaardentehuizen. Groningen:

Rijksuniversiteit Groningen, Sociologisch Instituut, 1967.

Held, Th. Institutionalization and Deinstitutionalization of the Life Course. Human Development 29 (1986) 157-162.

Henretta, J.C. Uniformity and Diversity: Life Course Institutionalization and Late-life Work Exit. The Sociological Quarterly 33 (1992) 2, 265-279.

Het bejaardenvraagstuk. Prae-adviezen en handelingen van het congres inzake het bejaardenvraagstuk. Scheveningen 1956. Assen: Van Gorcum, 1957. Het bejaardenvraagstuk in Nederland. Toelichting op een aantal panelen. [S.I]: Ministerie van Cultuur, Recreatie en Maatschappelijk Werk, [1966].

Het grote verzorgingstehuis voor bejaarden in zijn relatie tot het welzijn der bewoners. Den Haag: Centrale Directie van de Volkshuisvesting en de Bouwnijverheid, 1965.

Het ouder worden. Symposion voor studenten van de Faculteit der Geneeskunde der Katholieke Universiteit. Nijmegen: Thoben Offset, 1965.

Het werk van de ouderenbonden in Nederland. Utrecht: ANBO, 1980.

Heuvel, W, van den. Onderzoek over het ouder worden: Enkele ontwikkelingen en het belang ervan. Trefpunt Speciaal (1984) 46-48. Hoe denken bejaarden over de voor hen ontworpen huisvesting? [Groningen]:

Stichting Groningen voor Sociaal en Cultureel Werk, [1957].

Hofland, H.J.A. Het kale grijze tuig. In: Ewijk, T. van (Red.) In het jaar 2000. Utrecht/Antwerpen: Het Spectrum, 1982: 48-52.

Hollander, C.F. Ouderdom, spiegelbeeld der jeugd. [Rede uitgesproken bij de aanvaarding van het ambt van bijzonder hoogleraar in de medische gerontologie aan de Rijksuniversiteit te Utrecht op dinsdag 5 october 1976] [Utrecht], 1976.

Hombergh, H. van den. Geneeskunde, de vierde pijler in de hedendaagse bejaardenzorg. Katholieke Gezondheidszorg 25 (1956) 4, 100I09.

Horlings, M. Het dagelijks leven van bejaarden en hun houding tegenover de oude dag. Middelburg: Stichting Zeeland voor Maatschappelijk en 
Cultureel Werk, 1959 .

Houben, P.P.J. Toepassing van onderzoek in beleidsnota's inzake ouderenhuisvesting. Tijdschrift voor Gerontologie en Geriatrie 16 (1985) 2, 45-50.

Hudson, R. Misunderstood, critical, and new: divergent views of contemporary aging policy. The Gerontologist 32 (1992) 5, 708-7II.

Huisvesting van bejaarden. ['s-Gravenhage]: Centrale Directie van de Wederopbouw en de Volkshuisvesting, 1949.

Huisvesting van bejaarden. Richtlijnen voor de bouw en exploitatie van zelf. standige woningen en pensiontehuizen. Bouwcentrum: Rotterdam, 1953.

Huisvesting van bejaarden. Senviceflats en groepen woningen met dienstencentrum. Rotterdam: Bouwcentrum, 1967.

Huisvesting van bejaarden. Verpleegtehuizen. Rotterdam: Bouwcentrum, I955.

Huisvesting van bejaarden. Zelfstandige woningen en pensiontehuizen. Rotterdam: Bouwcentrum, I959.

Hunt, E.H. Paupers and Pensioners: Past and Present. Ageing and Society 9 (1989) 4, 407-430.

Integraal bejaardenbeleid. Aspekten van een integraal bejaardenbeleid in verband met de nota 'Bejaardenbeleid 1970' van de regering. Den Haag: NFB, $197 \mathrm{I}$.

Interim-advies inzake geriatrie in algemene ziekenhuizen. Uitgebracht aan de Minister van Volksgezondheid en Milieuhygiëne. Rijswijk: Centrale Raad voor de Volksgezondheid, 1982.

Interim-advies inzake het functioneren van verpleeghuizen. Uitgebracht an de Minister van Volksgezondheid en Milieuhygiëne. Rijswijk: Centrale Raad voor de Volksgezondheid, 1982.

Interim-rapport inzake de arbeid van bejaarden uitgebracht door een departementale werkgroep. 's-Gravenhage: [Ministerie van Sociale Zaken en Volksgezondheid], 1958.

25 jaar Algemene Bond van Bejaarden. Amsterdam: [Algemene bond van Bejaarden, 1970].

25 jaar Protestants Christelijke Ouderen Bond. Rijssen: РСОВ, 1985.

Janmaat, J.F.J. Weiterbildung im Alter: Vorbereitung auf die Pensionierung - Erfahrungen und Perspektiven in den Niederlanden. Aktuelle Gerontologie 2 (1972) 73 1-736.

Jansen, P.J.M. en Peeters, E.M. Volkshuisvesting geregeld. Analyse van overheidssturing met wetgeving vanaf 1945. Leiden: Onderzoekscentrum Sturing en Samenleving, 1989. 
Jefferys, M. (Ed.) Growing Old in the Twentieth Century. Londen [etc.]: Routledge, 1989.

Johnson, P., Conrad, C. en Thomson, D. Workers versus Pensioners:

Intergenerational Justice in an Ageing World. Manchester: University of Manchester Press, 1989.

Jones, R.A. On Merton's 'History' and 'Systematics' of Sociological Theory. In: Graham, L., Lepenies, W. en Weingart, P. (Eds.) Functions and Uses of Disciplinary Histories. Dordrecht [etc]: D. Reidel Publishing Company, 1983: $12 \mathrm{I}-142$.

Jongedijk, J.W. Het einde van het leven is ook leven. De ouder wordende mens in de samenleving. Overdruk uit Het Vaderland 1957/ 1958, 1959.

Kart, C.S. Review Essay: The end of conventional gerontology? Sodology of Health and Illness 9 (1987) I, 76-87.

Kastelein, M., Dijkstra, A. en Schouten, C.C. Care of the elderly in the Netherlands. A review of policies and services 1950-1990. Leiden: NIPG/ TNO, 1989.

Keune, C. en Zanden, G.H. van der. Beeld van ouderen. Een overzichtsstudie naar kennis inzake het beeld in de samenleving van oudere mensen. Rijswijk: Ministerie van Welzijn, Volksgezondheid en Cultuur, I980. [Kiers], G.F.E. Huisvesting van ouden van dagen. Maandblad voor kerkelijke armenzorg 19 (1928) I, I-9.

King, G.B. en Stearns, P.N. The retirement experience as a policy factor: an applied history approach. Joumal of Sacial History 14 (19808I) $589-6$ Is.

Kirk, H. Geriatric Medicine and the Categorisation of Old Age - the Historical Linkage. Ageing and Society I2 (1992) 4, 483-497.

Klinken, J. van. Het gezin en het bejaardenprobleem. AR-Staatkunde 27 (1957) 112-120.

Knipscheer, C.P.M. (Red.) Ouder worden, een uitdaging voor het familieverband. Nijmegen: NVG/NIG, 1984 .

Knipscheer, C.P.M. (Red.) Sociologie van het ouder worden sinds 1970. Onderzoek en beleid. Krimpen aan de IJsel/Nijmegen: NVG/NIG, 1985.

Knipscheer, C.P.M., Baars, J., Severijns, M. (Red.) Uitzicht op ouder worden. Een verkenning van nieuve rollen. Assen/Maastricht: Van Gorcum, 1988.

Knipscheer, K. Sociological research on age, aging and the aged in the Netherlands. Tijdschrift voor Gerontologie en Geriatrie 18 (1987) 2a, I30137. 
Knook, D.L. Oud worden, een natuurlijke zaak? Lochem: De Tijdstroom, 1978.

Knopper, E.V. Gelijke behandeling in de Aow. In: Levelt-Overmars, W.M. (Red.) Gelijke behandeling van vrouw en man ten aanzien van pensioenen. Deventer: Kluwer, 1988: 11-21.

Kohli, M. The World We Forgot: A Historical Review of the Life Course. In: Marshall, W.V. (Ed.) Later Life: The Social Psychology of Aging. London: Sage, 1986: 271-303.

Kohli, M. Ageing as a Challenge for Sociological Theory. Ageing and Society 8 (1988) 367-394.

Kohli, M. e.a. (Eds.) Time for retirement. Comparative Studies of Early Exit from the Labour Force, Cambridge: Cambridge University Press, 1991. Kohli, M. en Meyer, J.W. Social Structure and Social Construction of Life Stages. Human Development 29 (1986) 145-180.

Kohli, M. en Wolf, J. Altersgrenzen im Schnittpunkt von betrieblichen Interessen und Individueller Lebensplanung. Das Beispiel des Vorruhestands. Soziale Welt 38 (1987) 92-109.

Kondratowitz, H.-J. von. Die Medikalisierung des höheren Lebensalters. Kontinuität und $\mathrm{W}$ andlungen vom ausgehenden $\mathrm{I} 8$. bis zum frühen 20. Jahrhundert. In: Labisch, A. und Spree, R. (Hg.) Medizinische Deutungsmacht im sozialen Wandel des 19. und frühen 20 . Jahrhunderts. Bonn: Psychiatrie-Verlag, 1989: 207-222.

Kooy, C. van der. Van oude mensen vroeger en nu. Over de geschiedenis van de ouderdom en de zorg voor oude mensen. Deventer: van Loghum Slaterus, 1987 .

Laslett, P. The Significance of the Past in the Study of Ageing. Introduction to the Special Issue on History and Ageing. Ageing and Society 4 (1984) 4, 379-389.

Latour, B. Science in Action: How to Follow Scientists and Engineers through Society. Milton Keynes: Open University Press, 1987.

Latour, B. The Pasteurization of France. Cambridge [etc.]: Harvard University Press, 1988.

Leeden, C.B. van der. De ontwikkeling van diaconiehuis tot gemeentelijk tehuis voor ouden van dagen te Rotterdam 1906-1956. Rotterdam: s.n., 1956.

Lely, R. Overzicht van het Bejaardenwerk van 1948 tot 1955 . Raad en Daad [ro] (1955) 12-I4.

Leusen, A.J. van. Ouder worden en ... gelukkig zijn! Amsterdam: G.J.A. Ruys Uitgeversmaatschappij, [1952].

Lezingencyclus over bejaardenzorg. Arnhem: Stichting Gelderland voor 
Maatschappelijk Werk, I955.

Loo, L.F. van. 'Den arme gegeven...' Een beschnijving van armoede, armenzorg en sociale zekerheid in Nederland, 1784-1965. Meppel [etc.]: Boom, I98I.

Macintyre, S. Old age as a social problem. Historical Notes on the English Experience. In: Dingwall, R. e.a. (Eds.) Health care and health knowledge. London [etc.]: Croom Helm/New York: Prodist, 1977: $4 \mathrm{I}-63$.

Mannoury, J. Een gouden nap voor iedereen? Achtergronden van de totstandkoming van de Algemene Ouderdomswet. De Gids 152 (1989) 6, 446-460.

Means, R. en Smith, R. The development of welfare senvices for elderly people. London [etc.]: Croom Helm, 1985 .

Meijer, J.A.J. De huisvesting van bejaarden. Socialisme en Democratie ro (1953) 322-332.

Memorandum betreffende enige belangrijke punten inzake het bejaardenbeleid. Rijswijk: Ministerie van CRM/ISB, 1969.

Methorst, H.W. Enkele belangrijke demografische feiten. Mensch en Maatschappij 2 (1926) 407-429.

Michels, J.J.M. Verpleeghuizen voor langdurig zieken. In: Santema, S. (Red.) Intramurale gezondheidszorg. Beschrijving van de verschillende soorten van inrichtingen. Alphen aan de Rijn: Samson, 1970: 37-52.

Michels, J.J.M. Over chronisch zieken en bejaarden. Nijmegen: Dekker en Van de Vegt, 1974.

Miller, G. and Holstein, J.A. (Eds.) Constnuctivist Controversies. Issues in Social Problems Theory. New York: Aldine de Gruyter, 1993.

Minkler, M. en Estes, C.L. (Eds.) Critical Perspectives on Aging. The political and Moral Economy of Growing Old. Amityville, New York: Baywood Publishing Company, 1991.

Modemisering van oude bejaardentehuizen. Rotterdam: Bouwcentrum, 1962.

Moeniralam-van Wel, B. Onderzoek onderzocht. Analyse, evaluatie en perspektief van het sociaal-gerontologisch onderzoek in Nederland. Amsterdam: Noord-Hollandsche Uitgevers Maatschappij, 1977.

Mol. A. en Lieshout, P. van. Ziek is het woord niet: medicalisering, nonnalisering en de veranderende taal van huisartsgeneeskunde en geestelijke gezondheidszorg, 1945-1985. Nijmegen: sun, 1989.

Mulders, W.J.M. Noden van de bejaarden; en problemen rondom dit vraagstuk sociaal-economisch beschouwd. Nijmegen: Thoben Offset, 1966.

[Muller-Lulofs, M.G.] Oranjestein te Amerongen. Pro Senectute 
(Voor den Ouderdom). Amenzorg. Orgaan van de Vereeniging tot Verbetering van Amenzorg te Utrecht [31] (1923) 27, I-4.

Munnichs, J.M.A. De oude mens is het beeld van zijn leven. Katholieke Gezondheidszorg 25 (1956) 4, 117/120-121.

Munnichs, J.M.A. Enkele aspecten van de psychologie van de bejaarden. Maatschappijbelangen 120 (1956) 9, 344-345.

Munnichs, J.M.A. Voorbereiding op de pensionering. Jaanerslag Gemeenschappelijk Instituut voor Toegepaste Psychologie 1958. Nijmegen: GITP, 1958: 36-41.

Munnichs, J.M.A. De bejaarden in deze tijd. Enkele Aspecten van het Bejaardenvraagstuk. S.l.: Unie van Katholieke Diocesane Bonden van Bejaarden en Gepensioneerden in Nederland, [1962].

Munnichs, J.M.A. Ouderdom en eindigheid. Een bijdrage tot de psychogerontologie. Assen: Van Gorcum [etc.], 1964.

Munnichs, J.M.A. Oudere werknemers: een verkennende studie. ['s-Gravenhage]: SER, 1966.

Munnichs, J.M.A. Sociale gerontologie en sociaal-geontologisch onderzoek in Nederland. Nederlands Tijdschrift voor de Psychologie en haar grensgebieden 23 (1968) 458-473.

Munnichs, J.M.A. Ouder worden en bejaard zijn. Sociaal-gerontologische opstellen. Nijmegen: Dekker en Van der Vegt, 1969.

Munnichs, J.M.A. Role-patterns among ageing and aged teachers and steel-workers in the Netherlands. In: Havighurst, R.J., Munnichs, J.M.A., Neugarten, B. en Thomae, H. (Eds.) Adjustment to retirement. A crossnational study. Assen: Van Gorcum, 1969: 95-115.

Munnichs, J.M.A. Psychogerontologie: een jonge discipline. Nederlands Tijdschrift voor de Psychologie 42 (1987) 3-10.

Munnichs, J.M.A. Voorzieningen voor ouderen: visie op ouderdom. Deventer: Van Loghum Slaterus, 1987 (oorspr. 1978).

Munnichs, J.M.A. en Diesfeldt, H.F.A. Psychology of aging. An overview of research in the Netherlands. Tijdschrift voor Gerontologie en Geriatrie 18 (1987) 2a, 117-129.

Munnichs, J.M.A., Kwant, R.C. en Thung, P.J. Leven en eindigheid. Een psychogerontologische studie. Utrecht [etc.]: Het Spectrum, I965. Munnichs, J.M.A., Moor, R.A. de en Maltha O.P., A.H. Herfsttij van de levensloop. Beschouwingen over de ouderdom. Utrecht [etc.]: Het Spectrum, 1956.

Myles, J. Old Age in the Welfare State. The Political Economy of Public Pensions. Boston [etc.]: Little, Brown and Company, 1984. 
Myles, J. Postwar capitalism and the extension of social security into a retirement wage. In: Minkler en Estes (1991) op. cit. 293-309.

Na-conferentie Lunteren 1963. 's-Gravenhage: Nederlandse Federatic voor Bejaardenzorg, 1963.

Nederland wordt ouder maar wil het niet weten. De Groene Amsterdammer. Weekblad voor Nederland 27 september 1947.

NFB-Kommentaar op de Nota Bejaardenbeleid 1975 [Den Haag: NFB, 1975].

Nomenclatuur van vormen van accommodatie voor bejaarden in Nederland. 's-Gravenhage: Stichting NFB, s.a.

Nota Bejaardenbeleid. 's-Gravenhage: Staatsuitgeverij, 1970.

Nota Bejaardenbeleid. 's-Gravenhage: Staatsuitgeverij, 1975.

Nota Bouwstenen voor een ouderenbeleid. 's-Gravenhage: Staatsuitgeverij, 1982 .

Nota inzake de toekomstige ouderdomsvoorziening van de Minister van Sociale Zaken en Volksgezondheid en van de staatssecretaris van Sociale Zaken. 's-Gravenhage: Staatsdrukkerij- en Uitgeverij, 1952.

Onderzoek naar de levensomstandigheden, behoeften en wensen der bejaarden in de Watergraafsmeer. Amsterdam: Economisch en Sociaal Instituut, Vrije Universiteit, 1954.

Onderzoek naar de levensomstandigheden van de bejaarden in de gemeente Delft. Rotterdam: Nederlandsch Economisch Instituut, 1957.

Ontwikkelingen rond de voorbereiding op de pensionering. [Den Haag]: NFB, I974.

Oostvogel, F.J.G. Verzorgingsbehoeften van bejaarden. Een sociaal-geneeskundig onderzoek naar de behoeften van gegadigden voor een verzorgingstehuis. Nijmegen/Utrecht: Dekker \& Van de Vegt, 1968.

Oostvogel, F.J.G. Het probleem van de bejaarden en de Nederlandse oplossing. Medicinae Scientia Donat 3 (1970) 10, 48-50.

Oostvogel, F.J.G. Historische ontwikkeling van verpleeghuizen in Nederland. Medisch Contact 39 (1984) 2, 45-46.

Open huis over het tehuis. Amsterdam: Humanitas, 1976.

Opening van het tweede tehuis van Vredeheim. Maandblad voor kerkelijke armenzorg 13 (1922) 12, 186-189, 191.

Opneming in verzorgingstehuizen voor bejaarden. Procedure en samenwerking. Den Haag: NFB, 1967.

Oud in Nederland. Verslag. Den Haag: Nederlandse Federatie voor Bejaardenbeleid, 1982.

Ouder worden. Rotterdam: Studium Generale, 1980. 
Ouder worden ... zelfstandig blijven. Een brochure over flankerend bejaardenbeleid'. Rijswijk: Ministerie van Welzijn, Volksgezondheid en Cultuur, 1984 .

Ouderen willen nieuw beleid. Utrecht: cosBo Nederland, 1979.

Oudjes kijken. Den Haag: Nederlandse Federatie voor Bejaardenbeleid, 1974.

Overzicht van reacties en commentaren op de Nota Bejaardenbeleid 1975. Rijswijk: Interdepartementale Stuurgroep Bejaardenbeleid, 1976. Paillat, P. (Ed.) L'age à travers les ages. Gérontologie et société (1989) nr. 4.

Pampel, F.C. Review of Minkler en Estes (199I). Ageing and Society 12 (1992) I, 125-126.

Pelling, M. en Smith, R.M. (Eds) Life, death, and the elderly. Historical perspectives. London/New York: Routledge, 1991.

Philibert, M.A. The Emergence of Social Gerontology. Joumal of Social Issues 2 I (1965) 4-12.

Phillipson, C. Capitalism and the Construction of Old Age. London [etc]: Macmillan, 1982.

Phillipson, C. The development of european social gerontology. Ageing and Society 6 (1986) 1, 91-98.

Phillipson, C., Bernard, M. en Strang, P. (Eds.) Dependency and Interdependency in Old Age: Theoretical Perspectives and Policy Altematives. London: Croom Helm, 1986.

Phillipson, C. en Walker, A. Ageing and social policy. A Critical Assessment. Aldershot [etc.]: Gower, 1986.

Pley, G. Liefdewerk en bejaardenzorg. Verkenningen in de historie van de R.K. Stichting Verzorgings- en Verpleegtehuis Bemardus te Amsterdam, 1839-1989. Amsterdam: R.K. Stichting Verzorgings- en Verpleegtehuis Bernardus, 1989 .

Polisar, D. e.a. Where Do We Come From? What Are We? Where Are We Going? An Annotated Bibliography of Aging and the Humanities. Washington, DC: The Gerontological Society of America, 1988.

Pouw, A. Oud, maar wijs genoeg? De Nederlandse Vereniging voor Gerontologie 1947-1987. Lochem/Gent: De Tijdstroom, 1987.

Praag, Ph. van. Het bevolkingsvraagstuk in Nederland. Ontuikkeling van standpunten en opvattingen (1918-1940). Deventer: Van Loghum Slaterus, 1976.

Probleeminventarisatie bejaarden en bejaardenvraagstuk. Onderzoek uitgevoerd door de afdeling Research van het Gemeenschappelijk Instituut voor Toegepaste Psychologie te Nijmegen, in opdracht van het Ministerie van 
Cultuur, Recreatie en Maatschappelijk Werk. Rijswijk: Ministerie van CRM, 1973.

Problemen van de bejaardenzorg in hun veelzijdige samenhang. Studie van het Katholiek Sociaal-Kerkelijk Instituut (K.S.K.I.). Den Haag: K.S.K.I., I961.

Program voor bejaardenzorg. Amsterdam: dr. Wiardi Beckmanstichting, 1958.

Proosdij, C. van. Bejaarde patiënten. Geriatrie in theoric en praktijk. Leiden: Stafleu, 1972.

Proosdij, C. van en Sipsma, D.H. Dertigjaar vaderlandse geschiedenis. De lijdensweg van de klinische geriatrie in Nederland. Tijdschrift voor Gerontologie en Geriatrie is (1984) 3-5.

Quadagno, J.S. Aging in early industrial society. Work, Family, and Social Policy in Nineteenth Century England. New York [etc.]: Academic Press, 1982.

Rapport Arbeid voor Bejaarden. 's-Gravenhage: Nederlandse Federatie voor Bejaardenzorg, [1960].

Rapport inzake arbeidsmogelijkheden voor ouden van dagen. Leeuwarden: Stichting Friesland voor Maatschappelijk Werk, 1951.

Rapport inzake huisvesting voor ouden van dagen. Deel $L$. Leeuwarden: Stichting Friesland voor Maatschappelijk Werk, 1951.

Rapport van de commissie, door het dagelijksch bestuur benoemd om een onderzoek in te stellen naar den toestand van de zorg voor ouden van dagen in $\mathrm{Ne}$ derland. [Geschriften van de Nederlandsche Vereeniging voor Armenzorg en Weldadigheid te Amsterdam.] Haarlem: H.D. Tjeenk Willink \& Zoon, 1923.

Rapport van de commissie ter bestudering van het vraagstuk van de oude dag. Amsterdam: Sociale Raad, 1950.

Rapport van de Commissie van onderzoek in zake de gemeentelijke armenverzorging over de oudeliedenverzorging in gestichten. $\mathrm{Ge}$ meenteblad [Amsterdam] Afdeeling I (1918) Bijlage $\mathrm{H}$.

Rapport van de Studiecommissie voor Verplegingsinrichtingen voor Chronisch Zieken en Invalide Ouden van Dagen. Nationale Commissie voor de Oudeliedenzorg, 1951 .

Rapport van de subcommissie voor de bestudering van het vraagstuk van de pensioengerechtigde leeftijden. 's-Gravenhage: Staatsdrukkerij/Staatscommissie voor de pensioenwetgeving, 1951.

Rapport van het College van Advies der Anti-Revolutionaire Partij inzake de huisvesting van bejaarden met name in verzorgings- en verpleegtehuizen. 's-Gravenhage: [ARP], 1959. 
Rechten en welzijn van mensen in instituten. Amsterdam: Humanitas, 1978.

[Redactioneel]. Katholieke Gezondheidszorg 25 (1956) 4, 95.

Register van Sociaal-Gerontologisch onderzoek, 1945-1964. Amsterdam: Noord-Hollandsche Uitgevers Maatschappij, 1966.

Register van Sociaal-Gerontologisch onderzoek. Deel II, 1965-1973. Amsterdam: Noord-Hollandsche Uitgevers Maatschappij, 1975.

Register van Sociaal-Gerontologisch onderzoek. Deel III, 1974-1979. Amsterdam: Noord-Hollandsche Uitgevers Maatschappij, 1982.

Rhijn, A.A. van. Bejaardenzorg. Diakonia [1953] 183-184.

Richtlijnen voor de bouw en exploitatie van pensiontehuizen voor bejaarden. Utrecht: Sectie Bejaardenzorg van de Stichting Vrijzinnig Protestantse Centrale voor Maatschappelijk Werk, 1959.

Ringoir, D.J.B. Gerontologie, is dat misschien oude wijn in nieuwe zakken? TNO-Project (1984) 6, 240-243.

Robben, P. Ambulante geestelijke gezondheidszorg voor bejaarden, 1945-1992. Maandblad Geestelijke Volksgezondheid (1992) 11, 12091223 .

Roebroek, J.M. The 'Silent' Revolution. Structure, Development and Future of the Dutch pensions. Tilburg: Studierichting Sociale Zekerheidswetenschap, Katholieke Universiteit Brabant, 1991.

Roebuck, J. When Does Old Age Begin?: The Evolution of the English Definition. Joumal of Social History 12 (1979) 416-428.

Roebuck, J. en Slaughter, J. Ladies and Pensioners: Stereotypes and Public Policy affecting Old Women in England 1880-1940. Joumal of Social History 13 (1979) 105-1 14.

Rooy, P. de. Werklozenzorg en werkloosheidsbestrijding 1917-1940. Landelijk en Amsterdams beleid. Amsterdam: Van Gennep, 1979.

Royers, T. en Winters, W. 100 jaar pensioenstrijd in Nederland $1884-1984$. S.I.: s.n., 1984 .

Rubbens-Franken, E. De ouder wordende mens in onze samenleving. Bussum: A. Voorhoeve, 1953.

Rubbens-Franken, E. De 65-jarigen. Pensioen, arbeid, vrije-tijdsbesteding. Maatschappijbelangen 120 (1956) 4, 127-133.

Rubbens-Franken, E. Mogelijkheden voor tijdsbesteding door bejaarden. Utrecht: Stichting Vrijzinnig Protestantse Centrale voor Maatschappelijk Werk, 1956.

Rümke, H.C. Levenstijdperken van den man. Amsterdam: De Arbeiderspers, 1938. 
Santvoort, M.M. van. Gerontologie in Nederland. Een momentopname van het gerontologisch onderzoek in Nederland. Nijmegen: NIG, I988.

Santvoort, M.M. van. Onderzoek onderzocht. Deel II. Analyse, evaluatie en perspektief van het sociaal-gerontologisch onderzoek in Nederland. Amsterdam: Noord-Hollandsche Uitgevers Maatschappij, 1983 .

Schabel, P. De gezondheidszorg: van immuniteit tot publiek domein. In: Kreukels, A.M.J. en Simonis, J.B.D. (Red.) Publiek domein. De veranderende balans tussen staat en samenleving. Amsterdam/Meppel: Boom, 1988: 172-200.

Schön, D.A. Generative Metaphor: A Perspective on Problem-Setting in Social Policy. In: Ortony, A. (Ed.) Metaphor and Thought. Cambridge [etc.]: Cambridge University Press, 1982.

Schouten, J. (Red.) Geriatrische lessen voor verpleegkundigen. Lochem: De Tijdstroom, 1978.

Schouten, J. (Red.) Gerontologische problemen. Een inleiding. Alphen aan den Rijn/Brussel: Samson, I980.

Schouten, J., Leerling, C. en Bender, J. (Red.) Leerboek geriatrie. Utrecht/Antwerpen: Bohn, Scheltema en Holkema, 1985.

Schrama, P.G.M. De prepensioneringsfase in het arbeidsproces. Commentaar: Orgaan van de Centrale van Hogere Ambtenaren (1968) 39-44. Schreuder, J.Th.R. De verpleging van chronisch zieke bejaarden. ['s-Gravenhage]: Vereniging van Nederlandse Gemeenten, 1955.

Schreuder, J.Th.R. Oorzaken en gevolgen van veroudering. [Rede uitgesproken bij de aanvaarding van het ambt van bijzonder hoogleraar in de gerontologie aan de Rijksuniversiteit te Utrecht op maandag 28 april i969]. Leiden: Stafleu's wetenschappelijke uitgeversmaatschappij, 1969.

Schreuder, J.Th.R. (Dis)continuïteit in de gezondheidszorg voor bejaarden. Tijdschrift voor Sociale Gezondheidszorg ss (1977) 362-366, 375 .

Schroots, J.J.F. e.a. (Red.) Gezond zijn is ouder worden. Assen/Maastricht: Van Gorcum, 1989.

Schuyt, C.J.M. Het rechtskarakter van de verzorgingsstaat. In: Doorn, J.A.A. van en Schuyt, C.J.M. (Red.) De stagnerende verzorgingsstaat. Meppel/Amsterdam: Boom, 1978. Schuyt, C.J.M. De fragmentering van bestuur en beleid in de verzorgingsstaat. In: Boekaflevering Mens en Maatschappij. Deventer: Van Loghum Slaterus, 1979.

Schuyt, C.J.M. Tussen macht en moraal. Over de plaats van het recht in de verzorgingsstaat en de democratie. Alphen aan de Rijn/Brussel: Samson Uitgeverij, 1983 . 
Sheldon, J.H. A History of British Geriatrics. Modem Geriatrics (I971) I, 457-464.

Sipsma, D.H. Klinische geriatrie, een medische odyssee. Rede uitgesproken bij de aanvaarding van het ambt van hoogleraar in de Klinische Geriatrie aan de Rijksuniversiteit te Groningen op dinsdag 9 februari 1993. Groningen, 1993.

Sleeswijk, J.G. Alt werden und jung bleiben. Wiener Medizinische Wochenschnift (1925) 25, 1496-1 500 en (1925) 26, 1555-1563.

Sleeswijk, J.G. (Red.) De ouderdom van geneeskundig standpunt beschouwd. Een handboek voor artsen. Deel t. Algemeen Gedeelte. Deel II. Clinisch gedeelte. Amsterdam/Antwerpen: Uitgeverij Kosmos, 1948/1949.

Smissaert, H. Overzicht van het Nederlandsch Anmwezen. Haarlem: H.D. Tjeenk Willink \& Zoon, I90r.

Smith, R.M. The Structured Dependence of the Elderly as a Recent Development: Some Sceptical Historical Thoughts. Ageing and Soiety 4 (1984) $4,409-428$.

Sociale Zekerheid. Rapport van de commissie ingesteld bij beschikking van de Minister van Sociale Zaken van 26 maart 1943, met de opdracht algemeene richtlijnen vast te stellen voor de toekomstige ontuikkeling der sociale verzekering in Nederland. (3 delen) S.L.: s.n., 1945-1946.

Spek, J. van der. De psychologie van den Ouden dag. (Overdruk uit Ons godsdienstondenvijs, No. 6, Mei 1925) Zalt-Bommel: Uitg. Mij en Boekh. v.h. P.M. Wink, [1925].

Stavenuiter, M. Ouderen en ouderdom na 1750: een historiografisch overzicht. Tijdschnift voor Sociale Geschiedenis 16 (1990) 3, 217-243.

Stavenuiter, M. Verzorgd of zelfstandig. Ouderen en de levensloop in Amsterdam in de tweede helft van de negentiende eeuw. Groningen: proefschrift, 1993 .

Stearns, P. Old Age in European Society. London: Croom Helm, 1977. Tassel, D. van en Stearns, P.N. (Eds.) Old age in a Bureaucratic Society. New York [etc.]: Greenwood Press, 1986.

Thane, P. The muddled history of retiring at 60 and 65. New Society (1978) 234-236.

Thane, P. Geriatric medicine. In: Bynum, W.F. en Porter, R. (Eds.) Companion Encyclopedia of the History of Medicine. Londen: Routledge, 1993: vol 11, 1092-1115.

Thane, P. Een onvermoeibare levenslust. Beeld en zelfbeeld van oude vrouwen in Engeland. In: Stavenuiter, M., Bijsterveld, K. en Jansens, S. (Red.) Lange levens, stille getuigen. Oudere vrouwen in het 
verleden. Zutphen: Walburg Pers, 1995: 18 I-196.

Thane, P.M. The debate on the declining birth-rate in Britain: the 'menace' of an ageing population, 1920s-1950s. Continuity and change 5 (1990) 2, 1-23.

Thuiswonende bejaarden. Bijdrage ter stimulening van het bejaardenverk in de wijk. 's-Hertogenbosch: Katholieke Nationale Federatie voor Bejaardenzorg/Sectie van het Landelijk Sociaal Charitatief Centrum, 1964.

Tielens, G. Oud zit fout. Bilthoven: Ambo, 1974.

Tien jaar Gerontologisch Centrum Nijmegen 1967-1977. Nijmegen: Interfacultaire Vakgroep Sociale Gerontologie i.o., 1978.

Tijdsbesteding van bejaarden. Leiden: Commissie voor het Oudeliedenvraagstuk, Subcommissie Tijdsbesteding, 1955.

Timmermans, J.M. Overheid en ouderenprobleem in Nederland. In: Borghardt, M.B. e.a. (Red.) Sociale problemen in België en Nederland. [Amsterdam]: siswo, 1988: 101-111.

Townsend, P. The Structured Dependency of the Elderly: A Creation of Social Policy in the Twentieth Century. Ageing and Society 1 (1981) 1, 5-28.

Tuntler, J.H. Sociaal-geneeskundige kroniek. Tijdschrift voor Amwezen, Maatschappelijke Hulp en Kinderbescherming 20 (1941) 458, 24-26. Turksma, L. Senioren in de samenleving. Utrecht: Het Spectrum, 1982. Valk, L. van der. Van pauperzorg tot bestaanszekerheid. Anmenzorg in Nederland 1912-1965. Proefschrift Rotterdam, 1986.

Vanouds. Den Haag: NFB, [1975].

Veen, R.J. van der. De sociale grenzen van beleid. Een onderzoek naar de uitvoering en effecten van het stelstel van sociale zekerheid. Leiden/Antwerpen: Stenfert Kroese, 1990.

Veen, R.J. van der. Retoriek, symboliek en beleid. Beleid en Maatschappij I 8 (1991) 6, 303-311.

Veen, W.J. van der en Poppel, F. van. Institutionele zorg voor ouderen in de tweede helft van de rge eeuw. Een case-study. Tijdschrift voor Gerontologie en Geriatrie 23 (1992) 2, 60-66.

Veen, W.J. van der en Poppel, F. van. Institutional Care for the Elderly in the roth Century: Old People in The Hague and their Institutions. Ageing and Society 12 (1992) 2, 185-212.

Veen, W.K. van der. 'Ten tijde des avonds...'. Vijftig jaren bejaardentehuis 'Avondlicht' en wat daaraan vooraf ging: diakonale bejaardenhuisvesting te Groningen. Groningen: Diakonie Hervormde Gemeente, 1984.

Veldhuijzen van Zanten-Hyllner, M. De geschiedenis van de ver- 
pleeghuisgeneeskunde. Vox Hospitii 12 (1988) 2, 4I-43.

Velema, W. De oudedagsvoorziening in Nederland: toen, nu en in de toekomst. In: Krop, M. e.a. (Red.) Het achtste jaarboek voor het democratisch socialisme. Amsterdam: De Arbeiderspers, 1987: 57-89.

Verschure, J.C.M. Ouderdomsziekten. Katholieke Gezondheidszorg 25 (1956) 4, 132-135. Verslag 1955-1959. 's-Gravenhage: Nederlandse Federatie voor Bejaardenzorg, [1960].

Verslag over de periode 1962-1965. Den Haag: Nederlandse Federatie voor Bejaardenzorg, [1966].

Verslag over 1971 en 1972. Den Haag: Nederlandse Federatie voor Bejaardenbeleid, 1973.

Verslag van de Provinciale voorlichtingsdag over bejaardenhulp in het kader van de gezinsverzorging. Gehouden in het Huis der Provincie te Arnhem op 9 april 1965.

Versteijen, A. Bejaardentehuizen in Tilburg [Tilburg]: Provinciaal Opbouworgaan Noord-Brabant: [1960].

Verwey-Jonker, H. De bejaarden, slachtoffers van de geboortenbeperking? Socialisme en democratie 35 (1978) 9, 415-420.

Verzorgingsbehoefte van bejaarden in bejaardentehuizen 1963. Beleidsnota en rapport. Den Haag: Gerontologische Commissie Katholieke Vereniging van Bejaardentehuizen, 1964.

Verzorgingstehuizen voor bejaarden. Rotterdam: Bouwcentrum, 1970.

Viif jaar welzijnszorg voor ouderen. Den Haag: Nederlandse Federatic voor Bejaardenzorg, 1971 .

Voet tussen de deur. De toekomst van het verzorgingstehuis. Amsterdam: Humanitas, 1977.

Voor ouderen is de maat vol. Utrecht: COSBO, 1982.

Voorbereiding op de derde levensfase en het pensioneningssysteem. Deelrapport

(I). Den Haag: Stuurgroep voorbereiding op de derde levensfase van de Nederlandse Federatie voor Bejaardenbeleid, 1979.

Voorschriften en wenken voor het ontwerpen van verzorgingstehuizen voor bejaarden (1965). 's-Gravenhage: Ministerie van Volkshuisvesting en Ruimtelijke Ordening, 1966.

Voûte, P.A. Levenstempo. Een studie over veroudering. Leiden: H.E. Stenvert Kroese, 1952.

Walker, A. The Social Creation of Poverty and Dependency in Old Age. Joumal of Social Policy 9 (1980) I, 49-75.

Walker, A. Ageing and the social sciences: the north american way. Ageing and society 7 (1987) 235-41.

Walker, A. The Economic 'Burden' of Intergenerational Conflict. 
Ageing and Society 10 (1990) 4, 377-396.

Wall, R. Residential Isolation of the Elderly: A Comparison over

Time. Ageing and Society $4(1984) 4,483-503$.

Warren, L. Moral Economy and Old Age. Ageing and Society I3 (1993)

I, 107-I I 2.

Wegwijzer SOOM 1982-1987. Nijmegen: Nederlands Instituut voor Gerontologie, 1987.

Wehkamp, T. Voorbereiding op het ouder worden. Suggesta (no. 2). Amersfoort: De Horstink, 1980.

Wentholt, R. Bejaarden thuis. 's-Gravenhage: Ministerie van Maatschappelijk Werk, 1964 .

Weijers, 1. Tenug naar het behouden huis. Romanschrijvers en wetenschappers in de jaren vifftig. Amsterdam: SUA, 1991.

Winters, W. ANBO bestaat 85 jaar. 'Ik ga op voor hen wier levenszon ondergaat'. Leeftijd (1986) 4, 23-25.

Winters, W. 'Hoort regeerders van het land...' Uit de geschiedenis van het ouderenbeleid. Leiden: Stichting Burgerschapskunde [etc.], 1988.

Winters, W. De dalende ondergrens van de ouderdom. Spiegel Historiael. Maanblad voor geschiedenis en archeologie 9 (1990) 406-410.

Winters, W. Die staatshulp wenschen wij... Pensioenstrijd in Nederland. 's-Gravenhage: SDU uitgeverij, 1990.

Winters, W. Het domein van de ouderdom: uit de geschiedenis van de Nederlandse ouderenbeweging. In: Handboek 'Wonen en werken in een verzongingshuis'. Amersfoort: Academische Uitgeverij, r991: (par, 1.2) 1-23.

Wirtz, A.A. De bejaarde in de huidige samenleving. Katholieke Gezondheidszorg 25 (1956) 4, 114-116.

Wolf, H.C. de. 58 miljoen Nederlanders en hun bejaarden. Amsterdam: Uitgeverij Amsterdam Boek, 1977.

Zanten, J.H. van. De toeneming v.h. aantal oudelieden. De Sociale Verzekeringsgids I 8 (1938) 9, 135-137. Zelfstandig wonende bejaarden. Leeuwarden: Stichting Friesland voor Maatschappelijk Werk, 1960. Zelvelder-Van der Laan, C.Tj. Pensioen in zicht. Bedrijfsvoorbereiding van werknemers op de pensionering. 's-Gravenhage: Staatsdrukkerij- en uitgeverij/Ministerie van Maatschappelijk Werk, 1964.

Zesde advies Commissie Open School. Educatieve voorzieningen ter voorbereiding op de pensionering. Den Haag: Staatsuitgeverij, 1978.

Zilverdraden. Een tenugblik op de manifestatie 'Dag ouwe dag'. Den Haag: NFB, [1976].

Zon-Soete, C. van. Vier en een half jaar practijk. Maandblad voor 
kerkelijke ammenzorg 18 (I927) I, 3-9.

Zonneveld, R.J. van. Gezondheidsproblemen bij bejaarden. Resultaten van een sociaal-geneeskundig onderzoek bij 3000 personen van 65 jaar en ouder in de stad Groningen. Assen: Van Gorcum, 1954.

Zonneveld, R.J. van. De bejaarden in onze veranderende samenleving. In: Banning, W. e.a. Motief en functie. Bewogenheid en beweging in het maatschappelijk werk 1908-1958. Haarlem: Tjeenk Willink, [1958]: 25I-264.

Zonneveld. R.J. van (Red.) Geriatrie. Aspecten van de gezondheidszorg voor bejaarden. Assen: Van Gorcum, 1961.

Zonneveld, R.J. van. The health of the aged. Assen: Van Gorcum, 1961. Zonneveld, R.J. van. Geriatrie: omstreden werkelijkheid. Medicinae Scientia Donat 3 (1970) 10, 43-47.

Zonneveld R.J. van (Red.) Medische gerontologie. Assen: Van Gorcum, 1970.

Zonneveld, R.J. van. Sociale geriatrie. In: Zonneveld, R.J. van (Red.) Sociale geneeskunde. Een algemene inleiding. Utrecht: Oosthoek, 1970: 319-336.

Zonneveld, R.J. van. Forty years of gerontological research in the Netherlands. A comment on some topics. Tijdschrift voor Gerontologie en Geriatrie 18 (1987) 5, 298-99.

Zwier, J. Het overheidsbeleid ten aanzien van ouderen. Ars Aequi 37 (1988) 10, 633-642. 


\title{
Personenregister
}

\author{
Abbott, Andrew $\quad$ 134, 249, 251 \\ Gelder, W. van 232, 234 \\ Achenbaum, W. Andrew 25 \\ Goffman, E. $\quad$ I57 \\ Achterhuis, Hans 237 \\ Armstrong, David 25, 26, 35, \\ 147, I55 \\ Groen, J. I24-I26, 224 \\ Guillemard, Anne-Marie 18 , \\ 30, 31 \\ Baars, J. $\quad 189$ \\ Haber, Carole $24,25,119,120$, \\ 123,124 \\ Hattinga Verschure, J.C.M. 63 . \\ 67 \\ Havermans, F.M. 57 \\ Hofland, H.J.A. 1I-15, 221 \\ Hollander, C.F. 125 \\ Hudson, Robert 34 \\ Calhoun, Richard 25 \\ Carboni, David 147-150, 153 \\ Chowdhury, Sanjib Datta \\ I 57-I60, 204-206, 247, 25I \\ Chudacoff, H.P. $\quad 23,89$ \\ Cole, Thomas 19 \\ Conrad, Christoph $\quad 24,25$ \\ Cumming, E. 228 \\ Dam,J.C. van 64,226 \\ Diederich, J. $79,88,89$ \\ Egas, C. 72,77 \\ Estes, Caroll $\quad$ I 8 \\ Everts, J. 55, 70, 73, 82, 163 . \\ I65, 166 \\ Feenstra, G. 197,198 \\ Idenburg, $\mathrm{Ph} . J . \quad 51$ \\ Janmaat, J.F.J. 232, 233 \\ Kirk, H. 25 \\ Kleijn, A. 73 \\ Klompé, M. 171, 191, 200 \\ Knipscheer, C.P.M. $\quad 189$ \\ Kohli, Martin 22-24, 28-30, 34 . \\ 89 \\ Kondratowitz, Hans-Joachim \\ von $26,27,31,32$ \\ Latour, Bruno $\quad 121,122,152$, \\ 153,155, 249, 251 \\ Lely, R. 77 \\ Loo, K.J.M. van de 74 \\ Loon, P.C.J. van 58
}


Maas, P. van der 44,45

Means, Robin 18,20

Methorst, H.W. $4^{8}$

Milikowski, H.Ph. 63

Moor, R.A. 225

Munnichs, J.M.A. $74,75,79$. $192,226,227,229,230$

Muntendam, P. 54, 70,72, 73

Myles, John 18

Oosterbaan, 1.J.A. 99

Pasteur, L. I21

Phillipson, Chris 18, 20, 237

Proosdij, C. van 135, 146

Romein-Verschoor, Annie 58 , 199

Roolvink, B. 98, 101, 102, 109 , III, 113

Rümke, H.C. 50,185

Saane, M.van 99

Schnabel, Paul 152

Schouten, J. I35

Schreuder, J.Th.R. 75, 125-146, 149-155, 245, 249 . $25 \mathrm{I}$

Schuyt, C.J.M. 90-94, 115 . 246,251
Schut, W.F. 200

Sleeswijk, J.G. 49, 54, 69, 70, 73,126

Smith, Richard 32

Spek, J. van der $50,77,78$

Thane, Pat 31

Thiel, F.J.F.M. van 72,171 , 191

Thung, P.J. $\quad 126$

Thurlings, J.M.G. 225

Townsend, Peter $\quad 18$

Tuntler, J.H. 54

Turksma, L. 74

Uyl, Joop den $\quad 64,202,234$

Verrijn Stuart, C.A. 5o

Voûte, P.A. 123,124

Walker, Alan $\quad 18,33$

Warren, Marjorie $\quad 127,146,149$

Wehkamp, Th. 232, 234

Wirtz, A.A. $\quad 59,79$

Wolf, H.C. de 95

Zee, Bart van der 235

Zonneveld, R.J. van 127,135 .

I $45,149,223,224$ 


\section{Kennis \\ Openbare mening \\ Politiek}

Een serie onder redactie van

René Boomkens, Elsbeth Etty, Lolle Nauta,

Dick Pels en Gerard de Vries

\section{René Boomkens}

Kritische massa

Over massa, moderne ervaring en popcultuur

\section{Pierre Bourdieu}

Opstellen over smaak, habitus en het veldbegrip

Gekozen door Dick Pels

\section{Pierre Bourdieu}

De regels van de kunst

Wording en structuur van het literaire veld

Trudy Dehue

De regels van het vak

Nederlandse psychologen en hun methodologie 1900-1985

\section{Sjaak Koenis}

Tussen marge en professie Frankfurt en Chicago: twee visies op de praktische rol van sociologen

\section{Aafke Komter}

De macht van de dubbele moraal

Verschil en gelijkheid in de verhouding tussen de seksen 


\section{Bruno Latour}

Wij zijn nooit modern geweest

Pleidooi voor een symmetrische antropologie

Lolle Nauta en Gerard de Vries, red.

De rol van de intellectueel

Een discussie over distantie en betrokkenheid

Dick Pels

Het democratisch verschil

Jacques de Kadt en de nieuwe elite

\section{Amartya Sen \\ Welzijn, vrijheid en maatschappelijke keuze \\ Opstellen over de politieke economie van het pluralisme}

Robert J. van der Veen en Dick Pels, red.

Het basisinkomen

Sluitstuk van de verzorgingsstaat?

Rein de Wilde

Discipline en legende

De identiteit van de sociologie in Duitsland en de Verenigde Staten, I 870-1930 

De vergrijzing maakt pensioenen onbetaalbaar, voorspellen economen. Op congressen discussiëren medici over geheugenverlies op latere leeftijd. Bewindslieden kondigen aan dat bejaardenoorden hun langste tijd hebben gehad.

In veel van deze kwesties staan grenzen op het spel. Wanneer overschrijdt vergeetachtigheid de grens van het natuurlijke? Bestaat er nog een onderscheid tussen het verzorgingshuis en het verpleeghuis? Andere grenzen zijn meer impliciet. Zo wordt geruisloos vastgelegd wie tot de 'ouderen' behoren of wat tot het probleem van vergrijzing gerekend moet worden.

Over de geschiedenis van dergelijke grenzen gaat Geen kwestie van leeftijd. Wat ouderen van anderen onderscheidt, wat binnen en buiten 'natuurlijke' veroudering valt, wat als de essentie van de ouderdomsproblematiek wordt beschouwd en hoe de huisvestingsvoorzieningen van ouderen zijn gesitueerd, ligt niet voor eens en altijd vast. Aan de hand van naoorlogse discussies over de vergrijzing, de pensioengerechtigde leeftijd, natuurlijk verouderen en de ligging en indeling van verzorgingshuizen, komen deze grenzen aan de orde.

Hoe ontstonden de grenzen aan de hand waarvan de ouderdom als probleem, sociale categorie of levensfase werd gekarakteriseerd? En wat betekenden deze grenzen voor de praktijk van de ouderenzorg in Nederland?

De geschiedenis van de ouderdom, zo makt dit boek duidelijk, kan in ieder geval niet als 'een kwestie van leeftijd' worden afgedaan.

Karin Bijsterveld (I961) studeerde geschiedenis en is als universitair docent verbonden aan de vakgroep Maatschappijwetenschap en Techniek van de Rijksuniversiteit Limburg.

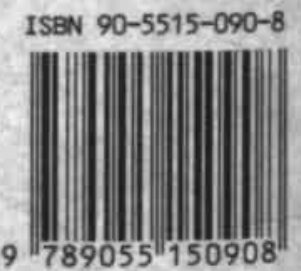

